\title{
The divestiture remedies under merger control in the US, the EU and China
}

Citation for published version (APA):

Shi, M. (2017). The divestiture remedies under merger control in the US, the EU and China: $A$ comparative law and economics perspective. [Doctoral Thesis, Maastricht University]. Datawyse / Universitaire Pers Maastricht. https://doi.org/10.26481/dis.20171003ms

Document status and date:

Published: 01/01/2017

DOI:

10.26481/dis.20171003ms

Document Version:

Publisher's PDF, also known as Version of record

\section{Please check the document version of this publication:}

- A submitted manuscript is the version of the article upon submission and before peer-review. There can be important differences between the submitted version and the official published version of record.

People interested in the research are advised to contact the author for the final version of the publication, or visit the DOI to the publisher's website.

- The final author version and the galley proof are versions of the publication after peer review.

- The final published version features the final layout of the paper including the volume, issue and page numbers.

Link to publication

\footnotetext{
General rights rights.

- You may freely distribute the URL identifying the publication in the public portal. please follow below link for the End User Agreement:

www.umlib.nl/taverne-license

Take down policy

If you believe that this document breaches copyright please contact us at:

repository@maastrichtuniversity.nl

providing details and we will investigate your claim.
}

Copyright and moral rights for the publications made accessible in the public portal are retained by the authors and/or other copyright owners and it is a condition of accessing publications that users recognise and abide by the legal requirements associated with these

- Users may download and print one copy of any publication from the public portal for the purpose of private study or research.

- You may not further distribute the material or use it for any profit-making activity or commercial gain

If the publication is distributed under the terms of Article $25 \mathrm{fa}$ of the Dutch Copyright Act, indicated by the "Taverne" license above, 


\section{THE DIVESTITURE REMEDIES UNDER MERGER CONTROL IN THE US, THE EU AND CHINA}

\section{A COMPARATIVE LAW AND ECONOMICS PERSPECTIVE}

Mengmeng Shi 


\title{
THE DIVESTITURE REMEDIES UNDER MERGER CONTROL IN THE US, THE EU AND CHINA
}

\section{A COMPARATIVE LAW AND ECONOMICS PERSPECTIVE}

\author{
DISSERTATION
}

to obtain the degree of Doctor at Maastricht University, on the authority of the Rector Magnificus Prof. dr. Rianne M. Letschert, in accordance with the decision of the Board of Deans, to be defended in public on Tuesday 3 October 2017, at 12.00 hours

by

Mengmeng Shi 


\section{Supervisors:}

Prof. dr. Michael G. Faure, Maastricht University

Prof. dr. Niels J. Philipsen, Erasmus University Rotterdam

\section{Assessment Committee:}

Prof. dr. Hildegard Schneider, Maastricht University (Chair)

Dr. Caroline Cauffman, Maastricht University

Prof. dr. Sharon Oded, Erasmus University Rotterdam

Dr. Stefan Weishaar, Rijksuniversiteit Groningen 
to my loving parents 致 我挚爱的父母 

ACKNOWLEDGEMENTS 

This book, while an individual work of my four-year research in the Institute for Transnational Legal Research (in Dutch: Maastrichts Europees instituut voor Transnationaal Rechtswetenschappelijk Onderzoek, "METRO") of the Faculty of Law of Maastricht University, could never have completed without help, supports and guidance from many people.

I first would like to express my deep gratitude to my supervisors, Prof. Michael Faure and Prof. Niels Philipsen. I still remember the first time I meet Niels was in 2011 in the law and economics lectures when I was following my LL.M. program in the Law Faculty of Maastricht University. Two years later, I was introduced to Michael by Niels after I decided to conduct a PhD research. Even if Michael and Niels are extremely busy, they read every chapter of my thesis carefully, always gave feedbacks promptly, and provided me with insightful comments and suggestions, all of which inspired me greatly to complete this book. I will always appreciate Michael's huge support and invaluable advice for my application for the scholarship and I will also remember the time I spent with Niels in his office, discussing my thesis and research. Their guidance, insights, knowledge and supports are invaluable.

My gratitude also goes to the China Scholarship Council ("CSC") and the Faculty of Law of Maastricht University. The financial support from CSC makes it possible for me to pursue my $\mathrm{PhD}$ degree in the Netherlands. The Law Faculty provides me with all the facilities needed to carry out my research.

I am also grateful to the members of the Assessment Committee: Prof. Hildegard Schneider, Dr. Caroline Cauffman, Prof. Sharon Oded and Dr. Stefan Weishaar for their thoughtful feedbacks. In particular, I would like to extend my appreciation to Caroline. She read every word of the draft book and provided very insightful comments, which incentivised me to improve my book at the final stage.

I wish to thank many professors and other researchers I met in the Future of Law and Economics series seminars, Ius Commune Research School as well as other seminars and conferences. My appreciation especially goes to Prof. Roger Van den Bergh, Prof. Wouter Devroe and Dr. Andreea Cosnita for their invaluable comments and feedbacks.

In addition, I feel grateful to these top-tier M\&A lawyers - Mrs. Rongrong Xu, Mr. Liang Ding and Mrs. Ying Yang - and those prestigious Chinese professors of competition law - Prof. Xiaoye Wang, Prof. Shiying Xu and an anonymous professor from a top Chinese University- for their acceptances of my interview invitations. Their insightful and thoughtful observations and opinions have helped me greatly in preparing the empirical research of this book.

I would also like to extend my appreciation to those colleagues from the Global Law Office (Beijing), where I conducted my internship at the late stage of my $\mathrm{PhD}$ research. Their help and guidance enabled me to obtain practical knowledge about competition law in China, which inspired me to improve the Chinese part of the book. My gratitude especially goes to Jinrong Liu, Shifang Guo, Qiuning Kang, Liang Gao, Lei Chen, Meng Hou, Ting Liang, Ruiqing Zhu and Bing Li.

Conducting a PhD abroad is a lonely and winding journey. Thanks to my friends in China and in the Netherlands, the journey becomes joyful. I will remember all these wonderful moments we shared for my whole life: the Christmas party in 2014, those tasty Sichuan hotpots, and the nights we spent in those lovely bars in Maastricht, talking about dream and life. My acknowledgements must go to: Ancui, Mengxing, Wenqing \& Zhenglong, Yu Zhao \& Xi Chen, Yingying, Liuhu, Yuan Tian, Shou Li, Yu Yan, Tianxiang, Taotao, Kelly Shang, Jiangqiu, Xiaowei, Li You, Wei Zhao, Feifei Wang, Chang Liu, Xingyu Luo, Binjing Zhu, Jia Ruan, Xueni Tan and Xinxin Wang. In particular, I would like 
to thank Jiaxin Huang, who is always patient and helps me through the most stressful times.

Last but not the least, I wish to express my deepest gratitude and appreciation to my father Guoxiang Shi and my mother Cuier Liu. They let me know that no matter how difficult the journey is or how far I go, they are always right here behind me. I dedicate this book to my loving parents, without whose unconditional love, support, understanding and encouragement, this book would not have been possible.

Mengmeng

Maastricht

25 August 2017 


\section{TABLE OF CONTENTS}

$\begin{array}{ll}\text { Acknowledgements } & 7\end{array}$

List of abbreviations 19

$\begin{array}{ll}\text { List of figures } & 20\end{array}$

$\begin{array}{ll}\text { List of tables } & 21\end{array}$

Chapter 1 Introduction $\quad 23$

1. Research Background 25

1.1. Competition and Mergers 25

1.2. Merger Control and Merger Remedies 28

1.2.1. Justification for Ex Ante Merger Control Policy 28

1.2.2. Different Types of Merger Remedies 29

2. Purpose and Research Questions 31

3. Methodology 32

3.1. Comparative Legal Analysis $\quad 32$

3.2. Law and Economics $\quad 32$

3.3. Legal Analysis, Case Analyses and Interviews 33

3.4. A Comparative Law and Economics Analysis 33

4. Structure 34

PART I ANALYSIS OF MERgER DIVESTITURES IN COMPETITION LAW 35

Chapter 2 Merger control and merger divestitures in the United States 37

$\begin{array}{ll}\text { 1. Introduction } & 39\end{array}$

2. Application of Merger Control Legislation in the US 40

2.1. The US Competition Authorities 40

2.1.1. Antitrust Division of the DOJ 40

2.1.2. FTC 41

2.2. Adjudicative Bodies 42

2.3. Transactions Caught by Merger Control Legislation 43

2.4. Jurisdiction 45

3. Procedures and Substantive Test of Merger Review 48

3.1. Merger Review Procedures $\quad 48$

3.1.1. Initial Waiting Period 48

3.1.2. Second Waiting Period 49

3.1.3. Investigations 49

3.1.4. Final Decision and Appeal $\quad 50$

3.2. Substantive Test of Merger Review

3.2.1. Market Definition $\quad 52$

3.2.2. Market Concentration 53

3.2.3. Competitive Effects 54

3.2.4. Ease of Entry 54

3.2.5. Efficiencies 54 
4. The Emergence and Evolution of United States Merger Divestitures 55

4.1. Divestitures before the HSR Act 57

4.1.1. Divestitures under the Sherman Antitrust Act 57

4.1.2. Divestitures under the Clayton Act 61

4.1.3. El Paso Natural Gas Company 63

4.2. Divestitures after the HSR Act $\quad 67$

5. Further Developments in US Merger Divestitures 69

5.1. FTC 70

5.1.1. The FTC's Changed Divestiture Policy 70

5.1.2. 1999 FTC Divestiture Study 71

5.1.3. The Development of Divestitures by the FTC 73

$\begin{array}{ll}\text { 5.2. DOJ } & 77\end{array}$

5.2.1. Background of the 2011 DOJ Policy Guide 77

5.2.2. Changes between the 2011 DOJ Policy Guide and the 2004 DOJ
Policy Guide

6. The FTC's and the DOJ's Merger Divestiture Policies 81

6.1. The Agencies' Common Ground 81

6.1.1. Preference for Structural Remedies 81

6.1.2. Requirements for Divestiture Assets 81

6.1.3. Criteria for Selecting A Suitable Buyer $\quad 82$

6.1.4. Requirement for A Shorter Divestiture Period 83

6.2. Differences between the Agencies' Divestiture Policies 84

6.2.1. Reasons for the Differences 84

6.2.2. The Agencies' Different Preferences of Divestiture Policies 86

7. Conclusion 95

Chapter 3 EU: divestitures under merger control in the European Union 97

1. Introduction 99

2. Application of Merger Control Legislation in the EU 100

2.1. A Brief History of Merger Control at the EU Level 100

2.2. Competition Authority in the EU 103

2.3. Transactions Caught by the Merger Regulation 104

2.3.1. Lasting Change in the Structure of the Undertakings Concerned 104

$\begin{array}{ll}\text { 2.3.2. Change of Control } & 104\end{array}$

2.3.3. Fully-Functional Joint Ventures 105

2.4. Jurisdiction: an EU Dimension 106

3. Procedures and Substantive Test of the EU Merger Review 108

3.1. Merger Review Procedures 108

$\begin{array}{ll}\text { 3.1.1. Referral Procedures } & 108\end{array}$

3.1.2. Phase I Procedures 110

3.1.3. Phase II Procedures 111

3.1.4. Final Decision and Judicial Review 112

3.2. The Substantive Test of Merger Review 113

3.2.1. Market Shares and Concentration 114

3.2.2. Anti-Competitive Effects 116

3.2.3. Countervailing Buyer Power and Market Entry 116

3.2.4. Efficiencies and the Failing Firm Defence 117

4. Merger Divestitures in the EU: Learning from the US 118

4.1. Background and Basic Aims of the 2001 EC Remedies Notice 118 
4.2. General Principles 119

4.2.1. Preference for Structural Remedies 119

4.2.2. Standard for Accepting Remedies $\quad 120$

4.2.3. Distinction between Conditions and Obligations 120

4.3. Merger Divestitures in the 2001 EC Remedies Notice 121

$\begin{array}{ll}\text { 4.3.1. Composition of Divestiture Packages } & 121\end{array}$

$\begin{array}{lr}\text { 4.3.2. A Suitable Purchaser } & 123\end{array}$

$\begin{array}{ll}\text { 4.3.3. Trustee } & 124\end{array}$

5. Schneider/Legrand: Lessons for EU Merger Divestitures 124

5.1. Schneider/ Legrand Merger 124

5.1.1. Litigation Review 124

5.1.2. Lessons for EU Merger Divestitures 126

5.2. 2005 EC Merger Remedies Study 129

5.2.1. The Divested Business Issues 129

5.2.2. Suitable Purchaser Issue 130

5.2.3. Trustee Issues 131

6. The 2008 EC Remedies Notice: the EU's Development in Merger Divestitures 132

6.1. General Principles 132

6.2. Design of Merger Divestitures 134

6.2.1. Composition of Divestiture Packages 134

$\begin{array}{ll}\text { 6.2.2. A Suitable Purchaser } & 137\end{array}$

6.3. Implementation of Divestitures 139

$\begin{array}{ll}\text { 6.3.1. Divestiture Process } & 139\end{array}$

6.3.2. Monitoring Trustees and Divestiture Trustees 140

7. Conclusion 141

Chapter 4 Merger divestitures in the us and the EU - future convergence? 143

1. Introduction 145

2. Cooperation in the Merger Control Field between the US and the EU 145

3. Background: The Competition Authorities 147

4. Design of Merger Divestitures 148

4.1. Preference for Merger Divestiture 148

4.2. Composition of Divestiture Packages 149

4.3. Crown Jewel Provisions and the Fix-It-First Remedies 149

4.4. Requirements for a Suitable Purchaser 150

5. Implementation of Merger Divestitures 152

5.1. Interim Preservation and Trustees $\quad 152$

5.2. Divestiture Process 152

6. Reasons for Differences and Common Ground 153

$\begin{array}{ll}\text { 7. Conclusion } & 154\end{array}$

PART II LAW AND ECONOMICS ANALYSIS OF MERgER DIVESTITURES 157

Chapter 5 A general introduction to merger divestitures from a law and economics $\begin{array}{ll}\text { perspective } & 159\end{array}$

1. Introduction 161

2. Mergers and Competition 162

2.1. Perfect Competition 162

2.2. Monopoly 163 
2.3. Effective Competition

3. Expected Effects of Mergers 166

3.1. Competition Concerns of Mergers 167

$\begin{array}{ll}\text { 3.1.1. Horizontal Mergers } & 167\end{array}$

3.1.2. Non-Horizontal Mergers 169

3.2. Efficiencies 172

3.3. Welfare Standard 175

3.3.1. Consumer Welfare 176

$\begin{array}{ll}\text { 3.3.2. Total Welfare } & 176\end{array}$

4. Choice of Merger Remedies 178

4.1. Incidence for Merger Remedies 178

4.2. General Principles for an Effective Merger Remedy 179

4.3. The Choice between Structural Remedies and Behavioural Remedies $\quad 180$

4.3.1. Problems in Merger Divestitures 181

$\begin{array}{ll}\text { 4.3.2. Use of Behavioural Remedies } & 183\end{array}$

5. Conclusion 185

Chapter 6 Composition risks - an application of screening theory 187

1. Introduction 189

2. Development of Information Asymmetry - A Brief Introduction 190

3. Literature Review 192

4. Occurrence of and Solutions to Composition Risks: from a Screening Theory

$\begin{array}{ll}\text { Perspective } & 195\end{array}$

4.1. Occurrence of Composition Risks 195

4.2. Solutions to Composition Risks: Are they Efficient? 197

4.2.1. Efficiency Effects of Screening: Taking the Health Insurance
Market as an Example

4.2.2. Inefficiency and Screening Costs in Merger Divestitures 202

4.3. Effectiveness of Screening Divestiture Packages by Risk-Reducing Provisions 203

$\begin{array}{ll}\text { 4.3.1. Divestitures with Full Information } & 203\end{array}$

4.3.2. Divestitures with Asymmetric Information and No Screening 204

4.3.3. Divestitures with Asymmetric Information and Screening Devices 205

5. Use of Risk-Reducing Provisions in the US and the EU 209

5.1. Recognition of Composition Risks 209

5.2. Risk-Reducing Provisions in Law 210

5.3. Risk-Reducing Provisions in Practice: Two Cases 211

$\begin{array}{ll}\text { 5.3.1. US } & 211\end{array}$

$\begin{array}{ll}\text { 5.3.2. EU } & 211\end{array}$

$\begin{array}{ll}\text { 6. Conclusion } & 212\end{array}$

Chapter 7 Asset risks: from a moral hazard perspective $\quad 215$

$\begin{array}{ll}\text { 1. Introduction } & 217\end{array}$

2. Literature Review 219

3. Assets Risks of Merger Divestitures: Moral Hazard Perspective 221

3.1. Moral Hazard in Merger Divestitures 221

3.2. Economics of Moral Hazard in Merger Divestitures 223

3.3. Possible Solutions (Legal Strategies) 225

3.3.1. Agent-Constraining Strategies: Rules and Standards 226

3.3.2. Principal-Empowering Strategies: Reward and Trusteeship 227 
4. Use of HSPs and Trustees in the US and the EU to Reduce Asset Risks 232

4.1. Recognition of Asset Risks 232

4.2. HSPs and Trustees in Law $\quad 232$

4.2.1. Use of HSPs 232

4.2.2. Use of Trustees 233

4.3. HSPs and Trustees in Practice 235

4.4. Summary 236

5. Conclusion 237

Chapter 8 Collusion risks - from the collusion theory perspective 239

1. Introduction 241

2. Literature Review 243

3. Why Collude? 247

3.1. Competition or Collusion 247

3.2. An Example of Collusion: from the Perspective of Bargaining Theory 249

3.3. Summary 252

4. How Divestitures Facilitate Collusion between the Merged Party and the

Purchaser and Possible Solutions $\quad 252$

4.1. Collusion-Facilitating Factors Caused by Divestitures 253

4.1.1. Symmetry 253

4.1.2. Multi-Market Contacts 254

4.1.3. Continuing Relationships 255

4.2. Possible Solutions 256

4.2.1. Consideration of Post-Divestiture Effects 256

4.2.2. Evaluations of the Purchaser's Incentives 257

4.2.3. Monitoring Required When a Continuing Relationship is Needed 257

5. Post-divestiture Collusion Risks in the US and the EU 258

5.1. Recognition of and Solutions to Post-Divestiture Collusion Risks 258

$\begin{array}{ll}\text { 5.1.1. US } & 258\end{array}$

5.1.2. EU 261

5.2. Nestle/Perrier: a Case with a Post-Divestiture Collusion Risk 263

6. Conclusion 264

Chapter 9 Challenges in realising the effectiveness of merger remedies 267

$\begin{array}{ll}\text { 1. Introduction } & 269\end{array}$

2. Justifying the CA's Predictions 270

2.1. Justification for an Ex Ante Merger Review Policy 270

$\begin{array}{ll}\text { 2.2. Investigations } & 270\end{array}$

2.3. Negotiations of Remedies $\quad 271$

3. Increasing the Requisite Degree of Certainties in Divestitures 272

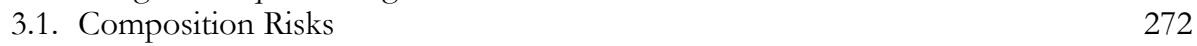

3.2. Asset Risks 273

3.3. Collusion Risks 274

4. Lessons Learnt 275

PART III MERger REVIEW AND MERger DIVESTITURES IN CHINA 277

Chapter 10 Legal framework of merger control and merger divestitures in china 279

$\begin{array}{ll}\text { 1. Introduction } & 281\end{array}$ 
2. Legal Framework of Merger Control in China 284

2.1. Legislation on Merger Control and Merger Divestitures 285

2.2. Competition Authorities: NDRC, SAIC and MOFCOM 286

2.3. Objectives 288

2.4. Mergers Caught by the Merger Control Legislation 288

2.5. Jurisdiction 290

3. Procedures and Substantive Test of the Chinese Merger Review System 293

3.1. General Merger Review Procedures 293

3.1.1. Pre-Notification Discussions 293

3.1.2. Simple Case Standards 294

3.1.3. Preliminary Investigations and In-depth Investigations 296

3.1.4. Final Decisions 297

3.2. Substantive Test of Merger Review 298

3.2.1. General Assessment of Anti-Competitive Effects 298

3.2.2. Market Share and Market Power 299

3.2.3. Market Concentration 300

3.2.4. Ease of Market Entry $\quad 300$

3.2.5. Efficiency and Efficiency Defence $\quad 300$

3.2.6. Impact on the National Economy 301

4. Merger Divestitures in China's Merger Control Law 302

4.1. General Principles 303

4.2. Design of Merger Divestitures 303

4.2.1. Composition of Divestiture Packages 304

$\begin{array}{ll}\text { 4.2.2. Suitable Buyers } & 305\end{array}$

4.3. Implementation of Merger Divestitures $\quad 307$

$\begin{array}{ll}\text { 4.3.1. Divestiture Process } & 307\end{array}$

$\begin{array}{ll}\text { 4.3.2. Trustees } & 308\end{array}$

4.3.3. Hold Separate Provisions (HSPs) 309

5. Conclusion 310

Chapter 11 Mofcom's practice in merger control and merger remedies: case analyses 313

1. Introduction $\quad 315$

2. MOFCOM's Merger Review $\quad 317$

2.1. MOFCOM's Substantive Analysis $\quad 320$

2.1.1. The Initial Performance $\quad 320$

2.1.2. A More Economic Approach 322

2.1.3. Summary 323

2.2. Timing of Merger Review $\quad 324$

2.3. Non-Competition Policy Consideration 326

3. Application of Merger Remedy 327

3.1. Behavioural Remedies $\quad 327$

$\begin{array}{ll}\text { 3.1.1. Forms of Behavioural Remedies } & 327\end{array}$

3.1.2. Hold Separate Provisions as Behavioural Remedies 329

3.1.2. Price Reduction 331

3.1.3. No Market Expansion 332

3.2. Structural Remedies $\quad 332$

3.2.1. Forms of Structural Remedies $\quad 332$

3.2.2. General Principles of Merger Divestitures 334

3.2.3. Composition Risks: Crown Jewels in Glencore/Xstrata 335 
3.2.4. Asset Risks: An HSP in Thermo Fisher/Life Tech

3.2.5. Collusion Risks: Purchaser Requirements and Transitional Agreement in Baxter/Gambro

3.3. MOFCOM's Preference: Structural Remedies or Behavioural Remedies? $\quad 341$

4. Conclusion

Chapter 12 Insights of MOFCOM's merger control and merger remedies - empirical evidence

1. Introduction

2. Methodology

2.1. Participants

2.2. Interview Questions

3. Results

3.1. General Questions

3.1.1. Lawyer Group

3.1.2. Scholar Group

3.2. Merger Review

3.2.1. Substantive Assessment

3.2.2. Time Limit

3.2.3. Consideration of Non-Competition Policies 359

3.2.4. Other Relevant Questions of Merger Review 361

3.3. Merger Remedies 363

3.3.1. Diverse and Non-traditional Forms of Behavioural Remedies 363

3.3.2. MOFCOM's Preference: Behavioural Remedies or Divestitures $\quad 365$

3.3.3. Use of the Fix-It-First Remedies 369

3.3.4. Potential Risks of Divestitures and the Effectiveness of Solutions 371

3.4. General Assessment and Suggestions 374

$\begin{array}{ll}\text { 3.4.1. General Assessment } & 374\end{array}$

$\begin{array}{ll}\text { 3.4.2. Suggestions } & 376\end{array}$

4. Conclusion

Chapter 13 A comparative law and economics analysis of merger divestitures in China 379

1. Introduction 381

2. Merger Control Policies in the US, the EU and China 383

2.1. Procedural Aspects 383

2.2. Substantive Aspect $\quad 384$

$\begin{array}{ll}\text { 2.2.1. Substantive Test } & 384\end{array}$

2.2.2. Consideration of Non-Competition Policies 385

3. Merger Divestitures in China: a Comparative Law and Economics Analysis 387

3.1. Composition Risks 387

3.1.1. Application of Screening Theory in Merger Divestitures 387

3.1.2. US and EU Practice 389

3.1.3. MOFCOM Practice $\quad 392$

3.2. Asset Risks 393

3.2.1. Moral Hazard in Merger Divestitures $\quad 393$

3.2.2. US and EU Practice $\quad 395$

3.2.3. MOFCOM Practice $\quad 397$

3.3. Collusion Risks 399 
3.3.2. US and EU Practice $\quad 400$

3.3.3. MOFCOM Practice $\quad 402$

3.4. Use of the Fix-It-First Remedies 403

3.5. Assessment of MOFCOM's Practice: Evidence from Interviews 405

4. Prevalence of Behavioural Remedies in China 409

4.1. Behavioural Remedies: Diverse and Flexible 409

4.2. Prevalence of Behavioural Remedies and Reasons 410

4.2.1. The Merging Parties' Reluctance to Propose Divestitures and MOFCOM's Compromise-Seeking Behaviour 411

4.2.2. Traditions of Corporate Surveillance and Dispersed Monitoring Costs 412

4.2.3. Other Reasons 414

5. Conclusion 415

Chapter 14 Concluding remarks and policy recommendations $\quad 417$

1. Answers to Research Questions and Main Findings 419

1.1. Answers to Research Question 1 and Main Findings from Part I 419

1.1.1. US 419

1.1.2. EU 420

1.2. Answers to Research Question 2 and Main Findings from Part II 423

1.3. Answers to Research Question 3 and Main Findings from Part III 424

2. Policy Recommendations $\quad 427$

2.1. Conduct Empirical Merger Remedies Study 427

2.2. Publish Policy Guide Regarding Merger Divestitures 428

2.3. Consider More Standards during Merger Remedies Negotiations 428

2.4. Use Intermediaries for Post-Divestitures Follow-Up 429

3. Research Limitations and Suggestions for Future Research 430

3.1. Law and Economics Analysis $\quad 430$

3.2. Empirical Study 430

3.3. Comparative Study 431

$\begin{array}{ll}\text { Epilogue } & 433\end{array}$

$\begin{array}{ll}\text { Valorisation addendum } & 437\end{array}$

$\begin{array}{ll}\text { List of cases } & 443\end{array}$

$\begin{array}{ll}\text { List of legislation } & 447\end{array}$

$\begin{array}{ll}\text { Bibliography } & 451\end{array}$

Curriculum vitae 作者简历 465 


\section{LIST OF ABBREVIATIONS}

ALJ

$\mathrm{AMB}$

AMEA

AML

CAs

CFI

CJ

CJEU

DG COMP

DOJ

ECJ

DWL

EEC

EU

FTC

GC

$\mathrm{HHI}$

HSP

JV

MOFCOM

MOFTEC

NBSC

NDRC

SAIC

TFEU

UK

US

WTO

Administrative Law Judge

Anti-Monopoly Bureau of the Ministry of Commerce of the People's Republic of China

Anti-Monopoly Law Enforcement Agency

Anti-Monopoly Law of the People's Republic of China

Competition Authorities

The Court of First Instance

The Court of Justice

The Court of Justice of the European Union

Directorate-General for Competition of the European Commission

U.S. Department of Justice

The European Court of Justice

Deadweight Loss

European Economic Community

European Union

U.S. Federal Trade Commission

The General Court

Herfindahl-Hirschman Index

Hold Separate Provision

Joint Venture

Ministry of Commerce of the People's Republic of China

Ministry of Foreign Trade and Economic Cooperation of the People's Republic of China

National Bureau of Statistics of the People's Republic of China

National Development \& Reform Commission of the People's Republic of China

State Administration for Industry \& Commerce of the People's Republic of China

Treaty on the Functioning of the European Union

United Kingdom

The United States of America

World Trade Organisation 


\section{LIST OF FIGURES}

Figure 1 Different Types of Mergers 26

Figure 2 Merger Remedies Universe $\quad 30$

Figure 3 Merger and Merger Divestitures at the EU Level 140

Figure 4 Divestiture Process at the EU Level 140

Figure 5 Consumer and Producer Surplus in Perfect Competition 164

Figure 6 Consumer and Producer Surplus in Monopoly (Loss in Efficiency) 164

$\begin{array}{lll}\text { Figure } 7 & \text { Input Foreclosure } & 170\end{array}$

$\begin{array}{lll}\text { Figure } 8 \text { Customer Foreclosure } & 170\end{array}$

Figure 9 Welfare Effects of Mergers -Williamson Merger Analysis 177

Figure 10 Development of the Theory of Asymmetric Information 192

Figure 11 Consumer Surplus in the Market with Full Information: No
Screening

Figure 12 Consumer Surplus in the Market with Asymmetric Information:
Costly Screening

Figure 13 Consumer Surplus in the Market with Asymmetric Information:
Screening at Reasonable Costs

Figure 14 Asymmetric Information and Risk-Reducing Provisions 208

Figure 15 Screening Divestiture Packages by Risk-Reducing Provisions 208, 388

Figure 16 Moral Hazard in Merger Divestitures 223

$\begin{array}{lll}\text { Figure } 17 \text { Legal Strategies for Protecting Principals 225, } 394 & 423\end{array}$

Figure 18 Divisions of Tasks between NDRC, SAIC and MOFCOM 287

Figure 19 Determining the Necessity of a Pre-merger Notification under
China's Merger Control System

Figure 20 Divestiture Process under China's Merger Control 308

Figure 21 Merger Review Process of the AMB of MOFCOM 356

Figure 21 Merger Review Process of the AMB of MOFCOM 384

Figure 22 Use of Remedies in MOFCOM's 29 Conditional Approvals 410 


\section{LIST OF TABLES}

Table 1 Result of the Size-of-Transaction and Filing Requirement (2017) 47

Table 2 Merger Statistics from 21 September 1990 to 31 March 2017 in the EU 118

Table 3 Four Possibilities of Profit Effects and Merger Remedies Incidence 178

Table 4 Choices between Structural Remedies and Behavioural Remedies 184

Table 5 Variables Considered in Garrod, Lyons and Medvedev's 2008 Paper 196

Table 6 Changed Total Social Surplus 201

Table 7 Cooperative and Non-Cooperative Profits after Divestitures 250

Table 8 Distribution of Profits Gained from Cooperation 251

Table 9 Main Competition Laws Enacted before the Enactment of the AML 283

Table 10 Main Legislation on Merger Control and Merger Divestitures in China 285

Table 11 Ambiguities in the AML Regarding Merger Review and Merger Divestitures

Table 12 Annual Number of MOFCOM's Decided Transactions (1 August 2008 - 30 December 2016)

Table 13 Approvals Subject to Merger Remedies in China (1 August 2008 to 20 June 2017)

Table 14 MOFCOM's Admissible Degree of Information from Different Providers

Table 15 Numbers of Conditionally-Approved Cases Decided by MOFCOM in Different Stages of Merger Review Procedures ( 1 August 2008 20 June 2017)

Table 16 Glencore/Xstrata's Joint Market Shares

Table 17 Forms of Behavioural Remedies under China's Merger Control (1 August 2008 - 20 June 2017)

Table 18 Forms of Structural Remedies under Merger Control in China (1 August 2008 - 20 June 2017)

Table 19 Possible Reasons for the Lengthy Merger Review in China and the Improvements Made by MOFCOM

Table 20 Possible Reasons for the Prevalence of Behavioural Remedies in China

Table 21 Use of Risk-Reducing Provisions and the Fix-It-First Remedies in Conditional Approvals in China by 20 June 2017

Table 22 Solutions Used for Reducing Asset Risks and Collusion Risks in China

Table 23 Differences and Developments of Divestiture Strategies Used by the FTC, the DOJ and the European Commission

Table 24 A Summary of Reasons of and Theoretical Solutions to Three Divestitures Risks

Table 25 Assessments of Merger Divestiture Policies in China 

Chapter

INTRODUCTION 



\section{Research Background}

\subsection{Competition and Mergers}

Competition may be understood as a complex interaction between different actors who are active in markets (either supply or demand side) in order to enhance their individual welfare. ${ }^{1}$ All players are bound by the rules of the game (i.e. the institutional framework), which may be understood as a set of incentives and constraints. ${ }^{2}$ Competition law is a part of such rules, which is assigned with the aims to, inter alia, promote and protect competition.

In a free market economy, mergers (referring to situations where two or more previously independent undertakings or parts of undertakings join together) ${ }^{3}$ and acquisitions (referring to situations where one or more persons acquire control of at least one undertaking or one or more undertakings acquire control of the whole or parts of one or more other undertakings) ${ }^{4}$ are likely to occur. Undertakings can be incentivised to merge for many reasons. As identified by Bris, Cabolis and Janowski, a first incentive is associated with the increased market power the merged firms will enjoy. ${ }^{5}$ It is generally believed that the merged firms can increase their market power by merging, which may enable them to keep or achieve high profits. Nevertheless, Stigler has pointed out controversially that, first, the merged firms can be unprofitable even when an anti-competitive merger increases aggregate industry profits; second, even if an anti-competitive merger is profitable, remainders outside the merger are usually even more profitable than the merging parties. ${ }^{6}$ This would suggest that to enjoy post-merger market power is only a minor incentive and that the primary reasons for horizontal mergers should be others in addition to market power and profits. ${ }^{7}$ A second incentive for undertakings to merge relates to the (potential) efficiency gains. ${ }^{8}$ Disregarding the controversy surrounding the debate whether efficiency gains should be considered in merger regulations, it has gradually become accepted that mergers can generate efficiencies. According to Roller, Stennek and Verboven (2006), efficiencies generated from mergers can be divided into five categories, namely, a. rationalisation of production; b. economies of scale/scope; c. technological progress; $d$. purchasing economies or savings in factor prices; and e. reduction of $\mathrm{x}$-inefficiency. ${ }^{9}$ Consumers can also be made better off if the benefits of these efficiencies can be passed on. Many market players consider mergers and acquisitions as methods to create and enhance their control over markets.

\footnotetext{
${ }^{1}$ Karl Homann and Andreas Suchanek, Ökonomik, Eine Einführung (Mohr Sieberk 2005) 206.

${ }^{2}$ Christian Kirchner, 'Goals of Antitrust and Competition Law Revisited' in Dieter Schmidtchen, Max Albert and Stefan Voigt (eds), The More Economic Approach to European Competition Law, vol 24 (Mohr Siebeck 2007) 12.

3 See: Council Regulation (EC) No 139/2004 on the Control of Concentration between Undertakings [2004] OJ L24, art 3.1(a) (hereinafter: 2004 EUMR). See also: Sec.7 of the Clayton Act, 15 U.S.C. SS 12-27 (2013).

4 See: 2004 EUMR, ibid, art 3.1(b).

${ }^{5}$ Arturo Bris, Christos Cabolis and Vanessa Janowski 'Chapter 2: The Effect of Merger Laws on Merger Activity: International Evidence' in Greg N. Gregoriou and Luc Renneboog (eds), Corporate Governance and Regulatory Impact on Mergers and Acquisitions: Research and Analysis on Activity Worldwide Since 1990 (Academic Press 2007) 17.

${ }^{6}$ See: George J. Stigler, 'Monopoly and Oligopoly by Merger' (1950) 40(2) Am Econ Rev 23, 23.

${ }^{7}$ Sven-Olof Fridolfssona and Johan Stenneka, 'Hold-up of Anti-Competitive Merger' (2005) 23 (9-10) Int J Ind Organ 753,754

${ }^{8}$ Bris, Cabolis and Janowski (n 5) 17.

9 See: Lars-Hendrik Roller, Johan Stennek and Frank Verboven, 'Efficiency Gains from Mergers' (EUROPA, 2005 ) <http://ec.europa.eu/dgs/competition/economist/efficiency_gains.pdf> accessed 28 August 2017.
} 


\section{Different Types of Mergers}

Depending on different functions or characteristics of the concerned industry, mergers can be divided into two categories, horizontal mergers and non-horizontal mergers (including vertical mergers and conglomerate mergers.) Figure 1 below presents these types of mergers.

Figure 1 Different Types of Mergers ${ }^{10}$

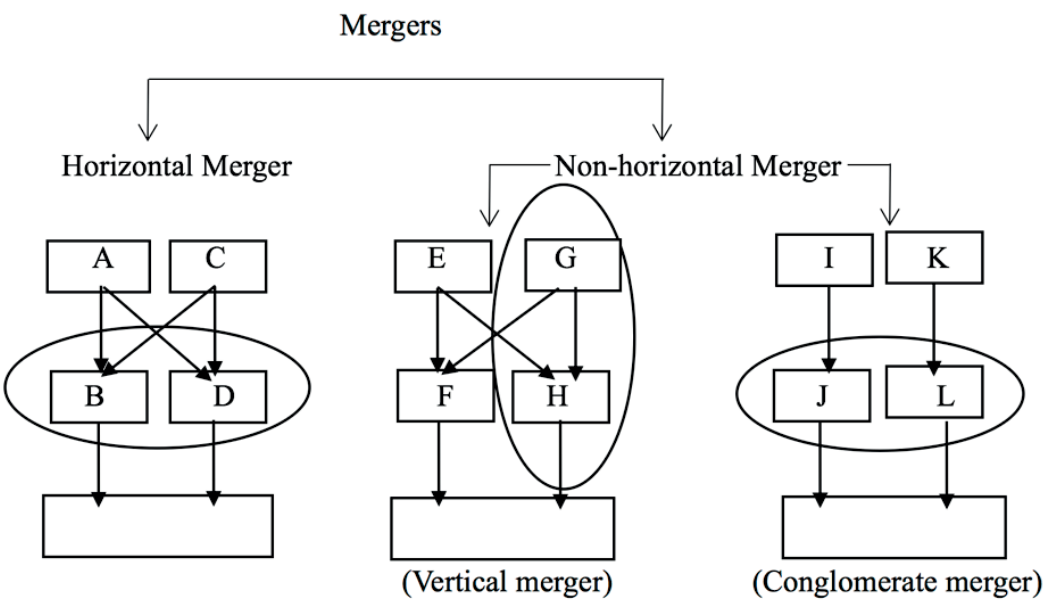

A horizontal merger is a business consolidation that occurs between firms who operate in the same industry, often as competitors offering the same goods or services. ${ }^{11}$ Horizontal mergers are common in industries with fewer firms, as competition tends to be less fierce and the synergies and potential gains in market share are much greater for merging firms in such an industry. In the above panel, firm B and firm D are on the same level in the same relevant industry. Famous horizontal mergers cases, for example, include Friesland/Campina (European companies, both parties are active in the production of various dairy products) ${ }^{12}$

${ }^{10}$ This figure is adopted from Simon Bishop and Mike Walker, The Economics of EC Competition Law: Concepts, Application and Measurement (Sweet \& Maxwell 2002) 349.

${ }^{11}$ In the EU, para. 5 of Howard A. Shelanski and Gregory Sidak, 'Antitrust Divestiture in Network Industries' (Winter 2001) 68(1) U Chi L Rev 1,1 reads,

[T] he purpose of this notice is to provide guidance as to how the Commission assesses concentrations when the undertakings concerned are actual or potential competitors in the same relevant market. In this notice such mergers will be denoted 'horizontal mergers'.

In the US, U.S. Department of Justice and the Federal Trade Commission: Horizontal Merger Guidelines (2010) (hereinafter: 2010 US Horizontal Merger Guidelines) states,

$[T]$ hese Guidelines outline the principal analytical techniques, practices, and the enforcement policy of the Department of Justice and the Federal Trade Commission (the "Agencies") with respect to mergers and acquisitions involving actual or potential competitors ("horizontal mergers") under the federal antitrust laws. Generally, the undertakings which are involved in the horizontal mergers are often (potential) competitors at the same level of the market.

See also: 'Horizontal Merger' (Investopedia) < http://www.investopedia.com/terms/h/horizontalmerger.asp> accessed 23 March 2017.

12 Case COMP/M.5046, Friesland Food/Campina (European Commission Decision) [17 December 2008] <http://ec.europa.eu/competition/mergers/cases/decisions/m5046_20081217_20600_en.pdf> accessed 18 April 2017. 
and Lenovo/IBM (one Chinese company and one American company, they have overlapping business in the area of personal PCs). ${ }^{13}$

Vertical mergers occur between two or more companies which operate at different levels of the supply chain and are generally in an upstream-downstream relationship. ${ }^{14}$ The most common involved rationale behind this type of mergers is to increase synergies created by the merging firms that would be more efficient operating as one. ${ }^{15}$ An example of a vertical merger is a car manufacturer purchasing a tyre company. Such a vertical merger would reduce the cost of tyres for the automaker and potentially expand business to supply tyres to competing automakers. In the above panel, the merger between undertaking firm $\mathrm{G}$ and firm $\mathrm{H}$ is a vertical merger which involves undertakings operating at different levels of the supply chain. Vertical mergers can be best understood from examining real world deals. One such merger occurred between Time Warner Incorporated, a major cable operation, and Turner Corporation, which produces CNN, TBS, and other programming. ${ }^{16}$

Conglomerate mergers refer to mergers that occur between companies that have no existing or potential competitive relationship either as direct competitors or as suppliers and customers. ${ }^{17}$ There are many reasons why companies conduct conglomerate mergers, such as to increase synergy and cross selling. Companies also merge to diversify and reduce their risk exposure. However, if a conglomerate becomes too large as a result of acquisitions, the performance of the entire firm can suffer. As shown in Figure 1 above, a merger between firm L and firm J would be a conglomerate merger. A famous case which falls within this category is the concentration between General Electric ("GE"), a "diversified industrial corporation" and Honeywell, "an advanced technology and manufacturing company". ${ }^{18}$

\footnotetext{
${ }^{13}$ More information about the case, see: Nathaniel Ahrens and Yu Zhou, 'China's Competitiveness-Myth, Reality, and Lessons for the United States and Japan. Case study: Lenovo' (Centre for Strategy \& International Study, 2013) <http://csis.org/files/publication/130129_competitiveness_Lenovo_casestudy_Web_0.pdf> accessed 23 March 2017.

${ }^{14}$ In the US, according to the U.S. Department of Justice, Merger Guidelines (1982), there is no explicit distinction between vertical merger and conglomerate mergers. They are collectively called "non-horizontal mergers". In the EU, para. 4 of the Guidelines on the Assessment of Non-Horizontal Mergers Under the Council Regulation on the Control of Concentrations between Undertaking [2008] OJ C265/07 (hereinafter: 2008 EU Non-Horizontal Merger Guidelines) reads,
}

[V]ertical mergers involve companies operating at different levels of the supply chain. For example, when a manufacturer of a certain product (the 'upstream firm') merges with one of its distributors (the 'downstream firm'), this is called a vertical merger.

15 See: 'Vertical Merger' (Investopedia) <http://www.investopedia.com/terms/v/verticalmerger.asp> accessed 17 February 2014.

${ }^{16}$ The proposed Time Warner-Turner merger was reviewed by the FTC. The transaction raised the FTC'S competitive concerns concerning cable program services and cable program distribution markets. Ultimately, the FTC voted to approve the merger but stipulated that the merger could not act in the interests of anticompetitiveness to the point at which the public good was harmed. For the statement of the Federal Trade Commission's views regarding this case, see: Federal Trade Commission, 'Analysis of Proposed Consent Order to Aid Public Comment' <https://www.ftc.gov/system/files/documents/cases/160711warnerbrosanalysis.pdf> accessed 14 April 2017.

${ }^{17}$ Dimitri Giotakos, 'GE/Honeywell: A Theoretic Bundle Assessing Conglomerate Merger Across the Atlantic' (2002) 23(3) U Pa J Int'l L 469, 473. In addition, in the EU, para. 5 of the 2008 EU Non-Horizontal Merger Guidelines (n 14) reads:

$[\mathrm{C}]$ onglomerate mergers are mergers between firms that are in a relationship which is neither horizontal (as competitors in the same relevant market) nor vertical (as suppliers or customers). In practice, the focus of the present guidelines is on mergers between companies that are active in closely related markets (e.g. mergers involving suppliers of complementary products or products that belong to the same product range).

${ }^{18}$ In this transaction, General Electric Company ("GE") proposed to acquire Honeywell International Inc., ("Honeywell"). For detailed information about the case and the European Commission's decision, see: Case No 
Although mergers can generate efficiencies, ${ }^{19}$ they can also lead, for example, to a state of monopoly and oligopoly, which may adversely affect effective competition in the market. It can be observed from the merger control history in the US that during the latterhalf of the nineteenth century, those newly-formed companies' wealth and power increased in the free and capitalist economy, coupled with the lack of government interference, resulting in the concentration of wealth, resources, and power into their hands. ${ }^{20} \mathrm{With}$ the concentrated market power and resources, some companies behaved strategically. ${ }^{21}$ Therefore, a merger control mechanism is needed to review mergers with (potential) anticompetitive effects.

\subsection{Merger Control and Merger Remedies}

\subsubsection{Justification for Ex Ante Merger Control Policy}

As mentioned above, a merger control mechanism is needed to review (possible) anticompetitive mergers. Naturally, the next question is, how can we effectively control mergers? The experience in the US and the EU indicates that the approach of controlling mergers by relying on competition policies which combat anti-competitive infringements (such as abuse of dominant position and anti-trust agreements) is likely to be inadequate and ineffective. ${ }^{22}$

One of the most crucial differences between competition policies that combat abuse of dominant position and anti-trust agreements on the one hand and merger control on the other hand is that, the former works ex post while the latter works ex ante. Under ex post competition policies, anti-competitive behaviour will be punished when it has been conducted, implying that competition policies preserve effective competition in the market mainly by penalising the misbehaving companies. The deterrence of the punishment may also prevent the companies from behaving undesirably. In contrast, under the ex ante merger control policy, the notified transactions will not be approved if they can significantly reduce or eliminate competition in the market. Therefore, merger review protects effective competition in the market by screening the notified mergers and only (at least) competition neutral mergers will be approved.

A separate merger control policy is needed because first, 'the enforcement of competition law prohibitions is imperfect'. ${ }^{23}$ The detection of a competition law infringement mainly relies on the Competition Authorities ("CAs") or whistle blowers. Put

\footnotetext{
COMP/M.2220 General Electric/Honeywell (European Commission Decision) [3 July 2011] <http://ec.europa.eu/competition/mergers/cases/decisions/m2220_en.pdf> accessed 19 April 2017.

${ }^{19}$ Both the US and the EU appear to have accepted the idea in recent years that mergers can contribute to efficiencies by, for example, introducing efficiency defence in merger control relevant documents. Such efficiencies can lower the costs of producing, which may result in a decrease in the price of products. Efficiencies may occur in markets where they are likely to outweigh any likely anti-competitive effect. See: Robert Pitofsky, 'Efficiency Consideration and Merger Enforcement: Comparison of U.S. and EU Approach' (2007) 30(5) Fordham Int'l LJ 1413, 1414.

Merger control, which defines the scope of application of divestitures in this book, refers to the procedures of reviewing both mergers and acquisitions under competition law. In this book, "merger" and "acquisition" are used as synonymous terms here.

${ }^{20}$ David S. Wise, 'Divestiture as A Private Remedy' (1982) 20(4) Duq L Rev 613, 615-616. See also: Earl W. Kintner, An Antitrust Primer: A Guide to Antitrust and Trade Regulation Laws for Businessmen (Macmillan 1964) 4.

${ }^{21}$ For a detailed exploration of the possible anti-competitive effects resulting from mergers, see: Chapter 5, sec.2.

${ }^{22}$ For an introduction of the history of merger control in the US and the EU, see: Chapter 2 and Chapter 3, respectively.

${ }^{23}$ Office of Fair Trading (UK), 'The Analytical Framework of Merger Control' (ICN Annual Conference), 4.
} 
differently, the undertakings concerned are unlikely to report themselves to the CA, claiming that they breach competition law. Unless the undertakings concerned are highprofile or the undertakings' infringements are so severe that they catch the CA's attention, it can be difficult for the CAs to detect their anti-competitive consequences. Furthermore, the CAs have to provide sufficient evidence to prove that the companies have infringed competition law, which can be quite difficult. Difficulties of detecting and proving competition law infringements may to some extent reduce the effectiveness of competition policy.

Second, the expost structural disentangling of a merged firm will be very costly and may even be impossible because sometimes the firms are too intermingled with each other. Lessons can be learnt from the US experience in divestitures, which will be explored in Chapter $2 .{ }^{24}$

Moreover, adopting an ex ante merger review mechanism can, to some extent, reduce the possibility of the companies' infringements of competition law because the unilateral effects and coordinated effects are always of the highest importance for the CAs when reviewing a merger.

As a result, ex ante merger review policies are necessary to screen mergers before their implementation to avoid the difficulties caused by any ex post mechanism, such as the difficulties in detecting and proving an infringement, and the risk of being unable to carry out structural remedies.

\subsubsection{Different Types of Merger Remedies}

When a merger raises anti-competitive concerns, the CA has the possibility of proposing a conditional acceptance, i.e. the $\mathrm{CA}$ requires the merging parties to make a commitment as a condition to approve the notified mergers. Such commitment is called a merger remedy. ${ }^{25}$ Merger remedies in fact change the binary character of the merger decision from a simple "yes or no" or "black or white" model to a more balanced approach. With the remedy tool, the CAs are able to extend the scope of merger control and to regulate market behaviour in a better way. ${ }^{26}$

Generally speaking, merger remedies can be divided into two categories, structural remedies and behavioural remedies. The former addresses the structure of the market, whereas the latter addresses the behaviour of the merged firms. Structural remedies generally involve the sale of physical assets by the merging firms. A behavioural remedy usually entails injunctive provisions that would, in effect, manage or regulate the merged firms' post-merger business conduct. ${ }^{27}$ In the US, anti-trust remedies comprise damages,

\footnotetext{
24 See: Chapter 2, sec.4.

${ }^{25}$ Patrice Bougette and Stephane Turolla, 'Market Structures, Political Surroundings, and Merger Remedies: An Empirical Investigation of the EC's Decisions' (2008) 25(2) Eur J Law Econ 125, 126.

${ }^{26}$ Patrick Rey, 'Economic Analysis and the Choice of Remedies' in Francois Lévêque and Howard Shelanski (eds), Merger Remedies in American and European Union Competition Law (Edward Elgar 2003) 129.

${ }^{27}$ Although in the US and the EU, almost all the legal documents adopt a binary distinction of merger remedies, there is one exception, namely, DG COMP European Commission, Merger Remedies Study (2005) (hereinafter: 2005 EC Merger Remedies Study). The study categorised remedies into seven types according to the nature of remedial measures: i.e. (1) commitments to transfer a business; (2) commitments to exit from a joint venture; (3) commitments to limit shareholding; (4) commitments to grant access; (5) commitments to change supply relationships; (6) commitments to abstain from certain conduct; and (7) other commitments. In this book, the binary distinction is adopted.
} 
including disgorgement, and injunctive relief, the latter consisting of structural and behavioural remedies. ${ }^{28}$ Figure 2 presents an overview of the merger remedies universe.

Figure 2 Merger Remedies Universe ${ }^{29}$

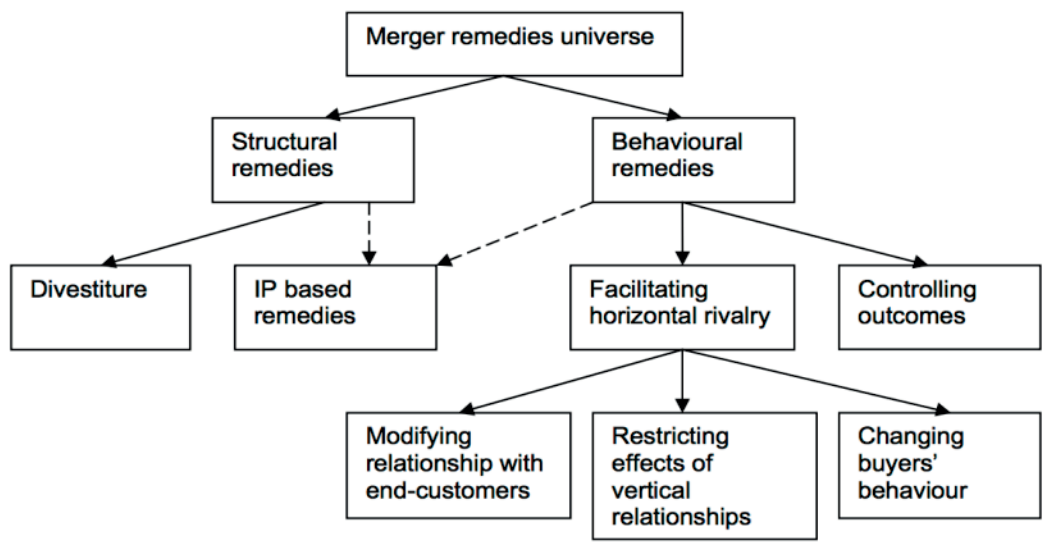

The scope of merger remedies must be cautiously addressed to ensure their effectiveness in eliminating the possible anti-competitive effects generated from mergers. If a remedy is too broad, it may create disincentives for vigorous competition; if it is under-inclusive, it will not be effective in deterring the prohibited conduct and in advancing competition in the market. ${ }^{30}$ The economic and social costs of a remedy should not exceed the competition gains achieved by it. ${ }^{31}$ Hence, to achieve the optimal remedy, the reviewing officials must weigh the relative costs and benefits of the chosen remedy. ${ }^{32}$

A merger divestiture remedy is one of the most typical structural remedies which has been widely used in many jurisdictions. Divestiture is used to refer to situations where the defendants are required to divest or dispossess themselves of specified property in physical facilities, securities, or other assets. ${ }^{33}$ According to the former European Competition Commissioner Mario Monti, 'the vast majority of the competition concerns that had arisen in merger cases had been addressed by means of divestiture'. ${ }^{34}$ The 2008 EC Remedies Notice states that 'divestiture commitments are the best way to eliminate competition concerns resulting from horizontal overlaps, and may also be the best means of resolving problems resulting from vertical or conglomerate concerns'. ${ }^{35}$ Additionally, the Federal Trade Commission ("FTC")'s 2012 Merger Remedies Statement states that, 'anticompetitive horizontal mergers are most often remedied by a divestiture; a proposal to

\footnotetext{
28 See: E. Thomas Sullivan, 'Antitrust Remedies in the US and EU: Advancing a Standard of Proportionally' (2003) 48(2) The Antitrust Bulletin 377, 396.

${ }^{29}$ Figure 2 is adopted from ICN Merger Working Group, 'Merger Remedies Review Project: Report for the Fourth ICN Annual Conference' (International Competition Network, June 2005) < http://www.internationalcompe titionnetwork.org/uploads/library/doc323.pdf> accessed 18 March 2017, 7.

30 Sullivan (n 28) 394.

31 See: Shelanski and Sidak (n 11).

32 ibid.

33 S. Chesterfield Oppenheim, 'Divestiture as Remedy' (1950-1951) 19 Geo Wash L Rev 120, 120.

${ }^{34}$ Mario Monti, 'The Commission Notice on Merger Remedies - One Year After' in Francois Lévêque and Howard Shelanski (eds), Merger Remedies in American and European Union Competition Law (Edward Elgar 2003) 3.

${ }^{35}$ Commission Notice on Remedies Acceptable under Council Regulation No 139/2004 and under Commission Regulation No 802/2004 [2008] OJ C267, para. 17 (hereinafter: 2008 EC Remedies Notice).
} 
divest one party's demonstrably autonomous, on-going business unit will usually expedite settlement'. ${ }^{36}$ Consequently, divestiture remedies play an increasingly important role in the merger control system to ensure the preservation of competition.

\section{Purpose and Research Questions}

Although divestitures may address the vast majority of competition concerns arising out of the merger cases, ${ }^{37}$ the divestiture remedies may still fail in many cases. ${ }^{38}$ There are mainly three risks that can occur in divestitures, namely, composition risks (referring to risks caused by an insufficient or an inappropriate composition of the divestiture packages) ${ }^{39}$; asset risks (referring to the deterioration of the value of the divestiture packages during the pending period before the completion of divestitures), ${ }^{40}$ and collusion risks (referring to risks that the buyer can collude with the merged party after the completion of divestitures rather than competing with it). ${ }^{41}$ Consequently, in order to effectively fulfil divestitures' expected goal of restoring competition and to achieve the aims of competition law, the CAs have to design divestitures in a way that can reduce the above-mentioned risks to the extent possible.

The ultimate aim of this book is to examine whether China's merger divestiture policies can effectively reduce the above-mentioned divestiture risks and thus serve the aims of the AML. ${ }^{42}$ Based on this purpose, there will be three main research questions.

Part I will analyse merger divestitures in competition law, limiting the scope of the research to the jurisdictions of the US and the EU, and answer the first question: what are the merger divestiture policies in the US and the EU and what are the main similarities and differences?

Part II will explore merger divestitures from a law and economics perspective, focusing on composition risks, asset risks and collusion risks and answer the second question: what are the possible reasons for the occurrence of composition/assets/collusion risks in divestitures and what can be the solutions to reduce those risks?

Part III will focus on China's merger review and merger remedies (mainly divestitures) and address the third question: are China's divestiture policies adequate and effective to reduce possible divestiture risks and serve the aims of the AML?

The methodology and structure of this book that will be discussed in sec. 3 and sec. 4 are thus adopted based on the research questions.

\footnotetext{
${ }^{36}$ Bureau of Competition of the Federal Trade Commission, Statement of The Federal Trade Commission's Bureau of Competition on Negotiating Merger Remedies (2012), 17 (hereinafter: 2012 FTC Remedies Statement).

${ }^{37}$ Monti (n 34).

38 According to the Competition Bureau of the Federal Trade Commission: A Study of the Commission's Divestiture Process (1999) (hereinafter: 1999 FTC Divestiture Study), although three-quarters of the divestitures studied appear to have been successful, the remaining divestitures did not work.

${ }^{39}$ UK Competition Commission, Merger Remedies: Competition Commission Guidelines (November 2008), sec.3.3 (a)

(hereinafter: UK Competition Guidelines). For the detailed analysis, see: Chapter 6.

$40 \mathrm{ibid}$, sec.3.3 (b). See also: Chapter 7 for the detailed analysis regarding the occurrence and solutions.

41 See: Chapter 8 for the detailed explorations regarding collusions risks.

42 The aims of the AML are to protect fair competition in the market, enhance efficiency, maintain consumer welfare and the public interest, and promote a healthy development of the socialist market economy. See: Standing Committee of the National People's Congress, Anti-Monopoly Law of the People's Republic of China (zhong hua ren min gong be guo fan long duan fa 中华人民共和国反垄断法) (Adopted 30 August 2007, entered into force 1 August 2008), art 1 (hereinafter: AML). For the detailed discussion in this regard, see: Chapter 10, sec.2.4.
} 


\section{Methodology}

\subsection{Comparative Legal Analysis}

Mattei indicated that in many situations, legal changes in one jurisdiction are the results of legal transplants. ${ }^{43}$ Legal transplanting and borrowing, to a large extent, provide the most fertile sources for legal development. ${ }^{44} \mathrm{It}$ is pointed out that '[T] he comparative method of legal research is a unique, systematic, jurisprudential method, which [can be applied] to gain new knowledge about the legal systems in respect of which we apply it, by taking cognisance of the similarities and differences of those legal systems'. ${ }^{45}$

Consequently, conducting a comparative legal research allows us to learn about other legal cultures to avoid similar mistakes and to develop and improve one's own legal system.

Accordingly, in Part I of this book, a comparative legal analysis is conducted, focusing on the merger divestiture remedies in competition law in the US and the EU, to explore divestiture policies that are used to reduce the above-mentioned divestiture risks. Good insights are expected to be obtained to refine or improve divestiture policies in China. It is worth keeping in mind that the US and the EU will be regarded as two examples rather than as models that should be followed or copied when policy recommendations are provided to China.

\section{Choice of Legal Systems}

It is pointed out that increased anti-competitive tendencies by market players led to the enactment of competition law across the globe. Today, there are over 80 countries with competition law, of which about 45 specifically provide for merger review. ${ }^{46}$ Among all, the US is one of the jurisdictions which cannot be omitted for its long history and rich experience in merger control enforcement. ${ }^{47}$

The EU regime has evolved very quickly and has rapidly approached the maturity of its predecessors in terms of legal framework and conceptual thinking (of merger review). ${ }^{48}$

\subsection{Law and Economics}

In some areas of law, it can be noticed that legal changes happen due to legal transplanting and borrowing. In these domains of law where efficiency will be taken as a goal, such as competition law, a law and economics analysis plays an important role since in its

\footnotetext{
${ }^{43}$ Ugo Mattei, 'Legal Change: The Comparative Law and Economic Perspective', Comparative Law and Economics (University of Michigan 1997) 124.

44 ibid, 124.

45 TJ Scott, 'The Comparative Method of Legal Research' <http://italeem.iium.edu.my/2014/pluginfile.php/ $155226 /$ mod_resource/content $/ 0 / J \% 20 S$ cott $\% 20-\% 20$ Comparative $\% 20$ research $\% 20$ perspectives $\% 20 \_$Private $\%$ 20law_.pdf $>$ accessed 14 April 2017, 1 .

${ }^{46}$ Bris, Cabolis and Janowski (n 5) 15.

${ }^{47}$ The Sherman Antitrust Act was adopted in 1890, which was the first federal piece of legislation in the US in the field of competition law. See: Maher M. Dabbah, 'Chapter 5: US Competition Law Regime' in Maher M. Dabbah, International and Comparative Competition Law (Cambridge University Press 2010) 233. This means that it has been more than 130 years since the first federal competition law was enacted in the US. For detailed discussion regarding the development of competition law and merger control system in the US, see: Chapter 2.

48 Vidyullatha Kishor, 'Competitive Merger Control Regulations - Lessons from EU and US' (Unpublished internship dissertation, Competition Commission of India, The West Bengal National University of Juridical Sciences 2012) 14.
} 
normative dimension it may work as a prestigious support to non-prestigious legal systems that have already reached an efficient solution without having the internal strengths to export it. In its positive dimension it helps to detect these phenomena at work'. ${ }^{49}$

A law and economics analysis is thus conducted in Part II to explore the reasons for the occurrence of composition risks, asset risks and collusion risks in merger divestitures and to explore solutions to reduce such risks. It is worth specifying that such solutions are theoretical rather than normative, meaning that any policy recommendation provided to China, although mainly based on the law and economics theory, will consider other factors, such as China's national conditions. In addition, divestiture policies in the US and the EU that are analysed in Part II are also examined from the perspective of law and economics to assess their effectiveness in reducing divestiture risks, so that China can learn from their practice and avoid making similar mistakes.

\subsection{Legal Analysis, Case Analyses and Interviews}

Part III examines China's divestiture policies in detail. In order to comprehensively explore what is China's merger review system and how does the responsible competition agency the Ministry of Commerce ("MOFCOM") - use merger divestitures ${ }^{50}$, various sources of information are integrated. First, a legal analysis is conducted in Chapter 10 to describe the legal framework of China's merger review system. Second, case analyses are presented in Chapter 11 to analyse how MOFCOM uses behavioural remedies and divestitures in practice and the solutions it uses to reduce those divestiture risks. Third, face-to-face semistructured interviews are held (results are presented in Chapter 12), taking into account the flexibility of semi-structured interviews and the possibility of observing the respondents during the face-to-face interviews. ${ }^{51}$ Such interviews are expected to provide good empirical insights into China's merger control and merger remedies.

\subsection{A Comparative Law and Economics Analysis}

Chapter 13 adopts a comparative law and economics approach to examine the similarities and differences of divestiture policies that are used by the CAs in China, the US and the $\mathrm{EU}$ to reduce composition/asset/collusion risks. Furthermore, assessments of MOFCOM's divestiture policies are made from the perspective of law and economics to examine whether MOFCOM's divestiture policies can effectively reduce those divestiture risks, so that the aim of the AML can be realised. It is pointed out in Chapter 13, however, that MOFCOM's approach in merger remedies can be different from the US and the EU due to different competition cultures and development paths of competition law.

\footnotetext{
${ }^{49}$ Mattei (n 43) 141.

50 There are three competition agencies in China, which have their authority in different fields of competition law. MOFCOM is in charge of merger review. For the detailed information regarding China's competition agencies, see: Chapter 10, sec.2.2.

51 See: Robert M. Lawless, Jennifer K. Robbennolt and Thomas S. Ulen, Empirical Methods in Law (Aspen Publishers 2010) 80-82.
} 


\section{Structure}

This book consists of three parts, divided into 14 chapters. Part I presents a legal analysis of merger remedies (mainly merger divestitures) in competition law in the US and the EU. Chapter 2 describes the merger control system and the emergence, evolution and development of the divestiture remedy in the US (at federal level). Similarly, Chapter 3 describes the merger control system and the emergence, evolution and development of the divestiture remedy at the EU level. As a concluding chapter of Part I, Chapter 4 summarises the observations obtained from Chapter 2 and Chapter 3, focusing on the CAs' similarities and differences concerning divestiture policies in these two jurisdictions.

Part II presents an analysis of three types of divestiture risks from the perspective of law and economics. Chapter 5 serves as a general introduction to this Part, which explains some basic questions regarding the application of law and economics theory in the field of competition law and merger review. Chapters 6,7 , and 8 respectively explore the reasons which may lead to the occurrence of composition risks, asset risks and collusion risks in divestitures and further provide theoretical solutions to reduce those risks. In addition, the effectiveness of those divestiture polices used in the US and the EU to reduce divestiture risks is also examined.

Part III focuses on China's merger review system and merger remedies. Chapter 10 draws a general picture of China's merger review system in law. Chapter 11 examines the merger remedies that are used in the conditionally-approved transactions to explore how MOFCOM uses merger remedies in practice. The results of interviews are communicated in Chapter 12 to provide some empirical insights of MOFCOM's practice in merger remedies. Chapter 13 takes a comparative law and economics approach to evaluate the effectiveness of MOFCOM's divestiture policies in reducing these divestiture risks, so that the aims of the AML can be realised to the extent possible.

Readers should be aware that, first, the theoretical part is presented following the comparative legal review par in this book. As mentioned, the ultimate goal of this dissertation is to analyse the effectiveness of the divestiture remedies in China. To realise this aim, two approaches are taken, namely, a comparative legal approach which studies merger divestitures in competition law in the US and the EU, and a law and economics approach to analyse the reasons for the occurrence of divestiture risks and the ideal solutions. The choice of law and economics theories used in Part II, however, largely depends on the observations made and analyses conducted in Part I. As a result, it was considered more appropriate and more logical to introduce the divestiture policies in law in the first place and then apply the law and economics theories to analyse these policies.

Second, Part I of this book includes some basic information regarding the merger review systems in the US (Chapter 2) and the EU (Chapter 3). It provides some background knowledge on "what is merger control" and "how do merger divestitures work", so that readers can better understand the law and economics analyses conducted in Part II (law and economic analysis of merger divestitures). Readers already familiar with general rules and procedures of merger review and merger remedies (divestitures) may turn immediately to Part II of this book, where the discussion on divestitures begins. 


\section{I}

\section{ANALYSIS OF MERGER DIVESTITURES IN COMPETITION LAW}

Part I presents a legal analysis of merger divestitures in competition law in the US and the EU. The aim of this part is to explore the question what are the merger divestitures policies in the US and the EU and what are the main similarities and differences in that regard? Accordingly, Part I consists of three chapters and is structured as follows:

- Chapter 2: Merger Control and Merger Divestitures in the US

- Chapter 3: Merger Control and Merger Divestitures in the European Union

- Chapter 4: Merger Divestitures in the US and the EU: Future Convergence?

Chapter 2 and Chapter 3 describe merger control and merger divestiture policies in EU competition law and US anti-trust law, respectively. Chapter 4 summarises the differences and similarities of the divestiture policies in these two jurisdictions. 



\section{Chapter}

\section{MERGER CONTROL AND MERGER DIVESTITURES IN THE UNITED STATES}





\section{Introduction}

In 2014, the FTC, one of the two competition agencies in the United States ("US"), had its 100th anniversary. ${ }^{52}$ The other competition agency under the unique merger control system, which is characterised as a dual-enforcement mechanism, is the Antitrust Division of the Department of Justice ("DOJ"). In the two-stage merger review procedures in the US, mergers, which satisfy the criteria set in the Hart-Scott-Rodino ("HSR") rules, ${ }^{53}$ must be notified to the FTC and the DOJ by both of the merging parties before implementation. ${ }^{54}$ The FTC and the DOJ have concurrent jurisdiction under the Clayton Act to review merger and acquisition ("M\&A") transactions. ${ }^{55}$ Nevertheless, only one of them will take clearance to investigate. It is generally held that 'most mergers are not anticompetitive, and many benefit consumers'. ${ }^{56}$

The development of merger divestitures in the United States can be divided into two periods: pre-HSR Act and post-HSR Act. The Sherman Antitrust Act ("the Sherman Act") and the Clayton Act were the two most important pieces of legislation in the merger control field during the pre-HSR Act period. In 1890, the United States enacted its first anti-trust law, the Sherman Act, as a response to the growth of trusts and their power in the American economy in the late nineteenth century. ${ }^{57}$ Under the Sherman Act, the divestiture remedy was first used in 1910 in Standard Oil Co. of New Jersey v. United States, 221 U.S. 1 (1910). Due to the ambiguities and uncertainties associated with the provisions of the Sherman Act, and to control mergers further, two new federal laws were introduced in 1914: first, the Clayton Act, which was further strengthened in 1950 by the second, the Celler Kefauver Antitrust Act. ${ }^{58}$ The Clayton Act determined the substantive test of merger control, namely, the Substantially Lessen Competition test (SLC-test). ${ }^{59}$

Later, in 1976, the HSR Act was enacted to close numerous loopholes in the United States' merger control system, considering that during the period before its implementation, there were strong incentives for the merging parties to speedily and surreptitiously implement the suspect mergers and then protract the ensuing litigation. ${ }^{60}$ The HSR Act has significantly changed merger control procedures in the US by introducing requirements such as the pre-merger notification and the mandatory waiting period. Such changes enable the agencies to have sufficient time to collect information

52. Federal Trade Commission, 'Our History' (2016) < https://www.ftc.gov/about-ftc/our-history> accessed 16 March 2017.

${ }^{53}$ The "HSR" refers to the Hart-Scott-Rodiono Antitrust Improvements Act, which was enforced in 1976 and has been incorporated into the Clayton Act. Title II of the HSR Act of 1976 established the Federal Premerger Notification Program. The FTC's Premerger Notification Office (PNO) promulgates and administrates the detailed rules and procedures for reporting transactions. These rules and procedures are collectively called "the HSR rules”. See: 15 U.S.C. $\int 18$ a (2013), Premerger Notification and Waiting Period.

54 See: 16 C.F.R. \801.1 (2013) (HSR Coverage Rules); 16 C.F.R. \802.1 (2005) (HSR Exemption Rules); 16 C.F.R. $\int 803.1$ (2006) (HSR Transmittal Rules).

${ }^{55}$ Merger control, which defines the scope of application of divestitures in this article, refers to the procedure of reviewing both mergers and acquisitions under competition law, "merger" and "acquisition" are used as synonymous terms here. See 15 U.S.C. \18a (a), (d) (2013).

${ }^{56}$ U.S. Department of Justice, Antitrust Division: Antitrust Division Policy Guide to Merger Remedies (2011), 1 (hereinafter: 2011 DOJ Policy Guide).

${ }^{57}$ Kishor (n 48) 14.

5815 U.S.C.A. $\int 45$ (West 2006) (The second law introduced in 1914 was the Federal Trade Commission Act. This Act provided that "unfair methods of competition in or affecting commerce, and unfair or deceptive acts or practices in or affecting commerce" are illegal).

${ }^{59}$ Clayton Act \ 7, 15 U.S.C. $\$ 18$ (2013).

${ }^{60}$ William J Baer, 'Reflections on Twenty Years of Merger Enforcement under the Hart-Scott-Rodino Act' (1997) 65 Antitrust L J 825, 828. 
during their investigations and to further determine whether to accept, prohibit or negotiate remedies with the notifying parties for the proposed transactions. Such changes increase the effectiveness of divestitures since before the enactment of the HSR Act, a merger transaction could be challenged several years after implementation and the assets were thus too assimilated with each other to be divested, resulting in large uncertainties and difficulties in successfully executing divestitures. ${ }^{61}$

In recent decades, with increased merger notifications, both the FTC and the DOJ have accumulated more experience concerning the design and enforcement of merger divestitures. They published their study and policy guide, e.g. A Study of the Commission's Divestiture Process by the FTC in 1999, and the Antitrust Division Policy Guide to Merger Remedies (2004 and 2011 versions) by the DOJ, where they summarised and stated, inter alia, their divestiture policies. These publications raised the questions regarding the divestiture policies of the FTC and the DOJ. What are these divestiture policies? Where did these differences and similarities of the CAs' divestiture policies come from? Moreover, what are the future developments of the FTC and the DOJ's divestiture policies? To answer these questions, this chapter is thus structured as follows.

The merger control legislation applicable in the US is explored in sec.2. In sec.3, the current merger review rules are described from the angle of procedural rules and substantive rules. Sec.4 investigates the emergence and evolution of the US merger divestitures. This section is further divided into two sub-sections: a. divestiture before the HSR Act marked with the enactment of the Sherman Act of 1890; and, b. divestiture after the HSR Act which was symbolized with the enforcement of the HSR Act. Next in sec.5, the more recent development of the divestiture remedies by the FTC and the DOJ is explored, which is featured by the 1999 FTC Divestiture Study ${ }^{62}$ and the 2011 DOJ Merger Remedies Policy Guide. In the sixth section, a detailed analysis of the common ground and differences between the FTC's and DOJ's divestiture policy is made. A conclusion is presented in sec.7.

\section{Application of Merger Control Legislation in the US}

\subsection{The US Competition Authorities}

The US competition law regime is unique since it has a dual enforcement mechanism at the federal level involving two different competition authorities: the Antitrust Division of the DOJ and the FTC. ${ }^{63}$ The DOJ and the FTC have concurrent jurisdiction under the Clayton Act to review M\&A transactions. Nevertheless, only one of the two agencies will take clearance to investigate.

\subsubsection{Antitrust Division of the DOJ}

The Antitrust Division is part of the Department of Justice which is an agency of the executive branch of the federal government. It enjoys exclusive competence under the Sherman Act in the field of restraining trade and creating monopolies, and works in close

\footnotetext{
${ }^{61}$ ibid, 828-831.

621999 FTC Divestiture Study (n 38).

${ }^{63}$ Dabbah (n 47) 233.
} 
collaboration with the Federal Trade Commission on merger control under the Clayton Act.

First, the Antitrust Division of the DOJ is the only authority which can bring an antitrust case to the federal courts under the criminal proceedings according to the Sherman Act of 1890 and Section 3 of the Robinson-Patman Act of 1936. ${ }^{64}$ The Criminal Enforcement Group within the Division is assigned the competence of criminal enforcement. ${ }^{65}$ Second, the Antitrust Division can also, pursuant to the Sherman Act of 1890 and the Clayton Act of 1914, start a civil anti-trust litigation in front of the federal courts. ${ }^{66}$ However, in some situations, the Division may be more willing to pursue civil rather than criminal litigation. This may occur, for example, when the relevant law is not clear enough; when the issues of laws or facts in the case are confusing; or when clear evidence established that the persons under an investigation were not aware of, or did not appreciate, the consequences of their actions. ${ }^{67}$ In proceedings on the grounds of civil enforcement, the Division will seek a court order to prohibit future infringements by the persons concerned and may require them to undertake steps to remedy a situation in order to put an effective end to the anticompetitive situation. ${ }^{68}$

The Division can act in the role of both investigator and prosecutor in either criminal or civil proceedings. It can investigate merger transactions and bring them to the courts through criminal or civil litigation. Once the federal courts decide to enjoin a transaction, the Division has to establish the facts and to demonstrate that remedies are necessary in a certain enforcement action. Besides, the Division can also negotiate with the merging parties either before filing any complaint or at any stage of the litigation to conclude a consent decree. ${ }^{69}$ However, such consent decrees have to gain final approval from the federal courts concerned before they become effective. ${ }^{70}$

\subsubsection{FTC}

The FTC was established in 1914 under the Federal Trade Commission Act ("FTC Act") which prohibited unfair methods of competition and unfair or deceptive acts or practices in or affecting trade. ${ }^{71}$ It is an independent regulatory agency that has the authority to

\footnotetext{
${ }^{64}$ Xiaoye Wang, 'Some Issues Surrounding the Anti-Monopoly Enforcement Authority in China', The Evolution of China's Anti-Monopoly Law (Edward Elgar in association with the Social Sciences Adacemic Press 2014) 231. The Robinson-Patman Act was created in 1936, which amended section 2 of the Clayton Act of 1916 in order to prevent unfair price discrimination, see: sections 2(a)- (f) of the Clayton Act, 15 U.S.C. 13(a)-(f) (2013). The Clayton Act of 1914 is discussed in detail in sec.4.1.2 below. For a detailed exploration of the Robinson-Patman Act, see: e.g. Donald S. Clark, 'The Robinson-Patman Act: General Principles, Commission Proceedings, and Selected Issues' (Federal Trade Commission, 1996) < https://www.ftc.gov/es/public-statements/1995/06/robinsonpatman-act-general-principles-commission-proceedings-and-selected $>$ accessed 8 December 2016.

${ }_{65}^{65}$ Dabbah (n 47) 234.

66 ibid.

${ }^{67}$ See: Donald I. Baker, 'To Indict or Not to Indict: Prosecutorial Discretion in Sherman Act Enforcement' (19771978) 63 Cornell L Rev 405.

${ }^{68}$ Dabbah (n 47) 235.

${ }^{69}$ When the CAs believe that a proposed transaction may have anti-competitive effects, it is possible for the parties and the CAs to enter into negotiations to seek a remedy at any time in the review process. Once they come to an agreement after negotiations, it will generally be necessary to set the agreement into a consent decree (if the transaction is dealt with by the DOJ) or a consent order (in case of the FTC). A consent decree needs to obtain approval from the federal courts before it becomes effective. Consent decrees or orders are the results of the negotiations between the parties concerned and the authorities. Such consent decrees or orders can be realised either before or after the FTC or the DOJ issued the complaints. This point is discussed in detailed below.

${ }^{70}$ The procedures concerning getting approval from the federal courts in case of consent decrees will be discussed in detail in sec.3.1.4.2.

${ }^{71}$ Dabbah (n 47) 235.
} 
enforce, among other statutes, the FTC Act and the Clayton Act. It reports to the US Congress directly. The FTC has three bureaus which handle all investigations and litigation, whereas only two - the Bureau of Competition and the Bureau of Economics - are assigned the authority of merger enforcement. ${ }^{72}$

First, similar to the Antitrust Division of the DOJ, the FTC has an investigative and prosecutorial role in the civil proceedings. According to Section 13 of the FTC Act and the Clayton Act, the FTC can investigate and bring the infringements of competition law through civil litigation before the federal courts in its role as a prosecutor when it seeks a preliminary injunction, ${ }^{73}$ asking the courts to impose a fine on the infringer, or asks the courts to imprison the infringer. ${ }^{74}$ Second, in contrast with the DOJ, the FTC can, pursuant to Section 5 of the FTC Act, act as an adjudicator and open administrative proceedings within the FTC in order to issue cease and desist orders to the offenders infringing the FTC Act. ${ }^{75}$ The adjudicative function of the FTC is handled by the Office of Administrative Law Judge ("ALJ"). ${ }^{76}$

Moreover, the FTC enjoys discretion at work. It does not have to launch civil litigation in all cases. It may seek voluntary compliance by entering into a consent order with the infringer when it is convinced that there has been an infringement of the law. A final approval from the courts is not needed to make a consent order become effective. ${ }^{77}$

\subsection{Adjudicative Bodies}

The adjudicative bodies of merger control in the US are the FTC, the federal courts and individual state courts.

First, as stated above, besides launching a civil litigation to the federal district courts under federal anti-trust law as a prosecutor, the FTC can also launch an administrative litigation under its authority of adjudication. Such administrative litigation against a merger transaction will be heard by the ALJ within the FTC.

Second, the US has a duel and parallel justice system: a nation-wide federal courts system under federal laws (at federal level) and a state courts system under state laws (at individual state level). The federal courts have the authority to review and challenge M\&A transactions under the federal anti-trust law, no matter whether the litigation is brought by the FTC, the DOJ, or a private plaintiff. An individual state court also has the authority to review M\&A proposals under both the federal anti-trust law and under its own state antitrust law. ${ }^{78}$

\footnotetext{
$72 \mathrm{~J} \mathrm{William} \mathrm{Rowley} \mathrm{and} \mathrm{Donald} \mathrm{I} \mathrm{Baker,} \mathrm{International} \mathrm{Mergers} \mathrm{:} \mathrm{the} \mathrm{Antitrust} \mathrm{Process,} \mathrm{vol} 2$ (Sweet \& Maxwell 1996) 1645.

${ }^{73}$ Dabbah (n 47) 236.

${ }^{74}$ Wang (n 64) 232.

${ }^{75}$ Diane P Wood, 'A Comparison of Merger Review and Remedy Procedures in the United States and the European Union' in Francois Lévêque and Howard Shelanski (eds), Merger Remedies in American and European Union Competition Law (Edward Elgar 2003) 68. See also: Wang (n 64) 231. Detailed procedures for the FTC's administrative proceeding will be explored in sec.3.1.4.1.

${ }^{76}$ Rowley and Baker (n 72) 1645.

77 ibid.

${ }^{78}$ D. Bruce Hoffman, 'Chapter 57: USA' in Nigel Parr and Catherine Hammon (eds), The International Comparative Legal Guide to: Merger Control 2012 (Global Legal Group 2012) 380. In practice, in merger cases, the federal courts are almost exclusive with respect to the cases brought under the federal antitrust law. The state courts seldom review and challenge merger cases. They are typically courts of general jurisdiction. In this dissertation, all the litigations are discussed at the federal courts level.
} 
Within the federal courts system, there are 94 federal trial courts ("district courts"), 12 intermediate appellate courts ("circuit courts of appeal") and the US Supreme Court. ${ }^{79}$ The individual state courts system has a similar arrangement. Usually, most states have a trial court level, an intermediate appellate court level, and a court of last resort (called the "Supreme Court" in most states). ${ }^{80}$ A case that violates state laws will be reviewed by an individual state court. However, if a case is also caught under the federal laws or Constitutional law, it can also be reviewed by the US Supreme Court.

Accordingly, the judicial enforcement model is adopted by the US in the competition law enforcement. Although the FTC Act assigns the FTC with the adjudication authority to open administrative litigation, generally, the courts are the prime decision-makers in the enforcement. This judicial approach results from various factors, such as the articulation of the competition law goals or the procedural environment. ${ }^{81}$

\subsection{Transactions Caught by Merger Control Legislation}

The landscape of the merger control system in the US has largely changed since the enactment of the HSR Act. ${ }^{82}$ The HSR Act was enacted in 1976 and mainly regulates the procedural aspects of the merger control system in the US. Under the HSR Act, both of the merging parties have to file a notification to both the DOJ and the FTC about their proposed transaction before implementation if the criteria in the HSR Act have been satisfied. Non-compliance of such compulsory requirements may be very likely to result in high civil fines. According to the HSR Act, any transaction that involves acquiring, directly or indirectly, any voting securities or assets of any other person may be required to make the notification if the value of such transactions meets the dollar-denominated reporting thresholds set by the FTC and which are changed annually.

The FTC's Pre-Merger Notification Office ("PNO") promulgates and administers the detailed rules and procedures for reporting transactions, which are collectively called "the HSR rules". ${ }^{83}$ In 2005, one major change was made in the HSR rules regarding the treatment of non-corporate interests, which took effect on 7 April $2005 .{ }^{84}$ This means that acquiring non-corporate interests is now also covered by the HSR rules, which was once not within the merger control area. Accordingly, transactions that involve acquiring voting securities, assets and non-corporate interests will have the possibility of being caught under the HSR rules.

\section{Voting Securities}

Under the HSR rules, the term "voting securities" means 'any securities which at present or upon conversion entitle the owner or holder thereof to vote for the election of directors of the issuer, or of an entity included within the same person as the issuer, or, with respect to

\footnotetext{
${ }^{79}$ Rowley and Baker (n 72) 1657.

80 ibid.

${ }^{81}$ For a detailed exploration in this regard, see: e.g. David J. Gerber, 'Constructing Competition Law in China: The Potential Value of European and U.S. Experience’ (2004) 3(2) Wash. U. Global Stud. L. Rev. 315, Section II: U.S. Antitrust Law Experience: Goals and Methods.

${ }^{82}$ See: sec .4 .2 for the exploration of why the HSR Act changed the landscape of the US merger control system.

${ }^{83}$ Hoffman (n 78) 381. These HSR rules are collected in the Code of Federal Regulation (CFR), namely 16 CFR 801- Coverage Rules, 16 CFR 802- Exemption Rules, and 16 CFR 803- Transmittal Rules. See: the HSR rules (n 53). ${ }^{84}$ See: Malcolm R. Pfunder, 'The New "Non-Corporate Interest" Rules Under the Hart-Scott-Rodino Act-A Detailed Look at How They Will Work' (The Antitrust Source, March 2005) < http://www.gibsondunn.com/ fstore/documents/pubs/Antitrust_Source-NonCorpInterestHSR-Mar05-Pfunder.pdf> accessed 19 April 2017.
} 
unincorporated entities, individuals exercising similar functions'. ${ }^{85}$ But the convertible debentures, options and warrants are excluded in sec.802 (31) from the application of mandatory notification in the HSR Act prior to the conversion, since they do not themselves have present voting rights and hence are convertible voting securities.

\section{Assets}

Concerning the definition of "assets", there is no explicit expression in the merger control legislation. Neither in the HSR Act, nor in the HSR rules. As is observed through all the statements or policy guides released by the FTC or the DOJ, the definition could be quite broad. Any "things" with exchange value can be called assets, no matter whether they are tangible or intangible. Intellectual property is one of the most typical examples of intangible assets. Consequently, the acquisition of intellectual property with a value exceeding the jurisdictional thresholds may also require an HSR filing if it otherwise meets the HSR filing tests and does not qualify for an exemption. ${ }^{86}$

\section{Non-corporate interests}

According to the HSR rules, non-corporate interests are defined as "an interest in any unincorporated entity which gives the holder the right to any profits of the entity or in the event of dissolution of that entity the right to any of its assets after payment of its debts. These unincorporated entities include, but are not limited to, general partnerships, ${ }^{87}$ limited partnerships ("LP"), 88 limited liability partnerships ("LLP"), ${ }^{89}$ and limited liability companies ("LLC"). .90

With the development of the US economy, non-corporate interests mergers happened increasingly. The changes mentioned above aim to include such mergers into the merger control system. This means the notification requirement in the HSR Act will also be

8516 CFR 801 (1), definitions. See: <http://www.ecfr.gov/cgi-bin/text-idx?c=ecfr\&sid=c39545bbddbc763805 $5 \mathrm{e} 2 \mathrm{~d} 701 \mathrm{e} 0608 \mathrm{a} 4 \& \mathrm{rgn}=$ div5\&view $=$ text\&node=16:1.0.1.8.86\&idno=16\#16:1.0.1.8.86.0.40.1 $>$ accessed 19 April 2017.

${ }^{86}$ Hoffman (n 78) 381.

${ }^{87}$ According to $\$ 101(6)$ of the 1997 Revised Uniform Partnership Act (RUPA) in the US, a general partnership is "an association of two or more persons to carry on as co-owners a business for profit," which consists of only general partners. Unless the partnership agreement provides otherwise, each partner has equal rights in the management and conduct of the partnership business ( $\$ 401(\mathrm{f})$ RUPA) and each partner is an agent of the partnership for the purpose of the partnership business (\$301(1) RUPA). The partners bear personal responsibility for the liabilities of the partnership. See: Andreas Cahn and David C. Donald, Comparative Company Law: Text and Cases on the Laws Governing Corporations in Germany, the UK and the USA (Cambridge University Press 2010) 40.

${ }^{88}$ The 2001 Revision of Uniform Limited Partnerships Act (ULPA 2001) in the US defines a limited partnership (LP) as "an entity, having one or more general partners and one or more limited partners ... formed under this Act." A limited partner has no power to represent or bind the LP (\$302 ULPA 2001) and the law expressly declares that an "obligation of a limited partnership, whether arising in contract, tort, or otherwise, is not the obligation of a limited partner.” (\$303 ULPA 2001). See: Cahn and Donald, ibid, 45.

${ }^{89}$ A limited liability partnership (LLP)'s structure is very similar to the general partnership, but with a liabilitylimiting function that applies to all partners (limited partners). The limitation of liability resulting from an LLP status arises from two basic rules. First, any obligation of a partnership incurred while the partnership is an LLP, whether arising in contract or in tort, is solely the obligation of the partnership (\$305(a), 306(c) RUPA). Secondly, a partner remains liable for personal misconduct(\$306(a) RUPA), but retains a right to indemnification from the partnership(\$401(c) RUPA). See: Cahn and Donald, ibid, 44.

${ }^{90}$ Section 201 of the Revised Uniform Limited Liability Company Act (RULLCA) in the US provides that, like a corporation, a limited liability company (LLC) is a "legal entity distinct from its members." Like a corporation, an LLC is established by the LLC's members drafting and approving a "certificate of organization" and by the secretary of state filing (i.e. registering) such articles (\$201 RULLCA). In brief, an LLC is a legal form of business organization with daily activities like a partnership but with limited liability similar to a corporation. See: Cahn and Donald, ibid, 45. 
applied to an acquisition that transfers the control to an existing or newly created unincorporated entity where the sum of the acquisition price of the non-corporate interest and the value of the non-corporate interest already held by the acquiring person meets the jurisdictional thresholds. ${ }^{91}$

\subsection{Jurisdiction}

Sec.7 of the Clayton Act is the main statutory provision in the US under which a merger transaction may be deemed as illegal if it will substantially reduce competition or has the likelihood to create a monopoly in the relevant market. Mergers in most industries will be regulated by the Clayton Act. Other federal agencies, however, also have enacted special standards and rules for mergers in certain industries, which are generally more lenient than the standards of the Clayton Act and the Sherman Act. ${ }^{92}$ These industries include banking, communications, defence, energy, shipping and transportation. Besides, mergers which have the potential to affect national security may be reviewed by the Committee on Foreign Investment in the Unites States ("CFIUS").

The transactions meeting the filing thresholds in the HSR Act and the HSR rules are required to be notified to both the FTC and the DOJ before their implementation. The US has a controversial and broad approach toward the territory jurisdiction in the anti-trust field, namely, "effects doctrine", whereby a state claims jurisdiction over a transaction even when the activities involved are outside the state but may have effects within that state.

In United State v. Aluminium Co. of America ("Alcoa"), the defendants were foreign companies and the merger agreement was concluded outside the US. The Court of Appeal for the Second Circuit made it clear that 'jurisdiction [would be] sufficient if [the] challenged agreement was intended to affect imports and did affect them [within the US]'.93 In 1995, the FTC and the DOJ issued Guidelines that further made it clear that they would challenge conduct that affects United States exports even if Unites States' consumers were not harmed. ${ }^{94}$

For mergers involving foreign companies, the agencies apply the standard of "direct, substantial and reasonably foreseeable" effects on the US commerce. ${ }^{95}$ Thus, if a merger involving foreign companies has the potential of affecting US commerce, the US will have jurisdiction over such transaction.

In practice, there is a "three-step" test to determine whether a certain merger transaction needs to be filed or not.

\footnotetext{
91 According to 16 CFR 801.1(b) (2), the "control" means (1)either (i) Holding 50 percent or more of the outstanding voting securities of an issuer or (ii) In the case of an entity that has no outstanding voting securities, having the right to 50 percent or more of the profits of the entity, or having the right in the event of dissolution to 50 percent or more of the assets of the entity; or (2) Having the contractual power presently to designate 50 percent or more of the directors of a corporation, or in the case of unincorporated entities, of individuals exercising similar functions.

${ }^{92}$ Rowley and Baker (n 72) 1622.

${ }^{93}$ Unites States v. Aluminium Co. of America, 148 F. 2d 416, $443-444$ (2d Cir, 1945). The "effect doctrine" set forth in the Alcoa case has been modified in other cases to include the concerns of international mergers.

94 See: The Federal Trade Commission and the U.S. Department of Justice: Antitrust Enforcement Guideline for International Operations (1995) < http://www.justice.gov/atr/public/guidelines/internat.htm> accessed 19 April 2017, sec.3.122.

95 ibid, sec.3.12.
} 


\section{The commerce test}

This test will focus on determining whether the acquiring person or the person whose voting securities or assets are being acquired is engaged in the US interstate commerce or in an activity affecting US interstate commerce. ${ }^{96}$ This test reflects the essence of the "effects doctrine". Transactions may have the possibility to be notified if they are conducted within the US or have effects on the US commerce, considering that such effects can eliminate competition in the relevant market within US, and ultimately bring impediments to consumer welfare.

\section{The size of transaction test}

As the name suggests, this test is to check the value of the to-be-acquired voting securities, assets or non-corporate interests. If the value of the transaction meets the dollar-dominated thresholds set and adjusted by the FTC annually, then the HSR filing may be required. ${ }^{97}$

The following rules will be applied to test whether the transaction needs the HSR filing (standard of 2017):

- If the transaction is valued at $\$ 80.8$ million (as adjusted) or less, no filing is required.

- If the transaction is valued at more than $\$ 323$ million (as adjusted), and no exemption applies, an HSR filing must be made and parties must wait until the statutory waiting period has expired before closing the deal.

- If the transaction is valued in excess of $\$ 80.8$ million (as adjusted) but is $\$ 323$ million (as adjusted) or less, only those transactions that also meet the size of person test (see below) require a filing. ${ }^{98}$

As the rules imply, the FTC will adjust the figures of the threshold every year. Currently in 2017 , the minimum threshold for the "transaction test" will be adjusted upward to $\$ 80.8$ million (2017). Transactions valued at more than $\$ 323$ million or more (2017) are subject to the HSR Act without reference to size-of-person test (the third test explored below). As observed, the figure for the threshold is in an upward trend. ${ }^{99}$

\section{The size of person test}

Whether the "size of person test" will be applied depends on the result of the "size of transaction test". First, if the value of a transaction exceeds $\$ 323$ million or more, which means the transaction is really a "big deal", both parties must notify to the agencies of such transaction directly and the size-of-person test will not be applied any more. Second, if the

\footnotetext{
${ }^{96}$ The FTC has laid out these three tests explicitly for determining whether a HSR filing is required. See: Federal Trade Commission, 'Steps for Determining Whether a HSR Filing Is Required' < http://www.ftc.gov/enforcement/ premerger-notification-program/hsr-resources/steps-determining-whether-hsr-filing>, accessed 19 April 2017. See also: Federal Register <https://www.ftc.gov/system/files/documents/federal_register_notices/2017/01/clayton_ 7a_publishe_1-26-17.pdf $>$ accessed 18 June 2017.

${ }^{97} \mathrm{ibid}$.

98 ibid.

${ }^{99}$ The minimum "Size-of-Transaction" test threshold in 2012 was $\$ 68.2$ million. In 2013 , the figure was $\$ 70.9$ million. Currently for 2014, the threshold has been increased to $\$ 75.9$ million. See: Federal Trade Commission, 'Federal Trade Commission Announces 2014 Threshold Revisions for HSR Act and for Clayton Act Section 8 Prohibition on Interlocking Directorates', (Proskauer, 21 January 2014) <http://www.proskauer.com/publications/ client-alert/federal-trade-commission-announces-2014-threshold-revisions/ > accessed 14 March 2017. See also: Federal Trade Commission, 'FTC Increases HSR Act Thresholds: "Size of Transaction" Test Raised to $\$ 70.9$ (2013)', (WTP, 14 January 2013) <http://www.wtplaw.com/documents/2013/01/ftc-increases-hsr-act-thresholdssize-of-transaction-test-raised-to-709-million > accessed 14 March 2017.
} 
value of a transaction is $\$ 80.8$ million or less, no notification is required since the agencies hold that such transaction is too small to cause any severe competition problem in the market. Accordingly, only when the value of a transaction is between $\$ 80.8$ million to $\$ 323$ million, will the size-of-person test be employed to further determine whether a transaction should be notified or not.

Only if these three tests (if applied) are all satisfied, is a notification required. As observed, the amount formulated in the "size of person test" is also following an increase. For example, for the year 2013, the size-of-person test required that either person in the transaction has annual net sales or total assets of at least $\$ 131.9$ million, and that the other person has annual net sales or total assets of at least $\$ 13.2$ million. For 2014, the two figures were raised to $\$ 151.7$ million and $\$ 15.2$ million, respectively. ${ }^{100}$

Table 1 Result of the Size-of-Transaction and Filing Requirement (2017)

\begin{tabular}{ll}
\hline Size of transaction & HSR Filing Requirement \\
\hline$\$ 80.8$ million or less & No \\
\hline$\$ 323$ million or more & Yes \\
\hline in excess of $\$ 80.8$ million but is $\$ 323$ million or less & $\begin{array}{l}\text { Yes, but only if one person's net sales or total assets } \\
\text { exceed } \$ 161.5 \text { million and the other person's net sales } \\
\text { or total assets exceed } \$ 16.2 \text { million }\end{array}$ \\
\hline
\end{tabular}

\section{Exemptions}

Even if one transaction meets the size of the transaction test and, when necessary, the size of the person test, an exemption may apply, which exempts the parties from the HSR filing requirement. According to the HSR Act and the HSR rules, the following transactions will be exempted:

1) Stock splits that do not increase the percentages owned by any person are exempt;

2) Acquisitions of small percentages of an issuer's voting securities solely for the purpose of investment are exempt;

3) Acquisitions of additional voting securities by persons who already hold 50 percent of the voting shares of an issuer are not reportable;

4) Acquisitions in the ordinary course of business, such as purchases of current supplies and used durable goods also are exempt;

5) Acquisitions of several categories of real property, such as unproductive real property, office and residential property, and hotels are not reportable.

6) Acquisitions in regulated industries, whose competitive effects are reviewed by other agencies, may be exempt or subject to modified reporting requirements.

7) Certain acquisitions of carbon mineral reserves.

8) Certain acquisitions by and from entities controlled by foreign governments.

9) Certain acquisitions between foreign sellers, assuming their collective U.S. assets and sales do not meet the jurisdictional thresholds.

10) Certain acquisitions of foreign assets, where the assets do not generate sales in the US in excess of the jurisdictional thresholds.

11) Certain acquisitions of foreign voting securities where the issuer does not hold US assets valued in excess of the jurisdictional thresholds and did not generate sales in excess of the jurisdictional threshold in the prior fiscal year.

\footnotetext{
100 See: Federal Trade Commission (2014) (n 99).
} 
12) Certain acquisitions in regulated industries, where another agency will review the competitive effects. Such acquisitions may be exempt or subject to modified filing requirements. ${ }^{101}$

\section{Procedures and Substantive Test of Merger Review}

\subsection{Merger Review Procedures}

If a transaction meets the thresholds and conditions set in the HSR rules, a HSR filing is required. Such formal notification of a proposed merger must be made to both the DOJ and the FTC. ${ }^{102}$ The DOJ and the FTC will further decide which agency takes responsibility to investigate the proposed transaction. Although there is no deadline for submitting such a notification after the contract or letter of intent of a merger is executed, the party may do the notification as soon as possible since the proposed merger transaction is not allowed to be implemented before getting approval from the agency. Besides the formal notification which is mandatory according to the HSR Act after the proposed transaction has been evaluated under the three-step test, an informal notification may also be made by the merging parties to the agencies (although it does not happen very often). In fact, besides the merging parties themselves, competitors of merging parties, customers and takeover targets also very often complain to the agencies. ${ }^{103}$ Besides, staff attorneys may become aware of the transactions by reviewing public securities law filings filed by companies within industries for which they have responsibility. ${ }^{104}$ In addition, mass media is also a source where some information about a non-notified transaction may be disclosed, providing the agencies with an important channel to control a merger.

After a notification is filed to the agencies, a two-stage procedure will follow, namely, an initial waiting period and a second request (if necessary). During the initial waiting period and the second waiting period, only one of the two agencies will investigate the transaction to determine whether such transaction may have an anti-competitive effect. To co-ordinate the investigation, the DOJ and the FTC have an internal clearance process, through which they may decide which agency will take clearance to investigate the proposed transaction.

At the end of the investigation, litigation may be launched by the agencies if they plan to block a transaction. Negotiation is also possible to settle the issues in a consent order (in case of the FTC) or a consent decree (in case of the DOJ).

\subsubsection{Initial Waiting Period}

Beginning on the date of the receipt of the notification by the FTC and the Assistant Attorney General in charge of the Antitrust Division of the DOJ, there will be a 30-day initial waiting period. One of the agencies, after an internal clearance process, will

\footnotetext{
${ }^{101}$ For Item 1-6, see: FTC, Hart-Scott-Rodino Premerger notification Program: Introductory Guide II- to file or not to file '(Federal Trade Commision, 2008), <http://www.ftc.gov/sites/default/files/attachments/premergerintroductory-guides/guide2.pdf> accessed 14 March 2017, Part VI, 15. For item 7-12, see: Hoffman (n 78) 382.

${ }^{102} \mathrm{It}$ is noteworthy that the introduction and exploration of the US merger review procedures in sec.3.1. are all based on 15 U.S.C. $\int 18 \mathrm{a}$ (2013), Pre-merger Notifications and Waiting Period. For more detailed information, see: 15 U.S.C. $\$ 18 \mathrm{a}(2013)$.

${ }^{103}$ Rowley and Baker (n 72) 1664.

104 ibid.
} 
investigate the proposed transactions to determine whether such transactions will have anti-competitive effects of substantially reducing competition in the market or have the potential to create a monopoly. The parties are not allowed to implement the proposed merger within the thirty-day period unless this period expires and they receive nothing from the agency.

There will be three potential results following the initial waiting period. First, if the agency takes no action against the proposed transaction, this means the parties can proceed with their merger after the expiration of the initial waiting period which ends on the $30^{\text {th }}$ day after the date of the receipt. It is worth noting that, under this situation, no formal decision or statement from either the FTC or the DOJ will be issued. In other words, the merging parties do not receive any formal explanation from the agency telling them why their transaction did not inspire a challenge. ${ }^{105}$ Second, the waiting period may be terminated earlier than thirty days if both agencies allow the parties to proceed with the transaction without any further inquiry. A notice of early termination must be published in the Federal Register ${ }^{106}$. Third, if the agency holds that the proposed transaction, if implemented, may have severe anti-competitive effects, it may decide to extend the waiting period for further investigation and require the parties to submit more information, which also means the beginning of the second waiting period.

\subsubsection{Second Waiting Period}

The FTC or the Assistant Attorney General of the Antitrust Division of the DOJ may, prior to the expiration of the 30-day waiting period (or 15-day waiting period in the case of a cash tender offer), require the submission of additional information or documentary material relevant to the proposed acquisition. ${ }^{107}$ The parties have nearly unlimited time to comply, but again, the proposed transaction will still be refrained from being implemented.

Unsolved merger issues left over from the initial waiting period will be further investigated during this phase. The FTC or the Assistant Attorney General of Antitrust Division of the DOJ may decide to extend the initial waiting period into the "second waiting period"- another 30 days (or 10 days in the case of a cash tender offer) from the date on which the parties to whom the request for submitting more information was made (or the acquiring person in the case of tender offers) have complied with the second request.

During the waiting period, if the agency thinks that the proposed transaction will have severe anti-competitive effects, it may file a motion to the appropriate federal courts, seeking a preliminary injunction to block the transaction.

\subsubsection{Investigations}

After the internal clearance process, during the initial waiting period, the agency staff will review the initial Pre-Merger Notification and Report Form, together with other methods, to decide whether a second request is necessary. For example, the agency may contact the parties and require them to voluntarily provide preliminary information and documents tailored to the specifics of the proposed transaction; early substantive consultations are also

\footnotetext{
105 Wood (n 75) 69.

106 The Federal Register is the daily newspaper of the federal government. It is a legal newspaper which is published on every business day by the National Archives and Records Administration (NARA). See: About the Federal Register (US National Archives, updated on 15 September 2016) <http://www.archives.gov/federalregister/the-federal-register/about.html > accessed 19 March 2017.

107 The HSR Act, (e) Additional information; waiting period extensions, 15 U.S. C, \18a (2013).
} 
strongly encouraged between the agency and the merging parties; agency staff may interview personnel of the merging parties to develop issues or narrow the second requests. They will further continue to actively interview customers, competitors and complainants, and to seek limited submissions from them in order to evaluate the outstanding issues. ${ }^{108}$

If it is determined that issuance of Second Requests is necessary, the agency staff will use the knowledge gained within the initial waiting period to tailor the Second Requests as narrowly as possible. ${ }^{109}$ Parties may also be required to provide the deposition testimony of client personnel, industry experts, and economists.

\subsubsection{Final Decision and Appeal}

After a comprehensive investigation, the DOJ or the FTC will make its final decision to decide whether to block or to allow the merger to proceed, perhaps with merger remedies, such as divestitures. However, before litigation is formally launched or negotiations begin, the agencies may accept a "fix-it-first" remedy ${ }^{110}$ which is proposed by the merging parties voluntarily before a merger is implemented.

\subsubsection{Litigation}

If the DOJ decides to block a transaction, it will file a motion to the federal district courts to seek a preliminary injunction, as well as a permanent injunction. The courts will determine whether to enjoin or not.

When the FTC decides to block a transaction, it will also seek a preliminary injunction by launching civil litigation through the federal courts. Unlike the DOJ, it will meanwhile file an administrative complaint in front of an ALJ under its competence of adjudication within the FTC. The merits of the case will thus be addressed in the administrative rather than in civil litigation. If the parties to the transaction lose before the federal courts, they may lose their power to call an end to the civil litigation. Abandoning the deal sometimes may not be enough for the merging parties to escape from all litigation since they may still face administrative litigation besides the civil procedure, unless they are willing to sign a consent agreement. ${ }^{111}$

If the agency staff or the merging parties are dissatisfied with the decision made by the federal district court, they can appeal such decision to the "circuit courts of appeal" and ultimately to the US Supreme Court. Regarding the administrative litigation, the opinion issued by the ALJ can also be appealed by the staff or by the merging parties to the full Federal Trade Commission. The full Commission will review the appealed opinion and issue its decision. If the decision made by the full Commission was again appealed, the federal intermediate appellate courts would review it. The US Supreme Court may review the decision made by the appeal courts if it was appealed.

\subsubsection{Negotiation - Consent Decrees/ Orders}

At any stage of the procedure, the parties can seek to open negotiations with the agencies if the agencies believe that the propose transaction may have anti-competitive effects. Divestitures are frequently used and are preferred by the agencies as a tool to clear the competition concerns raised in horizontal merger transactions. If an agreement concerning

\footnotetext{
${ }^{108}$ Department of Justice, 'Merger Review Process Initiative' (Department of Justice, updated on 25 June, 2015), <https://www.justice.gov/atr/merger-review-process-initiative-policy> accessed 2 June 2017.

109 ibid.

1101999 FTC Divestiture Study (n 38) 22. For details, see: sec.6.2.2.2 below.

${ }^{111}$ Rowley and Baker (n 72).
} 
the merger remedies is reached between the parties and the agencies, a consent order (in case of the FTC) or a consent decree (in case of the DOJ) will be issued. However, the DOJ and the FTC have different consent agreement procedures.

DOJ

Once a consent agreement is agreed upon between the notifying parties and the DOJ, all the proposed consent decrees must be approved by the federal district courts before they become effective. Under the Tunney Act, a consent decree cannot be finalized until the Antitrust Division has published it, along with a Competitive Impact Statement, in the Federal Register and accepts public comments for at least 60 days. ${ }^{112}$ Any written comments relating to such proposals and any responses by the United States to them should also be filed with the district court and published by the United States in the Federal Register within such 60 -day period. ${ }^{113}$ Then the district court will finally determine whether to approve the proposed consent order. "[W] hether it is in the public interest" is the standard for the approval. ${ }^{114}$

FTC

Regarding the FTC, since the civil litigation in a federal court and the administrative litigation within the full Commission may proceed at the same time, there will thus be two types of consent order procedures: before a complaint is filed ${ }^{115}$ and after a compliant is issued. ${ }^{116}$ First, if the agreement is reached before the FTC files a complaint to the federal district court, such an agreement should be endorsed by the Director of the Bureau of Competition and the Bureau of Economics. Then the Commission may either approve it or reject it. If accepted, a public comment thereby will begin. Second, if an agreement is reached after a complaint has been made and the administrative litigation has already started, the FTC complaint staff and the parties may together submit to the ALJ a proposed consent order, which must be approved by the Director of the Bureau of Competition. The administrative procedure will be halted upon such approval, followed by a public comment period.

No matter whether this consent agreement is reached before complaint or after complaint, the procedures are the same. ${ }^{117}$ The proposed consent order has to be published in the Federal Register for the first 30 days for receipt of comments if the Commission first approves it. All public comments will be received by the FTC and become part of the public record. After the expiration of the period, the Commission will again review all comments and evaluate the proposed consent orders to decide whether to accept or to reject.

\subsection{Substantive Test of Merger Review}

To decide whether to prohibit, accept or clear a proposed merger with remedies, substantive tests are required besides these procedural rules, which only touch the surface

\footnotetext{
112 Antitrust Procedure and Penalties Act (Tunney Act), 15 U.S.C. \$16(b) (2013).

113 ibid, $\int 16(\mathrm{~b})$.

114 ibid, $\int 16(\mathrm{e})(1)(\mathrm{A})$.

11516 CFR 2.31

11616 CFR 3.25(b).

11716 CFR 3.25.
} 
of a transaction. In the US, the substantial test for reviewing merger, the so called "SLC" test, is set out in the Sec.7 of the Clayton Act:

No person engaged in commerce or in any activity affecting commerce shall acquire, directly or indirectly, the whole or any part of the stock or other share capital and no person subject to the jurisdiction of the Federal Trade Commission shall acquire the whole or any part of the assets of another person engaged also in commerce or in any activity affecting commerce, where in any line of commerce or in any activity affecting commerce in any section of the country, the effect of such acquisition may be Substantially to Lessen Competition, or to tend to create a monopoly. ${ }^{118}$

With the passage of the Clayton Act, there have been a number of questions concerning the SLC test, such as, the standard of determining whether the lessening of competition is "substantial" and the definition of a "line of commerce" and an "activity affecting commerce." To answer these questions and provide a more substantive and practical assessment standard, in 2010, the DOJ and the FTC jointly released new Horizontal Merger Guidelines and Non-Horizontal Merger Guides, which update and replace the 1992 Merger Guidelines. ${ }^{119}$

\subsubsection{Market Definition}

The market definition helps to specify the line of commerce and section of the country where the competitive concern arises. In any merger enforcement action, the agencies will normally identify one or more relevant markets in which the merger may substantially reduce competition. Second, the market definition enables the agencies to identify market participants and measure market shares and market concentration. ${ }^{120}$ The market can be divided into two parts: the relevant product market and the relevant geographic market.

The Supreme Court has set a standard for the definition of a product market based on 'the reasonable inter-changeability of use or the cross-elasticity of demand between the product itself and substitutes for it'. ${ }^{121}$ In the 2010 Horizontal Merger Guideline, the hypothetical monopolist test is employed to evaluate whether groups of products in candidate markets are sufficiently broad to constitute relevant anti-trust markets; the agencies also apply the "small but significant and non-transitory increase in price" test ("SSNIP"), which was first introduced in the 1982 Merger Guideline released by the DOJ, ${ }^{122}$ to identify the smallest relevant market within which the hypothetical monopolist can still make profits by increasing price. ${ }^{123}$

With respect to the definition of a geographic market, the Supreme Court has stated that 'the area of effective competition in the known line of commerce must be charted by careful selection of the market area in which the seller operates, and to which the purchaser can practicably turn for supplies'. ${ }^{124}$ The 2010 Merger Guidelines suggest that the agencies may define geographic markets based on the locations of customers.

\footnotetext{
${ }^{118}$ Sec. 7 of the Clayton Act, 15 U.S.C. $\$ 18$ (2013).

1192010 US Horizontal Merger Guidelines (n 11).

120 ibid, part 4, 7.

${ }^{121}$ Brown Shoe Co. v. United States, 370 U.S. 294, 325 (1962).

${ }^{122}$ In the U.S. Department of Justice, Merger Guidelines (1982), which was released by the Department of Justice, the SSNIP test was for the first time introduced to define markets and to measure market power directly.

1232010 US Horizontal Merger Guidelines (n 11) part 4.1.1, 8.

${ }^{124}$ Tampa Elec. Co. v. Nashville Coal Co., 365 U.S. 320, 327 (1961).
} 


\subsubsection{Market Concentration}

The agencies normally calculate market shares for all firms that currently produce products in the relevant market with available data. Market shares are assigned to each person in the market, based on its actual or projected revenues in the relevant market.

Since the mid-1980s, the Herfindahl-Hirschman Index ("HHI") has been employed by the agencies in the merger review process as an indicator to measure market concentration. The HHI is defined as the sum of the squared market shares of all firms in the market. ${ }^{125}$ For example, company A, B, and $\mathrm{C}$ hold market shares of 50, 30 and 20 respectively. Then the HHI $=\left(50^{2}+30^{2}+20^{2}\right)=3,800$. The HHI always lies between zero (numerous firms in the market, each with almost zero market share) and 10,000 (monopoly). ${ }^{126}$ The increase in the HHI resulting from a merger can be calculated by doubling the product of the market shares of the merging parties. Based on agencies' experience, the agencies generally classify markets into three types:

- Unconcentrated Markets: HHI below 1500

- Moderately Concentrated Markets: HHI between 1500 and 2500

- Highly Concentrated Markets: HHI above 2500127

The Agencies employ the following general standards for the relevant markets they have defined:

- Small Change in Concentration: Mergers involving an increase in the HHI of less than 100 points are unlikely to have adverse competitive effects and ordinarily require no further analysis.

- Unconcentrated Markets: Mergers resulting in unconcentrated markets are unlikely to have adverse competitive effects and ordinarily require no further analysis.

- Moderately Concentrated Markets: Mergers resulting in moderately concentrated markets that involve an increase in the HHI of more than 100 points potentially raise significant competitive concerns and often warrant scrutiny.

- Highly Concentrated Markets: Mergers resulting in highly concentrated markets that involve an increase in the HHI of between 100 points and 200 points potentially raise significant competitive concerns and often warrant scrutiny. Mergers resulting in highly concentrated markets that involve an increase in the HHI of more than 200 points will be presumed to be likely to enhance market power. The presumption may be rebutted by persuasive evidence showing that the merger is unlikely to enhance market power. ${ }^{128}$

Besides, the agencies analyse market concentration through a multi-step process in which they: 1) determine the relevant markets that are affected by the transaction; 2) analyse whether entry into the identified market is feasible or difficult; 3) assess whether the merger is likely to cause anti-competitive effects in the form of increased prices or reduced output; 4) consider the various anti-trust "defences" that a party may raise. ${ }^{129}$

\footnotetext{
${ }^{125}$ Bishop and Walker (n 10) 3-016, 68.

126 ibid, 3-017, 68 .

${ }^{127} 2010$ US Horizontal Merger Guidelines (n 11) part 5.3, 19.

128 ibid.

${ }^{129}$ Hoffman (n 78) 386.
} 


\subsubsection{Competitive Effects}

During the late 1980s, the government relied heavily on the HHI calculations, which were suggested in the 1984 Merger Guidelines. ${ }^{130}$ Such an approach was changed in the 1992 Merger Guidelines, concerning the requirement that the reviewing agency posit a credible theory of anti-competitive injury. ${ }^{131}$ There are two types of competitive effects: unilateral effects and co-ordinated effects. ${ }^{132}$ Unilateral competition effects look at whether the merged party can increase market power without resorting to coordinated behaviour, such as raising the price, reducing product outputs. Coordinated competitive effects mean whether the merger will in some way make it more likely that post-merger, the remaining competitors in the market will be able to coordinate their otherwise competitive market activity by increasing prices or reducing output.

In the 2010 Guidelines, the DOJ and the FTC list some evidence which they think are informative in predicting the likely competitive effects of mergers:

- Actual Effects Observed in Implemented Mergers

- Direct Comparisons Based on Experience

- Market Shares and Concentration in a Relevant Market

- Substantial Head-to-Head Competition

- Disruptive Role of a Merging Party 133

\subsubsection{Ease of Entry}

Besides analysing the competition effects, the agencies will also have a look at the ease of entry. If it is easy for other competitors to enter into a relevant market after a merger, this means such a merger, to some extent, does not have severe anti-competitive effects. In order to examine whether the entry into the market will be available in a "timely, likely and sufficient" manner after mergers, the agencies will take into account various elements when reviewing the proposed transactions, for example: planning, design, and management; permitting, licensing, or other approvals; construction, debugging, and operation of production facilities; and promotion (including necessary introductory discounts), marketing, distribution, and satisfaction of customer testing and qualification requirements. ${ }^{134}$ As stated in the 2010 Guidelines (Part 9):

[A] merger is not likely to enhance market power if entry into the market is so easy that the merged firm and its remaining rivals in the market, either unilaterally or collectively, could not profitably raise prices or otherwise reduce competition compared to the level that would prevail in the absence of the merger. Entry is that easy if entry would be timely, likely, and sufficient in its magnitude, character, and scope to deter or counteract the competitive effects of concern.

\subsubsection{Efficiencies}

As noted in the 2010 Guidelines, part 10, 'competition usually spurs firms to achieve efficiencies internally. Nevertheless, a primary benefit of mergers to the economy is their potential to generate significant efficiencies and thus enhance the merged firm's ability and incentive to compete, which may result in lower prices, improved quality, enhanced service,

\footnotetext{
1302010 US Horizontal Merger Guidelines (n 11) part 3.1.1 (c).

131 Rowley and Baker (n 72) 1637.

132 See generally sec.2.3 in Chapter 1 of this book. A detailed analysis of the competition concerns of mergers is conducted in Chapter 5.

1332010 US Horizontal Merger Guidelines (n 11) part 2 (1), 3.

134 ibid, part 9, 28.
} 
or new products'. Under the merger control system, a balance should be struck between the expected efficiencies and benefits generated by a merger on the one hand and potential anti-competitive effects created by a merger on the other hand. Taking efficiencies into consideration is an attempt to reach the balance of these two.

The 2010 Merger Guideline made it clear that 'the agencies credit only those efficiencies likely to be accomplished with the proposed merger and unlikely to be accomplished in the absence of either the proposed merger or another means having comparable anti-competitive effects'. A failing firm defence ("FFD") may also be accepted according to the 2010 Merger Guideline, which notes that if the likely alternative to the contemplated merger is the failure of one of the merging firms, the merger will not harm competition and will not violate Sec.7 of the Clayton Act. ${ }^{135}$ In the US, the FFD was established on a case law basis. In 1930, the Supreme Court first determined the use of FFD in International Shoe Co. v. Federal Trade Commission ${ }^{136}$. In the recent 20 years, the FFD has gradually been recognised as a useful defence to clear the anti-competitive effects created by a merger; it still, however, fails to be accepted by either the agencies or the courts in most of merger cases. ${ }^{137}$

The DOJ and the FTC, as two competition authorities, are assigned the competence to investigate and seek to block the transactions through litigation. Besides, they can also negotiate with the merging parties during any stage of the merger review procedure to work out a remedy to restore competition in the relevant market to the pre-merger level if they believe such a transaction will create anti-competitive effects after implementation. Consequently, a merger review may lead to three different results. The agencies will allow a transaction to proceed if there are no competition concerns. A merger is likely to be blocked if such a transaction will bring severe anti-competitive effects. Merger remedies can be used as additional conditions so that the merging parties can proceed with the proposed transaction.

As one of the most widely used merger remedies, divestiture is frequently used by the agencies in the US as an effective tool to facilitate the realisation of the goals of merger control. Compared with other jurisdictions, such as the EU, the US has a longer history of ordering divestiture under merger control. The use of divestiture can be traced back to 1910, in which year divestiture was first ordered under the Sherman Act (see sec.4 below). The following parts present the emergence, evolution and development of divestitures in the US.

\section{The Emergence and Evolution of United States Merger Divestitures}

In 1910, the United States Supreme Court first used divestiture as a remedy in Standard Oil Co. of New Jersey v. United States, ${ }^{138}$ to correct the harm that it believed injunctive relief would not achieve. In Standard Oil, the Court indicated that a proper remedy is one that would

\footnotetext{
1352010 US Horizontal Merger Guidelines (n 11) part 11, 37.

${ }^{136}$ International Shoe Co v Federal Trade Commission, 280 U.S. 291 (1930).

${ }^{137}$ Helder Vasconcelos, 'Can the Failing Firm Defence Rule be Counterproductive?' (Oxford Economic Papers, 07 September 2012) <http://oep.oxfordjournals.org/content/65/2/567> accessed 18 March 2017.

138 Standard Oil Co. of N.J. v. United States, 221 U.S. 1, 4 (1911).
} 
effectively dissolve the combination found to exist in violation of the Sherman Act. 139 Later in 1961, Justice Brennan spoke for the Court in the case of United States v. E.I. du Pont de Nemours \& Co., with respect to infringement of the provisions in the Clayton Act:

It cannot be gainsaid that complete divestiture is peculiarly appropriate in cases of stock acquisitions which violate $\int 7$. . The very words of $\int 7$ suggest that an undoing of the acquisition is a natural remedy. Divestiture or dissolution has traditionally been the remedy for Sherman Act violations whose heart is intercorporate combination and control, and it is reasonable to think immediately of the same remedy when $\int 7$ of the Clayton Act, which particularizes the Sherman Act standard of illegality, is involved... Divestiture has been called the most important of antitrust remedies. It is simple, relatively easy to administer, and sure. It should always be in the forefront of a court's mind when a violation of $\int 7$ has been found. ${ }^{140}$

The E.I. DuPont case unquestionably established divestiture as the preferred merger remedy in Sec.7 of the Clayton Act, which deals with acquisitions of stocks and assets cases.

Since its emergence and evolution, divestiture has gradually become a preferred merger remedy in most merger cases for the two agencies, ${ }^{141}$ although the courts may still feel uncomfortable in ordering it. In fact, the choice of divestiture as a preferred remedy is also a reflection of the influence exerted by two main schools of thought, namely, the Harvard School and the Chicago School. The thought of the Harvard School regarding competition law and the enforcement is based on a "structuralist" approach. ${ }^{142}$ Under this approach, attention is focused on the structure of the market and industry. The core idea of the Harvard School is the Structure-Conduct-Performance ("SCP") model. ${ }^{143}$ As a result, this school of thought places more emphasis on structural remedies rather than on conductoriented remedies. ${ }^{144}$ During the period from approximately the mid-twentieth century up to the 1970s, the impact of this school of thought on United States competition laws reached unparalleled prominence. ${ }^{145}$

One of the major factors leading to the great discontent with the Harvard School of thought was 'the perceived disparity in the application of competition law arising out of the Harvard School approach'. ${ }^{146}$ Highly undesirable deterrence effects on firms participating in fierce competition were thought to be caused by this approach. The discontent with such factors, among others, set the ground for the Chicago School of thought to take root. The Chicago School contended that actual markets can be relied on to deliver important benefits to consumers, so that intervention should occur only in exceptional cases, such as

\footnotetext{
139 See: Jeffrey G. Huron, 'Section 16 of the Clayton Act: Divestiture An Intended Type of Injunctive Relief' (1987) 19 PAC L J 143, 149-150.

140 United States v. E.I. DuPont de Nemours \& Co., 366 U.S. 316 (1961), 328-331.

141 See also: California v. Am. Store Co., 495 U.S. 271, 285 (1990) (divestiture is the "remedy best suited to redress the ills of an anti-competitive merger."); Ford Motor Co. v. United States, 405 U.S. 562, 573 (1972) ("Complete divestiture is particularly appropriate where asset or stock acquisitions violate anti-trust laws").

142 Dabbah (n 47) 251.

143 See: Seanicaa Edwards, Albert J. Allen and Saleem Shaik, 'Market Structure Conduct Performance (SCP) Hypothesis Revisited using Stochastic Frontier Efficiency Analysis' <http://ageconsearch.tind.io/record/ 21350/files/sp06ed01.pdf?version=1> accessed 30 March 2017.

144 -, 'The Structure Conduct Performance Framework In Industrial Organizations Economics Essay' (UK Essays, 2015)

$<$ https://www.ukessays.com/essays/economics/the-structure-conduct-performance-framework-in-industrial-

organizations-economics-essay.php> accessed 1 April 2017.

${ }^{145}$ Dabbah (n 47) 251.

146 ibid, 253.
} 
when market failure occurs. In 1977, the Supreme Court decided the Sylvania case ${ }^{147}$ with an opinion that borrowed from a mode of economic analysis articulated by the Chicago School. ${ }^{148}$

On the other hand, the HSR Act can be deemed a milestone during the evolution of merger divestitures, under which the pre-merger notification program and the mandatory waiting period were introduced. Prior to the enactment of the HSR Act, the government was typically faced with the problem of seeking to remedy a merger several years after its completion. '[T] hat was a daunting, almost always hopeless, task because the assets had been intermingled and the acquired firm typically dissolved'. ${ }^{149}$ 'Thus, these divestitures were nothing more than "Pyrrhic Victories". 150

\subsection{Divestitures before the HSR Act}

\subsubsection{Divestitures under the Sherman Antitrust Act}

In the latter-half of the nineteenth century, post-Civil War industrialization in the United States was marked by a shift from sole proprietorship and partnership forms of business to corporation being the major form of business enterprise. A free and capitalist economy, coupled with the lack of government interference, conferred upon these newlyincorporated companies increased wealth and power, which resulted in the concentration of wealth, resources, and power into their hands. ${ }^{151}$ Moreover, the railroad pools, trusts, and holding companies that arose during the late 1800 s exemplify this point. ${ }^{152}$ Concentrated wealth and power enabled a few giants of economy to play their business strategies arbitrarily, whereas this undesirable conduct adversely affected society as a whole, resulting in a great clamour for government interference. ${ }^{153}$

The Sherman Antitrust Act was adopted as a government response to combat the misuse of trusts and combinations, so that a competitive market could be preserved. ${ }^{154}$ The Sherman Act of 1890 was the first federal piece of legislation adopted in the field of competition law. '[T] he Act contains two important pillars, on the basis of which American competition law enforcement was first initiated and has developed over the years, namely section 1 and section 2'. ${ }^{155}$

Section 1 focuses on anti-competitive behaviour in restraint of trade. ${ }^{156}$ It prohibits using contracts, combinations or conspiracy that have the actual effect of restraining the trade or commerce. ${ }^{157}$

147 Cont'l T.V. Inc. v. GTE Sylvania, Inc., 433 U.S. 36, 48-49 (1977).

148 Thomas B. Leary, 'The Essential Stability of Merger Policy in the United States' in Francois Lévêque and Howard Shelanski (eds), Merger Remedies in American and European Union Competition Law (Edward Elgar 2003$) 16$.

${ }^{149}$ Richard G Parker and David A Balto, 'The Evolving Approach to Merger Remedies' (Federal Trade Commission, May 2000) < https://www.ftc.gov/public-statements/2000/05/evolving-approach-merger-remedies> accessed 15 April 2017.

${ }^{150}$ In the context of divestitures, "pyrrhic victories" mean that before the enactment of the HSR Act, even if the competition agencies successfully required the merging parties to divest, such victories were pyrrhic since such postmerger divestitures were ineffective in restoring the lost competition caused by the implemented anti-competitive mergers. See: Kenneth G. Elzinga, 'The Antimerger Law: Pyrrhic Victories?’ (1969) 12(1) J L \& Econ 43.

${ }_{151}$ Wise (n 20) 615-616; see also: Kintner (n 20) 4-6.

${ }^{152}$ Kintner (n 20)4-6, 8 .

${ }^{153}$ Wise (n 20).

154 See: Tim A. Thomas (ed) $\int 54^{\prime}$, American Jurisprudence, Monopolies, Restraints of Trade, and Unfair Trade Practices (2 edn, Lawers Cooperative Publishing 2004). The Sherman Act: 15 U.S.C.A. \$S 1-3 (West 2004); 15 U.S.C.A. IS 4-7 (West 2015).

${ }_{155}$ Dabbah (n 47)238.

${ }^{156}$ Section 1 states: 
Even in the early years when the application of section 1 arose, the courts considered that given the absolute nature of the prohibition contained in the section, it was crucial to ensure that the prohibition decision would only be made upon certain types of restraints, namely, unreasonable restraints of trade. ${ }^{158}$

A line of judicial pronouncement during those years clearly showed that the ' $[\mathrm{T}]$ rue test of legality being whether the restraint imposed is such as merely regulates and perhaps promotes, competition, or whether it is such as may suppress or even destroy competition'. ${ }^{159}$ Based on this test and judicial reasoning, two different approaches were developed regarding the application of section 1 in practice: requiring the application of a rule of reason ${ }^{160}$ before determining whether a given situation was unlawful; and relying on per se prohibition ${ }^{161}$ under which a situation will be deemed illegal without any assessment of the situation being undertaken.

The focus of section 2 of the Sherman Act 162 is on unilateral conduct and monopolization. ${ }^{163}$ Since most cases, more or less, involve some aspects of transactions that fall under section 1, there have been few cases 'adjudicated on the basis of section 2 alone'. ${ }^{164}$ Distinguished from section 1 of the Sherman Act, which prohibits any conspiracy restraining trade, section 2 prohibits conspiracies to monopolise. By acting in concert, section 1 and 2 of the Sherman Act have the effect of prohibiting mergers that have the effect of monopolising a market.

In the Sherman Act, there were neither express provisions concerning the divestiture remedy, ${ }^{165}$ nor explicit authorisation of the divestiture remedy. Rather, in section 4:

Every contract, combination in the form of trust or otherwise, or conspiracy, in restraint of trade or commerce among the several States, or with foreign nations, is declared to be illegal. Every person who shall make any contract or engage in any combination or conspiracy hereby declared to be illegal shall be deemed guilty of a felony, and, on conviction thereof, shall be punished by fine not exceeding $[\$ 10,000,000]$ if a corporation, or, if any other person, $[\$ 350,000]$, or by imprisonment not exceeding [three] years, or by both said punishments, in the discretion of the court.

See: 15 U.S.C. $\$ 1$ (2013).

157 ibid.

${ }^{158}$ Dabbah (n 47) 239-240.

159 See: Bd. of Trade of Chi. v. United States, 246 U.S. 231 (1918).

${ }^{160}$ Cont'l T.V., Inc. v. GTE Sylvania, Inc., 433 U.S. 36, 49 (1977) (under the rule of reason approach, a court is required to 'weigh all of the circumstances of a case in deciding whether a restrictive practice should be prohibited as imposing an unreasonable restraint on competition'.).

161 See: Dabbah (n 47) 241. It states:

$[\mathrm{n}$ some situations, the use of the rule of reason approach would not be appropriate because the behaviour in question is manifestly anti-competitive and so should be deemed to be illegal per se. This means that there is no need for a court to examine whether the behaviour in question unreasonably restrains trade or harms competition and consumers: the mere existence of the behaviour will be enough to fall within the section 1 prohibition.

162 Section 2 states:

Every person who shall monopolise, or attempt to monopolise, or combine or conspire with any other person or persons, to monopolise any part of the trade or commerce among the several States, or with foreign nations, shall be deemed guilty of a felony, . . . or, if any other person, $[\$ 350,000]$, or by imprisonment not exceeding [three] years, or by both said punishment, in the discretion of the court".

See: 15 U.S.C. $\$ 2$ (2004).

163 See: Thomas (n 154).

164 Malla Pollack and Louis Altman, Callmann on Unfair Competition, Trademark and Monopolies (4 edn, Clark Boardman Callaghan 2004) \& 4.21. is sep?

${ }^{165}$ Before the enactment of the HSR Act, there only existed "relief" instead of "remedy" since all the reliefs were taken after the implementation of the merger. In this article, for the sake of conformity and convenience, the term "relief" and "remedy" are used as synonymous ones. See: 15 U.S.C. $\$ 1$ (2004). 
[T] he several district courts of the United States are invested with jurisdiction to prevent and restrain violations of sections 1 to 7 of this title; and it shall be the duty of the several United States attorneys, in their respective districts, under the direction of the Attorney General, to institute proceedings in equity to prevent and restrain such violations. ${ }^{166}$

Section 4 clearly shows that the authority to order divestiture under the Sherman Act is nevertheless undisputed and is derived from the inherent equity powers of the federal court. ${ }^{167}$ An essential aspect of a court of equity is that it possesses a degree of discretion, which assigns it the competence to adopt remedies to a particular case to prevent and restrain violations of section 1 to 7 of the Sherman Act. ${ }^{168}$ Theoretically, once a transaction violates the Sherman Act, the entire panoply of remedies, including divestitures, becomes available to both the DOJ and the courts, with the equitable power derived from section 4 of the Sherman Act. ${ }^{169}$ The divestiture remedy was expressly approved in early landmark cases, such as Standard Oil Co. v. United States, which was the first time the government sought divestitures, and since that time, a number of cases have ordered divestitures. ${ }^{170}$

The Supreme Court first ordered divestitures in Standard Oil. During the 1880s, Standard Oil gradually began to dominate the oil market in the United States and ultimately created a monopoly in the petroleum distribution industry by continuously integrating into refining sectors horizontally, and integrating vertically into service stations all over the United States. ${ }^{171}$ It was not Standard Oil's tremendous size alone that violated the Sherman Act. Instead, the Supreme Court condemned the company's monopolistic conduct by transferring stock of many diverse corporations to the central company. The Court ordered the company to divest the stock of the subsidiary corporation and transfer it back to the stockholders who had owned the stock prior to Standard Oil's acquisition. In addition, the Court divided Standard Oil into several geographically separate and competing firms. ${ }^{172}$ Ironically, some of the companies created by the 1911 divestiture order, which were

16615 U.S.C.A. $\int 4$ (2015).

167 See: Northern Sec. Co. v. The United States, 193 U.S. 197, 345 (1904).

${ }^{168}$ Stephan Fraidin, 'Dissolution and Reconstitution: A Structural Remedy, and Alternatives' (1965) 33 Geo Wash

L Rev 809, 903.

${ }^{169}$ See: A.D. Neale and D.G. Goyder, The Antitrust Laws of the United States of America: A Study of Competition Enforced by Law (3 edn, Cambridge University Press 1980).

170 See: United States v. Nat'l Lead Co., 332 U.S. 319, 323 (1947). It states:

In a proceeding in equity instituted under $\$[] 4$ of the Sherman Antitrust Act, the District Court found that defendants had violated $\int 1$ of the Act and [thus] issued a decree to prevent and restrain further violations." The decree approved a plan for divesting the defendants of their stockholdings and other financial interests in certain other companies or for the purchase of the entire stockholdings and other financial interests in such companies.)

See also: United States v. Crescent Amusement Co., 323 U.S. 173, 175 (1944) It states:

The divestiture provisions in the decree were: 1 . requiring each corporate exhibitor to divest itself of the ownership of any stock or other interest in any other corporate defendant or affiliated corporation, and enjoining it from acquiring any interest in those companies; 2. requiring one of the individual defendant to resign as an officer of any corporation (except Crescent) which is affiliated with any defendant exhibitor and enjoining him from acquiring control over any such affiliate by acting as officer or otherwise; 3 . requiring another of the individual defendants to resign as an officer of the affiliates (except one corporation of his choice) and enjoining him from acquiring any control over the others by acting as an officer or otherwise; and allowing a year from the date of the decree for completion of the divestiture.

171. See: Standard Oil, (Wikipedia) < https://en.wikipedia.org/wiki/Standard_Oil > accessed 18 March 2017.

172. See: Standard Oil Co. of N.J. v. United States, 221 U.S. 1 (1911), 75. 
supposed to be separate, and to compete with each other, eventually merged once again. ${ }^{173}$ This meant that the old Standard Oil Empire was being rebuilt. Although the divestiture order in this case merely involved the transferring of the acquired stock, the decision was still ground-breaking because it was the first time the Supreme Court sought to order divestitures.

Since then, the Supreme Court has become more flexible in formulating remedies for merger cases. Conduct injunctions ${ }^{174}$ can be used as complements even if divestitures have already been included in one decree. ${ }^{175}$ United States v. American Tobacco Co. ${ }^{176}$ was a 1911 Supreme Court case in which the Court found that a large number of persons and corporations ${ }^{177}$ had violated the Sherman Act of 1890 by seeking to monopolise practically all sectors of the tobacco industry. In that case, divestitures involved the unscrambling, creation, and dissolution of dozens of corporations. The defendants were also subjected to a range of injunctions, including prohibition against participation in any similar conspiracy and against any form of common ownership or control of the fourteen companies. ${ }^{178}$

Overall, although the Supreme Court took a direct role in formulating the reliefs (especially divestitures), many of the judges, especially those in the federal district courts, still felt timid in ordering divestiture as a remedy when the case infringed the Sherman Act. The use of divestitures was limited and only restricted to some cases involving enormous financial interests; it has 'never become a really significant Sherman Act remedy'. ${ }^{179}$ Such reluctance can be regarded as the result of the possible incapacity of the courts to deal with complex economic issues or data. Applications of divestitures can involve a few non-legal issues, such as the determination of the scope and composition of a divestiture package or the preservation of the value of the to-be-divested assets during the interim period. Consequently, capabilities are required for the judges to cope with complicated and sometimes enormous economic data and practical commercial issues, and to have a good understanding of it. The relevant data could be copied literally; however, it would still be uncertain whether the judges could comprehensively understand the non-legal aspects of the issues involved due to their lack of professional training. ${ }^{180}$

As a result, this gave rise to the reluctance of the judges to use divestitures. The notion that "divestiture is a harsh remedy" at that time also largely contributed to the judicial reluctance of imposing divestitures in the cases that violated the Sherman Act. ${ }^{181} \mathrm{~A}$ divestiture can be harsh because divestitures will lead to structural changes, which can be irreversible. Further, it can be extremely costly in the sense that it can involve large transaction costs, such as, negotiations or seeking a suitable buyer. Hence, the courts may lack confidence about the success of the divestitures and feel uncomfortable in ordering

\footnotetext{
173. See: Standard Oil Company and Trust, (Encyclopaedia Britannica, updated on 4 March 2015) <http://www.britannica.com/topic/Standard-Oil-Company-and-Trust> accessed 17 March 2017.

${ }^{174}$ Conduct injunctions in the merger cases under the Sherman Act, among others, include: prohibition for participating in certain activities. Kevin J. O'Connor, 'The Divestiture Remedy in Sherman Act, Section 2 Cases' (1 January 1976) 13 Harv J on Legis 687, 709.

175 ibid.

176 United States v. Am. Tobacco Co., 221 U.S. 106 (1911).

177 Such persons and corporations included: North Carolinians James Buchanan Duke, George W. Watts, and Benjamin N. Duke, as well as the American Tobacco Company, the R. J. Reynolds Tobacco Company, and Blackwell's Durham Tobacco Company. See: ibid, 142, 152.

178 ibid, 184-188.

${ }^{179}$ Michael C O'Connor, 'Comments, Divestiture in Light of the EL PASO Experience' (1969-1970) 48 Tex Law Rev 792, 793.

180 ibid, 793.

181 O’Conner (n 179) 793-794.
} 
divestiture. Such uncertainty and discomfort give rise to their willingness to choose conduct-based relief rather than divestitures in the infringements under the Sherman Act.

\subsubsection{Divestitures under the Clayton Act}

The enactment of the Sherman Act in 1890 by Congress can be seen as the government's first step to regulate an industrial system consisting of numerous units to maintain effective competition. ${ }^{182}$ However, ambiguities and uncertainties in the provisions of the Sherman Act gave rise to considerable dissatisfaction, even if the Supreme Court's attitude toward the applications of divestitures was quite progressive. ${ }^{183}$ It is believed that the Sherman Act was effective in eliminating monopolistic conduct, whereas it was insufficient to control corporate concentrations, which could result in future anti-competitive effects in the market. ${ }^{184}$ Thus, in 1914, Congress enacted the Clayton Act ${ }^{185}$ to complement the Sherman Act of 1890 in relation to increasing the government's control over corporate growth and providing persons who were adversely affected by the infringements of the regulations with redress, so that a competitive economy could be preserved.

In section 7 of the Clayton Act, a tool is provided to control mergers in the American competition law regime. ${ }^{186}$ Under section 7, acquisitions of stocks and assets ${ }^{187}$ are prohibited if they have or may have the effects of substantially lessening competition or creating monopolies. The contributions of the Clayton Act are, first, it established the substantive test to determine whether anti-competitive effects would be generated from the notified transaction. Second, it changed the Sherman Act's substantive standard under which only transactions that would truly harm competition would be prohibited. ${ }^{188}$ The emphasis in section 7 on the "probable" rather than the "actual effect" of an acquisition, which was required under section 1 and 2 of the Sherman Act, makes it of primary interest to both government and private parties seeking to attack a merger. ${ }^{189}$

Under the Clayton Act, the only specific statutory reference to divestiture as a proper remedy for a section 7 violation is found in section 11, which authorises the FTC to require

\footnotetext{
182 Notes, 'Availability of Divestiture in Private Litigation as a Remedy for Violation of Section 7 of the Clayton Act’ (1964) 49 Min L Rev 267, 268.

${ }^{183}$ Kishor (n 57) 16.

184 Notes (n 182).

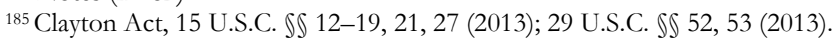

${ }^{186}$ The Clayton Act states the following:

No person engaged in commerce or in any activity affecting commerce shall acquire, directly or indirectly, the whole or any part of the stock or other share capital and no person subject to the jurisdiction of the Federal Trade Commission shall acquire the whole or any part of the assets of another person engaged also in commerce or in any activity affecting commerce, []where in any line of commerce or in any activity affecting commerce in any section of the country, the effect of such acquisition may be substantially to lessen competition, or to tend to create a monopoly.
}

See: 15 U.S.C. $\int 18$ (2013).

18715 U.S.C. $\int 18$ (2013). The Clayton Act of 1914 was further strengthened in 1950 through the Celler-Kefauver Amendments, strengthening $\int 7$ by making it applicable to asset acquisitions in addition to acquisition of stock. It "made sense to the extent that they eliminated the artificial distinction between acquisitions of assets and acquisitions of stocks." Leary (n 148). "The legal standards of Celler-Kefauver enforcement have been essentially structural in their thrust, that is, involving the determination of the relevant market and examining the merger's impact upon the number of firms, their market shares, and the trend of concentration in the market." Elzinga (n 150) 44.

${ }^{188}$ It is stated by the FTC that, "the Supreme Court decided that the Sherman Act does not prohibit every restraint of trade, only those that are unreasonable." Federal Trade Commission, 'The Antitrust Laws' <https://www.ftc.gov/tips-advice/competition-guidance/guide-antitrust-laws/antitrust-laws> accessed 16 March 2017. This implies that only transactions that truly harmed competition would be prohibited by the Sherman Act. ${ }^{189}$ Kintnter (n 151) 99-100. 
an offending corporation 'to cease and desist from such violations, and divest itself of the stock, or other share capital, or asset illegally held'. ${ }^{190}$ As described above, for the DOJ and the federal courts, the authority to order divestitures derives from the equitable power in section 4 of the Sherman Act. Under the Clayton Act, the DOJ and the federal courts were again not given express authority to order divestitures. However, they can do so, pursuant to section 15 of the Clayton Act, which states,

[T]he several [federal] district courts of the United States are invested with jurisdiction to prevent and restrain violations of [this Act], and it shall be the duty of the several United States attorneys, in their respective districts, under the direction of the Attorney General, to institute proceedings in equity to prevent and restrain such violations. ${ }^{191}$

Thus, it appears that 'the divestiture relief in the federal courts under section 7 of the Clayton Act arises from the same inherent equitable powers recognised under section 4 of the Sherman Act'. ${ }^{192}$

The Supreme Court's use of divestitures in United States v. E.I. du Pont de Nemours \& Co., 351 U.S. 377 (1975) can be regarded as its first announcement concerning the application of divestitures as appropriate merger remedies under section 7 of the Clayton Act, while the use of divestitures in the violations of the Sherman Act provides it with reliance. ${ }^{193}$

Du Pont owned some sixty-three million shares of General Motors stock, which had been found to give it an undue advantage over its competitors in dealing with General Motors, and this led to a violation of section 7 of the Clayton Act. Therefore, the Supreme Court reversed the District Court's judgment for dismissal, which further remanded the case to that court for a determination of 'the equitable relief necessary and appropriate in the public interest'. ${ }^{194}$ As urged by the Government, and in seeking to satisfy the Court's mandate, the trial court declined to order divestiture of stock, and ordered only the divestiture of voting rights, for fear that DuPont's disposal of General Motors would result in unduly harsh tax results for both companies. ${ }^{195}$

As a response to the Supreme Court's opinion that the proposed partial divestiture concerning transferring voting rights would not be an effective remedy, DuPont replied, inter alia, that 'it would be willing for all of its General Motors stock to be disenfranchised' and claimed that such an order would be sufficient to realise the purpose of section 7.196 The Court found that such relief would be "cumbersome and time-consuming" and would require policing that would unnecessarily involve the Government in private affairs. Therefore, it finally overturned the district court's plan and ordered complete divestitures. The Court concluded that the public is entitled to have surer and cleaner divestitures. The decision indicated that divestiture was preferred in the cases violating section 7 of the Clayton Act. ${ }^{197}$

The $d u$ Pont case can be regarded as the starting point, since it was in this case in which the use of divestitures began to largely increase and become a per se merger remedy in

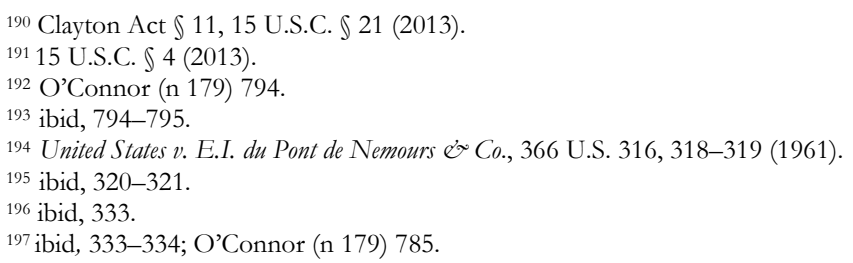


almost all the section 7 cases. ${ }^{198}$ Nevertheless, the Supreme Court might also have doubted the feasibility of the divestiture remedy, such as in United States v. Continental Can Co. ${ }^{199}$

In Continental, the Government sought to order divestitures to remedy the violation of section 7 of the Clayton Act, requiring Continental Can Company ("CCC") to divest the assets acquired in 1956 from Hazel-Atlas Glass Company ("HAG"). The District Court held that the Government had failed to prove reasonable probability of reducing competition in any line of commerce, and dismissed the complaint. The case was later reversed and remanded by the Supreme Court, insisting that such a merger violated section 7 of the Clayton Act. ${ }^{200}$ On remand, the District Court recognised the general applicability of the divestiture remedy: '[except in the most highly exceptional circumstances] the elimination of anti-competitive effects of the illegal merger ${ }^{201}$ is to be accomplished by a complete divestiture of all the acquired assets'. ${ }^{202}$ The Court found that the originally acquired entity had become so intermingled with the acquiring corporation that it was impractical to restore the acquired corporation as a separate and competitive corporation again. ${ }^{203}$ Finally, only a piecemeal sale of separate assets was ordered in the case. ${ }^{204}$

Overall, even when it was improved by the Celler-Kefauver Amendments in 1950, the merger control system under section 7 of the Clayton Act still failed to realise the goal of controlling the increasing corporate integrations due to the insufficiencies associated with the enforcement mechanism. ${ }^{205}$ Due to the difficulty in detecting the mergers before their implementation, as well as the excessive duration that merger litigation involves, the effectiveness of divestitures under the Sherman Act and the Clayton Act was largely crippled. The litigation history of United States v. El Paso Natural Gas Co. can be regarded as an example, which to a great extent demonstrated the defectiveness of merger control and merger divestitures during the pre-HSR Act period.

\subsubsection{El Paso Natural Gas Company}

\subsubsection{Litigation Review}

In July 1957, an anti-trust action was brought by the Federal Government in Utah District Court under section 7 of the Clayton Act against El Paso Natural Gas Company ("El Paso"), a company engaged in the business of transporting natural gas to distributors in California. The suit involved the government's post-acquisition challenge of El Paso's purchase of its potential competitor, Pacific Northwest Pipeline Corp ("PNW"). ${ }^{206}$ PNW was a gas pipeline company that had attempted to enter the California market, which at that time already had a supply line running from New Mexico to the Pacific Northwest. It wanted to sell excess supplies to customers in California, where El Paso was the sole supplier. El Paso promptly bought PNW, and the DOJ challenged the acquisition.

\footnotetext{
${ }_{198}$ O’Connor (n 179) 795-796. See: Fed. Trade Comm'n v. Procter \& Gamble Co., 386 U.S. 568, 568 (1967); United States v. Von's Grocery Co., 384 U.S. 270, 270 (1966); Fed. Trade Comm'n v. Consol. Foods Corp., 380 U.S. 592, 592 (1965). For a more detailed review of these cases, see: O’Connor (n 179) 795.

${ }^{199}$ United States v. Cont'l Can Co., 378 U.S. 441, 452-53 (1964). See also United States v. Pabst Brewing Co., 384 U.S. 546, 552 (1966).

${ }^{200}$ Cont'l Can Co., ibid, 443-444.

${ }^{201}$ Illegal merger here refers to mergers that will substantially lessen the competition in the market and are condemned by competition law in the U.S.

202 United States v. Cont'l Can Co., 1964 Trade Cases 80, 138 (S.D.N.Y. 1964).

$203 \mathrm{ibid}, 139$.

204 ibid, 143.

${ }^{205}$ Baer (n 60) 831.

${ }^{206}$ Utah Pub. Serv. Comm'n v. El Paso Nat. Gas Co., 395 U.S. 464 (1969).
} 
The Utah District Court proceeded with the trial of the government's antitrust action and ordered its dismissal. Seven years after the first litigation, in 1964, upon appeal, in United States v. El Paso Natural Gas Co., ${ }^{207}$ the Supreme Court ruled that the merger between these two companies had violated section 7 of the Clayton Act and ordered divestiture "without delay". ${ }^{208}$ A divestiture decree was agreed between the United States and El Paso after the case was remanded to the Utah District Court. During litigation, third parties, such as Cascade Natural Gas Company, were refused permission by the District Court to intervene and be heard. ${ }^{209}$

In 1967, upon appeal, after almost three years since the Court directed the District Court "to order divestiture without delay" in 1964, in Cascade Natural Gas Corp. v. El Paso Natural Gas Co., the Supreme Court held that 'no divestiture in any meaningful sense has been directed' and further made it clear that "divestiture without delay" meant 'P]acific Northwest or a new company be at once restored to a position where it could compete with El Paso in the California market'. ${ }^{210}$

Thus, the Court suggested some guidelines for an effective divestiture and the main parts can be summarised as follows:

1. Gas reserves: 'The gas reserves granted to the New Company must be no less in relation to present existing reserves than Pacific Northwest had when it was independent: and the new gas reserves developed since the merger must be equitably divided between El Paso and the New Company'. Besides, the proposed contracts about purchasing and gas gathering were not to be imposed on the New Company since it was proposed by El Paso and put the New Company in an unfavourable position.

2. Financial aspects: El Paso was allowed to sell the stock of West Coast Transmission Co., Ltd., brought into the merger by Pacific Northwest, which would bring high profits to El Paso, while the New Company obtained the stock of Northwest Production Co., which showed heavy losses. Thus, valuable and fairly liquid stock of West Coast Transmission was to be divested to the New Company to bring it working capital necessary to restore the competition in the market. The New Company should receive other assets or a reduction in debt of equivalent value as to the benefits El Paso enjoyed from PNW's tax loss carryovers to ensure the New Company's competitiveness.

3. Control of El Paso: The El Paso-Pacific Northwest combination will not begin to be severed until regulatory approvals have been obtained. Neither El Paso officers and directors nor owners of more than one-half of one percent of El Paso stock shall purchase New Company stock at a public offering. The prospect of an outright purchase of the assets of the New Company or its stock by outside interests was to be suggested. ${ }^{211}$

On the second remand, the District Court found out that El Paso's reserves were insufficient to satisfy the requirements of El Paso's and the divested company's customers. ${ }^{212}$ In order to ensure that 'the gas reserves granted the New Company be no

\footnotetext{
207 United States v. El Paso Nat. Gas Co., 376 U.S. 651 (1964).

$208 \mathrm{ibid}, 662$ ("Since appellees have been on notice of the antitrust charge from almost the beginning-indeed before El Paso sought Commission approval of the merger-we not only reverse the judgment below but direct the District Court to order divestiture without delay.").

${ }^{209}$ United States v. El Paso Nat. Gas Co., 465 F. Supp. 249, 250 (D. Colo. 1978).

${ }^{210}$ Cascade Nat. Gas Corp. v. El Paso Nat. Gas Co., 386 U.S. 129, 129-130 (1967).

211 See: ibid, 136-141.

212 O'Connor (n 179) 799.
} 
less in relation to present existing reserves than [PNW has] when it was independent' and to create a viable competitor in the California market, the District Court sought to choose an applicant to purchase the divested company. ${ }^{213}$ Several applicants ${ }^{214}$ submitted their plans and Colorado Interstate Gas Co. ("CIG"), a financially strong and experienced company, was chosen to be the purchaser. It was regarded as '[the] best qualified to make New Company a serious competitor' in California. ${ }^{215}$

In 1969, in Utah Public Service Commission v. El Paso Natural Gas Co., the Court required a further reallocation of gas reserves in order to restore the divested company to the same relative competitive position vis-a-vis El Paso in the California market as that which Pacific Northwest enjoyed immediately prior to the illegal merger'. ${ }^{216}$ In fact, selling the divested assets from one strong market player to another strong competitor can be problematic considering the risk of collective dominance. When arranging the reallocation, the district court was required to consider potential purchasers other than CIG and to take into consideration whether an award to a particular applicant would have any anti-competitive effects. ${ }^{217}$

Eventually, after seventeen years of lengthy litigation, divestitures were achieved. ${ }^{218}$

\subsubsection{Some Observations from El Paso}

\section{- Difficulties in detecting mergers before its implementation}

In El Paso, the divestiture remedy was ultimately successful, but at enormous cost, according to a lawyer who handled the matter for the government. ${ }^{219} \mathrm{El} \mathrm{Paso}$ was symptomatic of a merger review process that was not working under the merger control system of the Sherman and Clayton Acts. ${ }^{220}$ In cases like El Paso, Congress found that merging parties had strong incentives to implement merger transactions speedily and surreptitiously and then protracted the ensuing litigation, thereby creating the 'strong probability that the government would ultimately win only a partial or token divestiture order'. ${ }^{221}$ Due to the "midnight merger," it was difficult for the agencies to detect mergers before they occurred.

Another major problem in the merger control system was that the agencies lacked authority to require a waiting period before the merger could be implemented and to obtain preliminary injunctions to prevent the merging parties from executing their transactions. Consequently, even if the agencies could notice mergers before they occurred, it was still difficult for the agencies to take any effective preliminary injunctions to suspend the implementation of mergers. ${ }^{222}$ Due to this difficulty, divestiture could only be ordered after the mergers had implemented. This increases the uncertainties and risks for the effectiveness of divestitures.

\footnotetext{
213 See: Cascade/El Paso (n 210) 136-138.

${ }^{214}$ Applicants included, for example, Aspen, Continental-Pacific, Colonial, Great Lakes, Pacific Western, Pacific Northwest Pipeline, West Coast, and others. See: United States v. El Paso Nat. Gas Co., 291 F. Supp. 3, 33 (D. Utah 1968).

${ }^{215}$ Utah Pub. Serv. Comm'n v. El Paso Nat. Gas Co., 395 U.S. 464, 464 (1969).

216 ibid, 469.

${ }^{217}$ O'Connor (n 179) 469-470.

${ }^{218}$ S. REP. NO. 94-803, 69 (1976).

${ }^{219}$ Baer (n 60) 826.

$220 \mathrm{ibid}, 828$.

221 ibid.

222 ibid, 831.
} 


\section{- Excessive duration of merger litigation}

Since the first litigation in 1957 until the last one in 1976, the whole El Paso litigation lasted for almost twenty years. Moreover, it took seven years for the Supreme Court to make a decision requiring a divestiture without delay. The merger litigation was extremely excessive, with the aim of combatting anti-competitive and surreptitious mergers under section 7 of the Clayton Act. ${ }^{223}$

Because most of the merger cases were detected after their implementation, and given the incentives of the merged company to foster delay, the overall duration of merger litigation would be excessive. 'Congress found that the average post-acquisition case took five to six years to resolve'. ${ }^{224}$ After the long-time gap between the implementation of mergers and the order of divestiture, it is very likely that there is almost nothing left to be divested. In United States v. Pabst Brewing Co., 225 Pabst Blatz Brewing Company acquired by Blatz Brewing Company. After the implementation of the transaction, the former's assets (both tangible and intangible) were completely absorbed into Pabst Brewing Company, resulting in Blatz brewery's full dissolution. The implemented merger violated section 7 of the Clayton Act, hence, the District Court on remand required divestitures. However, because the acquired company was so assimilated into the acquiring one, the court action was extremely limited rather than requiring divesting the Blatz trademarks to another brewer. ${ }^{226}$ In such situations, even if the full divestiture was successfully achieved, '[T]he victory was likely to be so costly that it was pyrrhic'. ${ }^{227}$

\section{- Ineffective to achieve the goals}

The goals of American competition law are to restore competition in the market and to protect consumer welfare. More specifically, the intended purpose of the merger control system under the Sherman Act and the Clayton Act is to control the increasing concentrations in American industry. 228

Excessive duration of litigation indicates that on the one hand, the merged firm can make unlawful profits and enjoy other benefits from the illegal mergers; while on the other hand, competition and consumer welfare would be harmed due to the anti-competitive effects generated from that illegal merger. ${ }^{229}$ It was estimated that the illegal merger conferred on El Paso as much as ten million dollars profit annually. ${ }^{230}$ As proffered by the lawyer who handled the matter for the government in the Senate hearings:

Consider the extraordinary expenditure of time, as well as resources, which have been devoted to this [divestiture] effort. While there is no tally of the total cost that was made in seeing this case through to complete divestiture, it is safe to say that it ran into many millions, employed hundreds of lawyers, accountants and others, consumed great quantities of the scarce resources of our courts, and left a noncompetitive market structure in the gas industry in the west for a decade after that market structure had been declared unlawful by our highest court. Another incalculable, but very significant cost was the substantial loss of the time and talents of key El Paso executives from the important jobs of running a major utility and

\footnotetext{
223 ibid, 827.

224 ibid, 830 .

225 United States v. Pabst Brewing Co., 384 U.S. 546, 546 (1966).

${ }^{226}$ O’Connor (n 179) 796.

${ }^{227}$ Baer (n 60) 830.

228 ibid.

229 ibid, 829-830.

${ }^{230}$ S. REP. NO. 94-803, 69 (1976).
} 
developing new sources of energy supplies in a time of growing energy shortages because of the inordinate demands made upon them in the defence of this anti-trust proceeding. Surely, we can come up with a better way to enforce the important public policy of $\int 7$ of the Clayton Act. ${ }^{231}$

Considering divestitures under the Sherman Act and the Clayton Act, it is generally believed that in merger cases where divestiture was ordered, the costs will ultimately be passed on to customers. ${ }^{232}$ To put it in another way: even if a divestiture is achieved, the costs for that could be enormous and consumers would have to bear those costs.

\subsection{Divestitures after the HSR Act}

Prior to the passage of the HSR Act, it was common for the competition agencies to only detect a merger when it had already been implemented; and thus fail to restore competition to the market. ${ }^{233}$ This was caused by the loopholes in the merger control system, resulting in defectiveness of divestitures and leaving the agencies with only "Pyrrbic Victories." 234

It is believed that the effectiveness of divestitures can be increased only if the enforcement mechanism of merger control can be improved in a way that the competition agencies are enabled to detect a merger and obtain preliminary injunctions before the merger is implemented. ${ }^{235}$ Accordingly, in 1976, an attempt to fulfil the loopholes in the United States merger control system was made, that is, the enactment of the HSR Act. ${ }^{236}$ The objective of the HSR Act was two-fold: first, to limit harm to competition in the relevant market during the time gap (because an anti-competitive merger occurs only when the anti-trust agencies are able to solve the competitive problem); and second, to enable the agencies to effectively restore competition to its premerger level. ${ }^{237}$

The HSR Act addressed two types of problems associated with merger control in the United States: interim harm to competition and the inability to fully restore competition. The crucial idea behind the HSR Act was 'to detect and prevent illegal mergers prior to implementation'. ${ }^{238}$ 'The most noteworthy improvements the HSR Act has made are the pre-merger notification requirement and the mandatory waiting period after the notification. Under the HSR Act, as explained above, the "persons" who meet or exceed a statutory threshold must file a notification of the proposed transaction and provide relevant information to both the FTC and the DOJ.

A pre-merger notification requirement and submission of a basic amount of information enable the anti-trust agencies enough time to make a preliminary assessment of the transaction and to determine whether further review is necessary. After the filing, there will be mandatory waiting periods before implementing the transaction so that the antitrust agencies would have time to analyse the transaction. ${ }^{239}$ Prior to the expiration of the first waiting period, the FTC or the Assistant Attorney General of the Antitrust Division of the DOJ may request the merging parties to submit additional information if necessary, the

\footnotetext{
${ }^{231}$ Baer (n 60) 826-828.

232 O’Connor (n 179) 802.

2331999 FTC Divestiture Study (n 38) 1.

234 See generally Elzinga (n 150).

${ }^{235}$ John Warren Titus, 'Note: Stop, Look and Listen: Premerger Notification under The Hart-Scott-Rodino Antitrust Improvement Act' (1979) 1979 Duke L J 355, 355.

${ }^{236}$ Baer (n 60) 824-825.

${ }^{237} 1999$ FTC Divestiture Study (n 38) 1.

238 ibid, 3.

${ }^{239}$ Baer (n 60) 831.
} 
so called "Second Request." 240 The waiting period may be extended at the agencies' own discretion or by request. ${ }^{241}$ If necessary, a preliminary injunction will be sought by anti-trust agencies to prevent implementation of an acquisition. ${ }^{242}$

The litigation history and seventeen year-long wait for the divestitures in El Paso provides the most striking example of the benefits brought by the HSR Act. ${ }^{243}$ In supporting the pre-merger notification under the HSR Act, David K. Watkiss, chief counsel for the successful applicant in the El Paso divestiture proceeding, stated:

[] $\mathrm{f}$ a pre-merger notification requirement like the one proposed had been on the books 20 years ago, I would probably never have had this interesting experience, but more importantly, the public and the courts would have been spared the ordeal of the El Paso case. ${ }^{244}$

Without the pre-merger notification under the HSR Act, it would be very likely that the agencies would be unable to detect the unlawful merger before it occurred, whereas in Hoechst/Marion Merrell Dow, the suspicious mergers were investigated before their implementation. ${ }^{245}$ Further, it may be followed by a lengthy litigation just like that in El Paso, where divestitures were finally achieved at the cost of millions of dollars and decades of waiting. Without the HSR Act, divestitures would not occur unless through a consent agreement or through litigation, but the HSR Act which was effective, saved consumers' enormous amounts of money. With the facilitation of the HSR Act, the agencies take more initiatives in controlling suspicious merger transactions and divestiture becomes more effective.

In Hoechst/Marion Merrell Dow, ${ }^{246}$ divestitures were required in the consent order. The FTC in 1995 blocked a merger, which, as claimed, would save consumers up to $\$ 30$ million annually on prescription drugs'. ${ }^{247}$ In 1995, Hoechst AG proposed to acquire Marion Merrell Dow Inc. ("MMD"), which would 'create the third largest pharmaceutical firm in the world'. ${ }^{248}$

As pointed out, it was not the fact of the acquisition itself that caused any competition issues, but the serious potential anti-competitive effects generated from the mergers regarding four kinds of prescription drugs that raised the competition agencies' competitive concerns. The mergers could harm consumer welfare due to the large quantity of patients who needed these four kinds of prescription drugs to cure hypertension, angina, arteriosclerosis, and tuberculosis. ${ }^{249}$ To eliminate any anti-competitive effects, the merging parties were required to divest certain business regarding each of these four drug markets before their notified merger was approved by the FTC. ${ }^{250}$ It is claimed that the FTC's

\footnotetext{
24015 U.S.C. $\$ 18 \mathrm{a}(\mathrm{e})(1)(\mathrm{A})(2014)$.

24115 U.S.C. $\int 18 \mathrm{a}(\mathrm{e})(2)(2014)$.

24215 U.S.C. $\int 18 \mathrm{a}(\mathrm{f})(2014)$.

${ }^{243}$ Titus (n 235) 367.

244 ibid

245 Baer (n 60) 835

${ }^{246}$ In re Hoechst Ag, 120 F.T.C. 1010, 1010 (1995).

${ }^{247}$ William J. Baer, 'The Dollars and Sense of Antitrust Enforcement' (Federal Trade Commission, 25 January 1996) $<$ https://www.ftc.gov/public-statements/1996/01/dollar-and-sense-antitrust-enforcement> accessed 16 March 2017.

248 ibid.

249 ibid.

${ }^{250}$ Baer (n 60) 831 .
} 
action prevented that harm by obtaining substantial relief in four markets with annual sales of over 1.25 billion dollars. ${ }^{251}$

In Diageo plc ('Diageo") and Pernod Ricard S.A.'s ("Pernod"), the FTC authorised its staff to seek a preliminary injunction to block Diageo and Pernod's joint acquisition of Vivendi Universal S.A.'s ("Vivendi") Seagram Wine and Spirits business ("Seagram") after the parties were unwilling to divest a sufficient package. Seagram and Diageo were the top two and three rum sellers in the United States. According to the complaint, the transaction would reduce competition in the market for rum sold in the United States, as well as in individual states. ${ }^{252}$ Subsequently, the FTC negotiated a proposed consent order with the notifying party, under which Diageo was required, within six months of the acquisition of Seagram, to divest the Malibu rum business worldwide (assets that together did not constitute a stand-alone business) to a FTC-approved buyer. ${ }^{253}$ To reduce the risk of a failed divestiture, which could be caused by an insufficient or an inappropriately configured divestiture package, the FTC only accepted the proposed asset package with a crown jewel provision. Besides, a divestiture trustee was appointed to oversee the merging parties' compliance with the obligation of preserving the value of the to-be-divested assets during the interim period before the completion of divestitures. ${ }^{254}$

The mandatory pre-merger notification under the HSR confers on the competition agencies opportunities to seek preliminary injunctions when evidence shows that the notified merger can cause competition issues, so that unlawful mergers will not be implemented before getting any approval from the competition agencies. ${ }^{255}$ Pre-merger notifications, together with a mandatory waiting period, can be regarded as a big step forward in the right direction that promises greater success and more effective divestitures.

\section{Further Developments in US Merger Divestitures}

The HSR Act marked a new era for development of divestitures under the merger control system because the pre-merger notification and the mandatory waiting period after the notification required in the HSR Act enabled the divestitures to be executed before the assets had been scrambled. It can be concluded that the HSR Act also lays the foundation of modern divestiture procedures in the United States.

After getting final approval from the agencies with an agreed divestiture remedy, one of the most common scenarios is that the merging parties implement the transaction as soon as possible. Meanwhile, the agencies require the merging parties to finish divestitures in a limited time period. The divestiture process can be divided into two stages. The first is to enter into a binding agreement with a suitable purchaser and transfer the to-be-divested assets; the second is to close the transaction. The purchaser chosen by the merged party must be approved by the agencies. ${ }^{256}$

\footnotetext{
251 ibid.

${ }^{252}$ FTC Press Release, 'With Conditions, FTC Approves Joint Acquisition of Seagram Spirits and Wine by Diageo PLC and Pernod Ricard S.A.' (Federal Trade Commission, 2001) <https://www.ftc.gov/news-events/pressreleases/2001/12/conditions-ftc-approves-joint-acquisition-seagram-spirits-and> accessed 16 March 2017. ${ }^{253}$ In re Diageo Plc, et al., 133 F.T.C. 156, 156, 233-234 (2002).

${ }^{254}$ Jessica C. Strock, 'Setting The Terms of a Break-up: The Convergence of Federal Merger Remedy Policies' (2012) 53 Wm. \& Mary L. Rev 2147, 2162.

255 Titus (n 235) 380.

2561999 FTC Divestiture Study (n 38) 1.
} 
Before the early 1980s when the merger remedy policy began to change, preliminary injunctions were almost always the first option agencies sought out under the HSR Act. However, the agencies gradually became more willing to accept restructuring of the transactions or partial divestitures to eliminate anti-competitive effects since the early 1980s, when the policy began to change. ${ }^{257}$ During the mid-1980s, (at least) the FTC moved a step backward to litigation from settlements. The approach to avoid competitive problems changed again during the late 1980s and early 1990s, when the FTC began to become more flexible in using merger remedies. Since late 1999, to ensure the effectiveness of divestitures and for the sake of risk reduction, the DOJ and the FTC have begun to frequently use "fix-it-first remedies," "up-front buyer" provisions, or "crown jewel" provisions (the DOJ and the FTC have different preferences concerning these provisions, which will be discussed in Section 6 below)..$^{258}$

\subsection{FTC}

\subsubsection{The FTC's Changed Divestiture Policy}

Since the passage of the HSR Act, the FTC experienced significant changes in relation of enforcement philosophies and merger remedy approaches. ${ }^{259}$ Merger remedy policy during the HSR years through the present may be divided into five eras (see table below). ${ }^{260}$

\begin{tabular}{ll}
\hline Late 1970s & $\begin{array}{l}\text { The initial era when the FTC would virtually always seek to block } \\
\text { problematic mergers }\end{array}$ \\
\hline Early 1980s & $\begin{array}{l}\text { A period when the FTC employed various types of remedies, including } \\
\text { allowing the merging parties to solve their anti-trust problems without an } \\
\text { order (a "fix-it-first" remedy); }\end{array}$ \\
\hline Mid-1980s to early 1990s & $\begin{array}{l}\text { A time when the FTC typically would accept only a divestiture of a stand- } \\
\text { alone business or litigate to block the merger; }\end{array}$ \\
\hline Early to mid-1990s & $\begin{array}{l}\text { A period when the volume of consents swelled and many orders provided } \\
\text { for solutions involving less than the divestiture of a stand-alone business; } \\
\text { and }\end{array}$ \\
\hline Late 1999 to present & $\begin{array}{l}\text { The FTC scrutinises remedies proposed by merging parties with a } \\
\text { "sceptical eye" and often insists on risk-reduction provisions, such as up- } \\
\text { front buyer provisions and crown jewel provisions. }\end{array}$ \\
\hline
\end{tabular}

As highlighted above, the FTC is becoming more prudent and sophisticated in applying merger remedies, and has more frequently required the inclusion of risk reduction principles in the agreed consent order since the late 1990s, with the publication of the 1999 FTC Divestiture Study. ${ }^{261}$ There are several reasons that may explain why the FTC altered its approach to merger divestitures.

In the first place, the number of merger cases increased at a rapid pace. ' $[R]$ eported Hart-Scott-Rodino transactions have tripled since 1991, from 1,529 to 4,642 in the fiscal year $19999^{\prime}{ }^{262}$ Furthermore, it is worth pointing out that during this period, the total value

\footnotetext{
${ }^{257}$ Balto \& Parker (n 149) 4-5.

${ }^{258}$ For detailed exploration of the fix-it-first remedies, up-front buyer provisions and crown jewel provisions, see: sec.6.2.2.

${ }^{259}$ Casey R.Triggs, ‘Shielding Consumers from Risk: FTC Divestiture Policy’ (2002) 17 Antitrust 75, 75.

${ }^{260}$ This review regarding the developments of the FTC's divestiture policy is adopted from Triggs, ibid.

2611999 FTC Divestiture Study (n 38).

262 Balto \& Parker (n 149).
} 
of these reported transactions has increased from 169 billion to over 1.9 trillion dollars. ${ }^{263}$ Thus, ensuring the effectiveness of a remedy became an important task because it could have a large impact on the success of a merger transaction and ultimately influence the realisation of goals of competition policy.

Second, the interim period from the date the consent order was signed until the completion of divestitures needs to be shortened. Earlier divestiture orders called for the parties to complete the agreed upon divestitures within twelve months or more following final acceptance of the consent agreement by the FTC. ${ }^{264}$ Before the final acceptance of the consent agreement, a 60-day public comment period was required, followed by an additional month before the FTC would make its final decision. ${ }^{265}$ Therefore, on average, fifteen months were needed. ${ }^{266}$ Risks and uncertainties concerning the deterioration of the viability, marketability and competitiveness of the to-be-divested business will increase during the interim period.

The FTC began to reconsider its merger divestiture policy and put the emphasis on enhancing the effectiveness of the divestiture remedy. A more systematic review of past merger settlement was taken by the FTC. In 1999, the FTC issued its report specifically on divestitures.

\subsubsection{FTC Divestiture Study}

In August 1999, the FTC issued its comprehensive study, merely focusing on the divestiture remedy, which evaluated the results of numerous interviews 'for insights into the Commission's divestiture orders and divestiture process'. ${ }^{267}$ The report studied the cases from 1990 through to 1994 in which divestitures were ordered to remedy the anticompetitive effects created by mergers. In the study, obstacles to effective divestitures were analysed and recommendations to increase the effectiveness of divestiture remedies were provided. ${ }^{268}$ The study supported the view that divestitures had been successful remedies for anti-competitive mergers and conclusions were drawn from the study that divestitures could restore competition that would be lost as a result of a merger. ${ }^{269}$

The FTC identified several factors that could be detrimental to the effectiveness of the divestitures. From the respondent' ${ }^{270}$ side, three factors that could lessen the competitiveness of divested assets in the hands of the buyers ${ }^{271}$ were identified.

(1) Respondents urged the Commission to define limited divestiture packages. ${ }^{272}$

The scope of the divested assets is one of the vital factors to an effective divestiture because it can, to some extent, decide what kind of buyers the assets will attract or whether a suitable buyer will appear. It will also influence the viability and competitiveness of the

\footnotetext{
263 ibid.

2641999 FTC Divestiture Study (n 38) 39.

$265 \mathrm{ibid}, 39,43$.

266 ibid, 39.

267 ibid, iii.

268 ibid, 15.

$269 \mathrm{ibid}, 1$.

270 See: 2012 FTC Remedies Statement (n 36). The 1999 FTC Divestiture Study does not explain explicitly the meaning of respondent. According to the 2012 FTC Remedies Statement, the merging parties will be referred to as "respondents" once a complaint and order is issued by the FTC.

271 "Buyers" refers to the third party who is the acquirer of the divested tangible or intangible assets. They could also be called "purchasers" or "acquirers." See: ibid.

2721999 FTC Divestiture Study (n 38) 16.
} 
divested business later on. Because of the inadequate package, it could be hard to fully achieve the remedial purpose of the Commission's orders.

(2) Respondents urged the Commission to divest assets to weak buyers. ${ }^{273}$

It is quite natural that respondents choose weak buyers because they do not want to create a strong competitor who will threaten their own business. Thus, it is understandable that respondents are required to propose "acceptable" buyers rather than the one which is likely to be the strongest.

(3) Respondents took actions that diminished the viability of the business acquired by the buyers. ${ }^{274}$

Some buyers believe that respondents may undermine the buyers' efforts to establish their business deliberately, such as the respondents' failure to fully provide required technical assistance. Even if respondents deliberately do not take actions that will impede the success of the buyers, they naturally still have no incentives to help the buyers.

One of the reasonable explanations for respondents' performance during the divestiture may be that they are unwilling to divest their assets to others and further bring them success. On the buyer's side, the FTC also identified four factors:

(1) Buyers lack information. ${ }^{275}$

Among the reasons why buyers experience a lack of information about the to-be-divested assets is the unwillingness of the respondents to provide vital information. Due to the lack of information, buyers are likely to make mistakes in connection with acquiring ongoing businesses, as well as transfers of selected assets and pure technology transfers.

(2) Buyers perceive a lack of bargaining power. ${ }^{276}$

Many buyers perceive that they are in a weak position compared to that of the respondents because they fear that if they insist on more favourable terms, the respondents would divest the assets to some other bidder.

(3) Buyers do not often communicate with the Commission regarding difficulties in their dealings with respondent. ${ }^{277}$

The reason why buyers rarely communicate with the Commission is not because they are simply reluctant to do so, but rather because they fear that the conditions could worsen if they complain to the Commission about the respondents.

(4) Buyers' interests are different from the FTC's. ${ }^{278}$

The aim of the FTC is to create a viable competitor in the market to restore the effective competition; as for the buyers, they may choose to cooperate with respondents rather than compete with them for the sake of their own development. Consequently, methods should be applied to distinguish those buyers who are likely to compete from those who are likely to cooperate or to use the assets for other purposes.

273 ibid, 17.

274 ibid, 18-19.

275 ibid, 20.

276 ibid, 23.

277 ibid, 26.

278 ibid, 26-27. 
The FTC Divestiture Study proposed a number of recommendations that aim to increase the effectiveness of the divestiture remedies. For respondents, the study provided suggestions to incentivise them to achieve an effective divestiture, such as the appointment of auditor trustees. It is expected that with the combination of the trustees' professional knowledge and the FTC's 'technical knowledge and ... unrestricted access', the issues and disagreements between respondents and buyers can be solved and respondents' compliance with their obligations can be further monitored. ${ }^{279}$ This will be significantly helpful to create trust between the parties. The crown jewel provision, under which the agencies require the merging firms to divest additional assets if the defendant fails to divest within the time period required by the order, may also give respondents incentives to facilitate an effective divestiture. ${ }^{280}$ Additionally, it suggested facilitating the success of the buyer by ensuring that the buyer has easier access to important and accurate information before asking the buyer to compete in a complex market and giving the buyer certain requirements beyond basic due diligence. ${ }^{281}$

To analyse which approach of divestiture is most likely to contribute to effectiveness, it is necessary to review the development of divestitures by the FTC.

\subsubsection{The Development of Divestitures by the FTC}

\subsubsection{1. "Clean Sweep" Approach}

It is believed that most of the anti-competitive effects generated from mergers can be eliminated by divesting the overlapping assets. ${ }^{282} \mathrm{By}$ doing this, it can be ensured that the concentration degree regarding the relevant market will not be too high post-merger, resulting in the preservation of competition. Such a "clean sweep" approach (meaning that one of the parties has to divest all elements of its business that is related to a market on which the other merging party is also active $)^{283}$ is likely to work well in the retail markets, such as supermarkets and petrol stations. ${ }^{284}$

In the Exxon/Mobil case, the merging parties completed the merger after getting the approval from the FTC by conditionally agreeing to more than 2,400 stations across the country. ${ }^{285}$ To implement the transaction, Exxon and Mobil proposed to 'sell 2,431 petrol stations primarily in the north-eastern United States, California and Texas' in order to clear the agencies' competition concerns of price increases which can harm the consumer's welfare and to restore competition in the market. ${ }^{286}$

In Ahold/Pathmark, ${ }^{287}$ Ahold proposed to acquire another supermarket, Pathmark. ${ }^{288}$ As additional conditions for a clearance decision, Ahold was required to divest all of its "Edwards" chains rather than only several individual Edwards stores in various overlapping

\footnotetext{
${ }^{279}$ ibid, 29.

$280 \mathrm{ibid}, \mathrm{I30}$; see also Strock (n 254) 2150.

2811999 FTC Divestiture Study (n 38) 32.

282 Parker \& Balto (n 149).

283 See: ibid. It can also be called a "zero delta policy": the term takes its name from the use of changes in the Herfindahl-Hirschman Index (HHI) as a measure in the Merger Guidelines' screens for transactions' competitive effects.

284 ibid.

${ }^{285}$ CNN Money, 'Exxon-Mobil Merger Done' (CNN Money, 30 November 1999) <http://money.cnn.com/1999/ 11/30/deals/exxonmobil/> accessed 18 March 2017.

286 ibid.

${ }^{287}$ For the details, see: sec.5.1.3.2. "Divestiture of an Ongoing Business."

${ }^{288}$ Dana Canedy, 'Royal Ahold in Deal to Acquire Pathmark Stores' (N.Y.Times, 1999) < http://www.nytimes.com/ 1999/03/10/business/royal-ahold-in-deal-to-acquire-pathmark-stores.html> accessed 20 March 2017.
} 
markets to another rival. ${ }^{289}$ However, sometimes the "clean sweep" approach will not be sufficient because the market and industry are evolving. A greater set of businesses than the overlapping parts alone may be necessary to create a viable competitor in the market to restore competition.

In FTC v. Cardinal Health, Inc. and Bergen Brunswig Crop. and FTC v. McKesson Corp. and Amerisource Health Corp., ${ }^{290}$ the FTC held the opinion that the proposed divestitures were severely inadequate to clear the potential anti-competitive effects the merger could bring about and the court ultimately issued a preliminary injunction to block the transactions. ${ }^{291}$ McKesson Corp. was the largest full-service wholesale distributor of prescription drugs in the United States and Canada in relation to both size and sales. ${ }^{292}$ Based in California, Bergen was the country's 'largest supplier of pharmaceuticals to the managed care market' and the second largest wholesale distributor of pharmaceuticals. ${ }^{293}$ Cardinal Health, headquartered in Ohio, was the 'third largest wholesale distributor of prescription drugs, over-the-counter pharmaceutical products and health and beauty aids'. AmeriSource was the fourth largest wholesale distributor of pharmaceutical products and related health care services in the United States. These two mergers among the top-four national drug wholesalers would have made the strongest even stronger, and would directly reduce the number of wholesalers from four to two. Thus, the FTC challenged these two mergers. ${ }^{294}$

National level drug wholesalers provide unique services, such as twenty-four hour services, which is vital to the hospitals when certain drugs are in short supply or are needed urgently. In addition, hospitals or drugstores, can order various brands of drugs from one wholesaler instead of ordering from different manufacturers. Comparatively, wholesale distribution centres were of smaller scale than national ones. ${ }^{295}$ The merging parties proposed to divest the overlaps among them, namely, several drug wholesale distribution centres in the Northwest, which they thought would fully clear any potential anticompetitive effects generated from the notified merger. The FTC insisted that such divestitures would be far from sufficient because 'customers demanded firms that could provide a national service and divestiture of a handful of distribution centres could not compensate for the loss of two national competitors...' 296

Believing that ' [] $\mathrm{n}$ most instances, this nation's market system, the best in the world, is able to discipline itself, ${ }^{297}$ the court sought for any opportunity to allow the notified parties to proceed with the transaction. However, the court found that 'regional firms did not [manage to] offer the same level of competitive restraints as the national firms', and so rejected the proposed settlement and issued a preliminary injunction. ${ }^{298}$

The pharmaceutical industry is one of the most dynamic and important segments of the national economy. The distribution and delivery of prescription drugs from the manufacturer to the dispenser is not an easy task. The fast and efficient distribution of

\footnotetext{
${ }^{289}$ Parker \& Balto (n 149).

${ }^{290}$ Fed. Trade Comm'n v. Cardinal Health, Inc., 12 F. Supp. 2d 34, 34 (D.D.C. 1998).

291 ibid, 65-66, 68.

${ }^{292}$ FTC Press Release, 'FTC Will Seek To Block Mergers of Nation's Four Largest Drug Wholesalers into Two Companies' (Federal Trade Commission, 1998) < https://www.ftc.gov/news-events/press-releases/1998/03/ftc-willseek-block-mergers-nations-four-largest-drug-wholesalers> accessed 20 March 2017.

293 -, 'Bergen Brunswig Targets Managed Care' (L. A. Times, 30 September, 1995) < http://articles.latimes.com/ 1995-09-30/business/fi-51563_1_bergen-brunswig> accessed 25 March 2017.

${ }^{294}$ FTC (n 292).

295 See: Cardinal Health, 12 F. Supp. 2d, 43.

${ }^{296}$ Parker \& Balto (n 149).

${ }^{297}$ Cardinal Health, 12 F. Supp. 2d, 67.

${ }^{298}$ Parker \& Balto (n 149).
} 
prescription drugs is a critical component of the pharmaceutical industry. A national wholesaler plays a crucial role in the whole industry. Thus, competition between these national level top wholesalers may largely affect the consumers. Where competition is not only at a local level, but also at the national level, the approach of partial divestiture of solely overlapping assets will not be enough.

\subsubsection{Divestiture of an Ongoing Business}

The 1999 FTC Divestiture Study has indicated that divesting an ongoing business is more likely to result in a viable business than divesting selected assets to facilitate the buyer's market entry. The main reason for this is that an ongoing business indicates present possession of all resources that are needed for a viable operation, including tangible resources (e.g. physical facilities, equipment) and intangible resources (e.g. technician, management system, and customer lists). ${ }^{299}$ Further, the ongoing business has already succeeded in competition in the market, thus establishing that divestiture could be an effective remedy. ${ }^{300}$ Divestitures of entire assets are very likely to clear the FTC's competitive concerns. Nevertheless, under certain circumstances, divestiture of entire assets may still not be enough to clear all the anticompetitive concerns. The case of Ahold/Pathmark is an example of how important the "ongoing" requirement is when the FTC considers the feasibility and effectiveness of divestitures.

In 1999, Royal Ahold N.V. (a Dutch food retailer) proposed to merge with Pathmark Stores Inc. (a leading chain in metropolitan New York), by means of ' $\$ 250$ million in cash and the assumption of $\$ 1.5$ billion in debt'. ${ }^{301}$ Since Ahold gained entry into the market twenty years ago by purchasing the Carolinas-based Bi-Lo chain, it continuously carried out acquisitions and Pathmark was its ninth target in the American chain. Ahold was the 'leading supermarket operator on the Eastern Seaboard and the fourth-largest chain in the United States' at that time. ${ }^{302}$

The competitive concerns in this transaction were more serious than other previous supermarket merger cases because in prior cases a "clean-sweep" divestiture would be adequate to clear the agencies' competitive concerns. In most of those cases, the merging parties' aim was to enter a new market, so the merger created less likelihood of competition problems. ${ }^{303}$ Accordingly, disposing of overlapping business would be enough to lower the degree of concentration in the market. However, the situation in the Ahold merger case was quite different because Ahold intended more than simple entry into a new market. Instead, the Dutch enterprise wanted to directly eliminate its competitor. Pathmark was the head-to-head competitor with Edward, and Ahold already operated Edward. ${ }^{304}$ If the transaction received approval, the number of competitors in the market would decrease directly.

The parties initially proposed to divest several individual stores in various overlapping markets, but the agencies refused this proposal because it failed to satisfy the recent consent orders in the industry, namely the "clean sweep approach." Finally, the parties proposed to divest all of the Edwards stores with the aim to clear all competitive overlaps. However, another serious question arose: whether a suitable buyer existed that was able to purchase the divested-chain-supermarkets and had the ability to operate them at the same

\footnotetext{
2992011 DOJ Policy Guide (n 56) 8-9.

300 ibid.

${ }^{301}$ Canedy (n 288).

302 ibid.

${ }^{303}$ Parker \& Balto (n 149).

304 ibid.
} 
competitive level. ${ }^{305}$ Ahold was the fourth-largest chain of supermarkets in the United States, which meant that it owned superior resources in terms of foods/goods suppliers, mature supply chains, etc. ${ }^{306}$ It could prove very difficult to find a buyer with similar capability to Ahold that could provide the divested-Edwards with similar support. If the same degree of support could not be realised, Edwards would likely be unable to compete vigorously with the merged party after divestitures. In other words, the merged party might win back the market shares it lost in the divestitures and ultimately could build a quasidominant position in the market.

Accordingly, in the Ahold case, a divestiture of entire assets was no longer a suitable approach to clear the agencies' competitive concerns. Especially in chain supermarket cases, such as Ahold, divestiture of a certain number of supermarkets is insufficient. Whether the divested chains can compete and restore competition in the market depends not only on the number of stores, but also on other factors, such as suppliers and logistics. These resources cannot be divested along with the stores, but they can exert a large impact or even decide the competitiveness of the divested business. As stated in the 1999 FTC Divestiture Study, divestitures of ongoing business are more likely to contribute to a viable and competitive new competitor. ${ }^{307}$

At times, the merging parties will also provide a "mix-and-match" of assets. In that situation, the merging parties will offer to divest a combination of assets selected from both the merging firms. Compared with the "clean sweep" approach and the "ongoing" requirement, a mix-and-match approach requires agency's more scrutiny because assets raise more risk regarding whether the assets selected are able to operate as viable competitors in the market and restore competition. ${ }^{308}$

\subsubsection{Ongoing Relationship between the Merged Firm and the Acquirer of the Divested Assets}

The FTC Divestiture Study has stated that continuing relationships with respondents post divestiture 'may increase the vulnerability of buyers of the divested assets, particularly in those cases in which the divested assets comprise less than an ongoing business'. 309 However, continuing relationships between the buyers of divested assets and the merged party are still required in many divestitures in order to create a viable competitor. Such ongoing relationships, to some degree, facilitate the buyers' success in operating the "new business," especially in mergers involving the pharmaceutical industry or relating to patents. ${ }^{310}$

For the former, the acquirer must undertake a regulatory approval process, and may need a supply source during the interim. For the latter, the buyers need supports from the merging parties to better understand complicated patent information, commanded exclusively by the respondents. In still other cases, such continuing problematic relationships can ultimately lead the merging parties to abandon the transaction, such as in the case of Abbott/Alza. ${ }^{311}$

In 1999, Abbott Laboratories Inc. (Abbot) proposed to acquire Alza Corp. (“Alza”), 'a research-based pharmaceutical company with a growing portfolio of products and leading

\footnotetext{
305 ibid.

${ }^{306}$ Canedy (n 288).

307 See: Parker \& Balto (n 149); 1999 FTC Divestiture Study (n 38) 6.

308 Parker \& Balto (n 149).

3091999 FTC Divestiture Study (n 38) 12.

$310 \mathrm{ibid}$.

311 Parker \& Balto (n 149).
} 
drug delivery technologies'. ${ }^{312}$ Abbott was the nation's largest maker of medical diagnostic devices in the United States. At the time of the merger's proposal, Abbott already had an eighty percent share of the market. ${ }^{313}$ Alza was a research-based pharmaceutical products company, mastering core and leading drug delivery technologies. ${ }^{314}$ The FTC was convinced that the merger would significantly reduce competition in the pharmaceutical markets, and therefore challenged the merger. ${ }^{315}$

During the negotiations, Abbott proposed to sell the rights to Alza's potentially lucrative prostate cancer drug, Viadur, to an undisclosed buyer. Meanwhile, Abbott had made another prostate cancer treatment drug through its joint venture with Takeda Pharmaceuticals. Alza also claimed that it had already reached a supply-and-technology transfer agreement with a buyer for the prostate cancer treatment. ${ }^{316}$ However, the FTC rejected this proposal. ${ }^{317}$ The FTC concluded that, because Viadur was still pending approval from the Food and Drug Administration ("FDA"), and Abbott also had a new prostate cancer treatment drug, Viadur could lose its initiative in competition during the implementation of divestitures. ${ }^{318}$

Although Abbott claimed that Viadur could be rather lucrative, the proposed divestiture plan was still problematic. First, Viadur was still at the stage of research and development, pending uncertain FDA approval. Second, unlike Alza, the purchaser was a pharmaceutical company with limited experience of developing an innovative drug delivery system. ${ }^{319}$ This cast more doubt on Viadur's likelihood for success in the market. Third, in cases like Abbott, involving a pharmaceutical industry merger, a continuing relationship between the merged firm and the buyer of the divested assets may be inevitable. This is because technological support may be necessary for the buyer to get approval from the FDA, as well as for the future development of the new drug. In other words, the risk exists that the merged firm and the purchaser will collude to maximise joint profits rather than compete. In that case, competition would not be preserved in the market. The FTC's concerns became the final major hurdle for the deal and Abbott dropped the plan to buy Alza. ${ }^{320}$

\subsection{DOJ}

\subsubsection{Backeground of the 2011 DOJ Policy Guide}

In June 2011, the Anti-trust Division of the DOJ issued a revised Ant-itrust Division Policy Guide to Merger Remedies, updating the Division's 2004 version and aiming to 'provide

\footnotetext{
312 See: PR Newswire, 'ALZA Corporation Stockholders Approve Merger Agreement with Abbott Laboratories' (PR Newswire, 21 September 1999), <http://www.prnewswire.com/news-releases/alza-corporation-stockholdersapprove-merger-agreement-with-abbott-laboratories-74483762.html > accessed 25 March 2017.

${ }^{313}$ David Balto, 'Lessons from the Clinton Administration: The Evolving Approach to Merger Remedies' (2001) 69(5-6) Geo Wash L Rev 952, 971.

314 Johnson \& Johnson, 'Johnson \& Johnson Announces Completion of Merger with ALZA Corporation' (Investor, 22 June 2001) <http://www.investor.jnj.com/releasedetail.cfm?releaseid=63804> accessed 25 March 2017.

315 Bruce Japsen, 'Regulators Block Abbott Deal for Firm' (CHI. TRIB, 17 December 1999), <http://articles.chicagotribune.com/1999-12-17/business/9912170346_1_alza-abbott-shares-viadur> accessed 25 March 2017.

316 ibid.

317 See: Abbott Labs, 'Alza Call off Merger' (L. A. Times, 17 December 1999), <http://articles.latimes.com/ 1999/dec/17/business/fi-44783 > accessed 27 March 2017.

${ }^{318}$ Japsen (n 315).

${ }^{319}$ Parker \& Balto (n 149).

${ }^{320}$ Japsen (n 315).
} 
guidance to Anti-trust Division staff in their work analysing proposed remedies for mergers'. ${ }^{321}$

The reasons why the DOJ revised the policy guide may be that, first, as stated in the 2011 DOJ Policy Guide, the merger landscape had evolved significantly and the trend of globalisation had reshaped the face of many modern markets since 2004. ${ }^{322}$ Updates were necessary to reflect and satisfy the actual needs and changes in both the changing local and global markets. Further, the Obama administration seemed to take a more active approach toward anti-trust enforcement compared to its predecessors. ${ }^{323}$

The revised Policy Guide paid more attention to merger remedies, which may significantly influence whether expected efficiencies created by mergers can be preserved, while still doing away with the anti-competitive concerns. Further, on the one hand, between the FTC and the DOJ, '[T] he friskiness of consent settlement policies is not a new issue'. ${ }^{324}$ In this updated 2011 version of the Policy Guide, the DOJ changed some of the previously disfavoured policies, reflecting the convergence of the FTC's and the DOJ's divestiture policies. On the other hand, however, conflicts and issues existed between the DOJ and other anti-trust enforcement agencies, such as in American-European crossborder merger transactions. ${ }^{325}$ The new Policy Guide also reflected the intent to fill the policy gap between the DOJ and the European Commission, which released its new EC Remedy Notice in 2008. ${ }^{326}$

\subsubsection{Changes between the 2011 DOJ Policy Guide and the 2004 DOJ Policy Guide}

The 1999 FTC Divestiture Study focused specifically on the divestiture remedy, and analysed the question of how to fashion effective divestitures from the perspective of both the respondents and the buyers. In contrast, the DOJ Policy Guide aimed to provide an overall guide to merger remedies through a more systematic approach. The 2011 DOJ Policy Guide revised several aspects of the previous 2004 version. A brief introduction to those changes will be presented below.

\subsubsection{Structure}

The 2004 DOJ Policy Guide consisted of five parts: (1) overview, (2) guiding principle, (3) fashioning the remedy, (4) implementing the remedy, and (5) consent decree compliance and enforcement. In contrast, the new 2011 DOJ Policy Guide was quite different from the 2004 version, which included sections on tailoring effective remedies, types of remedies, additional considerations in choosing a remedy, implementing effective remedies

\footnotetext{
3212011 DOJ Policy Guide (n 56) 1. The first version of the DOJ Policy Guide was published in 2004, namely, U.S. Department of Justice, Antitrust Division: Antitrust Division Policy Guide to Merger Remedies (2004) (hereinafter: 2004 DOJ Policy Guide). It has been replaced by the 2011 version.

3222011 DOJ Policy Guide (n 56) 1.

323 See: Jonathan B. Baker and Carl Shapiro, 'Re-invigorated Merger Enforcement in the Obama Administration' (Lawprofessors, 2012) <http://lawprofessors.typepad.com/antitrustprof_blog/2012/06/re-invigorated-mergerenforcement-in-the-obama-administration.html> accessed 16 March 2017.

324 William Blumenthal, 'Reconciling the Debate over Merger Remedies: A Discussant's Proposed Decision Rule' (2001) 69 Geo Wash L Rev 978, 988.

${ }^{325}$ For example, the Boeing-McDonnell Douglas merger case. The FTC approved the notified merger by stating that the notified merger would not substantively lessen competition (see: Boeing Company/McDonnell Douglas Corp., FTC, file no. 971-0051 (July 1,1997) ). However, the European Commission held that the notified transaction was likely to strengthen the notifying parties' dominant market position (see: Commission Decision of 97/816, 1997 O.J. (L 336)).

326 See generally: 2008 EU Remedies Notices (n 35).
} 
and practical considerations, and compliance. ${ }^{327}$ The 2011 Policy Guide analyses the merger remedies more systematically, aiming to fashion effective merger remedies. The Guide explicitly categorizes three types of mergers and two types of remedies. Moreover, the Guide explored some additional and practical considerations to make the policy guide more pragmatic.

\subsubsection{Consumer $W$ elfare and Key Principles}

In its introductory section, the new Policy Guide claims that the standard of a successful merger remedy is that it 'must effectively preserve competition in the relevant market'. That is also the appropriate goal of merger enforcement. It is worth noting that the new guide points out that preserving competition includes not only restoring competition, but also "enhancing consumer welfare". ${ }^{328}$ In contrast, the 2004 Policy Guide placed more emphasis on restoring and promoting competition.

Three key principles are settled in Part I to ensure the effectiveness of merger remedies:

$[\mathrm{F}]$ irst, effectively preserving competition is the key to an appropriate merger remedy; second, the remedy should focus on preserving competition, not protecting individual competitors; third, a remedy needs to be based on a careful application of legal and economic principles to the particular facts of a specific case. ${ }^{329}$

To better identify different competitive issues, three types of mergers are also analysed in this part, including horizontal merger, vertical merger, and conglomerate mergers.

\subsubsection{Behavioural Remedy}

To better eliminate the potential anti-competitive effects generated from a proposed merger, the 2011 DOJ Policy Guide broadens its array of merger remedies, from structural remedies alone to a more flexible use of the conduct-oriented remedies, and a combination of both. 330

In the 2004 version, the DOJ stated that '[C]onduct relief is appropriate only in limited circumstances'. ${ }^{331}$ It further stated that the DOJ generally disfavoured conduct remedies because they were likely to continuously involve the Anti-trust Division of the DOJ and the courts in complicated market activities, which would result in 'direct, frequently substantial costs upon the government and the public'. ${ }^{332}$ In contrast, structural remedies do not involve such complications. Thus, in the previous version of the Policy Guide, the DOJ concluded that conduct remedies can be used as complementary and an adjustment to a structural remedy. ${ }^{333}$ In the new Policy Guide, the DOJ has substantially revised its position on conduct remedies, stating that 'conduct remedies can be an effective method for dealing with competition concerns raised by vertical mergers and also are sometimes used to address concerns raised by horizontal mergers (usually in conjunction with a structural remedy)'. ${ }^{334}$ The new Policy Guide further identifies several of the most common forms of conduct relief, including firewall, non-discrimination, mandatory licensing, transparency, antiretaliation provisions, and prohibitions on certain contracting practices. ${ }^{335}$

\footnotetext{
3272011 DOJ Policy Guide (n 56) ii-iv.

328 ibid, $1-2$.

329 ibid, 2.

330 ibid, 18.

3312004 DOJ Policy Guide (n 321) 18.

332 ibid, 17.

333 ibid, 18.

3342011 DOJ Policy Guide (n 56) 18.

335 ibid, 13-18.
} 


\subsubsection{Crown Jewel Provisions}

A "crown jewel" provision is a provision included in a consent agreement, which provides authority to divest additional assets if the parties are unable to sell the initially agreed-upon divestiture assets to a viable purchaser within a certain period. ${ }^{336}$ It typically requires the addition of certain specified and generally more valuable assets to the initial divestiture package. The new Policy Guide saw a great change of the DOJ's attitude towards the crown jewel provisions.

The DOJ did not favour crown jewel provisions in the 2004 DOJ Policy Guide. The DOJ identified two reasons to explain the rationale behind such a change. First, crown jewel provisions would only be ordered when the agencies believed that the original assets package was under-inclusive and that such concerns may further result in over-inclusion of divestiture assets. If the original divested assets were believed to be under-inclusive, this meant that the asset packages were generally too small and less valuable. In failing to create a new competitive competitor to restore competition in the relevant market to a premerger level, risks increased accordingly. Customers would thus suffer from the potential anti-competitive effects created by the mergers. Thus, the DOJ is likely to resort to a crown jewel provision to foster confidence in the merger. The risk then becomes that, once the agencies fail to decide a proper scope of assets, the lack of definite scope may lead to overinclusion of assets. The expected efficiency brought by merger transactions would then be offset by the too-wide-in-scope divestiture. Both under-inclusive and over-inclusive assets will ultimately harm customers. In the latter situation, customers will also be deprived of enjoying expected efficiency, such as lower prices brought by economy of scale. ${ }^{337}$

Second, crown jewel provisions provide the purchasers with an opportunity to manipulate divestitures. If there were a limited amount of purchasers and they knew the consent agreement included a crown jewel provision, they might intentionally protract negotiations with the merging parties until the expiration of time set so that they can buy more assets at an attractive price. Accordingly, the Anti-trust Division did not favour crown jewel provisions because it held that the agency must be highly confident of the effectiveness of a merger remedy when it is proposed to eliminate competition harm, rather than including more assets (such as, crown jewel provisions) when it turns out that the success of the remedies is uncertain. ${ }^{338}$

In contrast, in the 2011 DOJ Policy Guide, the DOJ confirms the use of crown jewel provisions by stating:

[]f an acceptable purchaser cannot be found for [the divestiture package], the parties [may] include additional valuable assets-'crown jewels'-to increase the likelihood that an appropriate purchaser will emerge .... [A] crown jewel provision may be necessary in those cases to ensure that the remedy will effectively preserve competition. ${ }^{339}$

Therefore, to ensure that it could attract a suitable buyer who can properly operate the tobe-divested business successfully, and finally restore competition to the pre-merger level, the DOJ changed its attitude towards crown jewel provisions. The DOJ's changed attitude also reduces the difference concerning divestiture policies between the DOJ's and the FTC's, which will be explored below.

\footnotetext{
$336 \mathrm{ibid}, 9$.

337 ibid, 36-37.

338 ibid.

339 ibid, 24-25.
} 


\section{The FTC's and the DOJ's Merger Divestiture Policies}

After the enactment of the HSR Act, the FTC and the Anti-trust Division of DOJ have more involvements in the merger control field than before. Both agencies spared their efforts to increase the transparency and certainty of the merger review process. With the publication of the 2011 DOJ Policy Guide, convergence concerning the FTC's and the DOJ's divestiture policy, to a greater or lesser extent, can be found because some changes in this new Policy Guide reflect the DOJ's changed divestiture preferences, which is in essence becoming more similar to the FTC's. Nevertheless, due to certain reasons, differences still exist. Because the notifying firms have no competence to decide which agency will take clearance to a certain merger transaction, they are in an uncomfortable position and facing uncertainties. Therefore, for merging parties, it will make it easier for them to satisfy the agencies' requirements to proceed with their proposed transaction if they are aware of the different divestiture approaches between these two agencies. For the agencies, understanding the differences and common ground of divestiture application can help them to cooperate with one another more effectively, and ultimately realise the goals of merger control. ${ }^{340}$ In the following sections, an exploration of the differences and common ground will be covered.

\subsection{The Agencies' Common Ground}

\subsubsection{Preference for Structural Remedies}

The FTC and the DOJ both have a preference for structural remedies-divestiture for example-over conduct-based remedies. In United States v. E.I. DuPont de Nemours \& Co., divestiture had been regarded as the preferred merger remedy in cases infringing section 7 of the Clayton Act, which deals with acquisitions of stocks and assets cases. In fact, in the 2012 Merger Remedies Statement, the FTC confirms its preference of divestiture in merger cases by stating, e.g., in the Merger Remedies Statement 2012, that '[A]nti-competitive horizontal mergers are most often remedied by a divestiture'. ${ }^{341}$ For the DOJ, it holds that 'structural remedies in many cases can be simple, relatively easy to administer and sure to preserve competition'. ${ }^{342}$

\subsubsection{Requirements for Divestiture Assets}

Two of the most important factors to ensure effective divestitures are choosing the proper divestiture assets and finding a suitable purchaser. The FTC and the DOJ share the same criteria for both. Concerning choosing divestiture assets, the criteria they employ aim first at assets that are attractive enough to attract any buyer to purchase. Second, the assets can set the foundation for a suitable purchaser to operate successfully and restore competition in the market to premerger level.

DOJ

To ensure the effectiveness of a divestiture, three requirements are laid out in the DOJ's 2011 Policy Guide concerning divestiture assets. First, any divestiture must include all assets necessary for the purchaser to be an effective, long-term competitor. Such

\footnotetext{
${ }^{340}$ Strock (n 254) 2166.

3412012 FTC Remedies Statement (n 36) 4.

3422011 DOJ Policy Guide (n 56) 6.
} 
'divestiture assets must be substantial enough to enable the purchaser to effectively preserve competition, and should be sufficiently comprehensive that the purchaser will use them in the relevant market and be unlikely to liquidate or redeploy them'. ${ }^{343}$

Second, an existing business entity is preferred. To create a viable competitor in the market with the divested-assets, physical assets alone are not enough. ${ }^{344}$ The Ahold/Pathmark case has shown that, in certain situations, other elements can also be vital to the success of the divestiture remedy, such as, personnel, suppliers, target customers and management systems. ${ }^{345}$ An existing entity, competing in the relevant market, implies that it has the resources and ability to successfully operate the divested business. Thus, this requirement, to the maximum extent, assures that the purchaser will be a viable and competitive competitor in the relevant market after purchasing the divested business. Further, the DOJ may accept fewer stand-alone assets when a set of acceptable assets can be assembled from both the merging parties. More than one existing asset may also be required to ensure the restoration of competition. 346

Third, if the to-be-divested assets are intangible, relevant rights should also be divested together. ${ }^{347}$ Take the trademark as an example. If both the merged firm and the "newly created firm" have the right to use the divested trademark, there is a high likelihood that consumers may be confused concerning who is the current owner of the trademark. This will lead to the dysfunction of the divestiture remedy since the merged firms can still make illegitimate profits by using the divested trademark. As such, the DOJ generally will require the merged party to relinquish all rights of the intangible assets. ${ }^{348}$

\section{FTC}

The FTC also requires that the to-be-divested assets should be an "autonomous, ongoing business unit." ${ }^{449}$ Like the DOJ, the FTC may also require the merging parties to divest all overlapping business (the clean sweep approach). Sometimes, the parties will propose to divest assets that are selected from both of the merging parties ("mix-and-match" approach). Both the FTC and the DOJ will only accept such assets after the parties show that the divestiture package includes all necessary components, and is able to create a viable entity that will effectively preserve competition. ${ }^{350}$

Although in comparison with the DOJ, the FTC seems to be more tolerant towards the "mix-and-match" approach when determining whether to accept a proposed divestiture plan, the FTC Merger Remedies try to dissuade the agencies from accepting such an approach. ${ }^{351}$

\subsubsection{Criteria for Selecting A Suitable Buyer}

The DOJ and the FTC's requirements for choosing a suitable purchaser are quite similar. Both agencies require that the purchaser must have the ability and incentives to operate the divested-business properly and restore the competition in the market to the pre-merger level.

\footnotetext{
343 ibid, $7-8$.

344 ibid, 8-9.

345 - 'AAI Warns FTC of Dangers in Supermarket Merger, Urges Careful Scrutiny of Ahold Acquisitions in Northeast' (Am. Antitrust Inst., 18 June 1999) <http://www.antitrustinstitute.org/node/10135> accessed 27 March 2017.

${ }^{346} 2011$ DOJ Policy Guide (n 56) 5.

$347 \mathrm{ibid}, 11-12$.

348 ibid.

${ }^{349} 2012$ FTC Remedies Statement (n 36) 5; see also: 1999 FTC Divestiture Study (n 38) 11.

3502012 FTC Remedies Statement (n 36) 6; see also: 2011 DOJ Policy Guide (n 56) 9.

${ }^{351}$ Logan M. Breed and David J. Michnal, 'Merger Remedies: The DOJ's New Guide to Old Differences with the FTC' (2005) 19 Antitrust 37, 37.
} 
DOJ

The 2011 DOJ Policy Guide provides three fundamental tests for selecting an acceptance purchaser. First, the ' $[\mathrm{D}]$ ivestiture of the assets to the proposed purchaser must not itself cause competitive harm'. In El Paso, discussed in sec.4.1.3 above, on the second remand, the proposed purchaser Colorado Interstate Gas Co. was quite problematic because it was already a financially strong and experienced company before receiving the divested business. Such divestiture would create another dominant company in the market, which would offset all efforts the divestiture remedy made to restore the competition. ${ }^{352}$

Second, the Anti-trust Division must be assured that the purchaser is incentivised to use the divested assets to compete in the relevant market. ${ }^{353}$ As revealed in the 1999 FTC Divestiture Study, the buyer's interests are different from the FTC's. ${ }^{354}$ That is also the reason why the DOJ adopted this test to make sure that the purchaser will operate the assets properly instead of making use of the business to realise other goals, for example, tacit collision with the merging parties to just make profits.

Third, a "fitness" test will be performed by the Anti-trust Division to ensure that the purchaser has 'sufficient acumen, experience, and financial capability to compete effectively in the market over the long term'. ${ }^{355}$ The Division will direct a sale to the purchaser which it deems the fittest, instead of comparing the relative fitness of multiple potential purchasers. ${ }^{356}$

\section{FTC}

Similarly, an acceptable buyer should have the potential to be a viable competitor and have the ability to restore competition in the relevant market to the level before the merger happened. ${ }^{357}$ With this aim, according to the 2012 FTC Remedies Statement, the buyer should have '(1) the financial capability and incentives to acquire and operate the assets, and (2) the competitive ability to maintain or restore competition in the market'. ${ }^{358}$

The FTC will determine whether the buyer is financially viable. The buyer not only should have sufficient financial strength to purchase the to-be-divested business, but it should also have the incentives and ability to operate the divested business viably to compete with the merged firm, so that competition can be restored. Additionally, the proposed buyer should also share the same objective as the FTC, which is to restore competition. Accordingly, 'T T] he buyer should have the experience, commitment, and incentive necessary to achieve'. 359

\subsubsection{Requirement for A Shorter Divestiture Period}

With the development of divestiture by the FTC and the DOJ, a shorter period of implementing and closing divestitures is required by both agencies to ensure the restoration of competition in the relevant market and to keep the to-be-divested assets as viable as possible. In earlier cases, the agencies allowed merging parties to proceed with their notified mergers without naming any buyer, or no time limits were imposed on the parties

\footnotetext{
3522011 DOJ Policy Guide (n 56) 28.

353 ibid.

3542012 FTC Remedies Statement (n 36) 26-27.

3552011 DOJ Policy Guide (n 56) 29.

356 ibid.

357 See: ibid.

${ }^{358} 2012$ FTC Remedies Statement (n 36) 10.

359 ibid, 9-10.
} 
within which they have to finish divesting within a certain period. ${ }^{360}$ Now, a time limit is usually set in the consent agreements, which gives the merging parties "three to six months" to finish the divestiture remedy, although in certain situations a divestiture period of twelve months can also be accepted. ${ }^{361}$ Such requirements or preference are also reflected in the policies, such as with up-front buyer provisions or crown jewel provisions, which aim at making the to-be-divested assets more attractive to ultimately attract a suitable buyer.

\subsection{Differences between the Agencies' Divestiture Policies}

It is still possible for merger cases, which have the potential of restraining competition in the relevant market, to obtain agency approval to proceed, but with additional conditions imposed by the agencies. When a merger is allowed to proceed with a divestiture requirement, this means that divestitures are used as a tool to relieve the anti-competitive effects created by such merger, so that competition in the relevant market can be restored to the pre-merger level.

Both agencies share the same goal. They consider that, from a general economic perspective, the aim of divestitures is to create a new competitor which has the ability and incentives to compete, innovate and expand in the market. Substantial differences regarding the divestiture preferences between the agencies, however, still remain. ${ }^{362}$

First, the DOJ and the FTC have expertise in different industries. Second, they have different internal structures concerning merger investigations, as well as negotiations and administration of consent agreements. Moreover, the consent procedures for both agencies are also different. All these factors may, to a greater or lesser extent, shed some light on the question of why the FTC and the DOJ have different merger divestiture preferences.

\subsubsection{Reasons for the Differences}

\subsubsection{Different Expertise}

In cases involving the pharmaceutical industry, it is very likely that the FTC will require the merging parties to divest a whole business line instead of only overlapping parts. In Rite Aid, Rite Aid proposed to acquire Revco, which would result in a single pharmacy chain with over 5,000 stores. Thus, Rite Aid proposed to divest some stores in geographic overlapping areas. The FTC rejected the proposed divestiture and ultimately sought an injunction to block the transaction. ${ }^{363}$ In the Premdor case, Premdor Inc. proposed to acquire the Masonite business of International Paper Company, the largest of only three significant manufacturers of moulded door skins, the primary component needed to manufacture moulded doors in the United States at that time. ${ }^{364}$ The DOJ finally permitted the transaction by requiring the acquiring firm, Premdor, to divest one facility and related

\footnotetext{
${ }^{360}$ Michael H. Byowitz and Lori S. Sherman, 'U.S. Antitrust Merger Remedies: FTC vs. DOJ?' (Wachtell, Lipton, Rosen \& Katr, 2009). <http://apps.americanbar.org/intlaw/calendar/spring2006/papers/WED230410 BYOWITZ_516.DOC> accessed 5 March 2017, 13.

361 ibid; see also: 1999 FTC Divestiture Study (n 38) 39.

${ }^{362}$ Strock (n 254) 2166.

363 See: FTC Press Release, 'FTC Will Seek to Block Rite Aid/Revco Merger' (Federal Trade Commssion, 17 April 1996), <http://www.ftc.gov/news-events/press-releases/1996/04/ftc-will-seek-block-rite-aidrevco-merger> accessed 37 March 2017.

364 See: United States v. Premdor, Inc., No. 01; CV01696, 2002 WL 1816981, *12, *14 (D.D.C. 5 April 2002).
} 
assets, and allowed it to keep the remainder of the target company's North American business in the related market. ${ }^{365}$ Thus, a different approach may be applied by the agencies when a transaction involves a specific industry.

Although both the FTC and the DOJ have concurrent jurisdiction to enforce the merger provisions under the Clayton Act, only one of the agencies takes clearance to investigate merger transactions. The agencies occasionally disagree as to which will analyse a given merger, especially in high-profile mergers, and mergers in "grey area" industries that may fall into the area of expertise of both agencies. ${ }^{366}$ In 2002, the Clearance Agreement was released by the FTC and the DOJ collaboratively. The agreement addressed the allocation of anti-trust responsibilities between the two agencies. The agency will take the responsibility to investigate the industry in which it has clearly superior expertise and handles related products. For example, the DOJ has expertise in metals, while the FTC's traditional specialities are in "petroleum and natural gas." Meanwhile the DOJ has conducted "historical work in electricity". The agreement assigned the "responsibility for communications, entertainment and media to [the] DOJ" and assigned all of energy industries to the FTC. ${ }^{367}$ Although the agreement tried to draw a clear boundary of allocating the responsibility to the agencies, it left some uncertainties. Therefore, the merging parties still have difficulty in predicting which agency will be responsible for their proposed merger. For example, when the agreement allocated media and entertainment mergers to the DOJ, some commentators, like Timothy Muris, argued that 'the FTC's [investigation of] the AOL/Time Warner merger gave it a superior claim to expertise in media and communications'. ${ }^{368}$

The agreement was abandoned by the agencies shortly after it was released. Nevertheless, it was confirmed that both the FTC and the DOJ have their own clear superior expertise in certain industries. Such different expertise can, to some extent, lead to different divestiture preferences under merger control when they tailor the divestiture remedy to a particular case involving certain industries. ${ }^{369}$

\subsubsection{Different Internal Structure}

The FTC and the DOJ have different structures when addressing the merger remedies during negotiations with merging parties. The FTC has two separate sections within the agency. One is dedicated to investigate the transactions, while the other is involved in negotiating the consent orders with the parties, and handles issues arising during the administration of such consent orders "without involvement of the staff" who are responsible for investigation. ${ }^{370}$ The structure of the DOJ is quite different from the FTC.

\footnotetext{
365 ibid, $* 12, * 17$.

366 See: Timothy J. Muris, 'Comments on The FTC-DOJ Clearance Process: before the Antitrust Modernization Commission' (Govinfo, 2005) <http://govinfo.library.unt.edu/amc/commission_hearings/pdf/Muris_ Statement.pdf $>$ accessed 17 March 2017, 5.

367 ibid, 9-10.

368 ibid, 10, 13. For detailed information regarding the AOL/Time Warner case, see: CNN Money, 'Competition Watchdog FTC approves media marriage, but with conditions' (CNN Money, 2000) < http://money.cnn.com/ 2000/12/14/deals/aoltimewarner/> accessed 30 March 2017. On 10 January 2000, the Internet service company America Online, Inc. (AOL) and the media giant Time Warner announced that AOL would buy Time Warner for more than $\$ 160$ billion in the largest merger in corporate history. Tom Johnson, 'Internet leader and entertainment firm to join forces; new company worth \$350B' (CNN Money, 10 January 2010) <http://money.cnn.com/2000/01/10/deals/aol_warner/> accessed 19 March 2017. On 14 December 2000, the FTC approved the merger.

${ }^{369}$ Muris (n 366) 2, 5.

${ }^{370}$ Byowitz \& Sherman (n 360) 31.
} 
The DOJ does not have separate sections for investigations and negotiations, which means that the consent decrees will be negotiated and administrated between the merging parties and the staff who are also responsible for investigating the transactions.

Such division of work within the FTC enables the staff to focus on their dedicated tasks. Since the staff in the DOJ are involved in both investigations and negotiations, they may have a comprehensive understanding over the whole transaction. ${ }^{371}$ However, they may also lack incentives and energy to order remedies compared with the FTC. Such structural differences between the FTC and DOJ will lead to the presumption that, overall, the FTC seems to be more involved in ordering remedies.

\subsubsection{Different Consent Procedures}

The procedures to make the proposed consent order or decree effective between the FTC and the DOJ are different, which may explain why the agencies have different merger divestiture preferences. Prior to the finalization of all the proposed consent decrees reached between the merging parties and the DOJ, a final approval from the federal district courts is required. The proposed consent judgements must be 'published by the United States in the Federal Register at least [sixty] days prior to the effective date of such judgment'. ${ }^{372}$ When assessing the proposed consent decrees, the courts have to ensure that these decrees would be in the public's interest. ${ }^{373}$

In contrast, for the FTC, although a thirty-day public comment is also required before a consent order can be finalized, approval for the order is generally not needed. A final decision is made within the FTC's discretion. In other words, unlike the DOJ, the FTC has the "last say" on whether to accept or reject the proposed consent order. ${ }^{374}$

Consent procedures for the DOJ are more complex than those of the FTC. In other words, the FTC enjoys more discretion and is more independent. This may explain why the DOJ prefers a "fix-it-first" policy to other divestiture policies, which will be discussed below while the FTC disfavours it.

\subsubsection{The Agencies' Different Preferences of Divestiture Policies}

During the past few decades since the enactment of the HSR Act, both the FTC and the DOJ have been more involved in the merger control field and have gradually formed their own preferences in ordering divestitures under merger control. Due to many reasons, the approaches they employ vary from each other. Among all the differences, the four most typical will be discussed, including, fix-it-first remedies, up-front buyer, crown jewel provisions and appointment of monitoring trustees.

\subsubsection{Fix-It-First Remedies}

One of the main differences between the FTC and the DOJ's divestiture approach under merger control is the DOJ's preference of "fix-it-first" remedies. ${ }^{375} \mathrm{~A}$ fix-it-first remedy means that the merging parties have proposed an identified purchaser and have entered into a binding agreement with that purchaser before the beginning of or during the merger review process, so that the reviewing agency will take such an agreement and the proposed purchaser into account when evaluating and deciding whether to clear or prohibit the

\footnotetext{
371 ibid.

372 Tunney Act, 15 U.S.C. \16(b) (2013).

373 ibid, S 16(e)(1).

${ }^{374}$ Strock (n 254) 2170, 2174.

375 ibid, 2169, 2170.
} 
transaction. Unlike the common divestiture procedures, once a fix-it-first provision is provided by the parties, the identification of the purchaser has been known to the agency before the reviewing agency makes a final decision. Accordingly, once the agency approves the merger transaction, the merging parties can implement the transaction and finish divestitures as soon as possible without searching for a suitable purchaser again. Therefore, it is expected that the risk of value deterioration of the to-be-divested assets during the interim period before the completion of divestitures can be reduced, given that the longer the divestiture period, the greater the risks of value deterioration will be.

A fix-it-first provision is frequently used by the DOJ in a consent agreement. In contrast to the DOJ's willingness to employ fix-it-first remedies, the FTC has no formal policy on it. ${ }^{376}$

In the 2011 DOJ Policy Guide, the DOJ states that 'a successful fix-it-first remedy eliminates the Division's competitive concerns and . . . the need to file a case.' ${ }^{377}$ The statement in the 2011 DOJ Policy Guide may explain why the DOJ allows the parties to fix the transaction by themselves first. The Division holds that under certain circumstances, compared with a decree, 'a fix-it-first remedy may . . . preserve competition in the market more quickly and effectively . . . , allowing the Division to use its resources efficiently'; Moreover, a fix-it-first remedy confers on the merging parties freedom and flexibility in designing and tailoring their divestiture plan. ${ }^{378}$ Generally, in a consent decree, a "clean sweep" approach may be applied to ensure that there is no overlapping business postmerger and that the to-be-divested assets are sufficient for the buyer to compete in the market by operating the divested business. In certain cases, even a greater set of assets will be required to divest. Nevertheless, such an approach has the risk of offsetting the expected efficiency brought by mergers. Economist Ronald W. Cotterill "examined the effectiveness of Royal Ahold's divestiture" and his data showed that 'in some markets the divested supermarkets were performing twenty-five percent below those stores that were not divested'. ${ }^{379}$ Through fix-it-first remedies, different purchasers are provided with the opportunity to design their divestiture plan to tail the assets to a specific proposed purchaser, which, to the maximum degree, enables the merging parties to preserve the expected efficiency generated from the proposed merger. ${ }^{380}$ It is also for the same reason that the DOJ has to "conduct an investigation" to determine both the nature and extent of the potential competitive harm and whether the proposed fix-it-first remedy will resolve it'. 381

Fix-it-first remedies can be preferred when structural-based and "clean" remedies are needed to render a merger. The DOJ states that it prefers a fix-it-first remedy when the buyer and the to-be-divested assets can be identified by the DOJ. ${ }^{382}$ However, the DOJ will

\footnotetext{
${ }^{376}$ Deborah Platt Majoras, 'Looking Forward: Merger and Other Policy Initiatives at the FTC'(Speech delivered at ABA Antitrust Section Fall Forum, Washington DC, 18 November 2004) <http://www.ftc.gov/sites/default/ files/documents/public_statements/looking-forward-merger-and-other-policy-initiativesftc/041118abafallforum_0.pdf > accessed 17 March 2017.

3772011 DOJ Policy Guide (n 56) 22.

378 ibid.

${ }^{379}$ See: Albert A. Foer, 'Toward Guidelines for Merger Remedies' (2001) 52 Case W Res L Rev 211, 215; see also Ahold Acquisition (n 345).

${ }^{380} 2011$ DOJ Policy Guide (n 56) 22.

381 ibid, 23.

382 P. Hewitt Pate, 'Antitrust Enforcement at the United States Department of Justice: Issues in Merger Investigations and Litigation’ (2003) 2003 Colum Bus L Rev 411, 422.
} 
accept a fix-it-first remedy only if such remedies need no continuing monitor and they can clear the anti-competitive effects. ${ }^{383}$

Once the fix-it-first remedies are accepted, the DOJ will forgo litigation and no consent decrees will be filed. As required in the Tunney Act, before finalizing all the consent decrees, the DOJ has to get approval from the federal district courts. Nevertheless, the Tunney Act does not apply in fix-it-first situations. ${ }^{384}$ In other words, the DOJ can decide whether to accept the proposed fix-it-first remedies without going through complex consent procedures. The Microsoft case may be a perfect example to explain why the DOJ prefers fix-it-first remedies.

The FTC began its investigation of Microsoft regarding its monopoly power, and finally suspended the investigation in late 1993 due to the Commissioners' two-to-two deadlock concerning whether to take further administration action. ${ }^{385}$ Afterwards, the DOJ decided to retrieve its investigations on Microsoft and initiated negotiations of settlements with Microsoft in June 1994. ${ }^{386}$ One month later, the DOJ filed a civil complaint under the Sherman Act, 15 U.S.C. $\iint 1$ and 2 (1973), charging Microsoft with unlawfully maintaining a monopoly of operating systems for IBM-compatible PCs and unreasonably restraining trade of the same through certain anti-competitive marketing practices. ${ }^{387}$ During the consent procedure, the federal district court issued an order denying the government's motion to approve the consent decree, stating that 'the Government has declined to provide the Court with the information it needs to make a proper public interest determination'. ${ }^{388}$ Later, the decision was revised by the United States Court of Appeals for the District of Columbia Circuit since the proposed transaction with the remedy is in the public interest, and thus, required to approve the consent order. ${ }^{389}$

This case demonstrates that the DOJ may face the risk of being refused by the court regarding the proposed consent agreement, resulting in a complex procedure. However, although the district courts rarely deny the DOJ's proposed consent orders, the DOJ still faces the risk of being carefully scrutinized by the public and going through the judicial reviews. Fix-it-first remedies generally enable the DOJ to avoid such risks.

In contrast, the fix-it-first remedies are not welcomed by the FTC, and historically are disfavoured. The FTC has no incentives to accept fix-it-first remedies since it does not have the risk of being carefully scrutinized by the court, like the DOJ to enforce a consent agreement. Instead, the FTC has the last say on whether to accept a consent order. The independent and discretionary power that the FTC enjoys results in it being more willing to enter into negotiations with the merging parties so that it can control the whole divestiture process, e.g., setting requirements for selecting divestiture assets or searching suitable buyers. However, some cases have demonstrated the tendency that the federal district courts may take the fix-it-first remedies proposal into account rather than directly accepting the FTC's objections. ${ }^{390}$

In FTC v. Libbey, Inc., Libbey proposed an acquisition of Newell Rubbermaid's Anchor Hocking. ${ }^{391}$ During the merger review procedures, the FTC sought to block the transaction

\footnotetext{
3832011 DOJ Policy Guide (n 56) 22-23.

384 Tunney Act, 15 U.S.C. \$16(b) (2013).

${ }^{385}$ United States v. Microsoft Corp., 159 F.R.D. 318, 321 (D.D.C. 1995).

386 See: Memorandum Opinion, United States v. Microsoft Corp., 159 F.R.D. 318 (D.D.C. 1995) (No. 94-1564), <https://www.justice.gov/sites/default/files/atr/legacy/2008/01/18/0102.pdf> accessed 18 March 2017.

${ }^{387}$ Microsoft Corp., 159 F.R.D., 321-323.

388 ibid, 332, 338.

389 See: United States v. Microsoft Corp., 56 F.3d 1448 (D.C. Cir. 1995).

390 Breed \& Michnal (n 351) 38-39.

${ }^{391}$ Fed. Trade Comm'n v. Libbey, Inc., 211 F. Supp. 2d 34, 37-38 (D.D.C. 2002).
} 
by requiring a preliminary injunction through litigation from a federal district court. Normally, the merging parties would choose to cooperate with the FTC to clear the agency's concerns by cooperating with the agency to negotiate a consent agreement before it launched the litigation. Instead of doing so, after the FTC filed a formal complaint, the merging parties tried to present a restructuring plan during the hearing for the preliminary injunction. Although Libbey failed and the federal district court still issued the preliminary injunction, having been convinced by the FTC that such merger would substantially lessen competition in the market, the district court rejected the FTC's contention not to consider the restructured agreement. ${ }^{392}$

In another transaction concerning Arch Coal's acquisition of Triton Coal, the FTC's complaint seeking a preliminary injunction to block the transaction was denied by the court. ${ }^{393}$ Arch Coal proposed to acquire Triton Coal and two other SPRB mines (North Rochelle and Buckskin), which all belonged to New Vulcan Coal Holdings. After the merging parties notified the agencies under the HSR Act, the FTC began to investigate and sought to block the transaction, considering that the merger would create coordinated effects in the relevant market by reducing the number of competitors from five to four, despite the parties' attempts to modify the transaction to include a divestiture of certain assets to a third party to restore the fifth competitor. The federal district court ultimately rejected the FTC's complaint since it held that the transaction would not "substantially lessen competition [in the market]". ${ }^{394}$

Although the courts' decisions in the above-mentioned cases have mixed results, these decisions still, to some extent, affect the FTC's attitude towards the fix-it-first remedies. The FTC may take the fix-it-first remedies into consideration instead of seeking to block mergers directly. For the merging parties, fashioning their own remedies may also be helpful before the courts. Accordingly, the difference concerning the attitude towards a fixit-first approach between the DOJ and FTC may have been reduced.

\subsubsection{Up-Front Buyer Provisions}

According to the DOJ's Policy Guide, an up-front buyer refers to a buyer that is proposed by the notifying parties and approved by the agencies before the implementation of the mergers. ${ }^{395}[\mathrm{G}]$ nder the up-front buyer provisions, the merging parties are required to find a qualified purchaser that is acceptable to the reviewing agency and to execute the divestiture agreement ... upon or very shortly after implementation of the merger'. ${ }^{396}$ Upfront buyer provisions are generally required when there is a risk of having difficulty finding an acceptable buyer. The difference between the fix-it-first remedy and up-front buyer provisions is that, with the latter, the agency does not know the identification of the proposed purchaser before it makes any decision. ${ }^{397}$

The distinct preference for ordering up-front buyer provisions also reflects another important difference between the DOJ's and the FTC's approach to merger divestiture. The FTC frequently employs up-front buyer provisions in the consent orders, while the DOJ has no preference to such provisions. As described in the 1999 FTC Divestiture

\footnotetext{
392 ibid, 38, 46.

${ }^{393}$ Federal Trade Commission, 'Statement of the Commission In the Matter of Arch Coal, Inc., et al.' <https://www.ftc.gov/system/files/documents/public_statements/568531/050613commstatement.pdf> accessed 16 March 2017, 2.

394 See: Fed. Trade Comm'n v. Arch Coal, Inc., 329 F. Supp. 2d 109, 114-115, 159 (D.D.C. 2004).

3952011 DOJ Policy Guide (n 56) 23-24.

396 ibid.

${ }^{397}$ Byowitz \& Sherman (n 360) 18-19.
} 
Study, the FTC often insists that firms propose an up-front buyer in order to minimise the amount of interim time between the implementation of mergers and the execution of divestitures. ${ }^{398}$ In the 2012 FTC Remedies Statement, it was noted that '[T] he Commission will typically require an up-front buyer if the parties seek to divest assets comprising less than an autonomous, ongoing business or if the to-be-divested assets are susceptible to deterioration pending divestiture'. ${ }^{399}$ By requiring an up-front buyer, the risk that no suitable acceptable buyers will be found will be reduced. Besides, an up-front buyer can also minimise the risk that the value of the pending to-be-divested assets will diminish during the period of finding an acceptable buyer. An up-front buyer will also be required by the FTC when the proposed divestiture package is mainly composed of intangible assets or the assets are limited with the premise that the FTC is convinced with the sufficiency of such assets regarding rendering the anti-competitive merger. ${ }^{400}$

The FTC has frequently required the inclusion of up-front buyer provisions in the situations where the proposed to-be-divested assets are not on a stand-alone basis. ${ }^{401}$ For example, in the Procter \& Gamble Company ("P\&G") and the Gillette Company's merger transaction concerning non-rechargeable battery powered toothbrushes, a proposed divestiture plan proposed by $P \& G$ concerning divesting Crest SpinBrush to Church \& Dwight was approved by the FTC. ${ }^{402}$ Crest SpinBrush was a brand for P\&G's batterypowered and rechargeable toothbrush business that was not operated separately. To reduce the risk of failing to find an acceptable buyer, Church \& Dwight was identified as an upfront buyer before the transaction's implementation. An up-front buyer may also be required in cases where the to-be-divested assets seem not to be attractive enough to a potential buyer. In Nestle Holding, Inc.'s acquisition of the ice cream business of Dreyer's Grand Ice Cream, Inc., the Commission authorised staff to seek a preliminary injunction to block the proposed transaction on the grounds that such a merger would reduce competition in the highly concentrated market for super-premium ice cream. ${ }^{403}$ 'Before the complaint was filed in a federal district court, the parties agreed to enter into a consent agreement to settle the charges'. ${ }^{404}$ The final order required the divestiture of ice cream, fruit bar, and distribution assets to CoolBrands International, Inc., which was also identified as an up-front buyer.

Despite the 2012 version of the FTC Merger Remedies Statement, an up-front buyer is typically required in certain situations. In recent years, the FTC has also approved several consent agreements in which an up-front buyer has not been identified. This may, to some extent, indicate that the FTC increasingly accepts consent agreements without up-front

\footnotetext{
3981999 FTC Divestiture Study (n 38) 39.

399 ibid, 6.

400 ibid, 7.

401 Byowitz \& Sherman (n 360) 19.

402 See: Federal Trade Commission, Procter \& Gamble Co. and Gillette Co., No. C-4151, 0510115’ (Federal Trade Commission, 15 December 2005), <https://www.ftc.gov/enforcement/cases-proceedings/0510115/proctergamble-company-gillette-company-matter> accessed 25 April 2017.

${ }^{403}$ See: Federal Trade Commission, 'Nestle Holdings, Inc., Dreyer's Grand Ice Cream Holdings, Inc., and Dreyer's Grand Ice Cream, Inc., No. C-4082, 0210174' (Federal Trade Commission, 6 November 2003), <https://www.ftc.gov/enforcement/cases-proceedings/0210174/nestle-holdings-inc-dreyers-grand-ice-creamholdings-inc $>$ accessed 20 March 2017.

404 ibid; for the detailed timeline of the case, see: Federal Trade Commission, Nestle Holdings, Inc.; Dreyer's Grand Ice Cream Holdings, Inc.; and Dreyer's Grand Ice Cream, Inc.' (Federal Trade Commission, 15 July 2005), <https://www.ftc.gov/enforcement/cases-proceedings/0210174/nestle-holdings-inc-dreyers-grand-ice-creamholdings-inc $>$ accessed 25 March 2017.
} 
buyers. ${ }^{405}$ The Alan B. Miller and Universal Health Services, Inc. ("UHS") case is a typical example reflecting that point. Under the terms of the proposed consent agreement in that case, UHS was required to divest the Peak Behavioural Health Assets ("Peak"), within six months after the Decision and Order was issued. No up-front buyers had been identified before the FTC approved the proposed divestiture plan. ${ }^{406}$ In the approved consent agreement, it further provided that if the to-be-divested assets were not sold to an approved acquirer within six months, a divestiture trustee would be appointed and empowered to divest. The purpose of this provision was to address the uncertainty of whether Peak alone was sufficient to attract an acquirer that would compete as effectively as UHS did prior to the merger. ${ }^{407}$

Unlike the FTC, the DOJ has no preference of requiring the parties to identify buyers of the to-be-divested assets before the agency will accept a consent agreement. The DOJ will only consider an up-front buyer in certain cases. In the 2004 version of the DOJ Policy Guide, the DOJ was silent on this issue. In the 2011 version, it noted that '[T] he Antitrust Division of the DOJ may enter into a consent decree agreeing to this type of up-front buyer proposal in cases where it determines that the proposed sale will effectively preserve competition in the relevant market post-merger'. ${ }^{408}$ In the new version of the Policy Guide, the DOJ identifies several benefits of up-front buyer provisions. First, from the perspective of the merging parties, it can shorten the whole divestiture process, providing more certainties about the transaction compared with searching for an acceptable buyer after the implementation of the merger. Second, for the DOJ, such provisions can be cost-saving since costs incur during longer investigations and post-merger divestment can be reduced. The certainties created by up-front buyer provisions can reduce the risk of unavailability of a suitable buyer, which can to some extent increase the effectiveness of divestitures in restoring competition.

The rationale upon which the up-front buyer provisions rest is to reduce the risk of unavailability of an acceptable buyer, which will ultimately cripple the effectiveness of divestitures or, even worse, the failure of divestitures. As stated above, both the FTC and the DOJ have expertise in different industries. Accordingly, they may face different risks when ordering divestitures. For example, the risk of wasting assets tends to be more prevalent in retail mergers that are within the purview of the FTC instead of the DOJ. 409 This is also confirmed by the reasons stated in the 2011 DOJ Policy Guide explaining why the DOJ requires up-front buyers. It stated:

[T]iming can be a critical factor [when] determining the parameters of an effective remedy. In some cases, the parties may pursue a pre-implementation "fix-it-first" remedy that may resolve the Division's competitive concerns without requiring . . . suit. In other cases, the parties may propose an up-front buyer for a specific package of divestiture assets. ${ }^{410}$

For example, for mergers involving the retail industry, the value associated with the brands can deteriorate quickly if the divestiture period is protracted and no appropriate

\footnotetext{
405 Alec Y. Chang, Ian G. John \& Steven C. Sunshine, 'FTC Increasingly Accepts Consent Agreements Without Upfront buyers' (SKADDEN, 29 November 2010), <https://www.skadden.com/sites/default/files/publications/ Publications2299_0.pdf $>$ accessed 18 March 2017.

${ }^{406}$ Federal Trade Commission, 'Analysis of Agreement Containing Consent Orders to Aid Public Comment - In the Matter of Alan B. Miller and Universal Health Services, Inc. 1' (2012), <http://www.ftc.gov/sites/default/ files/documents/cases/2012/10/121005uhsascendanal.pdf > accessed 25 March 2017.

407 ibid.

4082011 DOJ Policy Guide (n 56) 23-24.

${ }^{409}$ Pate (n 382) 423.

${ }^{410} 2011$ DOJ Policy Guide (n 56) 21.
} 
measure is taken to preserve the value. ${ }^{411}$ The longer the period of divestiture is protracted, the greater the risk of diminishing the value of the to-be-divested assets. Since the up-front buyer provisions address the certainty of whether the proposed assets are able to attract an acceptable buyer, and can shorten the pending period, it can be concluded that in cases involving certain industries, such as the case with retail mergers, up-front buyer provisions are very likely to be employed more frequently than those involving other industries.

\subsubsection{Crown Jewel Provisions}

As the name suggests, a crown jewel provision refers to a provision under which the merging parties have to divest an expanded or alternative divestiture package with more value if they fail to finish divesting the original divestiture package within the first period agreed upon by them and the agencies. ${ }^{412}$ Accordingly, the assets included in the crown jewel provisions are more "valuable" than the original one to attract an acceptable buyer who is able to operate the business to restore competition. The rationale behind why such provisions are ordered may be to alleviate the tense relationship between the agencies' concerns of unavailability of a suitable purchaser and the merging parties' unwillingness to divest valuable assets during the negotiations regarding the divestiture plan. ${ }^{413}$ Crown jewel provisions, in essence, are about who bears the risk. Before the publication of the 2011 DOJ Policy Guide, the DOJ and FTC had completely different attitudes toward the crown jewel provisions. The FTC frequently required crown jewel provisions in the consent orders, where the DOJ strongly disapproved of those provisions, reflected in the 2004 version of Policy Guide. With the release of its new Policy Guide, the DOJ changed its attitude and confirmed its use to increase the likelihood of emergence of an appropriate purchaser. ${ }^{414}$

A distinct shift towards the inclusion of crown jewel provisions in consent orders indicates a "true policy change" at the FTC. ${ }^{415}$ The FTC has used crown jewel provisions in consent orders as a last resort in the event no purchaser is interested in the original package. The 1999 FTC Divestiture Study concluded that the inclusion of crown jewel provisions may have an impact on incentivising respondents (the merging parties) to initially propose a sufficient package that is adequate to create a viable competitor in the relevant market, and therefore, to avoid the activation of provisions to divest the alternative divestiture package. ${ }^{416}$ The 2012 FTC Remedies Statement also had a similar statement- that is, crown jewel provision will be typically required in case the respondent fails to divest the original divestiture package in a timely manner. ${ }^{417}$

The 1999 FTC Divestiture Study also identified several grounds for the preference of crown jewel provisions. First, such provisions increase the availability of an acceptable buyer should the original divestiture package fail to attract buyers. Second, the risk of divesting larger packages of assets will incentivise the merged firm to preserve the value and marketability of the pending assets. The crown jewel provision is not used as a punishment for the merging parties should they fail to divest within the divestiture

\footnotetext{
411 Pate (n382) 423.

${ }^{412}$ Triggs (n 259) 75.

413 See: Carl Shapiro and Michael Sohn, '"Crown Jewel" Provisions in Merger Consent Decrees' (1997) 12 Antitrust 27, 27.

414 See: sec.6.2.2.2.

415 Shapiro \& Sohn (n 413) 29.

4161999 FTC Divestiture Study (n 38) 30.

4172012 FTC Remedies Statement (n 36) 21.
} 
period. ${ }^{418}$ Instead, it is used as a tool to speed up the whole divestiture, and ensure the availability of a suitable buyer, which will ultimately increase the effectiveness of divestiture.

In the merger cases regarding Rhone-Poulenc S.A. ("RP") and Hoechst AG ("Hoechst"), which formed into a new company, "Aventis", a crown jewel provision was required. ${ }^{419}$ In the original package, the Hoechst and RP were required to divest certain assets including those relating to RP's direct thrombin inhibitor drug Revasc. ${ }^{420}$ If Aventis failed to divest Revasc to an acceptable buyer on time, a trustee would be appointed by the FTC to accomplish the divestiture by divesting either Revasc or Hoechst's comparable drug Refludan, the only direct thrombin inhibitor then on the American market. ${ }^{421}$ Ultimately, the FTC made use of the crown jewel provision and the alternative packages were divested by the trustee.

Overall, the FTC uses crown jewel provisions more frequently than the DOJ does; however, it currently changes its preference to up-front buyer provisions and orders them more often than before. ${ }^{422}$

In terms of risk-reduction, the crown jewel provisions and up-front buyer provisions may have the same effect. In the Diageo/Pernod case mentioned in Section 4.2 above, a crown jewel provision was required in the consent agreement to ensure that an acceptable buyer would be found. Ultimately, the transaction was blocked by the FTC on grounds that the merging parties refused to divest sufficient assets. In this case, the crown jewel provision and the up-front buyer provision were actually substitutive since both have the effect of finding a suitable buyer.

In other cases, these two provisions were ordered at the same time. The FTC holds that:

[A]n up-front buyer does not necessarily eliminate the need for a crown jewel provision. Agreements with up-front buyers occasionally fall through. In such a case, the original asset package may be unattractive to any other buyer, so there may be a need to alter or expand the original divestiture package to accomplish relief if the "upfront" deal falls through. ${ }^{423}$

For example, in Chevron/Texaco, up-front buyer Avfuel was identified, and had the combined entity not sold Texaco's aviation fuel business in fourteen states to the up-front buyer, then Texaco's entire aviation fuel marketing would be divested. ${ }^{424}$

In fact, the FTC's trend of using crown jewel provisions may be on the decline. ${ }^{425}$ According to the FTC, the Aventis case was the single one in which a crown jewel provision

\footnotetext{
4181999 FTC Divestiture Study (n 38) 30-31.

${ }^{419}$ Federal Trade Commission, 'Hoechst AG, No. C-3919, Order Reporting and Modifying Order' (22 November 2002) <http://www.ftc.gov/sites/default/files/documents/cases/2002/12/hoechsmod.htm> accessed 20 March 2017.

420 Federal Trade Commission, 'Hoechst AG, No. C-3919, Decision and Order' (7 December 1999), <http://www.ftc.gov/sites/default/files/documents/cases/1999/12/hoechst.do_.htm> accessed 20 March 2017. 421 ibid.

${ }^{422}$ Elai Katz and Lauren Perlgut, 'Appraising Crown Jewel Provisions in the United States, Canada, and Europe' (Cabill Gordon \& Reindel LLP, 2009) <http://www.cahill.com/publications/antitrust-monthlycolumn/000086/_res/id=Attachments/index=0/Appraising $\% 20$ Crown $\% 20 J$ ewel $\% 20$ Provisions $\% 20$ in $\% 20$ the $\%$ 20United\%20States> accessed 19 March 2017.

${ }^{423}$ See: FTC, 'Frequently Asked Questions About Merger Consent Order Provisions'(Federal Trade Commission) <http://www.ftc.gov/tips-advice/competition-guidance/guide-antitrust-laws/mergers/merger-faq\#Crown Jewels> accessed 23 March 2017.

${ }^{424}$ FTC, 'Chevron Corp., No. C-4023, Decision and Order' < https://www.ftc.gov/sites/default/files/documents/ cases/1997/02/c3740.do.pdf > accessed 19 April 2017. In this case both the up-front buyer and a crown jewel provision were required.

${ }^{425}$ Byowitz \& Sherman (n 360) 27.
} 
was ordered. ${ }^{426}$ With regard to the DOJ, it had some concerns about ordering crown jewel provisions in the 2004 DOJ Policy Guide. However, in the 2011 DOJ Policy Guide, it already confirms the usage of crown jewel provisions. Meanwhile, the FTC confirms the use of the crown jewel provisions in both the 1999 Divestiture Study and the 2012 Merger Remedies Statement 2012. Accordingly, the FTC and the DOJ's different attitudes toward crown jewel provisions are exaggerated since very few of the FTC's recent merger cases have been resolved with crown jewel provisions, and the difference is narrowing. ${ }^{427}$

\subsubsection{Trustees}

The DOJ and FTC use trustees as a tool to facilitate divestitures in merger cases. For example, an operating trustee will be appointed by the FTC and the DOJ to take charge of the day-to-day management and operation of the to-be-divested assets to ensure that the value of the assets will not diminish during the pending period. The DOJ will appoint a selling trustee in a divestiture remedy when it thinks the merging parties may be unable to divest the assets within time frame, and thus, the selling trustee can make sure to divest the assets timely and in an effective manner. The FTC will appoint a "divestiture trustee" under similar situations as the DOJ does. ${ }^{428}$ The divergence between the DOJ and the FTC is the appointment of monitoring trustees, who are usually appointed to oversee the respondent's compliance with the consent agreements. The FTC requires a monitoring trustee more frequently than the DOJ does.

As described in the 1999 FTC Divestiture Study, auditor trustees, as independent observers, can be very helpful in resolving issues between the respondent and the buyer due to their professional knowledge and free access. They also can monitor the respondent's compliance of their obligations of the divestiture. ${ }^{429}$ It thus can be observed that the FTC is quite willing to require a trustee during the implementation of divestitures.

For the DOJ, it experienced an attitude change towards the use of trustees. As reflected in the 2004 DOJ Policy Guide, the use of trustees was quite limited. It stated that the situations for appointing monitoring trustees would be rare, limited to situations where 'the trustee's expertise is critical to an effective divestiture'. ${ }^{430}$ It further made it clear that in a certain transaction, a monitoring trustee's task '[w]ould simply duplicate, and could potentially conflict with the DOJ's own decree enforcement efforts'. ${ }^{431}$

In contrast, in the 2011 DOJ Policy Guide, it notes that the DOJ will consider appointing a monitoring trustee not only to review the respondent's compliance with the merger divestiture obligations, but also to oversee the merged party's compliance with a conduct remedy involving ongoing obligations. It further confirms that the function of a monitoring trustee as ' $\mathrm{A}]$ monitoring trustee with industry experience can reduce the burden on the [Antitrust] Division and the parties while ensuring that the parties adhere to the [consent] decree'. ${ }^{432}$ By comparing these two versions of the DOJ's policy guide, it is easy to notice the changing attitude of appointing monitoring trustees by the DOJ.

Accordingly, before the release of the 2011 DOJ Policy Guide, the different approaches concerning appointing monitoring trustees between the DOJ and the FTC were quite

426 See: 2012 FTC Remedies Statement (n 36) 9.

${ }^{427}$ Majoras (n 376) 8-9.

4282011 DOJ Policy Guide (n 56) 26.

4291999 FTC Divestiture Study (n 38) 30.

${ }^{430}$ Breed \& Michnal (n 351) 40.

${ }^{431}$ Marleen van Kerckhove, 'The EU Remedies Study: Toward Further Transatlantic Convergence in Merger Remedies?' (2006) 21 Antitrust 66, 68.

4322011 DOJ Policy Guide (n 56) 26. 
distinct. With the DOJ's changing attitude towards monitoring trustees, reflected in the new policy guide, such divergence is expected to become less obvious.

The FTC and the DOJ share the same standard for assessing an effective merger divestiture, and also have some common ground in ordering divestitures in practice. For example, both prefer structural remedies to conduct remedies in merger cases, and share the same criteria when setting the scope of divestiture assets and choosing suitable buyers. Both also require shorter divestiture periods than before. However, there still remain different approaches when ordering divestitures. '[T] he DOJ policy is supported by a more free-market view of competition, which assumes that the market will take care of competition issues itself, and which requires the government to play only a minimal role in controlling potentially anti-competitive situations'. 433 In contrast, the FTC prefers controlling the whole remedy procedure. In other words, the FTC has more involvement in ordering merger divestiture than the DOJ does. Over time, the FTC has gained a reputation for being the more "aggressive" of the two antitrust agencies. ${ }^{434}$

Regarding the different approaches of divestiture policies between the FTC's and the DOJ's, the two agencies try to make the divestiture procedures more transparent and predictable by publishing the FTC Merger Remedies Statement $(2003 / 2012)$ and the DOJ Policy Guide (2004/2011). It is worth noting that several changes have happened in the DOJ's new 2011 Policy Guide, indicating the DOJ's willingness to be more involved in divestiture practice. ${ }^{435}$ As described above, such changes are typically reflected in the approaches of approving the fix-it-first remedies, ordering up-front buyer provisions, crown jewel provisions, and appointing monitoring trustees. Accordingly, the divergences concerning the divestiture policies between the FTC and the DOJ are expected to be narrowed down and convergence will be the trend.

\section{Conclusion}

The Sherman Act and the Clayton Act are the two main pieces of legislation in the merger control field in the US. The substantive rule "Substantively Lessen Competition in the market (SLC test)" for reviewing mergers has been set up in the Clayton Act. With the passage of the HSR Act (which has been incorporated into the Clayton Act), the procedural rules have been largely changed with the introduction of a pre-merger notification and a mandatory waiting period after submitting the notification. Facilitated by the HSR Rules published by the FTC, a rigorous and complicated merger control system has thus been created. At every stage in the merger review procedure, beginning with the pre-merger notification, defined and practical tests will be applied to evaluate and determine whether the proposed transactions should be cleared, prohibited or allowed to proceed with additional conditions, such as divestitures.

As a typical structural remedy, divestiture is preferred by both the FTC and the DOJ for its simple and relatively easy administration. It is regarded as one of the most effective remedies in mergers involving horizontal overlaps. Recently, it has also been used in some vertical or conglomerate mergers (usually in combination with other remedies). The

\footnotetext{
${ }^{433}$ Strock (n 254) 2174.

434 See: Heidi N. Moore, 'Beware of the F.T.C.' (INTL'L N.Y. TIMES: DEALBOOK, 4 November 2010) <http://dealbook.nytimes.com/2010/11/04/beware-of-the-f-t-c/?_php=true\&_type=blogs\&_r=0.> accessed 16 March 2017.

4352011 DOJ Policy Guide (n 56) 1.
} 
question regarding the FTC's and the DOJ's different merger divestitures policy is raised with increased awareness of the fact that the effectiveness of merger divestitures can, to a large extent, influence the achievement of merger control goals, whereas the two competition agencies' different merger divestiture policies may more or less cripple the transparency, certainty, and predictability of the whole merger control procedures.

The discrepancy is, to some degree, caused by the FTC's and the DOJ's different expertise, different internal structure concerning merger investigation and negotiation and administration of consent agreements, and different consent procedures. When looking at the emergence, evolution and development of merger divestiture, it can be observed that merger divestitures have experienced great changes. Both the competition agencies have also developed their own divestiture policies with which they believe they can clear the anti-competitive effects that mergers may bring about.

Before the enactment of the HSR Act, since there was no pre-merger notification requirement, which means it is rather difficult for the competition agencies to detect merger transactions until the implementation. Divestiture during this period was likely to be a pyrrhic victory because the merged entities were so assimilated with each other that it was almost impossible to dismantle them. After the enactment of the HSR Act, the effectiveness of merger divestitures had increased a lot because the agencies were given the opportunity to become aware of merger transactions before implementation under the prenotification requirements. Furthermore, the mandatory waiting period grants the agencies opportunities to assess whether the transactions will or may cause anti-competitive effects.

During the recent decades, merger divestitures have greatly increased due to the developing practice of the FTC and the DOJ. On the one hand, some common grounds are shared by the two competition agencies. As the most important elements in merger divestitures, the appropriateness of composition of a divestiture package and the suitability of a buyer can have a substantial impact on the effectiveness of a merger divestiture. Similar criteria are adopted by both the competition agencies to ensure that the divested business can compete with the merged parties viably if operated by a suitable buyer, and ultimately restore competition to the market. On the other hand, discrepancy still exists when it comes to detailed divestiture design and enforcement policies. However, with the publication of the 2011 DOJ Policy Guide the DOJ changed its attitude towards some divestiture policies that used to be quite different from the FTC's. The increasing cases dealt with by the FTC in which the FTC failed to convince the court of its claims, showed that the FTC is very likely to rethink its strategy and divestiture policy in its future practice. Thus, it can be predicted that the discrepancies between merger divestitures are narrowing, leading to a convergence of the future divestiture policies development between the FTC and the DOJ. 


\section{Chapter}

\section{EU: DIVESTITURES UNDER MERGER CONTROL IN THE EUROPEAN UNION}





\section{Introduction}

In the EU, both the European Commission ("Commission") and the National Competition Authorities ("NCAs") have the competence to enforce EU competition rules, including Art.101-109 of the Treaty on the Functioning of the European Union ("TFEU") 436 , only the Commission, however, will take responsibility to evaluate merger transactions with an EU dimension. ${ }^{437}$ Under the merger review procedures, the Commission acts as the investigator, prosecutor and judge, which means that it can decide whether to prohibit or clear (maybe with additional conditions, such as divestitures) a proposed merger transaction by itself without resorting to other authorities. On the other hand, a judicial review against the Commission's decision in merger cases is also available for the parties to the European courts. Such appeals, nevertheless, are seldom brought. ${ }^{438}$

As described in Chapter 2, the Hart-Scott-Rodino Antitrust Improvements Act (the "HSR Act") is deemed a milestone in the development of US merger control policy, With the introduction of the pre-merger notification and the mandatory waiting period in the HSR Act, the US CAs, namely the FTC and the DOJ, were enabled to be aware of a merger transaction before its implementation and further investigate whether such transaction will substantively lessen competition in the market. In the European Union, the 1989 Merger Regulation ("1989 MR") was the first regulation that assigned to the European Commission the authority to control mergers at the EU level. ${ }^{439}$ In the 1989 MR, both the pre-merger notification and the mandatory waiting period were introduced, resulting in the similarity of the general merger control procedures between the US and the EU. Afterwards, in 2001, to better facilitate the implementation of merger remedies, the Commission released the 2001 EC Remedies Notice. ${ }^{440}$ It reflected and summarised the legislation and enforcement experience that the Commission had obtained since 1990, and provided both procedural and substantive guidance to the use of merger remedies, especially of divestitures. The 2001 EC Remedies Notice could be deemed as a typical example, showing that the EU learned from the US as far as the merger remedy is concerned at the beginning, and this notice was deeply influenced by the 1999 FTC Divestiture Study. ${ }^{441}$

Since the changed economic conditions and political situations, the revised EU Merger Regulation ("2004 EUMR") was enacted in 2004 after intensive negotiations, which replaced the $1989 \mathrm{MR}^{442}$ In the 2004 EUMR, the substantive test of merger review was changed from a "dominance test" to a so-called "SIEC test" (Significantly Impede Effective Competition). The newly introduced SIEC test is deemed to be analogous to the US SLC test (Substantially Lessen Competition) from the perspective that it adopts a more

\footnotetext{
${ }^{436}$ Treaty on the Functioning of the European Union [2007] OJ C326/47 (hereinafter: TFEU).

${ }^{437}$ A transaction will be regarded as with an EU dimension if it satisfies several criteria which are listed to evaluate whether a pre-merger notification should be made to the Commission. Details of the EU dimension is explored in sec. 2.4 below.

438 Andrew Renshaw and Jan Blockx, 'Judicial Review of Mergers in the EU' (2013) 58(2-3) Antitrust Bulletin 495, 496.

${ }^{439}$ Council Regulation (EEC) No 4064/89 on the Control of Concentrations between Undertakings [1989] OJ L395 (hereinafrer: 1989 MR).

440 Commission Notice on Remedies Acceptable under Council Regulation (EEC) No. 4064/89 and under Commission Regulation (EC) 447/98 [2001] OJ C68 (hereinafter: 2001 EC Remedies Notice).

${ }^{441}$ Ming Shang, Qi ye bing gou fan long duan kong shi - ou meng ji bu feng cheng yuan guo li fa zhi fa jing yan [Merger Control in EU and Several Member States - Legislation and Enforcement Practice 《企业并购反垄断控制一欧盟及部分成员国立 法执法经验》7 (Fa Lü chu ban she 2008) 367-379.

4422004 EUMR (n 3)
} 
economic approach in merger review. ${ }^{443}$ To keep the Commission's merger remedy policies up-to-date, a new Remedies Notice was published in 2008, which took the place of the 2001 EC Remedies Notice. ${ }^{444}$ The new Remedies Notice included the research results of the 2005 EC Merger Remedies Study conducted and released by the Directorate-General for Competition ("DG COMP") ${ }^{445}$ and combined the experience obtained from the Commission's enforcement practice, the court's decisions, and opinions received from the general public regarding the old 2001 EC Remedies Notice. The 2008 EC Remedies Notice comprehensively reflects the Commission's development of a merger remedies policy, especially of merger divestitures. To address the questions of what are the applicable merger control rules in the EU and how did merger divestitures emerge and develop there, the remainder of this chapter is structured as follows:

In sec.2, the applicable legislation on merger control in the EU is explored. Procedures and the substantive test of the EU merger review are investigated in sec.3. The fourth section explores how merger divestiture policies develop at the EU level. The focus in this section is on the 2001 EC Remedies Notice. The fifth section consists of two sub-sections: first, the case Schneider/Legrand is introduced and analysed, focusing on the problems that existed in the merger divestitures after the publication of the 2001 Merger Remedies Notice; second, the 2005 EC Merger Remedies Study which identified and summarised the drawbacks in designing and implementing effective merger divestitures is studied in detail. In sec.6, recent developments in the EU regarding merger divestitures are explored, including a discussion of the 2008 EC Remedies Notice (focus on the changing approaches the Commission employs when ordering divestitures). A conclusion is presented in sec.7.

\section{Application of Merger Control Legislation in the EU}

\subsection{A Brief History of Merger Control at the EU Level}

The EU merger control history post World War II can be generally divided into three phases, the 1950s, the 1960s to the 1980s and the 1990s onwards. The establishment of a competition unit at the EU level can be traced back to the beginning of early post World War II to the early 1960 s. ${ }^{446}$

The end of World War II saw the beginning of the leadership of the US in the economic world. On the one hand, the American post-war strategy was to (re)create an open world economy, under which money, goods and technology could move freely. ${ }^{447} \mathrm{On}$

\footnotetext{
${ }^{443}$ Kirchner (n 2) 12.

4442008 EC Remedies Notice (n 35).

4452005 EC Merger Remedies Study (n 27).

${ }^{446}$ In this section, only the development of the merger control at the EU level is discussed. For the development and evolvement of the competition law or merger control policy at national level in the Europe, see, for example: David J. Gerber, 'Europe and The Globalization of Antitrust Law' (1999) 14 Conn J Int'l L 15, 17; David J. Gerber, Law and Competition in Twentieth-Century Europe: Protecting Prometheus (Oxford University Press 1998). It is pointed out by Gerber (1999) that it is a misunderstanding that the EU competition law was transmitted from Germany's, who had copied from the US'. Actually, the EU competition law has its origins in Vienna in the 1890s, where, during that time, scholars explored to protect competition by laws. These scholars also proposed to protect competition administratively.

${ }^{447}$ Hubert Bush-Hansen, 'Rethinking the History of European Level Merger Control: A Critical Political Economy Perspective' (PhD thesis, Department of Intercultural Communication and Management of Copenhagen Business School 2008) 80.
} 
the other hand, the Marshall Plan ${ }^{448}$ gave the Western European countries strong incentives to incorporate into such an open global economy. Since the US had an occupying power in Germany (at least), the Americans were in a good position to exert their impact on post-war developments in Europe. ${ }^{449}$ One of the policies the US pursued was to control the cartels and huge concentrations in the German industry. Not only in Germany, but also elsewhere in Europe during that period, many industries had a tradition of high concentration or state involvement, especially in the steel sector and coal sector. In contrast, the US had enacted its very first competition law, namely the Sherman Act, in 1890 and has a tradition of anti-trust.

With the influence exerted by the US and the European countries' intention of rebuilding the economy, among other reasons, the Treaty Establishing the European Coal and Steel Community ("ECSC Treaty") was signed in 1951 and came into force in August 1952, in which the merger control rules are set out in detail in Art. 66.450

In 1957, the Treaty Establishing the European Economic Community ("EEC Treaty", also known as the Treaty of Rome) created the European Economic Community ("EEC"). Art. 85 of the Treaty of Rome prohibits cartels within the internal market. These infringing agreements or decisions will be deemed to be automatically void. Abuse of dominant position is prohibited by Art. 86. The Treaty on European Union ("TEU", also known as the Maastricht Treaty) was enacted on 1 November 1993, which created the European Union and amended the Treaty of Rome. The amended treaty was named as the Treaty Establishing the European Community ("TEC"). In addition, the above-mentioned two provisions were accordingly renumbered as Art.81 and Art. 82 of the TEC. Afterwards, with the enactment of the Lisbon Treaty on 1 December 2009 which amended the Maastricht Treaty and the TEC and renamed the TEC as TFEU, Art.81 and Art. 82 of the TEC were renumbered again as Art. 101 and Art. 102 of the TFEU. DG COMP within the European Commission is assigned the responsibility to enforce the competition provisions. Unlike the ECSC Treaty, however, the TEEC did not mention a word on merger control. It was more concerned with preventing the abuse of dominant position by undertakings instead of preventing market concentrations. ${ }^{451}$ By that time, the influence of the US had decreased

${ }_{448}$ The Marshall Plan, officially named the European Recovery Program (ERP), was named after the Secretary of State George Marshall. It was proposed by the US to rebuild European economies through economic support. The plan began in April, 1948 and ran for four years. The goals of this plan were to rebuild the war-devastated regions, remove trade barriers, modernize industries, and make Europe prosperous again. See: 'Marshall Plan' (Wikipedia, last modified on 16 April 2017) < http://en.wikipedia.org/wiki/Marshall_Plan\#cite_note-1> accessed 17 April 2017.

449 Bush-Hansen (n 447) 80.

450 The Treaty Establishing the European Coal and Steel Community created the European Coal and Steel Community [1952] (expired on 23 July 2002) was the first international organization based on the principle of super-nationalism. It was first proposed by the French foreign minister Robert Schuman on 9 May 1950 as a way to prevent further war between France and Germany. The ECSC Treaty also led to the formation of European Union. The first paragraph of Art. 66 of the ECSC Treaty reads:

Any transaction shall require the prior authorization of the High Authority, subject to the provisions of paragraph 3 of this Article, if it has in itself the direct or indirect effect of bringing about within the territories referred to in the first paragraph of Article 79, as a result of action by any person or undertaking or group of persons or undertakings, a concentration between undertakings at least one of which is covered by Article 80, whether the transaction concerns a single product or a number of different products, and whether it is effected by merger, acquisition of shares or parts of the undertaking or assets, loan, contract or any other means of control. For the purpose of applying these provisions, the High Authority shall, by regulations made after consulting the Council, define what constitutes control of an undertaking.

${ }^{451}$ Eleanor M. Fox, 'Monopolisation and Dominance in the United States and the European Community: Efficiency, Opportunity, and Fairness' (1986) 61 Notre Dame L Rev 981, 986. 
and the French political decision-makers no longer supported strong competition rules. ${ }^{452}$ The changed political and economic situations may, to some extent, explain the absence of merger control in the TEEC.

Period II from the1960s to the 1980s saw the gradually changing attitude of the EU towards merger control. During this period, several proposals of merger control at EU level had been made but all failed due to various reasons.

In 1962, the Regulation 17/62 was passed to set down the procedural guidelines for Art. 85 (now Art. 101 TFEU) and Art. 86 of the Treaty of Rome (now Art. 102 TFEU). ${ }^{453}$ As a result of the Commission's concerns that too many concentrations may impede the development and viability of smaller firms, the Memorandum on the Problems of Concentration in the Common Market was published in 1966 by the Commission. It was the first time for the Commission to state what is regarded as the place of merger in Community competition policy. ${ }^{454}$ With increasing awareness of the potential negative impacts brought by mergers, the Commission began to seek the authority to control mergers at the EU level in the early 1970s. The first Merger Regulation was drafted and proposed to the Council of the European Union in 1973 but failed due to strong opposition from countries such as the United Kingdom and Germany, which already had well-developed merger control rules at their national level and considered control over mergers as politically important. ${ }^{455}$

The failure of the 1973 Merger Regulation Proposal gave rise to the Commission's resort to Art. 101 of the TFEU to test whether it provided a possibility to control mergers. In the Continental Can case, ${ }^{456}$ the New York based metal packaging company proposed to acquire its Dutch licensee, Europemballage, by purchasing $80 \%$ of its shares. The Commission blocked this merger transaction by holding that Continental Can had enjoyed a dominant position in the relevant market already due to its acquisition of another German packaging factory one year ago, and acquisition of Europemballage would be an abuse of dominant position which would have eliminated competition in the packaging market if implemented. The Commission's negative decision was appealed by the parties to the Court of Justice ("CJ", former European Court of Justice, "ECJ") ${ }^{457}$, whereas the CJ supported the prohibition decision.

However, it was evident that Art. 101 of the TFEU is incapable of being used as an effective tool to control mergers in a systematic and coherent way. 458 Afterwards, in 1981, 1984 and 1986, attempts for enacting a Merger Regulation at the EU level all failed due to lack of support. After 20 years of negotiations, the Member States finally reached an

\footnotetext{
452 Bush-Hansen (n 447) 100.

${ }^{453}$ EEC Council: Regulation 17/62: First Regulation Implementing Articles 85 and 86 of the Treaty [1962] OJ 13. (now art 101 and art 102 of the TFEU).

454 See: Terry M Moe, 'Political Institutions: The Neglected Side of the Story' (1990) 6 (Special Issue) J L Econ \& Org 213, 213.

455 Alec Burnside and Carl Meyntjens, 'The EEC Merger Regulation and its Impact on Non-EEC Business' (1990) 1990 BYU L Rev 1373, 1377.

${ }^{456}$ Case 6-72, Europemballage Corporation and Continental Can Company Inc. v Commission of the European Communities (Judgement of the European Court of Justice) [21 February 1973] <http://eur-lex.europa.eu/legalcontent/EN/TXT/?uri=CELEX\%3A61972CJ0006> accessed 20 April 2017.

457 The Lisbon Treaty made some changes to the EU court structure. Among all, it changed the name of the Court of First Instance (CFI) to the General Court. The higher court, the European Court of Justice, was renamed as the Court of Justice. The Court of Justice of the European Union (CJEU) compromises three courts, the General Court, the Court of Justice and the Civil Service Tribunal. See: Court of Justice of the European Communities, 'The Treaty of Lisbon and the Court of Justice of the European Union' (EUROPA, 20 November 2009) <http://curia.europa.eu/jcms/upload/docs/application/pdf/2009-12/cp090104en.pdf> accessed 21 April 2017. 458 Burnside and Meyntjens (n 455) 1379.
} 
agreement regarding merger control, which symbolises the beginning of a new era of the EU merger control.

The Commission obtained the authority to control mergers at the EU level with the enactment of the EEC Merger Regulation in 1990, providing the legal foundation for the Commission to control those mergers which may have the effect of impeding effective competition among several Member States. Over the years, the Commission has developed and released a series of notices on implementing the merger regulation to facilitate the merging parties to better understand the procedures, the substance of merger review and other details concerning the practice of the 1989 MR.

Meanwhile during those years, discussions on revising the 1989 MR were continuing in order to keep it up to date in the light of the changed economic and political landscape in Europe and the world. Several amendments have thus been made. ${ }^{459}$ In 2004, a new version of the Merger Regulation was finally enacted by the European Council, namely, the 2004 EUMR, which replaced the old version.

\subsection{Competition Authority in the EU}

In the EU, both the Commission and the NCAs can directly enforce EU competition rules, including Art. 101 - Art. 109 of the TFEU, to protect effective competition in the internal market and to ensure that all companies compete equally and fairly. They have the authority to enforce EU competition policy in the field of cartels, abuse of dominance, merger control, and liberalised markets monitoring. Meanwhile, only the Commission is granted the authority to enforce the rules on state aid. With regards to merger control, all proposed mergers with an EU dimension have to be notified to the Commission before their implementation and theoretically, such mergers will be investigated by the Commission.

The Commission has a multi-role as the investigator, prosecutor and judge. It can investigate and prosecute a case if it has the evidence to believe that an infringement of competition rules has been made or will be made. It can also decide independently without any final approval from the Courts on whether to clear (maybe with remedies) such mergers. Commission decisions can be appealed to the General Court ("GC", former the Court of First Instance, "CFI") for the first instance and further be brought to the CJ. 460 DG COMP within the Commission plays a prominent role for the enforcement, and it is one of the DGs which executes the Commission's investigator and decision-maker role in the merger control field. ${ }^{461}$ Notifications made by the merging parties to the Commission will be dealt by DG COMP.

Thus, in contrast to the US judicial enforcement model, the EU adopts a very different approach, the administrative enforcement model, ${ }^{462}$ which means that administrators are

\footnotetext{
459 Such amendments include: Notes on Council Regulation (EEC) 4064/89[1998] <http://ec.europa.eu/ competition/mergers/legislation/notes_reg4064_89_en.pdf> accessed 19 April 2017; Council Regulation (EC) No 1310/97 of Amending Regulation (EEC) No 4064/89 on the Control of Concentrations between Undertakings [1997] OJ L180. For detail information of these old merger control regulation, see: European Commission, ‘Old Merger Control Regulation' (EUROPA, last update 25 November 2014) <http://ec.europa.eu/competition/ mergers/legislation/archive.htm> accessed 16 April 2017.

460 The Lisbon Treaty (n 457).

${ }^{461}$ The European Commission is divided into several departments and services. The department is known as Directorate-General (DG). The classification of these departments is based on the fields of policy they deal with, such as DG of Agricultural and Rural Developments, and DG of Climate Action. For more information, see: European Commission, 'Departments and Executive Agencies' (EUROPA) < http://ec.europa.eu/about/ ds_en.htm> accessed 16 April 2017.

${ }^{462}$ Gerber (1999) (n 446) 20. See also: Wang (n 64) 230.
} 
assigned with the responsibility to enforce competition law. In the context of the EU, the Commission works not only as an investigator and a prosecutor, but also as a decisionmaker. The administrative enforcement is one of the most distinctive features as well as a tradition of the competition law in the Europe, which has a close link to the development and evolution of competition law at the national level in the Europe.

\subsection{Transactions Caught by the Merger Regulation}

According to the 2004 EUMR, any concentration with an EU dimension should be notified to the Commission prior to its implementation. ${ }^{463}$ To assess whether a concentration will be caught by the Merger Regulation, Art. 3 of the 2004 EUMR states that ' $\mathrm{A}]$ concentration shall be deemed to arise where a change of control on a lasting basis resulting from mergers or acquisitions'. Thus, to evaluate whether a concentration falls within the context of the Merger Regulation, the following standards will be applied.

\subsubsection{Lasting Change in the Structure of the Undertakings Concerned}

The first criterion is a lasting change, which means such change should be stable rather than temporary. For example, generally, a credit institution which holds securities on a temporary basis which it acquired from other undertakings with the aim of reselling will not be deemed as a concentration. The reason for such a requirement may lie in that a lasting change has a higher possibility than the temporary one to change the relationship between undertakings and eventually leads to a change of concentration degree in the relevant market. Such a change may have the effect of impeding effective competition in the relevant market. A lasting change is often interpreted as at least a five-year period of stability. 464

Mergers and acquisitions can both lead to a changed structure of the undertakings concerned by changing from sole control into joint control, or vice versa. For a merger, the structure is changed between two or more previously independent undertakings or parts of the undertakings. ${ }^{465}$ These undertakings can amalgamate into a new undertaking and no longer exist as separate legal entities, or one undertaking is absorbed by another with the former one ceasing to exist as a legal entity. ${ }^{466}$ An acquisition can be realised by acquiring control in whole or parts of one or more undertakings directly or indirectly through purchasing of securities, contracts, or through any other means. ${ }^{467}$ It changes the structure of undertakings concerned in identity of person(s) or undertaking(s) holding sole or joint control.

The creation of a joint venture ("JV") can also be deemed as a concentration if such a JV can perform as an independent autonomous economic entity, namely, a fullly-functional JV. ${ }^{468}$ This will be explored in detail in point 3 below.

\subsubsection{Change of Control}

According to Art. 3(2) of the 2004 EUMR, '[C]ontrol shall be constituted by rights, contracts or any other means, which, either separately or in combination and having regard

\footnotetext{
4632004 EUMR (n 3) art 4.

${ }^{464}$ Edurne Navarro and others, Merger Control in the EU --- Law, Economics and Practice (2edn, Oxford University Press 2005) 2.06-2.10.

4652004 EUMR (n 3) art 3(1)(a).

${ }^{466}$ Commission Consolidated Jurisdictional Notice under Council Regulation (EC) No 139/2004 on the Control of Concentrations between Undertakings [2008] OJ C95/01, para. 9 (hereinafter: 2008 Jurisdictional Notice).

4672004 EUMR (n 3) art 3 (1)(b).

$468 \mathrm{ibid}$, art 4. See also: 2008 Jurisdictional Notice (n 466) para. 92.
} 
to the considerations of fact or law involved, confer the possibility of exercising decisive influence on an undertaking'. Thus, whether person(s) or undertaking(s) can have decisive influence on all or part of another undertaking(s) is the key point when determining whether there is a change of control.

Regarding decisive influence, it requires competence to take strategic commercial decisions instead of day-to-day management. ${ }^{469}$ Such strategic commercial decisions, for example, may include the power to veto a business plan or strategic investments, to fix the budget, to nominate or lay off managers or commissioners. In practice, the fact of being a majority shareholder itself is not enough to determine the existence of decisive influence since the level of shareholding has no direct relation to the exerting of such influence. Minority shareholders can also be deemed as owning decisive influence if they can block certain strategic commercial decisions. ${ }^{470}$

Sole control will be formed through a transaction if only one undertaking has decisive influence over the whole or part of another undertaking. ${ }^{471}$ Similarly, a transaction will lead to the creation of a joint control when two or more undertakings have the competence to make strategic commercial decisions jointly on whole or part of another undertaking. ${ }^{472}$ Change of control includes a change from sole to joint control, or vice versa.

\subsubsection{Fully-Functional Joint Ventures}

Art. 3 (4) of the 2004 EUMR defines a full function JV as 'a JV which performs on a lasting basis all the functions of an autonomous economic entity'. Accordingly, there are three criteria for determining whether a JV is a full function JV: joint control, lasting basis, autonomous.

Joint control: as the name suggests, a fully-functional JV at first should be an economic entity created and controlled jointly by two or more parent undertakings. Since 'control' can be explained as exerting decisive influence as described above, joint control refers to the situation where two or more undertakings (persons) have the possibility of exercising decisive influence over all or part of another undertaking, such as investing in new product markets, appointing or dismissing senior management. It implies that parent companies must reach consent agreement on major strategic commercial decisions concerning the JV. ${ }^{473}$ This, however, can also possibly lead to deadlock.

Lasting basis: as described in sec.2.3 (1) above, a lasting basis means stable or durable rather than temporary. A concentration may have the possibility to be caught by the Merger Regulation only if such concentration is carried out on a lasting basis. Such criterion is also applied to the creation of a fully-functional $\mathrm{JV}$.

Autonomous: a fully-functional JV is an independent and self-existent economic entity. In the 2008 Jurisdictional Notice, it provides three tests to evaluate whether a JV is autonomous enough to be regarded as fully-functional:

1. Whether a JV owns sufficient resources to operate independently in a market. ${ }^{474} \mathrm{~A}$ fully-functional JV can perform, in a market, the functions which are normally carried out by undertakings operating in the same market. In other words, it should have its own management system and sufficient access to various resources, such as personnel and finance;

\footnotetext{
469 See: 2008 Jurisdictional Notice (n 466) para. 16, 54 and 62.

470 ibid, para. 54.

471 ibid, para. 54.

472 ibid, para. 62.

${ }^{473}$ C.J. Cook and C.S Kerse, EC Merger Control (5 edn, Sweet \& Maxwell 2009) 2-031.

4742008 Jurisdictional Notice (n 466) para. 94.
} 
2. Whether a JV performs activities beyond a specific function for its parent undertakings. ${ }^{475}$ If a JV only carries out one specific function of its parent undertaking, such as accounting or auditing, this JV is very likely to be deemed as attached to the parents and not fully-functional enough;

3. What are the sale/purchase relations between a JV and its parents. ${ }^{476} \mathrm{~A} \mathrm{JV}$ is likely to be regarded as lacking autonomy if its parents account for its substantial sales or purchases.

If a JV is determined as "fully-functional" according to Art. 3 (4) of the 2004 EUMR, it may constitute a concentration in the context of the Merger Regulation. To further determine whether the merger regulation should be applied when evaluating the creation of a JV, Art. 2 (4) of the 2004 EUMR will be used. It states:

[T] he creation of a joint venture constituting a concentration pursuant to Art. 3 [of the 2004 EUMR] has as its object or effect the coordination of competitive behaviour of undertakings that remain independent, such coordination shall be appraised in accordance with the criteria of Article 81(1) and (3) of the Treaty (Art. 101 of the TFEU). ${ }^{477}$

Such a fully-functional JV is called a "cooperative joint venture". Those fully-functional JVs which will not lead to coordination of competitive behaviour are called "concentrative joint ventures."

Therefore, overall, two standards have to be satisfied when applying the 2004 EUMR to the creation of a JV:

a. According to Art. 3(4) of the 2004 EUMR: fully-functional JVs with the characteristics of joint control, lasting basis and autonomous.

b. According to Art. 2(4) of the 2004 EUMR: concentrative fully-functional JVs which will not lead to coordination of competitive behaviour of undertakings that remain independent.

\subsection{Jurisdiction: an EU Dimension}

Since both the Commission and the NCAs have the authority to enforce the EU competition rules, to better relocate jurisdiction between the Commission and NCAs in the merger control field, the Commission theoretically will only assess these merger transactions with an EU dimension. ${ }^{478}$ An EU dimension (or a "Community dimension") refers to a feature of a transaction which results from its satisfaction with certain turnover thresholds set in the 2004 EUMR. It is purely jurisdictional in nature and is applied without any regard to substantive issues. A merger transaction which satisfies the thresholds set in the 2004 EUMR will be deemed as having an EU dimension. Other non-EU dimension transactions will be evaluated by the NCAs. A referral of a merger proposal between the Commission and the NCAs, however, is also possible in certain situations which are explored in sec.3.1.1 below.

Any merger transaction with an EU dimension must be notified to the Commission before its implementation. Such notification will be dealt with by DG COMP. According

\footnotetext{
475 ibid, para. 95.

476 ibid, para. 97.

477 Art. 101 of the TFEU (n 436) prohibits anti-competitive agreements between companies.

478 According to the 2004 EUMR (n 3), concentrations include mergers, acquisitions and creation of concentrative full function joint ventures. In this dissertation, merger control is used as synonymous to concentration control. The term "merger" is used to cover mergers, acquisitions and creation of concentrative full function joint ventures.
} 
to Art. 1(1) - (3) of the 2004 EUMR, there are two sets of thresholds for determining the existence of an EU dimension:

\section{Primary thresholds:}

a. Aggregate worldwide turnover:

All undertakings concerned have a combined aggregate worldwide turnover $\geq € 5000$ million, and

b. Aggregate EU-wide turnover:

Each of at least two undertakings concerned have an aggregate EU-wide turnover $\geqslant € 250$ million, and

c. Transnational character:

Concentrations will not be deemed as having an EU dimension if each of the undertakings concerned achieves $2 / 3$ of its aggregate EU-wide turnover within one and the same Member State.

2. Secondary thresholds: merger transactions which do not satisfy the accumulative requirements set in the original test could still have EU dimension under Art. 1(3) of the 2004 EUMR if they satisfy the requirements in the second set test which lowers the standard of Euro-domination thresholds and emphasizes the transnational character.

a. Lowered aggregate worldwide turnover:

All undertakings concerned have a combined aggregate worldwide turnover $\geq € 2500$ million; and

b. Lowered aggregate EU-wide turnover:

Each of at least two undertakings concerned have an aggregate EU-wide turnover $\geqslant €$ 100 million; and

c. Transnational character:

Concentrations will not be deemed as having an EU dimension if each of the undertakings concerned achieves 2/3 of its aggregate EU-wide turnover within one and the same Member State; and

d. Aggregate turnover in each of at least three Member States:

- all undertakings concerned have a combined aggregate turnover $\geq € 100$ million; and

- each of at least two undertakings concerned have an aggregate turnover $\geq € 25$ million.

After being filtered by the thresholds, mainly two types of transactions will be caught by the Merger Regulation: transactions with an extremely large turnover, or transactions, although involving lower turnovers, which have a significant transnational character. Either of them, if being implemented, may affect the competition within the EU.

The 1989 MR was based on the concept of a "one-stop shop", which means that the Commission is given the sole authority over major transnational merger transactions. ${ }^{479}$ When negotiating the new merger regulation, the principle of one-stop shop is deepened by enlarging the scope of jurisdiction for the Commission, which also works as the thresholds for pre-merger notifications.

479 European Commission, 'Control of Concentrations between Companies' (EUROPA, 20 May 2014), <http://europa.eu/legislation_summaries/competition/firms/126096_en.htm> accessed 17 April 2017. 


\section{Procedures and Substantive Test of the EU Merger Review}

\subsection{Merger Review Procedures}

Similar to merger review procedures in the US, the main evaluation procedures for transactions with an EU dimension at the EU level also consist of two stages, the phase I procedures for an initial evaluation and the phase II procedures (if necessary) for an indepth investigation. Due to the multi-role of the Commission as investigator, prosecutor, and judge, it will investigate a merger transaction by itself and block it if evidence shows that such a transaction will significantly impede effective competition in the internal market. It is also possible that merger remedies, such as divestitures, will be imposed on the merging parties as additional conditions to proceed with proposed mergers. The Commission can decide whether to prohibit or clear (maybe with merger remedies) the proposed mergers without any final approval from any other authorities. Furthermore, a judicial review is possible to bring the Commission's decision in a merger case to the GC in the first instance and the CJ on appeal. ${ }^{480}$ The proposed mergers cannot be implemented before any clear decision from the Commission is obtained.

For mergers with an EU dimension, pre-merger notifications are required under the 2004 EUMR before the start of phase I procedures. Since merger control can benefit consumers, business, and the European economy as a whole, the Commission and the NCAs work in close collaboration in the merger control field. Thus, a referral of a proposed transaction is possible either before or after such notification from the Commission to the NCAs, or vice versa. This makes the EU merger control unique and distinguishes the EUMR from other merger control systems. ${ }^{481}$

In addition, in order to shorten the time span of merger review to the extent possible and to make it more focused and effective, a simplified procedure was introduced in 2000 by the Commission for mergers which presumably will not raise competition concerns. ${ }^{482}$ Due to the enactment of the new 2004 EUMR, the Commission accordingly revised the simplified merger review procedures and adopted the final revision on 5 December 2013. 483

\subsubsection{Referral Procedures}

The 2004 EUMR provides the legal framework for referrals between the Commission and the NCAs. Art. 4(4) and Art. 4(5) deal with referring transactions before any formal premerger notifications have been made to the Commission. Such a request of referrals is at the initiative of the merging parties. After a formal notification has been made, Art. 9 and Art. 22 in the 2004 EUMR also provide the possibility of a referral. The Member State(s) may either request a referral of a transaction with an EU dimension from the Commission, or refer a non-EU dimension transaction to the Commission.

\footnotetext{
${ }^{480}$ Renshaw and Blockx (n 438) 499.

${ }^{481}$ Juan Rodriguez, 'Merger Referrals under the EU Merger Regulation' <http://www.sullcrom.com/siteFiles/ Publications/Rodriguez_EAR_Merger_Referrals3.pdf> accessed 25 April 2017, 1.

${ }^{482}$ Commission Notice on A Simplified Procedure for Treatment of Certain Concentrations under Council Regulation (EEC) No 4064/89 [2000] OJ C207 (hereinafter: 2000 EC Simple Case Procedures).

483 The European Commission had adopted the final documents concerning the simplified merger review procedures, namely Commission Notice on a Simplified Procedure for Treatment of Certain Concentrations under Council Regulation (EC) No 139/2004[2013] OJ C366 (hereinafter: 2013 EC Simple Case Procedures). This replaces the old version, see: ibid.
} 


\subsubsection{Pre-Notification Referral}

In principle, a proposed merger with an EU dimension should be reviewed by the Commission. In certain circumstances, however, it may be more advantageous and more suitable if such a transaction can be assessed by the NCAs under national competition law instead of by the Commission under the Merger Regulation. For example, although a proposed transaction may satisfy the thresholds laid down in the 2004 EUMR, the potential anti-competitive effects may only affect the competition within one Member State. Thereby, according to Art. 4 (4) of the 2004 EUMR, such a case may be referred from the Commission to the Member State concerned.

According to Art. 4 (4) of the 2004 EUMR, before the merging parties file a formal notification to the Commission, they can inform the Commission by reasoned submission, stating that such a transaction, although with an EU dimension, may only affect competition in the relevant market within one Member State. After receiving such a submission, the Commission should transmit it to the Member State concerned without any delay. The Member State(s) concerned should reply whether it will accept such a submission within 15 working days after having received it. If no explicit disagreement has been received from the Member State(s), the Commission will decide to refer the whole or part of the case to the Member State concerned within 25 working days from the day of receiving the submission. Then the proposed merger will be evaluated under the national competition law.

Proposed merger transactions without an EU dimension theoretically are subject to Member States. Nevertheless, a voluntary procedure exists in the 2004 EUMR $^{484}$ under which the merging parties can notify the non-EU dimension transaction to the Commission since it may be more advantageous for the transaction to be reviewed by the Commission so that they can benefit from the one-stop shop principle instead of notifying and being reviewed by at least three NCAs.

For those transactions, procedures for referrals from the NCAs to the Commission, as provided in Art. 4 (5) of the 2004 EUMR, are similar to those for referrals from the Commission to the NCAs as described above. The merging parties must inform the Commission through a reasoned submission that the proposed transaction will be assessed by it before filing any formal notification to the NCAs. Without any delay, the Commission should forward such a submission to all Member States. After receiving the submission, any Member State who in principle has the jurisdiction over the transaction may express its disagreement within 15 working days. As long as at least one Member State disagrees, such a case will not be referred. Unless receiving explicit disagreement from at least one Member State, the transaction will be deemed as having an EU dimension and thus will be evaluated by the Commission. Such a decision will be made by the Commission within 25 working days from the day of receiving the submission.

\subsubsection{Post-Notification Referral}

After receiving the formal notification from the merging parties, the Commission may refer the notified merger to the competent NCAs of the Member States concerned by request under Art. 9 of the 2004 EUMR. The Member States have 15 working days from the day of receiving the copy of the notification to make the referral request if:

a. the proposed merger threatens to significantly affect competition in a market within that Member State, which presents all the characteristics of a distinct market, or

4842004 EUMR (n 3) art 4(5). 
b. the proposed merger affects competition in a market within that Member State, which presents all the characteristics of a distinct market and which does not constitute a substantial part of the common market. 485

Once such a request has been made to the Commission, the timeframe for the phase I procedure will be extended from 25 working days to 35 working days and the Commission has to decide whether to refer the transaction or not. If the Commission decides to refer, the competent NCAs of the Member States concerned should, within 45 working days from the referral, inform the merging parties and the Commission of its initial assessment and what future action it will take. ${ }^{486}$

Regarding those proposed mergers with a non-EU dimension which in principle should be evaluated by the NCAs under national competition law, it is also possible of being referred from the NCAs to the Commission under Art. 22 of the 2004 EUMR. The Member State(s) concerned may make a request to the Commission to examine the notified transaction if it affects trade between Member States and threatens to significantly affect competition within the territory of the Member State(s). ${ }^{487}$

After receiving the notification of the proposed merger transaction, the Member State(s) should make the request of referral within 15 working days to the Commission. ${ }^{488}$ Then the Commission will inform both the undertakings concerned and the competent NCAs of the Member States of the receipt of any request without delay. Any other Member State is also able to join the initial request within 15 working days from when it was informed by the Commission. ${ }^{489}$ After such a period has expired, the Commission should at least within 10 working days decide whether it will examine the request referred transaction. ${ }^{490}$ If no express decision has been made within the set timetable, the transaction will be deemed to be evaluated by the Commission. ${ }^{491}$

No matter whether it is a pre-notification or post-notification referral, the obtained flexibility increases the chance of best jurisdiction allocation between the Commission and the NCAs which deepens the one-stop shop principle which has been applied since the 1989 MR.

\subsubsection{Phase I Procedures}

As soon as the formal notification is received from the merging parties, the Commission should start to assess the proposed merger. ${ }^{492}$ The copies of the notification should also be forwarded to the NCAs of the Member States concerned. In principle, the timetable for the phase I period will be 25 working days from the receipt of the notification. ${ }^{493}$ As described above, the Member State(s) must within 15 working days after the receipt of the notification from the Commission decide whether to request a referral under art.9 of the 2004 EUMR. If such request is made, the 25 working days will be extended to 35 working days.

A State of Play meeting can be held between DG COMP and the merging parties in the process of the phase I period if the proposed transaction may raise serious anti-competitive

\footnotetext{
485 ibid, art $9(2)$.

486 ibid, art $9(6)$.

487 ibid, art $9(2)$.

$488 \mathrm{ibid}$, art 22(1).

$489 \mathrm{ibid}$, art 22(2).

$490 \mathrm{ibid}$, art 22(3).

$491 \mathrm{ibid}$, art 22(3).

492 ibid, art 6(1).

$493 \mathrm{ibid}$, art 10(1).
} 
effects. ${ }^{494}$ Normally, the meeting will be held within 15 working days from the beginning of the initiation of the phase I proceeding. Thus, the merging parties are given the opportunity to exchange information with DG COMP ${ }^{495}$ and also to discuss possible remedy proposals. ${ }^{496}$

With regard to merger remedies, such as divestitures, the merging parties can submit any proposal of remedies to the Commission on an informal basis, even before a notification. ${ }^{497}$ Such remedy proposals have to be submitted within no more than 20 working days from the date when the formal notification is received by the Commission. 498 Once the notifying parties submit the proposed remedies the deadline for phase I will also be extended by 10 working days, to 35 working days. ${ }^{499}$ According to the 2008 EC Remedies Notice, remedies in phase I can only be accepted if they are sufficient to clearly rule out serious doubts about SIEC-related competitive concerns. ${ }^{500}$

Theoretically, the Commission has to make its decision in its phase I investigation within 25 working days. There can be three main possibilities. First, decisions declaring that the 2004 Merger Regulation is inapplicable. Second, decisions declaring that the proposed merger is compatible with the Merger Regulation (maybe with additional remedies). Third, decisions to initiate the phase II procedures or referring to the competent NCAs. ${ }^{501}$

\subsubsection{Phase II Procedures}

Compared with the phase I procedures, the phase II procedures involve more detailed and in-depth investigations on the notified merger transactions to further determine whether such transactions will significantly impede effective competition in the internal market. In principle, the timetable for this period is 90 working days. ${ }^{502}$ It is possible, however, to be extended or for the Commission to "stop the clock" in certain circumstances. This will be discussed below.

When the second stage begins, a State of Play meeting will normally be held within 2 weeks to help the notifying parties to better understand the Commission's concerns and attitude towards the proposed transactions. ${ }^{503}$ Within about 6 weeks from the beginning of the phase II procedures, a Statement of Objections $(\mathrm{S} / \mathrm{O})$ will be issued by the Commission, in which all the Commission's competitive concerns about the notified transaction will be described, accompanying the invitation for the notifying parties to reply in writing within generally 2 weeks. ${ }^{504}$ With the issuance of the $\mathrm{S} / \mathrm{O}$, the Commission is obliged to make the file available to the notifying parties. Also within 2 weeks from the

\footnotetext{
${ }^{494}$ DG COMP European Commission: Best Practices on the Conduct of EC Merger Control Proceedings (2004), para. 33(a) (hereinafter: Best Practice for Merger Control Proceedings).

495 See: ibid, para. 30. It states that the objective of the State of Play meetings is to contribute to the quality and efficiency of the decision-making process and to ensure transparency and communication between DG Competition and the notifying parties.

496 See: ibid, para. 30.

${ }^{497} 2008$ EC Remedies Notice (n 35).

498 Best Practice for Merger Control Proceedings (n 494) para. 78.

4992004 EUMR (n 3) art 10(1).

5002008 EC Remedies Notice (n 35) para. 81.

501 See: 2004 EUMR (n 3) art 6(1).

5022004 EUMR (n 3) art 10(3).

${ }^{503}$ Best Practice for Merger Control Proceedings (n 494) para. 33(b).

504 There are neither provisions in relevant regulations nor suggestions in Best Practice that explicitly provide the deadline of the timing to issue the State of Objections. The timetable mentioned here is based on the Commission's practice. See: John J. Parisi, 'A Simple Guide to the EC Merger Regulation' $<$ http://www.americanbar.org/ content/dam/aba/publishing/antitrust_source/03_Jan05_parisi.authcheckdam.pdf > accessed 17 April $2017,9$.
} 
issuance of the $\mathrm{S} / \mathrm{O}$, it is possible for DG COMP to hold a formal Oral Hearing if the notifying parties request so.

Another State of Play meeting can be held following the reply to the S/O and the Oral Hearing to 'discuss the scope and timing of possible remedy proposals. ${ }^{505}$ Before the Commission makes any final decision after investigations, the Advisory Committee which consists of representatives of the competent NCAs will be consulted. ${ }^{506}$ They should deliver an opinion on the Commission's draft decision, and the Commission will communicate this opinion and its final decision to the addressee. ${ }^{507}$

As mentioned above, normally the Commission has to make its final decision no later than 90 working days after the initiation of this period. The 90 -working-day period can be extended at the request of the notifying parties. Such an extension, however, is up to 20 working days. In some cases, the period can be shorter than 90 working days once the Commission's competitive concerns are cleared. In other cases, the Commission may decide to "stop the clock" when the notifying parties fail to provide required information necessary for investigations. If so, the review procedures will last extremely long.

Remedies can be proposed by the merging parties to the Commission during the phase II period. Such a proposal should be made no later than 65 working days from the day on which the phase II procedure begins. ${ }^{508}$ If so, this timetable will be extended from 90 working days to 105 working days. No extension will be made if the merging parties propose merger remedies within 55 working days from the initiation of the second stage. 509 The standard for accepting the proposed remedies is that competition concerns raised in the Statement of Objection or serious doubts (in case of no issuance of S/O) have been cleared. ${ }^{510}$ Compared with phase I, remedies in phase II can be more specific after in-depth investigations.

\subsubsection{Final Decision and Judicial Review}

Generally, there are three main results for a final decision made by the Commission, namely, clearance, prohibition or clearance with merger remedies. ${ }^{511}$ In the US, if a consent agreement is reached between the merging parties and the Antitrust Division of the Department of Justice, final approval from the federal court concerned is necessary before the proposed agreement becomes effective. In contrast, the European Commission, as the decision-maker, has the last say on the decisions, although the Advisory Committee will deliver an opinion on the Commission's draft decisions. ${ }^{512}$

The legal standing for a juridical review is laid down in Art. 263 of the TFEU, which states, 'the Court of Justice of the European Union shall review the legality of legislative acts, of acts of the Council, of the Commission...'.

Thus, an appeal against the Commission's decisions in a merger case is possible to be brought to the GC for the first instance and to the CJ on appeal. According to the third paragraph of Art. 263 of the TFEU, ${ }^{513}$ a judicial review can be brought not only by the

\footnotetext{
505 Best Practice for Merger Control Proceedings (n 494) para. 33 (d).

5062004 EUMR (n 3) art 19(3).

$507 \mathrm{ibid}$, art 19(5).

5082008 EC Remedies Notice (n 35) para. 88.

5092004 EUMR (n 3) art 10(3).

5102008 EC Remedies Notice (n 35) para. 92

${ }^{511}$ For the detailed criteria concerning which decision can the Commission make at this stage, see: 2004 EUMR (n

3) art 8.

512 See: sec.3.1.3 above.

513 Para.3, art 263 of the TFEU (n 436) reads:
} 
addressee of the decisions, but also by third parties, who are directly involved but not part of the Commission's decision, such as the employees and competitors of the merging parties. In RJB Mining plc v. Commission, ${ }^{514}$ RJB was a privately-owned coal mining company established in the UK and Northern Ireland. It was a main competitor of another coal mining company, RAG. It appealed the Commission's decision concerning the approval for RAG's acquisition of SBW and Preussag Anthrazit GmbH, which led to the merger of the three remaining German coal-mining companies. One of the issues in the case was whether RJB, as a competitor of RAG, was able to appeal. Finally, it was recognised that RJB owned the standing for appealing the Commission decision to the GC. 515

Such an application for a judicial review should be made within 2 months and ten days after the notification of the decision has been addressed to the addressee. ${ }^{516}$ For third parties, the period starts to run after the publication of the decision in the Official Journal of the EU or from the moment they become aware of the decision. ${ }^{517}$

The standard for reviewing a Commission's decision is whether such a decision has a "manifest error". In Tetra Laval/Sidel, 518 on the one hand, the ECJ (European Court of Justice, now the Court of justice, "CJ") recognised the discretion the Commission enjoyed when assessing a merger, especially the assessment involving economic analyses; on the other hand, it also specified that such discretion regarding economic matters did not restrain the Courts from reviewing the Commission's decisions concerning information with an economic nature. Hence, a merger review made by the Commission at the EU level has to consider various factors to protect the internal market, as well as preserve the potential efficiency that the notified merger will bring.

\subsection{The Substantive Test of Merger Review}

The 1989 MR prohibited mergers that would 'create or strengthen a dominant position as a result of which effective competition would be significantly impeded' (so called "dominance test"). The substantive test of the EU merger review has been changed from the "dominance test" to the "SIEC test" since the passage of the 2004 EUMR. Art. 2 of the 2004 EUMR states that "[A]ny concentration which could significantly impede effective competition in the common market or in a substantial part of it, in particular as a result of the creation or strengthening of a dominant position, shall be declared incompatible with the common market'. Thus, the SIEC test, a simplified expression of "significantly impede effective competition", is deemed as the substantive test to assess whether a proposed merger should be cleared or prohibited.

\footnotetext{
Any natural or legal person may, under the conditions laid down in the first and second paragraphs, institute proceedings against an act addressed to that person or which is of direct and individual concern to them, and against a regulatory act which is of direct concern to them and does not entail implementing measures.

514 See: Case T-156/98, RJB Mining v Commission of the European Communities (Judgment of the Court of First Instance) [31 January 2001] <http://curia.europa.eu/juris/showPdf.jsf;jsessionid=9ea7d2dc30dbbad3450b 881f43f897e9f4bb262b2651.e34KaxiLc3qMb40Rch0SaxqTbNb0?text=\&docid=104160\&pageIndex=0\&doclang $=\mathrm{EN} \&$ mode $=1 \mathrm{st} \& \mathrm{dir}=\& o c c=$ first\&part $=1 \& \mathrm{cid}=85720>$ accessed 20 April 2017.

516 TFEU (n 436) art 263. See also: Rules of Procedure of the General Court (2015) OJ L105, art 102.

${ }^{81}$ Case C-12/03, Commissionv. Tetral Laval BV (Judgement of the European Court of Justice) [15 February 2005]< http:/ / curia.europa.eu/juris/document/document.jsf?text=\&docid $=49926 \&$ pageIndex $=0 \&$ doclang $=$ EN\&mode $=$ lst\&dir $=\&$ occ $=$ first\&part $=1 \&$ cid $=388021>$ accessed 20 April 2017, para. 38-39.
}

515 ibid, para. 69.

517 ibid, art 102 (2). 
The rationale for this change rests on the Commission's intention of taking a more economic approach to evaluate merger proposals, as well as its desire to fill the gap, arising from the dominance test.

Under the dominance test, a transaction would be prohibited only if these two cumulative conditions were both satisfied; first, such a merger creates or strengthens a dominant position; second, effective competition would thereby be impeded. ${ }^{519}$ Thus a gap appeared, namely, the dominance test cannot deal with the transaction in which the merging parties did not enjoy a dominant position in the market before or after the mergers, whereas their transaction can still significantly impede effective competition in the market. 520 Accordingly, a dominant position became the most important factor when assessing the proposed merger's compatibility with the 2004 EUMR under the dominance test. The assessment of such market leadership relied heavily on the market share of the company involved.

Although the SIEC test still uses familiar terminology, the wording of the test has been amended, and the two requirements in the "dominance test" are now alternatives instead of cumulative. Recital 25 of the 2004 EUMR indicates that '[A] significant impediment to effective competition in Art. 2(2) and (3) should be interpreted as extending, beyond the concept of dominance, only to the anti-competitive effects of a concentration resulting from the non-coordinated behaviour of undertakings which would not have a dominant position on the market concerned'. In other words, the creation or strengthening of a dominant position is now subordinated to the principle test of whether a concentration causes a significant impediment to competition. ${ }^{521}$ Thus, the SIEC test lays more stress on market power instead of on market leadership. This exactly fills the gap which the dominance test leaves.

Compared with market leadership which is usually assessed by market share, there is no defined level or a single method to determine the degree of market power a merged party enjoys. Thus, an evaluation of market power requires a comprehensive consideration of various factors, and market share is no longer the only important factor in this assessment.

So, the SIEC test fills the gap concerning non-coordination effects that arise from a merger in which the merging parties do not enjoy a dominant position. It also lays more emphasis on market power, which reflects the more economic approach which the European Commission employs.

\subsubsection{Market Shares and Concentration}

As described above, market shares play a prominent role in the dominance test in assessing whether a proposed merger enjoys a dominant position in the relevant market. Under the

${ }^{519}$ Case T-2/93, Air France v. Commission of the European Communities (Judgment of the Court of First Instance) [ May 19 1994] <http://curia.europa.eu/juris/showPdf.jsf?text=\&docid=103310\&pageIndex =0\&doclang=EN\& mode $=1$ st $\&$ dir $=\& o c c=$ first $\&$ part $=1 \&$ cid $=388240>$ accessed 20 April 2017, para. 79 reads:

It follows from those provisions that the Commission is bound to declare a concentration compatible with the common market where two conditions are fulfilled, the first being that the transaction in question should neither create nor strengthen a dominant position and the second being that competition in the common market must not be significantly impeded by the creation or strengthening of such a position. If, therefore, there is no creation or strengthening of a dominant position, the transaction must be authorised, without there being any need to examine the effects of the transaction on effective competition.

520 See: Lars-Hendrik Roller and Miguel de la Mano, 'The Impact of the New Substantive Test in European Merger Control' (2006) 2(1) ECJ 9, 15.

521 Sigrid Stroux, 'Book Review: Merger Control in the EU. Law, Economics and Practice. Second Edition Edurne Navarro, Andras Font, Janmie Folguera, and Juan Briones' (2006) 33(2) L I E I 199, 199. 
SIEC test, market shares provide a useful indication of the market structure and of the competitive importance of both the merging parties and their competitors. ${ }^{522}$

According to case law, $50 \%$ can be seen as the boundary. ${ }^{523}$ If a firm after a merger will have a market share of at least $50 \%$ in a relevant market, the existence of a dominant market position will be self-evident. Such a dominant position, however, may also exist even if the market shares of the after-merger firm remain below $50 \%$. Sometimes, although the merged firm is a smaller competitor, it can still enjoy its market power and raise competitive concerns, considering other combined factors, such as the number of competitors, the closeness of substitutes. ${ }^{524}$ Thus, the Commission has considered mergers to be problematic even when the market shares resulting from such mergers were between $40 \%-50 \%$, or even below $40 \% .525$ What is worth mentioning is that, normally, a merger will not be deemed to have a dominant market position if the market shares of the merging parties concerned are below 25\%. ${ }^{526}$

The HHI is employed in the Horizontal Merger Guidelines. ${ }^{527}$ The HHI can be used to measure concentration in a market and the change in that concentration induced by a merger. ${ }^{528}$ The HHI is calculated by summing the squares of the individual market shares of all the firms in the market. ${ }^{529}$ The change in the HHI (known as the "delta") is a useful index to reflect the change in concentration directly brought about by the merger. ${ }^{530}$ According to the Guidelines, proposed mergers can be divided into three categories based on the HHI:

1. Safe: horizontal competition concerns are unlikely to be identified if the postmerger HHI is below 1000. Thus, extensive analysis normally is not required.

2. Comparatively safe: horizontal competition concerns are also unlikely to be identified if the post-merger HHI is between 1000 and 2000 and a delta below 250, or above 2000 and a delta below 150. Except when one or more of the following factors is present:

(a) a merger involves a potential entrant or a recent entrant with a small market share;

(b) one or more merging parties are important innovators in ways not reflected in market shares;

(c) there are significant cross-shareholdings among the market participants;

(d) one of the merging firms is a maverick firm with a high likelihood of disrupting coordinated conduct;

(e) indications of past or ongoing coordination, or facilitating practices, are present;

(f) one of the merging parties has a pre-merger market share of $50 \%$ of more.

\footnotetext{
522 Guidelines on the Assessment of Horizontal Mergers under the Council Regulation on the Control of Concentrations between Undertakings [2004] OJ C31/03, para 14 (hereinafter: 2004 EC Horizontal Mergers Guidelines).

523 ibid, para. 17.

524 ibid.

525 ibid.

526 ibid, para 18

527 ibid, 16. See also: Chapter 2, sec.3.2.2.

${ }^{528}$ Ulrich Schwalbe and Daniel Zimmer, Law and Economics in European Merger Control (Oxford University Press 2009) 196.

5292004 EC Horizontal Mergers Guidelines (n 522) para. 16. The formula for HHI is: $H=\sum_{i=1}^{N} s_{i}^{2}$, where $S_{\mathrm{i}}$ is the
market share of firm i in the market, and N is the number of firms. See: Miroslav N Jovanovic, The Economics of
International Integration (Edward Elgar Publishing 2006) 79.
5302004 EC Horizontal Mergers Guidelines (n 522) para. 16.
} 
3. Dangerous: an extensive analysis of a proposed merger will be required if the HHI does not satisfy (1) or (2) above. ${ }^{531}$

\subsubsection{Anti-Competitive Effects}

The change of the substantive test from the dominance test to the SIEC test reflects the Commission's intention to employ a more economic approach when evaluating the notified mergers. Instead of relying heavily on market shares and the HHI to test the merging parties' market leadership, the Commission, since the enactment of the 2004 EUMR, lays more emphasis on studying the market power which the merging parties enjoy, to further evaluate the potential anti-competitive effects such mergers may create.

The anti-competitive effects are divided into two groupings, namely non-coordinated (or unilateral) effects and coordinated effects. The former refers to a situation where a merger significantly impedes effective competition by eliminating important competitive constraints on one or more firms without resorting to coordinated behaviour. ${ }^{532}$ The latter suggests that effective competition is impeded significantly by a merger by changing the nature of competition through coordinated behaviour between the merged firm and other competitors in the market.

In the 2004 Horizontal Merger Guidelines, the following non-coordinated effects will be examined. If one or more of them appear after a merger, it is very likely that such a merger will cause severe anti-competitive effects:

- Merging firms have large market shares;

- Merging firms are close competitors;

- Customers have limited possibilities of switching supplier;

- Competitors are unlikely to increase supply if prices increase;

- The merged entity is able to hinder expansion by competitors;

- The merger eliminates an important competitive force. ${ }^{533}$

In a concentrated market, a merger can also give rise to the creation and the strengthening of a collective dominant position. Such a situation will result in coordinated effects, for example, keeping the price above the competitive level or limiting production capacity, and thus impeding effective competition significantly. The Horizontal Merger Guidelines identify four conditions, with which, coordination is very likely to emerge. First, whether it is easy for competitors to reach a consensus regarding how the coordination should work. Second, whether competitors have monitoring devices to ensure that no competitors will deviate. Third, whether deterrent mechanism works well among competitors to keep the coordination sustainable. Fourth, the reaction of outsiders, such as non-coordinating firms, potential competitors and customers, should not be able to jeopardise the expected results of coordination.

\subsubsection{Countervailing Buyer Power and Market Entry}

The countervailing buyer power refers to the bargaining strength the buyers have towards the merged firms in commercial negotiations. If a merged firm is able to act to an appreciable extent independently of its customers who do not possess any countervailing

\footnotetext{
531 ibid, para. 19-20.

532 ibid, para. 22 (a).

533 ibid, para. 24-38.
} 
power, then it is very likely that such a merger will give rise to a significant impediment to effective competition. ${ }^{534}$

When assessing the potential anti-competitive effects that a merger may create, the ease of market entry will also be taken into account by the Commission. ${ }^{535}$ If a market is still sufficiently easy for other competitors to enter after a merger, it means such a merger is unlikely to create anti-competitive effects. These three standards to evaluate the ease of entry are: "likely, timely and sufficiently". ${ }^{536}$ "Likely" means it must be profitable for other competitors to enter the relevant market; 537 "timely" requires that entry would be swift and sustained to deter or defeat the exercise of market power; 538 "sufficiently" requires that entry must be sufficient in scope and magnitude to deter or defeat the anti-competitive effects of the merger. ${ }^{539}$

\subsubsection{Efficiencies and the Failing Firm Defence}

In the 2004 Horizontal Merger Guidelines, it confirms that 'the Commission considers any substantiated efficiency claim in the overall assessment of the merger'. ${ }^{540}$ It is generally accepted that efficiencies can be brought by a merger through, for example, economies of scale, which would result in reducing average costs for production. ${ }^{541}$ Additionally, the onestop-shop principle is regarded as essential in keeping the regulatory costs associated with an EU dimension merger at a reasonable level. ${ }^{542}$ In the EU, the over-reaching goal of competition law is to benefit consumers, as well as to protect the internal market. Thus, efficiencies in the context of the 2004 Merger Guidelines can be explained as "benefit consumers, be merger-specific and be verifiable". ${ }^{543}$

A merger may not be caught under the Merger Regulation if one of the merging parties is a failing firm. ${ }^{544}$ In Kali und Salz, the ECJ confirmed the availability of the failing firm defence under the 1989 MR. ${ }^{545}$ Such "failing firm" defence has to satisfy three conditions: first, without being merged, the failing firm would withdraw from the market in the near future due to its financial difficulties; second, the notified merger is the plan with least potential anticompetitive effects; third, the failing firm will inevitably exit the market without a merger. ${ }^{546}$ In fact, the failing firm defence has been applied rarely in the enforcement history under the Merger Regulation, and no particular trend towards an increase in the use of this defence as a result of the economic and financial crisis can be observed. ${ }^{547}$

\footnotetext{
534 ibid, para. 64.

535 ibid, para. 68.

$536 \mathrm{ibid}$, para. 68.

537 ibid, para. 69-70.

538 ibid, para. 74.

539 ibid, para. 75.

540 ibid, para. 77.

${ }^{541}$ For a detailed exploration of the potential efficiencies generated from mergers, see: Chapter 5.

${ }^{542}$ Claude Rakovsky and others, 'EC Merger Regulation Contributes to More Efficient Merger Control in EU' (EUROPA, 2009) < http://ec.europa.eu/competition/publications/cpn/2009_2_4.pdf> accessed 17 April 2017.

5432004 EC Horizontal Mergers Guidelines (n 522) para. 78.

544 ibid, para. 89.

545 See: Joint Cases C-68/94 and C-30/95, French Republic and Société commerciale des potasses et de l'arote (SCPA) and Entreprise minière et chimique (EMC) v Commission of the European Communities ("Kali und Salz"), (Judgement of the Court of Justice) [31 March 1998] < http://eur-lex.europa.eu/legal-content/EN/ALL/?uri=CELEX:61994 CJ0068 > accessed 19 April 2017.

5462004 EC Horizontal Mergers Guidelines (n 522) para. 89-90.

547 See: Directorate for Financial and Enterprise Affairs, 'Failing Firm Defence (Note by the European Commission)' (EUROPA, 22 September 2009) < http://ec.europa.eu/competition/international/multilateral/ failingfirmdefence.pdf $>$ accessed 17 April 2017.
} 


\section{Merger Divestitures in the EU: Learning from the US}

Since the enactment of the $1989 \mathrm{MR}$, the number of pre-merger notifications has experienced several ups and downs at the EU level, especially during 2008 and 2009, the time of the explosion of the global financial crisis. Up to 31 March 2017, the overall number of notified cases in the EU was $6522 .{ }^{548}$ The overwhelming majority of proposed mergers (5748 in total) is deemed as being compatible with the 2004 EUMR and is cleared directly in phase I. Another 275 proposals were cleared with remedies at the end of phase I. This number is higher than that in phase II (121). It is worth noting that most proposals in phase II are very likely to end with remedies because only 26 cases were prohibited and 28 were cleared without any further remedy.

Table 2 Merger Statistics from 21 September 1990 to 31 March 2017 in the EU 549

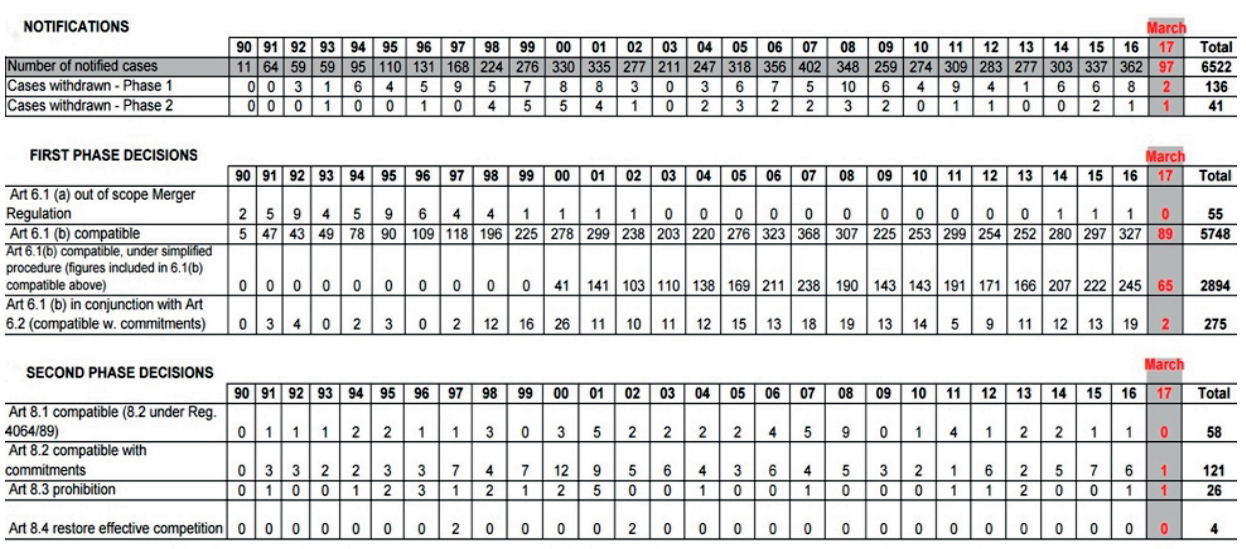

Accordingly, with the rising numbers of notified mergers falling within the EUMR jurisdiction, appropriate merger remedies become crucial for the Commission to better control mergers to restore competition to the pre-merger level, as well as for the merging parties to strive for permission for their proposed transactions. It is believed that the approach the EU takes in formulating merger remedies, especially divestitures, is moving closer to the established US practice. ${ }^{550}$

\subsection{Background and Basic Aims of the 2001 EC Remedies Notice}

It is believed that the policy, as well as the approach the EU takes towards merger remedies, is largely influenced by the established US practice in merger divestitures and by the 1999 FTC Divestiture Study, ${ }^{551}$ resulting in similarities between the EU and the US regarding the general merger divestiture rules and guidelines.

By learning from the US, the Commission desired to reach the maturity of its predecessor. With the publication of the 2001 EC Remedies Notice, a transparent, cohesive

\footnotetext{
${ }^{548}$ European Commission, 'Merger Statistics: 21 September 1990 to 31 March 2017' (EUROPA, March 2017) <http://ec.europa.eu/competition/mergers/statistics.pdf> accessed 17 April 2017.

${ }^{549}$ The table is adopted from the EC's official statistics publications. See: ibid.

${ }^{550}$ Eleanor Morgan, 'Steering Mergers Through the EU's Regulatory Rocks: Remedies under the EU Merger Control Regulation' (2002) 20(5) EMJ 549, 551.

${ }^{551}$ Monti (n 34) 3.
} 
and predictable regulatory scheme of merger remedies was expected to be improved. ${ }^{552}$ Further, two ultimate goals were expected to be realised. The first aim of the Notice was to ensure that the merger remedies raised by the merging parties were clear-cut and effective enough to clear the competition concerns raised by the Commission and to restore competition in the relevant market to the pre-merger level. ${ }^{553}$ The second aim was to ensure effective implementation of merger remedies and to shorten the whole time span. ${ }^{554}$

The 2001 EC Remedies Notice has overall seven parts, including the general principles, merger remedies, especially divestitures, and substantive and procedural rules on implementing remedies. In the following, the general principles and guidance on merger divestitures in the 2001 EC Remedies Notice will be studied.

\subsection{General Principles}

\subsubsection{Preference for Structural Remedies}

The 2001 EC Remedies Notice divided merger remedies into two categories: divestitures and other remedies, including, for example, terminating an exclusive agreement when a merger will result in foreclosure of competition due to the existing exclusive agreements; 555 granting the competitor of the merged party access to necessary infrastructure or key technology if a merger will lead to barriers or impediments for entry of the relevant markets; ${ }^{55}$ and providing a licensing arrangement by the merged party where a competition problem results from control of key technology. 557

The 2001 EC Remedies Notice specified that remedies which were structural in nature (such as divestitures) were preferable to other remedies because such remedies can straightforwardly prevent the creation or strength of a dominant position that infringes the 1989 MR under its "dominance test". 558 In addition, compared with other remedies, structural remedies were easier to enforce because no long-term monitoring is needed. Accordingly, in many cases, behavioural remedies in which the notified parties merely promise not to behave in a certain way are inadequate to clear anti-competitive effects generated from the notified mergers.

Such preference is established in Gencor v. Commission. ${ }^{559}$ Gencor was the parent company of a group, operating in mineral resources and metals industries. Implats was a company which executed Gencor's mineral activities. Implats was held by Gencor up to $46.5 \%$ and by the public up to $53.5 \%$. Lonrho was a parent company of a diversified group in similar industries to Gencor. Lonrho had $73 \%$ control of Eastplats and Westplats (together known under the name of "LPD"). The remaining $27 \%$ of the shares were held by Gencor through its subsidiary Implats. In the proposed merger transaction, Lonrho and Gencor proposed to acquire Implats in the first stage, and further made Implats have sole

\footnotetext{
552 James Halverson and Kenneth Ewing, 'Recent Developments in EU and US Merger Remedies' (Steptoe \&o Johnson LLP, May 2004) <http://www.steptoe.com/assets/attachments/27.pdf> accessed 17 April 2017, 59.

${ }_{553}$ Monti (n 34) 4.

554 ibid.

5552001 EC Remedies Notice (n 440) para. 27.

556 ibid, para. 28.

557 ibid, para. 29.

558 ibid, para. 9.

559 Case T-102/96, Gencor v. Commission (Judge of the Court of First Instance) $[25$ March 1999] < http:/ / curia.europa.eu/juris/document/document.jsf?text $=\&$ docid $=44521 \&$ pageIndex $=0 \&$ doclang $=$ EN\&mode $=$ lst\&dir $=\&$ occ $=$ first\&part $=1 \&$ cid $=390385>$ accessed 20 April 2017.
} 
control over LPD. As a result, Gencor and Lonrho would respectively have 32\% shares in Implats and the rest would be held by the public.

The Court held that such a merger may have the suspicion of creating or strengthening a dominant position in the market under the 1989 MR. It further made it clear that '[T]he purpose of the Regulation [1989 MR] is to prevent the creation or strengthening of market structures which are liable to impede significantly effective competition in the common market'. ${ }^{560} \mathrm{~A}$ commitment will be accepted only if it can clear the competition concerns and render a notified merger transaction compatible with the Merger Regulation. Thus, a commitment which is structural in nature may be favoured over a behavioural one since it changes the structure of the market directly. ${ }^{561}$

\subsubsection{Standard for Accepting Remedies}

Any acceptable merger remedy should fulfil the general standard: being able to be implemented effectively and the time span for the said implementation should not be long. ${ }^{562}$ The prominent goal of a commitment is to restore/preserve competition in the relevant market. Thus, whether a commitment can realise such a goal is the most important criterion to determine its acceptance. Furthermore, a short period for implementation can reduce various potential risks which may occur during the implementation of divestitures, as well as save administrative costs for the Commission.

Standards for accepting a commitment also differ according to the phase when such a commitment is provided. During phase I merger review procedures, merger remedies will be accepted only if such remedies can clearly rule out any "serious doubts" concerning the possibility of creating or strengthening a dominant position. ${ }^{563}$ The proposed merger transaction can be proceeded with once the (potential) serious doubts are completely cleared by the commitment submitted by the notifying parties. With regard to the standard in phase II, since an in-depth investigation will be taken by the Commission, competition concerns will be studied and analysed in a more detailed way. In such a situation, a commitment will be accepted by the Commission if it can eliminate the creation or strengthening of a dominant position. ${ }^{564}$

\subsubsection{Distinction between Conditions and Obligations}

To better realise the goal of restoring competition to the market to the pre-merger level, the Commission is responsible for ensuring the parties' compliance with the remedies. Thus, a distinction has been made between conditions and obligations of a commitment: ${ }^{565}$ conditions refer to the achievement of a commitment, such as the divestment of a subsidiary; any detailed step to realise such achievement is the merged party's obligation. Such a distinction enables the Commission to take different measures due to different situations. If an obligation is breached by the parties, the merger transaction can no longer be implemented. ${ }^{566}$

Besides, if the merged party fails to fulfil its obligations, the Commission is entitled to revoke the clearance decision concerning the merger proposal. The merged party also face

\footnotetext{
560 ibid, para. 317.

561 ibid, para. 319.

5622001 EC Remedies Notice (n 440) para. 10.

563 ibid, para. 11.

564 ibid.

565 ibid, para. 12.

566 ibid.
} 
the risks of being fined or pay periodic penalty payments. ${ }^{567}$ On the other hand, once the condition is not realised, the Commission may order any appropriate action it believes necessary to render competition in the market. ${ }^{568}$

\subsection{Merger Divestitures in the 2001 EC Remedies Notice}

As described in the principles, structural remedies are preferred by the Commission. Therefore, as one of the most typical structural remedies, the 2001 EC Remedies Notice attaches its focus on merger divestitures.

The idea that one of the most effective ways to restore competition in the market to the pre-merger level is to create conditions for the emergence of a new entity or to strengthen an existing entity may to some extent explain why divestitures are favoured over other remedies. ${ }^{569}$

The 2001 EC Remedies Notice laid its emphasis on the composition of the to-bedivested assets and the selection of a suitable buyer to assure an effective divestiture. Furthermore, other methods, such as the mandate of divestiture trustees, were also introduced.

\subsubsection{Composition of Divestiture Packages}

One of the vital elements in an effective and successful divestiture is that the divested business should be sufficient and appropriate so that it can compete with the merged firms in the relevant market on a lasting basis, if being operated by a suitable purchaser. According to the 2001 EC Remedies Notice, appropriate business referred to the existing business that can be operated on a stand-alone-basis. ${ }^{570}$ In other words, after divestitures, the business should be independent from the merged entity and have all conditions necessary for its daily operation and business.

\subsubsection{Greater Set of Assets than Overlapping Parts}

The Commission is aware of the fact that whether or not a business will be viable sometimes depends on the possession of complementary assets. ${ }^{571}$ Namely, certain products or services will be viable and competitive only if the purchaser has other joint products and services. As a result, when determining the scope of the to-be-divested business, besides divesting all the overlaps ("clean sweep" approach), a greater set of business may be included to ensure the viability and independence of the business. ${ }^{572}$

Unilever/Bestfoods is one of the cases which fully illustrate the approach the Commission employs when determining the scope of the to-be-divested business. ${ }^{573}$ In this case, Unilever filed a notification to the Commission, proposing a transaction in which it proposed to acquire sole control over Bestfoods. In the first place, Unilever proposed to divest a wide range of its brands, manufacturing facilities and supply arrangements in

\footnotetext{
567 ibid. See also: 2004 EUMR (n 3) art 14(2)(a),15(2)(a).

5682001 EC Remedies Notice (n 440) para. 12.

${ }^{569}$ Monti (n 34) 5.

5702001 EC Remedies Notice (n 440) para. 14.

571 Slaughter and May, 'The EU Merger Regulation: An Overview of the European Merger Control Rules' (Slaughter and May, 2012) <https://www.slaughterandmay.com/media/64572/the-eu-merger-regulation.pdf> accessed 10 April 2016, 3.

5722001 EC Remedies Notice (n 440) para. 117.

573 Case COMP/M.1990, Unilever/Bestfoods (European Commission Decisions) $\left[\begin{array}{llll}28 & \text { September 2000] }\end{array}\right.$ <http://ec.europa.eu/competition/mergers/cases/decisions/m1990_en.pdf> accessed 20 April 2017.
} 
different countries and regions to ensure the viability of the divested business. In the second place, to fully clear the Commission's competition concerns, various products were also proposed to be divested as complementary assets. By including complementary assets, better conditions were expected to be created so that the purchaser could fulfil the full value of the brands in the markets instead of gaining the current market shares alone. ${ }^{574}$

\subsubsection{Mix-and-Match Approach}

As the name implies, a mix-and-match approach refers to a situation where the to-bedivested business is a combined assets package chosen from both the merging parties. If the buyer of the to-be-divested business is an existing and active player in the market, it may be possible to divest certain parts of business chosen from both sides of the merging parties instead of divesting greater ones. Such an approach, nevertheless, is not favoured by the Commission since in the 2001 EC Remedies Notice, it stated that such an approach 'may create additional risks as to the viability and efficiency of the resulting business'. ${ }^{575}$ The Commission's negative attitude toward the mix-and-match approach is also echoed by both the FTC and the DOJ in the US. ${ }^{576}$

Although a mix-and-match assets package requires more scrutiny and should be assessed with greater care, in certain situations, the mix-and-match approach is also acceptable, provided that the Commission can be convinced that the buyer has the ability to integrate the chosen business effectively and immediately, ${ }^{577}$ and such selected business is viable enough to compete with the merged entity if operated by a suitable buyer.

An example related to this approach is Crown Cork \& Seal/CarnaudMetalbox. ${ }^{578}$ Crown Cork \& Seal, a leading American manufacturer of packaging, was permitted by the Commission to acquire CarnaudMetalbox, one of the largest French packaging companies, with conditional remedies in the form of divestitures. The Commission believed that such a notified proposal might cause serious competition concerns under the 1989 MR of creating or strengthening a dominant position. During the phase II of merger review procedures, five aerosol plants were required to be divested from both Crown Cork \& Seal and CarnaudMetalbox. ${ }^{579}$ The Commission held that with such a divestiture, the merged entity would not enjoy a dominant position in the EEA market for tinplate aerosol cans. ${ }^{580}$

\subsubsection{Crown Jewel Provisions}

Crown jewel provisions can be used to remedy the situations where the composition of a divestiture package is inappropriate. It means that if the merging parties fail to divest certain business to a suitable buyer within the appropriate short time span, they will have to divest an alternative divestiture package with at least equal value to the original one. The Commission introduced the so called "crown jewel provisions" in the 2001 EC Remedies Notice, which shared the same connotation to the US's. According to the 2001 EC Remedies Notice, the notifying parties can autonomously decide an alternative divestiture proposal, containing assets which have at least equal or higher value than the original

\footnotetext{
${ }^{574}$ Morgan (n 550) 553.

5752001 EC Remedies Notice (n 440) para. 18.

576 See: 2012 FTC Remedies Statement (n 36) 4. See also: 2011 DOJ Policy Guide (n 56) 8.

5772001 EC Remedies Notice (n 440) para. 18

578 Case IV/M.603, Crown Cork \& Seal/CarnaudMetalbox (European Commission Decision) [23 March 1996] <http://eur-lex.europa.eu/legal-content/EN/TXT/?uri=CELEX\%3A31996D0222> accessed 20 April 2017.

579 See: European Commission, 'Crown Cork \& Seal/CarnaudMetalbox: The Commission Imposes Strict Conditions' (EUROPA, 1995) <http://europa.eu/rapid/press-release_IP-95-1245_en.htm> accessed 17 April 2017.

580 ibid.
} 
divestiture package. ${ }^{581}$ In the crown jewel provisions, an explicit timetable should also be set to determine when the alternative divestiture package should be sold.

In Nestle/Ralston Purina, an alternative divestiture package was provided by the notifying party besides the original one. ${ }^{582}$ Nestle had a tradition of involvement in the production, marketing and sale of various food products, including pet food. It proposed to acquire Ralston Purina, an American company which had its primary activities in producing and selling pet food and cat box fillers. In the original divestiture package, Nestle proposed to divest its family brand of Friskies, together with Vital Balance. ${ }^{583}$ The divested brands were quite well known and accounted for significant sale shares in Spain. In the alternative package, the $50 \%$ shareholding of Ralston Purina in the Spanish joint venture with Agrolimen S.A would be divested in case the first packaged failed to be divested within an appropriate timetable.

\subsubsection{A Suitable Purchaser}

The Commission will accept a divestiture only if through such divestitures, viable business has been transferred to a suitable purchaser, resulting in the emergence of a new entity or the strengthening of an existing entity. Accordingly, choices of viable business and selections of suitable purchasers are inter-linked.

Normally, when determining whether a potential purchaser is suitable, the Commission will take into account various elements, including, inter alia, the relevant experience the purchaser has in the industry concerned and its financial conditions. A suitable purchaser should be 'a viable existing or potential competitor, independent of and unconnected to the parties, possessing the financial resources, proven expertise and having the incentive to maintain and develop the divested business as an active competitive force in competition with the parties'. ${ }^{584}$

Thus, the identity of a purchaser can affect the result of divestitures. The Commission, in some situations, may require the notifying parties to enter into a binding agreement with a purchaser for the to-be-divested business before they carry out the merger transaction, before it decides to clear the transaction. Such a purchaser is called an "up-front buyer." 585 The choice of the up-front buyer should be approved by the Commission.

The Commission for the first time required an up-front buyer in Bosch/Rexroth ${ }^{586}$ as a condition for approval. Bosch was a company whose activities were mainly in the field of motor vehicle technology, communications technology, consumer durables and producer goods. ${ }^{587}$ It proposed to acquire Rexroth, another company with a particular leading position in the axial piston pumps field. After an in-depth investigation during phase II of merger review procedures, the Commission held that this transaction would result in the dominant position of Bosch on the market for hydraulic piston pumps. To clear the Commission's competition concerns over creating a dominant position, Bosch proposed to sell its own radial piston pumps business to a competitor. However, the investigation

\footnotetext{
5812001 EC Remedies Notice (n 440) para. 22, 23.

582 Case COMP/M.2337, Nestle/Ralston Purina (European Commission Decision) [27 July 2001]

<http://ec.europa.eu/competition/mergers/cases/decisions/m2337_en.pdf > accessed 20 April 2017.

583 ibid, para. 67.

5842001 EC Remedies Notice (n 440) para. 49.

585 ibid, para. 20.

586 Case COMP/M. 2060, Bosch/Rexrot (European Commission Decision) $[2$ December 2000] <http://ec.europa.eu/competition/mergers/cases/decisions/m2060_de.pdf> accessed 20 April 2017.

587 See: European Commission, 'Commission Authorises Acquisition of Control of Rexroth by Robert Bosch GmbH subject to Conditions’ (EUROPA, 13 December 2000) < http://europa.eu/rapid/press-release_IP-001457_en.htm> accessed 17 April 2017.
} 
revealed that it was not sufficient to sell the business to restore effective competition in the market. To avoid the situation that Bosch would have been able to win back the market shares gradually after divestitures if the divested business was to be bought by a weak competitor, a strong competitor should be found. As a result, the Commission required Bosch to find a strong competitor before it decided to clear the proposed transaction. Finally, Bosch proposed Moog, a strong competitor in Europe as a purchaser, which was accepted by the Commission. ${ }^{58}$

\subsubsection{Trustee}

Other mechanisms were also introduced in the 2001 EC Remedies Notice to ensure quick and effective implementation of divestitures, such as hold-separate trustees and divestiture trustees.

The notifying parties have the responsibility to maintain the value of the divested assets during the interim period. Although the Commission may require the parties to offer remedies to maintain the independence, economic viability, marketability and competitiveness of the business, ${ }^{589}$ it can be difficult for the Commission to monitor the compliance with such remedies on a daily basis. As a result, a hold-separate trustee would normally be appointed by the parties and be approved by the Commission to oversee the parties' compliance with the interim preservation commitments.

Similarly, a divestiture trustee can be appointed to oversee the implementation of the remedies. ${ }^{590}$ The role of a divestiture trustee may vary depending on particular cases. For example, in a divestiture involving a crown jewel provision, a divestiture trustee has the responsibility to supervise the compliance of the parties to divest the business to a suitable buyer within a certain time limit. If the parties fail to achieve that, the divestiture trustee has an irrevocable mandate to sell the alternative package of divested business to a suitable buyer within a specific deadline at any price with prior approval from the Commission. ${ }^{591}$

\section{Schneider/Legrand: Lessons for EU Merger Divestitures}

\subsection{Schneider/ Legrand Merger}

\subsubsection{Litigation Review}

Schneider Electric SA ("Schneider") and Legrand SA ("Legrand") both were French groups with leading positions in the European low-voltage electricity distribution market. On 16 February 2001, Schneider filed a notification to the Commission, in which it proposed to acquire Legrand by means of a public offer for the exchange of almost all its shares. This was the beginning of the lengthy litigation of a series of Schneider/Legrand relevant cases which began in 2001 and ended in 2009.

\footnotetext{
588 ibid.

5892001 EC Remedies Notice (n 440) para. 50.

590 ibid, para. 53.

591 ibid, para. 54.
} 
Timetable for Schneider/Legrand relevant cases:

\begin{tabular}{|c|c|}
\hline Time & Events \\
\hline 16 February 2001 & $\begin{array}{l}\text { Schneider filed a notification to the Commission, proposing to acquire } \\
\text { Legrand. }\end{array}$ \\
\hline August 2001 & $\begin{array}{l}\text { Schneider completed the acquisition during the pending period of the } \\
\text { merger review procedures. }\end{array}$ \\
\hline 10 October 2001 & $\begin{array}{l}\text { Incompatible decision made by the Commission, }{ }^{592} \text { prohibiting the proposed } \\
\text { merger transaction. }\end{array}$ \\
\hline 30 January 2002 & $\begin{array}{l}\text { Demerger decision made by the Commission, }{ }^{593} \text { requiring Schneider to } \\
\text { divest the acquired Legrand. }\end{array}$ \\
\hline After demerger decision & $\begin{array}{l}\text { Schneider appealed both the incompatible decision and the demerger } \\
\text { decision to the GC. }\end{array}$ \\
\hline July 2002 & $\begin{array}{l}\text { Schneider entered into an agreement with Wendel Investissement and } \\
\text { Kohlberg Kravis Roberts \& Co. (Wendel/KKR), for them to acquire } \\
\text { Legrand. }{ }^{594}\end{array}$ \\
\hline 22 October 2002 & GC annulled both the Commission's decisions in its judgement. ${ }^{595}$ \\
\hline October 2002 & $\begin{array}{l}\text { The Commission began to re-examine the proposed transaction; } \\
\text { Schneider finally gave up its initial remedy proposal and decided to execute } \\
\text { the agreement with Wendel/KKR. }{ }^{596}\end{array}$ \\
\hline 10 October 2003 & $\begin{array}{l}\text { Schneider initiated a litigation against the Commission in front of the GC, } \\
\text { claiming compensation for its loss due to the Commission's annulled } \\
\text { negative decisions. }{ }^{597}\end{array}$ \\
\hline 11 July 2007 & GC upheld Schneider's claim. 598 \\
\hline After the GC's judgement & The Commission appealed the GC's judgement to ECJ. \\
\hline 16 July 2009 & ECJ confirmed the Commission's breach of Schneider's procedural right. 599 \\
\hline
\end{tabular}

The merger review procedure was initiated after Schneider filed the pre-merger notification to the Commission. During the pending period, however, Schneider completed the transaction in August 2001 before obtaining approval from the Commission.

592 Case T-310/01, Schneider/Legrand (COMP/M.2283) (European Commission Decision) [10 October 2001] OJ2004 L101. This decision declared that the proposed transaction to be incompatible with the common market. Thus, it is called hereinafter: incompatible decision.

${ }_{593}$ Case T-77/02, Schneider/Legrand (COMP/M.2283) (European Commission Decision) [30 January 2002] OJ2004 L101. This decision annulled Commission decision in Case T-310/01 (see: ibid) and required the merged firm to be separated. Thus, it is called hereinafter: demerger decision.

594 See: Herbert Smith LLP, 'ECJ Rules on Damages Claim in Schneider/Legrand Merger' (Herbert Smith LLP, 20 July 2009) <http://documents.lexology.com/8362fa68-f8e2-4469-b07f-5c47a2cdfcdb.pdf> accessed 18 April 2017. 595 See: European Commission, Judgments in Cases T-310/01 and T-77/02 (Schneider Electric SA v Commission): The Court of First Instance Annuls the Commission's Decisions Prohibiting the Concentration between Schneider and Legrand and Ordering Them to Separate Accordingly' (EUROPA, 2002) <http://curia.europa.eu/en/actu/communiques/cp02/aff/cp0284en.htm> accessed 18 April 2017.

596 Simon Holmes and Gordon Christian, 'European Union: Blocking Mergers Unlawfully: Following The Schneider / Legrand Decision, The Commission Now Risks Liability in Tort' (Mondaq, 6 June 2008) $<$ http://www.mondaq.com/x/61592/Antitrust+Competition/Blocking+Mergers+Unlawfully++Following+The +Schneider+Legrand+Decision+The+Commission+Now+Risks+Liability+In+Tort> accessed 18 April 2017.

597 See: Case T-351/03, Schneider Electric SA v Commission of the European Communities (Judgement of the Court of the First Instance) [11 July 2007] <http://curia.europa.eu/juris/showPdf.jsf?docid=71813\&doclang=EN $>$ accessed 19 April 2017.

598 ibid.

${ }^{599}$ Case C-440/07P, Schneider Electric SA v. Commission (Judgement of the European Court of justice) [16 July 2009] $<$ http://curia.europa.eu/juris/document/document.jsf?text=\&docid=72486\&pageIndex $=0 \&$ doclang=en\&mode $=$ lst\&dir $=\&$ occ $=$ first\&part $=1 \&$ cid $=396673>$ accessed 19 April 2017. 
After an in-depth investigation on the proposed merger, the Commission released its incompatible decision on 10 October 2001, stating that the proposed transaction was incompatible with the 1989 MR because such a merger, if completed, would have created and strengthened a dominant position with the effect of significantly restricting effective competition in the relevant market, and the remedies proposed by the parties were not sufficient to restore effective competition in the relevant market. ${ }^{600}$ On 30 January 2002, the Commission published its second decision, in which it required Schneider to divest Legrand within 9 months. ${ }^{601}$

After receiving the appeal from Schneider, the GC reviewed it through its expedited procedure, ${ }^{602}$ and made its decision on 22 October 2002, in which it annulled both the Commission's incompatible decision and the demerger decision. ${ }^{603}$ One of the most important reasons that the GC's annulment rested on was that there was a procedural irregularity which constituted an infringement of Schneider's defence right.

The GC found out that the rationale the Commission's final decision relied on was different from what had been stated in the Statement of Objections ("S/O") sent to Schneider. To be exact, Schneider initially proposed a merger remedy, dealing with all the areas where the activities were overlapping. ${ }^{604}$ It thought that the proposed remedy would have cleared all the prima facie competition concerns described in the S/O. Nevertheless, the Commission prohibited the transaction in the end. One of the reasons was its concerns over the leverage effect of Legrand's dominant position in the market for divisional and terminal electric boards in France. And the rationale it rested was not described in the S/O. Due to the unclear S/O and the discrepancy between the Statement of Objections and the Commission's decision, Schneider was denied any chance to defend itself or offer any modified remedies to render the proposed transaction to be compatible with the $1989 \mathrm{MR}$.

During the merger review procedures when the Commission re-examined the proposed merger transaction, Schneider also modified its remedy after initially proposing it. Nevertheless, the Commission rejected Schneider's proposed modified commitment for the reason that it had limited time for an adequate market testing to check the effectiveness of the commitment, as well as due to competitors' comments. ${ }^{605}$ This, more or less, was caused by the tight timeline in the $1989 \mathrm{MR}$, which made it impossible for the Commission to have a detailed study on the commitments proposed by the merging parties.

\subsubsection{Lessons for EU Merger Divestitures}

The merger divestitures policy in the EU is becoming more demanding and stringent with the enforcement of the 2001 EC Remedies Notice. In addition, in 2003, the Best Practice Guidelines concerning the model texts for merger divestitures and the trustee mandate

\footnotetext{
${ }^{600}$ Schneider/Legrand (n 592) para. 712.

${ }^{601}$ Schneider/Legrand (n 593) para. 1.

${ }^{602}$ GC's expedited procedure is also called "fast track" procedure. According to GC, such a procedure is designed to deal with cases of a particularly urgent nature, in particular in merger cases. For more detailed information on this topic, see: Kyriakos Fountoukakos, 'Judicial Review and Merger Control: The CFI's Expedited Procedure' [2002] 3 Competition Policy Newsletter <http://ec.europa.eu/competition/publications/cpn/2002_3_7.pdf> accessed 17 April 2017.

${ }^{603}$ European Commission (n 595).

${ }^{604}$ Antoine Winckler, 'Some Comments on Procedure and Remedies under EC Merger Control Rules: Something Rotten in the Kingdom of the EC Merger Control?' in Francois Lévêque and Howard Shelanski (eds), Merger Remedies in American and European Union Competition Law (Merger Remedies in American and European Union Competition Law, 1 edn, Edward Elgar 2003) 77.

605 ibid, 81.
} 
were released by the Commission (which has been replaced by the 2013 version). ${ }^{606}$ As described above, to ensure a quick and effective implementation of merger divestitures, the Commission adopts stricter and more risk-reducing provisions when negotiating merger divestitures with the parties, such as, requirements of divesting a greater set of business other than merely overlapping parts, inclusions of crown jewel provisions and up-front buyer provisions, and a requirement of mandating trustees. These all reflect the Commission's desire to set up a transparent, effective and coherent regulatory scheme for merger divestitures. The reality, however, is quite different from to what the Commission desires. The Schneider/Legrand merger can be considered as a typical example which reveals the drawbacks of the merger review system, ultimately resulting in deficiency of merger divestitures.

\section{A. Contradictions between the notifying parties and the Commission concerning their responsibility}

On the one hand, the notifying parties take the responsibility to propose proper merger remedies to render their transaction to be compatible with the Merger Regulation, with the aim to get a clearance decision from the Commission. On the other hand, the Commission has the burden to prove that such a proposed merger transaction may/will have the potential to raise serious competitive concerns which would have impeded effective competition significantly in the relevant market after completion.

During phase I of the merger review, a State of Play meeting will be held between DG COMP and the parties if DG COMP has doubts about the compatibility of the proposed merger. In phase II, a S/O will be sent by DG COMP to the notifying parties, in which it describes its competition concerns. As described above, in Schneider/Legrand, the S/O the Commission provided was unclear and discrepant from its final decision, which deprived Schneider of the chance to defend or to propose more focused remedies to clear the competition concerns described in the $\mathrm{S} / \mathrm{O}$.

Accordingly, whether the parties can fulfil their responsibility to propose a proper merger remedy also partially depends on what competition concerns the Commission describes in the S/O. It may not be realistic to expect that every specific competition concern has been identified clearly in the S/O. At least the Commission should ensure that the $\mathrm{S} / \mathrm{O}$ covers all the reasons and rationale it rests on when it makes a final decision.

On the other hand, since the S/O is not clear and explicit enough, for fear of being prohibited, the parties are likely to propose to divest a greater scope of business than is necessary. In practice, the Commission sometimes does require the parties to divest themselves of a greater set of business where no competition issues arise to ensure the viability of the divested assets, but such a large scope of divestitures still may result in a rise in the transaction costs for the merging parties, as well as for society as a whole.

\section{B. Lack of time for a detailed study of the proposed remedies}

According to the 2001 EC Remedies Notice, in phase II, the parties have to submit the commitments within 3 months from the date this period begins. ${ }^{607}$ On the one hand, it is reasonable to assume that it is better for the parties to submit the commitment as soon as

\footnotetext{
${ }^{606}$ DG COMP, European Commission, Best Practice Guidelines: The Commission's Model Texts for Divestiture Commitments and the Trustee Mandate under the EC Merger Regulations (2003). It is replaced by the 2013 version. See: DG COMP, European Commission, Best Practice Guidelines: The Commission's Model Texts for Divestiture Commitments and the Trustee Mandate under the EC Merger Regulation (2013) (hereinafter: 2013 EC Best Practice Guidelines). Please note that the word "commitments" in the context of the EU is generally the same as the word "remedies". In this book, these two words are used in general as synonyms. ${ }^{607} 2001$ EC Remedies Notice (n 440) para. 139.
} 
possible, taking into account that there needs to be time left for the Commission to have a detailed study of the proposed commitments, as well as to consult the third parties. On the other hand, the parties are intended to do so after they receive the S/O from the Commission. In practice, before the 2004 Merger Regulation came into enforcement, the Commission was likely not to accept the commitments even if they had been submitted late but within due time, because of the lack of remaining time for consulting and the complexity of the proposals. ${ }^{608}$

In Schneider/Legrand, the modified commitment proposed by the merging parties was refused by the Commission merely because the Commission did not have enough time for a detailed and adequate study of the proposed remedies. Thus, lack of time will also lead to other problems when ordering merger divestitures in practice besides the awkward situation Schneider faced.

Since the Commission becomes more willing to adopt risk-reducing provisions in merger divestitures, more negotiations and cooperation are expected between the Commission and the parties. Take up-front buyer provisions as an example. It is widely and frequently used by the FTC in the US because such a provision can reduce the risk of failing to find a suitable purchaser. ${ }^{609}$ Crown jewel provisions are also used by the FTC and the DOJ, with which, an alternative package of divested business is provided once the parties fail to complete divestitures within the limited time span.

All these provisions may prolong the time frame since they involve a lot of new information which needs to be negotiated by both the Commission and the parties. Only under a flexible timetable with the possibility of extension of time can these provisions be applied properly and effectively. Before the enforcement of the 2004 EUMR, the timetable for merger review under the 1989 MR was comparatively rigorous, implying that although the Commission is willing to order such risk-reducing provisions, it may find it difficult to require such provisions due to time pressure. ${ }^{610}$ Accordingly, the effectiveness of merger divestitures can, to some extent, be impeded.

Besides, it is also very important to protect the parties' procedural rights of defence during the merger review procedures. Such defence right not only grants the parties the chance to respond to the Commission's objections with counter-arguments, but also gives the parties the opportunity to tailor and narrow down their proposed remedies to clear the Commission's objections to win the clearance decision ultimately.

In the GC's judgment which annulled the Commission's incompatible decision and demerger decision for Schneider/Legrand, it stressed that the S/O should at the very least contain all of the Commission's objections in sufficiently clear wording so as to allow the notifying parties to exercise their right of defence. ${ }^{611}$ Thus, to keep the S/O clear is, to some extent, helpful for the parties to propose appropriate merger remedies, especially merger divestitures.

\footnotetext{
${ }^{608}$ Winckler (n 604) 80.

${ }^{609}$ See: 1999 FTC Divestiture Study (n 38).

${ }^{610}$ Winckler (n 604) 82.

${ }^{611}$ Frederic Louis, Anne Vallery and Sven Volcker, 'Commission Merger Control Analysis Again Severely Sanctioned by the European Court in the Schneider Case' (Wilmer, Culter \& Pickering, 23 October 2002) <http://www.wilmerhale.com/uploadedFiles/Shared_Content/Editorial/Publications/German_Publications/Sc hneider_Judgment2002-10-22_bulletin.pdf> accessed 18 April 2017.
} 


\subsection{EC Merger Remedies Study}

To better design and implement effective merger remedies, the Commission reviewed cases in which merger remedies had been ordered from 1996 to 2000 and published the Merger Remedies Study in 2005. The objectives of this study were, first, to identify serious issues arising in the design and implementation of remedies, second, to study the effectiveness of the Commission's merger remedy policy during 1996 to 2000, and third, to propose further improvements to the Commission's existing merger remedies policy and practice. ${ }^{612}$

It was the first time the Commission conducted such a merger remedies study, following the publication of the 1999 FTC Divestiture Study, which specifically focuses on merger divestitures. Overall, these two studies were conducted in a similar manner and came to essentially similar conclusions. ${ }^{613}$ In the 2005 EC Merger Remedies Study, remedies are divided into four categories: commitments to transfer a market position, commitments to exist from a JV, commitments to grant accesses, and other commitments. ${ }^{614}$ The Commission categorises first two types of remedies and one "other" remedy in the domain of "divestiture remedies".

\subsubsection{The Divested Business Issues}

Among all the problems which may affect the design and implementations of merger divestitures, the Merger Remedies Study identified that the most frequent one was the inadequate scope of the divested business, which accounted for $79 \%$ of the 84 divestiture remedies DG COMP studied. ${ }^{615}$ The missing of key assets was the main reason for such inadequacy. Accordingly, the Commission found out and concluded 5 considerations which must be taken into account when determining the proper scope of the divested business:

1) Upstream and downstream links between the divested business and parts of the parties' retained business;

2) Geographic scope of a viable and competitive divested business as compared to the geographic scope of the relevant market which may not be the same;

3) Critical size or mass of the divestiture package;

4) Considerations of product cycle effects, such as the maturity of the divested products, to compete against the innovative and new generation of products which the merging parties had retained, and

5) Issues in relation to intellectual property rights ("IPRs"). ${ }^{616}$

In practice, another difficulty in deciding the proper scope of the divested business concerns the Commission's deviated emphasis when choosing business. The Commission's approach of divesting merely overlapping parts of the merging parties' market activities could be problematic, since it paid too much attention to market structure and market shares, while neglecting the ability of the divested business to restore competition to the market. ${ }^{617}$ It seems that the FTC laid more weight on the fit between the divested assets

\footnotetext{
6122005 EC Merger Remedies Study (n 27) para.1, 137.

${ }^{613}$ Kenneth M Davidson, 'The Reports on Divestiture Remedies of the US FTC and EU DG COMP' (Antitrustinstitute, 15 February 2006) <http://www.antitrustinstitute.org/files/482.pdf> accessed 18 April 2017, 1. 6142005 EC Merger Remedies Study (n 27) para. 6, 138.

615 ibid, para. $5,140$.

616 ibid, para. 7, 140.

${ }^{617}$ See: Penelope Papandropoulos and Alessandro Tajana, 'The Merger Remedies Study-In Divestiture We Trust?' (2006) 8 ECLR 443, 446.
} 
and the capacities of the buyer, while the Commission focuses on the quantity of related and unrelated assets. ${ }^{618}$ Consequently, such a clean-sweep approach has at times resulted in insufficient consideration of the commercial value of the chosen divested business, without which the competitiveness of such business would have been impaired.

To ensure the effectiveness of divestitures to the extent possible, it is generally required, not only in the 2001 EC Remedies Notice, but also in the 2013 EC Best Practice Guidelines, that the to-be-divested business shall be viable, stand-alone and have the ability to compete with the merged party in the market effectively, if being operated by a suitable purchaser. Although the Commission preferred stand-alone business, in practice, carve-out divestitures (or "mix-and-match" divestitures) ${ }^{619}$ were also used by the Commission as a ratio of three to two to stand-alone divestitures in the Study samples. ${ }^{620}$ Serious implementation issues were raised by the carve-out merger divestitures. Take IP rights divestitures as an example. Divesting IP rights entails very complicated procedures, during which, an allocation of personnel is rather critical since it can influence the realisation of the goals of divestitures. Therefore, various additional arrangements should be completed together with the personnel allocation, such as providing the employees with the incentives to stay within the divested business; laying down obligations on the parties to allocate relevant key personnel to the buyers. The Study stressed that although carve-out divestitures were ordered in some cases, stand-alone divestitures were still preferred.

As described above, the 2001 EC Remedies Notice has considered the use of crown jewel provisions in merger divestitures when the parties fail to complete divestitures within a certain timetable. The Study further confirmed the use of crown jewels since such provisions may improve the effectiveness of divestitures by either 1. increasing pressure on the seller to implement the remedy in a timely fashion; or 2. avoiding stalemate where the seller failed to find a suitable purchaser for its first (preferred) remedy package. ${ }^{621}$ However, in practice, the Study pointed out that the crown jewels were seldom used. According to the Study, among all the cases the Commission studied, only 4 cases included such a provision. Three of them ended up with divesting the alternative package instead of the original to-be-divested package. The Study further stressed that the crown jewels would prolong the whole divestiture period and were likely to result in the delay of the divestiture time span.

\subsubsection{Suitable Purchaser Issue}

A suitable purchaser is another important factor when designing a divestiture. The Study recognised that the issue concerning the suitability of the purchaser was raised in 40 out of 84 divestiture remedies (48\%). ${ }^{622}$ It confirmed the existence of a purchaser risk (unavailability of a suitable purchaser), and identified that small companies, to some extent, may encounter greater difficulties to compete when acquiring a new business. ${ }^{623}$ Thus, it concluded that a purchaser should not be accepted if there is a better purchaser, and the following can be deemed as some criteria for selecting a suitable purchaser:

\footnotetext{
${ }^{618}$ Davidson (n 613).

${ }^{619}$ Carve-out divestitures involve the division of both tangible and intangible assets, as well as the allocation of personnel between the divested and retained business. Such business can be chosen from either side of the merging parties. Carve-out divestitures are similar to the "mix-and-match" divestitures. See: 2005 EC Merger Remedies Study (n 27) para. 56, 150.

620 ibid, para. 1,73 .

621 ibid, para. 10, 54 .

622 ibid, para. 97, 159

${ }^{623}$ Papandropoulos \& Tajana (n 617) 446.
} 
1) has the financial resources and proven expertise deemed necessary;

2) has the incentive to maintain and develop the divested business as an active competitive force in competition with the parties and other competitors; and

3) is independent and not connected to the parties;

4) does not create new competition concerns, nor increase the risk that the implementation of the commitments will be delayed; and

5 ) is expected to receive all necessary regulatory approval by NCAs and other regulatory bodies. ${ }^{624}$

An up-front buyer will be ordered when the viability of the divested business largely depends on the identity of the purchaser. In the Study, only one remedy included an upfront buyer provision. ${ }^{625}$ The up-front buyer provisions received both positive and negative comments from the interviewees. For the positive side, it was claimed that an up-front buyer can, first, speed up the divestiture process, resulting in reducing the risks of maintaining the viability of the divested business and shortening the transitional period during which competition is not yet fully restored; second, it can convince the Commission to the maximum extent that a proposed merger will not be completed unless the competition concerns are cleared; third, reduce the risks of the value of the divested business deteriorating during the interim period. ${ }^{626}$ The negative comments mainly focus on the idea that an up-front buyer provision may urge the notifying parties to carry out the sale in a rush to obtain a clearance decision from the Commission as soon as possible and to complete the merger transaction. Such a fire sale may grant little time to the purchaser to have a full command of relevant information concerning the divested business, or prove that an unsuitable purchaser was found. ${ }^{627}$

Accordingly, a balance must be struck between the goal of shortening the time frame for merger divestitures and the parties' attempt to rush the sale. When an up-front buyer provision is included in the divestitures, a proper pace should be set so that a suitable purchaser can be found, as well as to avoid the negative side-effect brought by a rushed sale. The Study also concludes that an up-front buyer can ensure that the parties try their best to implement the divestitures effectively within the time span. However, it should be borne in mind that negative side-effects may be produced under the pressure of completing the proposed transaction as soon as possible.

\subsubsection{Trustee Issues}

In the 2001 EC Remedies Notice and the 2005 EC Merger Remedies Study, the Commission distinguished between the hold-separate trustee and the divestiture trustee. Both trustees are appointed for, at least, the reason that it is almost impossible for the Commission to monitor the parties' compliance with their obligations on a daily basis. Thus, trustees play an important role in ensuring the effective implementation of merger divestitures. The hold-separate trustees are frequently used by the Commission, whereas the divestiture trustees have not been used very often. ${ }^{628}$

During the interim period, the parties usually provide a commitment to hold separately the divested business to preserve its economic viability, marketability and competitiveness.

\footnotetext{
${ }^{624} 2005$ EC Merger Remedies Study (n 27) para. 98, 159.

625 ibid, para. 33, 107.

626 ibid, para. 34, 107.

${ }^{627}$ ibid, para. 35, 107-108.

${ }^{628}$ Papandropoulos \& Tajana (n 617) 447.
} 
A hold-separate trustee is mandated to monitor the compliance with such a commitment. The Study confirms that the services of a hold-separate trustee are quite necessary in almost every instance for monitoring the interim preservation and hold-separate provisions. ${ }^{629}$ The main issues concerning the hold-separate trustee were the selection of the trustee, the scope of its function, its mandate, and its relationship with the parties, third parties and the Commission. ${ }^{630}$

Considering the fact that trustees were appointed within 4 weeks in merely $40 \%$ of all cases, it is necessary to ensure that a hold-separate trustee be appointed in the early stage.

\section{The 2008 EC Remedies Notice: the EU's Development in Merger Divestitures}

During the development of the EU merger divestitures, the 2001 Remedies can be considered as an example in which the Commission re-contextualised what it has learned from the established US practice in the merger remedy field. With the publication of the 2004 EUMR which changes the substantive test from the "dominance test" to the so called "SIEC" test, and the publication of the 2004 EUMR Implementation Regulation ${ }^{631}$ which allows an extension of the merger review deadlines to evaluate the remedies put forward by the parties in detail, the Commission seems to be going in the right direction to develop its merger remedies. In 2005, the Merger Remedies Study was released to study the effectiveness of designing and implementing merger remedies. In addition, much practical experience has been gained by the Commission from how the GC and the CJ deal with merger cases.

The revised 2008 EC Remedies Notice sets out general principles applicable to merger remedies to the Commission. Such a Notice reflects the Commission's evolving approach in the assessment, acceptance and implementation of remedies under the Merger Regulation. ${ }^{632}$ Compared with the 2001 version, the 2008 version is in far greater detail. It clarifies the Commission's general principles about merger remedies, re-emphasizes its preference for remedies of a structural nature (such as divestitures), sets more detailed legal standards for acceptable merger divestitures, and refines procedures for merger remedies, especially for divestitures. Accordingly, it has over double the size of the 2001 Notice. Meanwhile it is largely structured in the same way.

\subsection{General Principles}

The criterion for declaring a proposed merger transaction to be compatible with the 2004 Merger Regulation has changed in the revised Remedies Notice, in line with the changes in the substantive test. ${ }^{633}$ As analysed above in above sec.3.2, the SIEC test fills the gap the dominance test left when evaluating whether a merger should be blocked or not. A concentration will be prohibited if it may "Significantly Impede Effective Competition" in

\footnotetext{
${ }_{629} 2005$ EC Merger Remedies Study (n 27) para. 22, 61.

630 ibid, para. 81, 155.

${ }^{631}$ Commission Regulation (EC) No. 802/2004 of 7 April 2004 Implementing Council Regulation (EC) No. 139/2004 on the Control of Concentration between Undertakings [2004] OJ L133 (hereinafter: 2004 EUMR Implementation Regulation).

6322008 EC Remedies Notice (n 35) para. 2.

633 ibid, para. 4.
} 
the market, especially through creating or strengthening a dominant position. Thus, a merger remedy will only be accepted if it can modify the transaction to have no SIEC effect.

It is clear that it is the Commission's responsibility to demonstrate that a concentration would significantly impede competition. ${ }^{634}$ Consequently, the Commission can be anxious about obtaining all necessary information from the notifying parties. On the other hand, the notifying parties have the responsibility to formulate appropriate merger remedies proposals. ${ }^{635}$ Compared with the 2001 EC Remedies Notice, the new version reemphasises and further clarifies the burdens and responsibilities between the Commission and the notifying parties. It lays more obligations on the notifying parties, requiring them to provide more detailed information concerning the proposed merger remedies.

A new Form RM was introduced in the 2004 EUMR Implementation Regulation. ${ }^{636}$ It concerns both divestitures and other merger remedies. In general, it specifies the information to be provided by the parties when they intend to submit a proposed merger remedy to the Commission. Accordingly, in the new Remedies Notice, it is clarified that it is the notifying parties' obligation to provide the Commission with all necessary information for its assessment. Such information may include the object of the merger remedies and the terms/conditions for the implementation.

The revised Notice contemplates that the Commission might block a merger transaction if the parties fail to submit sufficient detailed information. ${ }^{637}$ However, such an approach may arouse the suspicion of laying too many burdens on the notifying parties, ${ }^{638}$ which is contradicted by what the GC stated in EDP $v$ Commission:

Even on the assumption that the Commission ....intended to make the parties to a notified concentration responsible for demonstrating the effectiveness of the proposed commitments, an exercise which is consistent with their interests, the Commission could not conclude that where there is doubt it must prohibit the concentration. ${ }^{639}$

Another important clarification the Commission makes in the general principles is the requirement of certainty concerning the acceptance of structural remedies, particularly the divestiture remedy. Such a requirement for certainty can be understood from two aspects. First, the proposed divestiture remedies should be sufficiently practical to be implemented. Further, such implementation should lead to an effective restoration of competition in the market, which means the divested business can actively compete with the merged party in the market on a lasting basis. In other words, the rationale behind the certainty requirement is to ensure that the proposed divestiture remedies can entirely clear the competitive concerns raised by the Commission and should be comprehensive and effective enough from all points of view. ${ }^{640}$ To comply with these principles, a divestiture remedy should

\footnotetext{
634 ibid, para. 6 .

635 ibid, para. 6.

636 See: 2004 EUMR Implementation Regulation (n 631) Annex IV: Form RM

${ }^{637}$ Greg Olsen, 'Revised EU Merger Remedy Guidance' (2008) 23 Antitrust 80, 81.

638 ibid.

${ }^{639}$ Case T-87/05, Energias de Portugal SA (EDP) v. Commission of the Europea (Judgement of the Court of First Instance)[21 September 2005] < http://curia.europa.eu/juris/document/document.jsf?text=\&docid=59907\& pageIndex $=0 \&$ doclang $=$ en\&mode $=1$ st $\&$ dir $=\& o c c=$ first $\&$ part $=1 \&$ cid $=427740>$ accessed 18 April 2017, para. 64 . ${ }^{640}$ Case T-210/01, General Electric Co. $v$ Commission of the European (Judgement of the Court of First Instance)[14 December 2005] <http://curia.europa.eu/juris/document/document.jsf?text=\&docid=57077\&pageIndex $=0 \&$ doclang $=E N \&$ mode $=l s t \& \operatorname{dir}=\& o c c=$ first $\&$ part $=1 \&$ cid $=427852>$ accessed 18 April 2017. See: Summary of the Judgement, (EUROPA, 2005) <http://curia.europa.eu/juris/showPdf.jsf;jsessionid=9ea7d2dc30db641bac8f
} 
also be able to be implemented effectively and require no further monitoring. In the 2001 version, however, the Commission required that no medium or long term monitoring was necessary for a divestiture remedy.

\subsection{Design of Merger Divestitures}

Like the 2001 EC Remedies Notice, the revised version specifies its preference for the remedies as structural in nature. In the 2008 EC Remedies Notice, a general distinction is made between divestitures, other structural remedies, and other commitments relating to the future behaviour of the merged entity. ${ }^{641}$ The so-called "other structural remedies" include, such as, granting access to key infrastructure, networks, key technology, ${ }^{642}$ and changing long-term exclusive contracts. ${ }^{643}$ Other non-structural remedies refer to promises by the parties to abstain from certain commercial behaviour. ${ }^{644}$

It is pointed out in the new Notice that although the appropriateness of a remedy should be assessed on a case-by-case basis, the divestiture remedies are still the best remedy to render the competition concerns in cases involving horizontal overlaps, as well as to solve the competition problem resulting from vertical or conglomerate concerns. ${ }^{645}$ Divestitures are deemed to be the benchmark for other types of remedies to assess their effectiveness and efficiency, ${ }^{646}$ suggesting that the Commission may consider using other types of remedies only if these remedies can achieve at least equivalent effects as divestitures. Remedies relating to the future behaviour of the merged entity may be acceptable only exceptionally in very specific circumstances. ${ }^{647}$

The Commission refines divestiture policy in the new Notice and provides far more detailed guidance concerning the composition of divested business and the selection of a purchaser. Moreover, risk-reducing provisions are introduced by the Commission with more details.

\subsubsection{Composition of Divestiture Packages}

In general, the Commission will accept a proposed divestiture remedy only if the to-bedivested business included is viable, on-going and can be operated on a stand-alone basis. ${ }^{648}$ These three requirements are actually closely inter-linked. The possibility for an effective implementation will be increased if a suitable purchaser operates the divested business which has its own key personnel, daily management, distribution system, and physical facilities and supply resources needed for production. The possibility of viability and commercial value for being competitive in the market should be taken into account by the Commission when assessing and determining whether the divested business can constitute an effective divestiture.

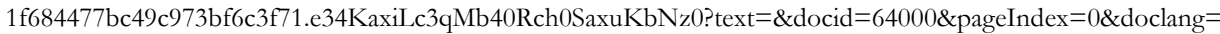
EN\&mode $=1$ st\&dir $=\& o c c=$ first\&part $=1 \&$ cid $=630639>$ accessed 19 April 2017. See also: 2008 EC Remedies Notice (n 35) para. 9.

${ }^{641} 2008$ EC Remedies Notice (n 35) para. 17.

642 ibid, para. 62-66.

643 ibid, para. 67-68.

644 ibid, para. 69.

645 ibid, para. 17.

${ }^{646}$ Antonio Capobianco, 'Working Party No.3 on Co-operation and Enforcement: Remedies in Merger Cases' (EUROPA, 15 June 2011) < http://ec.europa.eu/competition/international/multilateral/2011_jun_remedies. pdf $>$ accessed 19 April 2017, para. 10.

${ }_{647} 2008$ EC Remedies Notice (n 35) para. 17.

648 ibid, para. 23, 25, 32. 
The Commission puts it more straightforwardly in the revised Remedies Notice that ' $\mathrm{T}]$ he divested business has to contain the personnel providing essential functions for the business such as, for instance, group R\&D and information technology staff even where such personnel is currently employed by another business unit of the parties - at least in a sufficient proportion to meet the on-going needs of the divested business'. ${ }^{649}$

\subsubsection{Carve-outs / Mix-and-Match}

Although the Commission has a clear preference for an existing stand-alone business, ${ }^{650}$ it may also consider accepting the divested business which has existing strong links or is partially integrated with business retained by the parties. Such business needs to be carved out from the whole parts of business. Since this approach is usually not favoured by the Commission which has been described in the 2001 EC Remedies Notice and the 2005 EC Merger Remedies Study, the Commission provides more detailed guidance concerning the conditions for accepting the carve-outs.

The requisite requirement for accepting a carve-out is that it is certain that until the moment when the business is transferred to the purchaser, a viable business on a standalone basis will be divested and the risk of low viability and competitiveness resulting from the carve-outs will be reduced to a minimum. ${ }^{651}$ As a result, the Commission further requires in the Notice that the carve-out shall be started in the interim period. ${ }^{652}$

One important rationale the Commission rests on when considering the acceptance of carve-out is the principle of proportionality. This principle requires the Commission to limit its involvement and action to the degree necessary to achieve its objective. ${ }^{653}$ Put differently, how the Commission reacts should be in line with what it pursues. Noteworthy, on the one hand, it seems that the Commission is willing to consider the principle of proportionality when evaluating the sufficiency of a proposed merger remedy. On the other hand, para. 9 of the 2008 Notice Remedies states that 'the commitments have to eliminate the competition concerns entirely and have to be comprehensive and effective from all points of view'. In this context, the Commission even does not mention a word on the principle of proportionality as a constraint. This contradiction may, to some extent, explain why the carve-outs/mix-and-match approach is not favoured by the Commission.

\subsubsection{Crown Jewel Provisions}

The Commission has introduced the use of crown jewel provisions in the $2001 \mathrm{EC}$ Remedies Notice in a very general way. The 2005 EC Merger Remedies Study further indicated that crown jewel provisions were not used frequently in the analysed remedies. ${ }^{654}$ Comparatively, the revised Notice provides practical guidance concerning crown jewel provisions in greater detail.

In the US, the FTC and the Antitrust Division of the DOJ have different attitudes towards the inclusion of the crown jewel provisions. They also hold discrepant opinions on the positive and negative sides of the crown jewel provisions. Nevertheless, in practice, both of them order such provisions in the divestiture remedies (especially the FTC), possibly because such a provision can to some degree relieve the CAs' anxiety about the

\footnotetext{
649 ibid, para. 26.

650 ibid, para. 33.

651 ibid, para. 35.

652 ibid.

653 See: European Union, 'Proportionality Principle' (EUROPA) < http://europa.eu/legislation_summaries/ glossary/proportionality_en.htm> accessed 19 April 2017.

${ }_{654} 2005$ EC Merger Remedies Study (n 27) para. 5, 52.
} 
failure of divestitures. The Commission explicitly pointed out that it 'cannot take the risk that, in the end, effective competition will not be maintained [due to an ineffective divestiture]'. ${ }^{655}$ As a consequence, the Commission refines the policy and notes that the alternative package of the divested business will be accepted if there lacks certainty in the original package; and the parties promise to sell the alternative package if they fail to divest the original one to a suitable purchaser within the given timeframe. ${ }^{656}$

To assure the effectiveness of the divestitures, the value of the alternative divestiture package should at least be equivalent to the original one, and should have the capability of being implemented effectively.

\subsubsection{Non-Reacquisition Clause}

With the changed market structure resulting from divestitures, more viable competition is expected to be brought back into the market. However, there is a risk that the merged party, after a certain period, wins back its market shares by re-acquiring the divested business. This may again raise serious competition concerns. Thus, in order to maintain the structural effect, the Commission for the first time clarified in the 2008 EC Remedies Notice that such re-acquisition is not allowed after the divestiture remedies. The period generally is of 10 years. The non-reacquisition clause can ensure that the merged parties cannot subsequently acquire influence over the whole or parts of the divested business. ${ }^{657}$

\subsubsection{Other Forms of Divestitures}

Various forms of divestitures, such as divestitures of brands and licenses, and re-branding have been introduced in detail by the Commission. Nevertheless, these divestiture remedies occur less frequently. 658

A divestiture of licences (especially for IP rights) is generally not preferred by the Commission, as such a divestiture involves too many uncertainties. Such certainties will raise the risk of the licensee's failure to compete in the market immediately, and result in on-going relationship between the licensee and the divested party for, e.g., subsequent technical support. Take the pharmaceutical industry in the US as an example. The parties may propose to divest a license for producing a particular medicine to the purchaser. However, the fact is that this medicine is still waiting for the approval from the FDA. This will create great risks for both the purchaser and the Commission. The purchaser may not be able to compete with the merged party once he fails to get approval. For the Commission, the ultimate result can be that divestitures fail to render the merger transaction, and serious competition concerns still exist in the market which will significantly impede effective competition.

It is the same to re-branding divestitures. It is clearly stated in the revised Notice by the Commission that a re-branding divestiture carries substantially higher risks for restoring effective competition than a divestiture of business since there are huge uncertainties whether the purchaser (licensee) will successfully establish itself as an active competitor in the market based on the re-branded product. ${ }^{659}$

\footnotetext{
6552008 EC Remedies Notice (n 35) para. 45.

656 ibid.

657 ibid, para. 43.

${ }^{658}$ Sergio Sorinas, 'European Union: EU Merger Remedy' [2009] I F L R, <http://www.iflr.com/Article/ 2324298/European-Union-EU-merger-remedies.html> accessed 19 April 2017.

${ }^{659} 2008$ EC Remedies Notice (n 35) para. 40.
} 
Either divestitures of licences and brands or re-branding can be problematic since they do not have the requisite degree of certainty which is rather important for the Commission when assessing the proposed divestitures. Besides, overall, such forms of divestitures usually require an on-going relationship with the merged party and create serious doubts for the viability and competitiveness of the business based on such brands or licences. Lack of support for these forms of divestitures again confirms the Commission's clear preference for divestitures of viable and existing business with a stand-alone basis.

The Commission, on the other hand, may also consider accepting these divestitures when the notifying parties propose an up-front buyer or try to fix-it-first. These solutions, to some extent, increase the possibility of effective implementation of divestitures since the realisation of an effective implementation also largely depends on the suitability of purchasers.

\subsubsection{A Suitable Purchaser}

The Commission has identified a suitable purchaser as an important element it will consider when evaluating the appropriateness of the proposed merger remedies. ${ }^{660}$ In line with what was presented and suggested in the 2005 EC Merger Remedies Study, the Commission may require additional requirements for accepting a purchaser.

For example, in Posten $A B$ / Post Danmark $A / S$, a merger was proposed between two companies whose main activities were in the post field. In the decision, the parties were asked to put forward a modified and improved divestiture proposal, stating that the potential purchaser 'would have a proven expertise in the field of parcels, recognised brand in the field of parcels as well as an international presence in the field of parcels'. ${ }^{661} \mathrm{In}$ Sanofi-Aventis/Zentiva, a modified divestiture proposal was formulated by the parties to ensure the smooth transfer of the production of the divested business. The Commission requested that a provision should be added, which stated that 'the purchasers of the divestment businesses should have the capacity to take over production of the products concerned, either themselves or via third parties independent from the [merging] Parties'. ${ }^{662}$

Consequently, in the 2008 EC Remedies Notice, guidelines were set out in great detail by the Commission concerning the criteria of assessing the suitability of a purchaser:

- the purchaser is required to be independent of and unconnected to the parties,

- the purchaser must possess the financial resources, proven relevant expertise and have the incentive and ability to maintain and develop the divested business as a viable and active competitive force in competition with the parties and other competitors, and

- the acquisition of the business by a proposed purchaser must neither be likely to create new competition problems nor give rise to a risk that the implementation of the commitments will be delayed. Therefore, the proposed purchaser must reasonably be expected to obtain all necessary approvals from the relevant regulatory authorities for the acquisition of the business to be divested. ${ }^{663}$

\footnotetext{
660 ibid, para. 47.

${ }^{661}$ Case COMP/M.5152, Posten AB / Post Danmark. A/S (European Commission Decision) [21 April 2009], VI-4, para 182, <http://ec.europa.eu/competition/mergers/cases/decisions/m5152_20090421_20212_en.pdf > accessed 20 April 2017.

${ }^{662}$ Case COMP/M.5253, Sanofi-Aventis/Zentiva (European Commission Decision) [4 February 2009], V-2, para 5.3, $<$ http://ec.europa.eu/competition/mergers/cases/decisions/m5253_20090204_20212_en.pdf> accessed 20 April 2017.

${ }_{663} 2008$ EC Remedies Notice (n 35) para. 47.
} 
The purchaser may share different goals with the Commission when operating the divested business. Such risks have also been identified in the 1999 FTC Divestiture Study. As a result, the Commission specifies that a purchaser should be an industrial, rather than a financial purchaser for the reason that a financial buyer might not be able, or might not have the incentives, to develop the business as a viable and competitive force in the market. ${ }^{664}$

The Commission identifies three ways to ensure that the divested business is transferred to a suitable buyer. ${ }^{665}$ The most frequently used one is to transfer the business to a Commission-approved buyer within a fixed time frame after the completion of merger transactions. To create the requisite degree of certainty, the Commission may also adopt two other ways, namely, adding an up-front buyer provision or accepting the parties' fix-itfirst remedy in a merger divestiture.

\subsubsection{Up-front Buyers}

The Commission clarifies the situations where an up-front buyer may be considered in para. 54 and para. 55 of the 2008 revised Notice. First, an up-front buyer may be required when there is a risk of unavailability of a suitable purchaser. From the Commission's point of view, an up-front buyer can not only ensure the implementation of merger divestitures, but also provide greater incentives for the parties to enter into a binding agreement with the purchaser which is approved by the Commission as soon as possible so as to complete their own transactions. The Commission confirms that an up-front buyer and a crown jewel provision have the same effect under this scenario, with the same function to reduce the risk of failing to find any suitable purchaser for the to-be-divested business. ${ }^{666}$

Second, an up-front buyer will also be required when the value of the divested business is very likely to deteriorate during the interim period. ${ }^{667}$ The function of an up-front buyer in this scenario is that it can shorten the interim time spent on searching for a qualified purchaser.

In practice, in the merger transaction INEOS/Solvay, an up-front buyer provision was included considering that on the one hand, the proposed transaction can lead to a situation where none of the non-merging parties in the relevant markets can restrain the merged firm's capability of increasing prices, on the other hand, a qualified purchaser was thus important in this case to restore competition. ${ }^{668}$ It is pointed out that it seems that the use of up-front buyers in the EU is on a "rising tide". ${ }^{669}$

\subsubsection{Fix-It-First Remedies}

As described in the previous chapter, a fix-it-first remedy is widely used in the merger divestitures field in the US, especially by the DOJ. A fix-it-first remedy grants the parties

\footnotetext{
664 ibid, para. 49.

665 ibid, para. 50.

666 ibid, para. 54.

667 ibid, para. 55.

668 See: European Commission, 'Mergers: Commission Clears Acquisition of Certain INEOS Chlorovinyls Businesses by ICIG and Approves ICIG as Buyer of Divested Assets Linked to Approval of INEOS / Solvay Joint Venture' (EUROPA, 9 June 2015) < http://europa.eu/rapid/press-release_IP-15-5147_en.htm> accessed 19 April 2017.

${ }^{669}$ Competition Policy International, 'Rising Tide of 'Fix-It-First' and 'Up-front Buyer' Remedies in EU and UK Merger Cases' (Competition Policy International, 2016) < https://www.competitionpolicyinternational.com/rising-tideof-fix-it-first-and-up-front-buyer-remedies-in-eu-and-uk-merger-cases/> accessed 25 January 2017.
} 
more freedom to formulate their divestiture proposal. From the perspective of the CA, a fix-it-first remedy can increase the requisite degree of certainty in the sense that a purchaser has been found. On the other hand, however, such a remedy may to some extent increase the workload of the CA during the merger review because assessment of the proposed transaction and the proposed remedy have to be conducted in parallel.

The Commission for the first time introduced this remedy in the revised Remedies Notice. Under a fix-it-first remedy, the merging parties identify and enter into a binding agreement with a buyer before the beginning or during the process of merger review. In other words, compared with an up-front buyer whose identification is unknown to the Commission when it reviews the merger notification and the divestiture proposal, the Commission has known the identification of the buyer when it reviews the merger notification and it will assess whether the transfer of the proposed to-be-divested business to the identified buyer will be sufficient enough to remove the competition concerns entirely when it make its final decision. ${ }^{670}$

The Commission clarifies that a fix-it first remedy is welcomed when the identification of the purchaser has significant influence on the viability and competitiveness of the divested business. ${ }^{671}$ Thus, with regard to finding a suitable buyer, an up-front buyer has the equivalent effect of a fix-it-first remedy.

For example, in September 2016, the Commission accepted a fix-it-first divestiture remedy in Hutchison/VimpelCom. ${ }^{672}$ This was also the first time for the Commission to accept a fix-it-first divestiture remedy in a transaction concerned the mobile telecoms industry. The French telecommunications operator Iliad was proposed as the purchaser to the divested business. It is pointed out that there is a rising tide of the use of the fix-it-first remedy at the EU level. ${ }^{673}$

\subsection{Implementation of Divestitures}

\subsubsection{Divestiture Process}

As a response to the 2004 EUMR and the observations in the 2005 EC Merger Remedies Study, detailed guidance on the divestiture process has for the first time been introduced by the Commission, and this may increase the transparency and predictability of the merger divestitures process.

The whole divestiture process can be divided into two stages: entering into a final agreement and closing and transferring the legal title of the transaction. ${ }^{674}$ The first stage can further involve two sub-periods: the self-divesting period: the merging parties have to enter into a legally binding agreement with a suitable buyer who normally needs to be approved by the Commission, and; the trustee-divesting period: if the parties fail to divest the business, then a trustee will be appointed to divest the business with no limitation on the minimum price. ${ }^{675}$

As observed by the FTC and the DOJ, a shortened time span of divestitures can be helpful to increase the effectiveness of implementation since it reduces the risk of value

\footnotetext{
6702008 EC Remedies Notice (n 35) para. 56.

671 ibid, para. 57.

${ }^{672}$ European Commission, 'Mergers: Commission Approves Hutchison/VimpelCom Joint Venture in Italy, Subject to Conditions' (EUROPA, 1 September 2016) < http://europa.eu/rapid/press-release_IP-16-2932_en. htm> accessed 19 April 2017.

${ }^{673}$ Competition Policy International (n 669).

${ }^{674} 2008$ EC Remedies Notice (n 35) para. 97.

675 ibid.
} 
deterioration during the interim periods. There will be a trend that the divestiture period will be further shortened by the CAs. ${ }^{676}$ Similarly, the Commission also sets the time-table for divestiture as short as feasible. Generally, the parties have to complete the first divestiture period within about 6 months and they have another 3 months for the trustee divestiture if they fail to complete the divestment in the first period. ${ }^{677}$ Another 3 months are granted to the parties for closing the transaction. ${ }^{678}$ Merger and merger divestiture process at the EU Level are presented below:

Figure 3 Merger and Merger Divestitures at the EU Level

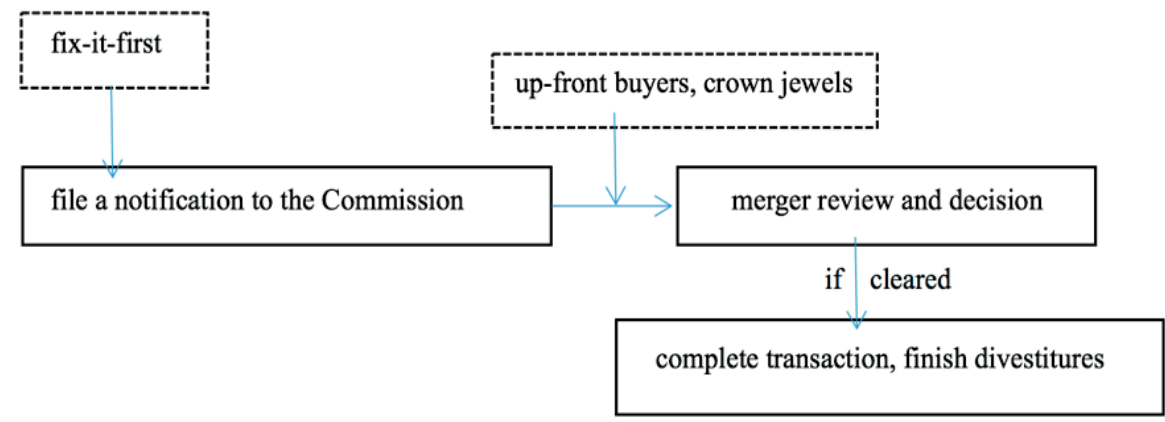

Figure 4 Divestiture Process at the EU Level

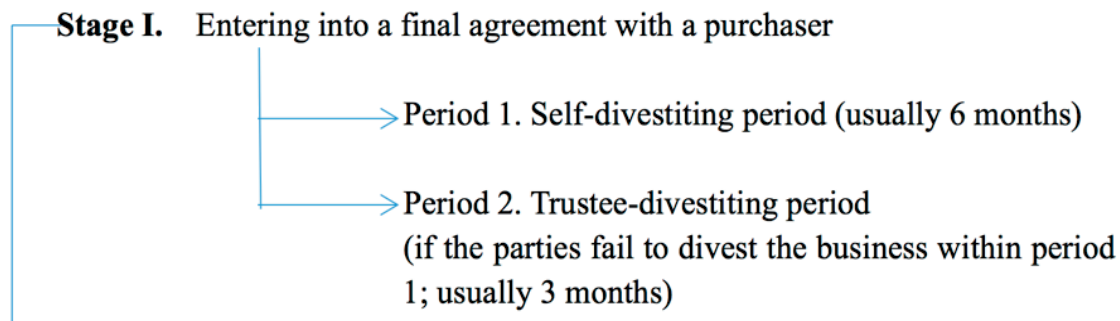

\section{Stage II. Closing the transaction (usually 3 months)}

\subsubsection{Monitoring Trustees and Divestiture Trustees}

Trustees play a significant role in monitoring the parties' compliance with commitments. The 2005 EC Merger Remedies Study has summarised the function of a trustee. Accordingly, in the revised 2008 EC Remedies Notice, the Commission acknowledges the use of trustees by specifying detailed rules and guidance. It states that trustees '[a]llow the Commission to ensure that the modification of the notified concentration, as proposed by the parties, will be carried out with the requisite degree of certainty'. ${ }^{679}$ A trustee can increase the degree of certainty to ensure an effective divestiture implementation, which is similar to the up-front buyer and a fix-it-first remedy.

\footnotetext{
${ }^{676}$ See: Chapter 2, sec.6.1.4.

${ }^{677} 2008$ EC Remedies Notice (n 35) para. 98

678 ibid.

679 ibid, para. 117.
} 
In line with the 2005 EC Merger Remedies Study, in the new Remedies Notice, trustees are divided into two categories, monitoring trustees and divestiture trustees. ${ }^{680}$ The main responsibility of monitoring trustees is to oversee the parties' implementation of their commitments during the interim period and the divestiture process. ${ }^{611}$ With regard to divestiture trustees, they are appointed during the trustee divestiture period when the parties fail to complete the divestment for the first time.

Both trustees are proposed by the parties. They can be either natural persons or legal persons, such as institutions. Normally the parties will propose several trustees as candidates and the Commission selects the one it thinks is the most suitable. The trustees are appointed by the parties, thus, their duties and obligations will be specified in detail in the trustee mandate, which will be concluded between the parties and the trustees. ${ }^{682} \mathrm{In}$ early cases such as Kimberly Clark/Scott (1996) ${ }^{683}$ and Sare Lee/Courtaulds (2000), ${ }^{684}$ trustees were deemed as the representatives of the parties and they were under the supervision of the parties instead of the Commission. Now the Commission makes it clear that trustees are under the supervision of the Commission, which means they are the "eyes and ears" of the Commission. The Commission may give instructions to the monitoring trustees and the parties are not able to give any order to the trustees unless such an order is pre-approved by the Commission. ${ }^{685}$ Concerning the divestiture trustees, they are granted an irrevocable and exclusive mandate to dispose of the divested business with no minimum price under the supervision of the Commission. ${ }^{686}$

On a case-by-case basis, the monitoring trustee may or may not be the same person / institution as the divesture trustee. The 2005 EC Merger Remedies Study indicated that one of the most serious problems concerning the trustees was the timing of the mandate. In the majority of the divestiture cases reviewed, the monitoring trustee was not appointed until more than a month after the effective date. ${ }^{687}$ Therefore, the Commission emphasises in the 2008 EC Remedies Notice that trustees should be mandated in time, with the approval from the Commission. ${ }^{688}$ The Commission Model Text for the trustee mandate, also declares that 'the parties' list of proposed candidates should reach the Commission no later than one week after the effective date'. ${ }^{689}$

\section{Conclusion}

The Commission was granted the authority to control mergers at the EU level from the enactment of the 1989 MR. It has released the revised Merger Regulation in 2004 to adapt to the changed political and economic conditions both in the EU and worldwide. One of the most prominent changes in the 2004 EUMR concerns the substantive test, which was

\footnotetext{
680 ibid, para. 117, 121.

681 ibid, para. 117.

682 ibid, para. 119.

${ }^{683}$ Case IV/M.623, Kimberley/Scott (European Commission Decision) [16 January 1996], para. 233-239, 63, <http://ec.europa.eu/competition/mergers/cases/decisions/m623_en.pdf> accessed 20 April 2017.

${ }^{684}$ Case COMP/M.1892, Sare Lee/Courtaulds (European Commission Decision) [8 May 2000], part 1.1, para. 9, 15, < http://ec.europa.eu/competition/mergers/cases/decisions/m1892_en.pdf> accessed 20 April 2017.

6852008 EC Remedies Notice (n 35) para. 118.

686 ibid, para. 121.

${ }^{687}$ Jonas S Bruecker and Thomas Hoehn, Monitoring Compliance with Merger Remedies- The Roles of the Monitoring Trustee' (2010) 6 Competition L Int'l 73, 74.

${ }^{688} 2008$ EC Remedies Notice (n 35) para. 123-124.

6892013 EC Best Practice Guidelines (n 606) para. 18.
} 
changed from the "dominance test" to the "SIEC test" (Significantly Impede Effective Competition). The 2004 EMUR Implementation Regulation further provides a more flexible time frame which grants the Commission and the merging parties more time to discuss merger remedies. ${ }^{600}$ This solves the problems existed in the previous merger remedies process as described above in sec.5.1.2.

Regarding merger divestitures, the EU has experienced the period as a beginner. The first Remedies Notice was published in 2001, which was largely influenced by the established-US practice in the merger divestiture field. ${ }^{691}$ However, due to loopholes and drawbacks in the merger divestiture scheme (as described in sec.5 of this chapter), afterwards, a merger remedy study was conducted by the Commission and was published in 2005, namely, the 2005 EC Merger Remedies Study. In this study, the Commission identified the obstacles to achieve an effective merger divestiture.

To satisfy the practical demands of merger remedies, the revised 2008 EC Remedies Notice was then published. It has a structure similar to the 2001 version, whereas it has doubled in size. The 2008 version provides detailed guidance on merger remedies, especially on merger divestitures, which reflects the Commission's desire to build a predictable, transparent and coherent regulatory divestiture scheme.

There are some similarities and differences between the CAs in the US and the EU. The question of whether there is a convergence in the future development of merger divestitures in the US and EU will be studied in the next chapter.

${ }^{690} 2004$ EUMR Implementing Regulation (n 631).

${ }^{691}$ See: Morgan (n 550). 


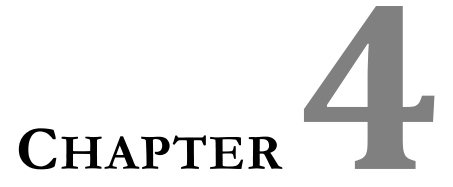

MERgER DIVESTITURES IN THE US AND THE EU - FUTURE CONVERGENCE? 



\section{Introduction}

US merger divestitures have experienced emergence, evolution and development in the past few decades. The FTC and the Anti-trust Division of the DOJ, as two CAs, have respectively published their study or policy guide regarding merger remedies, especially divestitures. ${ }^{692}$ As observed and described in the previous chapters, the EU, at the beginning, learned from the established-US divestiture practice, which was reflected in the 2001 EC Remedies Notice. ${ }^{693}$ Subsequently, to examine whether such a US-inspired approach would be desirable and workable in an EU context, a study was conducted by the Commission: the 2005 EC Merger Remedies Study. ${ }^{694}$ In 2008, a revised Remedies Notice was released by the Commission (replaced the 2001 version) as a response and summary to these developments. ${ }^{695}$

With an increasing number of mergers happening at the global level, it becomes even more important than before that mutual understanding and respect can be set up between the countries concerned, so that trade conflicts can be avoided or eliminated to the extent possible. It is possible that an international transaction has to be notified to the CAs in both the US and the EU. Having a good understanding of the common ground as well as the differences in the first place between the US and the EU in the merger divestiture field can be helpful to devise mechanisms to respect the genuine differences of view that obviously exist, and yet continue to move forward to deepen the common ground. ${ }^{696}$ Further, a comparison of merger divestitures in the US and the EU can provide an opportunity to evaluate whether the design and implementation of merger divestitures in these two jurisdictions are effective in reducing anti-competitive effects, which will be analysed from a law and economics perspective in the next part.

In this chapter, a comparison is made regarding merger divestitures in the US and the EU to explore the main similarities and differences in that regard. The chapter is thus structured as follows: first, the current cooperation in the merger control field between the US and the EU is presented in sec.2. Second, a comparison of the merger divestitures policies in the US and the EU is made, including an analysis of the background of the competition agencies (sec.3), the design of merger divestitures (sec.4), and the implementation of merger divestitures (sec.5). Next in sec.6, reasons for differences and the common ground of the merger divestiture policy is explored. A conclusion is drawn in sec.7.

\section{Cooperation in the Merger Control Field between the US and the EU}

For some time now, the issue concerning the extra-territorial application and enforcement of competition law in both the US and the EU has been recognised. The "effects doctrine" has been employed by the US, which was for the first time set up in United States $v$. Aluminum Co. of America ("Alcoa"). It stated that a state has jurisdiction over anticompetition transactions which may affect the market within the state, even if the activities

\footnotetext{
${ }^{692}$ For example, 1999 FTC Divestiture Study (n 38); 2004 DOJ Policy Guide (n 321); 2011 DOJ Policy Guide (n 56).

${ }^{693} 2001$ EC Remedies Notice (n 440).

${ }^{694}$ Kerckhove (n 431) 66. See also: 2005 EC Remedies Study (n 27).

${ }^{695} 2008$ EC Remedies Notice (n 35).

${ }^{696}$ Wood (n 75) 67.
} 
take place outside the state. ${ }^{697}$ In the EU, on the other hand, an "implementation test" is adopted, implying that EU competition law can be applied to agreements between the EU and outside parties which affects imports (but not exports) and to parties wholly outside the EU jurisdiction. ${ }^{698}$ Although the US "effects doctrine" and the European "implementation test" have minor practical differences, ${ }^{699}$ the differences regarding cooperation and coordination enforcement activities between these two powers are inevitable due to different ways of thinking and discrepant goals of competition law. ${ }^{700}$ Accordingly, mutual agreements have been reached between the US government and the European Commission with the aim to reduce conflicts and further deepen cooperation.

In 1991, the EU/US Competition Cooperation Agreement was signed and came into force ("1991 Agreement"). ${ }^{701}$ The Agreement was originally signed between the European Commission and the US government; however, it was successfully challenged by France since the Commission was acting ultra vires, ${ }^{702}$ resulting in the annulment of the agreement. Later in 1995, by a joint decision of the Council of Europe and the Commission, the Agreement was approved and declared applicable since the date it was originally signed. ${ }^{703}$ The Agreement provides mutual notification of cases in Article II, exchange of information in Article III, cooperation and coordination between the EU/US competition authorities in Article IV, a "tradition comity" procedure ${ }^{704}$ and a "positive comity" procedure 705 in Article VI and Article V respectively. ${ }^{706}$ It set up a fundamental framework for bilateral cooperation and coordination between the Commission, the FTC and the DOJ.

To further elaborate the principles of positive comity and the implementation of those principles in the 1991 Agreement, the 1998 EU/US Positive Comity Agreement was concluded between the European Commission and the US government. ${ }^{707}$ ' $[\mathrm{T}] \mathrm{he}$ agreement clarifies both the mechanics of the positive comity cooperation instrument, and the circumstances in which it can be availed of.' 708

\footnotetext{
${ }^{697}$ Unites States v. Aluminum Co. of America, 148 F. 2d 416, 443-44 (2d Cir, 1945).

${ }^{698}$ Rodney Edward Falvey and Peter John Lloyd, 'An Economic Analysis of Extraterritoriality' (Research Paper, University of Nottingham 1999) <http://www.nottingham.ac.uk/gep/documents/papers/1999/99-03.pdf> accessed 21 April 2017, 5 .

${ }^{699}$ Michael Faure and Xinzhu Zhang, 'Towards an Extraterritorial Application of the Chinese Anti-Monopoly Law that Avoids Trade Conflicts' (2013) 45 Geo Wash Int'l L Rev 501, 515.

700 See: sec.6 below.

701 Agreement between the Government of the United States of America and the Commission of the European Communities Regarding the Application of Their Competition Laws - Exchange of Interpretative Letters with the Government of the United States of America [1995] OJ L95, 47-52.

702 See: Case C-327/91, French Republic v Commission of the European Communities (Judgment of the Court) [ 9 August 1994] <http://eur-lex.europa.eu/legal-content/EN/TXT/?uri=ecli:ECLI:EU:C:1994:305> accessed 20 April 2017.

${ }^{703}$ Alexandr Svetlicinii, 'Cooperation Between Merger Control Authorities of the EU and the U.S.: A Viable Solution for Transatlantic Mergers?’ (2006) 7(3) UC Davis Bus L J 171,171.

${ }^{704}$ A "traditional comity" procedure by virtue of which each Party undertakes to take into account the important interests of the other Party when it takes measures to enforce its competition rules. See: European Commission, 'Bilateral Relations - United States of America' (EUROPA, last update 16 April 2012) <http://ec.europa.eu/ competition/international/bilateral/usa.html> accessed 18 April 2017.

${ }^{705}$ A "positive comity" procedure by virtue of which either Party can invite the other Party to take, on the basis of the latter's legislation, appropriate measures regarding anti-competitive behaviour implemented on its territory and which affects the important interests of the requesting Party. See: European Commission, ibid.

${ }^{706}$ For detailed information of this Agreement, see: European Commission, ibid.

${ }^{707}$ Agreement between the European Communities and the Government of the United States of America on the Application of Positive Comity Principles in the Enforcement of Their Competition Laws [1998] OJ L173, 0028 0031 .

${ }^{708}$ European Commission (n 704).
} 
As a supplement to the 1991 Agreement, the Commission and the US government reached an understanding in 1999, namely, the Administrative Arrangement on Attendance ("AAA"). ${ }^{709}$ The AAA is a mutual understanding rather than a new agreement, setting forth administrative arrangements between both competition authorities concerning reciprocal attendance to apply the 1991 Agreement.

Afterwards in 2001, a set of best practices was prepared by the EU-US Merger Working Group, which was established after the failure of the cooperation mechanism in GE/Honeywell in 2001.710 One of them is the 2001 Best Practices on Cooperation in Merger Investigations, which has been replaced by its 2011 version. ${ }^{711}$ According to the 2011 Best Practices, the aim of the document is to provide an advisory framework for inter-agency cooperation by setting forth best practices that the FTC and the DOJ in the US and the DG COMP in Europe will seek to apply. ${ }^{712}$

These documents together provide for a framework for cooperation and coordination of enforcement between the Commission in the EU and the DOJ and the FTC in the US in the merger control field. Since it is very likely that merger transactions at the international level involve both the US and the EU, better cooperation between these two entities can effectively reduce trade conflicts and facilitate mutual understanding. Accordingly, more cooperation can be expected in the future so that the CAs can work in close collaboration.

\section{Background: The Competition Authorities}

Since the US and the EU are trying to deepen their cooperation of merger control by concluding agreements or releasing Best Practices on merger investigations, it is important to understand in the first place what separates these two entities and what is the common ground they share.

As introduced in Chapter 2, the US adopts a dual enforcement mechanism. The FTC and the DOJ, as two competition authorities, are parallel and share the authority in the merger control field. Such a dual system enables these two authorities to work in close collaboration. For example, the FTC traditionally has its expertise in the electricity industry, whereas the DOJ is more experienced in the media industry. When the merging parties file a notification to both the FTC and the DOJ, they can internally decide who takes the responsibility to investigate the notified merger. Consequently, it can, to the extent

\footnotetext{
${ }^{709}$ For reports on the application of the Agreement between the EU and US, see: European Commission, 'Reports on Competition Policy' (EUROPA) < http://ec.europa.eu/competition/publications/annual_report/index.html> accessed 20 April 2017.

${ }_{710}$ Svetlicinii (n 703) 1. On 3 July 2001, the European Commission rejected the proposed merger between the General Electric Co. and Honeywell International Inc. See: Case COMP/M.2220, General Electric/ Honeywell (European Commission Decision) [3 July 2011] < http://ec.europa.eu/competition/mergers/cases/decisions/ m2220_en.pdf $>$ accessed 20 April 2017. This case was deemed an example demonstrating the inadequacy of contemporary international competition policy. Also, it was a typical example which exposed the inadequate cooperation in the merger control field between the US and EU regarding the extraterritorial application of competition law. See generally: Faure and Zhang (n 699). See also: Malcolm MacLaren, 'The GE/Honeywell Merger Case: Reaching the Limits of International Competition Policymaking' [2001] 2 Ger. Law J. <https://static1.squarespace.com/static/56330ad3e4b0733dcc0c8495/t/56bc3fcf2eeb81bc2dc741df/145517768 0024/GLJ_Vol_02_No_12_MacLaren.pdf> accessed 20 April 2017.

711 US-EU Merger Working Group: Best Practices on Cooperation in Merger Investigations (2011) <http://ec.europa.eu/competition/mergers/legislation/best_practices_2011_en.pdf> accessed 21 April 2017. 712 ibid, 1.
} 
possible, ensure that the proposed merger is dealt with by the most suitable authority which has rich experiences and professional knowledge in the industry concerned.

On the other hand, such a dual system can also bring negative side-effects. Although the FTC and the DOJ have mutual understanding on industry division, there still exist some "grey areas" where the division of work is unclear. This may result in wrangling with each other or passing the buck. Besides, these two authorities may have different preferences in some divestiture policy or guidance in practice, which can reduce the predictability and transparency of the whole divestiture scheme. For the notifying parties, this will increase the uncertainties of their proposed transactions. It is worth pointing out that with the accumulation of experience obtained from case law and practice and the on-going development of merger divestitures, the differences between the FTC and the DOJ in the merger divestiture fields are narrowing and a convergence can be expected in the future. ${ }^{713}$

In contrast with the system in the US, the European Commission is the only authority which is assigned the responsibility to review merger transactions with an EU dimension. The Commission has multi-roles as an investigator, prosecutor and decision-maker. Since the EU merger control is based on the concept of a "one-stop shop", it is reasonable and understandable that the Commission is the only authority because such an arrangement can, to the degree possible, simplify the notification procedure at the EU level. However, on the other hand, Member States also have their national competition laws which deal with merger transactions without an EU dimension. In addition, in some situations, it is also possible that an EU-dimension merger application can be referred from the Commission to the National Competition Agencies ("NCAs") concerned, vice versa.

Furthermore, both the US and the EU adopt two-stage merger review procedures. A proposed merger transaction will be cleared if it will not raise serious competition concerns, and this will "significantly impede effective competition" (EU "SIEC" test) or "substantially lessen competition" (US "SLC" test) in the market.

\section{Design of Merger Divestitures}

\subsection{Preference for Merger Divestiture}

Merger remedies can be generally divided into two categories, structural and behavioural. The 2001 Merger Remedies Policy Guide which was released by the Anti-trust Division of the DOJ states that divestitures are regarded as the most typical structural remedies. ${ }^{714}$ Behavioural remedies include for example, firewall provisions, non-discrimination provisions, mandatory licensing provisions, and transparency provisions. ${ }^{715}$ The $2005 \mathrm{EC}$ Merger Remedies Study released by DG COMP of the European Commission, however, did not adopt the structural/behavioural classification. It distinguished remedies in the following categories: (1) commitments to transfer a market position; (2) commitments to exit from a joint-venture; (3) commitments to grant access; and (4) (a small number of) other commitments. ${ }^{716}$ As described in Chapter 3, the European Commission's 2008 EC Remedies Notice basically opts for the structural/behavioural distinction. ${ }^{717}$

\footnotetext{
713 See: Chapter 2. See also: Mengmeng Shi, 'Merger Divestitures under the Dual Enforcement Mechanism: Whether A Convergence Exists Between the FTC and the DOJ?' (2016) 37 Whittier L Rev 67.

714 See: 2001 DOJ Policy Guide (n 692).

715 ibid, 12-17.

716 See: 2005 EC Merger Remedies Study (n 27).

717 See: 2008 EC Remedies Notice (n 35).
} 
Traditionally, remedies with a structural nature, especially divestitures, are favoured by the CAs in both the US and EU in merger cases, ${ }^{718}$ especially in horizontal mergers. Such preferences may result from the CAs' idea that divestitures can directly change the structure of the relevant market and thus create conditions for the emergence of new entity, or strengthen an existing competitor.

In the US, such a preference was set up in United States v. E.I. DuPont de Nemours \& Co.. ${ }^{719}$ In addition, the FTC shows such preference by stating 'anti-competitive horizontal mergers are most often remedied by a divestiture' in the 2012 FTC Remedies Statement. ${ }^{720}$

In the EU, the Commission for the first time confirmed its preference for merger divestitures in the 2001 Merger Remedies Notice, which is line with that the General Court stated in Gencor v. Commission. ${ }^{721}$

\subsection{Composition of Divestiture Packages}

When determining the composition of the to-be-divested assets, the criteria that the CAs in the US and the EU adopt can be concluded as follows: a suitable divestiture package should include all parts of the business which are necessary to contribute to a viable business. ${ }^{722}$ In the US, a clean-sweep approach is usually applied by the FTC, under which all the overlapping parts of the merging parties will be divested. ${ }^{723}$ The Commission has a similar approach. In addition, all these CAs may also accept a "mix-and-match" approach in some situations. ${ }^{724}$

Furthermore, the common standards for the selection of the assets in the divestiture packages can be summarised as follows: existing, on-going and autonomous. It is believed that a to-be-divested business which satisfies these three standards can increase the possibility of being viable and competitive after the completion of divestitures, if operated by a suitable purchaser.

\subsection{Crown Jewel Provisions and the Fix-It-First Remedies}

The Commission for the first time introduced crown jewel provisions in the 2001 Merger Remedies Notice by stating that that an alternative package of the divested business can increase the transferability. ${ }^{725}$ It also confirmed the function of crown jewel provisions in the 2008 version of the Merger Remedies Notice. The 2005 EC Merger Remedies Study revealed that crown jewels were not used frequently by the Commission. ${ }^{726} \mathrm{It}$ is believed that although so far the Commission has rarely used this provision, it can be expected that the Commission will use it more frequently in the future. ${ }^{727}$ Furthermore, the transfer of an alternative divestiture package suggests that divestiture process will be prolonged for

\footnotetext{
718 See: for example: 2011 DOJ Policy Guide (n 56) 1; 2012 FTC Remedies Statement (n 36) 4; 2008 EC Remedies Notice (n 35) para. 17; 2005 EC Merger Remedies Study (n 27) 171.

719 United States v. E.I. du Pont de Nemours \& Co., 366 U.S. 316 (1961).

7202012 FTC Remedies Statement (n 36) 4.

${ }^{721}$ Case T-102/96, Gencor v. Commission (Judge of the Court of First Instance) [25 March 1999] <http://eurlex.europa.eu/legal-content/EN/ALL/?uri=CELEX\%3A61996TJ0102> accessed 20 April 2017.

${ }^{722}$ For the FTC and the DOJ's requirements for divestitures assets see: Chapter 2, sec.6.1.2. For the European Commission's acceptable composition of divestiture packages, see: Chapter 3, sec.6.2.1.

${ }^{723}$ For the introduction of the FTC's "clean-sweep" approach, see: Chapter 2, sec.5.1.3.1.

${ }^{724}$ For the use of the "mix-and-match" approach in the US, see: Chapter 2, sec.6.1.2. For the use of the "mix-andmatch" approach in the EU, see: Chapter 3, sec.6.2.1.1.

7252001 EC Remedies Notice (n 440) para. 22.

726 See: 2005 EC Merger Remedies Study (n 27$) 52$.

${ }^{727}$ Papandropoulos and Tajana (n 617) 452.
} 
generally three months. Thus, the Commission usually requires a short time frame, which is also in line with the practice in the US. ${ }^{728}$

In the US, the FTC frequently orders crown jewel provisions in its consent orders, whereas the DOJ did not view this provision favourably, which was reflected in the 2004 version of the Policy Guide. With the release of the new Policy Guide in 2012, the DOJ has changed its attitude and confirms the use of crown jewel provisions to increase the likelihood of the emergence of an appropriate purchaser. ${ }^{729} \mathrm{It}$ is pointed out, however, that recently the FTC seems to move its interest from crown jewel provisions to up-front buyers. ${ }^{730}$

The notifying parties may submit a fix-it-first solution to the CAs before the start or during the process of merger review procedures. As a result, the identification of the purchaser has been known to the CAs during merger review and such remedy proposals will be evaluated together with the proposed transactions so that the CAs can determine whether the proposed divestment is sufficient to clear competition concerns created by the proposed merger and keep the competition effective in the market.

In the US, a fix-it-first remedy is especially favoured by the DOJ. The DOJ states that '[A] successful fix-it-first remedy can eliminate the Division's competitive concerns and the need to file a case'. ${ }^{731}$ The FTC, on the other hand, stated that it would not entertain a "fix-it-first" proposal, and historically did not favour its use. ${ }^{732}$ However, such discrepant attitudes of the DOJ and the FTC can be expected to change. As observed in Chapter 2, after being rejected by the Court concerning the non- consideration of a restructure agreement formulated by the parties, ${ }^{733}$ the FTC may begin to consider the parties' fix-it-first plan instead of seeking to block the transaction directly. In the EU, the Commission has considered the use of the fix-itfirst remedies and for the first time introduced it in the 2008 EC Remedies Notice. Despite this, the Commission seems not to be so keen on this remedy. ${ }^{734}$

Overall, both the DOJ and the Commission consider the acceptance of a fit-it-first remedy, although the DOJ seems to be keener on it. Although the FTC traditionally has no preference for such a remedy, it may in the future try to consider it if parties formulate such a remedy.

\subsection{Requirements for a Suitable Purchaser}

The Commission, the FTC and the DOJ basically share the same requirements when assessing the suitability of a purchaser. In brief, a suitable purchaser, firstly, should be independent; secondly, should have the ability and incentives to properly operate the divested business, so that it can compete effectively in the market with the merged parties on a lasting basis and; thirdly, there should be no further competition concerns created by transferring the business to such a purchaser. ${ }^{735}$ When evaluating the ability of a purchaser, it may refer to its financial conditions; experience in related industry the proposed concerns, etc.

\footnotetext{
${ }^{728}$ See: Chapter 2, sec.6.1.4.

729 See: Chapter 2, sec.5.2.2 (4).

730 See: Katz and Perlgut (n 422) 78.

7312011 DOJ Policy Guide (56) 22.

732 Breed and Michnal (n 351) 38.

733 See: FTC v. Libbey, Inc., 211 F. Supp. 2d 34 (D.D.C. 2002).

733 See: FTC v. Arch Coal, Inc., 329 F. Supp. 2d 109 (D.D.C. 2004); FTC v. Libbey, Inc., 211 F. Supp. 2d 34 (D.D.C. 2002).

${ }^{734}$ Héctor Armengod, 'Merger Control Procedure' (Latham \& Watkins, 2012) < https://www.lw.com/presenta tions/eu-merger-control-procedures-2012> accessed 20 April 2017.

735 See: 2008 EC Remedies Notice (n 35) para. 47; 2011 DOJ Policy Guide (n 56) 28; 2012 FTC Remedies Statement (n 36) 10.
} 


\section{An up-front buyer}

An up-front buyer can be required by the CAs when there is a purchaser risk (unavailability of a suitable purchaser).

The Commission has confirmed the use of an up-front buyer in the 2001 Merger Remedies Notice. For the first time it required an up-front buyer in practice in Bosch/Rexroth. ${ }^{736}$ The 2005 EC Merger Remedies Study states that an up-front buyer can only be required in exceptional circumstances. ${ }^{737}$ In contrast, without stressing "exceptional circumstances", the 2008 EC Remedies Notice clarifies in great detail the situations where an up-front buyer may be considered. This reflects the Commission's changing attitude toward the use an up-front buyer.

In the US, the FTC often insists on the inclusion of up-front buyer provisions in merger divestitures. It holds that an up-front buyer can shorten the interim time between the implementation of mergers and the execution of divestitures. ${ }^{738}$ An up-front buyer can be required especially when a merger transaction concerns the industry of supermarkets and other retail operations (e.g., retail pharmacies), which are particularly vulnerable to having their assets deteriorate during the search for a post order buyer. ${ }^{739}$

The DOJ, however, traditionally has no preference of requiring an up-front buyer, which is in line with the fact that the 2004 version of Policy Guide did not mention a word on this topic. In the 2011 version, it has a changed attitude and states that '[T] he Division [Antitrust Division of the DOJ] may enter into a consent decree agreeing to this type of up-front buyer proposal in cases where it determines that the proposed sale will effectively preserve competition in the relevant market post-merger'. ${ }^{740}$ Accordingly, the DOJ may use an up-front buyer more frequently than before.

Generally, an up-front buyer is usually required by the FTC in merger cases. The Commission and the DOJ both follow the trend to use an up-front buyer more often than before. ${ }^{741}$

\footnotetext{
${ }^{736}$ For example, Case COMP/M.6905, INEOS / SOLVAY / JV (European Commission Decision) [8 May 2014] <http://ec.europa.eu/competition/mergers/cases/decisions/m6905_20140508_20600_3967413_EN.pdf> accessed 20 April 2017. Case COMP/M.2337, Nestle/Ralston Purina (European Commission Decision) [27 July 2001] <http://ec.europa.eu/competition/mergers/cases/decisions/m2337_en.pdf> accessed 20 April 2017. Case COMP/M. 2060, Bosch/Rexroth (European Commission Decision) [2 December 2000] <http://ec.europa.eu/ competition/mergers/cases/decisions/m2060_de.pdf> accessed 20 April 2017.

${ }^{737}$ Kerckhove (n 694) 69.

7381999 FTC Divestiture Study (n 38) 3.

${ }^{739}$ FTC, 'Frequently Asked Questions About Merger Consent Order Provisions: Are there any industries in which the Commission has been more likely to require a buyer up front?' (Federal Trade Commission) < http://www.ftc.gov/tipsadvice/competition-guidance/guide-antitrust-laws/mergers/merger-faq\#BuyerUpFront> accessed 20 April 2017.

7402011 DOJ Policy Guide (n 56) 23-24.

${ }^{741}$ See: (EU) Competition Policy International (n 669); (the DOJ) for example, "the DOJ has required up-front buyers in each of the five TV and radio station mergers that involved divestitures." See: Gregory P. Luib, DOJ, FTC: More 'Upfront' About Divestiture Requirements Than Ever' (Dechert, 16 July 2016) <https://www.dechert.com/files/Uploads/Documents/DOJ,_FTC_More_'Upfront'_About_Divestiture_Require ments_Than_Ever_-_Dechert_-_25072016.pdf> accessed 24 January 2017.
} 


\section{Implementation of Merger Divestitures}

\subsection{Interim Preservation and Trustees}

One of the important aspects to ensure an effective implementation of merger divestitures is to preserve the viability, marketability and competitiveness of the to-be-divested business during the interim period from the CAs' conditional clearance decision to the actual completion of divestitures. Hold-separate provisions (HSPs) are thus used by the FTC, the DOJ and the Commission to reduce the risks of the deterioration of value of the to-bedivested business (asset risks). ${ }^{742}$

To reduce the above-mentioned asset risks, the FTC also appoints a trustee to oversee the parties' compliance with their commitments. During the implementation of divestitures, a divestiture trustee can be appointed to assure that the parties complete the divestment within a certain time frame. In case a hold-separate provision is included, a monitoring trustee will be appointed to oversee the operation of such hold-separate provisions.

The DOJ are different from the FTC in terms of the mandate of monitoring trustees. Before the publication of the 2004 Policy Guide, it rarely used either hold-separate provisions or monitoring trustees. In its 2011 Policy Guide, it notes that the DOJ may consider appointing a monitoring trustee 'not only to review the respondents' compliance with the merger divestiture obligations, but also to oversee whether the merged party is in compliance with a conduct remedy involving on-going obligations'. ${ }^{743}$

Similar to the FTC, the Commission usually mandates not only monitoring trustees to oversee whether the parties fulfil their obligations during the interim period, but also divestiture trustees in case the parties fail to complete the divestment within the time required. The divestiture trustees are granted the authority to sell the divested business with no limitation on minimum price, with prior approval from the Commission.

Thus, it can be concluded that all the CAs are aware of the importance of trustees which can be helpful to facilitate an effective implementation of merger divestitures, and trustees will be used quite often in merger divestitures to oversee the parties' compliance with their commitments and obligations.

\subsection{Divestiture Process}

The divestiture process in the US and the EU is similar, and, in general, consists of two periods, namely a period for finding a suitable buyer and doing the divestment, and a period for closing the transaction. It is noteworthy that a shorter divestiture processes is pursuing by the CAs, at least in the US. ${ }^{744}$

Timing can be especially important for divestitures concerning supermarkets and other retail operations (e.g., retail pharmacies). ${ }^{745}$ In general, the longer the divestiture process lasts, the more risks may occur. Normally, a time limit will be set in merger divestitures,

\footnotetext{
${ }^{742}$ This is also called asset risks. For a detailed exploration and analysis of asset risks from a law and economics perspective, see: Chapter 7.

7432011 DOJ Policy Guide (n 56) 26.

${ }^{744}$ For the requirement for a shorter divestiture period, see: Chapter 2, sec.6.1.4.

${ }^{745}$ FTC (n 739).
} 
usually ranging from 3 months to 6 months within which the parties are required to finish the divestment. ${ }^{746}$

\section{Reasons for Differences and Common Ground}

As one of the countries where mergers happened at an early age, the US has a tradition of anti-trust. It has been more than 100 years since the enactment of the Sherman Act in 1890. On the other hand, within Europe, even after World War II, many industries had a tradition of high concentration or state involvement. The European Commission did not obtain the authority to control mergers at the EU level until the implementation of the 1989 MR. ${ }^{747}$

Different cultural backgrounds and history, to some extent, lead to different ways of thinking between the US and the EU.

It is believed that the entire merger control system in the US, including merger divestitures, is more fact-based than that in the EU. ${ }^{748}$ The mandatory pre-merger notifications threshold set in the HSR Act results in a greater number of notifications from the merging parties in the US than that in Europe. ${ }^{74}$ The rationale for this is that a transaction is presumed benign unless evidence proves otherwise. Thus, with the US thinking, it is better to make a mistake and allow something through instead of making a mistake and blocking a potentially beneficial transaction. ${ }^{750}$

The EU, however, pays more attention to long-term prediction, ${ }^{751}$ which means, the Commission lays more emphasis on evaluating the future effects of a merger transaction. The Commission is likely to block a merger instead of remedying it, which is in a sharp contrast with what the US does. ${ }^{752}$

Furthermore, different goals of competition law may also to some extent lead to different policies in merger divestitures. In the US, it is generally agreed that the overreaching goal of anti-trust policy is to promote consumer welfare and to preserve a competitive market.753 In the EU, in addition to the goals of promoting consumer welfare, another over-reaching goal of competition policy is to promote competition in the internal market, 754 implying that European competition law is also concerned with unfair competitive advantages of dominant firms. ${ }^{755}$

\footnotetext{
746 See: 1999 FTC Divestiture Study (n 38) 39-40. See also: 2008 EC Remedies Notice (n 35) para. 98.

${ }^{747}$ For the exploration of the history of merger control in the EU, especially for the use of the precursor of Art. 101of the TFEU (n 436) in the Pre-Merger Regulation period, see: Chapter 3, sec.2.1.

${ }^{748}$ Wood (n 75) 72.

749 ibid.

750 ibid.

751 ibid, 73

752 ibid.

753 See: E. Thomas Sullivan, 'The Jurisprudence of Antitrust Divestiture: The Path Less Travelled' (2002) 86 Minn Law Rev 565, 571. See generally: Continental T.V. Inc. v. GTE Sylvania, Inc., 433 U.S.36 (1977); Broadcast Music Inc. v. Columbia Broadcasting Systems, Inc., 441 U.S. 1 (1979); NCAA v. Board of Regents of University of Oklahoma, 468 U.S. 85 (1984); Northwest Wholesale Stationers, Inc. v. Pacific Stationery and Printing Co., 472 U.S. 284 (1985); Business Electronics v. Sharp Electronics, 485 U.S. 7178 (1988).

754 See: D. J Gifford and R.T Kudrle, 'Alternative National Merger Standards and the Prospects for International Cooperation' in D.L.M. Kennedy and J.D. Southwick (eds), The Political Economy of International Trade Law: Essays in Honour of Robert E Hudec (Cambridge University 2002). See generally: D. J Gifford and R.T Kudrle, 'EU Competition Law and Policy: How Much Latitude for Convergence with the U.S.?' (2003) 48 Antitrust Bull 727; Philippa Watson, 'Portolio Effects in EC Merger Law' (2003) 48 Antitrust Bull 781.

${ }^{755}$ Faure \& Zhang (n 699) 514.
} 
The CAs in the US use merger remedies widely and prefer merger divestitures to other merger remedies since divestitures are believed to restore competition into markets more directly and effectively. Although at present, the DOJ and the FTC still have some different opinions regarding practical merger divestiture policy, both of them are willing to adopt risk-reducing strategies, such as crown jewel provisions or an up-front buyer, to ensure the effective design and implementation of merger divestiture. Merger remedies in Europe were quite simple at the beginning, and this was reflected in its two versions of the Merger Regulation (1989 and 2004) and the 2001 EC Remedies Notice. But the landscape is changing. Merger remedies have gained increasing attention, and the Commission is also trying to use different kinds of tools and strategies to ensure an effective merger remedy, especially merger divestitures. For example, during the divestiture process, the Commission rather frequently orders an up-front buyer to monitor whether the notifying parties observe their obligations.

\section{Conclusion}

Merger divestiture policies and practice have experienced changes during the past few decades in the US and the EU. With more practice in the merger control field, all the CAs in both jurisdictions are trying to explore and build a scheme of effective design and implementation of merger divestiture.

When the European Commission was developing its merger control system and merger divestitures, it was learning from the established-US practice, as confirmed by former Competition Commissioner Mario Monti. ${ }^{756}$ This also explains why at first glance the EU has a merger control system and merger divestiture policy similar to the US. As mentioned, due to different ways of thinking and different competition law goals, it is not surprising to find out that they are actually different in some aspects.

With more experience obtained from practice, merger divestitures policies in both the US and the EU are evolving. On the one hand, Monti pointed out that 'the US and the EU share a common fundamental vision of the role and limitations of public intervention...that the ultimate purpose of [public] intervention in the market-place should be to ensure that consumer welfare is not harmed'. ${ }^{757}$ In addition, they expect the same goal of merger divestitures: by divesting a certain set of business, conditions will be created for the emergence of a new entity or strengthening an existing entity. With proper operations of the divested business, the entities can be active on the market and compete effectively with the merged parties, so that competition will be preserved/restored in the market to the premerger level. This goal influences the two entities' approach towards merger control, as well as merger divestitures. Moreover, both the US and the EU are now exposed to the same evolution in economic thinking. ${ }^{758}$ The approach of a 'more economic analysis' will influence the approach that the CAs take to analyse the proposed merger transaction and the tools/strategies they adopt when designing and implementing a merger divestiture.

\footnotetext{
756 See: Monti (n 34).

${ }^{757}$ Mario Monti, 'Convergence in EU-US Antitrust Policy Regarding Mergers and Acquisitions: An EU perspective' (Speech delivered at UCLA Law First Annual Institute on US an EU Antitrust Aspects of Mergers and Acquisitions, Los Angeles, 28 February 2004) <europa.eu/rapid/press-release_SPEECH-04-107_en.pdf> accessed 20 April 2017.

758 ibid.
} 
With regard to the future developments of merger divestitures in the US and the EU, it is acceptable that they have different preferences or opinions since they have different ways of thinking and different competition law goals after all. However, with increasing international merger transactions involving both the US and EU, cooperation and coordination of enforcement between these two entities are more important than ever before in order to reduce trade conflicts, and this will be beneficial to both sides. Together with the observations made in the previous sections in this chapter, it can be predicted that convergence will be the trend regarding the future development of merger divestitures between the US and the EU. 



\section{II}

\section{LAW AND ECONOMICS ANALYSIS OF MERGER DIVESTITURES}

As a famous saying goes, happy families are all alike; every unhappy family is unhappy in its own way. When considering this saying in the context of merger divestitures, it can be understood as follows: whether a merger divestiture can have a "happy ending" depends on (at least) three elements: the composition of a divestiture package; preservation of viability and competitiveness of a divestiture package during the interim period; and the restoration of effective competition in the market after divestments. Successful merger divestitures are likely to have all the following characteristics: an appropriate composition of the divested assets, which includes all key assets and personnel; no deterioration of competitiveness and viability of the divested assets during the interim period, and; a suitable buyer, who, after purchasing the divested business, can compete with the merged party competitively. It follows that failures of merger divestitures are to some extent the result of the following three risks:

- composition risks- risks of a too constrained scope of the divestiture package or inappropriate configuration to attract a suitable buyer; ${ }^{759}$

- asset risks- risks of deterioration of the competitive capability of a divestiture package during implementation; ${ }^{760}$

- collusion risks- risks that the buyer can collude with the merged party after the completion of divestitures, rather than competing with it.

Subsequent to the comparison of the merger divestiture regimes of the US and the EU in Part I, this Part will explore merger divestitures from a law and economics perspective, focusing on the above-mentioned three risks and answer the second research question: what are the possible reasons for the occurrence of composition/assets/collusion risks in divestitures and what can be the solutions to reduce those risks? Part II is therefore structured as follows:

- Chapter 5: A General Introduction to Merger Divestitures from the Perspective of Law and Economics.

\footnotetext{
${ }^{759}$ UK Competition Guidelines (n 39) sec.3.3(a).

760 ibid, sec.3.3(b).
} 
- Chapter 6: An Application of Screening Theory to Reduce Composition Risks.

- Chapter 7: Solutions to Reduce Asset Risks: from a Moral Hazard Perspective.

- Chapter 8: Solutions to Reduce Collusion Risks: from the Perspective of Collusion Theory

- Chapter 9: Challenges in Realising the Effectiveness of Merger Remedies 


\section{Chapter}

\section{A GENERAL INTRODUCTION TO MERGER DIVESTITURES FROM A LAW AND \\ ECONOMICS PERSPECTIVE}





\section{Introduction}

Broadly speaking, a merger remedy is an intervention designed to avoid the anticompetitive effects of a merger, while not impeding the potential efficiency gains. ${ }^{761}$ Although the focus of this book is the merger divestiture remedy, readers should be aware that there are alternative forms of merger remedies. As introduced in Chapter 1, remedies can be behavioural (e.g. granting access to key infrastructure, or changing long-term exclusive contracts), structural (e.g. divestitures), or a combination of both, depending on the size and competition concerns of a particular merger application. Furthermore, the design and enforcement of a merger remedy can also vary in different jurisdictions due to different welfare standards and political considerations.

Divestiture remedies are preferred by the CAs in the US and the EU. ${ }^{762}$ Therefore, the effectiveness and efficiencies of merger remedies, especially merger divestitures, will to a large extent influence the realisation of the goals of merger laws. The effectiveness of a merger divestiture depends on whether the divested-business, after the implementation of divestment, is operated viably in the market concerned and competing with the merged firm actively, ultimately resulting in maintaining and indeed re-establishing effective competition in the market to the pre-merger level. ${ }^{763}$

Economics play an increasingly important role in competition law inquiries. ${ }^{764}$ Both the US and the EU are taking a more economic approach towards merger inquiries. Economic theory, to some extent, can facilitate the study and evaluation of the effectiveness and efficiency of merger divestitures with a more structured and accurate approach. Nevertheless, one may argue that there are fundamental differences concerning the prevailing merger laws and merger divestiture policies in the US and the EU. This is true to some extent. For example, these two jurisdictions pursue different competition law goals. For the US, the fundamental goal is to protect consumers. ${ }^{765}$ In contrast, European competition law is intended to achieve a multitude of goals. In addition to allocative efficiency, the most prominent goal is to promote integration between Member States. ${ }^{766}$ The main rationale behind this goal is the European Commission's intention to break down the national boundaries and to level the playing field for the market players. Economic theory can provide a benchmark to assess the effectiveness and efficiency of competition law and policy, regardless of the jurisdiction. ${ }^{767}$ Despite the US and the EU's differences in their merger laws, economic theory and principles can be used in the assessment, especially concerning the fact that a convergence regarding merger divestiture policies in these two jurisdictions can be predicted (as shown in Part I).

This chapter serves as a general introduction to merger divestitures, with the aim of exploring some closely relevant questions before providing insight into the merger

\footnotetext{
${ }^{761}$ Stephen Davies and Bruce Lyons, Merger and Merger Remedies in the EU: Assessing the Consequences for Competition (Edward Elgar 2007) 1.

762 See: (US) 1999 FTC Divestiture Remedy (n 38); 2012 FTC Remedies Statement (n 36); 2004 DOJ Policy Guide (n 321); 2011 DOJ Policy Guide (n 56). (EU) 2008 EC Remedies Notice Notice (n 35); 2001 EC Remedies Notice (n 440); 2005 EC Remedies Study (n 27). For a detailed exploration regarding the CAs' preference for divestitures in the US and the EU, see: Chapter 2, sec.6.1.1, Chapter 3, sec.4.2.1 and Chapter 4 in general.

763 Patrick A. McNutt, Law, Economics And Antitrust: Towards a New Perspective (Edward Elgar 2005) 332.

${ }^{764}$ Bishop and Walker (n 10) 2.

$765 \mathrm{ibid}, 7$. See also: John B. Kirkwood and Robert H. Lande, 'The Fundamental Goal of Antitrust: Protecting Consumers, Not Increasing Efficiency' (2008) 84(1) Notre Dame L Rev 191, 191.

${ }^{766}$ Roger Van den Bergh and Peter D. Camesasca, European Competition Law and Economics: A Comparative Perspective (Sweet \& Maxwell 2006) 1.

${ }^{767}$ Bishop and Walker (n 10) 7.
} 
divestiture remedy. In sec.2, the concept of effective competition is explored, by studying two extreme models of competition: perfect competition and monopoly, which illustrate the outcomes of a market without effective competition. Sec.3 analyses the expected effects of mergers, by exploring their potential anti-competitive effects and potential efficiencies. Sec.4 explores the principles of good remedies and the choice between behavioural remedies and divestitures, taking into account different types of mergers and some specific industries. A conclusion is then drawn in sec.5.

\section{Mergers and Competition}

It is evident that mergers can be very complex since they involve for example, complex preliminary business valuations and employee arrangements. In those countries with a merger review system, the situation can be even more complicated because mergers that satisfy certain criteria have to be notified to the competition agency before the implementation and go through merger scrutiny, with the risks of being rejected. Even though, as mentioned in Chapter 1, undertakings can still be incentivised to merge. ${ }^{768}$

Mergers which will "substantively reduce competition" (in the situation of the US), or "significantly impede effective competition" (in the situation of the EU) will be prohibited by the respective merger review system. One of the goals of merger control is to preserve effective competition in the market, so that consumers will at least not be made worse off, while producers will be made better off, as a result of a merger. ${ }^{769}$ Therefore, it is important to determine the definition of effective competition for the purpose of realising the goals of merger laws.

To explore this question better, two extreme models of competition, perfect competition and monopoly, will be analysed. Both theoretical models have important roles in defining the concept of 'effective competition' since they illustrate the outcomes of a market with no effective competition. In this section, the focus is laid on the consumer surplus and producer surplus in different models. They provide a basic set of tools to evaluate whether a market is subject to effective competition. ${ }^{770}$

\subsection{Perfect Competition}

In the perfect competition paradigm, there are many buyers as well as sellers that perfectly inter-changeable. ${ }^{771}$ No one can dictate the market price since the quantity of products bought by any buyers or sold by any sellers is too small compared with the total quantity of trade products to change the price. ${ }^{772}$ Information is perfectly available for all buyers and sellers and exit and entry of the market are free. ${ }^{773}$

\footnotetext{
768 See: Chapter 1, sec.1.1.

769 There is a controversy regarding the question whether a total welfare standard or a consumer welfare standard should be the only standard to be adopted by competition law. Despite this, consumer welfare is protected and is of the most prominence in both the US and the EU. Both regimes require that a merger should benefit consumers, or at least it cannot make consumer worse off. See: (EU) 2004 EC Horizontal Merger Guidelines (n 522); or (US) 2010 US Horizontal Merger Guidelines (n 11).

${ }^{770}$ Bishop and Walker (n 10) 16.

${ }_{771}$ Robert Cooter and Thomas Ulen, Law and Economics (6 edn, Prentice Hall 2011) 363.

772 Bishop and Walker (n 10) 22.

773 ibid.
} 
The price in the situation of perfect competition is equal to marginal costs, which means no firms are able to make positive profits. The amount and price of products are equal to what the consumers want to buy and how much they are willing to pay. Perfect competition implies the starting points for both allocative efficiency and productive efficiency.

Allocative efficiency, in the form of Pareto efficiency, concerns the satisfaction of the individuals' preferences. ${ }^{774}$ It means that it is impossible to make at least one person (or firm) better off without making anyone else worse off. ${ }^{775}$ In this scenario, the marginal costs are equal to the price. When the marginal costs of producing one extra unit are different from what consumers are willing to pay, there is allocative inefficiency. Put differently, if the marginal costs for supplying one extra product are lower than the amount consumers are willing to pay, then both the sellers and consumers will be better off when sellers produce one more product. This is inefficiency because the total social welfare would have been increased if the producers had produced one more product. If the marginal costs for one extra product are higher than what consumers expect, the total welfare would also have been increased if the producers had reduced their output.

Productive efficiency occurs when products are produced against the lowest possible price. ${ }^{776}$ In a market characterised by perfect competition, price is equal to marginal costs and average costs, implying no positive profits for producers. Accordingly, an inefficient firm will be unable to "make ends meet" and will thus finally be eliminated. Perfect competition provides the producers with incentives to produce efficiently to maximise their profits by reducing their costs. Once competition in the market is lessened, or firms enjoy greater market power, a slack in production will occur. The firms are less motivated to produce efficiently. Thus, social welfare will lose. Such a slack in production is also called X-inefficiency ${ }^{777}$.

\subsection{Monopoly}

General equilibrium is realised under perfect competition. It concerns the conditions under which the independent decisions of utility-maximising consumers and profit-maximising producers will lead to the inevitable establishment of equilibrium. ${ }^{778}$ Evidently, perfect competition is almost impossible in real life, due to market failures. One particular market failure is the disappearance of competition in the most extreme form, leading to a monopoly. A pure monopoly refers to a situation where there is only one firm in the market. From the perspective of efficiency, in a market characterised by a monopoly or a dominant market power, price is too high while output is too low. Thereby, consumer surplus will be lower and producer surplus will be higher compared with that in perfect competition. Allocative inefficiency will occur, represented by a deadweight loss. The following figures illustrate consumer surplus and producer surplus in a market characterised by perfect competition and monopoly, respectively.

\footnotetext{
774 See: Cooter and Ulen (n 771) 14.

775 ibid.

776 ibid, 13.

${ }_{777} \mathrm{X}$-inefficiency will appear when there is an internal slack within one firm. With the absence of such slack, firms will maximise their output by using the most efficient combination of inputs, which is also called "productive efficiency". See: Roger Van den Bergh, "The Economics of Competition Policy and the Draft of the Chinese Competition Law' in Thomas Eger, Michael Faure and Naigen Zhang (eds), Economic Analysis of Law in China (Edward Elgar 2007) 82.

$778 \mathrm{ibid}, 38$.
} 
Figure 5 Consumer and Producer Surplus in Perfect Competition ${ }^{779}$

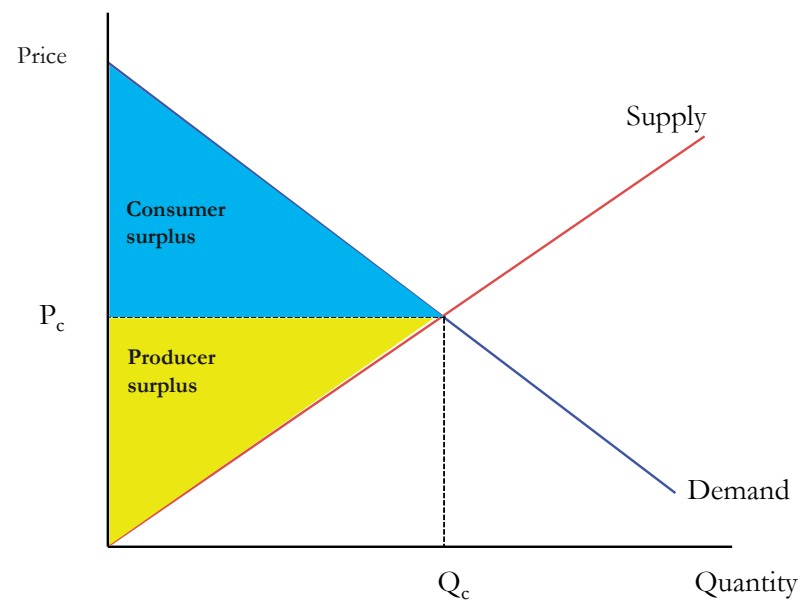

Figure 6 Consumer and Producer Surplus in Monopoly (Loss in Efficiency) ${ }^{780}$

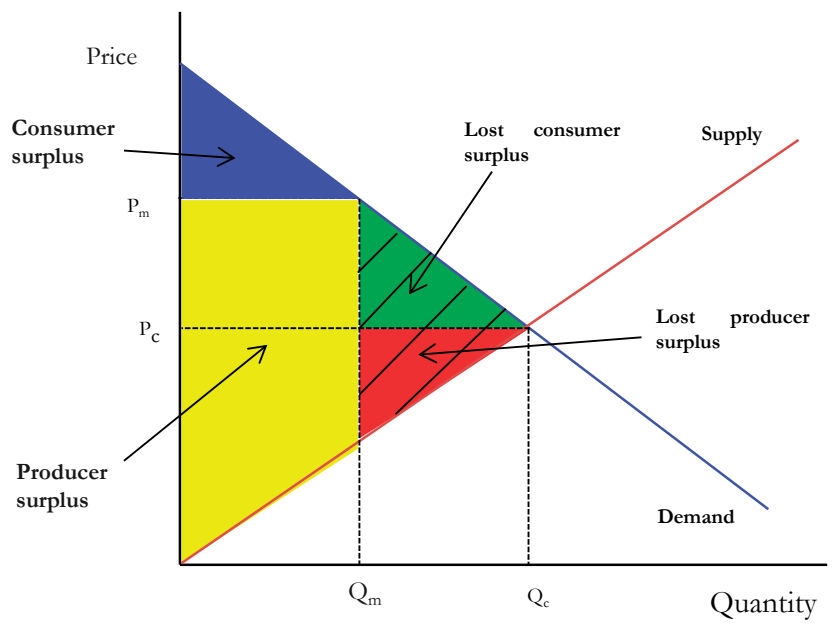

Consumer surplus concerns the sum of how much each unit sold is valued by consumers above its price. ${ }^{781} \mathrm{It}$ is a concept to reflect the difference between how much consumers are willing to pay for one product (represented by the demand curve) and what the consumer actually pays when buying (the market price). The blue area in Figure 5 is the consumer surplus in perfect competition (price: $P_{c}$, quantity: $Q_{c}$ ). In a market with monopoly or market power, the sellers will raise price and reduce output to maximise their profit. Thus, consumer surplus in Figure 6 is smaller than that in Figure 5, implying a lower consumer surplus.

Producer surplus represents the difference between the price in the market that producers collectively receive for their products and the sum of those producers' respective

\footnotetext{
${ }_{779}$ This figure is adopted from Cooter and Ulen (n 771) 28.

780 ibid, 29.

${ }^{781}$ Bishop and Walker (n 10) 2-015.
} 
marginal costs at each level of output (represented by the supply curve). ${ }^{782}$ When there is a monopoly or when concentrated market power exists in a market, as is shown in Figure 6, prices will rise from $\mathrm{P}_{c}$ to $\mathrm{P}_{\mathrm{m}}$ and output will be reduced from $\mathrm{Q}_{\mathrm{c}}$ to $\mathrm{Q}_{\mathrm{m}}$. Parts of the surplus are thus transferred from consumers to producers.

Monopoly gives rise to allocative inefficiency due to the differences between the marginal cost of production and the valuation of the marginal consumers. ${ }^{783}$ Generally, a deadweight loss will appear together with allocation inefficiency. A deadweight loss consists of two parts: a loss in consumer surplus and a loss in producer surplus, which is shown in Figure 6 (the shaded area). The red area represents loss in producer surplus. This means that social welfare would have been increased if the producers produce more units since the costs involved in producing an extra unit are lower than consumers' valuation. The green area represents the loss in consumer surplus. It suggests that social welfare will be improved if the price of products is lowered. A deadweight loss is the cost to the society caused by an inefficiently operated market.

Total welfare refers to the sum of consumer surplus and producer surplus. Total welfare is a notion which is designed to analyse the welfare effects on the whole economy. ${ }^{784}$

\subsection{Effective Competition}

Effective competition may sometimes be represented by a process of rivalry or the absence of restraints. ${ }^{785}$ However, these two definitions have certain drawbacks.

First, this definition provides no standard for the degree of rivalry that must be reached to make competition effective. In other words, is competition ineffective if there is no rivalry in the market? Evidently, that is not true because in some situations, a decrease in rivalry can promote competition after a merger if consumer welfare is increased.

Second, defining effective competition as a situation where there is no restraint is also inadequate since such a definition provides no explicit criterion of how few restraints can be put on a market player by another through an agreement. In an illegal agreement or case of collusion between firms, it may set restraints on others from one's own economic activities, resulting in a concentration of its own market power. Such concentration will lead to a loss in effective competition. However, any agreement or contract, to a greater or lesser extent, will put restraints on each other's economic activities, and most of these agreements or contracts are unlikely to impede effective competition.

Either of these two definitions, in fact, accurately describes the characteristics of effective competition. Generally speaking, preserving effective competition is one of the goals of merger laws, under which benefits are delivered to consumers. Accordingly, when defining effective competition in the context of merger control, emphasis should be laid on the outcomes of the competition instead of the process. ${ }^{786}$ This approach is also employed by the CAs in the US and the EU, who in recent years have taken a more economic approach when analysing merger applications. ${ }^{787}$

\footnotetext{
782 Van den Bergh and Camesasca (n 766) 84

${ }^{783}$ Bishop and Walker (n 10) 2-015.

${ }_{784}$ Van den Bergh and Camesasca (n 766) 84.

785 See: Bishop and Walker (n 10) 2-004-2-008.

786 Bishop and Walker (n 10) 2-008.

${ }^{787} 2004$ EC Horizontal Merger Guidelines (n 522) para. 8 reads:

[E]ffective competition brings benefits to consumers... the Commission prevents mergers that would be likely to deprive customers of these benefits by significantly increasing the market power of firms.
} 


\section{Expected Effects of Mergers}

Mergers are double-edged swords considering that on the one hand, a merger can generate efficiencies, such as economies of scale and scope, rationalisation of production, and cost savings. These hoped-for efficiencies can strengthen the competitiveness of the merged firms and ultimately benefit consumers if they can be passed on. Thereby both consumers and producers will benefit from mergers. In practice, the CAs in both the US and the EU will consider the efficiencies a merger may bring about when they make an overall evaluation of a proposed merger. ${ }^{788}$

On the other hand, mergers can also cripple competition, by eliminating the number of effective competitors in the market concerned, by foreclosing the entry of rivals, or by raising prices or reducing output. This will lead to inefficiency in production (" $\mathrm{X}$ inefficiency") and will ultimately harm consumers.

It is generally believed that non-horizontal mergers (namely vertical and conglomerate mergers) are less likely to create competition problems than horizontal ones. To some degree, they can even be pro-competitive. ${ }^{789}$ This can result from the fact that, first, nonhorizontal mergers involve firms at different levels in the market concerned, meaning that such a merger does not entail the loss of direct competition between the merging firms in the same relevant market. ${ }^{790}$

Second, non-horizontal mergers can bring about a wide range of efficiencies. For vertical mergers, the integration between the upstream and downstream firms can avoid the phenomenon of "double marginalisation". The integration of complementary activities or products within a single firm can decrease transaction costs and increase the possibility of coordination, resulting in better product design, improved production process and changed marketing strategy. ${ }^{791}$

For example, once vertical firms merge, complementarities are taken into account. An increase in the price of the merged firms' product will not only lead to an adverse impact on the demands of this product, but will also have a negative effect on the demand for its complementary products. ${ }^{792}$ Thereby, vertical mergers can stimulate the firms' incentives to reduce the price and/or improve the quality so that they can maximise their total profits. The situation in conglomerate mergers is similar when they involve complementary products or activities.

Given that there is a trade-off between the efficiency gains and the increased concentration of market power which may ultimately harm consumer welfare, ${ }^{793}$ the competition agencies should make an overall evaluation and consider the expected

\footnotetext{
In the Overview part of the 2010 US Horizontal Merger Guidelines (n 11) states that the competition agencies avoid unnecessary interference with mergers that are either competitively beneficial or neutral.

788 See: for example, 2010 US Horizontal Merger Guidelines (n 11) Part 10 - Efficiency. (EU) 2004 EC Horizontal Merger Guideline (n 522) Part VII - Efficiencies.

${ }^{789}$ Jonathan Green and Gianandrea Staffiero, 'Economics of Merger Control' in The 2007 Handbook of Competition Economics: Global Competition Review Special Report (GCR 2007) 9. In general, mergers can be divided into two groups: horizontal mergers and non-horizontal (vertical/conglomerate) mergers. For the definition and introduction of different types of mergers, see: Chapter 1.

${ }_{790}$ Bishop and Walker (n 10) 8-002.

7912008 EU Non-Horizontal Merger Guidelines (n 14) para.13.

${ }^{792}$ This is based on the cross price elasticity theory. For these complementary products, an increase in the price of one product will result in a reduction of the demand for a complementary product. For a detailed exploration of price elasticity theory, see: Cooter and Ulen (n 771) 38.

793 See: Fabienne IIzkovitz and Roderick Meiklejohn, 'European Merger Control : Do we need an Efficiency Defence' in Fabienne IIzkovitz and Roderick Meiklejohn (eds), European Merger Control : Do we need an Efficiency Defence (Edward Elgar 2006).
} 
efficiencies and potential anti-competitive effects of mergers to determine the net effects of mergers. In the following sections, the expected effects of mergers are explored, focusing on their potential anti-competitive effects as well as potential efficiencies. The welfare standard is also studied since the choice between different welfare standards can exert an influence on the competition agencies' trade-off decisions.

\subsection{Competition Concerns of Mergers}

Anti-competitive effects generated from mergers can be divided into two categories: unilateral effects and coordinated effects, which can have a perverse impact on competition in the concerned market. ${ }^{794}$ Unilateral effects are said to arise when the merged entity has the ability to increase prices or reduce quality to the detriment of consumers all by itself despite the responses of the remaining competitors. ${ }^{795}$ The adverse effects associated with coordinated effects depend on one or more competitors to the merged entity choosing to compete less vigorously post-merger. ${ }^{796}$ Naturally, preventing any anti-competitive mergers is of prime interest to regulators. ${ }^{797}$

\subsubsection{Horizontal Mergers}

\subsubsection{Unilateral Effects}

A horizontal merger involves firms that operate at the same level. A direct result of a horizontal merger is the convergence of all resources of the parties into one single firm. A horizontal merger may have unilateral effects ' $b$ b]y eliminating important competitive constraints on one or more firms, which consequently would have increased market power, without resorting to coordinated behaviour'. ${ }^{798}$ As a result, the prices charged by the merged entity may increase relative to their pre-merger level despite the competitive responses of rival firms. A merger with such characteristics is likely to give rise to unilateral effects. Such price increases are known as unilateral price increases.

Furthermore, a price increase can also be caused by coordinated agreements or collusion between merged firms and other firms. Such effects are called coordinated effects of mergers. Oligopoly theory confirms the common intuition that prices increase when the number of firms in the market concerned decreases. ${ }^{799}$ One of the reasons for a price increase is the concentration of market power. Suppose that there are many firms in the market and that the products they produced are perfect substitutes. Before the merger, the firms respectively set their price and output, taking no account of the influence of their price decision or output quantity on other firms' profits. If they increase prices before a

\footnotetext{
${ }^{794}$ Anti-competitive effects generated from mergers can be categorised into two categories in general: unilateral (non-coordinated) effects and coordinated effects. Bishop and Walker defined unilateral effects as '[they] are said to arise when the merged entity has the ability to unilaterally increase prices or reduce quality to the detriment of consumers despite the responses of the remaining competitors'. Coordinated effects may negatively influence the competition in a market through two or more market players choosing to compete less vigorously post-merger. See: Bishop and Walker (n 10) 350-351. See also: Chapter 5.

795 There are various forms of unilateral effects, such as one or more firms profitably increase prices and reduce output or quality of goods and services. The expression "increased prices" is therefore used as shorthand for these various unilateral effects in which a merger may result in competitive harm.

${ }^{796}$ Bishop and Walker (n 10) 7-004.

${ }^{797}$ Bris, Cabolis and Janowski (n 5) 16.

7982004 EC Horizontal Merger Guidelines (n 522) para. 22(a)

${ }^{799}$ Roller, Stennek and Verboven (n 9) 19.
} 
merger, customers will opt for other firms for the substituting products, resulting in their loss in sales. The increase in the margin sold at higher price will not exceed the costs resulting from fewer sales. ${ }^{800}$ After the merger, the merged firms are no longer rival competitors. This means they will maximise their profits, and consider the detrimental effects on each other when determining the price and quantity.

A price increase is one of the most well-known and typical anti-competitive effects that a merger can result in and as such can be deemed as a signal of a reduction of effective competition in the market concerned. It suggests the transfer of wealth from consumers to producers, 801 which is relevant to the distribution of resources. In addition, this distributional effect is also accompanied by the creation or strengthening of a deadweight loss due to the increased price above marginal cost, or reduction of output below the optimal level. In other words, mergers can result in allocative inefficiency. However, increases of price after a merger can also be limited in some situations. For example, the products the firms produce can be substituted by other firms; a high possibility of market entry; the newly merged firms have low market shares and thus enjoy little or no market power; or buyers enjoy strong countervailing bargaining power. ${ }^{802}$

\subsubsection{Coordinated Effects}

A horizontal merger is likely to give rise to coordinated effects when it consequently changes the market structure through, e.g. the reduction in the number of firms and the greater combined market share held by the merging party. Such mergers confer upon the merged firms and at least one of its remaining competitors the opportunities to reach and sustain a tacit agreement not to compete effectively with another and thereby raise prices. ${ }^{803}$ Such price increases, as one of the forms of coordinated effects, are termed coordinated price increases. The most important difference between unilateral effects and coordinated effects is that the former refers to a situation where a certain anti-competitive effect is realised by the merged firms alone, whereas the latter requires cooperation with other firms outside the merger transaction.

In a market with vigorous competition, if a firm sends a "signal" to stop competition and fixes its price at a higher level, its rivals might accept this because both the firm and its rivals can get more profits through higher prices and possible more sales, respectively. The change in the mode of competitive behaviour is therefore normally termed tacit coordination or tacit collusion. To reach collusion between the merged firm and at least one firm of the remaining competitors, the following criteria should be fulfilled: ${ }^{804}$ first, firms in the coordinating group are able to reach a tacit understanding. Second, firms can sustain any tacit understanding. This requires them to be able to: a. monitor that the tacit understanding is being adhered to by the other firms in the coordinating group; b. if a firm deviates from the tacit understanding, the other firms must be able to respond effectively to punish that firm. Third, for the tacit understanding to be sustainable, it must be immune from the potentially destabilising reactions of firms outside the coordinating group.

Mergers may change the nature of firms' conduct from competitive to collusive. As a result, the level of effective competition in the market concerned is reduced due to the generated coordinated effects, making it easier for the coordinating group to enjoy joint

\footnotetext{
${ }^{800}$ If this is not true, the firms would have raised the price to maximise their profits.

${ }^{801}$ Roller, Stennek and Verboven (n 9) 18.

802 See: IIzkovitz and Meiklejohn (n 793). See also: Roller, Stennek and Verboven (n 9).

8032004 EC Horizontal Merger Guidelines (n 522) para.39.

${ }^{804}$ Bisop and Walker (n 764) 7-050.
} 
market power. Such a market position may diminish the disciplining power of the product market on firm efficiency. ${ }^{805}$ Put differently, a reduction of competition may lead to inefficiency in production (also called "X-inefficiency"). On the one hand, due to less effective competition in the product market, management and employees are likely to be less motivated. The potential failure to maximise profits may lead to high production costs or sub-optimal allocation of personnel. ${ }^{806}$ On the other hand, there may be little incentive for the merged firms to invest in $\mathrm{R} \& \mathrm{D}$ if entry barriers are high. It is reasonable to assume that once the firms enjoy large market power in a market with high entry barriers, they are more likely to enjoy their current dominant position instead of sparing efforts and money in R\&D.

\subsubsection{Non-Horizontal Mergers}

Non-horizontal mergers are defined as mergers which involve firms that do not operate in the same level of the market. Two categories can be further distinguished: vertical mergers and conglomerate mergers. ${ }^{807}$

Although non-horizontal mergers are likely to be less harmful than horizontal ones, they can also have anti-competitive effects by changing the behaviour of the merged firms as well as their competitors in ways which may harm consumers.

\subsubsection{Unilateral Effects}

Unlike the unilateral effects of horizontal mergers, which can result in upward pressure on prices, non-horizontal mergers may lead to downward pressure on prices. On the one hand, such integration will create efficiencies, like reduction of transaction costs, considering that non-horizontal mergers usually occur between firms who operate in same relevant market. This, to some extent, can be beneficial to customers because the firms can produce more products at a lower price. On the other hand, competition concerns will arise if such low prices constitute a predatory price and leads to the marginalisation or exclusion of competitors.

\section{Vertical Mergers}

In practice, the primary unilateral effect of vertical mergers is foreclosure, which means the actual or potential rivals' access to supplies or markets is hampered or eliminated as a result of the merger. ${ }^{808}$ In other words, such mergers create competitively objectionable barriers to entry. ${ }^{809}$

Foreclosure can be identified into two types: input foreclosure and customer foreclosure.

\footnotetext{
${ }^{805}$ IIzkovitz and Meiklejohn (n 793) 60.

$806 \mathrm{ibid}, 60$.

${ }^{807} 2008$ EU Non-Horizontal Merger Guidelines (n 14) para.3. See also : Chapter 1, sec.1.1.

808 ibid, para. 18.

${ }^{809}$ U.S. Department of Justice: Non-Horizontal Merger Guidelines (1984), para. 4.21 (hereinafter: 1984 DOJ NonHorizontal Merger Guidelines).
} 
Figure 7 Input Foreclosure 810

\section{Input foreclosure}

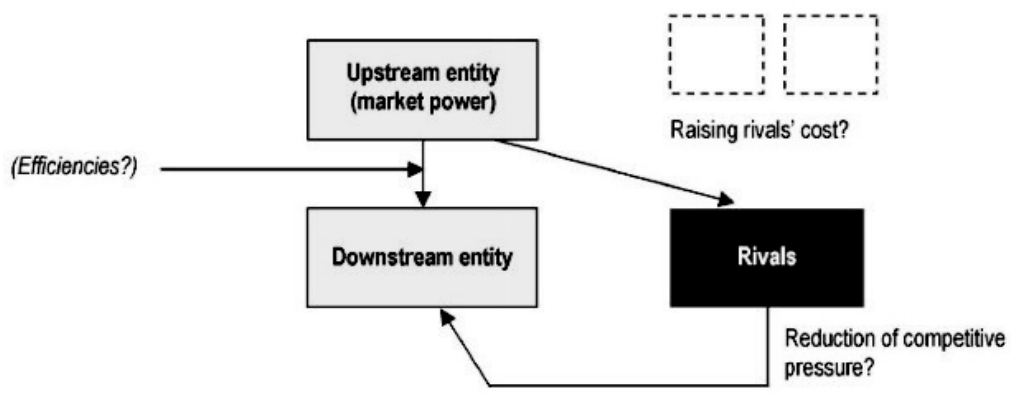

\section{Overall effect on consumers?}

The theory of harm associated with input foreclosure involves raising rivals' cost. Input foreclosure occurs when the integrated firms either stop supplying competing downstream firms (complete foreclosure) or do so only at higher price (partial foreclosure), resulting in both cases in an increase in the price of the upstream input post-merger.

Thereby, input foreclosure will potentially raise the costs of competing downstream firms, or create obstacles for other firms to enter the markets, so that the merged firm can preserve its upstream market power. ${ }^{811}$

Figure 8 Customer Foreclosure 812

\section{Customer foreclosure}

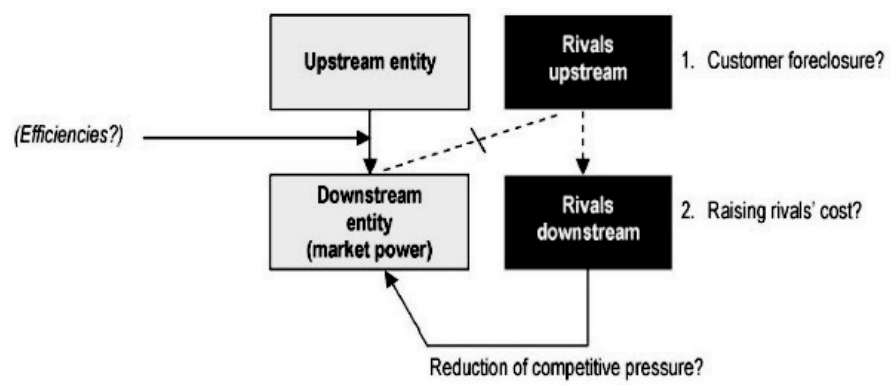

Overall effect on consumers?

\footnotetext{
810 This figure is adopted from the2008 EU Non-Horizontal Merger Guidelines (n 14) para. 30, "input foreclosure".

811 See: ibid.

812 This figured is adopted from the 2008 EU Non-Horizontal Merger Guidelines (n 14) para. 58, "customer foreclosure".
} 
Customer foreclosure, on the other hand, involves reducing rivals' revenues. It occurs when, post-merger, the downstream division of the integrated firm no longer sources supply from independent upstream firms. This reduces the sales volume of the upstream rival, which can lead to an increase in the average cost and/or the marginal cost of upstream competitors. ${ }^{813}$

\section{Conglomerate Mergers}

With regard to conglomerate mergers, a distinction can be made between mergers involving complementary products and mergers involving unrelated products. ${ }^{814}$ Products will be deemed as complementary when increases in demand for one product leads to increases in its complement; while unrelated products are those products that share no commonality, for example, they are not substitutes for each other. ${ }^{815}$ However, there are certain products that are not complementary from the perspective of consumers, such as milk and milk powder, but they can be sold to the same target consumers. They can also be regarded as complementary from the perspective of supermarkets for the reason that a limited offer in either of the products will reduce the whole attractiveness of the supermarkets. These products are thus considered to be within the neighbouring market. Basically, conglomerate mergers involving unrelated products are unlikely to raise competition concerns. ${ }^{816}$

Unilateral effects related to conglomerate mergers are primarily based on the theory of portfolio effects or range effects. This means that the market power deriving from a portfolio of brands exceeds the sum of its parts'. ${ }^{817}$ Put differently, a merger will be considered to raise portfolio effects when after the merger, the merged firms are able to increase the sales in one of their products with a weaker brand by leveraging advantage from another stronger brand. A merged firm may extend its portfolio power by tying or bundling. Tying is commonly defined as a dominant firm selling one product only on the condition that the buyer also purchases a different product or agrees not to purchase the tied product from another supplier. ${ }^{818}$ Bundling generally takes the form of bundling discounts, which means consumers will receive discounts or rebates when they purchase two products at one time, which can also be sold separately. ${ }^{819}$

Basically, the objective of portfolio power is not to extend the dominant market power from the primary market to the secondary market. The incentive of the merged firms to do so is to ensure that another efficient entrant will not enter the secondary market and has no access to the secondary market in the future, thus the merged firms can keep their high profits in the secondary market. ${ }^{820}$ However, it is worth pointing out that portfolio effects may have both positive and negative effects on consumers and firms. ${ }^{821}$ Potential efficiencies generated from mergers can result in cost savings which benefit the producers

\footnotetext{
813 See: ibid.

814 See: Bishop and Walker (n 10) 8-029.

815 ibid, 8-030.

816 ibid.

817 See: Case IV/M.938, Guinness/Grand Metropolita(European Commission Decision) [5 October 1997] OJ L228, para. 38.

818 The Unilateral Conduct Working Group, 'Report on Tying and Bundled Discounting' (The 8th Annual Conference of the International Competition Network, Zurich, June 2009) < http://www.internationalcompetition network.org/uploads/library/doc356.pdf > accessed 22 April 2017, 3.

819 ibid.

${ }^{820}$ Thibaud Verg, 'Portfolio Effects and Merger Control: Full-line Forcing as an Entry-Deterrence Strategy' (Econwpa, 2002) < http://econwpa.repec.org/eps/io/papers/0301/0301010.pdf> accessed 22 April 2017, 18. 821 ibid, 19 .
} 
and such a reduction in costs can also lead to a lower price, which is good for consumers. On the other hand, foreclosure can be caused when entry barriers are too high for new entrants to enter a market, which thus limits consumer choice. Accordingly, the competition agencies should analyse portfolio effects with great care.

\subsubsection{Coordinated Effects}

Theoretically, non-horizontal mergers can raise competitive concerns since such mergers may change the nature of competition in such a way that firms that previously were not coordinating their behaviour, are now significantly more likely to coordinate and raise prices or otherwise harm effective competition. ${ }^{822}$

A vertical merger can make it much easier for firms to reach and sustain a tacit understanding to compete less vigorously, perhaps by increasing the degree of symmetry between firms or by increasing the level of market transparency, or through the scope for increased information flows over the prices charged by rival firms. ${ }^{823} \mathrm{~A}$ conglomerate merger may influence the likelihood of a coordinated outcome in a given market by reducing the number of effective competitors. ${ }^{824}$ Overall, non-horizontal mergers will have fewer coordinated effects compared with horizontal ones.

\subsection{Efficiencies}

It is gradually being accepted that mergers can generate efficiencies. In practice, both the CAs in the US and the EU take efficiency gains into consideration when appraising a merger and further to decide whether to challenge it, although there is controversy surrounding whether the efficiency considerations in merger laws are necessary. First, it is difficult to verify and quantify the efficiency gains from mergers precisely. All efficiency gains are based on predictions before merger implementations. Moreover, due to information asymmetry between the notifying parties and the CAs, it can be hard for the latter to assess the efficiencies accurately. Second, it is possible that the efficiency gains from mergers can also be created by alternatives, such as internal expansion. However, some mergers admittedly do create significant efficiencies, such as technological progress or economies of scale and scope, which can lead to productive efficiency, the benefits of which are passed on to consumers. Accordingly, the key point of efficiency considerations is, to the extent possible, to strike a balance between the efficiency gains that will lead to productive efficiency and consumer welfare. 825

Conversely, the notifying parties may also raise the efficiency defence during a merger review. The notifying parties have discretion over providing merger remedies or raising an efficiency defence after they have notified the CAs. Usually, when the notifying parties decide to raise an efficiency defence, they will also propose remedies to assuage the CAs' competition concerns raised out of the notified mergers in case the efficiency defence is deemed to be insufficient, so that the merger review period can be shortened and their notified transactions can be cleared as soon as possible.

Thereby, potential merger efficiencies should be identified to compare the costs and benefits from a merger and assess the overall net effects. Roller, Stennek and Verboven

\footnotetext{
8222008 EU Non-Horizontal Merger Guidelines (n 14) para. 79.

823 Bishop and Walker (n 10) 8-043.

8242008 EU Non-Horizontal Merger Guidelines (n 14) para. 120.

825 This benchmark for such balance also depends on what welfare standard merger control laws adopt. For detailed exploration, see: sec.3.3 below.
} 
have grouped these efficiencies into five categories, based on the concept of production functions:
a. rationalisation of production;
b. economies of scale/scope;
c. technological progress;
d. purchasing economies or savings in factor prices;
e. reduction of $\mathrm{x}$-inefficiency. ${ }^{826}$

\section{a. Rationalisation of Production}

Rationalisation of production refers to 'the cost savings that may be realised by shifting resources from one plant to another, without changing the firms' joint production possibilities'. ${ }^{827}$ In other words, resources are reallocated between the merged firms to the optimal level so that firms can maximise their profits with lower production costs. Rationalisation of production can also further lead to short-run economies of scale (see point b below).

For example, firm A can produce a particular product at certain marginal costs. Firm B, in contrast, can produce the same product with extremely low marginal costs due to its advanced technology. A merger between these two firms is very likely to result in firm A's allocation of all of its production to firm B, ultimately leading to cost savings.

\section{b. Economies of Scale/Scope}

Economies of scale is a condition of production in which the greater the level of output, the lower the average cost of production'. ${ }^{828}$ There can be short-run economies of scale when the physical capital is held fixed. Other economies of scale may be long-run as the result of consolidation of the former independent firm's investment in physical capital. Short-run economies of scale can further be divided into two types that may be generated from a merger, namely, the elimination of duplication of indivisible tasks, and a form of rationalization of production. ${ }^{829}$

In some industries, some factors of production are technically impossible to divide. ${ }^{830}$ The input for certain products is impossible to be scaled down even if very small volumes are produced. In other words, no matter how small the size of a firm is, a certain amount of expenditure is required to continue the operation. One of the most typical examples in this regard is a power station. An increased amount of electricity suggests that indivisible input is spread over more units of output, implying the costs for generating per unit of electricity is lowered. Overall, the more units the power station produces, the lower costs per unit it needs. In the situation of rationalization of production, resources are better assigned by re-allocating production. After mergers, firms are able to make better use of former separate firms' physical facilities, or intangible property to lower their costs. Further, once the firm transfers the production, the fixed set-up costs for keeping one plant operating will be eliminated.

\footnotetext{
${ }^{826}$ Roller, Stennek and Verboven (n 9) 4.

827 ibid, 6 .

828 Cooter and Ulen (n 771) 29.

829 Roller, Stennek and Verboven (n 9) 7.

830 ibid, 7. See also: Johan Stennek and Frank Verboven, 'Merger Control and Enterprise CompetitivenessEmpirical Analysis and Policy Recommendations' in Fabienne IIzkovitz and Roderick Meiklejohn (eds), European Merger Control: Do We Need an Efficiency Defence? (Edward Elgar 2006).
} 
Long-run economies of scale can be realised when the merging firms' investments in physical capital are combined and integrated. ${ }^{831}$ By investing in improving producing technology, costs can then be scaled down. Before a merger, when the output of a firm is small, it is likely that the firm will invest little in producing technology and physical facilities; thereby products are being produced at higher costs. After the merger with increased production, more investment will be made and technology will be improved. Accordingly, costs are lowered with increased output. Furthermore, it is also possible that long-term economies of scale will be realised due to the improved specialization of production. Firms can have more specialised workers after a merger and the latter can concentrate on their own tasks with a finer division of labour. Advertising costs can also be lowered since now only one brand, rather than two, needs to be promoted.

Economies of scope measure the cost-savings resulting from firms' ability to provide a larger number of diversified products that are related in one way or another within one plant. The reasons for economies of scope may lie in the common public input. For example, sheep are the common public input for producing both wool and mutton. Once a firm producing wool merges with another firm producing mutton, then such a merger is likely to generate economies of scope due to the common public input: sheep. Thereby merged firms may have better quality control of sheep. However, it is also possible that such efficiencies can be created through the merged firms obtaining more market power in the market concerned.

\section{c. Technological Progress}

Mergers can lead to two forms of technological progress: process innovation and product innovation. The former refers to innovation that can reduce costs for producing, while the latter is about innovation that improves the quality of an existing product. 832

By merging, firms are able to achieve economies of scale or scope, which means that major investments in R\&D can be spread over a larger production base, and thus lower the impact of investment failures. ${ }^{833}$ Mergers enable the integrated firms to have greater access to capital markets and greater internal cash flows. ${ }^{834}$ Moreover, mergers can also help to internalize the benefits from R\&D. These factors together incentivise the merged firms to invest more in R\&D. 835

Further, Mergers can give rise to a diffusion of know-how, which should finally lead to technological progress. It can bring the firms closer to their joint production possibilities frontier, without shifting the frontier itself. ${ }^{836}$ By merging, the firm with less knowledge and skills gains the opportunity to learn from the other firm, which has superior know-how in all dimensions. A two-way diffusion of know-how can also be realised. Before a merger, these firms have their know-how in different areas. Yet by merging, they can mutually improve their complementary technologies mutually. Generally speaking, a two-way

\footnotetext{
${ }^{831}$ IIzkovitz and Meiklejohn (n 793).

832 Roller, Stennek and Verboven (n 9) 9.

${ }^{833}$ Magdalena Laskowska, 'Introduction to the Analysis of Technological Progress in Merger Control' (SSRN, October 2013) <http://ssrn.com/abstract=2337177> accessed 18 April 2017, 33.

834 ibid.

${ }^{835}$ For a detailed exploration on the effects of mergers on technological progress (case study), see: Magdalena Laskowska, 'Dynamic Efficiencies and Technological Progress in EC Merger Control' (SSRN, 2013) $<$ https://papers.ssrn.com/sol3/papers.cfm?abstract_id=2336956> accesed 20 April 2017. For an empirical study on the impact of cross-border mergers and acquisitions on the acquirers' R\&D, see: Joel Stiebale, 'The impact of Cross-Border Mergers and Acquisitions on the Acquirers' R\&D — Firm-Level evidence' (2013) 31(4) Int J Ind Organ 307.

836 Roller, Stennek and Verboven (n 9) 10.
} 
diffusion of know-how happens between merged firms that produce complementary products or firms that have complementary skills.

\section{d. Purchasing Economies}

Purchasing economies may result from a merger due to the imperfect competitive factors in the market. ${ }^{837}$

For example, a firm purchases its input from the supplier in the market. Before a merger, it is too small to be able to bargain with its supplier on prices or other purchase conditions. However, once it merges with a large firm, its bargaining power is increased, which means it can purchase input with more favourable conditions. Furthermore, it is also possible that it can have quantity discounts from the supplier once it makes larger purchases, even if there is no increase in bargaining power. This is because of the tariff discrimination between high and low users. In this situation, the prices from the suppliers are composed of two parts: a fixed fee and a floating price per unit, which enable the suppliers to offer different prices to different target users.

\section{e. Reduction in Slack}

As described in sec.2 above, a merger can lead to inefficiency in production due to the crippled effective competition in the market, resulting from a concentration of market power. Moreover, because of the asymmetric information between the shareholders and the management, it is likely that the management will fail to maximise the profits for the firms. The management may also have its own private goals besides achieving production efficiency of the firm, such as improving the personal prestige of its members. All these factors will result in internal post-merger inefficiency. ${ }^{838}$

It is also possible, however, that a merger can reduce such slack in production only if firms keep their internal efficiency, which is not only determined by management techniques, but also by other factors, such as pressure from the capital market. ${ }^{839}$ The management can be more active in improving production efficiency with appropriate internal incentives. Pressure from the capital market can be considered as an external incentive which encourages the firms to improve their market performance.

\subsection{Welfare Standard}

It is inevitable for the CAs to make trade-offs between the potential efficiencies resulting from mergers and the increases in the market power of the merged firms. When assessing mergers, the competition agencies have to make clear and keep in mind what merger laws are trying to achieve and to maximise. Therefore, the choice of the applicable welfare standard should be determined first. Different welfare standards can lead to different policy prescriptions. The two most common welfare standards are consumer welfare and total welfare. Under consumer welfare, the only objective of a merger control review is to evaluate the potential effects which the notified merger will have on consumer surplus. In the situation of a total welfare standard, both consumer surplus and producer surplus are assessed.

\footnotetext{
837 ibid, 12.

838 See: ibid, 13.

839 See: ibid, 14.
} 


\subsubsection{Consumer Welfare}

The essence of consumer welfare is to maximise consumer surplus. It can conflict with Pareto efficiency. Social welfare is maximised in the market with perfect competition, where price is equal to marginal cost and both allocative efficiency and productive efficiency are realised. From the perspective of consumer welfare, one may argue to lower the price below marginal cost so that consumer surplus can be further enlarged. However, this would lead to allocative inefficiencies. Pareto allocative efficiency requires that no one can be made better off without making another worse off. Producers are made worse off in terms of making negative profits in order to make consumers better off. Accordingly, the competition agencies may have trade-offs when they try to pursue these goals simultaneously.

According to consumer welfare, a merger will be blocked if it is likely to increase the merging parties' market power which may result in price increase, even if it can create technological progress or economies of scale/scope, leading to a reduction in production costs. It is worth noting that such an approach may have the risk of leading to a suboptimal outcome if the competition agencies apply it statically. From a dynamic and longterm perspective, a merger can create technology progress and diffusion of know-how. By investing in long-term $\mathrm{R} \& \mathrm{D}$, merging parties are expected to make more profits. Price may also be lowered due to a reduction in producing costs. If the competition agencies apply consumer welfare in a static approach and only focus on short-run consumer welfare, firms will be less motivated to invest in R\&D. 840

\subsubsection{Total Welfare}

Most economists hold that consumer welfare should not be the only efficiency goal. ${ }^{841}$ The CAs may clear a merger even if it may lead to concentration of market power, as long as it can achieve great efficiencies, resulting in a total social welfare increase. Such a criterion is also called potential Pareto improvement (sometimes called Kaldor-Hicks Efficiency). A potential Pareto improvement allows changes in which there are both gainers and losers but requires that the gainers gain more than the losers lose. ${ }^{842}$ There are rich quantities of literature supporting the total welfare standard and exploring how large the efficiency gains should be. One of the most influential contributions may be the merger analysis made by Williamson. ${ }^{843}$

Figure 9 is the scenario described by Williamson. Consider a market with homogeneous goods. Before a merger, the original price was $\mathrm{P}_{1}$, which was equal to $\mathrm{C}_{1}$ and already above competitive level due to the existing market power. In this situation, consumer welfare was the area of ACD. After a merger resulting in market power increase, prices rose to $\mathrm{P}_{2}$. Accordingly, consumer surplus became the area of ABE and consumer surplus marked in the blue area was transferred to producer surplus. A deadweight loss in the form of the shaded area was created. Nevertheless, if the merged firm succeeded in reducing average cost from $C_{1}$ to $C_{2}$, then there came productive efficiency, which was marked in yellow in Figure 9. In this case, efficiency gains were the production improvements. Thus, Williamson argued that a merger should be cleared if the efficiencies gains (yellow area) are larger than the deadweight loss (shaded area). This is also the essence of the efficiency defence.

\footnotetext{
840 See: Ilzkovitz and Meiklejohn (n 793).

841 Roller, Stennek and Verboven (n 9).

${ }^{842}$ Cooter and Ulen (n 771) 42.

${ }^{843}$ See: Oliver Williamson, 'Economics As an Antitrust Defense: the Welfare Trade-offs' (1968) 58(1) Am Econ Rev 18.
} 
Figure 9 Welfare Effects of Mergers -Williamson Merger Analysis

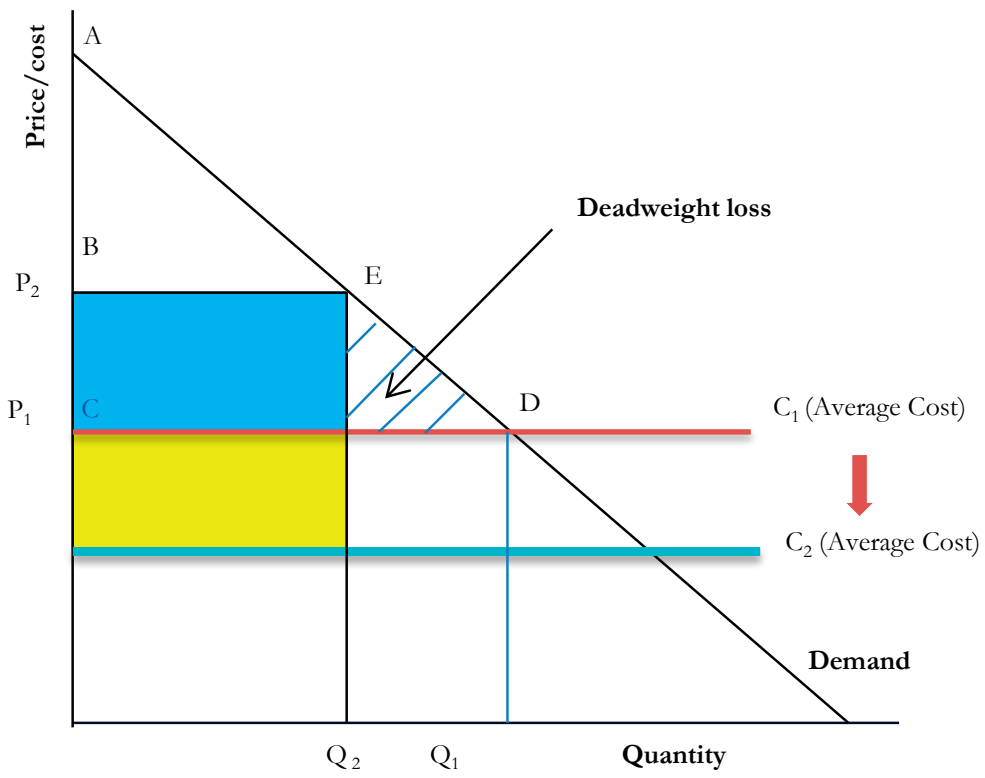

Accordingly, when making a cost-benefit analysis of mergers under a total welfare standard, a merger will be permitted if its benefits exceed its costs, which implies that the gainers (the merged firms) can compensate the losers (the consumers and maybe other competitors in the market). Thereby, it is crucial to assess the amount of efficiency gains and deadweight losses, to ensure that total social welfare is increased. However, it is quite difficult to determine the quantities of costs and benefits precisely, due to the fact that all efficiency gains concerning the notified merger are based on predictions before merger consummation.

The welfare standard is the benchmark when assessing a merger application, so that a balance can be struck where there are trades-offs between efficiencies, consumer welfare and other goals. It can also influence the design of merger remedies. Considering that consumer welfare is protected by both the CAs in the US and the EU, merger remedies are designed in a way that can be enforced in a timely and effective manner. Take merger divestitures as an example. Risk-reduction strategies are employed. The inclusion of crown jewel provisions is supposed to increase the attractiveness of the to-be-divested assets and to provide incentives for the merging parties to finish divestment on time. The inclusion of up-front buyer provisions is designed to reduce the risk of failing to find a suitable buyer (so-called buyer risks).

Therefore, the design of a merger remedy will be influenced by the chosen welfare standard. Meanwhile, both the design and enforceability of a merger remedy play a central role in the realisation of the goals of merger remedies. As mentioned, although this book focuses on merger divestitures; they are not the only option. Other forms of merger remedies can also be used concerning a particular merger application. 


\section{Choice of Merger Remedies}

Merger remedies can be complicated. An ill-adopted merger remedy will not only fail to realise any of its goals, but also create excessive costs and irreversible losses for either the merged firms in terms of depriving them of potential efficiencies gains, or the consumers due to the ineffective protection of competition. ${ }^{844}$ Take merger divestitures as an example. An effective and efficient merger divestiture remedy requires, e.g. an appropriate composition of the divestiture package, the preservation of competition in the divestiture package during the interim period, and a suitable purchaser which can compete with the merged firms after the completion of divestitures.

\subsection{Incidence for Merger Remedies}

In the US, additional conditions which are needed for a merger application to be permitted are usually settled through a consent agreement between the merging parties and the CAs. In the EU, the Commission is not in a position to impose remedies on the merging parties. ${ }^{845}$ The merging parties have the discretion to use merger remedies and the Commission is responsible for assessing the proposed remedies to determine whether they are capable of eliminating potential anti-competitive effects and preserving competition in the market concerned at the pre-merger level.

Duso, Gugler and Yurtoglu (2006), by using event study methodology, classified mergers according to the likely net effects of market power versus efficiency gains, and thereby identified situations where merger remedies should be applied. ${ }^{846}$

Table 3 Four Possibilities of Profit Effects and Merger Remedies Incidence 847

\begin{tabular}{lllll}
\hline & Positive Profits Merged Firms & Remedies & Negative Profits Merged Firms & Remedies \\
\hline Positive Profits Rivals & Market power increased & Yes & Efficiency decreased & Depends \\
\hline Negative Profits Rivals Efficiency increased & No & Efficiency decreased & No \\
\hline
\end{tabular}

The authors assume that the consumer welfare standard is followed by the CAs, so that a merger which reduces consumer welfare will be deemed anti-competitive. Accordingly, a merger might have four possible effects on the merging parties and rivals' profits:
a. positive profits for both firms;
b. only the rivals have positive profits
c. only the merged firms have positive profits;
d. negative profits for both firms. ${ }^{848}$

\footnotetext{
844 Papandropoulos \& Tajana (n 617) 443.

845 Peter L. Orosi, 'Claim Efficiencies or Offer Remedies? An Analysis of Litigation Strategies in EC Mergers' (2012) 30(5) Int J Ind Organ 578, 578.

${ }^{846}$ Tomaso Duso, Klaus Gugler and Burcin Yurtoglu, EU Merger Remedies: A Preliminary Empirical Assessment [2006] 81 GESY <http://www.sfbtr15.de/uploads/media/81.pdf> accessed 20 April 2017.

${ }^{847}$ Table 3 is adopted from Duso, Gugler and Yurtoglu's report, ibid.

${ }^{848}$ For a detailed introduction about how negative profits for both firms come about, see: Stigler (n 6). Stigler's idea of unprofitability post-merger is also supported by Martin K. Perry and Robert H. Porter, 'Oligopoly and the Incentives for Horizontal Merger' (1985) 75(1) Am Econ Rev 219; Raymond Deneckere and Carl Davidson, 'Incentives to Form Coalitions with Bertrand Competition' (1985a) 16(4) Rand J Econ 473; Raymond Deneckere and Carl Davidson, 'Coalition Formation in Non-cooperative Oligopoly Models, mimeo' (1985b) 11(1-4) Northwestern University 241; Stephen W. Salant, Sheldon Switzer and Robert J. Reynolds, 'Losses from
} 
Merger remedies should thus be applied when the merged firms have dominant market power, which may raise competition concerns such as price increases or collusion as described above.

In most situations, merger applications are cleared directly without any additional conditions. For those merger transactions which may generate efficiency gains, as well as anti-competitive effects, remedies may be applied. A fix-it-first remedy can also be proposed by the notifying parties. The primary reason for the notifying parties to propose a fix-it-remedy may lie in the hope that it will shorten the period of merger review.

As described above, the notifying parties have the discretion to decide whether to propose merger remedies, implying that it is possible for the merging parties to reject the proposed remedies, while the CAs believe that merger remedies should be applied. Such a disagreement will ultimately lead to a prohibition. The CAs consider various factors when assessing a notified merger. In addition to evaluating the possible anti-competitive effects, the CAs also weigh the hoped-for efficiency gains and then strike a balance between the "costs" and "gains". The degree of concentration of market power and potential efficiencies forms are the primary considerations. ${ }^{849}$

\subsection{General Principles for an Effective Merger Remedy}

Depending on various shapes and sizes of mergers, the forms of merger remedies may also vary from one to another. Regardless of a particular merger remedy, common principles and requirements are shared for assessing the appropriateness of a merger remedy.

Lévêque has set out four criteria which aim at achieving the goal of merger laws at the lowest costs: effectiveness, minimising administrative costs in both design and enforcement; minimising the loss in efficiencies, and efficient re-allocation of assets, which particularly concerns merger divestiture. ${ }^{850}$

Generally, a merger remedy should be capable of eliminating competition concerns and preserving competition in the market concerned to the pre-merger level. Thus, the first requirement for an appropriate merger remedy should be effectiveness. An appropriate merger remedy should be comprehensive and effective from all points of view. ${ }^{851}$

Lévêque pointed out that the other three criteria are the complements to ensure that goals of merger remedies can be achieved at least costs. ${ }^{852}$ Administrative costs involve costs in both design and enforcement. Basically, the former will be borne by the merging firms, whereas the competition agencies will bear the latter. An effective remedy should not involve large administrative costs. As is observed in previous sections, mergers are expected to bring about efficiencies, which can benefit both producers and consumers. A merger remedy, as an intervention, should ensure that such efficiencies are maximised without at least making consumers worse off. This requires the determination of the proper scope of merger remedies. In the situation of merger divestitures, efficient re-allocation of

Horizontal Merger: the Effects of An Exogenous Change in Industry Structure on Cournot-Nash Equilibrium' (1983) 28(2) Q J Econ 427.

849 See: Duso, Gugler and Yurtoglu (n 846).

850 See: Francois Lévêque, 'A Preliminary Assessment of Merger Remedies in the EU Electricity Sector' (Symposium of M\&As in the European Electricity Sector, Center for Industrial Economics, 4 October 2001).

8512008 EC Remedies Notice Notice (n 35).

${ }^{852}$ Lévêque (n 850) 2. 
assets plays an important role in reducing remedies cost. It can be understood as the to-bedivested assets should be sold to the buyers who value them most. ${ }^{853}$

Besides these general principles that can ensure the sound design of a merger remedy, its appropriateness also depends on its enforceability. Only when a remedy can be implemented effectively within a short period of time can it fulfil its "tasks". Accordingly, an effective merger remedy should be capable of preserving the hoped-for efficiencies generated by a merger to the extent possible, without compromising the benefits that result from maintaining competitive markets. ${ }^{854}$

There are also some other standards that might shed light on determining the effectiveness of merger remedies, such as: certainty. Balto pointed out that a remedy should be selected if it will preserve competition with as much certainty as possible. ${ }^{855}$ This criterion, to some extent, explains the inclusion of risk-reducing provisions in merger divestitures, such as fix-it-first or up-front buyer provisions, which can increase the certainty of an effective merger divestiture. Concerning the principles of procedures of a good merger remedy, transparency and accountability should also be the criteria when negotiating merger remedies, as argued by Oldale. ${ }^{856}$ Transparent and accountable procedural rules and negotiation processes increase the predictability and impartiality of the result of remedy negotiation.

\subsection{The Choice between Structural Remedies and Behavioural Remedies}

Generally, merger remedies can be divided into two groups, structural remedies and behavioural remedies. From the perspective of property rights, they can be defined as follows: structural remedies modify the allocation of property rights and create new firms, while non-structural remedies (or behavioural remedies) restrain the use of merged firms' property rights. ${ }^{857}$ The aim of a structural remedy is to change the post-merger market structure directly to restore the impeded competition to pre-merger level. A behavioural remedy aims at controlling the merger effects on the market to ensure that pre-merger effective competition will not be destroyed or crippled.

Divestitures are the most typical structural remedies which are widely used in many jurisdictions. A clean-sweeping divestiture may happen when the notified merger is likely to raise severe competition concerns. A full line of the merging parties' assets will be divested to a new entrant or an existing competitor. In the situation of partial divestitures, the to-bedivested assets may be selected from both sides of merging parties (also called "mix-andmatch"). Behavioural remedies have various forms. According to the 2011 DOJ Policy Guide, behavioural remedies can take the form of firewall provisions, which is designed to prevent the dissemination of information within a firm; non-discrimination provisions, which incorporate the concepts of equal access, equal efforts, and equal terms; mandatory licensing provisions, and such provisions are usually related to the divested intangible assets; transparency provision, which usually requires the merged firm to make certain

\footnotetext{
853 ibid.

8542011 DOJ Policy Guide (n 56) 2.

855 See: Balto (n 313).

856 Alison Oldale, 'Fixing Remedies in European Merger Control' (2002) July/August NERA Competition Policy Insights 1,1 .

${ }^{857}$ Massimo Motta, Michele Polo and Helder Vasconcelos, 'Merger Remedies in the European Union: An Overview' in Francois Lévêque and Howard Shelanski (eds), Merger Remedies in American and European Union Competition Law (Edward Elgar 2003) 109.
} 
information available to a regulatory authority that the firm otherwise would not be required to provide. ${ }^{858}$

\subsubsection{Problems in Merger Divestitures}

The US and the EU share the same preference for divestitures over behavioural remedies, as was described in Chapter 4. Compared with behavioural remedies, divestitures are supposed to be easier to apply, since they change the allocation of property rights within the industry, and thereby no surveillance is needed once implemented. ${ }^{859}$ In contrast, a behavioural remedy is perceived to be less effective in terms of it being less enforceable and requires long-term monitoring.

Although divestitures are preferred to other merger remedies by the CAs in both the US and the EU, the effectiveness of divestitures is still controversial among academics. Sceptics hold that such preference for divestitures needs to be justified. There is a large quantity of economic literature that studies the economics of merger remedies. For example, Cabral indicates in one of his articles that divestitures may have perverse effects on market entry after mergers:

$[B] y$ selling stores to potential rivals, merging firms may effectively buy them off, that is, dissuade them from opening new stores. This is good for the merging firms but bad for consumers: the latter prefer an asymmetric duopoly with more stores (at least sales but nevertheless entry by the rival firm) to a symmetric duopoly with fewer stores (asset) sales. ${ }^{860}$

Fridolfsson and Stennek explored how merger divestitures would affect the hold-up mechanism by basing their research on the Rubinstein-Stahl bargaining model. They concluded that in certain situations, 'merger divestitures may reduce welfare'. ${ }^{861}$

Farrell specified that during the processes of merger divestitures, the CAs are likely to over-trust the buyer who is perceived to be in a weak position with less bargaining power than the merging parties. ${ }^{862}$ It is strongly argued that buyers are likely to cooperate with the merged firms rather than being teammates of the competition agencies. ${ }^{863}$

Regarding the choice of a suitable buyer for the to-be-divested assets, Medvedev has carried out research by developing a Cournot model of a market and concluded that the CAs should be more active in selecting a suitable buyer and a new entrant should be preferred to an existing competitor. ${ }^{864}$

8582011 DOJ Policy Guide (n 56) 12-18.

859 Andreea Cosnita and Jean-Philippe Tropeano, Screening Divestitures: Structural Merger Remedies with Asymmetric Information [2005] Working paper, Amsterdam Center for Law \& Economics.

${ }^{860}$ Luis M. B. Cabral, 'Horizontal Mergers with Free-Entry: Why Cost Efficiencies May Be a Weak Defense and Asset Sales a Poor Remedy’ (2003) 21(5) Int J Ind Organ 607, 609.

${ }^{861}$ Fridolfssona and Stenneka (7) 754. For an extensive literature review on economic theory and economics of remedies, see: Davies and Lyons (n 761) 17.

862 See: Joesph Farrell, 'Negotiation and Merger Remedies: Some Problems' in Francois Lévêque and Howard Shelanski (eds), Merger Remedies in American and European Union Competition Law (Edward Elgar 2003).

863 ibid, 95.

864 See: Andrei Medvedev, Structural Remedies in Merger Regulation in a Cournot Framework [2004] Working paper, Amsterdam Centre for Law \& Economic.

The Cournot model of oligopoly assumes that rival firms produce a homogenous product, and each attempt to maximise profits by choosing how much to produce. All firms choose output (quantity) simultaneously. The Cournot model indicates the results which are of some importance to industrial economics. First of all, it can be shown that price will not in most cases equal marginal costs and Pareto efficiency is not achieved. Moreover, the degree to which each firm's price exceeds marginal cost is directly proportional to the firm's market share and inversely proportional to the market elasticity of demand. For more detailed information, see: OCED, 'Glossary of 
The preference for a divestiture, however, cannot be justified in some situations. First, divestitures can result in large transaction costs, especially in the context of the EU, where competition concerns may only appear in one national market. ${ }^{865}$ Merger divestitures can be quite complicated, and most of them involve not only the transfer of physical assets, but also intangible assets, such as intellectual property rights, and re-arrangement of personnel. Thereby, transaction costs can be quite large. Where the geographic market concerned is tiny and so has no severe effect on revenues, behavioural remedies which mainly focus on discouraging the merged firms from certain conduct may be sufficient. 866 The effects of behavioural remedies will be good if the quantity of customers concerned is large and there is easy access to information, so that the merged firms' behaviour can be monitored with ease.

Second, divestitures sometimes can result in additional competition problems, such as, post-divestiture collusion between the merged firm and the buyer of the divested assets (collusion risks). This problem may result from the incorrect perception that the buyer is a teammate of the CAs and is over-trusted by the CAs. ${ }^{867}$ In fact, the buyer's interests can be different from the CAs', which has been identified by the 1999 FTC Divestiture Study. ${ }^{868}$ It is very likely that the buyer may cooperate with the merged firms to maximise their joint profits if 'the price it pays reflects the effects on the merging parties of the divestiture's competitive significance', ${ }^{869}$ The buyer thus has no incentives to compete with the merged firms to the degree as it is supposed to. The financial pie that is divided between the buyer and the merged firms will shrink if the buyer insists on behaving in a competitionpreserving way.

When assessing the suitability of a buyer, the CAs may prefer an existing competitor or a potential new entrant with know-how and all resources that are needed to ensure the viably operation of the divested-assets on a long-term basis. However, collusion risks can arise due to the collusion-facilitating factors resulting from divestitures: symmetry and multi-market contacts. ${ }^{870}$ The selection of an existing competitor as the purchaser does suggest that the single dominant position of the merged firms is reduced, and the existing competitor is strengthened. This may result in a more symmetric distribution of market shares and other assets, which, it is believed, can facilitate collusion or joint dominance. ${ }^{871}$ In the situation where a new entrant which operates in a neighbouring product market but in a different geographic market is selected as the buyer, receiving the divested assets enables it to operate in the same product and geographic market as the merged firms. From an economic perspective, such multi-market contacts may lead to collusion. ${ }^{872}$

In contrast, the perceived disadvantages of behavioural remedies, such as the difficulty in enforcement and costly monitoring, may not impede their effectiveness in eliminating anti-competitive effects. For example, for sectors which are subject to industry-specific regulatory intervention, behavioural remedies may be favourable rather than other remedies due to the existing scheme of regulatory industrial monitoring, suggesting that the costs of

Statistical Terms - Cournot (Nash) Equilibum' (OECD, 1993) <https://stats.oecd.org/glossary/detail.asp? ID=3183> accessed 20 April 2017.

865 Davis and Lyons (n 761) 247.

$866 \mathrm{ibid}, 248$.

867 See: Farrell (n 862). It is pointed out in the article that in a certain situation, the buyer is likely to choose to cooperate with the merged firm rather than competing with it to maximise the joint profits.

8681999 FTC Divestiture Study (n 38) 27.

${ }^{869}$ Farrell (n 862) 97.

${ }^{870}$ Motta, Polo and Vasconcelos (n 857) 113.

871 ibid.

872 See: B. Douglas Bernheim and Michael D. Whinston, 'Multi-makret Contact and Collusive Behavior' (1990)

21(1) Rand J Econ 1, 1. 
long-term monitoring are dispersed. ${ }^{873}$ In addition, the long-term monitoring can also be achieved by market participants, ${ }^{874}$ such as competitors or consumers. These will to some extent reduce the burden of monitoring and lower the enforcement costs. Further, the diversity of the forms of behavioural remedies may also make it possible to address exactly the competition concerns without involving large transaction costs.

Moreover, behavioural remedies can be more suitable than merger divestitures in mergers concerning particular industries, which are discussed below.

\subsubsection{Use of Behavioural Remedies}

A price-controlling behavioural remedy may be difficult to monitor since the use of price caps involves a heavy degree of market intervention, which generally is regarded as outside the mission of a competition agency. ${ }^{875}$ In contrast, an access remedy is one of the most typical behavioural remedies that can grant access to competitors by restraining the merged firm from certain conduct.

The above-mentioned "access" may include, e.g. access to the market, access to information, and equal access to resources. Granting access can be a particular effective behavioural remedy for non-horizontal mergers because non-horizontal mergers, especially vertical mergers, are likely to create foreclosure through integration between the upstream firms and the downstream firms. Such anti-competitive effects can be eliminated or at least be controlled effectively by granting access to other competitors. Accordingly, the effectiveness of divestitures or behavioural remedies, to some extent, depends on the types of mergers.

Further, the CAs' practice and experience suggest that access remedies may perform well particularly in industries characterised by large fixed costs and a limited number of participants, ${ }^{876}$ such as telecommunications, media or pharmaceuticals.

A typical example is the Vivendi/Canal+/Seagram case. ${ }^{877}$ Vivendi S.A. ("Vivendi") proposed to acquire sole control over the Seagram Company Ltd. ("Seagram"). Vivendi was an active player in the communications industry and utilities. In addition, it had a $49 \%$ equity interest in Canal+, which was the largest pay-TV operator and also the first acquirer of premium films for pay-TV signed with a major US studio and in particular with Universal. ${ }^{878}$ Seagram was a Canadian-based company that was active in the entertainment industry. Its activities (i.e. music, film, TV programs) were conducted through its subsidiary Universal. Universal was one of the six major Hollywood studios, and produced feature films intended for initial theatrical exhibition and television programming. ${ }^{879}$ The notified merger would grant Vivendi a complete industrial chain, starting from program producing to TV program providing.

The European Commission worried that the notified merger would generate severe anti-competitive foreclosure effects because the upstream firm Seagram and the downstream firm Vivendi/Canal+ would be very likely to deny or limit the access to premium films to some downstream users or potential entrants. ${ }^{880}$ The merging parties

\footnotetext{
873 Papandropoulos \& Tajana (n 617) 449.

874 ibid.

${ }^{875}$ Alexander Italianer, 'Legal Certainty, Proportionality, Effectiveness: the Commission's Practice on Remedies' (Charles River Associates Annual Conference, Brussels, 5 December 2012), <http://ec.europa.eu/competition/ speeches/text/sp2012_07_en.pdf> accessed 21 April 2017, 6

${ }^{876}$ Rey (n 26) 131.

877 Case COMP/M.2050, Vivendi/Canal+/Seagram (European Commission Decision)[13 October 2000]

<http://ec.europa.eu/competition/mergers/cases/decisions/m2050_en.pdf> accessed 22 April 2017.

${ }^{878}$ Motta, Polo and Vasconcelos (n 857) 117.

879 Vivendi/Canal+/Seagra (n 877) para. 8.

${ }^{880}$ Motta, Polo and Vasconcelos (n 857) 117.
} 
modified their merger plan and proposed at the early stage of the merger review process a remedy which mainly concerned non-discriminating conduct regarding the online music and opportunities for other competitors to bid for Universal's first-window firms. ${ }^{881}$ This case was finally cleared subject to a further modified remedy in which the parties promised not to grant Canal+ first window rights covering more than $50 \%$ of Universal Production and co-production. ${ }^{882}$

Rey has concluded that mergers in industries such as media, telecommunication or pharmaceuticals share some common characteristics: first, the merging parties usually have large quantities of local loops in their respective home market, controlled by their large companies; second, there is almost no horizontal overlapping business concerned in the merger transactions. ${ }^{883}$ In these cases, access remedies can be effective. Big merged firms owning a large quantity of local loops are likely to discriminate against other operators. Take the Vivendi/Canal+/Seagram case as an example. Vivendi was active and had large local loops in communications and utilities industries. The merger between Vivendi and Seagram, which had a subsidy named Universal that produced feature films, would enable Vivendi to integrate its advantage in communications and utilities industries with Seagram's pay-TV services, and discriminate against other pay-TV operators by limiting their accesses to Universal productions. As is explored above, such foreclosure can be effectively solved by accessing remedies.

Table 4 Choices between Structural Remedies and Behavioural Remedies

\begin{tabular}{|c|c|c|}
\hline & Structural Remedies & Behavioural Remedies \\
\hline Advantages & $\begin{array}{l}\text { - Simple, relatively easy to administrate; } \\
\text { - High likelihood to preserve } \\
\text { competition }\end{array}$ & - Reversible \\
\hline Disadvantages & $\begin{array}{l}\text { - Possible large transaction costs } \\
\text { - Effectiveness may be reduced due to } \\
\text { different risks, such as collusion risks }\end{array}$ & $\begin{array}{l}\text { - Difficult to be enforced: costly and long- } \\
\text { term monitoring needed }\end{array}$ \\
\hline $\begin{array}{l}\text { Applicable merger } \\
\text { types or industries }\end{array}$ & $\begin{array}{l}\text { Especially suitable for horizontal } \\
\text { mergers; or mergers involving } \\
\text { overlapping assets }\end{array}$ & $\begin{array}{l}\text { - Especially suitable for non-horizontal } \\
\text { mergers } \\
\text { - Suitable for industries characterised by } \\
\text { large fixed costs and a limited number of } \\
\text { participants (such as telecommunications, } \\
\text { media or pharmaceuticals) }\end{array}$ \\
\hline
\end{tabular}

Divestitures seem to be less effective in mergers involving almost no horizontal overlaps because divestitures can only restructure the geographic market of local loops. In the Vivendi/Canal+/Seagram case, even if Vivendi agreed to divest parts of its facilities in communications and utilities industries to other operators, it was still unclear whetherany operators, except the buyer of the divested-assets, would have access to the films. Efficiencies generating from, such as, internalization of access charges are likely to be reduced by divestitures. ${ }^{884}$ The following table provides a general summary concerning the choice between structural remedies (divestitures) and behavioural remedies.

\footnotetext{
881 The first-window film is the first period of premium films availability on pay-TV. It is generally held by consumers as well as by the operator that the quality of first-window films is better than that of second-window films, which are also called "old" premium films. As a result, those pay-TV operators will lose their customers if there are no or limited first-window films available. See: Vivendi/Canal+/Seagra (n 877) para. 19.

${ }_{882}$ Motta, Polo and Vasconcelos (n 857) 117.

${ }^{883}$ Rey (n 26) 131.

884 ibid, 132.
} 


\section{Conclusion}

This chapter serves as a general introduction toward the law and economics analysis of merger divestitures in Part II. In this chapter, the expected effects of mergers have been analysed in detail. It explores the advantages and disadvantages of divestitures and behavioural remedies and further clarifies the situations where behavioural remedies will be more suitable than the generally favoured divestitures.

Both horizontal mergers and non-horizontal (unilateral and conglomerate) mergers can lead to anti-competitive effects. The former is likely to result in price increases and concentrations of market power; the latter has the likelihood of causing foreclosures. Either effect will impede effective competition in the market and ultimately harm consumer welfare. Mergers, however, can also generate efficiencies, such as rationalisation of production, economies of scale and scope, technological progress and diffusion of know-how, and reduction of slack in production.

When making an overall merger appraisal over a notified merger, efficiencies resulting from mergers will be taken into consideration by the CAs in the US and the EU. ${ }^{885}$ The merging parties may raise an efficiency defence when they notify mergers to the CAs. If an efficiency defence is accepted by the CAs, the notified merger will be cleared (maybe with remedies). Thus, the chosen welfare standard plays a central role in further ensuring how much weight should be given to efficiency gains.

In the US, the fundamental goal of anti-trust law is to protect consumer welfare. In the $\mathrm{EU}$, the Commission is assigned to realise a multitude of goals. Although consumer welfare is given large weight in the Commission's overall assessment, other goals such as market integration are also considered as an important aim. Thus, there may exist trade-offs. Overall, the EU applies a hybrid welfare standard so that a balance can be struck between allocative efficiency and productive efficiency. The Commission will clear a merger on the basis of efficiency gains only if consumers will not be made worse off and benefits resulted from the merger-specific efficiencies can pass on to consumers.

A merger remedy is introduced and designed to preserve the potential efficiencies a merger will create on the one hand, and to eliminate the anti-competitive effects a merger will result in on the other hand. A merger remedy is far more complicated than a yes or no decision since it involves a lot of elements in order to make it work effectively and efficiently.

Merger divestitures can strengthen an existing competitor or create conditions for the emergence of a new entrant by changing the structure in the market concerned directly, so that effective competition can be preserved. It is generally accepted that merger divestitures are straightforward and do not need long-term monitoring. However, they are also criticised for their harshness and irreversibility. Behavioural remedies are generally not favoured by the CAs due to the difficulties in implementation and because they require long-term monitoring, which will increase the cost of enforcement and administration. Whether a remedy can effectively fulfil its assigned tasks, to some extent, depends on the

\footnotetext{
885 The treatment of efficiency in merger review in the US is well-established in both judicial and administrative perspective. The main applicable legislation related to the efficiency defence is the 2010 US Horizontal Merger Guidelines (n 11). According to these guidelines, the CAs will note challenge a merger if cognisable efficiencies are of a character and magnitude such that the merger is not likely to be anti-competitive in any relevant market. See: 2010 US Horizontal Merger Guidelines (n 11), sec.10. An efficiency defence can be considered in the EU. The main legislation in the EU in this regard is 2004 EUMR (n 3) and 2008 EU Non-Horizontal Merger Guidelines (n 14). Although efficiencies will be taken into consideration when the CAs assess a notified merger, it seems that in these legislations, efficiency defence is deliberately described in a way to make it hard to be established.
} 
type of mergers and the industry concerned. In non-horizontal mergers in which foreclosure is the main competition concern, or mergers that involve industries such as media, pharmaceuticals or telecommunications, behavioural remedies, especially access remedies, are more suitable than divestitures. Basically, mergers in these industries are characterised by the involvement of companies that are of large scale and have large quantities of local loops in their respective home markets, or almost no horizontal overlaps involved in the merger transactions. 


\section{Chapter}

COMPOSITION RISKS - AN APPLICATION OF SCREENING THEORY 



\section{Introduction}

It has been suggested by Parker and Balto that the merging parties are likely to propose to divest their business with weak competitiveness or of low market value so that the potential buyer, after purchasing the business, will not be created as a strong rival. ${ }^{886} \mathrm{~A}$ so-called composition risk may thus occur. Composition risks can occur when a divestiture package has a scope which is too constrained or is inappropriately configured, such as the absence of key tangible/intangible assets or key personnel, resulting in the unavailability of a suitable purchaser, or the divested assets' incapability of being operated viably. 887

How to reduce the risks? First, this issue can be avoided if the CA has full information which is needed for an accurate assessment of the suitability of the proposed divestiture packages, such as the marketability and viability of the proposed divestiture package. Based on full information, the CA could determine precisely the appropriateness of the divestiture packages, and as far as possible, assure the effectiveness of divestitures.

Nevertheless, the reality is that it can be difficult for the CA to obtain full information. This might result from the fact that as the insider of the proposed transaction, the merging parties have private information regarding their notified transactions as well as the proposed divestiture packages, while such information is unknown to the CA. Moreover, the merging parties are unlikely to make a clean breast of all the valuable information. ${ }^{888}$ Asymmetric information may thus occur between the merging parties and the CA regarding the divestiture packages.

Such information asymmetry, to some degree, can be reduced by the CA's acquisition of information through investigations, such as consulting with relevant industrial associations, sending a questionnaire to relevant competitors and consumers, or opening hearings; or by its accumulated experience obtained from dealing with similar transactions. In addition, the potential buyer's attitude to the divestiture package can be regarded as a strong indication for the CA to verify the sufficiency of the proposed divestiture package because, generally a buyer cares most about the value of the divestiture package.

Information asymmetry can still exist. The CA may be unable to obtain all necessary information from its investigations, considering the time limit of merger review; or sometimes a potential buyer is a new market entrant and has limited knowledge regarding a sufficient divestiture package. Such asymmetric information between the merging parties and the CA brings large difficulties for the latter, as the uninformed party, to precisely determine the right scope of the divestiture packages, which can lead to type I errors (excessive divestitures) or type II errors (insufficient divestitures). The former occurs when the merging parties propose a divestiture package that is much greater than necessary to clear the anti-competitive effects; the latter refers to a situation where the competition agency agrees to an insufficient divestiture package. ${ }^{889}$ Accordingly, it is evident that composition risks are more likely to arise under type II errors considering the insufficiency of a divestiture package.

\footnotetext{
886 See: Parker and Balto (n 149).

887 UK Competition Guidelines (n 39) sec.3.3(a).

888 The reader should be aware that information asymmetry can also occur between the merging parties, for example, some shareholders have private information while others do not. In this Chapter, information asymmetry is only studied, in the context of merger divestitures, between the CAs and the merging parties.

${ }^{889}$ Luke Garrod, Bruce Lyons and Andrei Medvedev, 'Three Types of Inefficiency in Strategic Offers: Empirical Identification from Merger Remedy Settlements' (CCP, October 2008) <https://editorialexpress.com/cgibin/conference/download.cgi?db_name=IIOC2009\&paper_id=162> accessed 24 April 2017, 3. A detailed exploration of type I/II errors is presented in sec.4.1 below.
} 
To reduce the composition risks caused by the possible information asymmetry and to increase the degree of certainty of a successful divestiture, risk-reducing provisions can be employed by the CAs as screening devices, which refer to mechanisms that are used by the uninformed party (e.g. the CA) to differentiate between different informed parties (e.g. the merging parties). ${ }^{890}$ Risk-reducing provisions refer to provisions that can reduce various risks that could occur during the implementation of divestitures, such as up-front buyer provisions, crown jewel provisions, provisions of appointments of trustees, or holdseparate provisions (HSP). In the context of composition risks, risk-reducing provisions especially refer to up-front buyer provisions and crown jewel provisions.

To study the effectiveness of using risk-reducing provisions as screening devices to reduce composition risks, it is assumed that those divestiture packages proposed by the merging parties can be divided into two groups: good assets (referring to divestiture packages with sufficient assets that can attract a suitable buyer and can compete in the market effectively if being operated by a capable buyer) and bad assets (which are unable to fulfil the above-mentioned requirements). By applying screening theory, the effectiveness of using risk-reducing provisions is assessed in this chapter.

Subsequent to this introduction, a brief introduction of the development of information asymmetry theory is presented in sec.2. Sec.3 presents a literature review concerning the economic analyses of merger remedies, especially merger divestitures. In sec.4, an analysis is conducted to explore the question whether risk-reducing provisions can reduce composition risks effectively (from the perspective of screening theory). The use of risk-reducing provisions in the US and the EU is explored in sec.5. Sec.6 draws a conclusion.

\section{Development of Information Asymmetry - A Brief Introduction}

Asymmetric information refers to a situation where one side of an economic relationship has better information than the other. ${ }^{891}$ It can lead to many problems, such as fraud and cheating caused by the informed party's misuse of its private information and difficulties in reaching agreements or contracts.

The concept of asymmetric information was first introduced by George A. Akerlof in The Market for "Lemons": Quality and the Market Mechanism. ${ }^{892}$ Basically, there are two types of asymmetric information between parties in an economic relationship: bidden characteristics and bidden actions. The former refers to somethings that one side of a transaction knows about itself and which the other side would like to know but does not; the latter refers to actions taken by one side of an economic relationship that the other side of the relationship cannot observe. ${ }^{893}$ Hidden characteristics can lead to adverse selection, meaning the process of

\footnotetext{
${ }^{890}$ Joseph E. Stiglitz, 'The Theory of "Screening", Education, and the Distribution of Income' (1975) 65(3) Am Econ Rev 283, 283. For a detailed introduction of screening devices, see: sec. 2 below.

891 Michael L. Katz and Harvey S. Rosen, Microeconomics (3 edn, McGraw-Hill 1998) 553.

${ }^{892}$ George A. Akerlof, 'The Market for "Lemons": Quality and the Market Mechanism' (1970) 84(3) Q J Econ 488. The paper considers a second-hand car market where the sellers have more private information than the buyers regarding the quality of a specific used car. The author argues that due to the asymmetric information between the buyers and the sellers, sellers are incentivised to sell products of lower quality than average, while the buyers cannot assess the quality of second-hand cars. Overtime, the market will be full of "lemons" (products of poor quality) and good products will thus be driven out of the market.

${ }^{893}$ Katz and Rosen (n 891) 554.
} 
products of poor quality starting to dominate the market. ${ }^{894}$ Adverse selection occurs before any agreement is reached between parties. Hidden actions can result in moral hazard, which means, taking the insurance market as an example, that the insured changes his behaviour partly or entirely after purchasing insurance because his behaviour is unobservable to the insurance company while the latter has to bear the insured's costs; so that the probability of loss or the size of the loss increases. ${ }^{895}$ Moral hazard occurs after an agreement has been reached between parties. The detailed theory and application of moral hazard in the merger divestiture will be explored in Chapter 7.

To alleviate adverse selection, Spence designed a mechanism in his 1973 paper, which concerned the job market. ${ }^{896}$ In his model, high-ability job applicants, as the informed party, have full information about their ability and thus are able to differentiate themselves from low-ability job applicants by using their years of education as a signal. Such a mechanism used by the informed party is called signalling. In his model, "years of education" has no direct influence on the productivity of a job applicant. It is worth pointing out that, on the one hand, high-ability employees are more productive than lowability employees; on the other hand, there is no explicit connection between "more years of education" and "higher productivity". Years of education can to some extent reflect the job applicants' intelligent ability since it is assumed that it is comparatively easy for people with the higher intelligent ability to finish more years' education than those with less academic talent. However, it is noteworthy that intelligent ability is only one aspect of a job applicant's overall abilities. Other abilities can be, for example, the organizational ability or the team-work ability. In Spence's model, "years of education" is simply employed by the job applicants as a signal to reflect one aspect of their ability and to differentiate themselves rather than as a determinant of their overall ability. This also explains why in reality most employers consider other factors, such as working experience, when they select their employees.

It is also possible that the employers, as the uninformed party, wish to classify the job applicants into different groups based on their different productivity and skills, so that they can employ the most suitable applicants. This idea can be realised by setting out different employment requirements in the recruitment notices, such as minimum tasks that have to be performed per day. This mechanism is called screening, which was introduced by Stiglitz in his 1975 paper, The Theory of Screening, Education, and the Distribution of Income. ${ }^{897}$ Stiglitz acknowledged that there are various types of information in the world and one of the most important types of information is qualities. ${ }^{898}$ For example, employees can have different productivity levels, or different brands of cars can have various engine performances. The identification of these different qualities is called screening, and devices that are used to sort them out based on such qualities are called screening devices. ${ }^{899}$

The above mentioned Stiglitz's paper also took the job market as an example. The author first assumed that there were only two groups of job applicants: high ability applicants and low ability applicants. Further, the author assumed that there was a screening process during which the employers can differentiate between these applicants by

\footnotetext{
894 Lauri Auronen, 'Asymmetric Information: Theory and Applications' (CiteSeerX, 21 May 2013) $<$ http://citeseerx.ist.psu.edu/viewdoc/download?rep=rep1\&type=pdf\&doi=10.1.1.198.9252> accessed 22 April 2017.

${ }^{895}$ Cooter and Ulen (n 771) 48.

${ }^{896}$ Michael Spence, 'Job Market Signaling' (1973) 87(3) Q J Econ 355, 355.

${ }^{897}$ Stiglitz (n 890).

898 ibid, 283.

899 ibid.
} 
setting the number of tasks that have to be completed per day with different income. It demonstrated that there can be a Pareto-efficient separating equilibrium in the situation of full information, and a pooling equilibrium under asymmetric information without screening, which is not Pareto-optimal. ${ }^{900}$ An inefficient separating equilibrium can be reached in the situation where a market is characterised by asymmetric information and screening devices. ${ }^{901}$ Figure 10 shows the theoretical framework and development of information asymmetry theory.

Figure 10 Development of the Theory of Asymmetric Information ${ }^{902}$

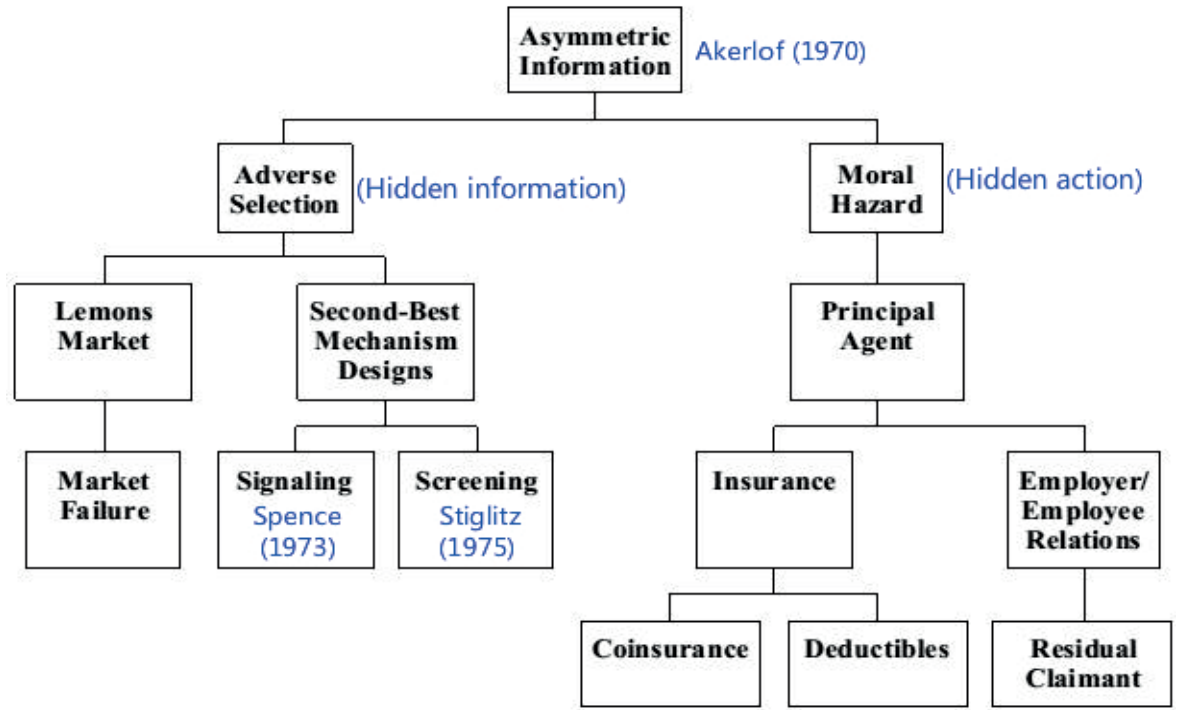

With the same goal of reducing asymmetric information, signalling and screening are different in so far as the former is employed by the informed party to differentiate itself, while the latter is used by the uninformed party to obtain information from the informed party. In the context of merger divestitures, since risk-reducing provisions are used by the CA (the uninformed party) rather than by the merging parties (the informed party), screening theory is thus employed in this chapter.

\section{Literature Review}

Economic literature focusing on merger remedies is limited in quantity but growing; meanwhile, most contributions are quite recent, with little published before 2001.903 Therefore, the literature review presented in this section contains not only studies which

\footnotetext{
${ }_{900}$ A pooling equilibrium refers to a situation where all the applicants end up in the same employment "pool" with the same income.

${ }^{901}$ For a detailed exploration of efficiency effects of screening, see: sec. 4 below.

902 Adopted from Michael E. Wetzstein, 'Chapter 23: Asymmetric Information' in Microeconomic Theory second edition: Concepts and Connections (2 edn, Routledge 2012) Summary.

${ }_{903}$ Davies and Lyons (n 761) 9.
} 
explore (the economics of) merger divestitures, but also those that address the application of information asymmetry theory (especially in the field of merger divestitures).

In Cabral's 2003 paper, the author argues that merger divestitures may have perverse effects on market entry. ${ }^{904}$ Fridolfsson and Stennek demonstrated that anti-competitive mergers can bring more benefits to competitors than to the merged firm, thus the firms' incentives to merge are reduced due to such positive externalities. ${ }^{905}$ They further point out that merger divestitures may reduce the strength of the hold-up mechanism, so that the merging firms can appropriate part of the strong positive externalities. ${ }^{906}$ The incidence of merger remedies, especially merger divestitures, has been explored econometrically. Lindsay's and others' 2003 paper indicates that merger divestitures are likely to be required if the proposed merger involves large market shares and thus creates barriers to market entry. ${ }^{907}$

Regarding the application of information asymmetry theory, Potters and Van Winden analysed the informational lobbying in a game setting. ${ }^{908}$ The informational lobbying refers to 'lobbying engaged in by interest groups [who] make use of their (alleged) expertise or private information to persuade the policymakers to implement particular policies, which are of importance to them'. ${ }^{909}$ The authors specified that lobbying messages from one interest group to the policymakers may be informative even if the interest groups and the policymakers have a substantial conflict of interest, and even if information costs involved in a message are independent of what the interest group reports and knows. ${ }^{910}$ Sanchirico (2001) proposed a model of evidence production in the situation with asymmetric information during the regulatory judicial and administrative processes of private behaviour. ${ }^{911}$ The author further argued that the evidence production implies that truth finding has no direct relevance to deterrence and "over-deterrence" may well be cost-effective. ${ }^{912}$

Lagerlof and Heidhues developed a model in which two firms propose to merge under asymmetric information concerning the merger specific efficiency gains, which are unknown to the competition agencies. ${ }^{913}$ It is recognised that the merging parties can strategically reveal their potential efficiency gains (such a process is called producing evidence) to the competition authority in order to get their merger applications approved. On the one hand, such information can to some extent improve the competition authority's merger decisions; on the other hand, the welfare can be reduced if such information revelations are excessively costly. Whether the reduction would happen depends on the merger control institution, in particular whether such institution includes an efficiency defence. In the paper, the authors '[derived] the optimal institution and [provided] conditions under which an efficiency defence is desirable', e.g. it is pointed out that an efficiency defence is more desirable if the efficiencies are high enough to lead to a lower market price. ${ }^{914}$ However, Medvedev argued that Lagerlof and Heidhues failed to consider 'the possibility of the

\footnotetext{
904 Cabral (n 860) 609.

${ }^{905}$ Fridolfssona and Stenneka (7) 754.

906 ibid, 755.

${ }_{907}$ Alistair Lindsay, Emanuela Lecchi and Geoffey Williams, 'Econometrics Study into European Commission Merger Decision since 2000’ (2003) 24(12) ECLR 673, 680.

908 See: Jan Potters and Frans van Winden, 'Lobbying and Asymmetric Information' (1992) 74(3) Public Choice 269.

909 ibid, 269.

910 ibid, 286.

911 See: Chris William Sanchirico, 'Relying on the Information of Interested-and Potentially Dishonest-Parties' (2001) 3(2) Am L Econ Rev 320.

912 ibid, 320.

913 See: Johan N. M. Lagerlof and Paul Heidhues, 'On the Desirability of an Efficiency Defences in Merger Control' (2005) 23(9-10) Int J Ind Organ 803.

914 ibid, 806.
} 
manipulation of results or cheating on behalf of the "bad" mergers since they showed that in an equilibrium, "bad" mergers would never invest in evidence production'. ${ }^{915}$ This is the opposite of Medvedev's conclusion, which indicates that both good mergers and bad mergers could produce evidence. In other words, bad mergers could manipulate or cheat the CA by exaggerating the potential merger-specific efficiencies.

One of the articles which are closely relevant to this chapter is Medvedev's 2006 paper, Efficiency Defence, Administrative Fuzziness, and Commitment in Merger Regulation. ${ }^{916}$ The paper developed a double signalling mechanism based on Spence's single signalling theory. The model looks at some effects of the inclusion of an efficiency defence in merger regulation, incorporating type I and type II errors into the CA's approval probabilities.

The author assumed that there were two categories of mergers: good mergers (mergers that generate efficiencies higher than required by the CA) and bad mergers (mergers with lower efficiencies than required). The merging parties to both types pf mergers have private information about the actual efficiency gains of the notified transaction, whereas such information is unknown to the CA. The merging parties have discretion to decide whether or to what extent they should reveal the private information to get their transactions approved. Generally, they can be incentivised to obtain approvals from the CA by revealing certain information to convince the CA that their notified merger is a good one. The CA, in turn, can use strategies after observing the double signals from the merging parties, which are used as a tool to distinguish good mergers and bad mergers, by changing the approval probabilities.

Different from Spence's single signalling model in which "years of education" is the only signal and is irrelevant to the productivity of an employee, double signals are applied in Medvedev's model, referring to the produced evidence (how much efficiency gains a merger can generate) and the way it has been produced (how much effort the merging parties spend to prove the potential efficiency gains). Furthermore, the choice of effort level affects the probability of success in producing the evidence. ${ }^{917}$ It is concluded that the separation of different merger types can lower the value of type I and type II errors made by the CA. A fuzzy approval rule is widely preferred if the CA can commit to certain policies. ${ }^{918}$

Another relevant article is Cosnita and Tropeano's paper, Negotiating Remedies: Revealing the Merger Efficiency Gains. ${ }^{919}$ The paper aimed at designing an optimal merger divestiture when there is asymmetric information between the CA and the merging parties regarding the amount of efficiency gains generated from a notified merger. A revelation mechanism was proposed, which considered divestitures as merger remedies with two other factors, "the regulation of the divestitures sale price" and "a merger fee [paid to the CA by the merging parties]". ${ }^{920}$ The rationale of the revelation mechanism is that, there are two alternatives available for all merger applicants: to divest a lower amount of assets and pay high merger fee to the CA, vise versa. The authors argue that generally, efficient mergers will

\footnotetext{
${ }_{915}$ Andrei Medvedev, Efficiency Defence, Administrative Furziness, and Commitment in Merger Regulation [2006] Working Paper No 06-8, Amsterdam Centre for Competition Policy, 4.

A merger can generate efficiencies. To approve a notified merger, the CAs may require the merging parties to demonstrate the possibility of the notified transaction to generate efficiencies to serve a multitude welfare standard. A good merger thus refers to a merger that has efficiencies higher than is required. A bad merger is a merger that has efficiencies lower than required. See: ibid, 5.

${ }^{916}$ Medvedev (n 915).

917 ibid, 17.

918 ibid, 17.

919 See: Andreea Cosnita and Jean-Philippe Tropeano, 'Negotiating Remedies: Revealing the Merger Efficiency Gains' (2009) 27(2) Int J Ind Organ 188.

920 ibid, 188.
} 
go for the first option to avoid large divestitures which may reduce the potential efficiency gains, whereas the less efficient mergers will choose the second alternative because they cannot "afford" high merger fee.

The similarities between Cosnita and Tropeano's article and this Chapter are that both explorations concern merger divestitures and the application of screening theory. A difference, however, is that in the above-mentioned article, divestitures are used by the CA as screening devices to reveal the asymmetric information regarding synergies generated from the proposed merger. Further, the authors proposed a revelation mechanism to determine an optimal merger divestiture. In this Chapter, risk-reduction provisions are used as screening devices by the $\mathrm{CA}$ in the context of merger divestitures, to reveal asymmetric information - the appropriateness of the composition of the proposed divestiture package. Readers should be aware that risk-reducing provisions can only alleviate composition risks, whereas they cannot completely eliminate them. Since there seems to be little (maybe no) literature on the economic analysis of the composition risks in merger divestitures context by applying screening theory, this chapter aims to fill this gap.

\section{Occurrence of and Solutions to Composition Risks: from a Screening Theory Perspective}

In this section, screening theory is applied to assess whether risk-reducing provisions can effectively reduce composition risks arising out of merger divestitures. Before addressing this question, there are two other questions that are worth exploring. First, in what situation would a composition risk occur? Second, under what conditions is it efficient to use risk-reducing provisions as screening devices to reduce composition risks? The answer to the first question provides an implication of when a screening device can be needed. The answer to the second question further determines whether screening devices are necessary. These are the pre-conditions that need to be considered before using risk-reducing provision to reduce composition risks.

\subsection{Occurrence of Composition Risks}

Due to asymmetric information, the CA may find it difficult to determine precisely the right composition of a divestiture package. The CA has to make the overall assessment based on the information it obtains from the merging parties and its investigations. Type I or type II errors are to a large extent caused by this difficulty.

Both types of errors can result in inefficiency. Excessive divestitures (type I errors) deprive the merging parties of the potential efficiencies that are expected to arise from a merger and thus lead to a reduction in the merging parties' surplus. Insufficient divestitures (type II errors) are likely to result in the survival of potential anti-competitive effects which can harm consumers and ultimately lead to a decrease in consumer surplus. Composition risks can be caused by type II errors due to the too limited scope or poor configuration of the divestiture packages. ${ }^{921}$ To better understand and solve composition risks, it is important to be aware of the situations where these risks would occur.

\footnotetext{
${ }^{921}$ For a detailed exploration concerning the relationship between asymmetric information, type I/II errors, composition risks and the use of risk-reducing provisions as screening devices, see: Figure 14 and Figure 15 below.
} 
Garrod, Lyons and Medvedev have conducted an empirical study concerning merger remedy settlements with the aim of predicting which and when three types of errors (type I/II/III) will occur, by setting up a model of bargaining against merger remedies. ${ }^{922}$ Type III errors arise when a merger divestiture agreement is delayed, requiring the CA's additional investigations. Such a delay can lead to an occurrence of compliance costs and a decrease of the merging parties' benefits. The authors first hypothesised that the occurrence of these three types of errors is relevant to the complexity of a merger and whether a delay is costly to the merging parties. ${ }^{923}$ The variables they use in the study are summarised as follows.

Table 5 Variables Considered in Garrod, Lyons and Medvedev's 2008 Paper

\begin{tabular}{|c|c|c|}
\hline Name for Variables & Findings & Tool Adopted to Measure the Variables \\
\hline Merger complexity & $\begin{array}{l}\text { Complexity mainly occurs } \\
\text { when the merged entity has a } \\
\text { market share in the } \\
\text { intermediate range, which } \\
\text { cannot be described as } \\
\text { sufficiently low or high }\end{array}$ & $\begin{array}{l}\text { 1. Markets: number of markets within a merger } \\
\text { 2. Uncertain: a subset of these markets where the } \\
\text { merged entity has a reported market share of } \\
\text { between }[35-45] \% \\
\text { 3. Coordaspects: nature of the competitive } \\
\text { assessment required } \\
\text { 4. V concern:(assume that a merger with vertical } \\
\text { anti-competitive effects will not be agreed in } \\
\text { Phase I) } \\
\text { 5. Index } 1990 \text { : (assume less delay in reaching } \\
\text { agreement if mergers involved industries which } \\
\text { have been scrutinised before) } \\
\text { 6. Coordexp1900: (assume less delay in reaching } \\
\text { agreements if mergers involve coordinated } \\
\text { effects) }\end{array}$ \\
\hline $\begin{array}{l}\text { The merging parties' cost } \\
\text { of delay }\end{array}$ & $\begin{array}{l}\text { Mergers with a large } \\
\text { proportion of markets are } \\
\text { unlikely to cause competition } \\
\text { concern to be agreed earlier }\end{array}$ & $\begin{array}{l}\text { Lowpre: measure the market proportion of a } \\
\text { merger involved with market shares below } 35 \%\end{array}$ \\
\hline Potential harm & $\begin{array}{l}\text { The merged firm's market } \\
\text { shares in the horizontally- } \\
\text { affected markets that cause } \\
\text { concern will increase the } \\
\text { potential harm }\end{array}$ & $\begin{array}{l}\text { Sls } 2 \text { and si: (assume that it would be less likely } \\
\text { that mergers will be agreed in Phase I where the } \\
\text { merged firm has large market shares in markets } \\
\text { that cause concern; further assume that in such } \\
\text { markets, the large firms' market share is only } \\
\text { increased by a small amount as a result of the } \\
\text { merger) }\end{array}$ \\
\hline $\begin{array}{l}\text { Political influence, and } \\
\text { international cooperation }\end{array}$ & $\begin{array}{l}\text { It is possible that staff of the } \\
\text { Commission or the } \\
\text { Competition Commissioner } \\
\text { have a bias in favour of } \\
\text { 'local' firms }\end{array}$ & $\begin{array}{l}\text { Eesonly, eeaus, usonly and others: the merging } \\
\text { parties' domiciles }\end{array}$ \\
\hline
\end{tabular}

The authors, after collecting and analysing the data concerning mergers at the EU level during the period from 1999 to 2006, concluded that the merging parties act strategically when they interact with the CA. During a preliminary investigation stage, a type I error is likely to occur when a relatively less complex merger is being appraised, while a type II error can occur if the merger application is complicated. Further, they suggest that type I errors are more common than type II errors in the EU dimension. Type III errors may

\footnotetext{
${ }_{922}$ Garrod, Lyons and Medvede (n 889) 4.

923 ibid, 3.
} 
arise once the European Commission is dealing with a merger application which may end up with a type II error. An agreement can be reached during the delay when the Commission carries out another investigation.

Based on the above conclusion, it is fair to predict that composition risks are likely to happen when the proposed merger is complex, implying that there can be more asymmetric information between the merging parties and the CA than in the less complex ones.

\subsection{Solutions to Composition Risks: Are they Efficient?}

Composition risks in merger divestitures have been recognised by several jurisdictions, such as the US, the EU or the UK. ${ }^{924}$ A divestiture package with a too constrained scope or an inappropriate configuration can result in the unavailability of a suitable buyer, or prevent the buyer, after the completion of divestiture, to operate the divested business viably in the market. ${ }^{925}$ The occurrence of composition risks implies the possibilities of the remaining of anti-competitive effects generated from a the notified merger and thus cripple the effective competition in the market concerned.

In practice, the CAs in the US and the EU can require the inclusion of risk-reducing provisions, such as, up-front buyer provisions or crown jewel provisions, to ensure the success of divestitures. Before evaluating whether such an approach is effective to reduce composition risks, it is important to explore in what conditions it is efficient to adopt screening devices to avoid the risk of making the screening a pyrrhic victory. To fully answer this question, the health insurance market is taken as an example.

\subsubsection{Efficiency Effects of Screening: Taking the Health Insurance Market as an Example}

Assume that there are only two groups of customers: one group is labelled as "high-risk customers" since they are careless about their health. They may smoke a lot or enjoy risky sports like hill skating, resulting in high possibilities of insurance claims. The other group is defined as "low-risk customers" because they care about their health and thus have few health problems and a low possibility of insurance claims. Further assume that the demand curve of group 1 for insurance is the same as group 2's, and is equal to the marginal willingness of customers in both groups to purchase insurance. The supply curve for the high-risk group and low-risk group is marked as $S_{1}$ and $S_{2}$, respectively. The marginal costs for insurance contracts for group 1 customers and group 2 customers are respectively marked as $\alpha_{1}$, and $\alpha_{2}$, where $\alpha_{1}>\alpha_{2}{ }^{926}$

\subsubsection{Market with Full Information and No Screening}

In the insurance market with full information, the insurance companies are fully aware of two types of customers, so that they can avoid loss by tailoring the insurance contracts with

\footnotetext{
924 (US) 1999 FTC Divestiture Study (n 38); 2012 FTC Remedies Statement (n 36); The Bureau of Competition of the Federal Trade Commission, Statement of The Federal Trade Commission's Bureau of Competition on Negotiating Merger Remedies (2004) (hereinafter: 2004 FTC Remedies Statement); 2004 DOJ Policy Guide (n 321); 2011 DOJ Policy Guide (n 56). (EU) 2008 EC Remedies Notice Notice (n 35); 2001 EC Remedies Notice (n 440); 2005 EC Merger Remedies Study (n 27). (UK) UK Competition Guidelines (n 39).

925 UK Competition Guidelines (n 39) sec.3.3 (a).

${ }_{926}$ The analysis in this section is adopted from Thomas J. Nechyba, 'Chapter 22: Asymmetric Information in Competitive Markets' in Microeconomics: An Intuitive Approach with Calculus (with Study Guide) (South-Western Cengage Learning 2010) 815. In the original context, the model considers car insurance.
} 
different prices to the targeted customers. Figure 11 illustrates how equilibrium prices are determined and how a competitive market allocates resources efficiently between the insurance companies and the customers.

Figure 11 Consumer Surplus in the Market with Full Information: No Screening ${ }^{927}$

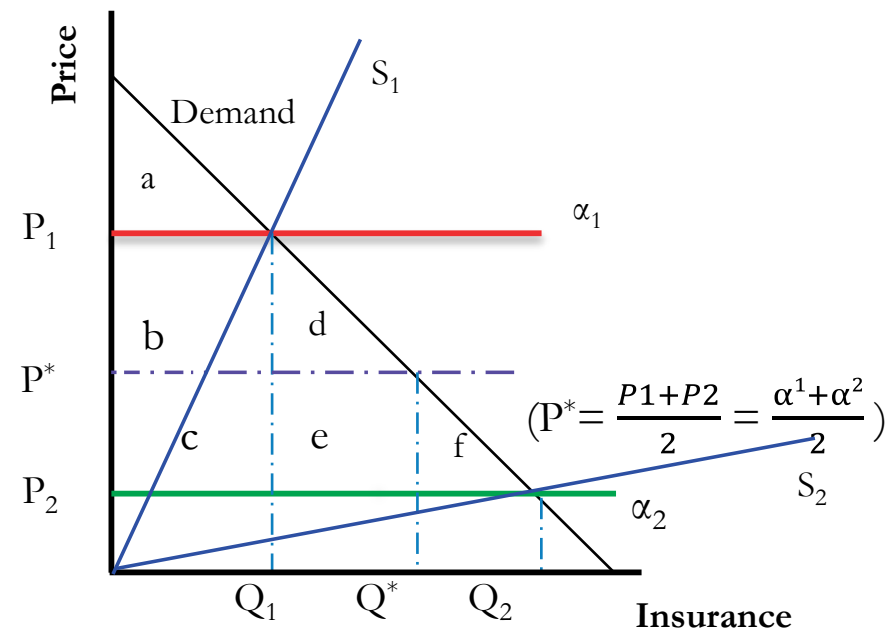

As is shown, both supply lines slope upwards because the higher the price is, the more insurance the insurance companies are willing to supply. Further, with the same price, lowrisk customers can purchase more insurance than high-risk customers since they have a lower possibility of having insurance claims; with the same amount of insurance, high-risk customers have to pay more than low-risk customers because they are more likely to claim compensation from the insurance company. Hence, the supply line for high-risk customers $\left(\mathrm{S}_{1}\right)$ is above the low-risk customer's $\left(\mathrm{S}_{2}\right) . \mathrm{P}_{1}$ and $\mathrm{P}_{2}$ are the equilibrium price for high-risk customers and low-risk customers respectively when the demand curve intersects with the supply lines $\mathrm{S}_{1}$ and $\mathrm{S}_{2}$ respectively.

When the price is $\mathrm{P}_{1}$, high-risk customers would purchase the quantity of insurance as $\mathrm{Q}_{1} ; \mathrm{Q}_{2}$ would be purchased by low-risk customers when the price is $\mathrm{P}_{2}$. The quantity $\left(\mathrm{Q}_{1}\right.$ and $\mathrm{Q}_{2}$ ) maximises social surplus, with equilibrium prices equal to marginal costs. The full information equilibrium is called full-information separating equilibrium since each type of customers ends up in separate insurance contracts with prices equal to marginal costs.

When the insurance companies can differentiate between high-risk and low-risk customers, the group 1 customers can get a consumer surplus that is equal to area (a) which is shown in the above figure. For low-risk customers, consumer surplus equals area $(a+b+c+d+e+f)$. Considering that in both situations, prices are equal to marginal costs, which means the insurance companies make zero profits, the total social surplus in the market with full information thus equals area $(2 a+b+c+d+e+f) .{ }^{928}$

927 ibid, 815.

928 See: ibid, 815. 


\subsubsection{Market with Asymmetric Information and No Screening Devices}

Now assume that information is asymmetric in the market: the customers have private information concerning their health conditions or living habits, which is unobservable to the insurance companies. Therefore, as the uninformed parties, the insurance companies would be unable to differentiate between these two groups. Furthermore, suppose that according to the insurance companies' experience, they only know that half of the customers are high-risk and the rest are low-risk. Accordingly, they would determine the price as $\mathrm{P}^{*}=\frac{P 1+P 2}{2}=\frac{\alpha 1+\alpha 2}{2}$ for all customers to avoid loss and is equal to marginal costs. ${ }^{929}$ Since high-risk customers and low-risk customers share the same demand curve, they would both purchase quantity $\mathrm{Q}^{*}$ at the price $\mathrm{P}^{*}$. This equilibrium is called a pooling equilibrium because both types of customers end up choosing the same amount of insurance contracts with the price equal to marginal costs.

Figure 11 indicates that high-risk customers are better off since the price they pay drops from $\mathrm{P}_{1}$ to $\mathrm{P}^{*}$. Their consumer surplus thus increases from area (a) to $(\mathrm{a}+\mathrm{b}+\mathrm{d})$. Low-risk customers, however, are made worse off because they have to pay more than what they pay in the situation of a full-information market. The consumer surplus thus drops from area $(\mathrm{a}+\mathrm{b}+\mathrm{c}+\mathrm{d}+\mathrm{e}+\mathrm{f})$ to $(\mathrm{a}+\mathrm{b}+\mathrm{d})$. Again, since the insurance companies do not make profits, the total social welfare is area $(2 \mathrm{a}+2 \mathrm{~b}+2 \mathrm{~d})$. Further, since area (b) equals to (c), area (d) equals to $(\mathrm{f})$, the total social welfare can also be written as $(2 \mathrm{a}+\mathrm{b}+\mathrm{c}+\mathrm{d}+\mathrm{f}) .{ }^{930}$ Compared with the total social welfare in the full-information market, the welfare area (e) is missing. In other words, asymmetric information leads to inefficiency.

\subsubsection{Market with Asymmetric Information and Screening Devices}

To analyse the efficiency effects in a market characterised by asymmetric information and screening devices, there are three situations that are discussed in this section: screening with zero or low costs; screening with extremely high costs and screening with reasonable costs.

\section{Screening with zero or low costs}

In a market with asymmetric information, it is possible that an insurance company provides two different packages of insurance contracts with different prices and insurance policies. In the packages, the insured have to pay the full premium and the coverage has already been determined in advance. In this situation, it is possible that customers may voluntarily sort themselves into different groups. The low-risk customers are willing to take insurance contracts with low premium with limited coverage, while the high-risks customers choose the insurance with high premium with wider coverage. If so, the screening costs will be zero or extremely low. It is evident that the resulting total social welfare would be similar to that in a full-information market. The total consumer surplus is thus maximised. Put differently, again, quantity $\mathrm{Q}_{1}$ would be purchased by high-risk customers at price $\mathrm{P}_{1}$, and low-risk customers would purchase quantity $\mathrm{Q}_{2}$ at price $\mathrm{P}_{2}$ (as shown in Figure 11 above).

\section{Screening with extremely bigh costs}

Conversely, it is likely that some high-risk customers would choose insurance packages designed for the low-risk customers. To differentiate the low-risk customers from the highrisk customers, the insurance companies may use some screening devices rather than

\footnotetext{
929 ibid.

930 See: ibid, 816.
} 
relying on the customers' voluntary sorting. For example, they may have to conduct some investigations before signing the insurance contracts. Screening costs are thus raised. Figure 12 illustrates the consumer surplus in the case of costly screening.

Figure 12 Consumer Surplus in the Market with Asymmetric Information: Costly Screening 931

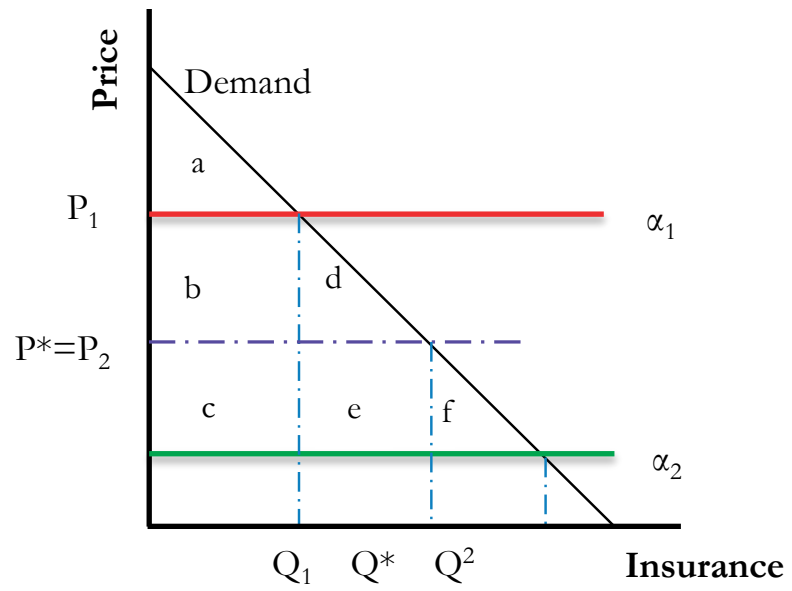

Assume that by adopting screening devices, the insurance companies can differentiate between two types of customers with extremely high screening costs C. Suppose that the insurance companies still make zero profits and do not incur losses. This means that the insurance companies have to pass such costs onto the customers. The price for high-risk customers cannot exceed $\mathrm{P}_{1}$ since if that happens, new insurance companies will emerge and simply set the price to $\mathrm{P}_{1}$. Therefore, the low-risks customers have to bear the costs and thus the price for them rises above $\alpha_{2}$, which equals to $\mathrm{P}_{2}=\alpha_{2}+\mathrm{C}$. Further assume that the screening costs are as high as $\left(\mathrm{C}=\mathrm{P}^{*}-\alpha_{2}\right)$, where $\mathrm{P}^{*}=\frac{\alpha 1+\alpha 2}{2}$. Then $\mathrm{P}_{2}$ can be rewritten as $\mathrm{P}_{2}=\mathrm{P}^{*}$. By screening, the high-risk customers have to pay $\mathrm{P}_{1}$ and the low-risk customers would pay $\mathrm{P}_{2}=\mathrm{P}^{*}$.

Compared with the asymmetric-information pooling equilibrium (market with asymmetric information and no screening, sec.4.2.1.2. above) as is shown in Figure 11, the price for low-risk customers remains unchanged (still $\mathrm{P}^{*}$ ), while the price for the high-risk customers rises from $\mathrm{P}^{*}$ to $\mathrm{P}_{1}$. As a result, the consumer surplus of the low-risk customers is still equal to the area $(a+b+d)$. Nevertheless, for the high-risk customers, their consumer surplus drops from the area $(a+b+d)$ to $(a)$. Since the insurance companies still make zero profits, the total social welfare with screening would be the area $(2 \mathrm{a}+\mathrm{b}+\mathrm{d})$. Compared with the full-information separating equilibrium, welfare $(c+e+f)$ is missing, which is also larger than the missing welfare in the pooling equilibrium in the asymmetric-information market. ${ }^{932}$ Table 6 below gives an overview of the changed total social surplus.

931 See: ibid, 818.

932 See: ibid, 818. 
Table 6 Changed Total Social Surplus

\begin{tabular}{llll}
\hline & $\begin{array}{l}\text { Full-information separating } \\
\text { equilibrium (or with zero/low } \\
\text { screening costs) }\end{array}$ & $\begin{array}{l}\text { Asymmetric-information } \\
\text { pooling equilibrium with } \\
\text { NO screening }\end{array}$ & $\begin{array}{l}\text { Asymmetric-information } \\
\text { pooling equilibrium with } \\
\text { COSTLY screening }\end{array}$ \\
\hline Total social welfare & $2 \mathrm{a}+\mathrm{b}+\mathrm{c}+\mathrm{d}+\mathrm{e}+\mathrm{f}$ & $2 \mathrm{a}+\mathrm{b}+\mathrm{c}+\mathrm{d}+\mathrm{f}$ & $2 \mathrm{a}+\mathrm{b}+\mathrm{d}$ \\
\hline $\begin{array}{l}\text { Deadweight loss } \\
\text { (DWL) }\end{array}$ & - & $\mathrm{e}$ & $\mathrm{c}+\mathrm{e}+\mathrm{f}$
\end{tabular}

Low-risk customers generally have to bear screening costs so that they can be differentiated from high-risks customers and thus pay lower premiums (compared with what they pay in a market with asymmetric information and no screening devices). However, if screening costs are extremely high, this means, on the one hand, high-risk customers and low-risk customers are differentiated, thus the former have to pay a higher premium; on the other hand, low-risk customers may have to pay the premium that is (almost) equal to what they pay in an asymmetric-information equilibrium situation due to high screening costs. In other words, what low-risk customers gain is less than what highrisk customers lose. In this case, it can be concluded that moving from a pooling equilibrium to an asymmetric-information separating equilibrium is inefficient. Accordingly, efficiency with reasonable screening costs is explored next, where "reasonable" means that the amount of costs involved should at least be lower than the potential gains that can be achieved after screening.

Screening with reasonable costs

With reasonable screening costs, we assume that $\mathrm{P}_{2}$ is in between $\alpha_{2}$ and $\mathrm{P}^{*}$, where $\mathrm{P}^{*}=$ $\frac{\alpha 1+\alpha 2}{2} .933$

Figure 13 Consumer Surplus in the Market with Asymmetric Information: Screening at Reasonable Costs 934

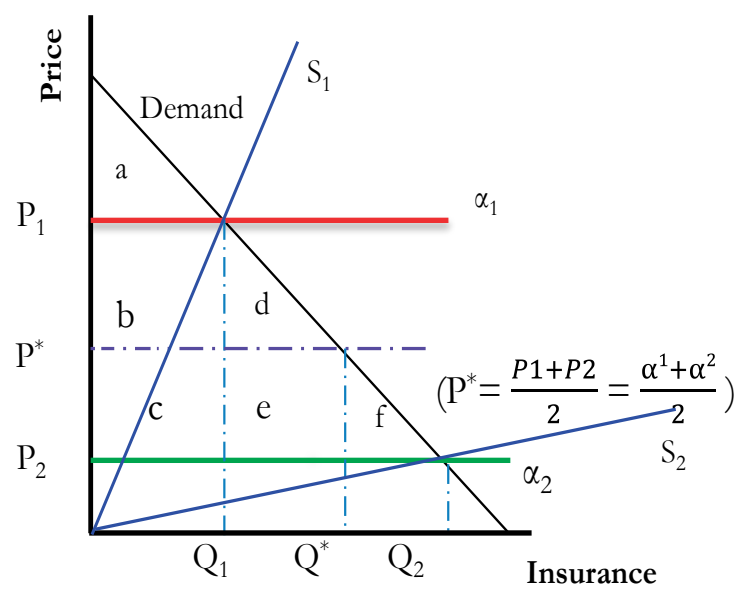

In this situation, the price for the high-risk customers is $\mathrm{P}_{1}$, resulting in their surplus equal to area (a). Price for the low-risk customers is $\mathrm{P}_{2}$, leading to a consumer surplus that equals

\footnotetext{
933 ibid, 818.

934 See: ibid, 818 .
} 
area $(a+b+d+g+i)$. With zero profits made by the insurance companies, the total social surplus is thus the area $(a+a+b+d+g+i)$. Compared to the full-information separating equilibrium, welfare $(h+j+k)$ is missing. It is worth pointing out that with the decrease of screening costs, area $(\mathrm{h}+\mathrm{j}=\mathrm{k})$ would become smaller, which means the welfare would move close to that in the full-information separating equilibrium.

\subsubsection{Inefficiency and Screening Costs in Merger Divestitures}

When comparing the total social welfare in the full-information separating equilibrium with that in the asymmetric-information pooling equilibrium, it is easy to find out that information asymmetry can lead to inefficiency since a deadweight loss ("DWL") occurs. This is also the same in the context of merger divestitures.

If the CA has full information concerning a notified merger, it will be therefore able to decide whether to approve the merger directly or conditionally with merger remedies. If a merger divestiture is needed, then the CA will determine the composition of the divestiture package precisely. Thereby it is assured that the merging parties can enjoy the generated efficiencies on the one hand, and the consumers will at least not be made worse off due to the generated post-merger anti-competitive effects on the other hand. ${ }^{935}$ Nevertheless, type I or type II errors are caused due to information asymmetry between the merging parties and the CA regarding the divestiture packages. Composition risks are thus created particularly due to type II errors, due to which insufficient divestiture packages are approved by the CA. Composition risks may lead to the purchaser's failure of operating the divested business vigorously in the market or even incurring losses, leading to a reduction in the buyer's welfare. In other words, the failure of the divested business to compete with the merged firms in the market vigorously implies that the potential anti-competitive effects which the merger brings about still remain, and the merged firms would be able to keep high profits by enjoying the increased concentration of market power after the mergers. Consumer welfare is therefore decreased. To avoid such inefficiency and keep the competition effective, the CA has to reduce composition risks.

However, as is shown in the insurance market example, whether it is efficient from the perspective of total social welfare to move from an asymmetric-information pooling equilibrium to an asymmetric-information separating equilibrium by using screening devices depends on the screening costs involved. In the example, it is assumed that the insurance company makes zero profit, thus the screening costs will ultimately be passed on to the customers, resulting in a higher premium. The total social welfare will be reduced if the screening is costly. In other words, a screening is efficient only if the screening costs are low or reasonable. The costs should not exceed the benefits that would be gained by screening. In short, the losses should not outweigh the gains. Regarding mergers, it is generally believed that time is of the essence. Any delay may reduce the expected benefits of a merger. The longer the negotiations on merger remedies take, the higher the cost will be for the merging parties. Accordingly, in a merger divestiture, the higher the screening costs are, the lower the benefits that the merging parties will enjoy from the transactions.

In the context of merger divestitures, to ensure the efficiency of using risk-reducing provisions as screening devices, the screening costs involved at least should not outweigh the benefits that the merging parties and the consumers can enjoy from the notified

\footnotetext{
935 Whether a merger can be approved is also to some extent influenced by the welfare standard that competition law adopts. If a consumer welfare standard is employed, then a merger will only be approved (maybe with remedies) if the notified mergers will benefit or at least will not harm the consumer welfare. For a more detailed exploration regarding welfare standard in competition law, see: Chapter 5.
} 
transactions. The benefits to the merging parties can be economies of scale/scope resulting from the notified merger. Consumers will also benefit if the cost-saving leads to lower prices of products. Generally, details of a risk-reducing provision are determined by negotiations between the merging parties and the CA. ${ }^{936}$ In fact, negotiations can involve large costs. For example, the monetary loss caused by the time lost. Hence, whether or not the parties are willing to compromise and cooperate with each other, the time involved for them to reach an agreement will have a great impact on negotiation costs, while time is valuable to both parties. The more time is spent on reaching an agreement, the more costs are involved. Time limits to some extent set an upper limit on the screening costs (at least time costs). It can be efficient for the CA to use risk-reducing provisions as screening devices to screen those merger applications as long as they can stick to the time limits set in the merger control law and do not protract a lengthy merger review.

\subsection{Effectiveness of Screening Divestiture Packages by Risk-Reducing Provisions}

Composition risks may occur due to asymmetric information concerning the divestiture package's market value, the key technology, or the key personnel. The CA has to make sure that a proper composition of business is divested so that effective competition can be restored to the market at pre-merger level. In this section, three situations are studied to analyse the effectiveness of risk-reducing provisions as screening devices to alleviate composition risks, namely, divestitures with full information, divestitures with asymmetric information and no screening devices and divestitures with asymmetric information and screening devices.

\subsubsection{Divestitures with Full Information}

Merger divestitures are used either upon the requirement of the CAs or due to the merging parties' voluntary proposals of the fix-it-first remedies. ${ }^{937}$ In either situation, negotiations will be followed between the merging parties and the CA to assess the suitability of the remedy proposal or to discuss the design and implementation detail. From the perspective of the CA, an accurate assessment or an effective discussion regarding the appropriateness of the composition of the divestiture packages largely depends on the information it possesses. Such information consists of various aspects, including the key technology concerned in the divestiture package, the key personnel, etc. As the gatekeeper of markets, the CA has the responsibility to ensure that competition will not be crippled by the proposed merger. Accordingly, as mentioned in Chapters 2 and 3, the general standards for the CAs in the US and the EU to approve a proposed divestiture package can be summarised as viability, autonomy and sufficiency.

\footnotetext{
${ }^{936}$ The negotiations between the CAs and the merging parties concerning the use of risk-reducing provisions can be regarded as a process of cooperative bargaining. Transaction costs of the bargaining can include, e.g. the time costs. For the details of bargaining theory in merger divestitures, see: Chapter 8 , sec. 3 .

${ }^{937}$ The merging parties may propose a fix-it-first remedy to speed up the merger view. A fix-it-first remedy is expected to speed up the merger review because with such a remedy, the merging parties submit their proposed divestiture plan at the start or during the process of merger review. In the submitted divestiture plan, composition and the buyer of the proposed to-be-divested assets have all been proposed, suggesting that the CA can simultaneously review the notified merger and the suitability of the proposed divestiture packages. In contrast, in the "normal" procedures, the CA will review the notified merger first and further to decide whether a divestiture remedy is needed, followed by negotiations concerning the determination of the composition and the suitable buyer. It is also possible that the CA will require the merging parties to improve their fix-it-first remedy if necessary. For the details of the use of the fix-it-first remedy in the US and the EU, see: Chapter 2 and Chapter 3, respectively.
} 
To test whether risk-reducing provisions can alleviate composition risks effectively, first assume that there are only two types of to-be-divested assets: one type is labelled as "good assets", referring to divestiture packages with sufficient assets; the other one is labelled as "bad assets", referring to the to-be-divested business that may give rise to composition risks due to the insufficiency. ${ }^{938}$

Further assume for the moment that the CA has all information that is needed for an accurate assessment of the proposed divestitures, implying the CA's capability of differentiating good assets and bad assets. Evidently, good assets will be accepted by the CAs and accordingly, the merging parties who propose good assets are very likely to get final permission from the CA to proceed with their transactions. ${ }^{939}$ In contrast, bad assets will be rejected by the CA. Accordingly, composition risks are reduced since insufficient divestiture packages will not be accepted.

On the one hand, the merging parties generally have strong desire to get their transactions approved; on the other hand, they may want to keep as many assets as possible. Thus, they will balance their benefits of being approved and the costs of divesting assets and choose the optimal amount of business that satisfies the CA's requirements for an acceptable divestiture package.

\subsubsection{Divestitures with Asymmetric Information and No Screening}

Assume now that there is asymmetric information and no screening devices are used. The CA approves a merger application with good divestiture packages and rejects bad divestiture packages (leading to the prohibitions of the notified mergers) if it can screen and differentiate these packages. However, in the absence of screening devices, the CA can hardly differentiate between them.

Meanwhile, considering the merging parties' desire to get their transaction approved, as the informed party, they may be incentivised to make use of their private information and only reveal information which is advantageous for them in obtaining approvals. For example, in order to get approval from the CA, the merging parties, whose proposed divestiture package is insufficient, may choose to exaggerate the value of the divestiture packages and attempt to convince the $\mathrm{CA}$ that their proposed divestiture package is sufficient to clear the anti-competitive effects. Approvals of insufficient divestiture packages (type II errors) are thus likely to result in composition risks. As mentioned, composition risk can lead to the failure to attract a suitable buyer or failure to compete with the merged parties effectively after being operated by the buyer.

Theoretically, a type I error can occur either because of the rejection of a sufficient divestiture package (because the CA believes that the proposed divestiture package is insufficient to remedy the anti-competitive effects), which may lead to the loss of potential efficiencies; or because the merging parties with good divestiture packages are required by the CAs to divest more assets. Rejecting a sufficient divestiture package means the prohibition of the notified merger. Hence, prohibiting an efficient or neutral merger can reduce the total welfare.

Therefore, either approving a "bad" divestiture package (type II error) or rejecting a sufficient divestiture package and/or requiring a too wide scope of a good divestiture package (type I error) can lead to inefficiency.

938 The idea is adopted from B. Douglas Bernheim and Michael D. Whinston, 'Chapter 21: Asymmetric Information' in Microeconomics (Irwin/McGraw-Hill 2008) Screening.

${ }_{939}$ Both in the US and the EU, after the CAs accept the divestiture proposal, a public comment period will follow. Only after that can the merging parties get their final approval concerning their notified mergers. 


\subsubsection{Divestitures with Asymmetric Information and Screening Devices}

Theoretically, screening can help to reveal hidden characteristics when information is asymmetric between parties. In the context of merger divestitures, one of the solutions to alleviate composition risks is to reveal whether a proposed divestiture package is good or bad so that the CA can decide whether to accept the proposed divestiture packages. To explore the rationale behind screening and to understand how screening devices can alleviate composition risks, a comparison between the merger divestitures and the job market is made in this section.

\subsubsection{Rationale bebind Screening: an Example of the Job Market940}

In practice, when the employer looks for new employees, he can design special requirements in the recruitment notice to screen the job applicants and to ensure that only suitable applicants will be attracted. Assume that there are only two types of job applicants for the position of machine repair: skilled applicants and newly-qualified applicants. Skilled applicants are able to repair machines faster than those new-hands with higher quality. Accordingly, the employer can make profits of 50 euros per task by employing an additional skilled mechanic and 25 euros for a less-skilled one.

If there is full information between the employer and the job applicants concerning, for example, the job applicants' working experience or skills, the two types of applicants will earn the equilibrium salary of 50 euros and 25 euros per task, respectively (assume that the employer makes zero profits). Accordingly, these two types of mechanics can choose how many tasks they want to perform per day by being provided with a different fixed salary rate, resulting in different salaries which they will get per day. In this situation, a separating equilibrium is reached.

When there is asymmetric information, the employer can no longer differentiate skilled applicants from less-skilled ones. Even if the employer still provides two alternatives of salary rates, it is evident that both types of job applicants will end up choosing the same high salary rate, suggesting that the less-skilled mechanics can earn more by performing the same numbers of tasks as compared with the situation with full information. It is easy to understand that such results are inefficient since the employer will face the risk of incurring losses because the salary he pays to the less-skilled mechanic is more than the profits the less-skilled mechanic brings to him.

To solve this problem, the employer can set requirements, e.g. certain numbers of tasks have to be finished per day, as a screening device to differentiate between these job applicants. For example, the employer can state in the recruitment notice that employees can earn 600 euros if they can finish 15 tasks per day (meaning 40 euros per task) and earn 125 euros if 5 tasks can be completed (meaning 25 euros per task). Mechanics will get nothing if they fail to finish the required minimum tasks. As the informed party, the job applicants know their ability better than the employer, such as how fast they can repair a machine. Job applicants will consider the benefits of receiving a high salary rate and the risks of earning nothing if they are unable to satisfy the requirements. Skilled applicants are hence likely to choose the first offer and less-skilled ones may choose the second offer. As a result, two types of applicants are effectively differentiated by laying requirements on the minimum tasks they have to finish per day. In other words, the employer can assume that only suitable job applicants will be attracted by designing his requirements in the

940 This example is adopted from Bernheim and Whinston (n 938). 
recruitment notice. This result is also an asymmetric-information separating equilibrium since different applicants end up with different choices of salary rate.

The reason why the equilibrium price for skilled workers in the situation of asymmetric information (40 euros/task) is lower than that in full information situation (50 euros/task) is that skilled-applicants have to bear the burden of screening. Since costs will be involved in screening, the employer will pass on the costs to employees. To avoid losses, the employer will provide a low salary rate unless he is assured that the workers have the higher ability. Put differently, a skilled mechanic has to work harder and make more efforts to convince the employer that he has high ability and deserves a higher salary; otherwise he can only get a low salary. It is also possible that the less-skilled applicant chooses to practice a lot to improve his skills so that he can get a high salary rate. Summing up, any applicant who wants to get a high salary rate has to make more effort.

\subsubsection{Adopting Risk-reducing Provisions as Screening Devices in Merger Divestitures}

On the one hand, the CA can face difficulties in determining the appropriate composition of the proposed divestiture package without all the necessary information. On the other hand, to get the proposed mergers approved, some of the merging parties can behave strategically by revealing only certain private information, which makes the situation even more difficult. Accordingly, risk-reducing provisions, such as up-front buyer provisions and crown jewel provisions, can be used as screening devices to differentiate between the proposed divestiture packages to ensure to the extent possible that only good assets will be accepted.

After the merging parties propose a divestiture proposal, negotiations between the merging parties and the CA will follow. During these negotiations, the CA will assess whether the proposed divestitures are sufficient to clear the potential anti-competitive effects. When the CA is unsure about the sufficiency of the proposed divestiture assets and to ensure that only good assets will be approved, the CA can require the inclusion of riskreducing provisions before making its decision. A divestiture package will be accepted if the merging parties agree to accept the inclusion of risk-reducing provisions. A divestiture package will be rejected if the merging parties refuse to accept the inclusion of risksreducing provisions.

Take up-front buyer provisions as an example. When the CA worries about whether a proposed divestiture package is sufficient to attract a suitable buyer, it will thus require the merging parties to include an up-front buyer provision. This means that the merging parties have to find a buyer for their proposed divestiture package and come into a final divestiture agreement with the buyer before the CA accepts the proposed consent order (in the situation of the FTC) for public comments. ${ }^{941}$ Such a buyer has also to be approved by the CA.

If the merging parties accept the up-front buyer provision, the benefit is that their divestiture package will be accepted by the CAs (with a high possibility of obtaining final approval concerning the notified merger if no one objects it during the public comment period). The risk they face is that they may fail to find a suitable buyer or the CA disapproves the proposed buyer. Accordingly, when considering whether to accept the upfront buyer provision, the merging parties have to balance the benefits and risks, considering the "quality" of their proposed divestiture assets to attract a suitable buyer,

941 See: FTC, 'Frequently Asked Questions about Merger Consent Order Provisions' (Federal Trade Commission) $<$ https://www.ftc.gov/tips-advice/competition-guidance/guide-antitrust-laws/mergers/merger-faq\#Buyer Up Front> accessed 23 March 2017. 
while the "quality" is the merging parties' private information. If the merging parties are confident concerning the quality of their proposed divestiture package, they will choose to accept the inclusion of an up-front buyer provision.

If a crown jewel provision is included, this means that the merging parties have to divest more assets than the originally proposed divestiture package if they fail to complete divestment within the first divestiture period. With the acceptance of crown jewel provisions, their merger notification together with the divestiture proposal will be accepted by the CA. To avoid activation of the provisions, the merging parties have to make sure that they can finish divestment in time. Accordingly, the merging parties who propose bad assets may choose to re-configure their divestiture package rather than accepting such provisions, which increases the risk of divesting more assets once such provision is activated.

In the job market example described in sec.4.3.3.1 above, although all job applicants want to earn high salaries, they have to consider their ability. The employer states clearly that employees can get 600 euros only if they can finish 15 tasks per day. Similarly, all the merging parties hope that their proposed mergers can be approved by the CA; however, they have to ensure that they can comply with the risk-reducing provisions if such provisions are included in the CA's decisions. Failures to comply with the provision can finally lead to the prohibition of their proposed merger. Accordingly, the merging parties have to decide whether to include such provisions or to further ameliorate their divestiture package.

The CA can thus differentiate good assets from bad assets by using risk-reducing provisions as screening devices because if the divestiture package is sufficient, the merging parties will accept the inclusion of risk-reducing provisions directly; if bad assets are proposed, the merging parties will try to improve their divestiture proposal further (only if the time limit set in the merger control law allows). The CA will approve a merger with good divestiture packages which are able to clear the potential anticompetitive effects. If the merging parties do not accept risk-reducing provisions and leave their divestiture package insufficient, their notified mergers will be disapproved. Generally, the merging parties will choose to further improve their divestiture packages.

Figure 14 summarises the above-mentioned three points: the relationship between asymmetric information, type I/II errors, composition risks, and risk-reducing provisions in merger divestitures. Figure 15 describes how risk-reducing provisions can be used as screening devices to reduce composition risks.

Similar to the skilled job applicants, the merging parties who proposed good mergers have to make more efforts than they do in the full information situation because they have to bear the costs of screening. In the case of full information, the CA can tell good assets from bad assets directly without screening. Thereby it approves good mergers and rejects bad assets. When information is asymmetric, the CA can no longer differentiate easily between these two types of divested assets. The merging parties (in particular those with bad assets) are likely to behave strategically by only revealing information to the CA which is beneficial to them. Since the CA will not approve a merger unless it is ensured that such mergers will not create anti-competitive effects, the merging parties have to make additional efforts to convince the CA that their divestitures are sufficient by accepting riskreducing provisions. 
Figure 15 Screening Divestiture Packages by Risk-Reducing Provisions

Asymmetric information between the merging parties and the CA

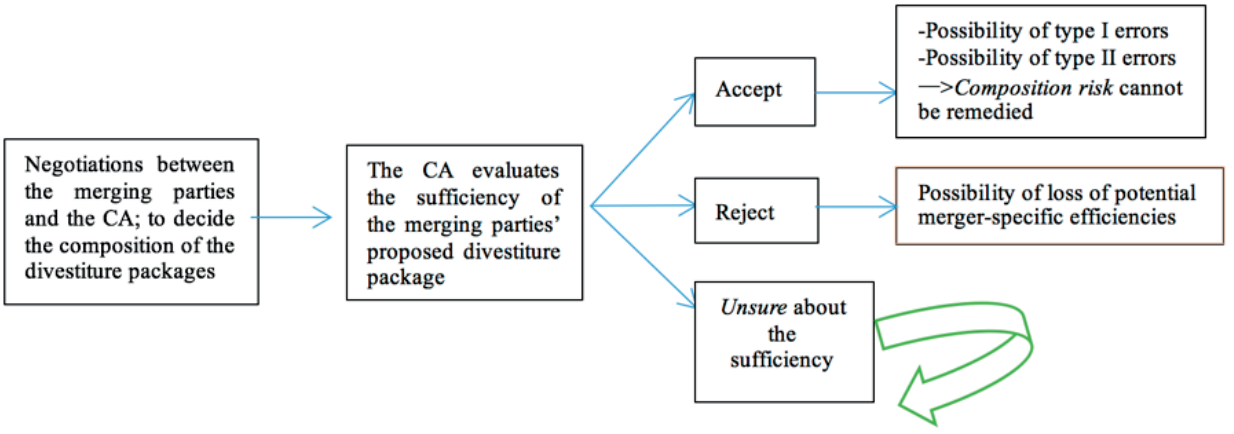

Screening by risk-reducing provisions

before the CA makes its decisions (see

Figure 15 below)

Figure 14 Asymmetric Information and Risk-Reducing Provisions

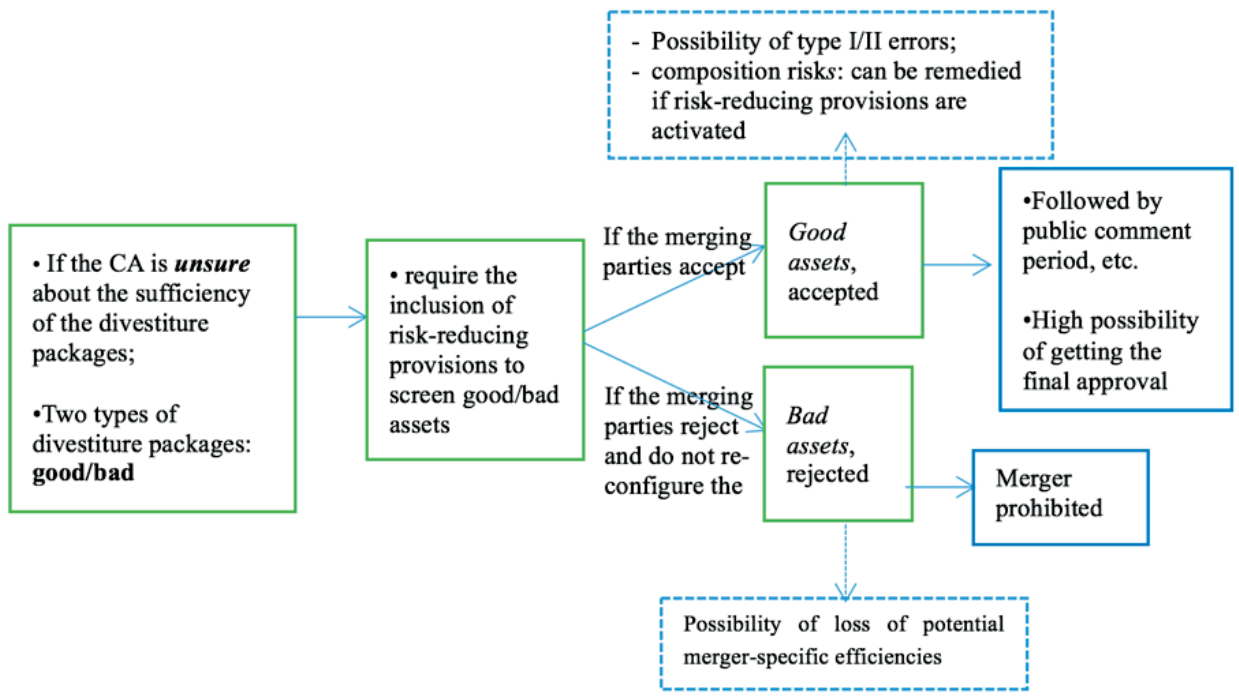

\subsubsection{Summary}

- Pre-condition: the CA feels unsure about the proposed divestiture package

The pre-condition for applying risk-reducing provisions such as screening devices to differentiate between good and bad divestitures packages is that "the CA is unsure about the sufficiency of the proposed divestiture packages." Hence, composition risks can occur when the CA approves an insufficient divestiture package directly without screening by risk-reducing provisions. In this situation, composition risks cannot be reduced ex ante or remedied ex post by risk-reducing provisions because the CA does not even include risk- 
reducing provisions. In addition, it is possible that a sufficient divestiture package is rejected directly, resulting in the prohibition of an efficient or neutral merger.

- Assumption: the merging parties are honest

The analysis of the effectiveness of risk-reducing provisions in reducing composition risks is based on the assumption that the merging parties are honest and do not behave opportunistically. This means that they will balance their benefits of receiving approvals to proceed with their notified merger and the burden of complying with these risk-reducing provisions. It is possible that some of the merging parties (especially those parties who proposed "bad" divestiture packages) are too desperate to obtain approval from the CA, so they accept the risk-reducing provisions which they may be unable to comply with. If so, a type II error can again arise, resulting in composition risks.

- Possibility to reduce composition risks expost

It is possible that even if the CA screens the proposed divestiture packages, composition risks can still occur due to the merging parties' opportunistic behaviour (accept the riskreducing provisions, regardless of their insufficient divestiture package). In this situation, although the risk-reducing provisions fail to differentiate good divested assets from bad divested assets $e x$ ante due to the merging parties' opportunistic behaviour, these provisions can still reduce composition risks ex post once they are activated. For example, a crown jewel provision can remedy the insufficiency of the divestiture package if it is activated.

- The merging parties with "good assets": bear the screening costs

When the CA screens the proposed divestiture packages by using risk-reducing provisions as screening devices, the merging parties with good assets have to bear more burdens due to the asymmetric information. They have to make more efforts than they do in the full information situation to signal themselves to the CA that the divestiture packages they propose are sufficient by accepting the inclusion of risk-reducing provisions directly.

- Possibility of losing efficiencies

There is a risk that the inclusion of risk-reducing provisions increases the possibility of type I errors since risk-reducing provisions increase the burden to the merging parties, whereas the originally proposed divestiture package would be adequate to clear the potential anticompetitive effects. Loss of potential efficiencies can also be caused by the prohibition of an efficient merger and a sufficient divestiture package. However, this is not regarded as a type I error since there is no implementation of divestitures.

\section{Use of Risk-Reducing Provisions in the US and the EU}

Risk-reducing provisions are theoretically able to alleviate composition risks in divestitures effectively, either ex ante or expost. The negative impacts that composition risks will bring to the effectiveness of divestitures have also been recognised by the CAs in the US and the EU. To reduce the composition risks, as well as to increase the requisite degree of certainty, the CAs frequently use various risk-reducing provisions in practice. In this section, analyses of two cases are made, in which risk-reducing provisions are required by the CA.

\subsection{Recognition of Composition Risks}

The existence and potential harm that result from composition risks have been recognised by the CAs in the US and the EU. The 1999 Merger Divestiture Study published by the FTC states that the too limited scope of the divestiture packages is one of the obstacles to 
effective divestitures. ${ }^{942}$ The DOJ has also recognised by stating in the DOJ's 2011 Merger Remedy Policy Guide that the scope of divestitures should have a clear identification of divestiture assets that are enough for the buyer to compete effectively in a timely fashion and over the long-term. ${ }^{943}$ In the EU, the Commission has clearly stated in its $2005 \mathrm{EC}$ Merger Remedies Study that the inadequate scope of the divested business was the most frequent among all design and/or implementation problems. ${ }^{944}$

\subsection{Risk-Reducing Provisions in Law}

Risk-reducing provisions are used by the CAs in both jurisdictions as a tool to reduce composition risks. The merging parties have to make more efforts to accept one or more of these provisions to convince the $\mathrm{CA}$ that the divestiture package they propose is sufficient to clear any potential anti-competitive effect. It is confirmed by the FTC that crown jewel provisions can incentivise the merging parties to initially propose a sufficient divestiture package to the creation of a viable competitor and the availability of a suitable buyer, so that more valuable assets will not be required to be divested in case they fail to complete divesting the original divestiture package within the divestiture period. ${ }^{945} \mathrm{Up}$ front buyer provisions are also required by the FTC to be included in merger divestitures if 'the parties seek to divest assets comprising less than an autonomous, on-going business or if the to-be-divested assets are susceptible to deterioration pending divestiture'. ${ }^{946}$ The pressure for the merging parties to find a qualified purchaser (should be assessed and approved by the $\mathrm{CA}$ ) can incentivise them to propose an adequate divestiture package, suggesting the reduction of composition risks.

With regard to the DOJ, it is currently changing its attitude towards up-front buyers from "no preference" to "may enter into an agreement with the inclusion of up-front buyers" for the reason which is quite similar to the FTC's, namely, an up-front buyer can overall shorten the divestiture period, and provide more certainty about the availability of a buyer. ${ }^{947}$ The DOJ now has a milder and more neutral attitude towards crown jewel provisions than before (It used to strongly dislike such provisions) by stating that crown jewels can 'increase the likelihood that an appropriate purchaser will emerge'. ${ }^{948}$

Similar to the FTC and the DOJ, the reason for the Commission to include up-front buyer provisions is that such provisions can speed up the divestiture process; and reassure the Commission that a potential problematic merger will not be implemented until the competition concerns are solved. ${ }^{949}$ Regarding crown jewel provisions, although it is confirmed by the Commission that they are used to a limited amount, they will be used more frequently. The Commission neither use these provisions as frequently as both the FTC and the DOJ do, nor be as experienced as the FTC and the DOJ are. With experience accumulated, the Commission is becoming more confident in requiring such provisions to solve composition risks.

Since more detailed exploration and practical examples about the use of risk-reducing provisions in the US and the EU have been made in Chapters 2 and 3, they will not be

\footnotetext{
9421999 FTC Divestiture Study (n 38) 16.

9432011 DOJ Policy Guide (n 56) 7.

9442005 EC Merger Remedies Study (n 27).

9451999 FTC Divestiture Study (n38) 30.

9462012 FTC Remedies Statement (n 36) 7.

${ }_{947} 2011$ DOJ Policy Guide (n 56) 23.

948 ibid, 24.

9492005 EC Merger Remedies Study (n 27) 107.
} 
repeated here. Overall, in practice, the CAs in the US and the EU use risk-reducing provisions to solve composition risks, which is in line with observations made above.

\subsection{Risk-Reducing Provisions in Practice: Two Cases}

\subsubsection{US}

As is described above, generally, both the FTC and the DOJ use various risk-reducing provisions quite frequently. It is possible that under certain conditions, two or more riskreducing provisions can be included in one merger divestiture agreement. The FTC has made it clear that the use of an up-front buyer provision does not eliminate the use of a crown jewel provision because occasionally no up-front buyer can be available, considering that ' $\mathrm{T}]$ he original asset package may be unattractive to any other buyer, so there may be a need to alter or expand the original divestiture package'. ${ }^{950}$ In the acquisition of American Home Products Corporation ("AHP") and Solvay, S.A. ("Solvay"), both a crown jewel provision and an up-front buyer provision were included in the divestiture agreement between the notifying parties and the FTC. 951

AHP proposed to acquire Solvay's animal health business. This proposed acquisition was believed to reduce the effective competition in the market for research, development, manufacture and sale of canine lyme vaccine, canine corona virus vaccine, and feline leukemia vaccine. As an additional condition for approving, these three types of Solvay's vaccine were required to be transferred to Schering-Plough or to an acquirer that had to receive the prior approval of the Commission. ${ }^{952}$ The original divestiture agreement between AHP and the acquirer would be terminated if AHP failed to divest three types of vaccine or the acquirer failed all necessary regulatory approvals. In that case, the Solvay Companion Animal Vaccine Assets would be divested, which included more assets and was more valuable than three types of vaccines. ${ }^{953}$

This case shows that more than one risk-reducing provision can be included in one merger agreement. It is evident that mergers such as the one mentioned above can generate efficiencies, such as economies of scale. However, effective competition can also be crippled. Accordingly, it is very important to ensure the effectiveness of divestitures to clear anti-competitive effects. In view of the asymmetric information, the FTC is unsure to some extent whether the divestiture package is sufficient. To screen the insufficient divestiture packages and to increase the degree of certainty, the FTC requires the merging parties to include risk-reducing provisions in the divestiture agreement. The more uncertainties the FTC has regarding the sufficiency of a proposed divestiture package, the more efforts it may require the merging parties to make to signal their proposed divestitures as "good ones".

\subsection{2. $E U$}

Although risk-reducing provisions in the EU were not used as often as in the US, with the publication of the 2011 Merger Remedy Notice, this situation has changed. ${ }^{954}$ The function

\footnotetext{
${ }^{950}$ FTC (n 423).

${ }^{951}$ FTC Dockt. No. C-3740 American Home Products Corporation (FTC Decision and Order) [20 May 1997].

952 ibid, II, 6 .

953 ibid, IV,12.

${ }^{954}$ Composition risks can also occur in the merger divestitures ordered by the National Competition Agencies (NCAs) in the Member States of the EU. The NCAs can also use risk-reducing provisions as screening devices to ensure that only good divestiture packages will be accepted. An example is the UK, see: UK Competition
} 
of risk-reducing provisions is recognised by the Commission, and it is believed that riskreducing provisions can be used more often than before in the future. ${ }^{955}$ Even before the new notice, up-front buyers have already been used by the Commission in divestitures, such as the $B A S F / C I B A$ case. ${ }^{956}$

In the notification made to the Commission, BASF SE ("BASF", Germany) proposed to acquire the control of the whole of CIBA Holding AG ("CIBA", Switzerland). Both companies were specialised in chemicals. The proposed merger raised severe competitive concerns of the Commission since the merging parties' strong position in several chemicals. To clear the Commission's concerns, BASF proposed divestitures with a wide range. In addition, BASF also proposed an up-front buyer to purchase its divested Ciba's entire Chimassorb 119 FL business (included in the wide range divestiture packages). The Commission made an overall assessment of the suitability of the up-front buyer and approved the proposed purchaser, believing it could be a viable buyer. ${ }^{957}$ The proposed merger transaction was thus approved by the Commission.

An up-front buyer can be required for different reasons. It seems that in this case, an up-front buyer was required because the Commission feared that the divested business proposed by BASF might be insufficient to attract a suitable purchaser. In other situations, the identification and suitability of the purchaser can be the key to the effectiveness of the divestitures. Usually, divestitures are extremely important if merger applications are complicated and can cause severe anti-competitive effects. As a result, the CA has to screen the proposed merger divestitures to ensure the effectiveness of the divestitures by requiring the merging parties to make more efforts in increase the certainty or the availability of a suitable purchaser.

\section{Conclusion}

To ensure a successful divestiture, one of the most important questions that need to be answered is: what assets should be divested? The composition of a divestiture package can have a large impact on a divestiture' effectiveness and further influence the realisation of the CA's merger control goals. The possible asymmetric information between the merging parties and the CAs, however, increases the difficulty for the latter to determine the appropriate composition of divestiture packages.

The merging parties are likely to have private information concerning the proposed divestiture packages, such as the key business, the key personnel, and the most important technology. Such information can be invisible to the CA. Thus, the CA can make type I (excessive divestitures) or type II errors (insufficient divestitures). It is also possible that the CA rejects a sufficient divestiture package, resulting in the loss of potential efficiency gains. In particular, type II errors can lead to composition risks, resulting in unavailabilities of suitable buyers or failures of the divested business to be operated successfully by the buyers after the completion of divestitures.

Guidelines (n 39). This Chapter limits its discussion of composition risks and the use of risk-reducing provisions at the EU level.

${ }^{955}$ The reason for this change, see: Chapter 3, sec.6

${ }^{956}$ Case COMP/M.5355 -BASF/ CIBA (European Commission Decision) [12 March 2009] <http://ec.europa.eu/ competition/mergers/cases/decisions/m5355_20090312_20212_en.pdf> accessed 24 April 2017.

957 ibid, para. 258 . 
Sec.4 indicates that decisions made in the context of information asymmetry and no screening devices can be inefficient. Whether it is efficient to use screening devices to move from an asymmetric-information pooling equilibrium to an asymmetric-information separating equilibrium depends on the screening costs involved. It is efficient only if the screening costs do not outweigh the benefits that would be generated by screening. In the US and the EU, the CAs usually use risk-reducing provisions, for example, crown jewel provisions or up-front buyers, to alleviate composition risks. To ensure the efficiency, the CA and the merging parties have to stick to the time limits strictly to avoid a lengthy merger review without excessive costs.

Further, by applying screening theory, it was argued that risk-reducing provisions are theoretically effective to alleviate composition risks ex ante or ex post. The CA can, in general, distinguish between good assets and bad assets by requiring the merging parties to include risk-reducing provisions in the divestiture agreement (if the merging parties do not behave opportunistically). By screening, mergers with good divestiture packages can be accepted and thus the merging parties will have a high possibility of final approval; while mergers with bad divestiture packages can choose to re-arrange the divestiture business, otherwise their mergers will be prohibited directly. Composition risks can, therefore, be avoided ex ante since the bad assets are ruled out in the first place. As is described, it is also possible that a composition risk can be remedied expost by the activation of a risk-reducing provision after the CA makes its decision. Such composition risk can be caused by the merging parties' opportunistic behaviour of accepting risk-reducing provisions, whereas their proposed divestiture package is, in fact, insufficient.

It is worth pointing out that, although risk-reducing provisions can be used as screening devices to reduce composition risks in merger divestitures, they cannot totally avoid composition risks. The CAs will use risk-reducing provisions only when they are unsure about whether the proposed divestiture packages are sufficient to clear the potential anticompetitive effects. In other words, it is possible that the CAs fail to make a correct evaluation concerning the divestiture package due to asymmetric information and approve an insufficient divestiture package without requiring the inclusion of risk-reducing provisions. In this situation, composition risks arise due to the insufficiency and are almost impossible to be remedied. So, it is safe to conclude that risk-reducing provisions can alleviate composition risks, but cannot totally avoid them.

Summing up, composition risks and asset risks (Chapter 7) can be caused by information asymmetry. Accordingly, to reduce these two risks, divestiture policies should be designed so as to provide the uninformed party (the CA) with appropriate devices to obtain information on the one hand; and to induce the informed party (the merging parties) to reveal their private information on the other hand. 



\section{Chapter}

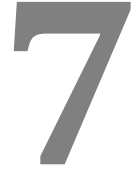

ASSET RISKS: FROM A MORAL HAZARD

PERSPECTIVE 



\section{Introduction}

During the interim period before the completion of a divestiture, the competitiveness, value or marketability of the tangible or intangible to-be-divested assets can be unintentionally or intentionally reduced by the merging parties. Such risks are called asset risks. ${ }^{958}$ On the one hand, the value of the to-be-divested assets can decrease due to the merging parties' negligence in operation. On the other hand, the merging parties may also be incentivised to reduce the value of the divestiture packages to avoid making the purchaser, who can be either an existing market player or a new market entrant, into a strong rival, so that they can enjoy the post-merger concentrated market power. One of the fundamental reasons for the occurrence of asset risks is the asymmetric information between the merging parties and the buyer. To be exact, on the one hand, it can be difficult for the buyer to observe how much effort or what actions the merging parties spend to preserve the viability and marketability of the divestiture packages during the interim period; on the other hand, what actions the merging parties take will affect the benefits of the buyer. The informed party's risk of behaving undesirably in such a situation is called moral hazard.

As described in Chapter 6, hidden characteristics and hidden actions are the two types of asymmetric information that one party of an economic relationship can have while the other party wishes to observe but actually does not. ${ }^{959}$ Such unrevealed information can affect the decision-making process on both sides' payoffs. Moral hazard may occur when the informed party of an economic relationship takes actions which may increase the risks of loss that are borne by the other. ${ }^{960}$ It is common in many situations, such as in the insurance market. The insured has fewer incentives to prevent his assets from loss (ex ante moral hazard) or he is likely to reduce his incentives to minimise the loss after an accident happened (ex post moral hazard); while in either situations, the insurance company has to bear the loss. ${ }^{961}$ In labour contracts, employees can slack off during working time, e.g. by chatting with each other or by having frequent coffee breaks, resulting in lower profits for employers. Or in a decision-making relationship, managers would not always make decisions in favour of the shareholders, whereas the decisions can have a large impact on the payoffs of managers as well as the utility of the shareholders. Accordingly, in an agentprincipal relationship, moral hazard may arise when the following conditions are satisfied: a. the agent takes an action that can affect both his payoffs and the principal's; $b$. the principal can only observe that the outcome and information concerning the activity which the agent takes is asymmetric; and $c$. the agent is likely to take undesirable actions.

Moral hazard is different from the hidden characteristic model (adverse selection), which has been discussed in Chapter 6 since, first, they occur at different phases of agreements. An adverse selection problem happens before any agreement is reached. Moral hazard occurs after an agreement has been reached. Second, solutions can be found in different strategies. To alleviate problems caused by hidden characteristics, a mechanism has to be designed to help to transfer information from one party to another. ${ }^{962}$ Signalling

\footnotetext{
958 UK Competition Guidelines (n 39) sec.3.3.

${ }^{959}$ Katz and Rosen (n 891) 554.

960 See: Bengt Holmstrom, 'Moral Hazard and Observability' (1979) 10(1) Bell J Econ 74.

${ }^{961}$ Economists make an important distinction between ex ante moral hazard and ex post moral hazard. The former is closely related to and is originated from the fire insurance temptation problem of arson or carelessness; the latter is relevant to the disability insurance temptation problem of malingering. See: George L. Priest, "The Current Insurance Crisis and Modern Tort Law' (1987) 96(7) Yale L J 1521, 1547.

962 Katz and Rosen (n 891) 577.
} 
and screening are usually employed by the informed party and the uninformed party respectively to reveal their private information. A lemon market can be largely avoided when the informed party such as a producer signals his high-quality products by providing, e.g. a product warranty; or the uninformed party, like an employer, screens the job applicants by requiring a certain education level. In contrast, problems caused by moral hazard can be solved if the informed party can be induced to behave desirably. In a principal-agent relationship, moral hazard can be alleviated if, a. the agent is constrained from certain inappropriate behaviour; or, b. the principal is empowered to control their agents' behaviour. ${ }^{963}$

During the interim period, the merging parties may intentionally reduce their efforts to keep the divestiture assets viable and competitive. For example, they may stop investing or reduce the investment in the to-be-divested business; transfer key personnel to the retained departments; or stop providing proper customer services. Such shirking behaviour can lead to a reduction of competitiveness and viability of the to-be-divested assets, ultimately resulting in potential losses to the purchaser after the completion of divestitures. If the purchaser can observe the merging parties' actions, he will restrain the merging parties from slacking off in operating the pending business by expressly writing down in the divestiture agreement that any dysfunctional behaviour will be penalised. However, such full observation is almost impossible because first, full observation can involve enormous financial, manpower and material resources, which can be rather costly; second, the result of the merging parties' shirking behaviour may be observed only after the completion of divestitures. Accordingly, considering the above-mentioned factors, other solutions have to be used to encourage the merging parties' desirable manners.

In practice, the FTC and the Antitrust Division of the DOJ and the European Commission generally require the inclusion of hold-separate provisions or asset-preserving provisions and a trustee in consent decrees (in the situation of the DOJ), consent orders (in the situation of the FTC) or the Commission's decisions. The hold-separate provisions or the asset-preserving provisions are collectively called $H S P(s)$, which can, together with the appointment of trustees, incentivise the merging parties to raise their efforts in preserving the viability of the divestiture packages. Basically, the FTC, the DOJ and the Commission share a very similar understanding towards the use of these provisions. Hold-separate provisions are designed to maintain the independence and viability of the divested assets and to effectively preserve competition in the market during the pendency of the divestitures. ${ }^{964}$ When a hold-separate provision is absent, assets-preserving provisions can be ordered (refer to the requirement of maintaining the assets of the pending divestiture). ${ }^{965}$ Such provisions will be required by the staff of the CA if there is concern about the interim competitive harm or deterioration of competitiveness of the divested assets during the interim period. ${ }^{966}$ Generally, a trustee can also be appointed to act as the "ear and eye" of the CA to, for example, monitor the parties' compliance with their obligations. ${ }^{967}$ The parties will be fined if they fail to comply with their obligations. Accordingly, it is assumed that by being required to hold separately the to-be-divested assets or by being monitored by a trustee during the interim period, the merging parties can raise their incentives to spend

\footnotetext{
963 Reinier Kraakman and others, The Anatomy of Corporate Law-A Comparative and Functional Approach (2 edn, Oxford University Press 2009) 38.

9642011 DOJ Policy Guide (n 56) 25.

9652012 FTC Remedies Statement (n 36) 17.

966 ibid, 17.

${ }^{967}$ There are different trustees, such as divestiture trustees or monitoring trustees. They are assigned with different tasks. For a detailed exploration, see: Chapter 2 and Chapter 3.
} 
enough effort on preserving the marketability of the to-be-divested assets. In this chapter, the effectiveness of adopting HSPs and trustees to assuage moral hazard is analysed from a moral hazard perspective. The remainder of this chapter is structured as follows.

After introducing the concepts of asset risks and moral hazard in the context of merger divestitures, sec. 2 reviews the relevant literature on moral hazard as well as applications of moral hazard theory in different legal fields. An analysis of asset risks in merger divestitures from a moral hazard perspective is made in sec.3. There are three sub-sections in sec.3: first, a more generalised concept of moral hazard and its meaning in the context of divestitures are presented; second, an economic analysis of moral hazard in merger divestiture is provided; third, possible solutions to alleviate asset risks by solving moral hazard are discussed. Sec.4 explores the effectiveness of the US and EU's approach of reducing asset risks through HSPs and trustees. Sec. 5 draws a conclusion.

\section{Literature Review}

As is pointed out by Dembe and Boden, moral hazard, as a concept having its origins from the insurance trade, has been used in various ways by different disciplines for more than 200 years. ${ }^{968}$ During the development of moral hazard theory, Arrow and Pauly are the two prominent economists that deserve special mention for their contribution to the economic analysis of decision-making process under uncertainties by applying moral hazard theory.

Arrow published an article in 1963, which considered health insurance in the incomplete markets. ${ }^{969}$ He supported government intervention in health insurance by stating that 'the welfare case for insurance of all sorts is overwhelming. It followed that the government should undertake insurance where the market, for whatever reason, has failed to emerge'. ${ }^{970}$ In the article, Arrow defined moral hazard as "the effect of insurance on incentives" 971 and predicted that the insured would increase their demand for medical care services, and prices for those services would thus rise. The author concluded that such moral hazard could be solved by doctors, considering the fact that although the insured can have wrong incentives to demand more medical care, the doctors could decide whether such medical treatment would be necessary. This conclusion was based on trust in the professional ethics and implied that breach of ethics was immoral. Accordingly, Arrow further suggested that the solutions to solve moral hazard could be laying more emphasis on health professional licensing, so that professional ethics can be better monitored.

As a comment on Arrow's conclusions and observations, Pauly (1968) challenged Arrow's support for government intervention in health insurance market by stating that the failure of emergence of certain insurance in the private market may be irrelevant to nonoptimality, and compulsory government intervention may result in inefficiency. ${ }^{972}$ Considering Arrow's implication that moral hazard in insurance can be a problem of

\footnotetext{
968 Allard E. Dembe and Leslie I. Boden, 'Moral Hazard: A Question of Morality?' (2000) 10(3) New Solut 257, 258. For a comprehensive review of the genealogy of moral hazard, see: Tom Baker, 'On the Genealogy of MoralHazard' (1996) 75(2) Tex Law Rev 237.

${ }^{969}$ Kenneth J. Arrow, 'Uncertainty and the Welfare Economics of Medical Care' (1968) 53(5) Am Econ Rev 941 , 941.

970 ibid, $945,961$.

971 ibid, 961.

${ }^{972}$ Mark V. Pauly, 'The Economics of Moral Hazard: Comment' (1968) 58(3, Part 1) Am Econ Rev 531, 531.
} 
immorality, Pauly indicated that moral hazard has little to do with morality and can be a rational economic behaviour. ${ }^{973}$

Pauly's observation that moral hazard is irrelevant to morality later became the conventional wisdom ${ }^{974}$ and it is generally believed that it is rational for the informed party to hide his actions and have the incentives to increase risks. ${ }^{975}$ More recently, risk-sharing, adverse selection and moral hazard have become the subjects of various studies, in which optimal contracts and market equilibrium are analysed and designed under incomplete information. ${ }^{976}$

Questions of when can imperfect information be used to improve a contract and how should additional information concerning the informed party's actions be used optimally are explored in the context of a principal-agent relationship. ${ }^{977}$ Harris and Raviv (1987) addressed these questions in a situation where the agent' actions (effort level) are unobservable to the principal. ${ }^{978}$ They developed a theory of contracts in which information is asymmetric between parties of the contract, and explore how additional information would affect the structure of contracts. The article studied the value of monitors who can provide information that allows the principal to observe any shirking behaviour conducted by the agent. Nevertheless, such monitoring is of limited interest since 'it is essentially equivalent to observing the agent's action directly' and 'one cannot expect imperfect monitoring to possess such strong characteristics in general'. ${ }^{979}$

Holmstrom (1979) explored the question of whether information from monitoring was valuable when the effort level was unobservable in the context of a principal-agent relationship. He began his exploration by first identifying that the first-best solution to the moral hazard problem is to invest resources into monitoring the actions (effort level) the agent takes and make use of such information when designing a contract. Accordingly, risks can be shared optimally between the principal and the agent by writing down detailed terms of penalising any dysfunctional behaviour. ${ }^{980}$ Perfect monitoring sometimes is impossible or rather costly. Accordingly, the second-best solution would be to use imperfect estimators of actions in a contract. Therefore, key questions would be: when can imperfect information of actions improve a contract and how can such information be used optimally? The author argued that optimal contracts will be second-best owing to the moral hazard problem, when only the payoff is observable. ${ }^{981}$ Any imperfect information of hidden actions or the state of nature can be used to improve contracts. ${ }^{982}$ In other words, monitoring is always of value.

Shavell (1979) studied the question of how to design a contract that can result in a Pareto-optimal outcome. He explored this question by arranging different payment schedules in two situations: when the principal has knowledge only about the outcome of

\footnotetext{
973 ibid, 531.

${ }^{974}$ Baker (n 968) 269.

${ }^{975}$ Sheila C Dow, 'Economics and Moral Sentiments: The Case of Moral Hazard' (CES Workshop on 'Facts, Values and Objectivity, Coimbra, March 2010) 3.

${ }^{976}$ David P. Baron and David Besanko, 'Monitoring, Moral Hazard, Asymmetric Information, and Risk Sharing in Procurement Contracting' (1987) 18(4) Rand J Econ 509, 510.

${ }^{977}$ For example, Robert Wilson, 'The Theory of Syndicates' (1968) 36(1) Econometrica 119; Michael Spence and Richard Zeckhauser, 'Insurance, Information, and Individual Action' (1974) 61(2) Am Econ Rev 296; Milton Harris and Artur Raviv, 'Optimal Incentive Contracts with Imperfect Information' (1979) 20(2) J Econ Theory 231.

978 See: Harris and Raviv, ibid.

${ }^{979}$ Holmstrom (n 960) 75.

980 ibid, 74.

981 ibid, 89

982 ibid, 89 .
} 
the agent's activity, and when he also has (maybe imperfect) information about the agent's effort level. ${ }^{983}$ Shavell proved that in the first situation where only the outcome of the agent's activity is observable to the principal, then (i) if the agent is risk-neutral, there will be Pareto optimality if the payoffs are based on the outcome alone; (ii) if the agent is riskaverse, then the payoff should partially depend on the outcome, meanwhile never leave the agent to bear all the risks. ${ }^{984}$

In the second situation where both the effort level and the outcome of the agent's activity are observable to the principal, then (iii) if the agent is risk-neutral, there will be no changes in his payoffs compared with that in (i); (iv) if the agent is risk-averse, then there is a real question of whether the information of monitoring is valuable. Whether risks can be shared optimally between the principal and the agent in this situation has a lot to do with the accuracy of information obtained from monitoring. If the information concerning effort level is accurate, the payment schedule can be arranged as follows: the agent gets his payoffs consisting of two parts: a very low fixed fee plus a floating fee based on his effort level (how much he can earn additionally). If such information is inaccurate, using such information means the creation of another risk because the payment schedule can fail to reflect the agent's true effort level, resulting in either exposing the agent to too many risks, or providing too few incentives for the agent to make the right effort.

As described above, this is the question that is explored by Harris and Raviv. ${ }^{985}$ Shavell proved that in situation (iv), how much the agent should be paid depends, to some extent, on his effort level. In other words, information from monitoring is always useful, which has also been proven by Holmstrom. ${ }^{986}$ It is worth pointing out that the value of information of monitoring declines to zero in a situation of (ii) and (iv) when the efficiency of effort becomes small or grows large.

To my knowledge, there is no literature concerning the application of moral hazard theory in the merger divestiture field. In this chapter, an economic analysis is applied to explore the effectiveness of applying HSPs and trustees to reduce assets risks in merger divestitures which can cause the moral hazard problem.

\section{Assets Risks of Merger Divestitures: Moral Hazard Perspective}

\subsection{Moral Hazard in Merger Divestitures}

In the 1960 s, the mainstream literature began to focus on the decision-making process under uncertainty given moral hazard. ${ }^{987}$ During the exchange between Arrow and Pauly, Pauly specified that the analysis of moral hazard is applicable not only to fire insurance, but also to other types of insurance, such as automobile collusion insurance, or marine insurance. ${ }^{988}$ The range of application of moral hazard has again been enlarged by Stiglitz by stating that ' $[\mathrm{A}] \mathrm{lmost}$ all economic relations are affected by risk, and by the problems of

\footnotetext{
983 See: Steven Shavell, 'Risk Sharing and Incentives in the Principal and Agent Relationship' (1979) 10(1) Bell J Econ 55.

984 ibid, 56

985 See: Harris and Raviv (n 977).

986 See: Holmstrom (n 960).

987 Dow (n 975) 3.

988 Pauly (n 972) 531.
} 
insurance and incentives to which this gives rise'. ${ }^{989}$ Moral hazard in the insurance market can be defined as a risk that the insured has fewer incentives to limit his exposure to risky activities or spend less efforts to minimise the loss once an accident has happened, given that the resulting loss would be borne by the insurance company. ${ }^{990}$ This can give rise to difficulties for the insurance company to set the right premium and indemnity and can finally lead to a market failure. ${ }^{991}$

The enlarged application of moral hazard to some extent results from the generalised understanding of "insurance", which originally refers to insurance provided by an insurance company. In fact, it is easy to understand that moral hazard can arise in any economic relationship if an "agreement" has been reached between the informed party and the uninformed party, while the former's activity is unobservable to the latter. In other words, such an agreement to some degree serves the same function as "insurance". Holmstrom has nicely formulated this: '[A] problem of moral hazard may arise when individuals engage in risk sharing under conditions such that their privately taken actions affect the probability distribution of the outcome. ${ }^{992}$

It can be generally concluded that a moral hazard problem is characterised as: (i) hidden actions taken by the informed party, while such actions are unobservable to the other party; and (ii) losses caused by such actions should be partially or totally borne by the uninformed party. As mentioned above, in a principal-agent relationship, moral hazard can be alleviated either by constraining the agent from behaving inappropriately or by facilitating the principal to control his agent's behaviours.

In the context of merger divestitures, it is evident that the merging parties are likely to have private information concerning the propsed divestiture package. Furthermore, the actions taken by the informed merging parties can be unobservable to the uninformed (proposed) buyer, while the latter has to bear the losses caused by the merging parties' hidden actions. Accordingly, moral hazard can arise, which can be defined as follows (in the context of merger divestitures): the merging parties are likely to or have the incentives to reduce the competitiveness of the to-be-divested business during the interim period before the completion of a divestiture, so that the purchaser will not become their strong rival by purchasing the business. The (proposed) purchaser has to incur the potential losses resulting from a failed merger divestiture caused by the merging parties' shirking behaviour in keeping the pending business viable and competitive during the interim period. The following Figure 16 presents the situation graphically.

Figure 16 describes two situations where moral hazard can occur: it can occur when the merging parties are allowed by the CAs to proceed with the notified merger before entering into a divestiture agreement with a buyer (interim period-A), or; when a divestiture agreement is reached between the merging parties and the buyer before an approval for the notified merger is granted by the CA (interim period-B), such as in the situation where a fix-it-first remedy is proposed by the merging parities, suggesting that the merging parties have entered into a divestiture agreement with the buyer when they notify the merger to the CA and before they get approval from the CA.

\footnotetext{
${ }^{989}$ Joseph E. Stiglitz, 'Risk, Incentives and Insurance: The Pure Theory of Moral Hazard' (1983) 8(26) Geneva Pap Risk Ins 4, 8.

${ }_{990}$ Robert H. Frank, Microeconomics and Behaviour (McGraw-Hill 1991) 193.

${ }^{991}$ Kangoh Lee, 'Moral Hazard, Insurance and Public Loss Prevention' (1992) 59(2) J Risk Insur 275, 275.

${ }^{992}$ Holmstrom (n 960) 74.
} 
Figure 16 Moral Hazard in Merger Divestitures

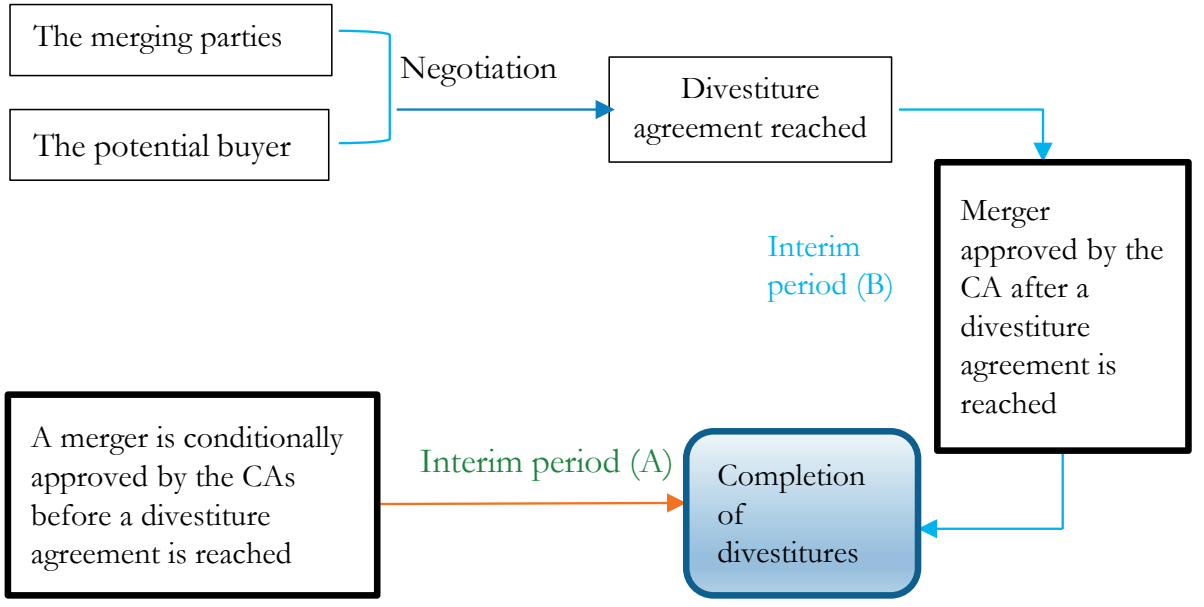

Whether a divestiture can be successful largely depends on the "quality" of the divested business, that is, viability, competitiveness, and marketability. As mentioned in the Introduction section of this chapter, asset risks can occur due to the merging parties' intentional or unintentional (negligence) undesirable behaviour. When exploring the solutions to alleviate asset risks in merger divestitures, it is not necessary to make a distinction between "intent" and "negligence" because either of them will result in the deterioration of value of the divested business.

\subsection{Economics of Moral Hazard in Merger Divestitures}

The relationship between the merging parties and the buyer can be regarded as a principalagent relationship. As the agent, the merging parties have private information concerning the efforts that they spend in order to preserve the value of the divestiture packages. Before the completion of divestitures, the merging parties operate the to-be-divested assets on behalf of the buyer to preserve the viability and competitiveness of these assets before the completion of divestitures. Moral hazard can occur since the merging parties' actions are likely to be unobservable to the buyer, which provides the merging parties with the incentives to reduce the value of the pending assets.

In a merger divestiture, the utility of the merging parties depends on (at least) two factors: the payment they can get from the buyer for purchasing the divestiture packages and the slackness they can have. The higher the payment is, the more benefits they will get; the more slackness they can have, the more benefits they can obtain. Slackness here refers to the merging parties' undesirable actions and failures to keeping the divestiture packages competitive and viable. For example, the merging parties no longer keep investing in the to-be-divested business, or they may transfer the key personnel to other departments which will not be divested. If they reduce the investment in the divested assets, they can make other use of the capital which can bring them benefits.

The utility of the buyer in a merger divestiture is also related to (at least) two factors: the price it pays to the merging parties for the divestiture package and the competitiveness of its purchased assets which may largely determine the buyer's potential post-divestment 
profits. The lower the payment, the more benefits it will gain; the more competitive and viable the divested business is, the higher possibility that the buyer can compete with the merged firm and thus make profits. The marketability and viability of the divested assets, however, is determined by the merging parties during the interim period.

Evidently, both the merging parties and the buyer want to maximise their utility. Negotiations can be made between two parties concerning the price of the divestiture package, to make the price acceptable to both parties. However, it is impossible for the parties to negotiate 'how many efforts the merging parties should put to keep the value of the divestiture packages'. This is because the merging parties have the tendency to slack off, whereas the purchaser will require the merging parties to spend high efforts. Whether the buyer can make profits by operating the purchased assets vigorously largely depends on whether the merging parties spend enough effort in keeping the competitiveness of the divested assets during the interim period. Meanwhile, the merging parties' undesirable manners can be unobservable to the buyer. Accordingly, to alleviate asset risks, the key point is to induce the merging parties to behave desirably by constraining them from certain inappropriate behaviour or by enabling the buyer to control the merging parties' behaviour.

\section{Observable actions}

As mentioned, the merging parties can have the incentives to shirk their responsibility of preserving the viability and competitiveness of the to-be-divested business to increase their benefits. However, such undesirable behaviours can be observed by the purchaser if there is no asymmetric information between the merging parties and the buyer. The buyer thus will prevent the merging parties from slacking off by writing down detailed terms in the divestiture agreement that any inappropriate actions will be penalised, as implied by Holmstrom. ${ }^{993}$ It is also possible that the merging parties may fail to find a suitable buyer if the value of the to-be-divested assets is severely reduced, or the buyer will lower his acceptable price for the divestiture package. In neither of these situations can the merging parties increase their benefits by slacking off. Put differently, the merging parties are unlikely to slack off when they have to bear the risks and losses caused by their own undesirable behaviour.

\section{Unobservable actions}

In contrast to the situation of "observable actions" mentioned above, once there is information asymmetry between the merging parties and the buyer, resulting in the merging parties' actions being invisible to the buyer, it is reasonable to predict that the merging parties can take undesirable actions to maximise their utility.

Accordingly, the key idea to solve the moral hazard problem is to incentivise the merging parties to take desirable actions by constraining them from taking opportunistic actions or by empowering the buyer to control the merging parties' behaviour. For example, such an incentive mechanism can be a contract or a policy. ${ }^{994}$ Generally, there are two legal strategies, namely, regulatory strategies (also called the agent-constraining strategy) and governance strategies (also called the principal-empowering strategy), which are studied in the following section.

\footnotetext{
${ }^{993}$ Holmstrom (n 960) 74.

${ }_{994}$ Bernheim and Whinston (n 938)21-33.
} 


\subsection{Possible Solutions (Legal Strategies) ${ }^{995}$}

When the moral hazard problem occurs, naturally, the most direct solution can be to reveal the informed party's unobservable actions because moral hazard is exactly caused by the informed party's hidden actions. One of the natural solutions is to reveal such hidden actions and to write down explicitly in the contract that any dysfunctional behaviour will be penalised. ${ }^{996}$ Nevertheless, full observation concerning the hidden actions can be rather costly. Other possible solutions (legal strategies) are explored in this section.

There are two subsets of legal strategies that can be used to alleviate moral hazard in a principal-agent context, namely, regulatory strategies and governance strategies. ${ }^{997}$ The former refers to strategies that regulate substantive norms and behavioural guidelines for the agents. The agents have to comply with these specifically-formulated norms, so that their undesirable behaviour can be constrained. Hence, regulatory strategies are also called "agent-constraining" strategies. ${ }^{998}$ Governance strategies, in contrast, refer to strategies that enable the principals to control the agents' behaviour. Hence, these strategies can be called "principal-empowering" strategies. ${ }^{999}$ According to Kraakman and others, strategies for protecting principals can be summarised as follows:

Figure 17 Legal Strategies for Protecting Principals 1000

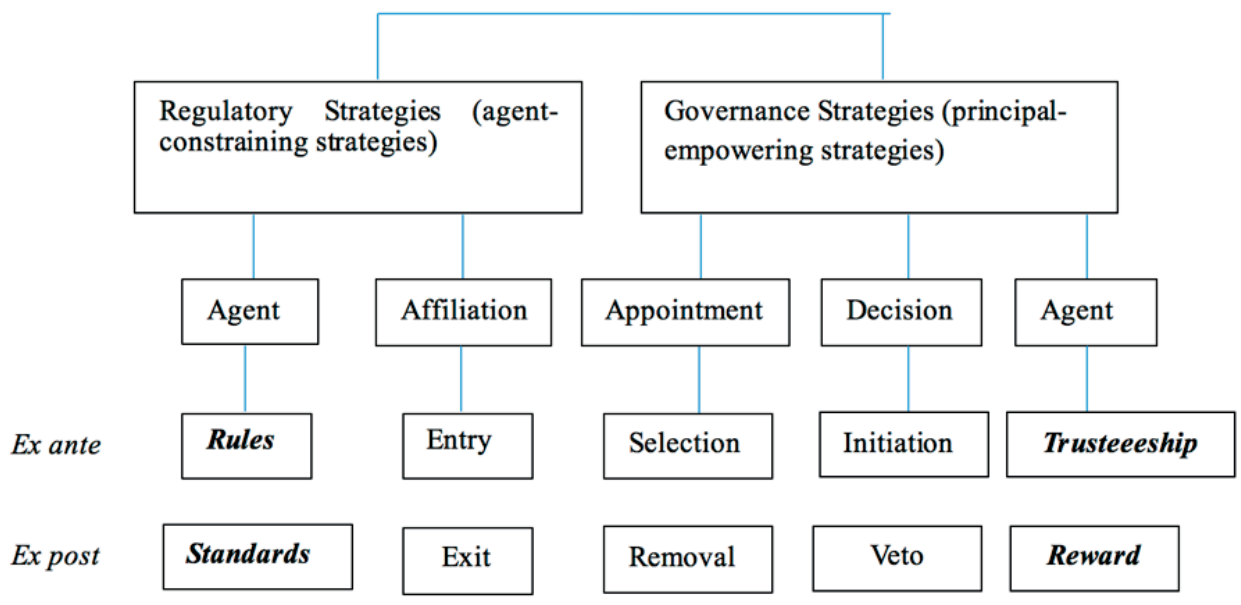

Considering the special context of merger divestitures, in this section, strategies such as rules and standards and trusteeship and reward are explored to evaluate whether they are effective in reducing moral hazard in the context of merger divestitures.

\footnotetext{
${ }^{995}$ Legal strategies refer to strategies that employ various substantive laws to reduce the principal's weak position in the principal-agent relationships. See: Kraakman and others (n 963) 37. It is also possible that other solutions, such as increasing the agent's moral sensitivity, can also be used to alleviate the moral hazard problem. For example, see: Douglas E. Stevens and Alex Thevaranjan, 'A Moral Solution to the Moral Hazard Problem' (SSRN, 22 May 2008) < http://dx.doi.org/10.2139/ssrn.1138279> accessed 25 April 2017.

996 Holmstrom (n 960) 74.

${ }_{997}$ Kraakman and others (n 963) 38.

998 ibid.

999 ibid.

1000 This table is adapted from Kraakman and others (n 963) 39.
} 
It is noteworthy that, given the special context of merger divestitures, although the moral hazard problem is studied between the merging parties and the buyer in a principalagent relation, the CA, as the third party, can still use strategies to reduce the possibility of the merging parties' moral hazard so that the merging parties can be incentivised to raise their efforts in keeping the competitiveness of the divested business. This is because, first, the CA is the public authority which is assigned the authority to control mergers. As the gate-keeper of the market, it has the responsibility to prohibit any merger that can cripple effective competition. It should also allow a merger to proceed if it is beneficial or at least neutral, after being rendered by merger remedies. Second, as mentioned in Figure 16, moral hazard can also occur during the interim period A, when the proposed merger and divestiture plan have been approved by the CA before any formal divestiture agreement has been reached between the merging parties and the buyer. In this situation, the CA should take the responsibility to induce the merging parties' desirable conduct to operate the divestiture business appropriately. Last but not least, it is generally believed that the buyer shares the same goal as the CA in terms of that both of them want a successful divestiture. ${ }^{1001}$ For the buyer, a successful divestiture means viable divested assets, as well as future profits. For the CA, it means the restoration of effective competition to, more or less, the pre-merger level, and the elimination of the merged party's market dominance. Therefore, the strategies used by the CA are also beneficial to the buyer.

\subsubsection{Agent-Constraining Strategies: Rules and Standards}

As the name suggests, the aim of an agent-constraining strategy is to constrain the agent's opportunistic behaviour. One of the most widely used set of agent-constraining strategies include: rules and standards. ${ }^{1002}$ The former means that specific constraints are formulated by the lawmakers to require or prohibit certain agents' behaviour. The agents have to comply with these rules when they perform their tasks. The latter refers to a situation where only general requirements or criteria are formulated, while the adjudicators are assigned to determine whether such requirements or standards are satisfied by the agents after they act. One of the main differences between rules and standards is that rules regulate the agents' behaviour ex ante, whereas standards are used as general criteria by the adjudicators to determine the agents' compliance expost. ${ }^{1003}$

When applying agent-constraining strategies in the context of merger divestitures to reduce asset risks caused by the merging parties' moral hazard, there is one question that needs to be answered in the first place, that is: should we choose rules, standards, or both? To answer this question, the irreversibility of divestitures has to be taken in account firstly.

Rules

Divestitures are regarded as a straightforward merger remedy since there is no need for long-term monitoring after the completion. However, just as the saying goes, every sword

\footnotetext{
${ }^{1001}$ As pointed out in Chapter 5, there is a risk that the buyer can collude with the merged party rather than competing with it after the completion of divestitures. Such risks have to be avoided when designing and implementing divestitures to assure an effective divestiture. These risks will be studied in Chapter 8 as "collusion risks" in detail. Accordingly, when exploring why the CA, as third party, can use strategies to reduce moral hazard, it is based on the assumption that the buyer shares the same goals as the CAs.

1002 Kraakman and others (n 963) 39.

1003 There is a lot of literature concerning the differences between rules and standards, see: (for example) Francesco Parisi, 'Rules Versus Standards' in Charles K Rowley and Friedrich Schneider (eds), The Encyclopedia of Public Choice (Springer 2004); Louis Kaplow, 'Rules Versus Standards: An Economic Analysis' (1992) 42(3) Duke L J 557; Pierre J. Schlag, 'Rules and Standards' (1985) 33 UCLA L Rev 379.
} 
has two sides. Divestitures can also be "harsh" due to their irreversibility. Once a divestiture is completed, it is almost impossible to be restored to the original situation (or that would involve large transaction costs). Accordingly, a successful divestiture requires a careful design and implementation. For example, the CA has to ensure that the composition of the divestiture package is appropriately configured, a suitable buyer is available and selected, and the value of the pending assets during the interim period is preserved. Any defect in the above-mentioned factors can lead to a failed divestiture. Considering the irreversibility of merger divestitures, specific and well-defined ex ante rules can be effective in restraining the merging parties from shirking from operating the pending business, so that moral hazard can be alleviated.

During interim period $\mathrm{A}$, the authority can require the merging parties to observe certain rules by requiring the inclusion of specific provisions in its final approval decisions. During interim period $\mathrm{B}$, when the authority requires the merging parties to comply with certain "rules", these rules are included in the authority's final decision. Since a divestiture agreement is reached between the merging parties and the buyer, to ensure that the merging parties comply with these rules until the end of agreement, the "rules" can also be added in the divestiture agreement.

\section{Standards}

Standards can be effective from the perspective that, first, standards provide the CAs with criteria for expost evaluating and determining whether such standards are satisfied by the merging parties. If not, the CA can make new decisions to urge the merging parties to preserve the value of the pending business. Second, evaluation ex post concerning the merging parties' compliance with their obligations can also to some extent have deterrence impacts on the merging parties, which incentivise them to fulfil their tasks and obligations. Accordingly, standards can, more or less, reduce moral hazard in the context of merger divestitures.

However, the effectiveness of standards might be limited in the sense that even if the CA scan prove that the merging parties fail to satisfy the standards and further revise its decisions to induce the merging parties' desirable behaviour, the restoration of the lost value caused by the merging parties' slackness remains uncertain.

When applying agent-constraining strategies to reduce moral hazard in merger divestitures, specific rules and general standards can be formulated by the lawmakers to, on the one hand, ex ante require the merging parties to take necessary actions to preserve the marketability and viability of the pending business during the interim period and prohibit the merging parties from any opportunistic behaviour that can damage the value of the pending business; on the other hand, assess the merging parties' compliance with their obligations expost.

\subsubsection{Principal-Empowering Strategies: Reward and Trusteeship}

In contrast to agent-constraining strategies which focus on constraining the agent's behaviour, a principal-empowering strategy facilitates the principal to control his agent's behaviour, so that the agent can be induced to desirable manners. One of the sets of principal-empowering strategies is the reward strategy and the trusteeship strategy. ${ }^{1004}$

${ }^{1004}$ Kraakman and others (n 963) 42. 


\subsubsection{The Reward Strategy}

The reward strategy means that the agents will be rewarded if they successfully advance the interests of their principals. ${ }^{1005}$ In more generalised words, the agent will be rewarded additionally if he performs his tasks well by maximising his principal's interests rather than advancing his own interests. The reward can be granted to the agent based on the results of his performance. The definition of the reward strategy further suggests that such strategy can also be used to induce the agent's desirable behaviour expost, meaning the principal can control his agent's behaviour after the agent acts. The reward strategy is one of the most widely used strategies in employment contracts.

For example, employees are usually provided with a performance-based salary plan, which means that the agent (employee) will be paid for successfully advancing the principal (employer)'s interest. ${ }^{1006}$ The rationale behind such a plan has been explored and explained in Shavell's 1979 article. ${ }^{1007}$ According to this article, there are two factors that can determine the employee's payoff: the observable outcome of his activity and his effort level when carrying out his activity. It is identified that for a risk-neutral employee, no matter whether his effort level can be observed by the employer, he receives his payoffs that are equal to the outcomes alone minus a constant (such as costs involved in performing certain tasks) shared by the employer. If an employee is risk-averse, his salary should only partially depend on the outcomes, and should also reflect his effort level. It is pointed out by Shavell that information concerning his effort level, even imperfect, is always of value to improve a contract. Accordingly, a performance based salary plan is such a plan that is partially based on the outcome an employee achieves, meanwhile making use of the imperfect information to reflect the employee' effort level.

In practice, a performance-based salary consists of two parts: a fixed part, which means that the employee can get a certain amount of reward even if he shirks during all the working hours; and a floating part, referring to the extra payment that is determined by the employee's working performance, such as the car salesman can get $2 \%$ of the selling price for every additional cars he sells. The fixed part of the salary has to satisfy the employees' lowest salary anticipation, otherwise they may quit. The float part of the salary aims at reflecting the employees' effort level. By conferring on them extra payoffs, it is expected that employees can be incentivised to make more efforts while working. Put differently, by arranging the salary schedule like this, the employees can be incentivised to work harder to earn extra income besides the fixed salary. This is based on the assumption that the harder the salesman works, the more cars he can sell, resulting in more payoffs. By offering a performance-based salary plan, the principal can "control" his agent's behaviour by incentivising them to work hard.

Whether such a plan can lead to an efficient result, however, largely depends on the arrangement of the salary plan: what is the proportion that the fixed part and the floating part account for, respectively. In the case of a salary plan consisting of a high-percentage fixed part and a low-percentage floating part, a risk-averse employee may have less incentive to work hard because he already earns a high salary (even if he slacks off frequently during working time). For a risk-taker, he can be deterred from working hard because he can still get limited extra income due to the low-percentage floating part. Furthermore, if a salary plan is arranged as: a low-percentage fixed part and a high-

\footnotetext{
1005 ibid.

100643.

1007 See: Shavell (n 983).
} 
percentage floating part, a risk-averse employee may quit the job since such a plan exposes him to a great risk of earning little money, given his effort level.

In the context of merger divestitures, on the one hand, when the price regarding the divestiture package is determined, the merging parties are likely to have slackness, leaving all the risks and costs of "failing to operate the divested business vigorously" to the buyer. On the other hand, Farrell indicated that when the divestiture price is fixed and does not vary with what the buyer gets, the buyer can have incentives to get as profitable a business as possible. ${ }^{1008}$ The difficulty here is that the buyer does not exactly know what to ask for due to the information asymmetry. Hence, although the fixed price to some extent may incentivise the buyer to ask the merging parties to keep the divested business as profitable as possible; it can still be hard for the buyer to incentivise the merging parties to do so.

Accordingly, the reward strategy, as a solution to solve the moral hazard problem in merger divestitures in order to ultimately reduce asset risks, can be applied as follows: make the final price that is paid by the buyer to the merging parties variable, which provides the merging parties with the opportunity to be "rewarded" if they behave desirably. In other words, the merging parties are provided with monetary incentives to increase their efforts in preserving the divested business viable and competitive. Thereby, the buyer can "control" the merging parties by inducing their desirable manners.

Suppose that the price the buyer pays to the merging parties is composed of two parts: a fixed part plus a floating part. The floating part can be determined by the changes of market shares of the divested business during the interim period. Such changes can be evaluated after the completion of divestitures. Market shares are used as an indirect estimator to reflect whether the divested business is operated competitively. For example, additional $€ A$ will be rewarded to the merging parties if the market shares increase $\mathrm{B} \%$ (or at least do not decrease). With such a payment schedule, on the one hand, the merging parties find it possible to gain an additional floating payment if they spend high efforts in operating the divested business, leading to an increase of the divested business's market shares. On the other hand, they will only get the fixed part if they make no efforts. Therefore, the merging parties will compare the marginal costs of making more efforts in operating the divested business and the marginal earnings of increasing the divested business's market shares. They will choose a point of effort where the marginal costs equal the marginal earnings.

It is noteworthy that, first, similar to the example concerning the employment contract, whether such reward strategy can induce the merging parties to a desirable manner largely depends on the arrangement of the proportion of the fixed payment and the floating payment. The merging parties can be de-incentivised if the amount of the fixed part is too high. They are likely to have insufficient incentives to make extra efforts to keep the marketability and value of the divested business. On the contrary, if the fixed part is too low, this means the merging parties are exposed to a high risk of receiving a low payment, given their effort level. Accordingly, it is important to arrange an appropriate reconciliation of the fixed part and the floating part of the final price to provide the merging parties with proper incentives.

Second, the reward strategy can be less practical in the context of merger divestitures. In the example considers car salesman, it is impossible for the employer to monitor the salesman's whole day activity, so that the number of cars sold in a month becomes the indirect estimator used by the employer to evaluate how hard the salesman works, assuming that the more cars he sells, the harder he works. Such an estimator makes it easy

${ }^{1008}$ Farrell (n 862) 98. 
for the employer to evaluate his employees and as such the estimator can to some degree reflect the effort level of the salesman. The drawback of this estimator is that it is possible that the salesman works very hard but still fails to sell any car.

Similarly, changes of market shares during the interim period can be a good estimator that can to some extent reflect the effort the merging parties spend on keeping the value and marketability of the divested business. Such an estimator, however, has several obvious limitations. First, it can take quite a while for the merging parties' efforts to be reflected in market shares. Considering that there is a trend that a short divestiture process is required by the competition agencies, there is a risk that there is inadequate time for the merging parties' effort to be reflected in market shares before the completion of divestitures. Second, sometimes there is no direct causality between the merging parties' effort and the estimator, such as the market shares of the divested business, like the salesman's effort and the number of cars he sells. Sometimes even if the merging parties spend enough efforts in keeping the viability of the business, its marketability can still decrease due to other elements, such as other rivals' successful marketing strategy. Such a decrease does not directly mean that the divested business is not viable any more. Further, it can be hard to find a suitable estimator. For example, it might be difficult to reveal the merging parties' slackness if they transfer the key personnel from the divested business to another department since the buyer might have no idea who is the key personnel.

Accordingly, in the situation of merger divestitures, the reward strategy can theoretically alleviate asset risks by changing the payment schedule from a fixed outcome-based one to a "fixed outcome-based one + a floating effort-based one" that provides the merging parties with incentives to keep the viability of the divested business. Nevertheless, there are several limitations that can largely cripple the effectiveness and feasibility of the strategy. As mentioned above, it is difficult to set a reasonable proportion of the fixed part and the floating part of the payment. It can be even more difficult to find a suitable estimator that can reflect the merging parties' effort level.

\subsubsection{The Trusteeship Strategy}

In the context of merger divestiture, the trusteeship strategy can be defined as follows: to alleviate asset risks caused by moral hazard, resources can be invested on monitoring the merging parties' behaviour to incentivise them to take appropriate actions and thus the tobe-divested business' value will not be reduced. A trusteeship strategy seeks to remove conflicts of interest ex ante, so that no personal gains will be obtained when the agent does not serve his principal well. ${ }^{1009}$ Put differently, the reward strategy enables the principal to control his agent's behaviour after the agent's action by granting the agent additional rewards based on the result of his performance, whereas the trusteeship strategy can be used by the principal to induce the agent's desirable manners before he acts, by monitoring.

One of the most typical examples of the application of the trusteeship strategy is the employment of an independent director or a supervisory board in the field of corporate governance. In a corporation, the manager acts as an agent to manage the corporation on behalf of the shareholders, who are the principals. It is possible, however, that the manager pursues other goals to maximise his own benefits rather than the shareholders'. Such goals may include expanding his personal social network, increasing his personal reputation, or simply maximising his salary. Therefore, an independent director or a supervisory board is appointed to ensure that decisions are made in the interests of the principal since the independent director will not gain any personal benefits from making decisions being

${ }^{1009}$ Kraakman and others (n 963) 43. 
partial to the manager or to certain minority of shareholders. By removing the possibility of gaining any personal benefits from not serving the principal, the agent can be incentivised by their other factors, such as their reputational concerns.

Regarding merger divestitures, to alleviate asset risks by reducing the merging parties' moral hazard, an "independent trustee" can be employed. Such an independent trustee can monitor the merging parties' behaviour and make sure that the parties make appropriate decisions. As a result, the possibility of moral hazard is eliminated ex ante. It is noteworthy that, first, the key point to ensure the effectiveness of the trusteeship strategy is to ensure that the independent trustee will not obtain any personal gains by disproportionately benefiting the merging parties.

Second, as mentioned, the CA can use strategies to incentivise the merging parties although the moral hazard problem is explored in a principal-agent (the merging parties and the buyer) context. Accordingly, the requirement of appointing an independent trustee can be made by the CA when it conditionally approves a merger application. It is generally assumed that the CA to some extent shares the same goal as the buyer, namely, the divested business can compete with the merged party viably if it is operated by a suitable buyer. The purchaser can hence make profits from the divested business, while the competition is restored to the market.

Third, moral hazard can occur during either the interim period A or B. The reward strategy can be applied in the interim period B. In contrast, the trusteeship strategy can be used in the interim period A, when a merger is conditionally approved by the CA. In this situation, to reduce the possibility of the merging parties' moral hazard problem, the CA can require them to include certain provisions in the merger approval decision that aim at preserving the value of the divested business during the interim period, and further to require the appointment of trustees to monitor the merging parties' behaviour. In contrast with the reward strategy, the trusteeship strategy is used to remove the possibility of moral hazard ex ante. ${ }^{1010}$ Accordingly, to ensure the effectiveness of the trusteeship strategy, it is important to make sure that such requirements are included in a divestiture agreement that is reached between the merging parties and the buyer.

Overall, the key point in alleviating asset risks in merger divestitures is to solve the moral hazard problem that can occur during the interim period. Given the special context of merger divestitures, rules, standards, the reward strategy and the trusteeship strategy can be used as solutions to reduce asset risks.

First, standards can reduce asset risks by providing the CAs with general criteria to assess expost whether the merging parties comply with their obligations. The CA can revise its decisions once it notices and proves that the merging parties fail to meet the standards. The potential problem of this strategy is that even though the CA improves its decisions, it remains unknown whether the lost value caused by the merging parties' shirking can be restored.

Second, the reward strategy can facilitate the principal (the buyer) to control the merging parties' behaviour by providing them with monetary incentives ex post. It, however, is difficult to assure the effectiveness of the reward strategy due to some significant limitations (mentioned above).

Third, well-defined rules can restrain the merging parties from undesirable manners $e x$ ante. The trusteeship strategy, in contrast, can be used by the CA to monitor the merging parties' behaviour and to induce them to desirable manners ex ante, as long as the trustees appointed will not obtain any personal gains from being partial to the merging parties.

$1010 \mathrm{ibid}, 43$. 
Considering the effectiveness and feasibility, as well as the irreversibility of merger divestitures, rules and the trusteeship strategy can be more practical and easier to be applied to reduce asset risks in the context of divestitures.

\section{Use of HSPs and Trustees in the US and the EU to Reduce Asset Risks}

\subsection{Recognition of Asset Risks}

The 1999 FTC Divestiture Study pointed out that the merging parties may behave strategically to undermine the value of the divestiture package and prevent the buyer from succeeding. ${ }^{1011}$ It further noted that the merging parties can have different goals between the CAs' and the buyer, and thus have adverse incentives. ${ }^{1012}$ The 1999 FTC Divestiture Study suggested that the merging parties' undesirable behaviour should be taken into account when designing a divestiture. ${ }^{1013}$ In addition, the 2012 FTC Remedies Statement considers HSPs when there is a risk that the competitive strength of the pending divestiture package can be harmed or reduced during the interim period. ${ }^{1014}$

Regarding the DOJ, the 2011 DOJ Policy Guide states that a hold separate provision and an asset preservation clause will be considered to maintain the competitiveness and marketability of the divestiture package during the pending period before the completion of divestitures. ${ }^{1015}$

The European Commission indicated in the 2008 EC Remedies Notice that the merging parties have the responsibility to preserve the value of the divestiture package and protect it from any possible risk of loss in competitiveness before the completion of divestitures. ${ }^{1016}$ To realise this, different strategies, such as hold separate provisions can be included. ${ }^{1017}$

\subsection{HSPs and Trustees in Law}

\subsubsection{Use of HSPs}

In practice, to provide the merging parties with specific rules, the CAs in the US and the EU frequently require the inclusion of HSPs in the consent agreements (in the situation of the US) or in the Commission's decisions (in the situation of the EU). ${ }^{1018}$ Such "rules" are expected to foster the merging parties' desirable manners. Under a hold-separate provision, the merging parties have to 'hold separate at least those assets that the parties are required to divest'. ${ }^{1019}$ An asset preservation provision requires the merging parties to maintain the

\footnotetext{
10111999 FTC Divestiture Study (n 38) 18.

1012 ibid.

1013 ibid, 18.

10142012 FTC Remedies Statement (n 36).

10152011 DOJ Policy Guide (n 56).

10162008 EC Remedies Notice Notice (n 35) para. 108.

$1017 \mathrm{ibid}$, para. 110.

1018 Although the names for approval concerning merger notifications are different in the US and the EU, for convenience, they are collectively called approval decisions below.

10192012 FTC Remedies Statement (n 36) 17.
} 
viability and good-will during the divestitures process. ${ }^{1020}$ Generally, either hold-separate provisions or asset preservations provisions are designed to keep the divested business as viable and competitive as possible.

It is noteworthy that once HSPs are required by the CAs, they become final on the merging parties. ${ }^{1021}$ According to the 2012 FTC Remedies Statement, even though such provisions are not final until some time period after the merging parties execute the divestiture agreement which contains the consent order, these provisions will directly be included in the divestiture agreement between the merging parties and the buyer, stating that parties 'agree to comply with the proposed Decision and Order and the Order to Hold Separate and Maintain Assets from the date they execute this Consent Agreement'. ${ }^{1022}$ In other words, regardless of whether the divestiture agreements are reached between the merging parties and the buyers before or after the approval from the CA, HSPs will always be effective for the merging parties. This also explains why in this chapter, although the moral hazard problem is studied between the merging parties and the buyer in the principal-agent relationship framework, the CAs, as the third party, can still require the inclusion of HSPs to incentivise the merging parties to raise their effort level.

It is expressly pointed out by the Commission that to maintain the viability, marketability and competitiveness of the divested business, the merging parties have to maintain 'fixed assets, know-how or commercial information of a confidential or proprietary nature, the customer base and the technical and commercial competence of the employees'. ${ }^{1023}$ The merging parties have to maintain the conditions of the divested assets the same as before the merger, and especially provide sufficient resources. ${ }^{1024}$ Different "indexes" are thus employed by the CAs to measure and evaluate whether the merging parties' comply with these provisions. For example, to ensure that the merging parties maintain necessary levels of capital spending on the pending assets to keep the pending assets' daily operation the same to that before the merger, the merging parties are required to provide plans which state the previously anticipated or planned capital level to the FTC. ${ }^{1025}$

Summing up, once HSPs are required by the CAs in their conditional approval decisions, they become final to the merging parties. Furthermore, by employing detailed measures or evaluation "indexes", the CAs are able to assess the merging parties' compliance with such provisions. It is safe to predict that HSPs can theoretically reduce asset risks caused by the merging parties' moral hazard effectively, if the merging parties comply with them. To further reduce the possibility of moral hazard, the CAs generally appoint trustees for monitoring.

\subsubsection{Use of Trustees}

The trusteeship strategy is used by the CAs in the US and the EU to monitor the merging parties' compliance with the "rules" and thus spend sufficient effort in preserving the divested business' competitiveness. Trustees are appointed because it can be difficult for the CAs to monitor each merger transaction considering their limited resources. Trustees

\footnotetext{
10202011 DOJ Policy Guide (n 56) 25.

10212012 FTC Remedies Statement (n 36) 17.

1022 ibid.

10232008 EC Remedies Notice (n 35) para. 110

1024 ibid, para. 110.

10252012 FTC Remedies Statement (n 36) 17.
} 
are thus appointed to work as the "ear and eye" 1026 for the CAs to monitor the merging parties. There are different types of trustees in these two jurisdictions.

\subsubsection{1. $E U$}

In the EU, there are two types of trustees: monitoring trustees and divestiture trustees. ${ }^{1027}$ As described by Figure 4 in Chapter 3, the divestiture process in the EU consists of two stages. Generally, a monitoring trustee is appointed during the first divestiture period to monitor the parties' compliance with their proposed remedies, in particular, their obligations during the interim period and the divestiture process. ${ }^{1028}$ If the merging parties fail to complete divestitures in the period 1, a divestiture trustee can be appointed in the trustee-divesting period to help the merging parties to dispose of the business, under the supervision of the Commission. ${ }^{1029}$

The merging parties have to propose to the Commission one or several trustees once the Commission has made its conditionally approval decisions. ${ }^{1030}$ After being assessed and approved by the Commission, the proposed trustee will be appointed by the merging parties based on the appointment mandate. ${ }^{1031}$ The Commission has the discretion to select trustees who it thinks are the most suitable. Appointing trustees can, to the extent possible, assure that the parties will effectively carry out their commitments and comply with their obligations during the interim period.

Furthermore, as mentioned above, in the case where an HSP is required by the Commission, generally a hold-separate manager will also be required to be appointed by the parties. The hold-separate manager should have 'the necessary expertise, because he will be responsible for the management of the business and the implementation of the holdseparate and ring-fencing obligations'. ${ }^{1032}$ The hold-separate manager is responsible for managing the divested business and implementing HSPs. The monitoring trustee has the authority to issue instructions to the hold-separate manager and remove him when he is no longer qualified. ${ }^{1033}$

\subsubsection{US}

Regarding the FTC in the US, it is stated in the 2012 FTC Remedies Statement that an independent third party can be appointed if the divested business is not stand-alone and thus additional assistance must be provided by the merging parties. ${ }^{1034}$ The independent third party (monitors) has to command certain expertise concerning the divested business. Monitors are responsible for overseeing the parties' compliance with the consent orders. ${ }^{1035}$ The monitor appointed in the situation where HSPs are included is called a "hold-separate trustee" or "hold-separate monitor". It is assigned with the task to monitor the operations of the hold-separate business. ${ }^{1036}$ Unlike the Commission's approach under which trustees are proposed and appointed by the merging parties, in the context of the

\footnotetext{
1026 ibid, 18.

${ }^{1027}$ For detailed information concerning trustees in the EU merger control field, see: 2008 EC Remedies Notice Notice (n 35) para. 117-122.

1028 ibid, para. 117.

1029 ibid, para. 121.

1030 ibid, para. 124.

1031 ibid, para. 124..

1032 ibid, para. 112.

1033 ibid.

10342012 FTC Remedies Statement (n 36) 16.

1035 ibid, 18.

1036 ibid, 17.
} 
FTC, trustees/monitors are recommended by the staff within the FTC and are appointed by the FTC; however, they are compensated by the merging parties. ${ }^{1037}$

The DOJ differentiates three categories of trustees based on their different obligations: operating trustees, monitoring trustees and selling trustees. ${ }^{1038}$ An operating trustee, who is responsible for the daily management of all or part of the to-be-divested business, will be considered when the DOJ believes that the merging parties "have the ability and incentives" to behave undesirably and strategically during the divestiture process. ${ }^{1039} \mathrm{~A}$ monitoring trustee is appointed to 'review a defendant's [the merging parties] compliance with its decree obligations to sell the assets to an acceptable purchaser'. ${ }^{1040}$ When the parties fail to finish the divestitures within the timeframe prescribed in the consent decree, a selling trustee will thus be appointed to complete the divestitures and to ensure the implementation of consent decrees. ${ }^{1041}$

To reduce asset risks by providing the parties with incentives to raise their effort in operating the divested assets, operating trustees will be appointed. Their obligations are to oversee the daily management of the to-be-divested business and to assure that the holdseparate business is operated competitively. ${ }^{1042}$ Unlike the FTC which will appoint a holdseparate monitor if HSPs are required, the DOJ will consider appointing an operating trustee only if it believes that the parties are likely to mismanage the divested business. ${ }^{1043}$ In the situation of the DOJ, trustees are nominated and appointed by the DOJ. ${ }^{1044}$

\subsection{HSPs and Trustees in Practice}

In practice, both the FTC and the DOJ in the US have required HSPs and the trustees in merger divestitures. According to the FTC's Frequently Asked Questions About Merger Consent Order Provisions, a monitoring trustee will usually be appointed in the situation where a hold separate order is required to monitor the merging parties' compliance and to oversee the business. ${ }^{1045}$ Sometimes the merging parties can be required to preserve the assets to be divested without being required to operate the assets separately, such as in Glaxo/SmithKline Beecham case.

In Glaxo/SmithKline Beecham, Glaxo Wellcome plc (Glaxo) and SmithKline Beecham plc (SB) proposed to merge. ${ }^{1046}$ After investigations, the FTC decided to approve the merger application with a condition that required the parties to divest pharmaceutical products in six markets. ${ }^{1047}$ Further in this case, the parties were required to maintain the business and a monitor was appointed. ${ }^{1048}$

\footnotetext{
103722012 FTC Remedies Statement (n 36) 16.

${ }^{1038}$ For detailed introduction and exploration of the role and function of these trustees, see: Chapter 3. 10392011 DOJ Policy Guide (n 56) 26.

1040 ibid, 26.

1041 ibid, 27.

1042 ibid, 26.

$1043 \mathrm{ibid}, 26$.

1044 ibid, 26-27.

1045 FTC, 'Frequently Asked Questions About Merger Consent Order Provisions: Hold Separate Orders' (Federal Trade Commission) < https://www.ftc.gov/tips-advice/competition-guidance/guide-antitrust-laws/mergers/mergerfaq\#Hold Separate Orders> accessed 25 April 2017.

1046 FTC Dockt. No. C-3990 Glaxo/SmithKline Beecham (FTC Decision and Order) [18 December 2000].

1047 See: ibid.

${ }^{1048}$ FTC Dockt. No. C-3990 Glaxo/SmithKline Beecham (FTC Order to Maintain Assets; Trust Agreement) [18 December 2000].
} 
In the EU, the Commission also required the inclusion of HSPs or the appointment of trustees in merger divestitures. For example, in Life Technologies/Thermo Fisher, a monitoring trustee was appointed. ${ }^{1049}$ Thermo Fisher Scientific Inc. ("Thermo Fisher") intended to acquire sole control over Life Technologies Corporation ("Life Technologies") and thus notified the Commission. The merger application was approved by the Commission later after an investigation when the Thermo Fisher agreed to divest its HyClone business, gene modulation business, and polymer-based magnetic beads business. ${ }^{1050}$ Besides, a monitoring trustee was appointed to oversee the parties' compliance with their obligations. ${ }^{1051}$

\subsection{Summary}

As is observed, both HSPs and trustees are used by the CAs in the US and the EU to alleviate asset risks resulting from moral hazard. HSPs provide the merging parties with behavioural rules, while the trustees can further ensure the compliance. With the inclusion of HSPs, the merging parties will have the obligation to preserve the value and viability of the divested business during the interim period. Such rules restrain the merging parties from slacking off in preserving the value of the to-be-divested assets, so that asset risks can thereby largely be alleviated. Put differently, the rules provide the merging parties with incentives to raise their effort level. On the other hand, the effectiveness of HSPs largely depends on the merging parties' compliance. Accordingly, once an HSP is required by the CA or the CA believes that the parties have the incentives to mismanage the divested business, a trustee with the obligation to monitor whether the parties operate the business competitively will be appointed as soon as possible (from the very beginning of the interim period). Trustees can to a large extent reveal the merging parties' possible strategic actions and thus incentivise them to behave desirably.

Although the FTC, the DOJ and the Commission divide trustees into different categories and assign them with different responsibilities, monitoring the merging parties' compliance with their obligations and implementing the CAs' (conditional) approvals of merger applications are, generally, of primary importance. Trustees are appointed by the merging parties in the situation of the EU and are appointed by the CAs in the US; however, they all have to be assessed and approved by the CAs as early as possible during the divestiture process. These trustees generally should have the necessary expertise concerning the divested business. Accordingly, the trustees can ex ante removing any opportunity for the merging parties to have a moral hazard problem.

Furthermore, although trustees are compensated by the merging parties, ${ }^{1052}$ trustees work as "ears and eyes" of the CAs. ${ }^{1053}$ This suggests that, first, the CAs are always kept informed about the parties' actions. Once the CAs notice and prove that the merging

${ }^{1049}$ Case COMP/M.6944, Thermo Fisher Scientific/Life Technologies (European Commission Decision) [26 November 26 2013] <http://ec.europa.eu/competition/mergers/cases/decisions/m6944_20131126_20212_3661859_ EN.pdf $>$ accessed 25 April 2017.

1050 European Commission Press Release, 'Mergers: Commission clears acquisition of Life Technologies by Thermo Fisher, subject to conditions' (EUROPA, 26 November 2013) < http://europa.eu/rapid/pressrelease_IP-13-1167_en.htm> accessed 26 April 2017.

1051 European Commission 'Monitoring Trustee in Case COMP/M.6944 - Thermo Fisher Scientific/ Life Technologies' (EUROPA, 2013) < http://ec.europa.eu/competition/mergers/cases/additional_data/m6944_ 4108_3.pdf> accessed 25 April 2017.

1052 See: 2012 FTC Remedies Statement (n 36) 16; 2013 EC Best Practice Guidelines (n 606).

10532011 DOJ Policy Guide (n 56) 26. 
parties fail to fulfil their obligations in the approval decisions or fail to comply with HSPs, the CAs can take further actions. Such as in the situation of FTC, the parties violating the consent orders can be exposed to a civil penalty. ${ }^{1054}$ Second, trustees work for the CAs. If they provide disproportionate benefits to the merging parties and such partiality is discovered by the CAs, their reputation will be harmed. Accordingly, trustees have to take a neutral position when making their decisions so that they can fulfil their tasks.

The FTC specifies that '[T] he most effective monitors have been those who established a positive working relationship with the parties as well as with the buyer'. ${ }^{1055}$ 'The rationale is that the interests of these three parties: the merging parties, the buyer and the trustees, are to some extent inseparable. The trustees' obligation is to monitor the parties' compliance with their obligations. From the perspective of the merging parties, due to the HSPs and monitoring from the trustees, they can only close the transaction by fulfilling what they are required to do. For the buyer, his benefits will be influenced by the merging parties' effort in operating the divested business.

Summing up, first, HSPs can be deemed as specific rules under which the merging parties have to take appropriate measures to keep the marketability and competitiveness of the pending business. Second, trustees help the buyer (the CA) to control the merging parties' behaviour by monitoring. Such trustees are required to be appointed in the early divestiture process, which ex ante solves moral hazard to the maximum early extent.

\section{Conclusion}

Asset risks can occur during the interim period of divestitures and are likely to lead to difficulties for the buyer to operate the divested business successfully after the completion of divestitures. In fact, reduction of value of the divested business can be largely caused by the merging parties' moral hazard. Moral hazard, in the context of merge divestitures, refers to the informed party (the merging parties)'s risk of behaving undesirably to reduce the viability, marketability and competitiveness of the divested business, whereas the buyer will bear the resulting losses. Thus, addressing this moral hazard problem can, to a large extent, alleviate such asset risks.

The merging parties can shirk when their actions are invisible to the buyer, while the payment of the pending business has been determined. Theoretically, according to Kraakman and others' analysis, the solutions to alleviate moral hazard can be categorised as agent-constraining strategies and principal-empowering strategies. ${ }^{1056}$ Rules and standards is one set of the agent-constraining strategies, which can constrain the agent from taking opportunistic manners. The reward strategy and the trusteeship strategy is one pillar of the principal-empowering strategies, which helps the buyer (the CA) to control the merging parties' behaviour. Considering the feasibility and the effectiveness, and divestitures' irreversibility, rules and the trusteeship strategy can be more effective than standards and the reward strategy in solving moral hazard in the situation of merger divestitures.

Both in law and in practice, the CAs in the US and the EU use HSPs and trustees to reduce asset risks. HSPs provide the merging parties with behavioural rules. Furthermore, different "indexes" are adopted to evaluate the merging parties' compliance. The merging parties' compliance is further ensured by trustees' monitoring. Trustees can observe the

10542012 FTC Remedies Statement (n 36) 20.

1055 ibid, 16.

1056 See: Kraakman and others (n 963). 
merging parties' behaviour, which incentivises the merging parties to raise their efforts in preserving the value of the divestiture package. It is safe to conclude that HSPs and trustees can effectively assuage asset risks caused by moral hazard.

It is assumed in this chapter that the buyer and the CA share the same goal to preserve the viability and competitiveness of to-be-divested assets to the extent possible. Based on this assumption, the CA, as the gatekeeper of the market, can be regarded as a quasiprincipal and thus take strategies to reduce the moral hazard problem during the interim period. Actually, this assumption is true most of the time. However, there is a risk that the buyer and the CAs can have discrepant goals and conflicts of interest. The buyer may choose to cooperate with the merged firm after divestiture to maximise their joint profits rather than competing. Such risk can be called collusion risk, which will be explored in Chapter 8 from the perspective of bargaining theory and collusion theory. 


\section{Chapter}

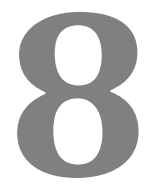

COLLUSION RISKS - FROM THE COLLUSION THEORY PERSPECTIVE 



\section{Introduction}

A merger may lead to the loss of a firm, resulting in a reduction of the number of competitors in the market concerned and a concentration of the merged party's market power. Oligopoly theory confirms the common intuition that prices increase when the number of firms in the market concerned decreases. ${ }^{1057} \mathrm{It}$ is generally believed that collusion is easier if the number of competitors in the market is small. ${ }^{1058}$ In other words, a merger might lead to collusion if it results in the loss of a firm, reducing the number of competitors in the market.

A merger divestiture can re-distribute resources and market power directly between the merged party and the purchaser, so that the merged party's concentrated market share and/or market power can be reduced. Furthermore, divestitures can also restore the number of competitors to the pre-merger level if the purchaser is a new market entrant, implying that the possibility of coordination can be reduced, given the above-mentioned argument of "more competitors, less collusion." 1059

Nevertheless, even if an existing competitor is strengthened or a new market entrant is created, it is possible that competition cannot be restored to the pre-merger level due to collusion between the merged firms and the purchaser. Collusion here refers to these "agreements" (explicit or tacit) which enable the firms to raise prices above the competitive level. Such "agreements", in general, include a mechanism of rewards and punishments that can facilitate the sustainability of such agreements. ${ }^{1060}$ Collusion risks in this chapter refer to the risks that the merged party and the purchaser of the divested assets may have the incentives to collude rather than competing to maximise their profits. ${ }^{1061}$ Post-merger collusion can be reached between the buyer and the merged party through bargaining if such bargaining is efficient and the arrangement concerning the distribution of the joint profits is acceptable to both parties. Readers should be aware that although, as mentioned above, mergers can make collusion easier (in other words, mergers can make collusion easier between the merged party and any remaining competitor in the market), this chapter limits its scope to the (possible) collusion between the merged party and the purchaser of the divested assets (see sec.3 below for details).

The following insights may, to some extent, explain the occurrence of collusion risks between the merged firm and the purchaser. First, the idea that collusion is easier when the number of competitors is small does not directly suggest that collusion becomes hard if the number of competitors is increased. Simply increasing the number of competitors in the

\footnotetext{
${ }^{1057}$ Roller, Stennek and Verboven (n 9) 19.

${ }^{1058}$ Kai-Uwe Kuhn, 'The Coordinated Effects of Mergers' in Paolo Buccirossi (ed), Handbook of Antitrust Economics (The MIT Press 2008) 115. The author also argues that there is a slight flaw in the argument that "the more firms in the market, the harder it is for the firms to reach collusion". For an introduction of this argument, see: sec.2 below.

It is also identified that "mergers may also make coordination easier, more stable and more effective for firms", 2004 EC Horizontal Merger Guidelines (n 522) para. 39. This opinion is also held by other official documents regarding merger control. For example, 2008 EU Non-Horizontal Merger Guidelines (n 14) para.19; 2010 US Horizontal Merger Guidelines (n 11) 24; 1984 DOJ Non-Horizontal Merger Guidelines (n 809) 29. Given that collusion can be understood as one of the coordinated effects, it means that mergers can also make collusion easier.

${ }^{1059}$ In this chapter, collusion and coordination are used interchangeably, although they can have different meanings. For a detailed exploration of the differences between these two concepts, see: Jonathan B. Baker, 'Mavericks, Mergers and Exclusion: Proving Coordinated Competitive Effects under the Antitrust Laws' (2002) 77(1) N.Y.U. L Rev 135, 137.

1060 Kuhn (n 1058) 107.

1061 The reasons (incentives) why the merged party and the buyer choose to collude is explored in sec.3.
} 
market may not reduce the risks of collusion. Such perception has been closely related to the structural presumption, having its origin in United States v. Philadelphia National Bank. ${ }^{1062}$ It means that the plaintiff (the CAs) can challenge a merger by simply showing that such a merger would largely increase the market concentration if completed. ${ }^{1063}$ Put differently, under the structural presumption, a merger would directly be assumed as harmful to competition if it eliminates competitors (reduces the number of competitors in the market), given the idea that the loss of a firm will facilitate collusion. ${ }^{1064}$ The standard for assessing a notified merger now has been evolving during the development of merger control laws, however, the structural presumption has been deeply rooted into merger control thinking. ${ }^{1065}$ In fact, the number of competitors is simply an indicator rather than a determinant when deciding whether post-merger collusion will occur. Kuhn has indicated that the claim that 'collusion is very hard in a market with many competitors' can be problematic. ${ }^{1066}$ Collusion can be difficult to be realised only when the competitors' amount of assets rather than the number of competitors in the market is increased. ${ }^{1067}$ Suppose that the number of competitors in the market is fixed, the collusion is difficult to sustain when a market is declining. ${ }^{1068}$ Since increased assets can lead to a supply that is larger than demand, collusion becomes hard with more assets and larger firms.

Therefore, simply preserving the number of competitors to the pre-merger level can be insufficient to restore competition. Restoration of the market structure does not directly imply restoration of competition. ${ }^{1069}$ To ensure the effectiveness of divestitures, the purchaser of the divested assets has to compete with the merged party vigorously, so that more "assets" can be created.

Second, divestitures can facilitate collusion, especially collusion between the merged firm and the purchaser of the divested assets. On the one hand, it assumes that the concentration degree of the relevant market or the merged party's market power can be reduced by the merging parities' divestment of their assets to another competitor. On the other hand, such re-distribution can lead to collusion-facilitating symmetry between the merged party and the buyer. ${ }^{1070}$ Stigler specified the factors that a sustainable collusion requires: first, the parties have to strike an agreement concerning the prices and market shares; second, they must have a mechanism to detect any deviation. ${ }^{1071}$ Symmetry between the merged firm and the buyer resulting from the divestiture remedy may, to some extent, create the above-mentioned conditions. Such symmetry between the merged party and the buyer can be their symmetric position of market shares, production costs, technology, etc. In addition, multi-market contacts in both product markets and geographic markets and structural links and contractual agreements concerning supply (also regarded as a "continuing relationship" and "frequent interactions" between the buyer and the merged

\footnotetext{
1062 United States v. Philadelphia National Bank, 374 U.S. 321 (1963).

1063 Baker (n 1059) 139.

1064 ibid, 137.

1065 ibid, 139.

1066 See: Kuhn (n 1058) 115.

1067 ibid, 115.

${ }^{1068}$ Marc Ivaldi and others, The Economics of Tacit Collusion (Report for DG Comp, European Commission, 2003)

$<$ http://ec.europa.eu/competition/mergers/studies_reports/the_economics_of_tacit_collusion_en.pdf > accessed 26 April 2017, 27

${ }^{1069}$ Davies and Lyons (n 761) 247

1070 Massimo Motta, Compsotion Policy: Theory and Practice (Combridge University 2004) 147.

1071 George J. Stigler, 'A Theory of Oligopoly' (1964) 72(1) J Pol Econ 44, 44.
} 
party after the completion of divestitures) resulting from divestitures are also regarded as collusion-facilitating factors. ${ }^{1072}$

To study the reasons for the occurrence of post-divestiture collusion risks and the possible solutions, the remainder of this chapter is structured as follows.

A literature review is presented in sec.2, reviewing and summarising some closely relevant literature concerning collusion risks of divestitures, the economics of collusion, and conditions created by divestitures that can facilitate collusion. Sec.3 explores two questions: what are the incentives for the merged party and the purchaser to collude and how can such collusion be arranged. Sec.4 studies the questions why divestitures can especially lead to collusion between the merged party and the purchaser, and what are the possible solutions to alleviate collusion risks. In sec.5, empirical studies and guidelines conducted and published by the CAs in the US and the EU are analysed to explore the CAs' recognition of post-divestiture collusion risks and the effectiveness of solutions they use in reducing collusion risks. A conclusion is drawn in sec.6.

\section{Literature Review}

In this section, literature that exactly concerns post-divestiture collusion risks is presented. In addition, literature concerning the economics of collusion is also reviewed.

\section{Collusion risks in divestiture remedies}

Farrell is aware of post-divestiture collusion risks by asking is the buyer an ally of competition?' 1073 By applying bargaining theory in an informal way, the author argued that the buyer can have incentives to collude with the merged firm to maximise their joint profits. ${ }^{1074}$ Furthermore, the author implied that joint dominance can be created if the parties collude after divestitures and they can have large market power altogether. ${ }^{1075} \mathrm{~A}$ notified merger can enable the merging parties to have a dominant market position, whereas a divestiture can cause joint dominance after mergers.

Motta, Polo and Vasconcelos studied several problems related to collusion risks in merger divestitures. ${ }^{1076}$ First, a divestiture may fail to restore competition in the market due to the continuing relationship between the buyer and the merged party. ${ }^{1077}$ For example, the merging parties have frequent interactions with the buyer to provide the latter with supportive information in the case of transferring intangible property. Such a continuing relationship provides the purchaser and the merged party with opportunities to collude.

Second, a non-aggressive buyer can collude with the merged party. ${ }^{1078}$ The authors made a comparison between an aggressive buyer and a non-aggressive buyer, given their attitude towards pricing strategies. The authors argued that a non-aggressive buyer is more likely to use a soft pricing policy, or choose to cooperate with the seller to maximise its profits since a non-aggressive buyer's profits would be lower than those of an aggressive buyer.

\footnotetext{
1072 See: (for example) Ivaldi and others (n 1068); Motta (n 1070).

1073 Farrell (n 862) 96.

1074 ibid.

1075 ibid, 97.

1076 See: Motta, Polo and Vasconcelos (n 857).

1077 ibid, 112.

1078 ibid, 113.
} 
Third, a merger divestiture can lead to symmetry and multi-market contacts by strengthening an existing market player, whereas these two factors can facilitate collusion. ${ }^{1079}$ Similar to Farrell's observations, the authors believed that making an existing competitor be evenly matched to the merged firm may suggest a symmetric distribution of resources such as market shares and production costs between them, while symmetry facilitates collusion. Further, the authors pointed out that divestitures provide the merged party and the buyer with opportunities to interact within one geographic or product market. Such multi-market contacts can also facilitate collusion.

To avoid collusion risks, the authors suggested that the suitability of a purchaser should be assessed carefully to ensure that it has the right incentives to compete with the merged party. ${ }^{1080}$ An up-front buyer provision should be used more frequently.

Papandropoulos and Tajana doubted the effectiveness of structural remedies by stating that structural remedies, such as divestitures, may cause additional competition problems, like collusion. ${ }^{1081}$ Davies and Lyons also questioned whether it is always true to presume that structural remedies are better than behavioural remedies. ${ }^{1082}$ It is recognised that divestitures are generally the best merger remedies; however, the effectiveness of a divestiture can be crippled due to the buyer's failure to operate the divested business vigorously. ${ }^{1083}$

Observations in de Valois Turk's article are consistent with the findings of the abovementioned Motta, Polo and Vasconcelos's article in the sense that divestitures can facilitate collusion due to a continuing relationship, multi-market contracts, and symmetry between the merged firm and the buyer. ${ }^{1084}$ The author suggested that the CAs should assess the suitability of a buyer with care and a monitoring trustee should be appointed so that the CA can obtain the information concerning the continuing relationship between the merged party and buyer consistently.

\section{The economics of collusion}

There is rich literature concerning the economics of collusion. For example, in Marshall and Marx's 2012 book which explores cartels and bidding rings from the perspective of the economics of collusion, the authors studied the function of the so-called plus factors and super plus factors. ${ }^{1085}$ Such factors are believed to assist to predict or determine the existence of collusion. Plus factors are "the body of economic circumstantial evidence of collusion", while super plus factors refer to "those plus factors that deliver a strong [inference] of collusion". ${ }^{1086}$ Analysing the existence of the economic circumstantial evidence provides a new approach to diagnose collusion. Moreover, the authors modified the "five forces diagram for collusion" adopted from Michael Porter's five forces diagram. ${ }^{1087} \mathrm{~A}$ structure which aims to control the secret deviations of collusion was

\footnotetext{
1079 ibid.

1080 ibid, 116.

1081 Papandropoulos \& Tajana (n 617) 449.

1082 Davies and Lyons (n 761) 247.

1083 ibid, 247.

1084 Maurice de Valois Turk, 'The European Commission's Revised Remedies Notice- the Trustee's Perspective' (2009) 7 ECLR 332, 338.

1085 See: Robert C. Marshall and Leslie M. Marx, The Economics of Collusion: Cartels and Bidding Rings (The MIT Press 2012).

1086 Marshall and Marx, ibid, 213.

${ }^{1087}$ See: Marshall and Marx, ibid, 94 (Figure 5.1). See also: Michael E. Porter, Competitive Strategy: Techniques for Analyzing Industries and Competitors (Free Press 1980).
} 
designed by the authors based on the above-mentioned article by Stigler, ${ }^{1088}$ including the pricing structure, allocation structure and enforcement structure. ${ }^{1089}$

Kovacic has also explored plus factors which allow differentiation between concerted conduct and parallel conduct and further to diagnose the collusion. ${ }^{1090}$ The author pointed out that operational criteria (plus factors) will be employed by the US court to determine whether a pattern of parallel conduct stems from collusive agreements, ${ }^{1091}$ Such criteria/factors include: whether there exists a rational motive for the firms to act in concert, or; whether concerted actions can be the only explanation for certain phenomena. ${ }^{1092}$ In 2011, Kovacic and others (2012) published a research paper concerning plus factors and agreements in the context of merger control. ${ }^{1093}$ The authors described the function of plus factors by using an analogy as ' $[D]$ etecting a cartel is much like diagnosing whether a disease is present... The plus factors are symptoms that can make the diagnosis more reliable'. 1094 The authors provided taxonomy of plus factors and a coherent methodology for ranking these plus factors in an order of probative values. ${ }^{1095}$

Baker indicated that the traditional structural approach regarding the prediction of the occurrence of collusion concerns the loss of firms. ${ }^{1096}$ The author analysed this question from the perspective of "mavericks", which refers to those firms which "have a greater economic incentive to deviate from the terms of coordination than do most of its rivals'. ${ }^{1097}$ It is argued that the existence of a maverick can limit collusion in the market. Thus, the occurrence of a merger's coordinated effects can be predicted from the perspective of whether it will absorb a maverick, or, in other words, whether the maverick's constraint on coordination will be reduced after a merger.

Kuhn, however, argued that Baker's argument that 'a merger should be deemed as competitively neutral if the incentives of the maverick remain the same post-merger' is not convincing from the collusion theory perspective. ${ }^{1098}$ It is argued that Baker's analysis will hold only if firms' collusion degree is completely subject to the constraints imposed by the maverick. Otherwise the price can still rise even if the degree of collusion is constrained by the maverick. ${ }^{1099}$

Kovacic and others (2005) studied the likelihood of a merger's coordinated effects by quantifying the incremental gains from post-merger collusion among any subset of remaining firms. ${ }^{1100}$ It is believed that payoffs drive behaviour. ${ }^{1101}$ Firms are unlikely to engage in collusion if the payoffs from collusion are small. Accordingly, the quantification

\footnotetext{
1088 Stigler (n 1071).

1089 Marshall and Marx (n 1085) 107 (Figure 6.1).

1090 See: William E. Kovacic, 'Antitrust Policy and Horizontal Collusion in the 21st Century' (1997) 9 (2) Loyola Consum Law Rev 97.

${ }^{1091}$ It is inadequate to determine that a certain concerted conduct stems from agreement by simply demonstrating the existence of parallel conduct. The firm can claim that they just behave in a parallel manner because it is rational for them to make a certain response. See: Paul P. Craig and Gráinne de Búrca, EU Law: Text, Cases and Materials (4 edn, Oxford University Press 2008) 961.

1092 Kovacic (n 1090) 102.

1093 William E. Kovacic and others, 'Plus Factors and Agreement in Antitrust law' (2012) 110(3) Mich L Rev 393.

1094 ibid, 426.

1095 ibid, 435.

${ }^{1096}$ Baker (n 1059) 137.

1097 ibid, 140.

${ }^{1098}$ Kuhn (n 1058) 134.

1099 ibid, 134.

${ }^{1100}$ William E. Kovacic and others, Quantitative Analysis of Coordinated Effects [2005] CAPCP Working Paper, Penn State University.

1101 ibid, 2.
} 
of payoffs can to some extent function as a signal to determine the likelihood of collusion between firms.

There is abundant literature concerning the exploration of collusion-facilitating factors. For example, Ivaldi and others' 2003 report enumerated factors that can facilitate collusion, such as, entry barriers, frequent interactions, market transparency and multi-market contact. ${ }^{1102}$ Motto also summarised some collusion-facilitating factors, which are similar to Ivaldi and others'. ${ }^{1103}$ The author argued that the key points in sustaining collusion are, first, the participants should be able to detect a deviation promptly; second, there should be punishment for the deviation. ${ }^{1104}$ Ivaldi and others' report indicated that asymmetries in cost and capacity hinder collusion. This observation is consistent with other academics' observations. ${ }^{1105}$ For example, Compte, Jenny and Rey explored tacit collusion in the context of Bertrand supergames with (asymmetric) capacity constraints. ${ }^{1106}$ When there are asymmetric capacity constraints among competitors, any merger involving large firms will hurt collusion because such a merger may exacerbate the large firms' gains from deviation, while reducing the small firms' ability to retaliate. ${ }^{1107}$ Due to the asymmetric capacity constraint, the small firms may fail to detect a deviation or the punishment is insufficient to prevent the large firms from deviating. Accordingly, asymmetry in capacity constraint hinders collusion, even if a merger reduces the number of competitors.

Vasconcelos explored the relationship between tacit collusion, cost asymmetries and mergers in his 2005 paper. ${ }^{1108}$ By analysing the tacit collusion in quantity-setting supergames involving cost-asymmetric firms, the author argued that, first, the scope of collusion can be reduced by a merger if such a merger increases the distributional asymmetry of asset holdings between the largest and the smallest competitor; second, collusion can be facilitated when a merger increases the size of the smallest firm. ${ }^{1109}$ The narrowed size of the gap between the largest and the smallest firm leads to a worse symmetrical distribution of asset holdings between competitors.

In addition, Bernheim and Whinston studied the effects resulting from multi-market contacts on the degree of collusion that firms can sustain in the context of repeated competition. ${ }^{1110} \mathrm{By}$ exploring various models that were characterised with multi-market contacts and collusive behaviours, the authors concluded that a multi-market contact can

\footnotetext{
1102 ibid, 2

1103 See: Motta (n 1070).

1104 ibid, 139.

${ }^{1105}$ In addition to these articles, readers are referred also to the official merger guidelines published by the CAs in the US or the EU (n 1058); Stephen Daviesy, Matthew Olczakz and Heather Coles, Tacit Collusion, Firm Asymmetries and Numbers: Evidence from EC Merger Cases [2007] Working Paper No 07-7, Centre for Competition Policy Working. The article concerned an empirical study and identified the European Commission's (implicit) model of joint dominance.

1106 Olivier Compte, Frederic Jenny and Patrick Rey, 'Capacity Constraints, Mergers and Collusion' (2002) 46

(1) Eur Econ Rev 1. The Bertrand model is one of the basic duopoly models. In the simplest form of this model, it assumes that there are only two firms in the market which sell perfectly substitute products. These two firms compete with each other by altering prices simultaneously to maximise their profits. The Bertrand supergames mean that in the game, the firms repeatedly set their prices. For a detailed introduction regarding the Bertrand supergames, see: (for example) Andrew Schotter, 'Chapter 19: The World of Oligopoly: Preliminaries to Successful Entry' in Microeconomics: A Modern Approach (South-Western Cengage Learning 2009); Jean Tirole, The Theory of Industrial Organization (The MIT Press 1988).

${ }_{1107}$ Compte, Jenny and Rey, ibid, 17.

${ }^{1108}$ Helder Vasconcelos, 'Tacit Collusion, Cost Asymmetries, and Mergers' (2005) 36(1) RAND J Econ 39.

1109 ibid, 55.

1110 Bernheim and Whinston (n 872).
} 
have real effects in practice and it can facilitate collusion by relaxing the incentive constraints which limited the degree of collusion. ${ }^{1111}$

Generally, collusion risks have been recognised by academics. Moreover, there is abundant literature that explores factors that facilitate collusion in the context of mergers. However, there seems to be little literature that analyses collusion between the merged party and the buyer in the context of merger divestitures, and to systematically study how the CAs in the US and the EU recognise these risks and how they deal with them. This chapter thus has the modest aim to contribute to this field.

\section{Why Collude?}

The exploration of the post-divestiture collusion risks in this chapter is limited to collusion between the merged firm and the purchaser of the divested assets, considering that, first, one of the factors that determine the effectiveness of a divestiture (in the sense of restoring competition) is whether the purchaser of the divested assets can compete with the merged party vigorously.

Second, divestitures can facilitate collusion, especially collusion between the merged party and the purchaser, who would not be able to collude in the absence of divestitures. With the distribution of assets from the merged party to the purchaser, market power can accordingly be distributed symmetrically. Or, divestitures enable the merged party and the purchaser to have multi-market contacts. Both symmetry and multi-market contacts facilitate collusion.

In this section, the reasons why the merged party and the purchaser collude are explored, followed by a simple example to demonstrate how collusion can be arranged between the merged firm and the purchaser of the divested assets. Such an example is analysed from the perspective of bargaining theory. The answers to these questions are expected to provide us with some insights to better understand why divestitures can lead to collusion risks between the merged firm and the purchaser, as well as to shed light on the possible solutions to reduce the post-divestiture collusion risks.

\subsection{Competition or Collusion}

When exploring why collusion risks occur between the merged party and the purchaser of the divested assets, starting with the basic question of why firms compete may provide us with some insights. Baker tried to answer this question from two perspectives: legal and economic. ${ }^{1112}$ It was first assumed that firms compete because laws required them to do so. However, this assumption was overthrown since the author further argued that although competition was protected and promoted by anti-trust law, it was not mandatory. ${ }^{1113}$ Firms, such as those producing luxury products, can charge prices that are far above the competitive level, whereas the anti-trust law does not disapprove of such behaviour. Further, it is possible that other competitors in the market raise their prices for certain products simply because they anticipated that the leading firms would raise their prices

\footnotetext{
1111 ibid, 22.

1112 See: Baker (n 1059) 157.

1113 ibid, 157.
} 
rather than because of any agreement or collusion. In other words, the act of raising prices in itself does not violate anti-trust law.

In fact, firms compete for economic reasons. In short: payoffs drive behaviour. ${ }^{1114}$ Between competition and collusion, rational firms will choose an option which can bring them more profits. ${ }^{1115} \mathrm{It}$ is quite common that firms compete with each other by lowering their prices. According to the theory of demand and supply, sales are predicted to rise if firms lower their prices, potentially resulting in more profits. Firms are willing to compete by lowering prices as long as the additional profits made from selling more products exceed the lost profits incurred due to the price cuts. ${ }^{1116}$

This is true especially when the customers are sensitive to the price changes, and the general price in the market for certain products is above the competitive level (high profits). By slightly lowering the prices, firms can make more profits from the increased sales. Generally, how much firms can earn from competition by lowering prices depends on the specific markets and industries involved, or whether and to what degree consumers have concerns about the price changes. This also to some extent explains why competition in certain industries is fiercer than in others. Accordingly, firms (including the merged party and the purchaser) are willing to engage in competition if the resulting profits are higher than those derived from non-competing situations.

However, in some situations firms engage in competition by offering extremely low prices. Such predatory pricing strategy can be used by firms to squeeze out other competitors, so that they can make long-term high profits by seizing market shares, obtaining a dominant position in the market, or creating/increasing entry barriers. ${ }^{1117}$ Furthermore, predatory prices also enable firms to obtain the exclusionary long-term effects - e.g. reputation and financial effects - at the cost of sacrificing the current profits. ${ }^{1118}$ However, the predatory pricing strategy might not be rational. Whether firms can maximise their long-term profits by sacrificing the current profits to squeeze out other competitors also depends on other factors, such as the entry barriers to the relevant market. Other firms may consistently enter the market if the entry barrier is low, meaning that firms engaging in a predatory pricing strategy can find it difficult to squeeze out their competitors.

Accordingly, if there exists a way which is more attractive to them in the sense of making more profits at lower costs, it is reasonable to predict that firms will choose "such a way" rather than lowering their price (or even use predatory pricing strategy). Firms can coordinate with each other and reach an "agreement" (explicit or tacit) to sustain a higher price above the competitive level. As pointed out before, to reach collusion, the following conditions have to be satisfied:

- Firms have to bargain with each other over the prices that are more attractive than price-cutting, and share the same goal that they want to achieve; ${ }^{1119}$

- There must be a mechanism which enables firms to detect any cheating in a timely manner; ${ }^{1120}$ and

\footnotetext{
1114 Kovacic and others (n 1100) 2.

1115 In general, most of the firms in the market care a lot about their profits. However, it is noteworthy that not all firms only care about profits. Firms can also care about their reputation or the effects of their products on the environment.

${ }^{1116}$ Baker (n 1059) 158.

1117 Predatory pricing can violate competition law since it can be deemed as an abuse of dominant position.

1118 John Vickers, 'Abuse of Market Power' in Paolo Buccirossi (ed), Handbook of Antitrust Economcis (The MIT Press 2007) 419.

1119 Baker (n 1059) 158.

${ }^{1120}$ Motta (n 1070) 140
} 
- A reliable punishment should follow a deviation, which can provide sufficient deterrence effects. ${ }^{1121}$

Baker argued that firms compete when they cannot overcome difficulties in satisfying these conditions of collusion. ${ }^{1122}$ Since reaching such "agreement" also involves transaction costs, we further argue that collusion is more attractive than competition to firms if, first, the payoffs a firm can obtain are larger than what it can gain from competition; second, if the costs for reaching an "agreement" do not exceed the benefits it can bring.

The following section presents a very simple example to describe how collusion can be arranged in the context of merger divestitures. That is, the merged firm and the purchaser of the divested assets agree that the purchaser stops engaging in price competition, so that the merged firm can make more profits from increased sales resulting from slightly lowered prices. Then by splitting the payoffs, both of them can benefit. By analysing from the perspective of bargaining theory, we can better understand how divestitures can facilitate collusion in terms of increasing the efficiency of bargaining and reducing transaction costs.

\subsection{An Example of Collusion: from the Perspective of Bargaining Theory}

To realise a post-divestiture collusion between the merged firm and the purchaser, they have to reach a consensus over the prices which should be more attractive than undercutting prices, as well as other details, such as a reward mechanism reward or a punishment mechanism. Accordingly, bargaining will occur between firms.

A bargaining situation is a situation where two or more parties have an interest to cooperate, while they have no idea how to cooperate. ${ }^{1123}$ Bargaining thus refers to any process through which the parties try to reach an agreement. ${ }^{1124}$ There are at least two factors that can influence the parties' incentives to bargain, namely, efficiency and distribution. ${ }^{1125}$ If bargaining involves excessive transaction costs that outweigh the benefits from cooperation, then the bargaining can be deemed as inefficient and the parties may withdraw from bargaining. Moreover, if the distribution of the cooperative surplus (referring to the value created by exchanging resources from one party to another party who values the resources more ${ }^{1126}$ ) is unacceptable to even one of the parties, the bargaining party (parties) will also give up the bargaining.

As a result, collusion can be more profitable than competition only if such collusion is efficient and the distribution of cooperative surplus is acceptable to all the firms involved. An example of collusion is presented as follows in post-divestiture context.

\section{An Example of Collusion}

Suppose that firm A and firm B are allowed to merge by divesting a certain amount of assets to the purchaser - firm $\mathrm{C}$. The merged firm has to divest assets to the buyer, so that their post-divestiture joint profits can be represented as: $\mathrm{Vm}-\mathrm{Vd}$, where $\mathrm{Vd}$ means the profits that can be generated from the divested assets. The profits for the purchaser after divestitures are thus: $\mathrm{Vp}+\mathrm{tVd}, \mathrm{t}>0$. To simplify the process, we omit the potential cost savings that can be generated from the merger. Moreover, $t$ here refers to a variable that

\footnotetext{
1121 ibid.

1122 Baker (n 1059) 159.

1123 Abhinay Muthoo, 'A Non-Technical Introduction to Bargaining Theory' (2000) 1(2) World Econ 145, 146.

1124 ibid, 147.

1125 ibid.

${ }^{1126}$ Cooter and Ulen (n 771) 75.
} 
describes the change of the divested assets' value to the purchaser. First, it should be more than zero, which means that the value of the divested assets should be positive to the buyer, otherwise the buyer will not purchase them. Second, if $0<\mathrm{t}<1$, it means that the divested assets are more valuable to the merged party than to the purchaser. Or, if $t \geq 1$, it means that the value of the divested assets for the purchaser is equal to or more than for the merged party.

If the merged party and the buyer compete vigorously, there is a likelihood that a price war can follow. Both of the parties choose to lower their prices as a (short-term) strategy in order to seize market shares. Accordingly, profit differences between the merged firm and the buyer can be small. However, if they can reach an (tacit or explicit) "agreement", they might make more profits. Hence, further assume the following situations:

a. no asymmetric information between the merged party and the buyer concerning their respective payoffs in both situations of cooperation and non-cooperation;

b. the transaction costs involved in bargaining do not outweigh the benefits they would get from cooperation;

c. both parties agree upon the distribution plan regarding the profits; and

d. customers in the relevant market are sensitive to price changes.

The purchaser and the merged firm can agree that, first, the purchaser will not engage in price competition; second, the merged firm will transfer a certain percentage of its profits to the purchaser. As a result, the merged party can make more profits by slightly lowering its prices, resulting in more profits. By transferring part of the profits from the merged firm to the purchaser, the joint profits are maximised and both firms make more profit than they earn when competing. The following table illustrates the above-mentioned collusion.

Table 7 Cooperative and Non-Cooperative Profits after Divestitures

\begin{tabular}{lll}
\hline & Monthly Profits of the Merged Firm & Monthly Profits of the Purchaser \\
\hline If compete & 5 million & 3 million \\
\hline If cooperate & 8 million & 2 million \\
\hline Profits differences & $\begin{array}{l}\text { If compete: } 2 \text { million } \\
\text { If cooperate: } 6 \text { million }\end{array}$ \\
\hline Total non-cooperative profits & $(\mathrm{Vm}-\mathrm{Vd})+(\mathrm{Vp}+\mathrm{tVd})=8$ million \\
\hline Total cooperative profits: & $(\mathrm{Vm}-\mathrm{Vd})+(\mathrm{Vp}+\mathrm{tVd})=10$ million \\
\hline
\end{tabular}

Table 7 indicates that when the merged party competes with the purchaser vigorously, the buyer is supposed to manage to seize some of market share, resulting in small profit differences between the merged firm and the buyer. When they collude, the purchaser agrees not to engage in price competition. As a result, the merged party can make more profits than what it earns from competition by slightly lowering its prices. Meanwhile, the purchaser makes fewer profits in the situation of cooperation because the consumer opts for the merged firm' products due to the lower prices. A reduction in the purchaser's sale leads to a reduction in its profits.

It is observable that the total cooperative profits are larger than that in the noncooperative situation. In other words, if collusion can be reached, both the purchaser and the merged party can make more profit. Further, whether they can reach collusion depends on, for example, whether the distribution of the cooperative surplus is acceptable to both parties. The following table gives an example, describing how the distribution can be arranged. 
Table 8 Distribution of Profits Gained from Cooperation

\begin{tabular}{lll}
\hline & Profits of the Merged Party & Profits of the Purchaser \\
\hline Before distribution & 8 million & 2 million \\
\hline After distribution & 8 million -1.5 million=6.5 million $>5$ & 2 million +1.5 million $=3.5$ million $>3$ \\
& million (profits in non-cooperation) & million (profits in non-cooperation) \\
\hline
\end{tabular}

It can be observed from Table 8 that when the merged firm and the purchaser bargain over the distribution of the cooperative surplus, the merged party can transfer as much as 1.5 million of its profits to the buyer, resulting in its own profits as 6.5 million and the buyer will thus gain 3.5 million. By arranging the distribution like this, both the merged party and the buyer are able to get higher profits than what they will get in the non-cooperative situation.

Moreover, according to bargaining theory, outside options and inside options can also influence the outcomes of bargaining. ${ }^{1127}$ For example, a married couple can bargain over whether they should divorce. There will be an outside option if either husband or wife meets someone who seems to be more attractive to them than each other. In contrast, the inside option would be the payoffs they gain from sustaining the marriage. In the context of the bargaining between the merged party and the buyer concerning whether they should cooperate after the completion of divestitures, outside options can be understood as the payoffs that parties would gain from not reaching an agreement; while the inside options can be understood as the payoffs they would obtain from the cooperation agreement. The key principle concerning outside options and inside options is that: first, when both parties' outside options are sufficiently unattractive, a player facing more attractive inside options will have higher bargaining power; second, when both parties' outside options are sufficiently attractive, then it is mutually beneficial for the parties to execute the outside option; third, when one party's outside options are sufficiently attractive, both parties' inside options will no longer have any impact on the outcome of bargaining and the one with sufficiently attractive outside options will be in a more favourable position. ${ }^{1128}$

Therefore, outside options can be the profits that the merged party and the purchaser would make respectively when they compete with each other; while inside options are the distributed profits they would receive in the situation where they decide to cooperate and collude. According to the above-mentioned key principles, the merged party and the buyer's inside options will play the key role in determining the bargaining outcome when their outside options are sufficiently unattractive, compared to their inside options. Considering the fact that both parties want to maximise their profits, it can be predicted that they are very likely to choose to cooperate rather than competing with each other.

It is assumed at the beginning of this section that there is no asymmetric information between the merged party and the buyer, and the transaction costs (at least) do not outweigh the benefits that are generated from the parties' cooperation. In fact, these two factors are interlinked. To be exact, asymmetric information can largely increase the transactions by resulting in a delayed outcome. It is argued that bargaining is especially inefficient when there is information asymmetry between the bargaining parties. ${ }^{1129}$ Excessive duration of negotiations between bargaining parties to reveal the private information, such as the party's (parties') payoffs from successful bargaining, can protract a bargain, resulting in high transaction costs. In addition, there are also empirical studies

1127 See: Muthoo (n 1123) 158.

1128 ibid, 158.

${ }^{1129}$ Joseph Farrell, 'Information and the Coase Theorem' (1987) 1(2) J Econ Perspect 113, 115. 
which support that bargaining parties will bargain to a joint-profit-maximising outcome, when there is full information between two or three bargaining parties. ${ }^{1130}$ Evidently, in reality, it is rather difficult to satisfy the conditions of no asymmetric information and low transaction costs when the buyer bargains with the merged party. However, divestitures can facilitate collusion since they can create conditions which can to a great extent reduce information asymmetry and transaction costs. This point will be discussed in sec. 4 below.

\subsection{Summary}

It can be concluded that, first, firms are likely to compete for economic reasons rather than legal ones. Most firms are profit-driven, which can have a large impact on their choice between competition and collusion. They are very likely to collude if it can bring them more profits than competition. Second, by analysing the example from the perspective of bargaining theory between the merged party and the purchaser, it is observed that both parties can earn higher profits when they collude rather than compete, by distributing the profits from the merged party to the purchaser. Third, an agreement is more likely to occur if the bargaining is efficient and the distribution of the cooperative surplus is acceptable to the bargaining parties.

It is worth pointing out that the collusion described in sec.3.2 just serves as a simple example to show how collusion can be arranged between the merged firm and the buyer to maximise their joint profits. As explained at the beginning of sec.3, despite the fact that mergers can bring about coordinated effects, such as the possibility of collusion between the merged firm and any non-merging party in the market, divestitures can make collusion between the merged firm and the purchaser of the divested assets more likely, because divestitures can create conditions for such collusion. Sec. 4 thus focuses on the collusionfacilitating outcomes that can result from merger divestitures.

\section{How Divestitures Facilitate Collusion between the Merged Party and the Purchaser and Possible Solutions}

Similar to the assumption in sec.3, suppose that after the completion of divestitures, the market power the merged firm would have can be written as: $\mathrm{Vm}-\mathrm{Vd}$. The purchaser's market power would be: $\mathrm{Vp}+\hat{\mathrm{V} d}(\mathrm{t}>0)$. Thus, both parties' total market power after

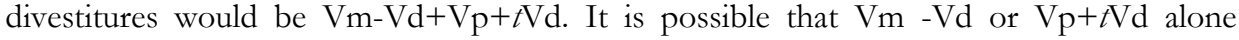
would not cause any competitive concerns, whereas $\mathrm{Vm}-\mathrm{Vd}+\mathrm{Vp}+\hat{\mathrm{V} d}$ can generate anticompetitive effects. In other words, the merged firm or the purchaser alone will not be able to cause any impediment to competition. However, if they collude, the concentrated market power may harm competition in the relevant market. Exploring how divestitures facilitate collusion can shed light on the solutions to reduce such risks.

\footnotetext{
${ }^{1130}$ Elizabeth Hoffman and Matthew L. Spitzer, 'The Coase Theorem: Some Experimental Tests' (1982) 25(1) Journal Law Econ 73, 95. See also: (for example) Elizabeth Hoffman and Matthew L. Spitzer, 'Experimental Tests of the Coase Theorem with Large Bargaining Groups' (1986) 15(1) J Legal Stud 149; Farrell (n 1129).
} 


\subsection{Collusion-Facilitating Factors Caused by Divestitures}

\subsubsection{Symmetry}

Symmetry has been recognised as a factor that can facilitate collusion, meaning that firms in a similar position with similar resources are more likely to cooperate with each other to ameliorate their situations. ${ }^{1131}$ Different parties' similar resources, such as a business network or financial ability, are expected to surmount the problem of "who takes more advantage of the other's resources". Due to their similar position, they can make use of their concentrated resources to the maximum extent and thus collectively improve their performance.

Divestitures do not simply involve a transfer of business from the merged party to the purchaser. It can exert a more profound impact on the seller and the purchaser because what the merged party divests is not only the business itself, but also the abundant resources bound to the business, such as stable customers of certain popular products, cost-savings that can be generated from the innovative technology, potential high profits which can be made from exclusive patents or high reputation among customers derived from well-known brands, etc. All these resources can be seen as various dimensions of symmetry.

Divestitures can lead to symmetry between the merged party and the purchaser by distributing the above-mentioned resources symmetrically between them. Such similarities can reduce the information asymmetry between these parties concerning, for example, producing costs or commercial strategies.

Symmetry can especially facilitate collusion when the purchaser is an existing competitor in the market. This is because, generally, such an existing competitor is active in the same product market concerned or the same geographic market concerned before purchasing the divested business; or it has already been a head-to-head competitor of the merged firms. The purchaser has rich experience in the relevant industry that the divested business concerns; or it has its own stable customers or mature management system. It is generally believed that all these above-mentioned factors can enable the purchaser to have the ability to operate the divested business vigorously. Once it purchases the divested business, it is conferred with more resources which can lead it to a more advantageous position to compete with the merged party, so that competition is expected to be restored.

On the other hand, such expectation sometimes cannot be fulfilled because the advantages of being a suitable purchaser can also be the disadvantages that can cripple the effectiveness of divestitures. For an existing competitor who is already active in the market before the merger and divestitures, divestitures can distribute resources or even market power symmetrically between the merged firm and the buyer. Such similarities confer upon the merged firm and the purchaser similar market positions, which can reduce information asymmetry between them. Furthermore, a reduction in information asymmetry is conducive to reduce bargaining costs.

Moreover, theoretical literature also argues that asymmetry can hinder collusion. For example, as described in the literature review section in this chapter, Compte, Jenny and Rey have suggested in the context of mergers that asymmetries in capacity constraints between parties may be pro-competitive becasue such asymmetries hurt tacit collusion. ${ }^{1132}$ Fonseca and Normann further provided experimental evidence to support Compte, Jenny

${ }_{1131}$ Motta (n 1070) 147.

1132 See: Compte, Jenny and Rey (n 1106). 
and Rey's argument. ${ }^{1133}$ Besides, Vasconcelos suggested that a merger can hinder collusion if it increases asymmetry concerning producing costs among competitors. ${ }^{1134} \mathrm{Kuhn}$ argued that findings that 'asymmetries in capacity or asset holdings can hinder collusion' cannot be generalised and understood as all asymmetries can hinder collusion; moreover, increased symmetry does cause significant coordinated effects. ${ }^{1135}$

Accordingly, it is safe to conclude that, first, merger remedies which aim at increasing symmetry in the post-merger market can be problematic. ${ }^{1136}$ Second, divestitures facilitate collusion between the merged party and the purchaser because they can distribute resources symmetrically between them. Given that asymmetry can hinder collusion, the symmetrically distributed resources can result in the occurrence of collusion. Third, symmetry can facilitate collusion between the merged party and the purchaser, especially when the purchaser is an existing competitor in the relevant market. ${ }^{1137}$

\subsubsection{Multi-Market Contacts}

"Multi-market contacts" has been identified as another factor that facilitates collusion. ${ }^{1138}$ As the name suggests, it refers to the situation where 'the same firms meet in more than one market'. ${ }^{1139}$ Markets refer to both product markets and geographic markets. An example of a multi-market contact is that firm A and firm B both are active in manufacturing cars. Further, both of them also produce tyres. In this example, firm A and firm B have multi-market contacts in the manufacturing industry of both cars and tyres.

A divestiture package can consist of various assets. They can be tangible or intangible, such as trademarks which enjoy high reputation among customers, innovative technology that can generate cost-savings, or physical manufacturing facilities for certain products. By purchasing the divested assets, the purchaser is given the opportunity to enter into a different product or geographic market which it has not operated in before. As a result, after purchasing the divested assets, the purchaser and the merged party may operate in the same product or geographic market.

Multi-market contacts between the merged party and the buyer can further facilitate their collusion for at least two reasons. First, multi-market contacts provide the parties with an opportunity to obtain the other parties' private information. For example, before purchasing the divested assets, the merged party and the purchaser operate in different geographic areas and produce similar products. After the completion of divestitures, they can operate in the same geographic market and thus share the same supplier within that area. It is possible that by cooperating with the same supplier for a long term, they can indirectly acquire some private information concerning, for example, prices for raw materials, production costs, estimated profits, etc. As mentioned, in the context of bargaining, information is one of the most important factors to reach an agreement. Moreover, revealing private information can be time-consuming and involve large transaction costs, whereas multi-market contacts reduce such costs. Accordingly, through contacts in multimarkets, it can be easier for the parties to reach an agreement.

\footnotetext{
1133 See: Miguel A. Fonseca and Hans-Theo Normann, 'Mergers, Asymmetries and Collusion: Experimental Evidence' (2008) 118(527) Econ J 387.

1134 See: Vasconcelos (n 1108).

1135 Kuhn (n 1058) 119.

${ }^{1136}$ Fonseca and Norman (n 1133) 398.

1137 See: Motta, Polo and Vasconcelos (n 857) 113.

1138 Ivaldi and others (n 1068) 48.

${ }^{1139}$ Motta (n 1070) 148.
} 
Second, multi-market contacts cripple the isolation of different markets and facilitate collusion which would otherwise not occur. ${ }^{1140}$ To illustrate this, assume that both the merged firm and firm $\mathrm{C}$ are two firms based in area $\mathrm{X}$, which produce bottled mineral water. The market shares they account for are $65 \%$ and $15 \%$ in that area, respectively, suggesting that there is strong asymmetry concerning market shares between these two parties. Further, according to observations obtained from relevant research (see literature review), it has been proved that asymmetry can hinder collusion. Thus, it is hard for the merged party and firm $\mathrm{C}$ to collude in area $\mathrm{X}$ due to the strong asymmetry of market shares.

In order to receive approval from the $\mathrm{CA}$, the merged party divested a production line of several brands of bottled mineral water in area $\mathrm{Y}$ while firm $\mathrm{C}$ purchased the divested assets. As a result, firm $C$ (the purchaser) obtains the entry of bottled mineral water market in area $\mathrm{Y}$. In area $\mathrm{Y}$, after the completion of divestitures, the merged party and the purchaser's market shares are $15 \%$ and $65 \%$, which is just the opposite to that in area $\mathrm{X}$. Again, if both parties only meet in area $\mathrm{Y}$, they are very likely not to collude because of the strong asymmetry. However, meeting in both area $\mathrm{X}$ and area $\mathrm{Y}$ enables the parties to collude. This is because when considering whether they should cooperate, the merged party and the purchaser will take their market shares in both areas into consideration as a whole rather than separating them. Put differently, the total market shares for the merged party in area $\mathrm{X}$ and area $\mathrm{Y}$ are $80 \%$, which is equal to the purchaser's. Moreover, if the parties collude, there will be a high likelihood that a joint dominance will follow, which would hurt competition as well as consumer welfare. Multi-market contacts thus can facilitate collusion which would not occur in individual markets by softening asymmetries.

Overall, divestitures enable the purchaser to have multi-market contacts with the merged firm, which provide the parties with the opportunities to obtain each other's private information and soften asymmetries in individual markets. Revealing private information increases the efficiency of collusive bargaining and leads to a reduction in transactions costs, while reduced isolation of different markets increases symmetry between firms, incentivising them to collude.

\subsubsection{Continuing Relationships}

Divestitures sometimes require a continuing relationship between the merged firm and the purchaser, meaning that the merged party supports the purchaser to help it with the operation of the divested assets. For example, they may reach a cooperative agreement, in which the merged firm has to keep providing the purchaser with certain resources for a certain period to ensure that the purchaser can be independent in producing such resources.

Although a continuing relationship is expected to help the purchaser to operate the divested business better, such cooperative agreements/continuing relationship can facilitate collusion ${ }^{1141}$ between the merged firm and the buyer for at least two reasons.

First, information asymmetry is reduced due to the continuing relationship. Collusion requires firms to first reach an agreement on the prices and the achievable goals. The example in sec.3.2 shows that firms' incentives to bargain partially depend on whether the bargaining is efficient. A bargain will be regarded as inefficient from the perspective of firms if an agreement is struck with considerable delay, involving large transaction costs. Put differently, the efficiency of bargaining will be increased if firms know what each other's payoffs will be in the situation of both cooperation and non-cooperation.

\footnotetext{
1140 See: Ivaldi and others (n 1068) 48; Motta (n 1070) 149; Motta, Polo and Vasconcelos (n 857) 114.

${ }^{1141}$ Ivaldi and others (n 1068) 54.
} 
The continuing relationship provides the merged party and the purchaser with the opportunity to exchange information concerning prices or sales explicitly or implicitly. Since there is less information asymmetry due to the continuing relationship, the efficiency of a bargain is increased, resulting in a timely "agreement". In other words, collusion is thus facilitated.

Second, the continuing relationship increases transparency between the merged party and the purchaser. It is argued that markets are deemed as imperfectly transparent if competitors' actions are unobservable and the demand conditions are sufficiently uncertain, so that competitors' actions are impossible to be predicted from market data. ${ }^{1142}$ Further, it is experimentally proved that a tacit collusion can be inefficient due to the absence of communication (for example, no explicit bargaining over the goals of an agreement). ${ }^{1143} \mathrm{~A}$ failure of coordination can result from the strategy uncertainties, meaning whether a firm will take a collusive strategy depends on others' reasoning. ${ }^{1144}$ Put differently, some firms believe that it is too risky to have the payoff-dominant strategy and thus possibly lower their prices to increase the sales, resulting in more profit; meanwhile other firms incur losses because they adopt a risk-dominant strategy and set collusive prices, which results in a decline in sales. A continuing relationship can increase the efficiency of bargaining by making the firms' actions and strategies predictable and observable to others.

The continuing relationship provides the merged firm and the purchaser with the opportunity to communicate and interact frequently, so that they can obtain each other's private information. Such information enables them to predict each other's potential actions and dominant strategies with more ease.

\subsection{Possible Solutions}

\subsubsection{Consideration of Post-Divestiture Effects}

As studied in Chapter 6 and Chapter 7, composition and value-preserving of the divestiture package during the interim period of the divestiture package, and the suitability of a purchaser are three key factors when designing and implementing a divestiture to increase its effectiveness. Nevertheless, it is possible that even when a divestiture package is sufficient and a proposed purchaser is suitable, a divestiture can still fail. Imagine that the potential purchaser is experienced in the neighbouring market with strong financial strength. By purchasing the divested business, it gains entrance into another market, resulting in multi-market contacts with the merged firm; or by purchasing the divested business, the buyer will be in a symmetric market position with the merged firm, or after divestiture, a continuing relationship is needed between the merged firm and the purchaser to support the purchaser's operation of the divested business. These resulting factors, as discussed above, can facilitate collusion especially between the merged firms and the buyer.

Hence, when designing a divestiture, attention should be paid to the potential postdivestiture effects, such as, the market position that the purchase will enjoy after the completion of divestitures, or the effects the divestiture will have on the structure of the market if the divested business is purchased by the proposed purchaser. In practice, this

\footnotetext{
1142 See: Edward J. Green and Robert H. Porter, 'Noncooperative Collusion under Imperfect Price Information' (1984) 52(1) Econometrica 87.

1143 See: John B. Van Huyck, Raymond C. Battalio and Richard O. Beil, 'Tacit Coordination Games, Strategic Uncertainty, and Coordination Failure' (1990) 80(1) Am Econ Rev 234.

${ }^{1144}$ Kuhn (n 1058) 125.
} 
consideration is closely linked to the choice of a qualified buyer to ensure that the abovementioned collusion-facilitating conditions will not be created.

\subsubsection{Evaluations of the Purchaser's Incentives}

Another solution to reduce post-divestiture collusion risks between the merged firm and the purchaser is that an assessment should be made concerning the proposed purchaser's incentive to compete when determining its suitability.

Although it can be difficult to assess the purchaser's incentives to compete, the price negotiations between the merged firm and the purchaser can to some extent reflect the purchaser's incentives. Generally, the more profit it expects to make from the divestiture package, the higher the price it will be willing to pay for the divestiture packages, and the more it cares about the price negotiations. Comparatively, if a purchaser has few interests in operating the divested business or it has the intention to collude with the merged firm or has a soft pricing policy, it may be willing to pay limited prices for the divested assets or it will put less emphasis on the price negotiations. Further, it is a bad sign if the purchaser pays nothing for the assets. ${ }^{1145}$

Considering that prices can to some extent reflect the buyer's incentives to compete, the CAs should be kept informed about the process of price negotiations between the merged firm and the purchaser. The agencies can be aware of whether the purchaser has the incentive to compete, so that collusion between the purchaser and the merged firm can be reduced in the first place by avoiding selecting a purchaser who lacks incentives to compete. ${ }^{1146}$ By requiring the merged firm and the purchaser to report relevant information during price negotiations, the agencies can thus be informed.

\subsubsection{Monitoring Required When a Continuing Relationship is Needed}

Divestitures involving a continuing relationship between the merged firm and the purchaser should be evaluated with extra care, and monitoring can be included before the completion of divestitures.

It is understandable that transitional services or supportive information can be needed on a lasting basis in some situations. As described above, such support is supposed to help the purchaser better operate the divested business. However, these services and information can result in a close relationship between the merged firm and the purchaser, which can facilitate collusion. For example, after the divestment, due to the lasting and/or close relationship, the merged firm can still have the purchaser's information concerning sales data. ${ }^{1147}$

One of the most direct ways to avoid such risks is to avoid a continuing relationship. That is, when evaluating the suitability and sufficiency of the merging parties' proposed divestiture package, the CA can require the merging parties to provide other assets which will not involve a continuing relationship. In some situations, however, a continuing relationship is inevitable due to the specific characteristics of the industry concerned. An example would be industry concerning hi-technology, where supportive service will be a must before the purchaser is able to fully understand and make use of such technology. Thus, another method to solve collusion risks caused by the continuing relationship is by monitoring.

\footnotetext{
1145 Farrell (n 862) 97.

1146 See: Papandropoulos \& Tajana (n 617); Farrell (n 862).

1147 Turk (n 1084) 338.
} 
Considering that the competition agencies may not have enough time and energy to carry out monitoring by themselves, such monitoring can be realised by trustees. A trustee can be appointed to work for the agencies, and he can be authorised to look up relevant information, documents that the merged firm provides to the purchaser. Trustees can monitor whether the merged firm and the purchaser exchange confidential business data and information which can be helpful to reach collusion. By appointing a trustee, the competition agencies are allowed to get a good grasp of the on-going relationship and the degree of information sharing between the merged firm and the purchaser. ${ }^{1148}$

\section{Post-divestiture Collusion Risks in the US and the EU}

\subsection{Recognition of and Solutions to Post-Divestiture Collusion Risks}

\subsubsection{US}

Both the FTC and the DOJ have published some policy guides, which conclude the status quo of the merger remedies, provide guidance concerning the CA's remedies policies, and give suggestions and recommendations to ameliorate the merger remedies. Such study and policy guides include: the 1999 FTC Divestiture Study, ${ }^{1149}$ the 2012 FTC Remedies Statement, ${ }^{1150}$ and the 2011 DOJ Policy Guide, 1151 which are explored from the perspective of recognition of, and solutions to, collusion risks in this section.

\subsubsection{FTC}

The 1999 FTC Divestiture Study

In the 1999 FTC Divestiture Study, the FTC identified some obstacles which reduce the effectiveness of divestitures and further provided suggestions to overcome these obstacles. The FTC pointed out that the buyer's interests can be different from the FTC's. ${ }^{1152}$ There can be two reasons for the divergence.

First, cooperation with the merged firm can bring the purchaser benefits. For example, the purchaser benefits from transitional arrangements provided by the merged firm after the divestment, so that it decides to continue such arrangement after the transitional period ends. By doing this, both the merged firm and the purchaser can get benefits. However, it is possible that such continuing relationship results in an implicit cooperation rather than in competition.

Second, the purchaser may lack incentives to compete in the market because the reason why it bought the divested business is to make use of the divested business to develop its other products, or to make a profit by re-selling it. In other words, the purchaser is incentivised to buy the divested business for other reasons than competition.

The FTC also stated in the Divestiture Study that divestitures should be designed to ensure the buyer's competition with the merged firm rather than cooperating or colluding. ${ }^{1153}$ It suggested that divestitures can facilitate collusion between the merged firm

\footnotetext{
1148 ibid, 338.

11491999 FTC Divestiture Study (n 38).

11502012 FTC Remedies Statement (n 36).

11512011 DOJ Policy Guide (n 56).

11521999 FTC Divestiture Study (n 38) 26.

1153 ibid, 27.
} 
and the purchaser because the post-divestiture continuing relationship can lead to implicit partnership between the merged firm and the purchaser, and a lack of incentives to compete can also reduce the effectiveness of divestitures.

\section{FTC Remedies Statement}

The FTC published a new version of the Merger Remedies Statement in 2012, which replaced the 2003 version. In the Statement, the FTC emphasised the suitability of a buyer when it explored the question of how to ensure the effectiveness of divestitures from the perspective of the buyer, and it identified that divestitures can cause additional competition issues when a continuing relationship is needed, and provided solutions to solve the issues.

\section{(1) Limiting the duration of a continuing relationship and appointing trustees}

The FTC identified that when the divested assets are primary the intellectual property or other intangible assets (such as licences), it is likely that transitional arrangements and services, such as supply agreements, technical assistance, or other supportive information are needed. The agency further identified that a continuing relationship can also be needed when the divested assets are not stand-alone and on-going, requiring the merging parties to provide additional assistance to the buyer. ${ }^{1154}$ In the 2012 FTC Remedies Statement, the FTC explicitly pointed out that such a continuing relationship can cause competitive issues and thus requires complex monitoring. ${ }^{1155}$

As described in the previous section, a continuing relationship between the merged firm and the buyer can facilitate collusion. In order to reduce collusion risks caused by the continuing relationship, the FTC specified that it will attempt to avoid transitional services to ensure that a continuing relationship will not be developed. Further, if such postdivestment supports are inevitable, the staff of the FTC will at least seek to shorten the duration of these agreements and may require independent monitoring. ${ }^{1156} \mathrm{~A}$ trustee can hence be appointed to carry out such monitoring. ${ }^{1157}$ Such trustees work for the agency and serve as the "ears and eyes" of the agency.

These solutions which the FTC uses are in accordance with what has been discussed in the sec.4.2.3. Accordingly, collusion risks resulting from a continuing relationship can be effectively reduced by the FTC's solutions. That is, monitoring the on-going relationship between the merged firm and the purchaser to ensure that they comply with their obligations by appointing a trustee if necessary.

\section{(2) Requirements for a suitable purchaser}

A purchaser will be accepted by the FTC if, first, it has the financial capability and incentives to purchase and operate the divested assets; and second, it has the ability to compete with the merged firm to restore competition in the market. ${ }^{1158}$

The pre-conditions for the purchaser to compete with the merged firm after the completion of divestitures are that it must have both sufficient financial ability and incentives. Accordingly, the above-mentioned requirements set by the FTC can ensure that only those purchasers who have financial ability and incentives to compete will be approved.

\footnotetext{
11542012 FTC Remedies Statement (n 36) 16.

1155 ibid, 9 .

1156 ibid.

1157 ibid, 16.

1158 ibid, 10 .
} 
(3) Recognition of the buyer's different objectives from the FTC's

In the Statement, the FTC indicated that when evaluating the terms of the divestiture agreement, it will mainly consider the information it gets from the buyer. Nevertheless, the staff of the FTC will not rely on the buyer's information solely, considering that sometimes the buyer's interests and incentives are different from the FTC's objectives, ${ }^{1159}$ as stated in the 1999 FTC Divestiture Study.

\subsubsection{2. $D O J$}

Similar to the 2012 FTC Remedies Statement, the 2011 DOJ Policy Guide aims to provide guidance to the staff of the Anti-trust Division of the DOJ when they analyse the proposed merger remedies. Regarding the post-divestiture collusion risks, generally, the DOJ analyses this problem from two perspectives: the general goal of divestitures and the requirements for approving a purchaser.

\section{(1) General goal for an effective divestiture}

The DOJ emphasises that the goal of a divestiture is to effectively preserve competition in the market by ensuring that the purchaser has sufficient incentives to compete and it is conferred with sufficient divested assets. ${ }^{1160}$ This implies that the DOJ has been aware that the purchaser's incentive to compete plays an important role in realising the goal of divestitures.

\section{(2) No further competition harms caused by a purchaser}

As a suitable purchaser, it must not in itself cause competition harm. ${ }^{1161}$ Imagine a situation where the notified merger has a high likelihood of leading the merged firm to a dominant position in the market. If the purchaser of the divested business is another large competitor in the market, a joint dominance becomes a possibility. It will become even worse if these two firms cooperate rather than competing. Such post-divestiture collusion risks will not only largely reduce the effectiveness of divestitures, but also cause additional detrimental effects to the competition. Further, to avoid collusion risks, the DOJ pointed out that a new market entrant can be chosen as a purchaser of the divested assets if the notified merger is likely to lead to coordinated effects among the existing competitors in the market. The DOJ argues that a harmful collusion can be caused if a merger leads to the loss of a maverick, which is in accordance with Baker's observation. ${ }^{1162}$ Hence, the divested business will be divested to a firm which, after purchasing the divested business, is similar to the disappeared maverick in terms of having the incentives and interests to compete.

\section{(3) Incentives of the purchaser to compete}

The DOJ observed that there are possibilities that the seller can sell its assets to a weak buyer by sacrificing a higher price to ensure that the purchaser will not become a strong rival. The agency continued its observation by stating that a firm with strong incentives to compete will be willing to accept higher prices. Hence, a weak buyer and an aggressive buyer can be differentiated by observing the prices that they are willing to pay for the divested assets. Moreover, the weak buyer can simply aim to make profits by reselling the divested business rather than operating it. Since these wrong incentives can reduce the

\footnotetext{
1159 ibid, 13.

11602011 DOJ Policy Guide (n 56) 7.

1161 ibid, 28.

1162 ibid, 28 (footnote 54). See also: Baker (n 1059).
} 
effectiveness of a divestiture, the agency requires that a suitable purchaser has to have the incentive to compete with the merged firm.

This approach is in accordance with the solutions that have been discussed in sec. 4.2 above. Prices for the divested business can to some extent reflect the purchaser's incentive to compete. An aggressive buyer is more willing to pay high prices for the divested business than a less aggressive buyer. Although the DOJ has realised this, it does not further deepen its observation by providing any guidance on how to evaluate the purchaser's incentives, whereas an effective solution can be the one which enables the CAs to keep informed concerning the price negotiations between the merged firm and the purchaser.

(4) "Fitness" Test

The DOJ clarified that it will assess the proposed purchaser by performing a "fitness" test. ${ }^{1163}$ It will consider the purchaser's relevant experience and financial ability to determine whether it has the ability and incentives to operate the divested business and compete actively in the market for a long term.

\subsection{2. $E U$}

The 2008 EC Remedies Notice stated that a qualified purchaser should be independent from the seller and have the financial resources, expertise, incentives and ability to operate the purchased business to participate in the competition with the merged firm and other competitors in the market. ${ }^{1164}$

The 2005 EC Merger Remedies Study stated that the general requirements for a suitable buyer would be:

(1) have the proven expertise; (2) financial resources deemed necessary; (3) have the incentives to maintain and develop the divested business as an active competitive force in competition with the parties and other competitors; (4) be independent and unconnected from the parties; (5) should not create new competition concerns, nor increase the risk that the implementation of the commitments will be delayed; and (6) should be expected to receive all necessary regulatory approvals by both competition authorities and other regulatory bodies. ${ }^{1165}$

Among all the requirements, there are three requirements which can reduce postdivestiture collusion risks.

\section{(1) Incentives to compete actively}

The Commission pointed out that the purchaser may lack incentives to actively compete with the merged firm. ${ }^{1166}$ The Commission argued that the lack of incentives is one of the leading reasons that lead to an ineffective divestiture.

According to the Commission's research and investigation, a lack of incentives was detected in different cases. ${ }^{1167}$ For example, first, the purchaser stopped the operation of the divested business shortly after its purchase. Second, the purchaser quickly resold the divested business. Third, the purchaser bought the divested business for a really low price or even for free. Besides, sometimes a divestiture can even cause competition issues

\footnotetext{
11632011 DOJ Policy Guide (n 56) 29.

11642008 EC Remedies Notice (n 35) para. 48.

11652005 EC Merger Remedies Study (n 27) 99.

1166 ibid, 102.

1167 ibid, 103.
} 
because the purchaser operates the divested business half-heartedly. In all these above examples, the purchaser failed to operate and compete actively in the market. It is possible that in these cases, divestitures merely restored the number of competitors in the market to the pre-merger level rather than really restoring competition.

Accordingly, to provide the purchaser with incentives to compete, the Study suggested that, first, a business plan from the purchaser concerning its arrangement to the divested business after purchasing it should be presented to the Commission, as well as to the trustee; ${ }^{1168}$ second, sometimes a smaller new market entrant will be chosen as the purchaser since the Commission observed that small firms may be more aggressive and have more incentives to compete, compared with those large existing competitors. ${ }^{1169}$

These solutions in fact can be effective in reducing collusion risks between the merged firm and the buyer. By requiring the purchaser to submit a business plan, the CA can learn about what the future development of the divested business will be and the trustee can better monitor the purchaser to see whether it complies with the plan. Further, such a business plan also to some extent reflects whether the purchaser is an aggressive buyer or just an "absent-minded" buyer, which provides the CA with a reference to determine whether the purchaser has incentives to compete. Choices of a new and small market entrant reflect that the Commission in fact takes the post-divestiture effects into account when evaluating merger remedies because divesting the divestiture package to a large existing competitor can cause additional competition issues, such as joint dominance.

\section{(2) Independence of a purchaser}

The Commission further identified that the independence of a purchaser can also be important to realise the effectiveness of divestitures. In other words, the purchaser should be independent of and not connected to the merged firm. ${ }^{1170}$ Similar to the CAs in the US, the Commission holds that on-going connections or transitional agreements can result in a continuing relationship between the merged firm and the purchaser. Such a continuing relationship can cause the purchaser's heavy reliance on the merged firm and ultimately results in potential cooperation or collusion between the merged firm and the purchaser.

\section{No new competition concerns}

The EC pointed out that the choice of a purchaser should not create new competition concerns. ${ }^{1171}$ It means that, first, the approval of a purchaser should not give rise to additional competition concerns at the national level. Second, a suitable purchaser from the perspective of the EU competition should also be able to obtain the necessary approvals from the national authorities. Third, a large established purchaser may not be a suitable purchaser due to the possibility of joint dominance, whereas a small player may be more suitable.

Summing up, according to the 2005 EC Merger Remedies Study, the Commission has been aware of collusion risks, although the FTC in the US seems to have a profounder understanding of collusion risks. Solutions have also been proposed by the Commission to solve such risks. However, in the 2008 EC Remedies Notice, collusion risks have not been emphasised sufficiently and thus there is no specific and direct solution.

\footnotetext{
1168 ibid, 104.

1169 ibid.

1170 ibid, 105

1171 ibid, 106.
} 


\subsection{Nestle/Perrier: a Case with a Post-Divestiture Collusion Risk}

Nestle/Perrier was a merger case with an EU dimension which was characterised with a post-divestiture collusion risk mainly caused by symmetry between the large and leading competitors after divestitures. ${ }^{1172}$

In 1992, a notification was made to the Commission in which Nestle proposed to take over Perrier. Nestle was a leading firm that was active in the French bottled water industry with its market share $17.1 \%$ at the time of the merger. ${ }^{1173}$ Perrier was a firm which was also specialised in the French bottled water industry, accounting for $35.9 \%$ of the market shares. ${ }^{1174}$ Evidently, such a merger raised the Commission's competitive concerns and could probably be prohibited since according to the "dominance test" under the 1989 Merger Regulation (1989 MR), a merger would be prohibited if it would 'create or strengthen a dominant position as a result of which effective competition would be significantly impeded'. ${ }^{1175}$

The notifying parties further proposed to divest Volvic, one of Perrier's major mineral sources, to their major competitor, BSN. BSN was another firm active in the French bottled water market, which accounted for a market share of $23 \%$. By proposing such a divestiture plan, the notifying parties aimed to clear the Commission's competition concern because after the divestitures, neither the merged firm ("Nestle+Perrier-Volvic") nor the purchaser ("BSN+Volvic") would be dominant in the market according to the market share test. Theoretically, the "dominance test" under the 1989 ECMR would approve a merger if it would not result in a dominant position of the merged party. However, this divestiture plan was deemed as insufficient to clear the potential anti-competitive effects, given that the Commission at that time was attempting to enlarge the scope of the EU Merger Regulation by explaining the "dominance test" in a way that any merger would be prohibited if it either creates or strengthens the merged firm's dominant position or an oligopolistic dominance in the market. ${ }^{1176}$

Finally, the notified merger was approved by the Commission with an enlarged scope of divestiture. First, Volvic would still be divested to BSN; second, the notifying parties' other famous brands would also be divested to another third party. Such an arrangement raised concerns about the post-divestiture collusion risks mainly because by divesting Volvic to BSN, the capacity constraint was relaxed and distributed symmetrically between large and leading firms in the market. As argued by Compte, Jenny and Rey, such symmetry can facilitate collusion between the merged firm and the purchaser. ${ }^{1177}$ The authors in their article conducted a comprehensive analysis concerning why these divestitures can reduce capacity asymmetry and facilitate collusion. Generally, their conclusions are summarised as follows:

(a) The divestitures (selling Volvic to BSN) maximised the possibility of collusion due to the symmetric distribution of capacity;

\footnotetext{
1172 Case IV/M190, Nestle/Perrier (European Commision Decision)[22 July 22 1992] <http://eurlex.europa.eu/legal-content/EN/TXT/?uri=CELEX\%3A31992D0553> accessed 26 April 2017.

1173 Compte, Jenny and Rey (n 1106) 18.

1174 ibid.

11751989 MR (n 439). This merger regulation has been replaced by the new merger regulation: 2004 EUMR (n 3). In the 2004 version, the substantive test changes from the "dominance test" to the so-called "SIEC test". For a detailed exploration of this point, see: Chapter 3, sec.3.2.

1176 Compte, Jenny and Rey (n 1106).

1177 See: ibid.
} 
(b) The possibility of collusion can be minimised if Nestle merged with Perrier without divesting Volvic to BSN because capacity asymmetry hinders collusion;

(c) The arrangement chosen by the Commission (divesting Volvic to BSN + divesting other brands to another independent firm) can be regarded as a solution that balances between the maximum possibility and minimum possibility for the merged firm and the purchaser to reach collusion. ${ }^{1178}$

Nestle/Perrier is a merger case which fully describes how collusion risks can be caused after divestitures due to symmetric distribution of capacity between firms. Moreover, this case also shows the importance of evaluating the post-divestitures effects in reducing collusion risks and ensuring the effectiveness of divestitures.

\section{Conclusion}

Divestitures can to some degree lead to the occurrence of collusion risks after divestitures. First, restoration of market structure does not directly imply restoration of competition. Competition cannot be restored by simply creating another competitor or by distributing resources between the merged firm and another firm. Second, an inappropriately configured divestiture can even facilitate collusion, especially collusion between the merged firm and the purchaser.

As identified by Stigler and further elaborated by Marshall and Marx systematically, collusion can be realised if firms reach a consensus about the collusive prices, and further determine the mechanisms by which firms can detect and punish deviations. All these details have to be determined by bargaining between firms. During a bargaining process, there are two elements that can determine whether an agreement can be struck with ease, namely: efficiency and distribution. Efficiency means that an agreement is reached through bargaining without considerable delay which involves large transaction costs. Distribution refers to allocating the cooperative surplus between colluding firms.

The reasons why divestitures can facilitate collusion are that divestitures can, generally, reduce the information asymmetry between the merged firm and the purchaser, so that efficiency and distribution problems can be solved. In detail, divestitures can lead to symmetry, multi-market contacts and a continuing relationship between the merged firm and the purchaser, while all these factors have been identified as collusion-facilitating.

Hence, the solutions to reduce the post-divestiture collusion can be summarised as follows:

- Evaluating the post-divestiture effects when assessing the effectiveness of a merger remedy;

- Ensuring that the buyer has the right incentives when purchasing the divested business by monitoring the process of price negotiations;

- Avoiding a continuing relationship between the merged firm and the buyer, or appointing a trustee to monitor such on-going relationship if such relationship is inevitable.

In practice, in general, the CAs in the US and the EU have recognised the postdivestiture collusion risks between the merged firm and the purchaser. They also have introduced solutions to reduce such risks. Both of them mainly focus on assuring the

1178 ibid, 21. 
suitability of a purchaser. Generally, a suitable purchaser should have the financial ability and incentives to operate the divested business and compete in the market. Besides, postdivestiture effects have also been taken into account. The FTC pointed out that a continuing relationship can cause competitive issues and thus requires complex monitoring. ${ }^{1179}$ Moreover, it is identified by the CAs that the buyers can have divergent interests with the agencies'.

The possible problem is that although the CAs in both jurisdictions have considered the post-divestiture effects, it seems that they understand this question from the perspective of the possibility of any creation of joint dominance. Thus, a large established company may not be favoured, whereas a smaller company can be chosen as the purchaser. However, the analysis conducted in this chapter indicates that besides the possibility of joint dominance, considerations of symmetry and multi-market contracts between the seller and the buyer during the assessing of a qualified buyer can also eliminate collusion risks.

Compared with the DOJ and the European Commission, the FTC seems to have a more profound understanding, given that it has indicated the possibility of post-divestiture collusion risks in a more explicit way and applies more straightforward solutions to reduce collusion risks. However, how post-divestiture collusion risks are dealt with in practice in these two jurisdictions and which competition agencies do better in reducing these risks remain difficult questions to answer.

11792012 FTC Remedies Statement (n 36) 9. 



\section{Chapter}

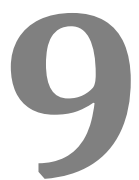

\section{Challenges in REALising THE EFFECTIVENESS OF MERGER REMEDIES}





\section{Introduction}

A merger remedy reflects the CAs' intention of changing the merging parties' behaviour or their structure in order to realise the goals of merger policy, such as promoting efficiencies, protecting consumers or preserving effective competition in the market. Nevertheless, markets often change quickly. Put differently, what the CA tries to do is to assess a proposed merger through merger review procedures and to predict the future competition in the market by ordering merger remedies. However, it actually can be hard to make such predictions given the possibly quickly-changing market. Thus, questions naturally arise: is it justified for the CA to predict the future development of a market by imposing merger remedies when there are considerable uncertainties? Is it realistic to expect that merger remedies can restore competition in this situation?

The answer to the first question may be closely linked to the uncertainties in merger reviews. A merger review, in essence, is about the CA's prediction of whether anticompetitive effects will result from a proposed merger if it is allowed to be implemented. On the one hand, the CA may find it difficult to evaluate the likelihood of a notified merger generating anti-competitive effects because the notified merger has not even been implemented. On the other hand, merger remedies are designed based on the conclusions of the merger reviews. This means that the substantive assessments provide a preliminary answer to the question of whether and to what extent a notified merger should be remedied. Accordingly, the above-mentioned challenge of merger remedies which is likely to be the result of the uncertainties of merger review, raises doubts as to the question whether it is justified for the CA to use remedies as tools to judge the future development of a market.

Regarding the realisation of the goals of merger remedies, one should be aware that it is almost impossible to conclude that one remedy will be one hundred percent successful, regardless of whether the market is changing or not. However, one can attempt to ensure the success of remedies to the extent possible by increasing the requisite degree of certainties when designing a remedy. Chapters 6,7 and 8 exactly explored this point. As a concluding chapter of Part II, therefore, Chapter 9 will explore how to overcome the challenges in merger remedies to the extent possible by recalling and summarising what has been discussed in previous chapters. The reminder of this chapter will be structured as follows.

Following this introduction, sec.2 explores why an ex ante merger review policy is still needed despite the possible uncertainties discussed above. In addition, the CA's investigations and negotiations of remedies are discussed from the perspective of reducing the uncertainties of merger review. Solutions are discussed in sec.3 by focusing on the question of how to increase the required degree of certainties in merger divestitures. The discussion is mainly based on the conclusions of Chapters 6,7 and 8. Lessons learnt from these analyses are summarised in sec. 4 . 


\section{Justifying the CA's Predictions}

\subsection{Justification for an Ex Ante Merger Review Policy}

The uncertainties of merger remedies have a close link to the uncertainties in merger review. Merger review generally is about the CA's prediction of the future development of the notifying parties once the proposed transaction has been implemented. Due to the premerger notification requirements, the $\mathrm{CA}$ has to make such predictions with many uncertainties because the notified mergers have not been implemented. Even if there are uncertainties, it does not suggest that it is not justified for the CA to do so.

Chapter 1 has explored the reason why the ex post policies of competition law prohibitions (such as the abuse of a dominant position and cartel agreements) were inadequate in controlling mergers and why an ex ante merger review mechanism is needed. ${ }^{1180}$ Competition policies, that combat the abuse of a dominant position and antitrust agreements, work ex post, meaning that entities would be punished only after the infringements have been conducted. Nevertheless, detecting and proving an infringement can be difficult. More importantly, controlling mergers by applying such expost mechanism can make the structural disentangling of the merged firm impossible, considering that these firms sometimes can be assimilated with each other so much. Thus, it is justified for the CA to make ex ante assessments before mergers have been implemented to ensure that competition in the market will not be impeded and further require merger remedies when necessary based on its prediction.

\subsection{Investigations}

A merger remedy can be needed to render the possible anti-competitive transaction compatible with merger control policy on the one hand, and to preserve potential efficiencies on the other hand. Whether the proposed transaction will bring anticompetitive effects is the preliminary question that needs to be answered before any merger remedy is used. Although there are uncertainties in ex ante merger control, such uncertainties can be reduced by the CA's investigations.

During the assessment, the CA can collect relevant information from the notifying parties, through its investigations, such as questionnaires and hearings, or from its consultancy with consumers and competitors. These can to some extent alleviate the information asymmetry between the CA and the notifying parties and enable the CA to predict the future development of the merged firm in a comparatively objective and informative way. Besides, the economic toolkits are playing an increasingly important role in merger review. The compelling evidence of this is that a more economic approach is now adopted by the CAs in both the US and the EU (which has been explored in Part I). Economic analysis, to some extent, can serve as a tool to increase the scientific creditability of merger review. ${ }^{1181}$ Considering that a merger remedy is designed based on the CA's substantive assessment, the increasing certainties resulting from reliable substantive assessment can to a large extent lead to the increase of certainties in merger remedies.

\footnotetext{
${ }^{1180}$ For a detailed exploration regarding the justification for an ex ante merger control policy, see: Chapter 1, sec.1.2. ${ }^{1181} \mathrm{It}$ is also pointed out that the economic approach in merger control can also cause different problems, such as the reduction in legal certainty. For a detailed exploration in this regard, see: (for example) Arndt Christiansen, The "More Economic Approach"in EU Merger Control-A Critical Assessment [2005] Working Paper No. 21, Deutsche Bank Research.
} 


\subsection{Negotiations of Remedies}

Although a remedy may be required by the CA, it is the merging parties who should propose a remedy proposal in the first place. ${ }^{1182}$ In other words, merger remedies are not imposed by the CA unilaterally. Negotiations will be followed between the merging parties and the CA regarding the design and implementation. An agreement of a remedy can be struck only if such a remedy can reduce the CA's competition concerns on the one hand, and satisfies the merging parties' development plan by reasonably predicting the concerned market's future development on the other hand.

On the one hand, the CA can be more informed than imagined. Take the FTC and the DOJ as an example. Although the merging parties have to make notifications to both agencies, only one agency can take the responsibility to investigate the notified transaction. The division of responsibility is based on their expertise. ${ }^{1183}$ Put differently, the FTC or the DOJ can be quite familiar with the development and competition situation of certain industries, so that they can reasonably predict the development of the industry within a certain period, can have a better understanding of the issues in the notified transactions, and seek to remedy the issues during the negotiations.

On the other hand, the merging parties, as the market participates, are assumed to have knowledge about the market concerned. To strike an agreement, a merger remedy should be acceptable for both the CA as well as the merging parties to eliminate potential anticompetitive effects on the one hand, and satisfy the reasonable prediction of the concerned market's future development on the other hand. When negotiating a remedy, the merging parties can give their opinions regarding the development of industry or reveal more information, so that the remedies can be designed in a way that can address the competitive concerns in spite of the uncertainties.

Summing up, ex ante merger review policies can remedy the loopholes resulting from the practice of controlling mergers by an expost policy of competition law prohibition. It can be justified for the CA to make its prediction regarding the proposed mergers with uncertainties and further require a remedy when necessary.

It is further justified for the CA to predict the future development of the notifying parties by requiring remedies because the uncertainties in merger review can be reduced by the CA's investigations and the application of economic toolkits. The increasing creditability of merger review may largely enable the $\mathrm{CA}$ to make its decision in a comparatively objective and informative way.

Moreover, detailed negotiations of merger remedies between the CA and the merging parties can reduce the information asymmetry so as to increase the certainties of merger remedies. However, as is pointed out in Chapters 6 and 7, information between the merging parties and the CA is still likely to be asymmetric, although the CA's investigations and negotiations can to some extent reduce this asymmetry. This is also the reason why strategies are needed to ensure the effectiveness of merger remedies.

\footnotetext{
${ }^{1182}$ For example, according to the documents published by the FTC, the DOJ and the EC, it can be noticed that the CAs will assess the appropriateness of a proposed remedy to see whether the proposed remedies can preserve competition. This suggests that a remedy should be proposed by the merging parties in the first place. See: for example, 2012 FTC Remedies Statement (n 36); 2011 DOJ Policy Guide (n 56); 2008 EC Remedies Notice (n 35). ${ }^{1183}$ For the detailed information regarding this point, see: Chapter 2, sec.6.2.1
} 


\section{Increasing the Requisite Degree of Certainties in Divestitures}

It has been explored in this book that risks may arise during the design and implementation of divestitures, which may reduce the effectiveness. These risks include: composition risks, asset risks and collusion risks.

\subsection{Composition Risks}

Composition risks can occur when a divestiture package is too limited in scope or is inappropriately configured, resulting in the unavailability of a suitable purchaser, or the divested assets' incapability of being operated competitively. ${ }^{1184}$

From the perspective of information asymmetry, an explanation for such composition risks concerns hidden characteristics, referring to information that one side of a transaction has and which the other side would like to have but does not. ${ }^{1185}$ In the context of divestitures, it implies that the merging parties, as the insider of the proposed merger, are the more informed party which has more private information than the CA regarding, e.g. the key assets of the divestiture package and the key personnel of the business. Moreover, it is also possible that the merging parties do not reveal all the information to the CA when notifying their transactions.

The CA, as the uninformed party, can reduce such information asymmetry during merger review and the negotiations of merger remedies through its investigations or by requiring the merging parties to submit more documents. Forms of investigations are various, such as consulting experts, soliciting opinions from the merging parties' competitors, industry associations, or consumers. These investigations can to some extent reveal more hidden characteristics. However, information asymmetry can still exist due to the difficulties in obtaining full information. Accordingly, there is a possibility that problems of excessive-divesting or insufficient-divesting can be caused, probably jeopardizing the possible efficiencies. An excessive divestiture means that the merging parties have to divest more assets than necessary, whereas the insufficient divestitures refer to divestitures which would be inadequate to clear all the anti-competitive effects. Therefore, composition risks are more likely to arise when an insufficient divestiture package is required.

In practice, the CAs in the US and the EU use risk-reducing provisions, such as crown jewel provisions or up-front buyer provisions to reduce composition risks. According to the exploration in Chapter 6, such risk-reducing provisions, if designed well, can effectively and efficiently reduce composition risks.

Screening devices can be used by the uninformed party to reveal the informed party's hidden characteristics. Screening devices refer to mechanisms that are used by the uninformed party (e.g. the CA) to differentiate between different informed parties (e.g. the merging parties). ${ }^{1186}$ For example, in the insurance market, we assume that there are two groups of customers: the high-risk group and the low-risk group. The former is more likely to file claims than the latter. In the insurance market with asymmetric information, the customers as the informed party have private information concerning their health conditions or living habits, which is invisible to the uninformed party - the insurance

\footnotetext{
1184 UK Competition Guidelines (n 39) sec.3.3 (a).

1185 Katz and Rosen (n 891) 554.

1186 Stiglitz (n 890) 283.
} 
companies. To differentiate between these two groups, an insurance company may provide two different packages of insurance contracts with different prices and insurance policies. In the packages, the amount of the premium and the coverage in the insurance contracts has already been determined in advance. Thus, the low-risk customers may be willing to take insurance contracts with low premiums and limited coverage, while the high-risk customers choose the insurance with high premiums and wider coverage.

The mechanism of applying risk-reducing provisions in the context of divestitures as screening devices to reduce composition risks is: generally, a divestiture package can be a good (sufficient) one or a bad (insufficient) one. During the merger reviews, if the CA was unsure about the sufficiency of the package, it would require the inclusion of risk-reducing provisions. A divestiture package will be accepted by the CA if the merging parties agree to accept the inclusion of risk-reducing provisions, otherwise a divestiture package will be rejected if the merging parties fail to accept the inclusion of risks-reducing provisions and leave the divestiture package insufficient.

The use of risk-reducing provisions can be efficient if the screening costs involved at least do not outweigh the benefits the notified merger can generate for the merging parties, as well as for the consumers.

\subsection{Asset Risks}

During the interim period before the completion of divestitures, there is a risk that the competitiveness of the divestiture package can be physically or non-physically, intentionally or unintentionally diminished. Such risks are called asset risks. ${ }^{1187}$

According to asymmetry information theory, asset risks can be caused by moral hazard. It refers to a situation that in an economic relationship, the uninformed party finds it difficult to observe the informed party's conduct, meanwhile the informed party's conduct probably has an impact on the uninformed party's benefits. In other words, the risks of loss caused by the informed party's undesirable conduct will be borne by the uninformed party. ${ }^{1188}$

In the context of asset risks, moral hazard means that during the interim period before the completion of divestitures, the merging parties, as the uninformed party, may intentionally or unintentionally behave undesirably, resulting in the reduction of the marketability, viability and competitiveness of the divested business. Moreover, such reduction will bring difficulties for the purchaser to operate the business viably after the completion of divestitures. Ultimately, losses may be incurred if the purchaser fails to operate the business successfully.

It has been discussed in Chapter 7 that the key point to reduce asset risks in divestitures is to alleviate the moral hazard that occurs during the interim period. Therefore, the merging parties have to be incentivised to behave desirably. In the US and the EU, the hold-separate provisions (HSP) and trustees are used by the CAs to reduce asset risks. Under a hold-separate provision, the merging parties are required to operate the divested business independently by e.g. continuing to provide necessary resources and isolating sensitive commercial information. A trustee can be appointed by the merging parties to monitor the merging parties' compliance with their obligations. According to Chapter 7, the use of the HSPs and trustees can reduce asset risks and thus increase the effectiveness of divestitures.

\footnotetext{
${ }^{1187}$ For a detailed exploration of asset risks, see: Chapter 7, sec.3.3.

1188 See: Holmstrom (n 960).
} 
Regulatory strategies and governance strategies are the two subsets of legal strategies that can be used to alleviate moral hazard in a principal-agent context. ${ }^{1189}$ The former regulates substantive norms and behavioural guidelines for the agents; while the latter, in contrast, refers to strategies that enable the principals to control the agents' behaviour. Accordingly, under regulatory strategies, the agents have to comply with these specificallyformulated norms, so that their undesirable behaviour can be constrained. Hence, regulatory strategies are also called "agent-constraining" strategies. ${ }^{1190}$ In contrast, governance strategies can be called "principal-empowering" strategies.

Considering the special context of divestitures, only agent-constraining strategies -rules and standards- and principal-empowering strategies -reward and trusteeship- are explored in Chapter 7 to assess the effectiveness of reducing moral hazard in divestitures. "Rules" means that specific constraints are formulated by the lawmakers to require or prohibit certain agents' behaviour. "Standards" refer to a situation where only general requirements or criteria are formulated, while the adjudicators are assigned to determine whether such requirements or standards are satisfied by the agents after they act. ${ }^{1191} \mathrm{~A}$ reward strategy means that the agents will be rewarded if they successfully advance the interests of their principal. ${ }^{1192}$ A trusteeship strategy seeks to remove conflicts of interest ex ante between the agent and the principal, so that no personal gains will be obtained when the agent does not act in his principal's interest. ${ }^{1193}$ Although theoretically, all of these four strategies can be used in reducing moral hazard, the rule strategy and the trusteeship strategy can be more practical and easier to be applied in the context of divestitures to reduce asset risks, considering the effectiveness and feasibility, as well as the irreversibility of merger divestitures.

The use of the HSPs provides the merging parties with "behavioural rules", which lay constraints on the merging parties ex ante. To further ensure the merging parties' compliance with their obligations, trustees are thus appointed. Trustees can incentivise the merging parties to behave desirably.

\subsection{Collusion Risks}

Collusion risks in the context of divestitures refer to the risks that, after the completion of divestitures, the purchaser colludes tacitly or explicitly with the merged firm rather than competing with it in order to maximise their joint profits.

It is believed that divestitures are straightforward remedies which can restore competition in the market by requiring the merging parties to divest their business to an existing competitor or a new market entrant. By strengthening a competitor or creating a new competitor, it is believed that the merging parties' concentrated market power can be relocated. However, it is pointed out that divestitures sometimes cannot realise this expectation. It may cause additional competition concerns.

Competitors in the market may have the incentives to cooperate with each other to maximise their profits. Generally, firms have the intrinsic incentives to seek for profits. They are likely to choose to collude rather than competing if the former can bring them more profit. Moreover, if the bargaining is efficient, meaning the gains from cooperation

\footnotetext{
${ }^{1189}$ Kraakman and others (n 963) 38.

1190 ibid.

$1191 \mathrm{ibid}, 39$.

1192 ibid, 42.

1193 ibid, 43.
} 
outweigh the bargaining transaction costs, and the distribution of profits obtained from cooperation is acceptable for the competitors in the market, then an agreement may be reached.

Although collusion is possible among all the competitors, collusion between the merged firm and the purchaser can have a higher likelihood given these collusionfacilitating factors caused by divestitures. First, divestitures can lead to the symmetrical relocation of resources between the merging parties and the purchaser, whereas symmetry has been recognised as a factor that can facilitate collusion. ${ }^{1194}$ Second, divestitures enable the merged firm and the purchaser to have multi-market contacts if these firms operate in different or neighbouring markets. "Multi-market contacts" have been identified as another factor that facilitates collusion. ${ }^{1195}$ Third, divestitures sometimes require a continuing relationship between the merged firm and the purchaser. Such continuing relationship can also facilitate collusion ${ }^{1196}$ because it not only provides both parties with the opportunity to exchange information; but also increases transparency between these two parties.

Possible solutions to reduce collusion risks can be that, the CA should assess the postdivestiture effects when evaluating the suitability of the proposed remedies to avoid any symmetric position between the merged firm and the purchaser. Second, the incentives of the purchaser in buying the to-be-divested assets should also be analysed to make sure that the purchaser would operate the assets to compete with the merged firm. Third, extra care is needed when a divestiture involves a continuing relationship. Trustees can be appointed when such continuing relationship is needed to monitor the merged firm and the purchaser's compliance with their obligations.

In practice, Chapter 8 has showed that the CAs in the US and the EU have recognised the post-divestiture collusion risks between the merged firm and the purchaser. Therefore, they use various methods to prevent these risks, such as limiting the duration of a continuing relationship, or assessing the incentives of the potential buyer when evaluating the suitability of the buyer. According to the analysis, these strategies can effectively reduce collusion risks.

\section{Lessons Learnt}

An ex ante merger policy and a pre-merger notification system have been introduced to address the difficulties in detecting and proving an anti-competitive merger via the expost policies of competition law prohibitions, as well as the difficulties in implementing a structural remedy. Merger review decisions are generally made with uncertainties given the ex ante function of merger control policy. Despite this, the CA can still have a comparatively objective and reasonable prediction about the future development of the merging parties based on information it obtains from various forms of investigation, and the application of economic toolkits during the substantive test. The design of merger remedies is firstly based on the substantive assessment of merger review, which can recognise what needs to be remedied. With reasonable prediction obtained from substantive assessment, the uncertainties for designing a remedy can thus be reduced.

In addition, such challenges can be further overcome by the CA and the merging parties' knowledge about the concerned industry. On the one hand, the CA's knowledge

\footnotetext{
1194 Motta (n 1070) 147.

1195 Ivaldi and others (n 1068) 48.

1196 ibid, 54.
} 
about certain industries can be more comprehensive than imagined. On the other hand, as market participants, the merging parties can negotiate and communicate with the CA regarding the development of industry. This, however, requires an effective channel for communication between the merging parties and the CA.

Whether the CA can require a merger remedy in the situation of a changing world also depends on whether the remedies can be designed in a way that can effectively address the competition concerns. This means that the appropriateness of a merger remedy should be assessed by considering the conditions of the market at the time when the merger decision was made. Therefore, the key issue is to ensure that such remedies can effectively restore competition, taking into account the market conditions at that time.

During the design and implementation of divestitures, it is pointed out that various risks, especially composition risks, asset risks and collusion risks can reduce the effectiveness of divestitures. Chapters 6, 7, and 8 have explored these risks from the perspective of the information asymmetry theory and collusion theory. It has been proved that risk-reducing provisions, the HSPs and trustees, and different strategies that are currently used by the CAs in the US and the EU can effectively and efficiently reduce these risks, leading to an increase in the effectiveness of divestitures.

Summing up, large uncertainties do not suggest that it is unjustified or impossible for the CA to predict the future development of the market by imposing remedies. Crucial points are to increase the scientific credibility of substantive tests, the smooth communications between the merging parties and the CA, and the requisite degree of certainties in divestitures. These strategies explored in previous chapters have been proved to be able to increase the effectiveness of divestitures. 


\section{III}

\section{MERGER REVIEW AND MERGER DIVESTITURES IN CHINA}

Passed on 30 August 2007 and enacted on 1 August 2008, the Anti-Monopoly Law of the People's Republic of China (“AML”) has drawn wide attention. Merger control, as one of the most important pillars in competition law, is regulated in the AML. ${ }^{1197}$ There are a number of relevant documents that have been released after the implementation of the AML, covering, for example, the thresholds of the pre-merger notifications, the measures for merger review, and the procedures for simple cases. ${ }^{1198}$ Many (interim) guidelines, provisions or guiding opinions were published in succession.

Part III will especially focus on China's merger review and merger remedies (mainly divestitures) and address the third research question: are China's divestitures policies adequate and effective to reduce possible divestiture risks and serve the aims of the AML? Part III consists of four chapters:

- Chapter 10: Legal Framework of Merger Control and Merger Divestitures in China

- Chapter 11: MOFCOM's Practice in Merger Control and Merger Remedies: Case Analyses

- Chapter 12: Insights of MOFCOM's Merger Control and Merger Remedies Empirical Evidence

- Chapter 13: A Comparative Law and Economics Analysis of Merger Divestitures in China

\footnotetext{
1197 "Merger" in this book is used as a synonym for "concentration" which is used in the context of the Chinese Anti-Monopoly Law.

${ }^{1198}$ For a detailed exploration of the procedures for a "simple" case under the Chinese merger control system, see: sec.3.1.2 in Chapter 10.
} 



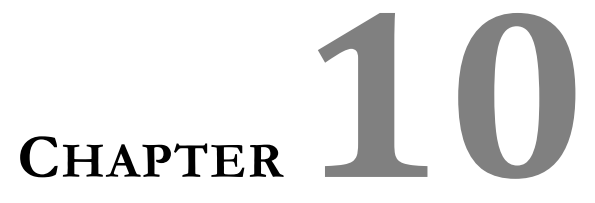

LEGAL FRAMEWORK OF MERGER CONTROL AND MERGER DIVESTITURES IN CHINA 



\section{Introduction}

From August 2007 until the time of writing (June 2017), it has been almost ten years since the passage of the Chinese Anti-Monopoly Law ("AML"). ${ }^{1199}$ The AML is the first law of this kind in China which systematically regulates anti-trust conduct. With the promulgation and implementation of the AML, 'China has the potential, alongside the European Union and the United States, to develop into a key jurisdiction in deciding whether a transaction can be completed or not'. ${ }^{1200}$

The AML is the core of the competition law in China, which mainly regulates three pillars of anti-trust conduct, namely, monopolistic agreements between undertakings; abuse of dominant market positions of undertakings; and merger control (in the language of the AML: concentrations of business operators). ${ }^{1201}$ The AML applies to any anti-trust conduct within the territory of the People's Republic of China that has the effect of eliminating or restricting competition domestically. ${ }^{1202}$

In fact, before the enactment of the AML, China had competition policies scattered in different laws, administrative rules or regulations. In general, the development of China's competition law and competition policies can be distinguished into three periods, divided by two symbolic policy changes: the publication of the Reform and Open-Door policy in 1978 and the determination of the goal to establish a socialist market economy in $1992 .{ }^{1203}$

The first period began with the establishment of the People's Republic of China until the implementation of the Reform and Open-Door policy in 1978. During the first period, China had a nationally planned economy, meaning that the economy in the market was centrally planned. ${ }^{1204}$ In other words, there was no competition in the market because, for example, the variety of products and the number of products were decided by the central authority. Naturally, there was no competition policy.

The implementation of the Reform and Open-Door policy in 1978 symbolised the start of the second period, which ended with the determination of the goal to establish a socialist market economy in 1992. The Reform and Open-Door policy was first proposed by Deng Xiaoping. The policy means that on the one hand, reforms have to be made domestically; on the other hand, China should "open its door" to "outsiders" rather than remain isolated. Serious discussions concerning the enactment of competition law began several years after Deng's rise to power. ${ }^{1205}$ During the second period, China's economic system transferred from a centrally planned economy to a planned market economy. Compared with the centrally planned economy, the planned market economy is characterised with more liberalisation. It refers to 'an economy in which decisions regarding investment, production, and distribution are based on supply and demand'. ${ }^{1206}$ Although some changes had happened, there was still limited competition in the market

\footnotetext{
1199 AML (n 42) art 3.

${ }^{1200}$ Moritz Lorenz, 'The New Chinese Competition Act' (2008) 29(4) ECLR 257, 263.

1201 AML (n 42) art 3.

1202 ibid, art 2.

1203 See: Ming Shang, 'Antitrust in China- A Constantly Evolving Subject' (2009) 5(1) Competition L Int'l 4.

1204 Xiaoye Wang, 'Why does China Need an Anti-Monopoly Law?', The Evolution of China's Anti-Monopoly Law (Edward Elgar 2014) 4.

${ }^{1205}$ H. Stephen Harris, 'The Making of an Antitrust Law: The Pending Anti-Monopoly Law of the People's Republic of China' (2006) 7(1) Chi J Int'l L 169, 172.

1206 Paul Gregory and Robert C Stuart, Comparing Economic Systems in the Twenty-First Century (7 edn, George Hoffman 2004) 538.
} 
under the planned market economy. Accordingly, legislation regarding competition was rare. ${ }^{1207}$

During this period, the Provisions Rules on the Development and Protection of Socialist Competition were issued in $1980 .{ }^{1208}$ It was the earliest competition provision in China, ${ }^{1209}$ which for the first time confirmed the necessity of anti-trust law in China. It further pointed out that monopolistic conduct should be prevented, except that conducted by certain departments and units of the central government because they were designated to do so by the State. ${ }^{1210}$ In other words, this conduct reflected the will of the State. In 1987, the Regulation on the Administration of Advertisement was adopted and enacted. ${ }^{1211}$ The Regulation is still effective and it indicates that 'monopoly and unfair competition shall be prohibited in advertising operations'. ${ }^{1212}$

1992 was an important turning point regarding the development of competition policies in China because, in this year, the goal of establishing the socialist market economy was explicitly put forward and was finally determined by the $14^{\text {th }}$ National Congress of Communist Party of China. ${ }^{1213}$ The root of the interest of economic liberalisation and competitive markets originated from the rule of Xiaoping Deng. ${ }^{1214}$ One year later, in 1993, the first anti-trust law - the Anti-Unfair Competition Law ${ }^{1215}$ - was adopted and enacted. According to Art. 2 of the Anti-Unfair Competition Law, unfair competition refers to 'acts of operators which contravene the provisions of this Law, with a result of damaging the lawful rights and interests of other operators, and disturbing the socio-economic order'. It is believed that another main function of the Anti-Unfair Competition Law is to protect consumers. ${ }^{1216}$ Subsequently, the Price Law was adopted in 1997 and came into force the

\footnotetext{
1207 See: Shang (n 1203).

1208 State Council of the People's Republic of China, Provisions Rules on the Development and Protection of Socialist Competition (guo wu yuan guan yu kai zhan he bao bu she hui zhu yi jing zheng de zan xing gui ding 国务院关于开展和保护 社会主义竞争的暂行规定) (Adopted and entered into force 17 October 1980, repealed 6 October 2001).

${ }^{1209}$ Jingyuan Ma, 'Market Integration as the Goal of Competition Law: The EU Experience and Its Implications for China' in Niels Philipsen, Stefan E. Weishaar and Guangdong Xu (eds), Market Integration: The EU Experience and Implications for Regulatory Reform in China (Springer 2015) 20.

${ }^{1210}$ Provisions Rules on the Development and Protection of Socialist Competition (n 1208) para 3.

1211 State Council of the People's Republic of China, Regulation on the Administration of Advertising (guang gao guan li tiao li 广告管理条例) (Adopted 26 October 1987, entered in force 1 December 1987)

$1212 \mathrm{ibid}$, art 4.

${ }^{1213}$ Dan Zhu, 'Historical Review: Establishing the Socialist Market Economy (li shi jie dian: jian li she hui zhu yi shi chang jing ji ti zhi 历史节点: 建立社会主义市场经济体制)' (People, 11 October 2011) <http://cpc.people.com.cn/GB/104019/104740/8150356.html> accessed 29 April 2017.

${ }^{1214}$ Christopher Hamp-Lyons, 'The Dragon in the Room: China's Anti-Monopoly Law and International Merger Review' (2009) 62(5) Va L Rev 1577, 1595.

${ }^{1215}$ Standing Committee of the National People's Congress, Anti-Unfair Competition Law of the People's Republic of China (zhong bua ren min gong he guo fan bu zheng dang jing zheng fa 中华人民共和国反不正当竞争法) (Adopted 2 September 1993, entered into force 1 December 1992). Since 2010, the State Administration for Industry and Commerce (SAIC) and the Legislative Affairs Office of the State Council jointly organised experts to conduct investigations on amending the Anti-Unfair Competition Law. In February 2016, the draft revised version of the Anti-Unfair Competition Law was published for public comment. See: The Legislative Affairs Office of the State Council, 'Opening of Public Comments for the Anti-Unfair Competition Law of the People's Republic of China (drafted revised version) (guo wu yuan fa zhi ban gong shi guan yu gong bu 《zhong hua ren min gong he guo fan bu zheng dang jing zheng fa (xiu ding cao an song shen gao)》g gong kai zheng qiu yi jian de tong zhi 国务院法制办公室关 于公布《中华人民共和国反不正当竞争法（修订草案送审稿）》公开征求意见的通知)'(Chinalaw, 25 February 2016) <http://www.chinalaw.gov.cn/article/cazjgg/201602/20160200480277.shtml> accessed 29 April 2017. As at the time of writing (June 2017), the final version of the revised Anti-Unfair Competition Law is not available.

1216 Xinzhu Zhang and Yanhua Zhang, 'The Anti-Monopoly Law in China: Where Do We Stand?' (2007) 3(2) CPI $185,187$.
} 
next year. ${ }^{1217}$ It mainly regulates undertakings' pricing behaviour with the aim to stabilise the general price level of the market, and to protect the lawful rights and interests of consumers and undertakings. ${ }^{1218}$ The following Table 9 presents the main laws, administrative regulations and ministerial rules which were published during this period. These policy instruments are ranked chronologically from the earliest to the latest based on the date of enactment.

Table 9 Main Competition Laws Enacted before the Enactment of the AML

\begin{tabular}{ll}
\hline Date of Enactment & Instruments \\
\hline 1 December 1992 & $\begin{array}{l}\text { Anti-Unfair Competition Law of the People's Republic of China (under } \\
\text { revision) }\end{array}$ \\
\hline 24 December 1993 & $\begin{array}{l}\text { Certain Regulations on Prohibiting Anti-Competitive Practices of Public } \\
\text { Enterprises }\end{array}$ \\
\hline 1 May 1998 & Price Law of the People's Republic of China \\
\hline 1 January 2000 & Bidding Law of the People's Republic of China ${ }^{1220}$ \\
\hline 21 April 2001, revised 8 & $\begin{array}{l}\text { Regulations on the Prohibition of Regional Blockades in Market Economy } \\
\text { Activities }{ }^{1221}\end{array}$ \\
\hline 1 Nonuary 2011 & Interim Provisions on Preventing Acts of Price Monopoly ${ }^{1222}$ \\
\hline
\end{tabular}

Simply reading the names of these policy instruments, readers can notice that there are quite a few new policy instruments that have been passed and enacted during the abovementioned $3^{\text {rd }}$ period (1992-present), with the aim to legislatively support the establishment of a socialist market economy. These instruments are dispersed among the different levels of laws.

Regarding merger control, MOFCOM in 2003 promulgated and implemented the Interim Provisions for Foreign Investors to Merge Domestic Enterprises, which was replaced by the new 2006 version. ${ }^{1223}$ The 2006 version was further revised in 2009 in order to make it compatible with the AML. ${ }^{1224}$ It especially attaches its focus on the mergers between

1217 Standing Committee of the National People's Congress, Price Law of the People's Republic of China (zhong bua ren min gong he guo jia ge fa 中华人民共和国价格法) (Adopted 29 December 1997, entered into force 1 May 1998).

$1218 \mathrm{ibid}$, art 1.

${ }^{1219}$ State Administration for Industry \& Commerce, Certain Regulations on Probibiting anticompetitive practices of Public Enterprises (guan yu jin zhi gong yong qi ye xian zhi jig zheng xing wei de ruo gan gui ding 关于禁止公用企业限制竞争行 为的若干规定) (Adopted and entered into force 24 December 1993).

1220 Standing Committee of the National People's Congress, Bidding Law of the People's Republic of China (zhong bua ren min gong he guozhao biao tou biao fa 中华人民共和国招标投标法) (Adopted 30 August 1999, entered into force 1 January 2000).

${ }^{1221}$ State Council of the People's Republic of China, Provisions of the State Council On Probibiting Regional Blockeade in Market Economic Activities(guo wu yuan guan yu jing zhi zai shi chang jing ji huo dong zhong shi xing di qu feng suo de gui ding 国务院关于禁止在市场经济活动中实行地区封锁的规定) (Adopted and entered into force 21 April 2001, revised 8 January 2011).

1222 National Development \& Reform Commission, Interim Provisions on Preventing Acts of Price Monopoly (z̧bi zabi jia ge long duan xing wei de zan xing gui ding 制止价格垄断行为暂行规定) (Adopted 18 June 2003, entered into force 1 November 2003).

${ }^{1223}$ Ministry of Commerce, Provisions on the Takeover of Domestic Enterprises by Foreign Inverstors (2006 Revision) (guan yu wai guo tou zi zhe bing gou jing nei qi ye de gui ding 关于外国投资者并购境内企业的规定) (Adopted 8 August 2006, entered into force 8 September 2006).

${ }^{1224}$ Ministry of Commerce, The Ministry of Commerce's Decision on Revising <Provisions on the Takeover of Domestic Enterprises by Foreign Investors $>$ (shang wu bu guan yu xiu gai < (guan yu wai guo tou zi zhe bing gou jing nei qi ye de gui ding $>$ de jue ding 商务部关于修改 <关于外国投资者并购境内企业的规定 $>$ 的决定)(Adopted and entered in force 22 June 2009). 
foreign and domestic undertakings. With the enactment of the AML, the scope of merger control was largely widened. Moreover, detailed rules and provisions regulating the implementation of merger control have also been published.

To summarise, the development of competition law in China has experienced three periods. During the third period, numerous policy instruments were published. The State Administration for Industry \& Commerce ("SAIC"), the National Development \& Reform Commission ("NDRC") and the Ministry of Commerce ("MOFCOM") are the three departments that are actively engaged in anti-trust enforcement. Even though the AML (at least the merger control part) uses similar wording to the US or the EU Merger Regulation, it is unique due to China's special legal, cultural and economic conditions. It is believed that '[T] he AML is different because China is different'. ${ }^{1225}$ Accordingly, this Chapter aims to present a comprehensive analysis of the legal framework of merger control and merger divestitures in China. The remainder of this Chapter is structured as follows.

Subsequent to this Introduction, the legal framework of merger control in China is explored in sec.2, in which the effective legal instruments of merger control are summarised. The merger control system in China is studied from both a procedural and a substantive perspective in sec.3. Sec.4 studies China's merger divestitures, attaching special attention to the Provisions on Imposing Restrictive Conditions on Concentrations of Undertakings (for Trial Implementation $)^{1226}$. A conclusion is drawn in sec.5.

\section{Legal Framework of Merger Control in China}

Since the late 1990s, many foreign investors have been keen on taking over domestic Chinese undertakings in order to gain entry and obtain a strategic position in the promising Chinese market. ${ }^{1227}$ Merger control thereby seems to become an important task for the Chinese government to ensure that these foreign investors will not "dominate" the domestic market by merging with domestic undertakings. However, it is believed that the primary impetus and incentives for the enforcement of comprehensive competition law were China's accession to the WTO in 2002. ${ }^{1228}$ To further deepen the domestic economic reform and enhance competitiveness, China has to make its anti-trust legislation compatible with that in other main jurisdictions, such as the US and the EU. Accordingly, the Provisions on the Takeover of Domestic Enterprises by Foreign Investors (revised in 2009) were enacted in 2003, which can be regarded as a response to such demands.

In 2008, the Anti-Monopoly Law was enforced (passed in 2007), in which merger control was covered. In this section, the legal framework of China's merger control system is explored.

\footnotetext{
1225 Hamp-Lyons (n 1214) 1597.

${ }^{1226}$ Ministry of Commerce, Provisions on Imposing Restrictive Conditions on Concentrations of Undertakings (for Trial Implementation) (jing ying zhe ji zhong fu jia xian zhi xing tiao jian de gui ding (shi xing) 经营者集中附加限制性条件的规 定 (试行)) (Adopted 04 December 2014, entered into force 5 January 2015) (hereinafter: MOFCOM Provisions on Merger Remedies).

${ }^{1227}$ Ping Lin and Jinging Zhao, 'Merger Control Policy under China's Anti-Monopoly Law' (2012) 41(1) Rev Ind Organ 109, 110.

${ }^{1228}$ Harris (n 1205) 176.
} 


\subsection{Legislation on Merger Control and Merger Divestitures}

The AML is the core of the competition law as well as the merger control system in China. It has 8 chapters in total, covering the fields of monopolistic agreements, abuse of dominant position and merger control. Merger control is regulated in Chapter 4, where, inter alia, the definition of "concentrations of business operators", the mandatory premerger notification requirements, the procedures and substantive test of merger review and the use of merger remedies are introduced. In addition to the AML, there are other rules which provide detailed rules or guidance on how merger review is implemented. The following Table 10 summarises the most relevant legislation on merger review and merger divestitures, again in chronological order from the earliest to the latest according to the date of enactment.

Table 10 Main Legislation on Merger Control and Merger Divestitures in China

\begin{tabular}{|c|c|}
\hline Date of Enactment & Instruments \\
\hline $\begin{array}{l}22 \text { June } 2006 \text { (revised in } \\
2009 \text { ) }\end{array}$ & $\begin{array}{l}\text { Provisions of the Ministry of Commerce on Concentration of a Domestic } \\
\text { Enterprise by Foreign Investors }\end{array}$ \\
\hline 1 August 2008 & Anti-Monopoly Law of the People's Republic of China \\
\hline 3 August 2008 & $\begin{array}{l}\text { Provisions of the State Council on Thresholds for Prior Notification of } \\
\text { Concentration of Undertakings }{ }^{1229} \text { ("MOFCOM Merger Thresholds Provisions") }\end{array}$ \\
\hline 24 May 2009 & $\begin{array}{l}\text { Guide of the Anti-Monopoly Committee of the State Council for the } \\
\text { Definition of the Relevant Market }\end{array}$ \\
\hline 1 January 2010 & $\begin{array}{l}\text { Measures for the Undertaking Concentration Examination } 1231 \text { ("MOFCOM } \\
\text { Measures for Merger Review") }\end{array}$ \\
\hline 1 January 2010 & Measures for the Undertaking Concentration Declaration ${ }^{1232}$ \\
\hline 5 September 2011 & $\begin{array}{l}\text { Interim Provisions on the Assessment of the Effect of the Concentrations of } \\
\text { Undertakings on Competition }{ }^{1233} \text { ("MOFCOM Provisions on the Assessment of } \\
\text { Mergers") }\end{array}$ \\
\hline 1 February 2012 & $\begin{array}{l}\text { Interim Measures for Investigating and Handling Failure to Legally Declare } \\
\text { the Concentration of Undertakings }{ }^{1234} \text { ("MOFCOM Fail-to-Notify Provisions") }\end{array}$ \\
\hline
\end{tabular}

${ }^{1229}$ State Council of the People's Republic of China, Provisions of the State Council on Thresholds for Prior Notification of Concentration of Undertakings (guo wu yuan guan yu jing ying zhe ji zhong shen bao biao zhun de gui ding 国务院关于经营者 集中申报标准的规定) (Issued and entered into force 3 August 2008) (hereinafter: MOFCOM Merger Thresholds Provisions).

1230 Anti-Monopoly Committee of the State Council, Guide of the Anti-Monopoly Committee of the State Council for the Definition of the Relevant Market (guo wu yuan fan long duan wei yuann bui guan yu xiang guan shi chang jie ding de zhi nan 国 务院反垄断委员会关于相关市场界定的指南) (Issued and entered into force 24 May 2009).

${ }^{1231}$ Ministry of Commerce, Measures for the Undertaking Concentration Examination (jing ying zhe ji zhong shen cha ban fa 经营者集中审查办法) (Issued 24 November 2009, entered into force 1 January 2010) (hereinafter: MOFCOM Measures for Merger Review).

${ }^{1232}$ Ministry of Commerce, Measures for the Undertaking Concentration Declaration (jing ying zhe ji zhong shen bao ban fa 经 营者集中申报办法) (Issue 11 November 2009, entered into force 1 January 2010).

${ }^{1233}$ Ministry of Commerce, Interim Provisions on the Assessment of the Effect of the Concentrations of Undertakings on Competition (guan yu ping gu jing ying zhe ji zhong ying xiang de zan xing gui ding 关于评估经营者集中竞争影响的暂行 规定) (Issued 29 August 2011, entered into force 5 September 2011) (hereinafter: MOFCOM Provisions on the Assessment of Mergers).

1234 Ministry of Commerce, Interim Measures for Investigating and Handling Failure to Legally Declare the Concentration of Undertakings (wei yi fa shen bao jing ying zheji zhong tiao cha chu li zan xing ban fa 未依法申报经营者集中调查处理暂 行办法) (Issued 30 December 2011, entered into force 1 February 2012) (hereinafter: MOFCOM Fail-to-Notify Provisions). 


\begin{tabular}{ll}
\hline Date of Enactment & Instruments \\
\hline 12 February 2014 & $\begin{array}{l}\text { Interim Provisions on Standards Applicable to Simple Cases of Concentration } \\
\text { of Undertakings }\end{array}$ \\
\hline 18 April 2014 ("MOFCOM Provisions of Simple Cases")
\end{tabular}

On the one hand, these rules and guidelines increase the transparency and comprehensiveness of China's merger control system, which are two important elements in increasing the effectiveness of merger control. One the other hand, it is not difficult to notice that almost half of the rules mentioned in Table 10 are either interim provisions or for trial implementation, implying that, first, China is exploring a suitable approach regarding its enforcement of merger control; second, it also reflects China's special national conditions, that is, China is a country which is undergoing social transformations in many aspects. ${ }^{1239}$

\subsection{Competition Authorities: NDRC, SAIC and MOFCOM}

Whether China can establish and safeguard competition in the market largely depends on whether China has an effective competition authority. ${ }^{1240}$ According to Art. 9 of the AML, the Anti-Monopoly Commission established by the State Council is responsible for "[o]rganising, coordinating and guiding the anti-monopoly work" and it is also assigned with the authority to, inter alia, draft competition policies, and formulate and publish antimonopoly guidelines. ${ }^{1241}$ Moreover, the Anti-Monopoly Law Enforcement Agency

\footnotetext{
1235 Ministry of Commerce, Interim Provisions on Standards Applicable to Simple Cases of Concentration of Undertakings (guan yu jing ying zhe ji zhong jian yi an jian shi yong biao zhun de zan xing gui ding 关于经营者集中简易案件使用标准的暂 行规定) (Issued 11 February 2014, entered into force 12 February 2014) (hereinafter: MOFCOM Provisions of Simple Cases).

1236 Anti-Monopoly Bureau of the Ministry of Commerce, Guiding Opinions of the Anti-Monopoly Bureau of the Ministry of Commerce on Declaration of Simple Cases of Concentration of Undertakings (for Trial Implementation) (guan yu jing ying zhe ji zhong jian yi an jian shen bao de zhi dao yi jian (shi xing)关于经营者集中简易案件申报的指导意见(试行)) (Issued and entered into force 18 April 2014) (hereinafter: MOFCOM Guiding Opinions on Declaring Simple Cases).

${ }^{1237}$ Ministry of Commerce, Guiding Opinions on Declaring the Concentration of Undertakings ((guan yu jing ying zhe ji zhong shen bao de zhi dao yi jian 关于经营者集中申报的指导意见) (Issued and entered into force 6 June 2014) (hereinafter: MOFCOM Guiding Opinions on Merger Declarations).

1238 MOFCOM Provisions on Merger Remedies (n 1226).

${ }^{1239}$ Since the $3^{\text {rd }}$ Plenary Session of the $11^{\text {th }}$ Central Committee of the Communist Party of China (CPC) (1978), China has gone through several great social transformations. After the $3^{\text {td }}$ Plenary Session in 1978, China determined the Reform and Open-door Policy and laid its emphasis on developing the economy. After the $14^{\text {th }}$ CPC National Congress in 1992, China decided to change from a planned economy to a market-oriented economy. According to the $11^{\text {th }}$ Five-year Plan, the Chinese socio-economic transition can be understood as, for example, transition into a resource-saving society; transition into an environmental-friendly society; and a shift to an innovation-oriented country. See: China Pictorial, 'China's 11th Five-year Plan and the Future Development (“shi yi wu” gui hua yu zhong guo wei lai fa zhan fang xiang“十一五”规划与中国未来发展方向)” (Xinhua net, 29 November 2005) <http://news.xinhuanet.com/politics/2005-11/29/content_3852517.htm> accessed 29 April 2017.

1240 Wang (n 64) 230.

1241 AML (n 42) art 9
} 
("AMEA") designated by the State Council is responsible for the enforcement of the AML. ${ }^{1242}$ Thus, the Anti-Monopoly Commission is assigned with the administrative authority to guide the work of the AMEA.

There is no article in the AML that explains what exactly these competition agencies are (in the language of the AML: AMEA). In practice, there are three main competition agencies: NDRC, SAIC, and MOFCOM. These three competition agencies share authority to enforce the AML in different fields and enforce other competition laws based on their expertise. The following figure presents the divisions of their tasks.

Figure 18 Divisions of Tasks between NDRC, SAIC and MOFCOM1243

State Council

\begin{tabular}{|c|c|c|}
\hline Anti-monopoly Commission & \multicolumn{2}{|c|}{$\begin{array}{c}\text { AMEA } \\
\text { (enforcement authority) }\end{array}$} \\
\hline $\begin{array}{l}\text { NDRC: } \\
\text { - Authorised by the } \\
\text { Interim Provisions on } \\
\text { Preventing the Acts of } \\
\text { Price Monopoly } \\
\text { - Enforces price } \\
\text { related monopolistic } \\
\text { conduct }\end{array}$ & $\begin{array}{l}\text { MOFCOM: } \\
\text { - Authorised by the } \\
\text { Provisions on the } \\
\text { Takeover of Domestic } \\
\text { Enterprises by Foreign } \\
\text { Inverstors } \\
\text { - Enforces merger } \\
\text { control }\end{array}$ & $\begin{array}{l}\text { SAIC: } \\
\text { - Authorised by the } \\
\text { Anti-Unfair } \\
\text { Competition Law } \\
\text { - Enforces non-price } \\
\text { related monopolistic } \\
\text { conduct; abuse of } \\
\text { dominant position }\end{array}$ \\
\hline
\end{tabular}

Figure 18 indicates that these three CAs share the enforcement authority of the AML. NDRC is responsible for enforcing any price related rules of the AML, whereas SAIC enforces any non-pricing related rules. MOFCOM is assigned the authority to review merger applications.

Regarding China's institutional model of merger control, similar to the European Union, an administrative enforcement model is adopted by MOFCOM. ${ }^{1244}$ MOFCOM acts as an investigator, prosecutor and judge. MOFCOM is responsible for merger review through investigations and prosecutions. Moreover, it is also a decision-maker, suggesting that no final approval from courts is needed to validate MOFCOM's decisions. If the

\footnotetext{
1242 ibid, art 10.

1243 See: Zhang and Zhang (n 1216) 189. See also: Slaughter and May, 'Competition Law in China' (Slaughter and May, November 2016) <https://www.slaughterandmay.com/media/879862/competition-law-in-china.pdf> accessed 29 April 2017; Sop Choi Yo and Youn Youn Sang, 'The Enforcement of Merger Control in China: A Critical Analysis of Current Decisions by MOFCOM' (2013) 44(8) ICC 948, 953.

${ }^{1244}$ For the detailed exploration of the European Commission's multiple roles, see: Chapter 3, sec.2.2.
} 
parties concerned do not consent with MOFCOM's decisions, they can apply for an administrative reconsideration to MOFCOM in writing, possibly followed by an administrative litigation if the parties concerned are dissatisfied with the results of administrative reconsiderations. ${ }^{1245}$

\subsection{Objectives}

The aims of the AML are to protect fair competition in the market, enhance efficiency, maintain consumer welfare and the public interest, and promote a healthy development of the socialist market economy. ${ }^{1246}$ Such multi-dimensional objectives, however, can be contradictory in some situations.

On the one hand, a notified merger can promote the socialist market economy by generating efficiencies and enhance its competitive capability. On the other hand, consumer welfare can be reduced since the merger confers on the merged undertaking concentrated and increased market power, leading to a higher possibility of a price increase or output reduction. Considering that it is unclear (at least in law) whether there is any priority among these goals, it is difficult to predict whether MOFCOM will choose to protect consumer welfare or the national economy.

Moreover, the AML's multitudes of goals can also result in the difficulty in determining the suitability of merger remedies. A merger remedy can be designed in a way which either lays its emphasis on protecting the consumer's welfare or preserving the potential efficiencies generated from the proposed merger.

\subsection{Mergers Caught by the Merger Control Legislation}

Similar to the situation in other jurisdictions, such as in the US and the EU, a pre-merger notification is also mandatory under the AML if the proposed merger satisfies the notification thresholds set in the MOFCOM Merger Thresholds Provisions.

Before the enactment of the AML, there was a distinction between mergers in domestic undertakings and mergers involving foreign investors. According to Chapter 5 of the Provisions on the Takeover of Domestic Enterprises by Foreign Investors (revised in 2009), mergers between domestic undertakings and foreign investors should be notified to both MOFCOM and SAIC if such mergers meet the thresholds in the MOFCOM Merger Thresholds Provisions. After the enactment of the AML, such distinction is eliminated since MOFCOM revised the Provisions on the Takeover of Domestic Enterprises by Foreign Investors in 2009 by stating that all thresholds-satisfying mergers involving foreign investors should be notified to MOFCOM alone, which is the same for domestic mergers. ${ }^{1247}$

Accordingly, all mergers, as long as they meet relevant thresholds, have to be notified to MOFCOM, regardless of whether foreign investors are involved. To determine whether a merger falls within the scope of the "merger control system", Art. 20 of the AML reads:

The concentration of business operators refers to the following circumstances:

1. Merger of business operators;

\footnotetext{
1245 See: Ministry of Commerce, Implementation Measures for Administrative Reconsideration of the Ministry of Commerce (shang wu bu xing zheng fu yi shi shi ban fa 商务部行政复议实施办法) (Adopted 9 April 2001, entered into force 1 July 2004).

1246 AML (n 42) art 1.

${ }^{1247}$ Ministry of Commerce (n 1224) para 1.
} 
2. A business operator acquires control over other business operators by acquiring their equities or assets; or

3. A business operator acquires control over other business operators or is able to exert a decisive influence on other business operators by contract or other means.

The further clarification of the meaning of "control" and "decisive influence" is provided in the MOFCOM Guiding Opinions on Merger Declarations, which were issued and revised by MOFCOM in 2014.

\section{Determination of control and decisive influence}

To evaluate whether a merger falls within the scope of the AML, the meaning of control should be firstly clarified. According to Art. 3 of the MOFCOM Guiding Opinions on Merger Declarations, control in the context of the AML refers to both sole control and joint control.

It can be difficult to determine whether a proposed merger will confer the undertaking(s) with decisive influence on the other undertaking(s). ${ }^{1248}$ Such decisive influence can be assessed from two perspectives: legal and factual. Merger agreements or the articles of associations can be used as legal evidence to prove the decisive influence. This legal evidence, however, is not the only basis. It is possible that although there is no term in the merger agreements or in the articles of association which grants the merging parties the right of exerting decisive influence, the undertaking can still enjoy the decisive position after the implementation of a merger due to, for example, the dispersed equities of other undertakings. In other words, the undertaking can enjoy de facto control even if no legal proofs can be found.

To better determine whether the proposed merger will enable the undertaking to have sole or joint control over another undertaking, the MOFCOM Guiding Opinions on Merger Declarations provides some factors that can be taken into consideration:

1. The purpose of the proposed transaction and future business plans;

2. The changes in the shareholding structures before and after the merger;

3. The voting agenda and mechanism of shareholder's meeting, past attendance rate and resolutions;

4. The structure and voting mechanism of the board of directors and the board of supervisors;

5. The appointment and dismissal of senior executives;

6. The relationship between shareholders and directors, and whether there are votes by proxy or persons acting in concert in place; and

7. Whether there is a significant commercial relationship or cooperation agreement between the undertakings.1249

In fact, the wording which the AML and the Declaration Opinion adopted is quite similar to the 2004 EUMR.1250 According to Art. 3 of the 2004 EUMR, '[A] concentration shall be deemed to arise where a change of control on a lasting basis resulted from mergers or acquisitions'. There are two key points, namely, a lasting change of control and change of control. A lasting change implies that such change should be stable rather than temporary considering that stable changes have a higher possibility to change the structure of the market. Further, decisive influence, to a large extent, is exerted through the change of

1248 MOFCOM Guiding Opinions on Merger Declarations (n 1237) art 3.

${ }^{1249}$ The English translation of Art. 3 of the MOFCOM Guiding Opinions on Merger Declarations is adopted from Slaughter and May (n 1243).

12502004 EUMR (n 3) art 3.1(a). 
control. Whether a concentration enables an undertaking to control other undertakings depends on whether it can have a decisive influence on other undertakings.

It is safe to conclude that the AML shares the same criteria with the 2004 EUMR in deciding whether a proposed merger falls within the scope of the merger control law.

\section{Joint venture}

Although the AML is silent on whether the creation of a JV is a concentration, the MOFCOM Guiding Opinions on Merger Declarations clarify that the merger control legislation is applicable to the creation of a JV if at least two undertakings jointly control it. ${ }^{1251}$

It is noteworthy that only the creation of a concentrative and fully-functional JV will fall within the jurisdiction of the 2004 EUMR in the EU. According to Art. 3 (4) of the 2004 EUMR, a fully-functional JV is a JV 'which performs on a lasting basis all the functions of an autonomous economic entity'. The creation of a JV will constitute a "concentration" within the meaning of the 2004 EUMR if the JV is a concentrative and fully-functional JV; otherwise, Art. 101 of the TFEU may be applied. ${ }^{1252}$

The rationale to distinguish between a concentrative and fully-functional $\mathrm{JV}$ and a cooperative and fully-functional $\mathrm{JV} /$ non-fully-functional $\mathrm{JV}$ is that the former is an independent undertaking which can change the structure of the market, whereas the latter is just an undertaking which takes over one specific task of its parent undertakings, implying that any possible anti-competitive effects are actually caused by the anticompetitive agreements rather than by the merger (the creation of a JV). Therefore, the key point in eliminating the resulted anti-competitive effects is to prevent such agreements. Rules addressing monopolistic agreements can be more suitable. Such a distinction enables the CA to better "suit the remedy to the case". From this perspective, merger review might not be the appropriate tool to reduce the anti-competitive effects caused by a non-fullyfunctional JV.

MOFCOM can be overloaded if all creations of JVs that satisfy Art. 4 of the MOFCOM Guiding Opinions on Merger Declarations are deemed as "concentrations" and thus have to be reviewed by MOFCOM once they also meet the thresholds in the MOFCOM Merger Thresholds Provisions. Moreover, both NDRC and SAIC share the authority to enforce anti-competitive agreements. No distinction between fully-functional and non-fully-functional JVs may lead to inefficient relocation of enforcement responsibility between NDRC, SAIC and MOFCOM.

\subsection{Jurisdiction}

The merging parties are required to notify their proposed merger to MOFCOM if the mergers fall within the scope of Art. 20 of the AML and meet certain thresholds. ${ }^{1253}$ The AML in itself does not contain the said thresholds. Two days after the enactment of the AML, on 3 August 2008, the State Council published the MOFCOM Merger Thresholds Provisions, in which detailed thresholds were stipulated. ${ }^{1254}$ One of the reasons why the thresholds were not included in the AML was that during the meetings of the Standing

\footnotetext{
${ }^{1251}$ MOFCOM Guiding Opinions on Merger Declarations (n 1237) art 4.

${ }^{1252}$ For relevant regualtions regarding the creation of JVs under the 2004 EUMR (n 3), see: Chapter 3, sec.2.3.3.

1253 AML (n 42) art 21.

1254 MOFCOM Merger Thresholds Provisions (n 1229).
} 
Committee of the National People's Congress to discuss the draft AML, commissioners had different opinions concerning the thresholds which were drafted by the State Council. ${ }^{1255}$

According to Art. 3 of the MOFCOM Merger Thresholds Provisions, mergers that reach any threshold as follows should be notified to MOFCOM before their implementation:

\section{Thresholds for transactions with large turnover:}

- The combined worldwide turnover of all the undertakings concerned in the preceding fiscal year is more than RMB 10 billion yuan, and the national turnover within China of each of at least two of the concerned undertakings in the preceding financial year is more than RMB 400 million yuan; or

\section{Thresholds for significant national effects:}

- The combined nationwide turnover within China of all the undertakings concerned in the preceding year is more than RMB 2 billion yuan, and the nationwide turnover within China of each of at least two of the concerned undertakings in the preceding financial year is more than RMB 400 million yuan.

Thus, when determining whether a merger should be notified to MOFCOM, the following test should be followed:

Figure 19 Determining the Necessity of a Pre-merger Notification under China's Merger Control System

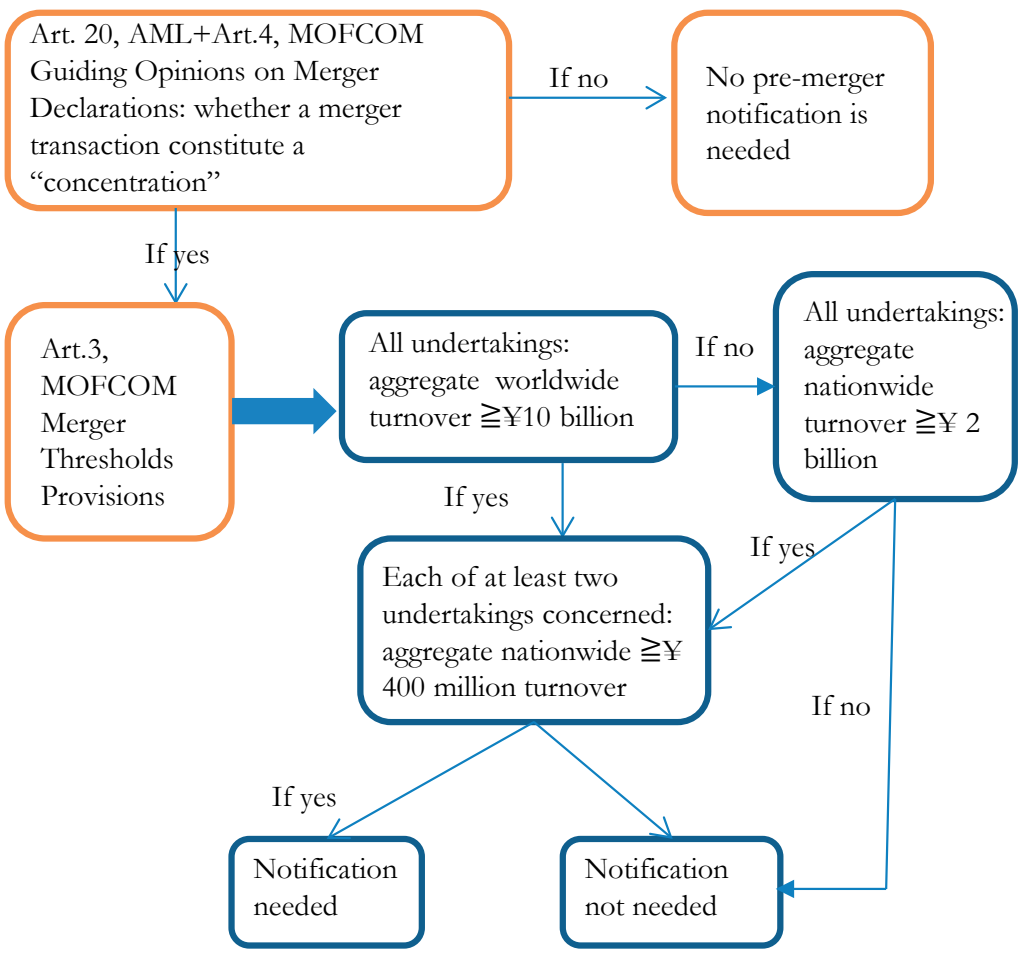

1255 Xiaoye Wang, 'Comments on Concentrations of Undertakings in the China's AML (zhong guo fan long duan fa “jing ying zhe ji zhong”de ping xi 中国反垄断法“经营者集中”的评析) (iolaw, 2008)<http://www.iolaw.org.cn/ showNews.aspx?id=17210> accessed 29 April 2017. 
These two thresholds are not accumulative, meaning that a merger should be notified to MOFCOM if either of these two thresholds is satisfied. In the US, there is a "three-step" test to determine whether the competition agencies have the jurisdiction over a merger and whether the merger should be notified to them, namely, the commerce test, the size of transaction test, and the size of person test. ${ }^{1256}$ In the EU, the Commission has jurisdiction over a merger only if such merger has an EU dimension, suggesting that the transaction either has a significant transnational character or involves an extremely large turnover. ${ }^{1257}$

The thresholds stipulated in China's MOFCOM Merger Thresholds Provisions are quite similar to the US and the EU. A proposed merger which meets the first thresholds implies that large turnovers are involved. A satisfaction of the second thresholds implies that the proposed merger can have a large impact on the market within China due to the large nationwide turnover.

It is noteworthy that, first, the MOFCOM Merger Thresholds Provisions stipulate that when calculating the turnover, if the proposed merger involves special industries or sectors, such as banking, insurance or securities, notification thresholds in other provisions issued by other specialised ministries will prevail. ${ }^{1258}$

Second, MOFCOM can investigate a merger even if the merger does not meet the thresholds stipulated in the MOFCOM Merger Thresholds Provisions if MOFCOM believes that such a merger will or may have the effects of eliminating or restricting competition in the market. ${ }^{1259}$ However, there is no provision or rule that clarifies the standard under which MOFCOM can start such investigations. Generally, this will happen if the concerned merger is high-profile and draws wide attention, or a merger involves a special industry which can have a large impact on the economy.

Third, MOFCOM should send a notification to the merging parties if MOFCOM believes that they fail to make the pre-merger notification, requiring them to provide information and documents to explain whether their merger falls within the scope of Art. 20 of the AML and whether the notification thresholds are reached. ${ }^{1260} \mathrm{~A}$ merger review procedure will follow after MOFCOM receives such information and documents.

The MOFCOM Fail-to-Notify Provisions came into force on 1 December 2012. ${ }^{1261}$ The Provisions regulate that the merging parties may face the risk of being fined up to RMB 500,000 if the merger transaction is implementing before any notification is made. ${ }^{1262}$ Besides, MOFCOM can also require the merged firm to take the following measures to restore the undertakings to the pre-merger situations:

a. stop implementing the merger;

b. dispose equity or assets within the prescribed time limit;

c. transfer the business within the prescribed time limit;

d. other necessary measures. ${ }^{1263}$

In addition, according to Art. 15 of the Provisions, MOFCOM can announce to the public its decision regarding a Fail-to-Notify merger.

\footnotetext{
1256 See: FTC (n 96).

1257 See: Chapter 3, sec.2.4.

${ }^{1258}$ MOFCOM Merger Thresholds Provisions (n 1229) art 3.

$1259 \mathrm{ibid}$, art 4.

${ }^{1260}$ MOFCOM Fail-to-Notify Provisions (n 1234) art 6.

1261 ibid.

$1262 \mathrm{ibid}$, art 13.

1263 ibid.
} 
Although the amount of the fine is rather limited, compared to the turnover of these merger transactions, the publication of MOFCOM's decision is very likely to have adverse impact on the merging parties' reputation, while reputation is quite important to the undertakings. As a result, the MOFCOM Fail-to-Notify Provisions may to some extent reduce the numbers of illegal merger transactions.

\section{Procedures and Substantive Test of the Chinese Merger Review System}

\subsection{General Merger Review Procedures}

The merger review procedures in China consist of two stages, the preliminary review stage and the in-depth review stage.

The MOFCOM Guiding Opinions on Merger Declarations emphasise that a premerger discussion is possible if the merging parties apply in writing before they make formal notifications to MOFCOM. ${ }^{1264}$ Such discussions are not mandatory. Such discussions can be quite helpful for the merging parties to obtain the information concerned and help the merging parties to prepare for the formal notifications. After the merging parties make a formal notification to MOFCOM, MOFCOM will evaluate the sufficiency of the submitted documents and information to determine whether to accept the case. A preliminary investigation will follow after the notification is formally accepted. Decisions of approval of the notified mergers or the opening of an in-depth investigation will be made in writing. ${ }^{1265}$ The notifying parties are permitted to proceed with their notified transaction if MOFCOM decides not to open an in-depth investigation or MOFCOM fails to make its final decision within the timeline. ${ }^{1266}$ At the end of the indepth investigations, MOFCOM can decide whether to approve the notified merger directly, prohibit it, or approve it with additional conditions (with merger remedies). ${ }^{1267}$

\subsubsection{Pre-Notification Discussions}

Once a proposed merger satisfies the notification thresholds, the merging parties have to make a notification to MOFCOM before the implementation of such a merger. The MOFCOM Guiding Opinions on Merger Declarations clarify that if a concentration is conducted by means of "merger", then the merging parties concerned should make the notification. ${ }^{1268}$ Otherwise, notifications should be made to MOFCOM by the undertaking which will obtain control after the completion of the merger.

It is possible that there are two or more merging parties which have the obligations to make notifications. If so, the merging parties can strike an agreement to decide which undertaking should fulfil the obligation. Once the agreed-upon obligator fails to make the notifications, other undertakings will not be relieved from the legal liabilities resulting from the failure of making notifications, even if there is an agreement which addresses the notification obligation. ${ }^{1269}$

\footnotetext{
1264 MOFCOM Guiding Opinions on Merger Declarations (n 1237) art 9.

1265 AML (n 42) art 25.

1266 ibid, art 25.

1267 ibid, art 28.

${ }^{1268}$ MOFCOM Guiding Opinions on Merger Declarations (n 1237) art 13.

1269 ibid.
} 
Regarding the timing of the notification, there is no explicit rule in the US or in the EU. Normally, the merging parties will make the notifications as soon as possible so that they can get the final decision from the CAs to determine whether the proposed mergers can be implemented. In China, it is stipulated that the notifications must be made once a merger agreement is struck. ${ }^{1270}$

As mentioned, a pre-notification consultation with MOFCOM is possible for the merging parties through a written application. According to Art. 9 and Art. 10 of the MOFCOM Guiding Opinions on Merger Declarations, to apply for the pre-notification discussions, the merging parties have to provide information concerning the overview of the proposed merger, basic information of the merging parties, matters they wish to be discussed and proposed time and date for the discussions etc. An application of prenotification discussions will not be approved unless the merging parties provide sufficient information as required in Art. 10 of the MOFCOM Guiding Opinions on Merger Declarations. MOFCOM will also require the merging parties to submit supplementary documents and material if it thinks the information received is incomplete. ${ }^{1271}$

The merging parties can discuss with the Anti-Monopoly Bureau ("AMB") of MOFCOM to, for example, determine whether a mandatory notification is required; enquire about the documents and files that need to be submitted when making the formal notifications; or enquire any other legal or factual issues. ${ }^{1272}$ In addition, they can also consult with the AMB regarding whether their proposed merger can be reviewed by MOFCOM as a "simple case" (this are discussed in the next section).

By discussing with MOFCOM, the merging parties can get familiar with the procedures of merger review and get to know the documents that are required for the formal notification. When making formal notification to MOFCOM, it is very important to make sure to submit complete documents and materials. As is stipulated in Art. 15 of the MOFCOM Guiding Opinions on Merger Declarations, acceptance of these documents does not imply that the AMB of MOFCOM has placed the case on file. The clock for the preliminary investigation period will only start when the AMB receives complete information and the "waiting time" before the start of a preliminary investigation can be rather long if MOFCOM requires additional information.

\subsubsection{Simple Case Standards}

After more than 5 years since the implementation of the AML, the MOFCOM Provisions of Simple Cases were promulgated and enforced on 11 February 2014. ${ }^{1273}$ Those merging parties which have the obligation to notify MOFCOM of their proposed merger transactions thus have an alternative of applying for so-called simple cases rather than the normal ones, if they satisfy the criteria in the MOFCOM Provisions of Simple Cases. The AMB also released the MOFCOM Guiding Opinions on Declaring Simple Cases which clarifies some practical issues. ${ }^{1274}$

According to the MOFCOM Provisions of Simple Cases, a case will be regarded as a simple case if it satisfies the following criteria:

1. For a horizontal merger: if the merging parties are in the same relevant market, and their combined market share is less than $15 \%$ in this market;

\footnotetext{
1270 ibid, art 14.

1271 ibid, art 12.

1272 ibid, art 11.

${ }^{1273}$ MOFCOM Provisions of Simple Cases (n 1235).

${ }^{1274}$ MOFCOM Guiding Opinions on Declaring Simple Cases (n 1236).
} 
2. For a vertical merger: if the merging parties have an upstream-downstream relationship, and their combined market share is less than $25 \%$ in both the upstream market and the downstream market;

3. For a conglomerate merger: if the merging parties are neither in the same relevant market nor in an upstream-downstream relationship, and their combined market share is less than $25 \%$ in any of the transaction-relevant markets;

4. For the establishment of a JV which is outside the territory of China: such a JV should not engage in business activities within the territory of China;

5. For the acquisition of equity or assets from an overseas enterprise: such overseas enterprise must not engage in business activities within the territory of China;

6. For the reduction of the number of controlling shareholders: through the proposed merger, a JV which was controlled by two or more undertakings will be controlled by one or more undertakings. ${ }^{1275}$

In addition, it is possible that a merger will not be regarded as a simple case even if it satisfies the above criteria if the transaction is in any of the following situations. ${ }^{1276}$ The MOFCOM Provisions of Simple Cases also states three circumstances in which MOFCOM may revoke its decision of recognising a merger as a simple case. ${ }^{1277}$

Unless the merging parties notify their proposed transaction as a simple case, the proposed merger will be regarded as an ordinary case. ${ }^{1278}$ Once the merging parties have identified their transaction as a simple case, they have to submit relevant documents and information. The form named as Merger Review Form for Simple Cases is available for the merging parties to notify their proposed transaction as a simple case. ${ }^{1279}$

It is reasonable to assume that one of the AMB' aims in introducing simple cases procedures is to simplify and speed up the merger review procedures for those merger transactions which are unlikely to bring anti-competitive effects to China's internal market competition. Compared with a normal case, the procedure for a simple case is less complicated and the time limit is shortened. ${ }^{1280}$ This is also the reason why the merging parties are willing to notify their transactions as a simple case. Such assumption is partially based on the observation that China's MOFCOM Provisions of Simple Cases are similar to those of the European Commission. ${ }^{1281}$ In the EU, generally, a simple case can be 'declared compatible with the internal market, within 25 working days from the date of notification', ${ }^{1282}$ whose deadline is much shorter than that of the non-simple case procedures.

\footnotetext{
1275 MOFCOM Provisions of Simple Cases (n 1235) art 2.

1276 ibid, art 3.

$1277 \mathrm{ibid}$, art 4.

${ }^{1278}$ MOFCOM Guiding Opinions on Declaring Simple Cases (n 1236) art 2.

1279 ibid, art 4.

1280 According to MOFCOM's Routine Press Conferences, almost all the simple cases have been concluded in the preliminary investigation (within 30 days). See: MOFCOM's Routine Press Conferences, 'The 9th Report of MOFCOM's 2015 Working Summary: to actively promote the enforcement of anti-monopoly law and to maintain fair competition in the market (2015 nian shang wu gong zuo nian zhong zong shu zhi jiu:ji ji tui jin fan long duan zhi fa, wei hu shi chang gong ping jing zheng 2015 年商务工作年终综述之九: 积极推进反垄断执法 维护市 场公平竞争) (MOFCOM, 1 January 2016) <http://www.mofcom.gov.cn/article/ae/ai/201601/20160101 235053.shtml> accessed 29 April 2017.

12812013 EC Simple Case Procedures (n 483). This replaced the old version 2000 EC Simple Case Procedures (n 482). Accordng to Art. 26 of the 2013 EC Simple Case Procedures, the Commission will issue a short-form decision to confirm that the notified transaction is eligible for a simple case procedure. 1282 ibid.
} 
However, by the time of writing (June 2017), there is no provision that stipulates the procedures for simple cases. Ning and others pointed out that on the one hand, a substantive review is needed to determine whether a transaction can be regarded as a simple case; on the other hand, according to the current merger review procedures, during the stage before the preliminary investigation starts, MOFCOM will mainly assess the sufficiency of the submitted documents and information to decide whether to accept the notification. ${ }^{1283}$ This means that a substantive review will be conducted only if a case is accepted. Thus, the dilemma is: a substantive review is very like to be needed before the acceptance of a case in order to make sure that such a transaction is eligible for simple case procedures, whereas, under the current merger review procedures, such substantive review will only be conducted after the acceptance of the case.

\subsubsection{Preliminary Investigations and In-depth Investigations}

\subsubsection{Time Limits}

Once MOFCOM receives complete documents and materials, the 30-day preliminary investigation will begin. ${ }^{1284}$ The AML stipulates that MOFCOM's main aim during this period is to determine whether an in-depth investigation is necessary. Thus, there can be two results at the end of the preliminary investigation: commence an in-depth investigation or not commence an in-depth investigation. The merging parties are permitted to proceed with the notified merger if they receive a decision stating that no further investigation is necessary or MOFCOM fails to make its decision within 30 days. A merger will not be prohibited directly in the preliminary investigation since MOFCOM is only concerned whether a further investigation is needed at this stage. If MOFCOM has competitive concerns about the merger, a further investigation will be commenced

Due to the ambiguity regarding the substantive test of the merger review, it is possible that an in-depth investigation commences simply because MOFCOM does not manage to finish the investigations within the first 30 days. This point will be discussed in sec.3.2. below.

A 90-day in-depth investigation will start from the date when MOFCOM decides to start a further investigation. ${ }^{1285}$ Art. 29 of the AML stipulates that merger remedies can be imposed by the competition agency when it does not prohibit a merger to reduce the potential anti-competitive effects that the notified merger can generate.

MOFCOM can decide to extend the timeline of 90 days to 150 days (at most) in one of the following circumstances:

a. the merging parties agree with such extensions;

b. further verification is needed for the submitted documents and materials;

\footnotetext{
1283 See: Xuanfeng Ning, Dandan Ran and Muqing Zheng, 'MOFCOM Has One Important Step Forward on Building Simple Merger Cases Procedures: Publication of the MOFCOM Provisions of Simple Cases (shang wu bu zai jian yi cheng xu zhi du jian she shang mai chu de zhong yao yi bu: shi shi jian yi an jian shi yong biao zhun 商务部在简易程序制度建设上迈出的重要一步：实施简易案件适用标准)' (Chinalawsight, 6 March 2014)<http://www.chinalawinsight.com/2014/03/articles/corporate/antitrustcompetition $/ \% \mathrm{E} 5 \% 95 \% 86 \% \mathrm{E} 5 \% 8 \mathrm{~A} \% \mathrm{~A} 1 \% \mathrm{E} 9 \% 83 \% \mathrm{~A} 8 \% \mathrm{E} 5 \% 9 \mathrm{C} \% \mathrm{~A} 8 \% \mathrm{E} 7 \% \mathrm{AE} \% 80 \% \mathrm{E} 6 \% 98 \% 93 \% \mathrm{E} 7 \% \mathrm{~A} 8 \%$ $8 \mathrm{~B} \% \mathrm{E} 5 \% \mathrm{BA} \% 8 \mathrm{~F} \% \mathrm{E} \% 88 \% \mathrm{~B} 6 \% \mathrm{E} \% \mathrm{BA} \% \mathrm{~A} 6 \% \mathrm{E} \%$ BB $\% \mathrm{BA} \% \mathrm{E} 8 \% \mathrm{AE} \% \mathrm{BE} \% \mathrm{E} 4 \% \mathrm{~B} 8 \% 8 \mathrm{~A} \% \mathrm{E} 8 \% \mathrm{BF} \% 88 \% \mathrm{E}$ $5 \% 87 \%$ BA $\%$ E7\%9A $\% 84 \%$ E $\% 87 \% 8 D \%$ E $\%$ A6\%81\%E4\%B8\%80\%E6\%AD $\%$ A5\%EF\%BC $\% 9$ A $\%$ E $\%$ AE $\%$ 9E/> accessed 29 April 2017.

1284 AML (n 42) art 24.

1285 ibid, art 26.
} 
c. significant changes happen concerning the merging parties after the notification has been made. ${ }^{1286}$

\subsubsection{Investigations}

Detailed measures for investigations are stipulated in the MOFCOM Measures for Merger Review. ${ }^{1287}$ Either during the preliminary investigations or the in-depth investigations, the merging parties are allowed to deliver their opinions concerning the notified merger by submitting written statements to MOFCOM. ${ }^{1288}$ Further, MOFCOM can consult with relevant units or individuals during merger reviews, such as relevant governmental departments, industrial associations, non-merging undertakings or consumers. ${ }^{1289}$

Hearings can be held by MOFCOM in either investigation period with the aim of conducting investigations, collecting relevant information and evidence, and listening to the opinions of other non-merging parties. ${ }^{1290}$ Such hearings can be held at the request of the merging parties or initiated by MOFCOM. It stipulates that when a hearing is decided upon, MOFCOM should not only notify the merging parties, but also notify their competitors, undertakings from the merging parties' upstream and downstream industries, and representatives from other relevant enterprises. ${ }^{1291}$ In addition, experts and representatives from industry associations and relevant governmental departments can also be invited to attend the hearings.

\subsubsection{Final Decisions}

During the in-depth investigations, MOFCOM should notify the merging parties of its concerns about the notified merger and provide the merging parties with a reasonable time limit to allow them to submit their opinions or defences (in written form). ${ }^{1292}$ As a response to address MOFCOM's competitive concerns, the merging parties can negotiate with MOFCOM about merger remedies. ${ }^{1293}$ Such a remedy should be proposed by the merging parties, followed by negotiations between the merging parties and MOFCOM regarding the design and implementation. MOFCOM has the last say on whether the proposed merger remedies are sufficient to clear its competition concerns. ${ }^{1294}$ At the end of this period, MOFCOM will decide whether to approve or prohibit the notified merger or to approve a merger with merger remedies.

MOFCOM will publish its decisions of prohibitions or approval with merger remedies. ${ }^{1295}$ As mentioned above, according to the AML, a judicial review is possible if the merging parties are dissatisfied with the decisions made by MOFCOM. To be exact, the merging parties must first apply for an administrative reconsideration. If they are still dissatisfied with the decisions of an administrative reconsideration, they can file an administrative lawsuit to the courts.

\footnotetext{
1286 ibid, art 26.

1287 MOFCOM Measures for Merger Review (n 1231).

1288 ibid, art 5.

1289 ibid, art 6 .

1290 ibid, art 7.

1291 ibid, art 7.

$1292 \mathrm{ibid}$, art 10.

$1293 \mathrm{ibid}$, art 13.

1294 ibid, art 14.

1295 AML (n 42) art 30.
} 


\subsection{Substantive Test of Merger Review}

When assessing whether the notified merger should be approved (maybe with remedies) or prohibited, the substantive test applied in China's merger control law is: whether the merger will or may have the Effects of Eliminating or Restricting Competition (EERC test). ${ }^{1296} \mathrm{~A}$ notified merger will be prohibited if it will or may eliminate or restrict competition. A merger remedy can also be required by MOFCOM if it holds that the remedies are necessary to be included as additional conditions to reduce the potential anticompetitive effects. ${ }^{1297}$

In the US, according to Sec.7 of the Clayton Act, a merger will be prohibited if it Substantially Lessens Competition, or tends to create a monopoly (SLC test). ${ }^{1298}$ Art. 2 of the 2004 EUMR stipulates that '[A]ny concentration which could Significantly Impede Effective Competition in the common market or in a substantial part of it, in particular as a result of the creation or strengthening of a dominant position, should be declared incompatible with the common market'("SIEC test"). ${ }^{1299}$ In contrast to "substantively" in the US SLC test or "significantly" in the EU SIEC test, the AML and other rules and provisions do not mention a word on the degree of "eliminating or restricting competition". Put differently, it is ambiguous if a notified merger will be prohibited when it has or may have the effects of significantly eliminating or restricting competition, or when it has or may have the effect of leading to any elimination or restriction of competition.

Such ambiguity gives rise to the difficulty in determining whether an in-depth investigation is necessary (which has been discussed briefly in sec.3.1.2.1). For example, if the AML clarifies the substantive test as "significantly eliminate or restrict competition", then any notified merger which does not reach the degree of "significantly" can be approved (maybe with remedies). If MOFCOM is unsure about whether the degree of "significantly" is reached at the end of the preliminary investigation stage, an in-depth investigation will follow. However, due to the lack of an explicit standard in China's EERC test, it is possible that an in-depth investigation is commenced simply because MOFCOM fails to finish its investigations in stage I.

According to Art. 25 of the AML and Art. 3 of the MOFCOM Provisions on the Assessment of Merger, MOFCOM should consider the following factors when evaluating a notified merger:

1. the merging parties' market share and market power in the relevant market;

2. the degree of market concentration in the relevant market;

3. the impact of the merger on market entry and technological innovation;

4. the impact of the merger on consumers and other non-merging undertakings;

5. the impact of the merger on the development of the national economy;

6. other factors affecting competition in the market should be taken into account. ${ }^{1300}$

\subsubsection{General Assessment of Anti-Competitive Effects}

In accordance with the analysis in Chapter 5, the Chinese merger control law also divides the anti-competitive effects of a merger into two categories: unilateral effects and

\footnotetext{
$1296 \mathrm{ibid}$, art 3 and art 28.

1297 ibid, art 29.

1298 Sec.7 of the Clayton Act, 15. U.S.C. $\$ 18$ (2013).

12992004 EUMR (n 3) art 2.

${ }^{1300}$ MOFCOM Provisions on the Assessment of Mergers (n 1233).
} 
coordinated effects. ${ }^{1301}$ Art. 4 of the Provisions on Assessment of Merger stipulate 3 tests addressing the evaluation of a notified merger. First, MOFCOM will consider whether the merger will create or strengthen the merging parties' ability, incentives and possibility to unilaterally eliminate or restrict competition in the relevant market. Second, when there are only a few non-merging undertakings in the relevant market, MOFCOM will also assess whether the notified merger will create or strengthen the ability, incentives and possibility of the merging parties and the non-merging undertakings to collectively eliminate or restrict competition. Third, when the merging parties are not competitors in the same relevant market, MOFCOM will focus its attention on assessing whether the notified merger will give rise to the effects of eliminating or restricting competition in the upstream or downstream market or in the relevant market.

Although the Chinese merger control law does not distinguish expressly between horizontal mergers and non-horizontal mergers, one can observe that the first and second rules described above are generally applied to a horizontal merger, whereas the third rule can be employed when a non-horizontal merger (including vertical or conglomerate merger) is concerned.

\subsubsection{Market Share and Market Power}

Market share is deemed as an important factor in analysing, as well as directly reflecting the structure of the relevant market, and the merging parties and the non-merging undertakings' market position. Furthermore, in assessing the merging parties' market power, the following should be taken into account:

1. the merging parties' market share and the competition status in the relevant market;

2. the substitution level of the merging parties' products or service;

3. the non-merging parties' production capacities, and the substitution level of products and service between the merging parties and the non-merging undertakings';

4. the merging parties' control over the sales in the market and their ability in obtaining raw materials;

5. the ability of the buyer of the merging parties to switch suppliers;

6. the merging parties' financial strength and the technical capabilities;

7. the buyer power of the downstream buyer of the merging parties;

8. other factors that should be considered. ${ }^{1302}$

Market share and market power are two important factors when assessing whether a notified merger will bring anti-competitive effects. Unilateral or coordinated anticompetitive effects can be the concerns if the merging parties have a high market share and strong marker power, which imply that the merged undertaking can have a dominant position in the market. Chinese merger control law provides no "safe harbour". In the EU, according to case law, $50 \%$ is deemed as a threshold. ${ }^{1303}$ The merging parties' dominant market position can be self-evident if their market share is above $50 \% .{ }^{1304}$ Such a safe harbour to some extent works as an indicator which enables the merging parties to selfevaluate their proposed merger and possibly propose a fix-it-first remedy to the CA. The missing of such a safe harbour threshold in China's merger control law can to some extent

\footnotetext{
1301 See: sec.3 of Chapter 5.

1302 MOFCOM Provisions on the Assessment of Mergers (n 1233) art 5.

13032004 EC Horizontal Merger Guidelines (n 522) para.17.

${ }^{1304}$ For a detailed introduction of these points, see: Chapter 3, sec.3.2.1.
} 
result from its limited experience. The determination of such threshold requires empirical evidence, whereas MOFCOM is still exploring the merger control field. Moreover, the answer to this question may be found by analysing MOFCOM's decisions (Chapter 11).

\subsubsection{Market Concentration}

Market concentration is another factor which plays an important role when evaluating a notified merger. The Provisions on Assessments of Mergers indicate that the HHI can be used as an indicator to reflect the concentration degree of the market concerned. ${ }^{1305}$ The HHI is defined as the sum of the squared market shares of all firms in the relevant market. ${ }^{1306}$ It is pointed out that a merger has a high possibility of bringing anti-competitive effects of eliminating or restricting competition if the post-merger level of the HHI is high and the increase in the HHI is great. ${ }^{1307}$ However, there is again no "safe harbour" in China's merger control law, which can work as an indicator to determine whether their proposed merger will cause a high degree of market concentration.

The HHI has been employed by the competition agencies in the US since the mid1980s to measure market concentration. Also, it is used by the European Commission, according to the Horizontal Merger Guidelines. ${ }^{1308}$ Both jurisdictions consider the postmerger level of the HHI and the increase of the HHI (known as "delta" in the EU). ${ }^{1309}$

Since there is also no threshold provided in any existing provisions in China, information can again only be obtained from the decisions made by MOFCOM.

\subsubsection{Ease of Market Entry}

The ease of entry into the relevant market is considered as a factor to assess whether the notified merger will create anti-competitive effects. Barriers to the market entry can be created or increased after the implementation of a merger due to the merged firm's increased or newly-obtained market power. Such market power confers on the merged firm more power to control resources, sales channels, technology progress, and key facilities.

A merger will have less anti-competitive effects if market entry is open and the nonmerging undertakings can react to the merged undertaking's anti-competitive conduct. Such a market entry should be available in a manner of "likely, timely and sufficient". ${ }^{1310}$

\subsubsection{Efficiency and Efficiency Defence}

A merger review has to strike a balance between the potential efficiencies and the potential anti-competitive effects. It is pointed out in the Provisions on Assessments of Merger that, first, a merger has two sides. ${ }^{1311}$ It means that on the one hand, a merger can reallocate resources optimally, which can have a positive impact on technical innovations. On the other hand, a merger can also impede the development of technology by discouraging the merged undertaking from engaging in competition or investing in $\mathrm{R} \& \mathrm{D}$, due to its increased post-merger market power. Moreover, the merged undertaking can even deter the non-merging undertakings from investing, exploring and developing the technology by exerting its market power.

\footnotetext{
${ }^{1305}$ MOFCOM Provisions on the Assessment of Mergers (n 1233) art 6.

1306 Bishop and Walker (n 10) 68.

${ }^{1307}$ MOFCOM Provisions on the Assessment of Mergers (n 1233) art 6.

13082004 EC Horizontal Merger Guidelines (n 522) para. 16.

13092010 US Horizontal Merger Guidelines (n 11) part 5.3, 19. See also: ibid.

${ }_{1310}$ MOFCOM Provisions on the Assessment of Mergers (n 1233) art 7.

1311 See: ibid, art 8.
} 
Second, a merger can increase efficiency by realising the economy of scale and scope, which can enhance product diversification and cost-saving. ${ }^{1312}$ Such efficiency can benefit the consumer. However, a merger can also lead to price rises, output reduction, quality decrease, and reduction in investment in $\mathrm{R} \& \mathrm{D}$, which will harm the consumer benefits.

Third, a merger can incentivise the undertakings in the relevant market to improve product quality and decrease prices since competitive pressures are increased in the relevant market after the merger. ${ }^{1313}$ But the merged undertaking can also eliminate or reduce competition in the market by reducing the ability of the non-merging undertakings to enlarge or compete by exerting its obtained or strengthened market power. Further, a merger can also have foreclosure effects in the upstream or downstream industry.

Fourth, a merger can foster the expansion of business scale and enhance the competitiveness of a certain industry, so that efficiency can be obtained or strengthened, leading to the promotion of national economic development. ${ }^{1314}$ Nevertheless, sometimes a merger can also cripple the effective competition in a certain industry and impede its developments.

Summing up, during the merger review, MOFCOM will consider the pros and cons of a merger and try to strike a balance so that the potential efficiency generated from the merger can be preserved, while eliminating the potential anti-competitive effects.

Theoretically, a "defence" is also possible in the Chinese merger control law. Art. 28 of the AML states that MOFCOM can decide not to prohibit a merger application if the positive impact generated from the merger exceeds the anti-competitive effects. Art.12 of the MOFCOM Provisions on the Assessment of Merger stipulates that when MOFCOM assesses a merger application, factors such as "a failing undertaking" or the potential efficiency generated from the notified merger should be taken into account.

\subsubsection{Impact on the National Economy}

Art. 28 of the AML states that 'MOFCOM shall prohibit a merger if such merger will or may have effects of eliminating or restricting competition'. The AML also stipulates that the merger's impact on the national economy should be taken into account. ${ }^{1315}$ This actually reflects the uniqueness of the substantive test in Chinese merger control law and a question thus appears: what decision will MOFCOM make when a merger is likely to eliminate or restrict competition, whereas the merger will have a positive impact on the national economy?

This question arises because first, there is no explicit criterion addressing the question of "to what degree competition will or may be eliminated or restricted that can lead to a prohibition of a notified merger." As in the US, a merger will be prohibited if it substantially reduces competition. In the EU, a merger will be deemed as incompatible with EU merger control laws if it significantly impedes effective competition. If there is such requirement in the EERC test, one can predict that the merger will be approved (maybe with remedies) if it does not eliminate or restrict competition to a certain degree, no matter what impact it will bring to the national economy.

Second, it is pointed out that one of the most important industrial and economic policies in China is to enhance the competitiveness of some large undertakings so that they

\footnotetext{
1312 ibid, art 9.

1313 ibid, art 10 .

1314 ibid, art 11.

1315 AML (n 42) art 27.
} 
can be internationally competitive. ${ }^{1316}$ Considering this policy, MOFCOM may prefer to protect the national economy rather than the competition in the market when a merger involves certain industries which are relevant to the country's economic lifeline and national security. Such industries can be military industry, national power grid or national petroleum and chemical, etc. Furthermore, a notified merger may be prohibited if such a merger involves a large Chinese undertaking and a foreign undertaking in order to "protect" the Chinese undertaking, even if such a merger can promote competition. ${ }^{1317}$ According to Wang (2008), the best way to enhance an undertaking's competitiveness from a long-term perspective is through competition. ${ }^{1318}$ Using laws and policies as tools to promote an undertaking's development will never be a wise choice since monopoly will impede the innovative spirit of a country, whereas competition is the real impetus for improvement. ${ }^{1319}$

\section{Merger Divestitures in China's Merger Control Law}

According to Art. 29 of the AML, a merger remedy (in the language of the AML: restrictive conditions) can be imposed by MOFCOM to reduce potentially anti-competitive effects generated by the proposed merger when it decides not to prohibit a merger. ${ }^{1320}$ This is the only provision in the AML concerning merger remedies. There was no provision or rule concerning merger remedies until 2010 when the Interim Provisions on Implementing the Divestitures of Assets or Business under Merger Control were issued by MOFCOM. ${ }^{1321}$ This provision specifically focused on merger divestitures. In 2014, a more comprehensive provision on merger remedies (MOFCOM Provisions on Merger Remedies) was issued, replacing the 2010 MOFCOM Divestiture Provisions, which entered into force on 5 January 2015.1322 The MOFCOM Provisions on Merger Remedies are more comprehensive and the wording of the rules is structured in a way which is quite similar to the remedies rules and policies in the US and the EU.

After the publication of the MOFCOM Provisions on Merger Remedies, the AMB published an article with the aim to shed light on China's merger remedy policy. ${ }^{1323} \mathrm{It}$

\footnotetext{
1316 Wang (n 1255).

1317 For example, MOFCOM/2009-22, Probibition on Merger concerning Huiyuan Fruit Juice/Coca-Cola (MOFCOM Decision) [18 March 2009] <http://fldj.mofcom.gov.cn/article/ztxx/200903/20090306108494.shtml> accessed 29 April 2017. This is the first merger which was prohibited by the MOFCOM since the enactment of the AML.

1318 Wang (n 1255).

1319 ibid.

1320 AML (n 42) art 29.

${ }_{1321}$ Ministry of Commerce (MOFCOM), Interim Provisions on Implementing the Divestitures of Assets or Business under Mergers Control (guan yu shi shi jing ying zhe ji zhong zi chan buo ye wu bo li de zan xing gui ding 关于实施经营者集中资 产或业务剥离的暂行规定)(Issued and entered into force 5 July 2010, repealed 5 January 2015) (herein: 2010 MOFCOM Divestiture Provisions).

1322 MOFCOM Provisions on Merger Remedies (n 1226).

1323 Anti-Monopoly Bureau of the Ministry of Commerce, 'Anti-Monopoly Bureau of the Ministry of Commerce: Some Insights Concerning the MOFCOM Provisions on Merger Remedies (shang wu bu fan long duan ju fu ze ren guan yu 《guan yu jing ying zhe ji zhong fu jia xian zhi xing tiao jian de gui ding (shi xing) de jie du》商务部 反垄断局负责人关于《关于经营者集中附加限制性条件的规定（试行）》的解读)' (MOFCOM, 17 December 2014) <http://www.mofcom.gov.cn/article/zhengcejd/bl/201412/20141200835988.shtml> accessed 29 April 2017.
} 
stated that divestitures, as one of the most typical structural remedies, are the most effective remedies to reduce the anti-competitive effects generated from a merger. ${ }^{1324}$

In this section, merger remedies policies and rules, especially merger divestitures, are explored in detail (according to the MOFCOM Provisions on Merger Remedies) from the following perspectives: general principles, the design of divestitures and the implementation of divestitures. Comparisons with the rules and policies in the US and the EU are also made.

\subsection{General Principles}

The MOFCOM Provisions on Merger Remedies divided merger remedies into three categories, namely: structural remedies, such as divestitures of tangible assets or intangible rights; behavioural remedies, such as opening access to networks and key technologies (including patents or other intellectual property), and termination of exclusive agreements; and hybrid remedies, which are the combination of both structural remedies and behavioural remedies. ${ }^{1325}$ Hence, fundamentally, the Provisions adopt the dichotomy of remedies: structural and behavioural. The former gives rise to the structural changes of the merging parties' assets, while the latter changes the merging parties' behaviour. Such dichotomy is also adopted by the CAs in the US and the EU.

The Provisions stated that a divestiture package should include all the assets that are needed for a successful business, including the merging parties' tangible or intangible assets, equities, key personnel and agreements with their customers, and supply agreements. The divestiture package can also include the subsidiaries, branches or certain departments of the merging parties. ${ }^{1326}$

Trustees can be appointed when merger divestitures are imposed in a merger decision. Trustees should be appointed by the merging parties and such appointments should be approved by MOFCOM. A trustee can be a natural person, a legal person, or other organisations established according to the law. There are two categories of trustees, namely, the monitoring trustees and the divestiture trustees. The former is appointed to monitor the merging parties' fulfilment of their obligations during the self-divesting period, while the latter is appointed to implement divestitures during the trustee-divesting period. ${ }^{1327}$

\subsection{Design of Merger Divestitures}

MOFCOM will notify the merging parties about its competition concerns. Such notification is similar to the Statement of Objections ("S/O") issued by the European Commission during its Phase I or Phase II investigations, in which the Commission's competitive concerns about the notified mergers will be described. ${ }^{1328}$ The difference is that MOFCOM will only issue such notifications during the in-depth investigation stage. ${ }^{1329}$ Once the merging parties receive such notifications from MOFCOM, they can

\footnotetext{
1324 ibid.

1325 MOFCOM Provisions on Merger Remedies (n 1226) art 3.

1326 ibid, art 3.

${ }^{1327}$ For a detailed introduction concerning the divestiture process, see: sec.4.3.1 below.

${ }^{1328}$ For an introduction of the in-depth investigations of merger review in the EU, see: Chapter 3, sec.3.1.3.

${ }^{1329}$ MOFCOM Provisions on Merger Remedies (n 1226) art 10.
} 
submit their merger remedy proposal as a response to address MOFCOM's concerns. Such proposals should be submitted 20 days before the end of the in-depth investigations. ${ }^{1330}$

MOFCOM will assess the effectiveness, feasibility and timeliness of the proposed merger remedy plan. Negotiations are possible between the merging parties and MOFCOM to revise the proposed merger remedy to ensure the sufficiency to clear any potential anti-competitive effects generated from the notified merger. When appraising the merger remedy proposal, MOFCOM can ask for comments and opinions from the relevant governmental departments, industry associations, other non-merging undertakings and consumers by means of sending surveys and questionnaires, holding public hearings, inviting experts for discussions, or other means. ${ }^{1331}$

According to these merger remedy guidelines and studies published by the CAs in the US and the EU, as well as the divestiture practices in these two jurisdictions, when designing a divestiture to assure the effectiveness to the extent possible, attention has to be paid to the sufficiency of the divestiture package and the suitability of a purchaser. In the next section, the requirements for the design of merger divestitures in China's merger control law are explored from the perspectives of determination of the composition of a divestiture package, requirements for a suitable buyer, and the possibility of a fix-it-first remedy.

\subsubsection{Composition of Divestiture Packages}

\subsubsection{General Requirements}

The sufficiency of a divestiture package is crucial to ensure a successful divestiture. The MOFCOM Provisions on Merger Remedies require that a divestiture package should include all the assets that are needed for protecting effective competition in the market. ${ }^{1332}$ Such assets can be both tangible and intangible. There is no rule, however, which clarifies the approach that MOFCOM employs when choosing the to-be-divested assets.

The FTC and the DOJ share similar requirements when determining the composition of divestiture packages in the sense that, first, both of them prefer an existing and an ongoing business; second, a mix-and-match approach (meaning the to-be-divested assets are chosen from both sides of the merging parties) will only be applied when the agencies are convinced that such assets are sufficient for an effective divestiture.

Besides, a "clean sweep" approach is applied by the FTC. A clean sweep approach means an approach under which a divestiture package includes the merging parties' overlapping business. According to the case law in the US, it can be concluded that a clean sweep approach can be effective if a merger involves retail markets, such as supermarkets and petrol stations. ${ }^{1333}$

After the enactment of the 2008 EC Remedies Notice, the situation in the EU is similar to the US. ${ }^{1334}$ The general requirements for the to-be-divested assets are: viable, on-going, and can be operated on a stand-alone basis. ${ }^{1335}$ The Commission will also consider carveouts, meaning divesting parts of the merging parties' assets. The requisite requirement for

\footnotetext{
1330 ibid, art 6.

1331 ibid, art 8 .

1332 ibid, art 4.

${ }^{1333}$ For details, see: Chapter 2, sec.5.1.3.

13342008 EC Remedies Notice (n 35).

1335 ibid, para. 23, 25, 31 .
} 
accepting carve-outs is that, until the moment when the business is transferred to the purchaser, the to-be-divested parts are still viable. ${ }^{1336}$

Comparatively, it is observable that the requirements in the MOFCOM Provisions on Merger Remedies are simple and general.

\subsubsection{Crown Jewel Provisions}

Crown jewel provisions are introduced in the MOFCOM Provisions on Merger Remedies. According to Art. 7 of the Provisions, when MOFCOM has concerns about the successful implementation of the proposed divestitures, it can include a crown jewel provision in its final decision, requiring the notifying parties to provide an alternative divestiture package with at least equivalent value to the original package.

Crown jewel provisions to some extent can ensure a timely divestiture by imposing the risk of divesting more assets on the merging parties. Crown jewel provisions have also been used by the FTC, the DOJ and the Commission. The FTC has a preference for crown jewel provisions and has frequently required the inclusion of the provisions in consent orders. In contrast, before the publication of the 2011 DOJ Policy Guide, the DOJ strongly disliked the provisions (reflecting in the 2004 version) ${ }^{1337}$. The DOJ now is changing its attitude towards crown jewel provisions by confirming their function to increase the likelihood of the emergence of a purchaser. The Commission will also consider the use of crown jewel provisions if the original divestiture packages lack the certainties of attracting an appropriate buyer within the time frame. ${ }^{1338}$

The MOFCOM Provisions on Merger Remedies do not explain the importance of the sufficiency of the divestiture packages. However, according to the analysis that has been done in Chapter 6, composition risks which are caused by the insufficiency of the divestiture packages can largely cripple the effectiveness of divestitures. Moreover, such risks have been recognised by both the CAs in the US and in the EU. From a legal perspective, it is unknot known whether MOFCOM has been aware of composition risks. ${ }^{1339}$

\subsubsection{Suitable Buyers}

\subsubsection{General Requirements}

The availability of a suitable buyer can have a large impact on the realisation of the effectiveness of a divestiture package. MOFCOM will assess the suitability of the proposed buyer by the merging parties. ${ }^{1340}$ A suitable buyer should satisfy the following requirements:

1. be independent of the merging parties;

2. have the resources, capability and incentives to compete in the market after having purchased the divested assets;

3. be approved by other institutions;

4. not allowed to purchase the divested assets being financed by the merging parties;

\footnotetext{
1336 ibid, para. 35.

13372011 DOJ Policy Guide (n 56).

13382008 EC Remedies Notice (n 35) para. 45.

${ }^{1339}$ Questions that remain unanswered in law will be explored through case analysis (Chapter 11) or from an empirical perspective (Chapter 12).

${ }^{1340}$ MOFCOM Provisions on Merger Remedies (n 1226) art 12.
} 
5. MOFCOM's other requirements. ${ }^{1341}$

In general, a buyer should have the financial strength and the incentives to compete. Financial strength suggests that the purchaser will have enough resources and investment to operate the divested business. Incentives to compete to some extent imply that the purchaser will not collude with the merged undertaking after the completion of divestitures to maximise their joint profits (this risk is also known as collusion risk, which has been explored in Chapter 8).

The requirements set by MOFCOM are generally similar to those in the US and the EU, which also emphasise the buyer's independence, incentives and capability of the purchaser. It is unknown, however, whether or in what situations MOFCOM will prefer an existing competitor or a new market entrant. According to the observations in the previous chapters, either the new market entrant or the existing competitors have their own advantages and disadvantages. An existing competitor can have more resources, stronger financial strength or more experience in the industry that the divested business concerns, whereas there is a risk of joint dominance if the merged undertaking and the existing competitor both have a large market share in the relevant market. A small and new market entrant, on the one hand, can be weak; on the other hand, it can be aggressive and have strong incentives to compete.

The MOFCOM Provisions on Merger Remedies do not provide any detailed guidance addressing the assessment method of a buyer's resources, capability and incentives, like the DOJ does ("fitness" test). ${ }^{1342}$

\subsubsection{Up-Front buyer Provisions}

MOFCOM can require the inclusion of up-front buyer provisions in its decisions. An upfront buyer provision requires the merging parties to find a buyer and enter into a formal divestiture agreement before the implementation of the notified merger. Such a buyer should be approved by MOFCOM. MOFCOM indicates that an up-front buyer provision will be considered in the following situations:

1. when there is a risk that the competitiveness and marketability of the to-be-divested assets will deteriorate during the interim period before the completion of the divestitures;

2. when the identification of the buyer will exert a decisive impact on the restoration of competition in the market;

3. when there is a third party that claims rights over the to-be-divested assets. ${ }^{1343}$

Like crown jewel provisions, up-front buyer provisions are also used by the CAs in the US and the EU. The CAs may consider the inclusion of an up-front buyer when there are buyer risks ${ }^{1344}$ or asset risks. ${ }^{1345}$ As observed in Chapter 2, the FTC has frequently used upfront buyer provisions in the consent orders to ensure the availability of the buyer. The DOJ, on the other hand, has no preference for such provisions. The European Commission in the 2008 EC Remedies Notice clarifies the situations where it will consider

\footnotetext{
1341 ibid, art 11.

1342 The DOJ can conduct a fitness test to evaluate whether the proposed buyer has sufficient acumen, experience, and financial capability to compete in the market. See: 2011 DOJ Policy Guide (n 56) 28.

${ }^{1343}$ MOFCOM Provisions on Merger Remedies (n 1226) art 14.

1344 Buyer risks refer to the risks of unavailability of suitable buyers.

1345 See: Chapter 7.
} 
the inclusion of up-front buyer provisions. ${ }^{1346}$ The use of up-front buyer provisions at least reflects that MOFCOM has been aware of the possibility of asset risks.

\subsubsection{Fix-It-First Remedy}

There is one short sentence in the MOFCOM Provisions on Merger Remedies which implies that a fix-it-first remedy may be accepted by MOFCOM, '[T] he notifying parties can submit a merger remedy proposal before MOFCOM raises any objections concerning the notified merger due to its potential anti-competitive effects of eliminating or restricting competition'. ${ }^{1347}$

A fix-it-first remedy means that the merging parties identify and enter into a binding agreement with a buyer before the start of or during the merger review process, so that the CAs can review the proposed divestitures plan and the notified mergers to decide whether to approve the transaction (with divestitures). MOFCOM clarifies that a merger remedy proposal can be submitted before the merging parties receive formal notification (in the language of the EU: Statement of Objections) from MOFCOM, stating its competition concerns. ${ }^{1348}$

\subsection{Implementation of Merger Divestitures}

\subsubsection{Divestiture Process}

According to the MOFCOM Provisions on Merger Remedies, the divestiture process in China is divided into two stages: the implementing stage and the closing stage. Moreover, an implementing stage can further be divided into two periods: self-divesting period and trustee-divesting period. ${ }^{1349}$ A self-divesting period begins once MOFCOM approves the notified merger subject to divestiture. During this period, the merging parties have to find a suitable purchaser and enter into a formal and binding divestiture agreement. If the merging parties fail to implement divestitures within the timeframe, then a trustee-divesting period begins. During the trustee-divesting period, divestiture trustees will take the responsibility to find a purchaser and strike an agreement with the purchaser. In addition to the proposed purchaser, MOFCOM will also review the draft divestiture agreements to ensure that the agreements are compatible with its decisions. ${ }^{1350}$

The timeline for the self-divesting period and the trustee-divesting period will be decided by MOFCOM. If there is no explicit timeline in the decisions, generally the merging parties have to implement the divestitures within 6 months. ${ }^{1351}$ It is also possible for the timetable to be extended for another 3 months (at most), but the merging parties have to explain the reasons for the extension to MOFCOM. ${ }^{1352}$ MOFCOM will assess the reasons and decide whether to approve the application of extension or not. During the trustee-divesting period, trustees should also implement divestitures within 6 months. There is no possibility to extend the trustee-divesting period. The divesting trustee can sell the to-be-divested assets with an unreserved price. ${ }^{1353}$

\footnotetext{
13462008 EC Remedies Notice (n 35) para. 55-56.

1347 MOFCOM Provisions on Merger Remedies (n 1226) art 6.

1348 ibid, art 6.

$1349 \mathrm{ibid}$, art 10.

$1350 \mathrm{ibid}$, art 12.

1351 ibid, art 13.

1352 ibid, art 13.

1353 ibid, art 22.
} 


\section{PART III. DIVESTITURES IN CHINA}

During the closing stage, the divested assets and relevant legal rights have to be transferred from the merging parties to the purchaser within 3 months. An extension is possible by an application from the merging parties. However, the MOFCOM Provisions on Merger Remedies are silent on the maximum number of months that can be extended in the closing stage. Figure 20 summarises the divestiture process under China's merger review procedures.

Figure 20 Divestiture Process under China's Merger Control

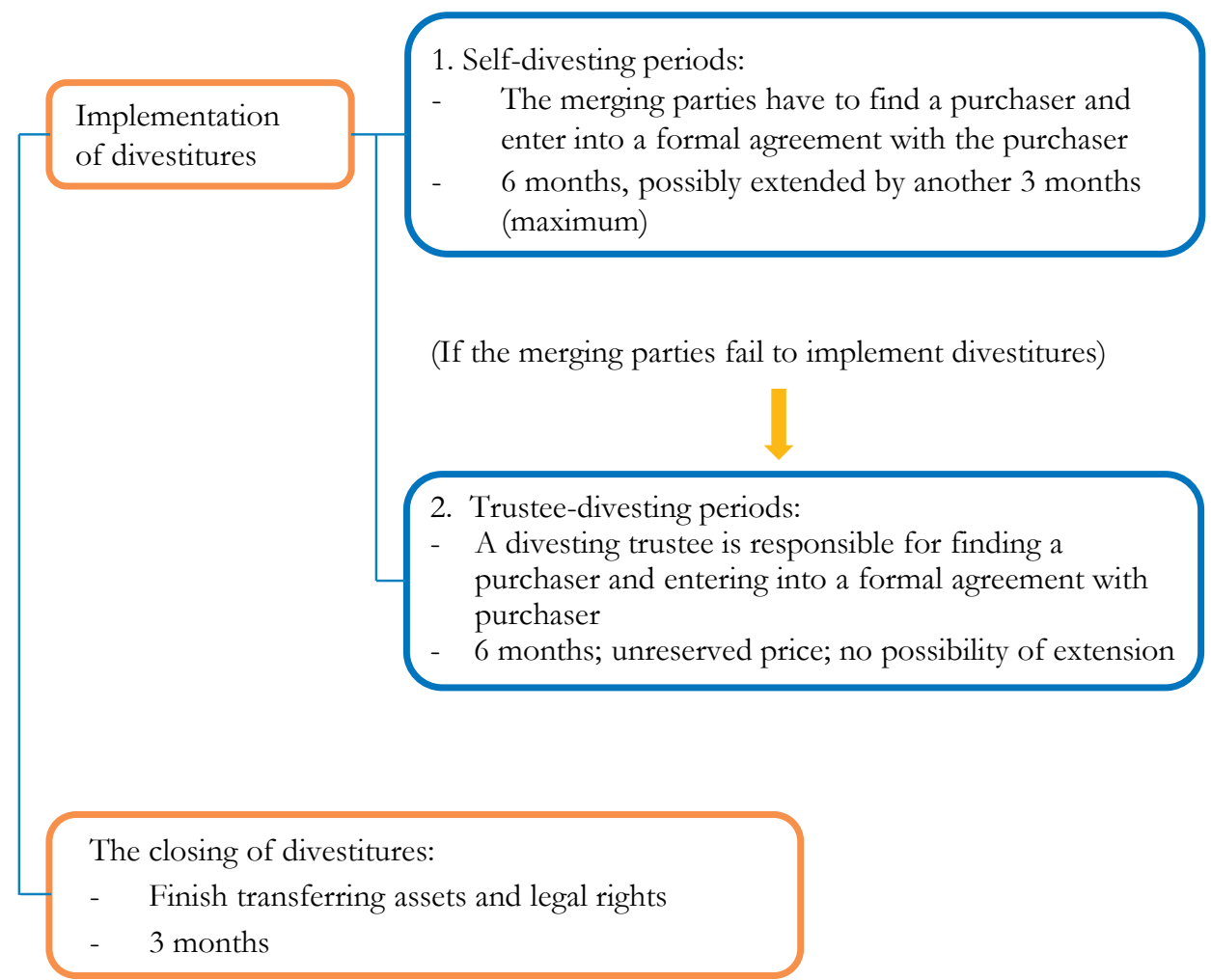

\subsubsection{Trustees}

As is described in the General Principles, there are two kinds of trustees, monitoring trustees and divestiture trustee, which have different responsibilities during different divestiture processes.

\section{Requirements}

Proposals of trustees should be proposed by the merging parties and approved by MOFCOM. Appointment contracts of trustees have to be signed between the merging parties and the purchaser. Art. 18 of the MOFCOM Provisions on Merger Remedies stipulates that the proposal of monitoring trustees should be submitted to MOFCOM within 15 days since MOFCOM has made the decision of approving the notified merger 
with divestiture remedies. A divestiture trustee should be nominated 30 days before the trustee-divesting period begins. ${ }^{1354}$ The merging parties should pay the trustees.

The requirements for selecting the monitoring trustees and the divestiture trustees are as follows:

1. They should be independent of the merging parties and the purchaser;

2. They should have professional knowledge, technology and experience concerning the divested business;

3. They should be able to provide a feasible working plan;

4. They should monitor the merging parties' selection process of a purchaser;

5. Other requirements made by MOFCOM. ${ }^{1355}$

\section{Obligations}

Generally, monitoring trustees are responsible for overseeing the merging parties' compliance with their obligations during the self-divesting period. They work under the supervision of MOFCOM and take the responsibilities as follows:

1. Ensure that the merging parties comply with the rules and regulations in the MOFCOM Provisions on Merger Remedies, obligations in the decisions made by MOFCOM and other relevant obligations;

2. Assess the suitability of the purchaser nominated by the merging parties and the drafted divestiture agreements. Assessment reports should be submitted to MOFCOM;

3. Monitor the merging parties' compliance with the divestiture agreements and report to MOFCOM;

4. Mediate issues between the merging parties and the potential purchasers;

5. Submit reports and provide other relevant information required by MOFCOM. ${ }^{1356}$

Divestiture trustees are responsible for finding a suitable buyer for the divestiture package and they are entitled to sell the divestiture package with no limitation on the minimum price. ${ }^{1357}$

\subsubsection{Hold Separate Provisions (HSPs)}

As explored in Chapter 7, to reduce assets risks, the CAs in the US and the EU frequently include HSPs in the decisions and the appointment of a hold-separate manager to operate the separated to-be-divested assets during the interim period. Such provisions are helpful to preserve the viability, competitiveness and marketability of the to-be-divested assets.

Art. 20 of the MOFCOM Provisions on Merger Remedies regulates that before the completion of divestitures, the merging parties have to fulfil the following obligations to preserve the viability, competitiveness and marketability of the to-be-divested business:

1. Keep the to-be-divested assets independent from the merging parties' retained business, and manage the to-be-divested assets with the most suitable methods;

2. Any behaviour which may have negative impacts on the to-be-divested assets is prohibited, including employing the key personnel of the to-be-divested assets, or obtaining the to-be-divested assets' commercial secrets and other confidential information;

\footnotetext{
1354 ibid, art 18.

$1355 \mathrm{ibid}$, art 19.

1356 ibid, art 21.

1357 ibid, art 22.
} 
3. Assign a special manager, who will be responsible for managing the to-be-divested business. Such a manager should work under the supervision of the monitoring trustee. Appointment and replacement of the manager should be approved by the monitoring trustee;

4. Assure that all the potential purchasers have fair and reasonable access to sufficient information on the to-be-divested assets; assess the commercial value and potentiality of the to-be-divested assets;

5. Provide the purchaser with necessary support and assistance if required, and ensure a smooth transfer and stable operation of the divested assets;

6. Transfer the divested assets to the purchaser on time and finish other legal procedures.

The MOFCOM Provisions on Merger Remedies further stipulate that under the monitoring of monitoring trustees, the merging parties have the obligation to submit reports to MOFCOM to state their compliance with the merger review decisions, the implementation of divestitures and the execution of other obligations in the agreements. ${ }^{1358}$

\section{Conclusion}

The development of competition law and competition policies in China has experienced three periods. The enactment of the AML in 2008 can be regarded as one of the milestones during the development of China's competition law for its modern concepts and system, symbolising a new era of the legislation and practice in the anti-trust field in China.

The AML provides a very general legal framework of merger control. Other provisions, such as the MOFCOM Merger Thresholds Provisions, play an important role in enriching and confirming China's merger control system. Like the US and the EU, China has adopted a two-stage investigation system and a mandatory pre-merger notification system. Any merger, falling within the scope of Art. 20 of the AML, has to be notified to MOFCOM if the proposed merger meets certain thresholds. Mergers that will or may eliminate or restrict competition will be prohibited. A merger remedy can be required by MOFCOM if it decides not to prohibit it.

Merger remedy policies and rules (mainly in the field of merger divestitures) which are introduced in the recently published MOFCOM Provisions on Merger Remedies are quite similar to those in the US and the EU. Such policies and provisions include crown jewel provisions, up-front buyer provisions, appointments of trustees, and hold-separate provisions. As observed, these divestiture policies and regulations can effectively reduce composition/asset/collusion risks arising from divestitures.

However, there are also some questions that remain unanswered (see Table 11 below) and thus need further clarification.

1358 ibid, art 20. 
Table 11 Ambiguities in the AML Regarding Merger Review and Merger Divestitures

\begin{tabular}{|c|c|}
\hline Legislative arrangements & Questions/Potential risks \\
\hline \multicolumn{2}{|l|}{ Merger Review } \\
\hline There are three competition agencies in China. & $\begin{array}{l}\text { The division of authority between three CAs might } \\
\text { reduce the effectiveness of anti-trust policies. }\end{array}$ \\
\hline $\begin{array}{l}\text { No distinction is made between fully- } \\
\text { functional/non-fully-functional JVs. }\end{array}$ & $\begin{array}{l}\text { - It might reduce the effectiveness of the AML since } \\
\text { some cases may fall within the scope of "monopoly" } \\
\text { rather than "concentration". } \\
\text { - It might lead to the risk of MOFCOM's overload. }\end{array}$ \\
\hline Multi-dimensional goals of the AML. & $\begin{array}{l}\text { - There might be trade-offs when there is a } \\
\text { contradiction between different goals. } \\
\text { - The multi-dimensional goals of the AML might affect } \\
\text { the design of merger remedies. }\end{array}$ \\
\hline $\begin{array}{l}\text { Ambiguities in the EERC test (the absence of the } \\
\text { degree requirement). }\end{array}$ & $\begin{array}{l}\text { - It might lead to difficulties in deciding whether a } \\
\text { notified merger should be approved in the first stage } \\
\text { (there is a risk that an in-depth investigation is } \\
\text { commenced simply because the MOFCOM cannot } \\
\text { finish the investigations during the preliminary } \\
\text { investigation stage). } \\
\text { - It might reduce the transparency and predictability of } \\
\text { the AML from the perspective of the merging parties. }\end{array}$ \\
\hline $\begin{array}{l}\text { There is no clear standard to determine when } \\
\text { MOFCOM can investigate a merger even the }\end{array}$ & $\begin{array}{l}\text { It may reduce the practicability, predictability and } \\
\text { transparency of the merger review system. }\end{array}$ \\
\hline
\end{tabular}
transaction does not satisfy the notification thresholds.

No safe harbour threshold is provided in assessing It can result in difficulties for the merging parties to the market shares and the degree of market design their transactions.

concentration.

\begin{tabular}{ll}
\hline Merger Divestitures & \\
\hline $\begin{array}{l}\text { It remains unclear whether MOFCOM has been } \\
\text { aware of composition risks, asset risks and } \\
\text { collusion risks when designing divestitures. }\end{array}$ & The effectiveness of divestitures can be reduced. \\
\hline $\begin{array}{ll}\text { Selection standards for an appropriate purchaser } \\
\text { are to some extent not clear. }\end{array}$ & $\begin{array}{l}\text { It is unknown in what situations that an existing } \\
\text { competitor or a new market entrant will be preferred } \\
\text { by MOFCOM as a buyer. } \\
\text { The approach for MOFCOM to assess the sufficiency } \\
\text { of the buyer's resources to operate the divested assets } \\
\text { is unclear. }\end{array}$
\end{tabular}

The reasons why the above-mentioned questions arise are complex, are those which may concern the legislative tradition, cultural background, the circumstances of the national economy, or other practical reasons. Two approaches will thus be taken to answer those questions. First, case analyses will be conducted in Chapter 11 to see how MOFCOM deals with these questions in practice. Second, interviews will also be conducted to provide some empirical insights regarding MOFCOM's practice in merger divestitures (Chapter 12). 



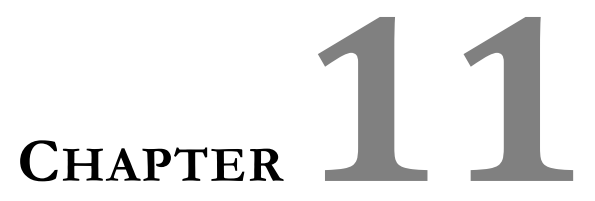

MOFCOM'S PRACTICE IN MERGER CONTROL AND MERGER REMEDIES: CASE ANALYSES 



\section{Introduction}

According to the data published on MOFCOM's websites, there is an upward trend concerning the number of cases that MOFCOM decided. It is quite interesting to find out that only the numbers of decided transactions are published regularly, whereas other information, such as the total numbers of notifications received and accepted by MOFCOM are only mentioned through MOFCOM's various Press Conferences.

MOFCOM's data publication regarding merger review can be divided into two categories: unconditional approvals and conditional approvals/probibitions. Full text of conditionally-approved decisions or prohibited decisions will be published right after they are made, which is in compliance with Art. 30 of the AML. ${ }^{1359}$ In contrast, the total number of unconditional approvals has only been made available on a quarterly basis since the $4^{\text {th }}$ quarter of $2012 .{ }^{1360}$ Even so, only limited information, such as the names of the merging parties and the date for approval are made available.

The following table summarises the number of MOFCOM's decided transactions from 1 August 2008 to 30 December 2016 (unconditional approvals, conditional approvals and prohibitions).

There are several observations that can be drawn from Table 12. First, the number of MOFCOM's reviewed transactions has grown exponentially over the past 8 years from 2008 to 2016. The publication of two legal documents may to some extent explain the increase.

In 2012, MOFCOM published the Interim Measures for Investigating and Handling Failure to Legally Declare the Concentration of Undertakings ("MOFCOM Fail-to-Notify Provisions"). ${ }^{1361}$ The Provisions provide detailed regulations regarding how to deal with failures of making pre-merger notifications. Art. 13 of the MOFCOM Fail-to-Notify Provisions combined with Art. 48 of the AML, enable MOFCOM to impose a fine of up to RMB 500,000 on the parties which fail to make a pre-merger notification. ${ }^{1362}$ In addition, MOFCOM can publish the names of the fail-to-notify merging parties to the public, exposing them to reputational risks. ${ }^{1363}$

${ }^{1359}$ AML (n 42). Art. 30 of the AML states, 'The Competition Agency should publish its decision to the public if the decision concerns a conditional approval or a prohibition'.

${ }^{1360}$ Before the $4^{\text {th }}$ quarter of 2012, the statistics of MOFCOM's reviewed transactions was only available from 1 August 2008 to 30 September 2012 with no details of quarterly or annual statistics during the period from 2008 until the $3^{\text {rd }}$ quarter of 2012 .

${ }^{1361}$ MOFCOM Fail-to-Notify Provisions (n 1234).

1362 ibid, art 13 reads:

If, after the investigations, the merging parties are proved to fail to make pre-merger notifications, MOFCOM can impose a fine up to RMB 500,500 and require the merging parties to restore the concerned business to the pre-merger level by taking the following measures... .

Art 48 of the AML (n 42) states:

Where the business operators implement the concentration in violation of this Law, the AntiMonopoly Law Enforcement Agency under the State Council shall order them to stop the concentration, to dispose shares or assets, transfer the business or adopt other necessary measures to restore the market situation before the concentration within a time limit, and may impose a fine of less than 500,000 yuan.

${ }^{1363}$ MOFCOM Fail-to-Notify Provisions (n 1234) art 15. For example, MOFCOM announced on 4 January 2017 that a fine (RMB 300,000) was imposed on Canon Inc. /Toshiba Medical Systems Corporation for their failure to make a pre-merger notification. See: Department of Treaty and Law of MOFCOM, 'MOFCOM's Decisions of Administrative Penalty No. 2016/965' (AMB of MOFCOM, 4 January 2017) <http://fldj.mofcom.gov.cn/article/ ztxx/201701/20170102495433.shtml> accessed 2 May 2017. 
Table 12 Annual Number of MOFCOM's Decided Transactions (1 August 2008 - 30 December 2016) ${ }^{1364}$

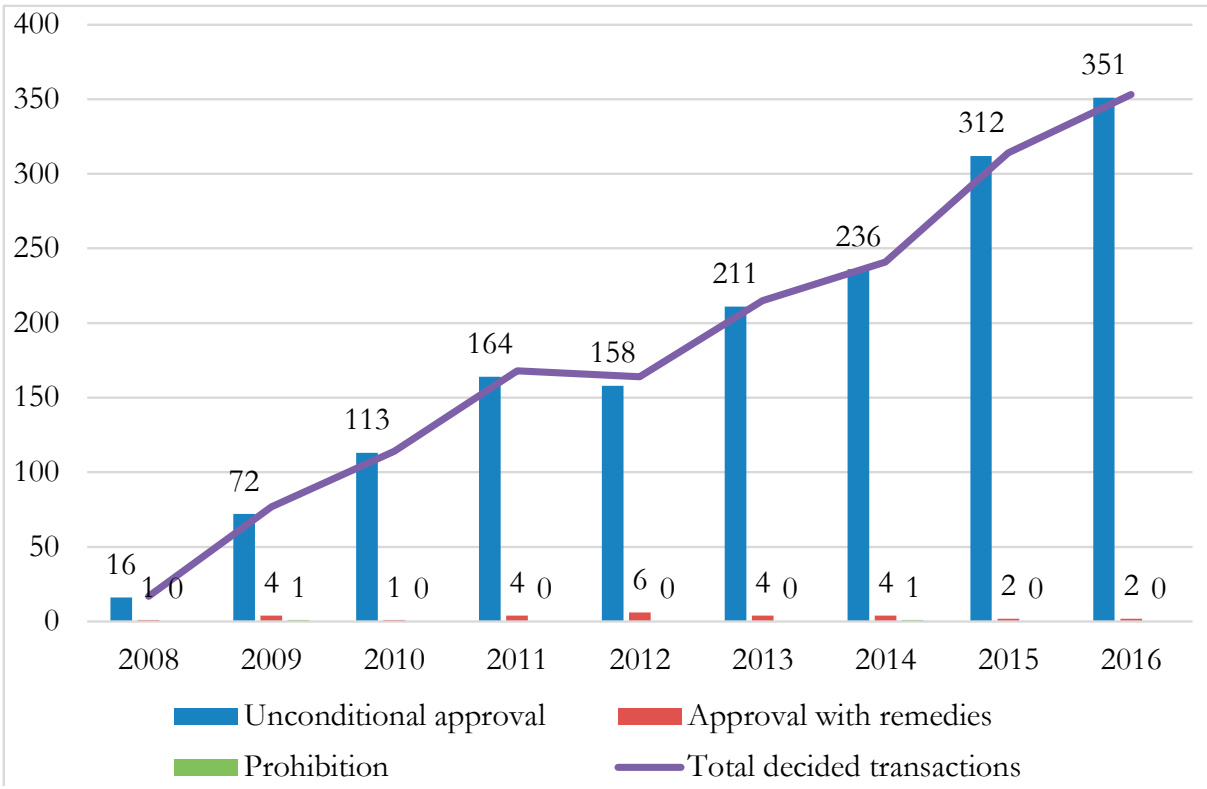

Another document is the Interim Provisions on Standards Applicable to Simple Cases of Concentration of Undertakings ("MOFCOM Provisions of Simple Cases"), which was enacted on 12 February 2014. 1365 The Provisions stipulate the criteria for determining "simple cases". Although MOFCOM has not published any procedural provisions for simple cases, it is believed that merger review procedures for simple cases should be/are less complicated than the procedures for ordinary ones and thus have a shortened time limit of merger review. ${ }^{1360}$

Second, Table 12 demonstrates that the vast majority of these transactions are approved unconditionally. It was pointed out by Ming Shang the former Director General of the AMB of MOFCOM- in 2011 that 'the percentage of cases approved unconditionally is higher for MOFCOM than for the European Commission'. ${ }^{1367}$

\footnotetext{
${ }^{1364}$ Due to the reasons explained in the text as well as in footnote above, the annual data in Table 12 regarding the period from 2008 to 2012 is adopted from Freshfields Bruckhaus Beringer, 'China's Anti-Monopoly Law: The Story So Far and What's Next?’ (Lexology, 23 September 2015) <http://www.lexology.com/library/detail. aspx?g=2f59e1e2-d4d0-4d21-b4eb-b47af28fc0c9> accessed 2 May 2017. For the list of MOFCOM's unconditionally-approved cases from 2013, see: MOFCOM, 'Lists for Unconditional Approved Cases' $(M O F C O M)<$ http://fldj.mofcom.gov.cn/article/zcfb/> accessed 2 May 2017; For a detailed list of all conditionally approved cases and prohibited cases, see: MOFCOM, 'Public Notices' (MOFCOM) $<$ http://fldj.mofcom.gov.cn/article/ ztxx/> accessed 2 May 2017. In Table 12, numbers of total decided transactions refer to the aggregated numbers of conditional approvals, unconditional approvals and prohibitions. 1365 MOFCOM Provisions of Simple Cases (n 1235).

${ }^{1366}$ For a detailed exploration of the MOFCOM Provisions of Simple Cases, see: sec.3.1.2, Chapter 10. Some empirical insights regarding this question will be presented in Chapter 11.

1367 See: Feideng Deng, H. Stephen Harris and Yizhe Zhang, Interview with Ming Shang, former Director General of the Anti-Monopoly Bureau under the Ministry of Commerce of the People's Republic of China (Beijing, 7 January 2011). For the text of the interview, see: <http://www.edgewortheconomics.com/files/documents/ Fei_Deng_Interview_with_Shang_Ming_in_the_Antitrust_Source.pdf $>$ accessed 2 May 2017.
} 
Third, as Table 12 further indicates that, by the end of 2016, there were in total 28 transactions which were approved conditionally, whereas only 2 transactions were prohibited. ${ }^{1368}$ Ming Shang specified that most of the transactions were horizontal mergers and most transactions concerned manufacturing industries, including petroleum, chemicals, machinery manufacturing, automotive, etc. ${ }^{1369}$

With the aim of exploring the questions mentioned in the first paragraph, subsequent to the Introduction, the rest of this Chapter is structured as follows.

In sec.2, substantive and procedural features of MOFCOM's merger review are explored. Merger remedies are analysed in sec.3 with a special focus on the strategies MOFCOM uses to reduce composition risks, asset risks and collusion risks. There will be three sub-sections. A conclusion is drawn in the last section.

\section{MOFCOM's Merger Review}

By 20 June 2017, there are 29 transactions that have been approved by MOFCOM subject to merger remedies. Among all, there are 15 decisions in which pure behavioural remedies were required; 5 transactions were approved subject to pure structural remedies and hybrid remedies were used in 9 transactions. ${ }^{1370}$ Table 13 below groups all these cases based on different types of remedies. ${ }^{1371}$

\footnotetext{
${ }^{1368}$ By 20 June 2017, the number of total conditional approvals is 29. See: Table 13 below.

1369 See: MOFCOM, 'Press Conference of MOFCOM's Anti-monopoly Progress in 2012 (shang wu bu zhao kai "2012 nian fan long duan gong zuo jing zhan"zhuan ti xin wen fa bu hui 商务部召开“2012 年反垄断工作进展”专题新闻发布会”) (MOFCOM, 28 December 2012) <http://www.mofcom.gov.cn/article/ae/slfw/201212/20121208504842. shtml> accessed 2 May 2017. See also: Deng, Harris and Zhang (n1367).

${ }^{1370}$ Cases that were approved by both structural remedies and behavioural remedies, such as UTC/Goodrich (2012), are categorised into "structural remedies" alone. See: MOFCOM Public Notice 2012/35: Conditional Approval for the Notified Merger-UTC/Goodrich (MOFCOM Decision) [15 June 2012] < http://fldj.mofcom.gov.cn/article/ ztxx/201206/20120608181083.shtml> accessed 30 April 2017

${ }^{1371}$ In the following sections, these cases will be analysed based on different emphases in these sections.
} 


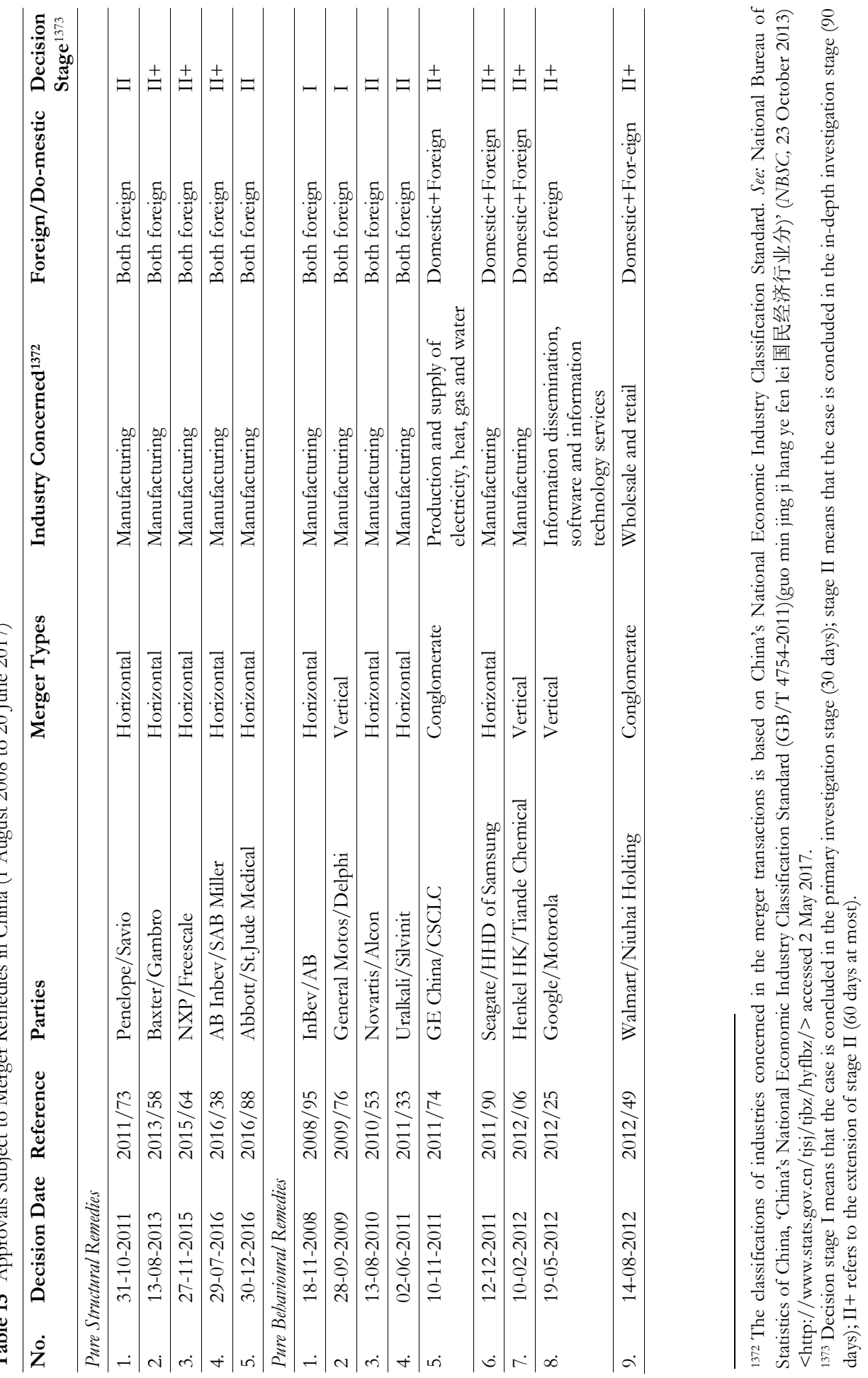



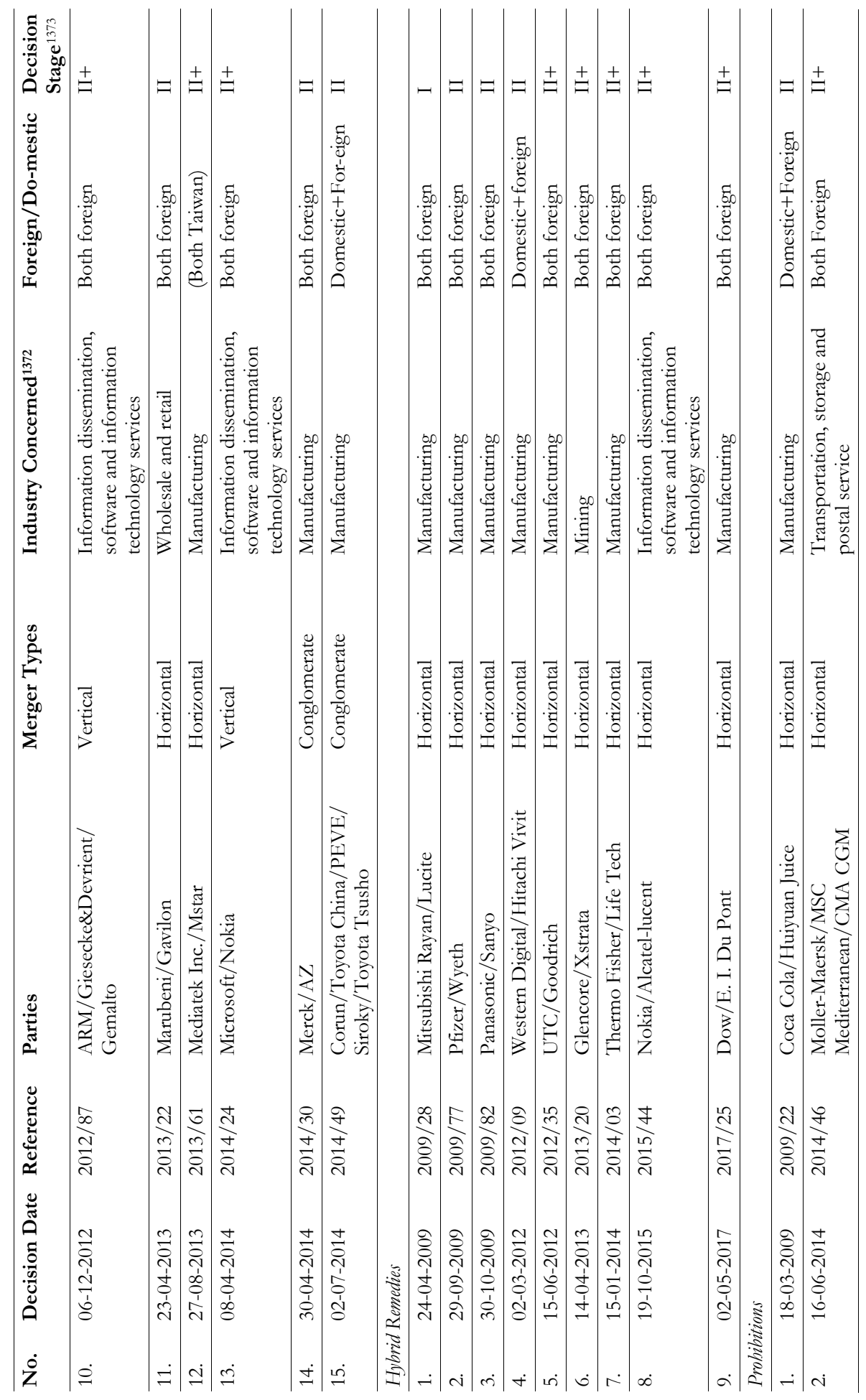


\subsection{MOFCOM's Substantive Analysis}

According to the AML, a transaction will be regarded as anti-competitive if there is evidence showing that after the implementation, the transaction will or may have the effects of eliminating or reducing competition in the market. ${ }^{1374}$ Although it seems that MOFCOM's merger review performance during the initial period after the enactment of the AML was barely satisfactory due to its limited experience and analytical toolkits, MOFCOM is improving its performance by, inter alia, employing a more economic approach.

\subsubsection{The Initial Performance}

\subsubsection{InBev/Anheuser-Busch}

InBev/Anheuser-Busch was the first conditionally approved case since the enactment of the AML on 1 August 2008. ${ }^{1375}$ The published decision was rather short, to the point of being terse.

InBev, a Belgian leading brewery, proposed to acquire the US's largest brewery Anheuser-Busch ("AB") in 2008. The notification was made to MOFCOM on 10 September 2008 and was approved in November 2008. MOFCOM stated in its decision that the notified transaction would significantly enhance the merging parties' competitiveness and thus reduce competition in China's beer industry based on the assumed high post-merger market shares. To mitigate the possible anti-competitive effects in the future, the merging parties were subject to several restrictive conditions.

According to the published decision, the high post-merger market share was the only tool that MOFCOM used to assess the transaction's potential effects on competition. Moreover, even if the post-merger high market shares would be high, it is insufficient to prove the existence of anti-competitive effects without defining the relevant market appropriately.

In fact, beer consumption can vary greatly in different geographic locations. Zhang \& Zhang's article (2009) analysed this case in great detail and pointed out that the relevant geographic beer market in this case should be defined as regional rather than as the whole Chinese beer market, considering that due to the contractual agreements between breweries and retailers, the latter can only sell beers from certain breweries and are not allowed to sell other breweries' beer. ${ }^{1376}$

The true reason why MOFCOM approved the transaction conditionally may be its mission to protect the national economy, or, put differently, the fear that all of the China's leading breweries would be controlled by foreign investors. The main concern in this case

\footnotetext{
1374 The substantive test "EERC" is adopted under the Anti-Monopoly Law in China. For the detailed introduction regarding this EERC test, see: Chapter 10, sec.3.2.

1375 For the full text of this decision, see: MOFCOM Public Notice 2008/95: Conditional Approval for the Notified Merger InBev/AB (MOFCOM Decision) [18 November 2008] <http://fldj.mofcom.gov.cn/article/ztxx/200811/ 20081105899216.shtml> accessed 28 April 2017.

1376 Xinzhu Zhang and Vanessa Yanhua Zhang, 'Chinese Merger Control: Patterns and Implications' (2009) 6(2) J C L\&E 477, 483. InBev and AB were two leading breweries in the world. Both firms had huge equity investments in large China-based breweries. The brewery industry in China is characterised by high concentration and fast growth. On the one hand, there are four leading breweries in China: Tsingtao Breweries, Chinese Resources Snow Breweries, Beijing Yanjing Brewery and Zhujiang Brewery; on the other hand, AB had 27\% equity interest in Tsingtao Breweries and InBev had $28.56 \%$ equity interest in Zhujiang Brewery.
} 
might not have been the competition concerns, but the concerns from Chinese competitors. Such guess is to some extent confirmed by the behavioural remedies required in this case: the merging parties were not allowed to enlarge their equity interest in the Chinese breweries. ${ }^{1377}$ Such non-typical forms of behavioural remedies were also used by MOFCOM in other cases, which will be explored in sec.3 below.

\subsubsection{Mitsubishi Rayan/Lucite}

Mitsubishi Rayan/Lucite, a case decided on 24 April 2009, which was the first case where divestitures were required by MOFCOM. ${ }^{1378}$ Compared with the InBev/AB case, MOFCOM made improvements (at least) by defining the relevant product market and relevant geographic market in the decision. Overlaps in the product market of Methyl methacrylate ("MMA") in China were identified.

Resting on the following two reasons, MOFCOM made its conditional approval decision. First, the transaction would enable the merged firm to have a high market share $(64 \%)$ in China's MMA market, which would be much higher than that of its competitors. Such high market share would result in the merged firm's dominant position and thus enable the merged firm to eliminate or restrict its competitors.

Second, the transaction could have foreclosure effects on downstream competitors since the merged firm, after the completion of the merger, could leverage its dominant position in the upstream MMA market to the downstream market.

The reasons MOFCOM provided seem to be debatable. Like the InBev/AB case, high post-merger market share was again used as a prima facie evidence to prove the (likely) existence of anti-competitive effects. However, high market shares do not directly imply the likelihood of eliminating or reducing competition in the market because other factors, such as technological innovation or entry barriers, also play an important role in sustaining competition in the relevant market.

Furthermore, as unilateral effects, input foreclosures or customer foreclosures are more likely to occur in vertical mergers, while portfolio effects or range effects usually occur in conglomerate mergers by the merged firm's leverage of its advantage from one product to another. ${ }^{1379}$ Such effects are even more likely to occur if the relevant products are neighbouring products. In this case, although Mitsubishi Rayan also did business in the MMA's downstream markets, it was insufficient for MOFCOM to assume that Mitsubishi Rayan would be able to foreclose the downstream markets by simply demonstrating its post-merger high market share. The reason why foreclosure effects occur is that a vertical merger directly eliminates the upstream-downstream relationship between the merging parties and enables them to become one entity, which would result in difficulties of the other upstream/downstream consumers to access to resources. The proposed transaction only resulted in a horizontal overlap, whereas whether the merged firm can leverage its advantage, also largely depends on other factors, such as entry barriers.

Accordingly, in this case, it is inadequate for MOFCOM to draw such conclusions by simply demonstrating the induced high post-merger market shares and it's granted assumption that the merged firm would thus be able to foreclose the downstream market by leveraging its advantage in its upstream market.

1377 See: $\operatorname{InBev} / \mathrm{AB}$ (n 1375).

1378 See: MOFCOM Public Notice 2009/28: Conditional Approval for the Notified Merger - Mitsubishi Rayan/Lucite (MOFCOM Decision) [24 September 2009] <http://fldj.mofcom.gov.cn/article/ztxx/200904/2009040619 8805.shtml> accessed 2 May 2017.

${ }^{1379}$ For a detailed introduction regarding unilateral effects resulted from non-horizontal mergers, see: Chapter 5, sec.3.1.2.1 


\subsubsection{A More Economic Approach}

A more economic approach is taken by MOFCOM to help obtain evidence and to increase the scientific credibility of the merger review. ${ }^{1380}$ Compared with the initial decisions in which market share was the only tool during the assessment of a transaction, more tools are employed.

\subsubsection{Pfizer/Wyeth}

The HHI was for the first time used in Pfizer/Wyeth to measure the degree of market concentration. ${ }^{1381}$ In the decision, MOFCOM defined mainland China as the relevant geographic market and the medicine for human beings (including JIC and N6A) and products for animal health as the relevant product market. MOFCOM assessed the competition effects in three regards: the increase of post-merger market share, an increase of the HHI, and the difficulties of market entry.

First, the decision pointed out that after the implementation of the notified transaction, the merging parties would account for a market share of $49.4 \%$, which would be much higher than their rivals'.

Second, MOFCOM studied the degree of market concentration by using the HHI. The post-merger HHI would be 2182, with an increase as 336. The notified merger was thus deemed as a "dangerous transaction". Unlike in the US or the EU, in China's merger review system, there is no explicit provision or measure that provides the thresholds for determining whether a notified merger is safe, comparatively safe or dangerous. ${ }^{1382}$ This case, to some extent, provides an implication regarding how MOFCOM determines the threshold in practice.

Third, MOFCOM held that the notified merger would increase entry barriers by stating that innovation in the medicine industry is characterised as high-cost (range from $\$ 2.5$ million to $\$ 10$ million on average) and long-time cycle (about 3 to 5 years on average). MOFCOM stated that the merged firm would be able to restrict other competitors' development by enlarging in the domestic market.

\subsubsection{Thermo Fisher/Life Tech}

In July 2013, MOFCOM received a notification, in which Thermo Fisher Scientific Inc. proposed to acquire Life Technologies Corp. This transaction involved 59 products which were deemed to have horizontal overlaps. ${ }^{1383}$ An independent third-party consultancy was employed to conduct a quantitative analysis regarding the concerned competition issues. The assessment can be divided into three tiers.

First, the degree of market concentration. Like Pfizer/Wyeth, an HHI test was conducted. MOFCOM stated that among all the 59 products, there were 13 products that

\footnotetext{
${ }^{1380}$ Fei Deng and Yizhe Zhang, Interview with Ming Shang, former Director General of the Anti-Monopoly Bureau under the Ministry of Commerce of the People's Republic of China (Beijing, 7 March 2014). For the text of the interview, see: <http://www.americanbar.org/content/dam/aba/publishing/antitrust_source/ apr14_shang_intrvw_4_8f.authcheckdam.pdf $>$ accessed 2 May 2017.

${ }^{1381}$ For a full text of this decision, refer to: MOFCOM Public Notice 2009/77: Conditional Approval for the Notified Merger - Pfizer/Wyeth (MOFCOM Decision) [29 September 2009] <http://fldj.mofcom.gov.cn/article/ztxx/ 200909/20090906541443.shtml> accessed 28 April 2017.

${ }^{1382}$ For a detailed introduction to the application of the HHI in the US, see: Chapter 2, sec.3.2.2; for the use of the HHI in the EU, see: Chapter 3, sec.3.2.1.

${ }^{1383}$ For a full text of this decision, see: MOFCOM Public Notice 2014/03: Conditional Approval for the Notified Merger Thermo Fisher/Life Tech (MOFCOM Decision) [15 January 2014] <http://fldj.mofcom.gov.cn/article/ztxx/ 201401/20140100461603.shtml> 28 April 2017.
} 
needed further investigation, considering that the post-merger HHI was higher than 1500 and the increase was higher than 100. Taking into account the Pfizer/Wyeth decisions, it can be predicted that, in practice, a transaction is likely to be regarded as dangerous if the postmerger HHI is above 2000 with an increase over 300, and if the HHI is above 1500 with an increase over 100, then further investigations will be needed (comparatively safe). It remains uncertain what is the threshold for safe transactions.

Second, the projection of price rise. A Profit-HHI regression analysis and an illustrative price rise test were conducted. The result was that prices of 12 products were predicted to rise by more than $5 \%$.

Third, a competition assessment. To better evaluate the potential competitive effects, a quantitative analysis was conducted. Such analysis included on-site investigations of Thermo Fisher (China) Company and Life Tech's laboratory, a questionnaire to industrial participants and customers, symposiums with e.g. industrial experts and industrial participants, and international meetings with DG COMP and the FTC.

This case fully demonstrates that MOFCOM is enriching its toolkit for merger review and is employing a more economic approach. There are also other cases that show MOFCOM's progress and efforts in improving its merger review. For example, in Merck/ $A Z$, an independent third-party consultancy was employed to conduct an economic analysis of the competition issues concerned. ${ }^{1384}$

\subsubsection{Summary}

From InBev/AB to Thermo Fisher/Life Tech, evidently, MOFCOM is improving and refining its merger review. The "more economic approach" is similar to the European Commission's practice, which is reflected in the change of substantive test from a dominance test under the 1989 MR to an SIEC test under the 2004EUMR. ${ }^{1385}$

During MOFCOM's merger review, economic theory such as unilateral competition effects, were applied in reviewing a notified merger. Economic tools, such as the HHI test or an illustrative price rise test are employed to assess the potential competitive effects that the transaction will/may bring to the relevant market. Furthermore, additional details were made available in the published decisions, implying that MOFCOM is getting more confident in its merger review.

In addition, MOFCOM frequently solicits opinions from different parties when assessing a transaction, such as relevant departments or local governments, relevant industry associations, or customers. These opinions can, first, help MOFCOM to verify the information it gets from the notifying parties; second, help MOFCOM to get more information which it cannot obtain from the notifying parties.

A report from a well-known Chinese law firm, King \&Wood Mallesons, provides an interesting summary regarding MOFCOM's admissible degree of information from different providers, which is presented in Table 14.

\footnotetext{
${ }^{1384}$ For a full text of this decision, see: MOFCOM Public Notice 2014/30: Conditional Approval for the Notified Merger Merck/AZ (MOFCOM Decision) [30 April 2014] <http://fldj.mofcom.gov.cn/article/ztxx/201404/ 20140400569060.shtml> accessed 28 April 2017.

${ }^{1385}$ For more information regarding the change of substantive test of merger control in the EU, see: Chapter 3, sec.3.2.
} 
Table 14 MOFCOM's Admissible Degree of Information from Different Providers ${ }^{1386}$

$\left.\begin{array}{|l|l|l}\begin{array}{l}\text { Departments of } \\ \text { Government }\end{array} & \begin{array}{l}\text { Industry } \\ \text { Association }\end{array} & \begin{array}{l}\text { Up/downstream } \\ \text { companies }\end{array}\end{array}\right\}$

It can be observed from Table 14 that MOFCOM values the information and opinions from departments of (relevant local) governments the most during its investigations. By contrast, the information and opinion from industrial associations are of less importance and value. Up/downstream companies and the notified companies' competitors' information play the least important role in a merger review.

Although MOFCOM does not disclose any information regarding this topic, Table 14 may to some extent provide some practical information and implications. The results of interviews with those Chinese M\&A lawyers may further shed light on this topic (see Chapter 12).

It is reasonable to predict that MOFCOM will deepen the more economic approach, meaning that more economic tools and theory will be applied. As Ming Shang pointed out, the scientific creditability of merger review can, to a large extent, be enhanced. Nevertheless, market shares still play an important role in the assessment. Considerations of industrial policy (national economy) are very likely to continue to influence MOFCOM's decisions, especially the design of merger remedies (will be explored in sec.3 below).

\subsection{Timing of Merger Review}

According to Art. 24 and Art. 26 of the AML, after the acceptance of the notifications, the CA has at most 30 days to conduct a primary investigation (stage I investigation), possibly followed by a 90-day in-depth investigation (stage II investigation) if MOFCOM believes that the notified transaction will or can eliminate or restrict competition. Further, an extension is possible when the 90-day is due. Such an extension can be at most 60 days. Based on Table 13, Table 15 provides a summary about the numbers of published cases (conditional approvals or prohibitions) that were decided during stage I, stage II or an extension of stage II.

Evidently, one-half of the published cases (conditional approvals and prohibitions) were concluded during the extension of in-depth investigations. In fact, MOFCOM only accepts a notification when it thinks the submitted information is complete. Generally speaking, the merging parties have to wait for another one or several months to provide additional information before MOFCOM accepts their notifications. ${ }^{1387}$ Table 15 indicates that most of these conditionally-approved transactions were decided during the extension of stage II when MOFCOM made its decisions just before the expiration of the extension period. Accordingly, for half of these transactions, the duration of the merger review can be almost or even much longer than 180 days (waiting period before acceptance +30 -day primary investigation +90 -day in-depth investigation +60 -day extension).

\footnotetext{
${ }^{1386}$ This table is adopted from Xuanfeng Ning and others, 'China's Merger Control: 5-year's Enforcement Review' (Thomson Reuters, 2013) <http://www.westlawchina.com/NewsLetter/view.php?id=86> accessed 2 May 2017. King \& Wood Mallesons is one of the top-tier law firms in China.

${ }^{1387}$ For a detailed discussion for the pre-acceptance waiting time under merger control in China from an empirical perspective, see: Chapter 12, sec.3.2.2.
} 
Table 15 Numbers of Conditionally-Approved Cases Decided by MOFCOM in Different Stages of Merger Review Procedures ( 1 August 2008 - 20 June 2017)

\begin{tabular}{llll}
\hline & Stage I & Stage II & Extension of Stage II \\
\hline 2008 & 1 & - & - \\
\hline 2009 & 1 & $4^{1388}$ & - \\
\hline 2010 & - & 1 & 2 \\
\hline 2011 & - & 2 & 5 \\
\hline 2012 & - & 1 & 3 \\
\hline 2013 & - & 1 & 2 \\
\hline 2014 & - & 2 & 21389 \\
\hline 2015 & 1 & & 1 \\
\hline 2016 & - & 1 & 1 \\
\hline By 20 June 2017 & - & - & 16 \\
\hline (in total) & 3 & 12 &
\end{tabular}

There are six cases which were withdrawn just before the expiration of the extension of an in-depth investigation. The merging parties had to submit the notifications again to re-start the clock. These cases are: Dow/E. I. Du Pont (2017), NXP/Freescale (2015), Mediatek Inc./Mstar (2013), Marubeni/Gavilon (2013), Glencore/Xstrata (2013) and Western Digital/Hitachi Vivit (2012). ${ }^{1390}$ For these cases, the merger review was extremely lengthy. Take Mediatek Inc./Mstar as an example. The merging parties had withdrawn their first notification, meaning they had waited for more than 180 days. For the second notification, MOFCOM had not decided the case until 2 days before the expiration of the stage-II extension, resulting in a record-breaking lengthy time limit of 13 months in total.

The vast majority of the notified transactions were approved without any additional conditions, thus only the names of the merging parties are made public. It seems to be too hasty to draw the conclusion that in general MOFCOM's merger review is too lengthy.

\footnotetext{
1388 Including one prohibited transaction: Huiyuan Fruit Juice/Coca-Cola (n 1317).

${ }^{1389}$ Including one prohibited transaction: MOFCOM Public Notice 2014/46, Moller-Maersk/MSC Mediterranean/CMA CGM (MOFCOM Decision) [17 June 2015] <http://fldj.mofcom.gov.cn/article/ztxx/201406/20140600628586. shtml> accessed 28 April 2017.

1390 These six cases are: 1. MOFCOM Public Notice 2017/25: Conditional Approval for the Notified Merger - Dow/E. I. Du Pont (MOFCOM Decision) [2 May 2017] <http://fldj.mofcom.gov.cn/article/ztxx/201705/20170502 568075.shtml> accessed 2 May 2017;

2. MOFCOM Public Notice 2015/64: Conditional Approval for the Notified Merger - NXP/Freescale (MOFCOM Decision) [27 November 2015] <http://fldj.mofcom.gov.cn/article/ztxx/201511/20151101196182.shtml> accessed 29 April 2017;

3. MOFCOM Public Notice 2013/61: Conditional Approval for the Notified Merger-Mediatek. Inc./Mstar (MOFCOM Decision) [27 August 2013] <http://fldj.mofcom.gov.cn/article/ztxx/201308/20130800269821.shtml> accessed 29 April 2017;

4. MOFCOM Public Notice 2013/22: Conditional Approval for the Notified Merger - Marubeni/Gavilon (MOFCOM Decision) [24 April 2013] <http://fldj.mofcom.gov.cn/article/ztxx/201304/20130400100376.shtml> accessed 29 April 2017;

5. MOFCOM Public Notice 2013/20: Conditional Approval for the Notified Merger - Glencore/Xstrata (MOFCOM Decision) [16 April 2013] <http:// fldj.mofcom.gov.cn/article/ztxx/201304/20130400091222.shtml> accessed 29 April 2017;

6. MOFCOM Public Notice 2012/09: Conditional Approval for the Notified Merger - Western Digital/Hitachi Vivit (MOFCOM Decision) [2 March 2012] <http://fldj.mofcom.gov.cn/article/ztxx/201203/20120307993758. shtml> accessed 28 April 2017.
} 
Nevertheless, it is safe to say that at least for these conditional approved or prohibited cases, the time limit is quite long. ${ }^{1391}$

Table 15 further indicates that since 2011, more transactions were decided during the extension of stage II. During the period from 2008 to 2010, however, all published transactions were decided during stage II. In fact, this is not a coincidence. According to an interview with Ming Shang, in 2011, there were some adjustments that had been made within the AMB to re-assign the functions of different divisions, namely, pre-notification consultation, pre-acceptance review of notification materials, post-acceptance investigation and review, and the AMB's self-monitoring. ${ }^{1392}$ For each accepted notification, a team consisting of three or more persons with various backgrounds would be needed. ${ }^{1393}$

Nevertheless, such re-assignments dispersed MOFCOM's limited manpower. Briefly speaking, within the AMB, there are two different types of case teams: pre-acceptance case teams and post-acceptance case teams. For example, case team A takes the responsibility to investigate a notified transaction to assess whether the submitted information is sufficient. Once the transaction is accepted, case team B will take over the case and start the preliminary investigation. With such arrangements, duplication of effort arises since case team $\mathrm{B}$ has to go over the transaction again, whereas case team $\mathrm{A}$ has already become familiar with the transaction. Although Ming Shang claimed that these adjustments functioned well, ${ }^{1394}$ the fact was that according to the published decisions, the merger review became quite lengthy after the re-organisations.

The good news is that MOFCOM is now trying to reduce the time limit of the merger review. According to one of the Press Conferences held by MOFCOM, it stated that compared with the annual average filling time in 2014, the time frame has been shortened by $13 \%$ in 2015 , while the total amount of notifications in 2015 was larger than that in 2014. ${ }^{1395}$ One of the reasons for such improvements can be that most of the notified transactions are subject to the simple cases, which are decided after the primary investigations (within 30 days). ${ }^{1396}$ This will help the AMB to focus its attention on those complicated cases.

The most noteworthy change is that since 15 September 2015, the pre-notification consultation division was abolished. ${ }^{1397}$ The division will work with other divisions to deal with the transactions from notification to conclusion. This means that the distinction between the pre-acceptance case team and the after-acceptance case team is cancelled. The same case team will be responsible for a notification from the very beginning to the end of the merger review. The adjustment can to some extent help the AMB's limited manpower.

\subsection{Non-Competition Policy Consideration}

It was held by MOFCOM that the proposed transaction between Glencore/Xstrata could bring anti-competitive effects to China's copper concentrate, zinc concentrate and lead concentrate

\footnotetext{
1391 The possible reasons for a lenghy merger review suggested by those Chinese competition law professors and lawyers are presented in Chapter 12, sec.3.2.

1392 Deng and others (n 1367).

1393 ibid.

1394 ibid.

1395 MOFCOM (n 1280). Questions of why and how MOFCOM speeds up the merger review procedures were answered by those Chinese competition law professors and lawyers. Answers are presented in Chapter 12, sec.3.2. 1396 ibid.

${ }^{1397}$ Freshfields Bruckhaus Deringer (n 1364).
} 
market. ${ }^{1398}$ The main competition issue in this case was whether the notified transaction would enhance the merging parties' control over these three mineral markets. The main approach MOFCOM applied was to assess the merging parties' market shares of production, supply, and supply to China/third party of these three minerals in the global market.

Table 16 Glencore/Xstrata's Joint Market Shares

\begin{tabular}{lllll}
\hline & Production & Supply & Supply to China / third party & Demand in China \\
\hline Copper concentrate & $7.6 \%$ & $9.3 \%$ & (To China:) $12.1 \%$ & $\begin{array}{l}68.5 \% \text { of the total domestic } \\
\text { supply was imported }\end{array}$ \\
\hline Zinc concentrate & $11.2 \%$ & $17.8 \%$ & (To China:) $9 \%$ & $\begin{array}{l}28.9 \% \text { of the total domestic } \\
\text { supply was imported }\end{array}$ \\
\hline Lead concentrate & $6.8 \%$ & $7.6 \%$ & (To third party:) $9 \%$ & $\begin{array}{l}27.3 \% \text { of the total domestic } \\
\text { supply was imported }\end{array}$ \\
\hline
\end{tabular}

Table 16 provides a simple summary of the merging parties' market shares. The main idea is that these market shares were quite low and they were very likely to be regarded by the CAs in the US as with little likelihood of causing anti-competitive effects. ${ }^{1399}$ Nevertheless, MOFCOM concluded that the transaction would largely enhance the merging parties' ability to control these markets. MOFCOM's true concern might have been that the transaction may have a negative impact on China's imports, considering the important factor that China relies heavily on imports of these three minerals. Once this transaction was completed, the merged firm may raise prices by exerting their concentrated market power, which may harm the interests of China's importer.

Another case that demonstrates the trade policy is Marubeni/Gavilon. ${ }^{1400}$ Similar to Glencore/Xstrata, the proposed transaction concerned soybean imports. China is the largest soybean importer in the world, while the soybean-crushing firms in China are characterised as a low degree of concentration, with small scale and weak bargaining ability. The transaction was ultimately approved with behavioural remedies to mitigate the anticompetitive effects.

\section{Application of Merger Remedy}

By 20 June 2017, there were overall 29 cases that had been approved conditionally subject to either structural remedies, behavioural remedies, or hybrid remedies (as indicated in Table 13). In this section, MOFCOM's practice of merger remedies is explored.

\subsection{Behavioural Remedies}

\subsubsection{Forms of Behavioural Remedies}

Forms of behavioural remedies vary depending on different transactions. Ning and others' article (2013) comprehensively categorised these behavioural remedies. Table 17 further updates the information based on their research.

\footnotetext{
1398 See: Glencore/Xstrata (n 1390).

${ }^{1399}$ Davis Polk \& Wardwell LLP, ‘China Antitrust Review 2013’ (Davis Polk \& Wardwell LLP, 27 January 2014) $<$ http://w.davispolk.com/sites/default/files/01.27.14.China_.Antitrust.Review.2013.pdf $>$ accessed 3 May 2017. 1400 See: Marubeni/Gavilon (n 1390).
} 
Table 17 Forms of Behavioural Remedies under China's Merger Control (1 August 2008 - 20 June 2017) $)^{1401}$

\begin{tabular}{|c|c|c|}
\hline \multicolumn{2}{|c|}{ Forms of Behavioural Remedies } & \multirow{2}{*}{ 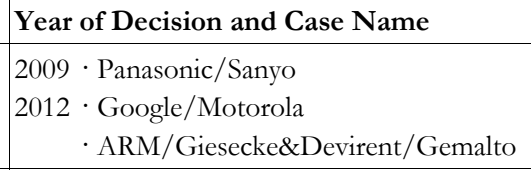 } \\
\hline \multirow{7}{*}{ Typical forms } & Open Access & \\
\hline & FRAND principle & $\begin{aligned} 2009 & \cdot \text { General Motors/Delphi } \\
2012 & \cdot \text { Henkel HK/Tiande } \\
& \cdot \text { Google/Motorola } \\
& \cdot \text { ARM/Giesecke\&Devirent/Gemalto } \\
2013 & \cdot \text { Marubeni/Gavilon } \\
2014 & \cdot \text { Corun/Toyota } \\
\cdot & \text { Microsoft/Nokia } \\
\cdot & \text { China/PEVE/Siroky/Toyota Tsusho } \\
2015 & \cdot \text { Nokia/Alcatel-lucent }\end{aligned}$ \\
\hline & Firewall provisions & \begin{tabular}{|c}
$2011 \cdot$ Seagate/Samsung HDD \\
$2012 \cdot$ Western Digital/Hitachi Vivit \\
$\cdot$ Google/Motorola \\
$2013 \cdot$ Marubeni/Gavilon \\
$\cdot$ - MediaTek/Mstar
\end{tabular} \\
\hline & Termination of exclusive agreements & $2010 \cdot$ Novartis/Alcon \\
\hline & No exclusive agreements in the future & 2017 · Dow/E. I. Du Pont \\
\hline & Transitional assistance provisions & $\begin{array}{l}2009 \cdot \text { Pfizer/Wyeth } \\
2012 \cdot \text { UTC/Goodrich }\end{array}$ \\
\hline & $\begin{array}{l}\text { Commitments of no abuse of market } \\
\text { power }\end{array}$ & $\begin{aligned} 2011 & \cdot \text { GE China/CSCLC } \\
& \cdot \text { Seagate/Samsung HDD } \\
2012 & \cdot \text { Western Digital/Hitachi Vivit } \\
& \cdot \text { ARM/Giesecke\&Devirent/Gemalto }\end{aligned}$ \\
\hline \multirow{5}{*}{$\begin{array}{l}\text { Non-typical } \\
\text { forms }\end{array}$} & $\begin{array}{l}\text { Continue to supply and provide } \\
\text { services }\end{array}$ & $\begin{aligned} 2011 & \cdot \text { Uralkali/Silvinit } \\
& \cdot \text { Seagate/Samsung HDD } \\
2012 & \cdot \text { Western Digital/Hitachi Vivit } \\
2013 & \text { - Glencore/Xstrata } \\
2014 & \cdot \text { Microsoft/Nokia } \\
2017 & \cdot \text { Dow/E. I. Du Pont }\end{aligned}$ \\
\hline & No market expansion & $\begin{array}{l}2008 \cdot \text { InBev/AB } \\
2009 \cdot \text { Mitsubishi Rayan/Lucite } \\
2010 \cdot \text { Novartis/Alcon }\end{array}$ \\
\hline & Hold separate provision $^{1402}$ & \begin{tabular}{|l}
$2011 \cdot$ Seagate/Samsung HDD \\
$2012 \cdot$ Western Digital/Hitachi Vivit \\
$2013 \cdot$ Marubeni/Gavilon \\
· MediaTek/Mstar
\end{tabular} \\
\hline & Quit Chinese market & $2010 \cdot$ Novartis/Alcon \\
\hline & Limit online sales & $2012 \cdot$ Walmark/Niuhai Holding \\
\hline
\end{tabular}

1401 This table is adopted from Ning and others (n 1386).

${ }^{1402}$ The meaning of hold separate provisions here is different from that in the context of the US or the EU. This will be explored in detail in sec.3.1.2. below. 


\begin{tabular}{l|l|l}
\hline Forms of Behavioural Remedies & Year of Decision and Case Name \\
\hline & Price reduction & $2014 \cdot$ Thermo Fisher/Life Tech \\
\cline { 2 - 3 } & No tying sales & $2014 \cdot$ Merck/AZ \\
\hline
\end{tabular}

Table 17 suggests that, first, forms of behavioural remedies used in China are quite flexible and diverse. Second, in addition to those conventional behavioural remedies, such as continue to supply and provide services and promise to abstain from certain behaviour, which are also used in the US or the EU, there were also some remedies which are quite unique. They are, no expansion within a certain period, hold-separate behavioural remedies, quit Chinese market, limit online sales, and price reduction. In the following section, attention is focused on three of them, hold-separate remedies, price reduction and no market expansion, which may cause additional concerns.

\subsubsection{Hold Separate Provisions as Behavioural Remedies}

In the context of merger control in the US or the EU, hold-separate provisions are usually used as an interim tool in a divestiture, under which the merging parties are required to operate the to-be-divested business separately during the interim period to keep the viability, saleability and marketability of the to-be-divested business. Basically, they are used to ensure the preservation of the value of the to-be-divested business. In contrast, in China, these provisions are used by MOFCOM as behavioural remedies. Under these provisions, the merged parties have to operate certain parts of their business separately even after the implementation of the proposed transactions.

There are four cases in which such provisions are included, MediaTek/Mstar (2013) ${ }^{1403}$, Marubeni/Gavilon (2013) ${ }^{1404}$, Western Digital/Hitachi Vivit (2012) ${ }^{1405}$ and Seagate/Samsung HDD (2011). ${ }^{1406}$ Take Seagate/Samsung HDD as an example.

On 19 May 2011, Seagate and Samsung notified their proposed transaction to MOFCOM. ${ }^{1407}$ The notifying parties were allowed to proceed with their transaction subject to a hold separate provision. According to MOFCOM's decision, after the completion of the transaction, Seagate had to operate Samsung HDD as an independent competitor in the market. The main requirements included (but were not limited to):

1. Seagate has to set up an independent subsidiary after the completion of the notified transaction to take the responsibility of pricing and marketing the business of Samsung HDD separately. The independent teams of both Seagate and Samsung must report relevant issues to the monitoring trustees.

2. During the interim period before the setup of the above-mentioned independent marketing teams and before they take charge of the business, Samsung HDD will be sold by the original Samsung marketing teams. Marketing plan and monthly sales records during the interim period shall be reported to the monitoring trustee.

3. After the completion of the transaction, Seagate will ensure the complete independence of the marketing teams of Samsung HDD.

\footnotetext{
${ }^{1403}$ Mediatek Inc./Mstar (n 1390).

1404 Marubeni/Gavilon (n 1390).

1405 Western Digital/Hitachi Vivit (n 1390).

1406 See: MOFCOM Public Notice 2011/90: Conditional Approval for the Notified Merger - Seagate/Samsung HDD

(MOFCOM Decision) $[12$ December 2011] <http://fldj.mofcom.gov.cn/article/ztxx/201112/20111207 874274.shtml> accessed 29 April 2017.

1407 See: ibid.
} 
4. Seagate will ensure the independence of Samsung products' production line. Any relevant technical support or changes should be reported to the monitoring trustee.

5. Seagate will ensure Samsung HDD's independence and strictly comply with a reasonable pricing plan. Fix and revision of the pricing plan should be reported to the monitoring trustee.

6. Seagate will set up an innovation centre for the Samsung products to enhance Samsung product's production efficiency and competitiveness. All the technical support, exchange of information and relocation of personnel should be reported to the monitoring trustee.

In general, the main idea was that Seagate had to completely keep the independence of Samsung HDD products regarding the pricing, marketing and producing. To realise this aim, Seagate had to set up an independent team and an innovation centre. Any change which may influence the independence has to be reported to the monitoring trustee.

The use of such remedies can result from some practical considerations. First, the hold separate requirements can be modified by MOFCOM upon the merged firm's application after several years' practice. MOFCOM will investigate to ensure that the modifications of the original requirements will not raise competition concerns. Regarding the Seagate/Samsung case, MOFCOM abolished the above-mentioned requirements 1 and 2 in 2015. ${ }^{1408}$ This means that such provisions are, to some extent, reversible. The merging parties may also be willing to accept the provisions because they might be released from the obligations some day in the future. Furthermore, divestitures can be difficult to be implemented due to the difficulties in finding a suitable buyer. Hold-separate behavioural remedies completely overcome this difficulty.

It seems that one of the biggest differences between a divestiture and Chinese hold separate provisions concerns the question of who operates the business. In a divestiture, the business is operated by another competitor, whereas under a Chinese hold separate provision, the business is still operated by the merged firm. MOFCOM expects and believes that these hold separate provisions will have the same effect as divestitures. ${ }^{1409} \mathrm{It}$ remains unknown and needs more empirical evidence to see whether such provisions can fulfil the expectation. The concern is, will such hold separate provisions put too much burden on the merged firm, resulting in a possible reduction of efficiency?

First, as the example shows, the monitoring trustee plays an important role in overseeing the merged firm's compliance with these requirements and obligations. On the one hand, any change which may influence the independence of the business must be reported to the monitoring trustee. On the other hand, the monitoring trustees, regarded as the ears and eyes of MOFCOM, work under the supervision of MOFCOM and have to report to MOFCOM. In other words, compared with the situation of divestitures, MOFCOM's enforcement costs rise since it has to spend time and energy on assessing the merged firms' compliance. Considering MOFCOM's limited resources and increasing numbers of notifications, the question naturally arises: can MOFCOM deal with such a monitoring burden?

Second, the merged firm is deprived of the freedom to develop its business. Any change of personnel or exchange of information has to be reported to the monitoring

1408 See: MOFCOM Public Notice 2015/43: Modifications of the Conditional Approval in Seagate/Samsung HDD (MOFCOM Decision) [22 October 2015] <http://fldj.mofcom.gov.cn/article/ztxx/201510/201510 01144105.shtml> accessed 3 May 2017.

${ }^{1409}$ Ning and others (n 1386). 
trustees. Furthermore, the merged firm has to comply with other requirements in corporate law or securities law after the completion of a merger, meaning there can be even more restrictions on the merged firm.

Third, by merging with another firm, efficiencies are expected to be generated from, for example, rationalisation of production, economies of scale and scope, or technological progress. For most firms, they merge for more synergies and efficiencies. However, if the merged firm has to keep certain business completely separate, this means that the merged firm's ability to create efficiencies is reduced. Worse, the merged firm has to keep investing in the separated business to keep it viable and marketable. This further reduces the merged firm's possible synergies and efficiencies.

In fact, the core question is whether the hold separate provision is designed to protect the competition, or to protect the competitors? A merger may lead to the concentration of market power into one firm. Accordingly, under a divestiture, to restore competition, such market power can be crippled by transferring the merged parties' business to another existing/new competitor, to make the buyer and the merged firm match in strength. A Chinese hold separate provision, however, does not involve any transfer of the concentrated market power to another competitor. It remains unknown whether the Chinese hold separate behavioural remedies can have the same effects as a divestiture.

\subsubsection{Price Reduction}

Price reduction in certain products is one of the behavioural remedies which is available in the Chinese behavioural remedies toolkit and is quite unique compared with the forms of behavioural remedies in the US and the EU.

For example, Thermo Fisher/Life Tech was approved subject to hybrid remedies. ${ }^{1410}$ Besides these divestiture remedies, Thermo Fisher was also required to reduce the price list for SSP kit and SDS-PAGE protein standards in the Chinese market at a rate of $1 \%$ annually with no reduction of discount offered to the Chinese dealers for the next 10 years since the publication of MOFCOM's decision (2014).

In Thermo Fisher/Life Tech, the main concern was a post-merger price increase. Thus, a price reduction remedy was required. However, the price-reducing remedy seems to raise a concern because it, to some degree, placed MOFCOM in an awkward price-fixing position. As the competition agency, MOFCOM's primary function is to realise the aims of competition law. The pre-merger notification mechanism is used to intervene and screen these mergers before implementation to ensure that only (at least) neutral mergers will be approved (maybe with remedies). Once the transactions raise competition concerns, the function of merger remedies should be limited to render the transaction compatible with competition law without impeding the function of the market economy itself. MOFCOM's price-fixing behaviour may unnecessarily intervene in such a function, considering that the price and quantity are determined by the interaction of supply and demand in the market. ${ }^{1411}$ Such remedies stood in a sharp contrast with the position that the CAs in the US, EU and UK take because they are not willing to engage in price-fixing. ${ }^{1412}$

\footnotetext{
1410 Thermo Fisher/Life Tech (n 1383).

1411 Cooter and Ulen (n 771) 28.

${ }^{1412}$ Michael Han and Stephen Ryan, 'Remedies in Chinese Merger Control Law - Themes, Recent Cases and Developments' (2014) 15(3) B L I 201, 217.
} 


\subsubsection{No Market Expansion}

InBev/ $A B$ case was one of the most typical cases in which the merged firm was approved to proceed with their proposed transaction subject to the requirement that no market expansion was allowed within a certain period:

1. Any increase in equity interest above the $27 \%$ which at the time $\mathrm{AB}$ held in Tsingtao Breweries, was not allowed.

2. Any change of InBev's controlling shareholders or any change of the shares that the controlling shareholders hold should be notified to MOFCOM.

3. Any increase in equity interest above the $28.56 \%$ which at the time InBev held in Zhujiang Breweries, was not allowed.

4. Any attempt to hold equity interest in China Resources Snow Breweries and Beijing Yanjing Breweries is not allowed. ${ }^{1413}$

A merger remedy can be imposed only if the CA can prove that this notified transaction, after implementation, will or can eliminate or reduce competition in the future. Besides, the remedy should be designed in proportion to the potential anti-competitive effect. Thus, the above-mentioned remedies in $\mathrm{InBev} / \mathrm{AB}$ were quite debatable from the perspectives of that, first, based on the exploration regarding the substantive aspect of this case in sec. 2 above. It is insufficient to conclude that the notified merger would raise competition concerns by simply demonstrating the high post-merger market shares (even without defining the relevant market). Such ambiguity in the substantive analysis will lead to difficulties in determining the extent to which the transaction should be remedied.

Second, MOFCOM's concern in this case was that the merged firm's future expansion may harm competition. It seems that MOFCOM interprets "the negative impact" in a way which is too broad. ${ }^{1414}$ As said before, merger remedies can be used to eliminate any anticompetitive effect caused by this transaction. If potential anti-competitive effects may be caused by the merged firm's further conduct, such as expansion, then other competition agencies, such as NDRC or SAIC, can investigate under China's competition law. Thus, merger remedies are not the type of "once and for all" measures.

Third, for all the unique behavioural remedies, the core question might be, whether such behavioural remedy is a merger condition or a merger remedy? Merger remedies are used to eliminate anti-competitive effects, whereas conditions can be used as tools to clear not only competition concerns, but also non-competitive concerns, such as concerns about trade policy, industry policy, national economy, or on the future development of the domestic competitors. Put in another way, in some situations, merger conditions may have little to do with competition. As indicated in sec.2, non-competition considerations may not only influence the result of a merger review, but also influence the design of merger remedies.

\subsection{Structural Remedies}

\subsubsection{Forms of Structural Remedies}

Divestiture is the quintessence of structural remedies. Other forms of structural remedies include, for example, licencing of intellectual property rights, which are structural in nature. ${ }^{1415}$ These access remedies are also known as quasi-structural remedies. Although

\footnotetext{
${ }^{1413} \mathrm{InBev} / \mathrm{AB}$ (n 1375).

1414 Qian Hao, 'Merger Remedies in China: Developments and Issues' (2010) 6(2) C L I 13, 14.

14152011 DOJ Policy Guide (n 56).
} 
they may look like behavioural remedies, they actually may go well beyond behavioural remedies on the basis that they need to be designed in detail and may have large impacts on the structure of the merging parties, as well as the industry concerned; thus they are structural in nature. ${ }^{1416}$

There are 11 cases in total in which structural remedies were imposed (including these cases in which hybrid remedies were included). Like Table 17, Table 18 divides those cases into two categories: typical structural remedies and non-typical structural remedies.

Table 18 Forms of Structural Remedies under Merger Control in China (1 August 2008 - 20 June 2017)

\begin{tabular}{|c|c|c|}
\hline \multicolumn{2}{|c|}{ Forms of Structural Remedies } & \multirow[b]{2}{*}{\begin{tabular}{|l} 
Year of Decision and Case Name \\
$2009 \cdot$ Pfizer/Wyeth \\
$\cdot$ Panasonic/Sanyo \\
$2012 \cdot$ Western Digital/Hitachi Vivit \\
$\cdot$ UTC/Goodrich \\
$2013 \cdot$ Glencore/Xstrata \\
$\cdot$ Baxter/Gambro \\
$2014 \cdot$ Thermo Fisher/Life Tech \\
$2015 \cdot$ NXP/Freescale \\
$2016 \cdot$ Abbott/St.Jude Medical \\
$2017 \cdot$ Dow/E. I. Du Pont
\end{tabular}} \\
\hline Typical forms (divestitures) & Divest existing business & \\
\hline & Divest capacity & $2009 \cdot$ Mitsubishi/Lucite \\
\hline & Divest patent & $2015 \cdot$ Nokia/Alcatel-lucent \\
\hline & $\begin{array}{l}\text { Divest equity interest in } \\
\text { competitors }\end{array}$ & $\begin{array}{l}2011 \cdot \text { Penelope/Savio } \\
2014 \cdot \text { Thermo Fisher/Life Tech } \\
2016 \cdot \text { AB InBev/SABMiller }\end{array}$ \\
\hline $\begin{array}{l}\text { Non-typical forms } \\
\text { (quasi-structural remedies) }\end{array}$ & (none) & \\
\hline
\end{tabular}

As indicated in Table 18, all of these cases were subject to traditional forms of structural remedies. Most of the divestitures were designed to restore competition by creating new competitors or strengthening existing competitors, whereas in three cases, the divestitures were designed to sever the relationship between the merging parties and their competitors.

Among all these cases, Glencore/Xstrata was the first case in which the merger remedies were published together with MOFCOM's decision in 2013. Afterwards, almost all the remedies, including Baxter/Gambro, Thermo Fisher/Life Tech, NXP/Freescale, AB InBev/SABMiller and Abbott/St. Jude Medical were published except the Nokia/Alcatel-lucent. The reason could be that the information was quite sensitive considering a patent divestment was imposed in this case. Thus, the publication of remedies can be the trend, which may increase the transparency of MOFCOM's enforcement.

Unlike the situation in behavioural remedies, where MOFCOM's decisions can be quite different from that in the US and the EU, MOFCOM's practice in the scenario of structural remedies is similar to the above-mentioned two jurisdictions. For example, MOFCOM's decision in $A B$ InBev/SABMiller was particularly similar to the decisions in these two jurisdictions. Among these three jurisdictions, the Commission was the first one

1416 Peter Alexiads and Elsa Sependa, 'Structural Remedies under European Union Antitrust Rules' (Gibson Dunn, 1 February 2013) <http://www.gibsondunn.com/publications/Documents/AlexiadisSependa-StructuralRemedies. pdf $>$ accessed 2 May 2017, 22. 
which lit the green light for the transaction subject to AB InBev's commitment to divest SABMiller's business in several European countries to the Japanese brewer Asahi. ${ }^{1417}$ Similarly, the global transaction won its conditional approval from the DOJ by promising to divest all the Miller brands in the US. ${ }^{1418}$ Also, in Pfizer/Wyeth ${ }^{1419}$ or UTC/Goodrich ${ }^{1420}$, both the Commission and MOFCOM approved these cases subject to structural remedies.

It is emphasised by the Commission that a divestiture is acceptable only if it meets the requisite degree of certainty of enforcement and such changes made to the structure of the merged firm will be "workable and lasting" enough to reduce the anti-competitive effects. ${ }^{1421}$ Attention is thus naturally focused on how to increase the requisite degree of certainty and reduce possible risks during the design and implementation of divestitures. In practice, various strategies are used by the Commission to reduce risks that could by caused by an inappropriate composed divestiture package, or unavailability of a suitable buyer, or a reduction in the value of the divestiture package during the interim period before the completion of divestiture. Such risk-reducing approach is actually also adopted by the CA in the US by applying different strategies to ensuring the effectiveness of divestitures. ${ }^{1422}$

According to the published merger remedies, it can be observed that MOFCOM also uses these strategies in the structural remedies. Therefore, the following section explores what strategies are used by MOFCOM to ensure the effectiveness of divestitures.

\subsubsection{General Principles of Merger Divestitures}

First, in most of the cases, the to-be-divested assets are selected from one of the merging parties, either the acquirer or the acquired, while it was only in one case that the divestiture package was composed of business from both sides of the merging parties.

For example, in the Pfizer/Wyeth case, Pfizer, as the acquirer, was required to divest all the products under the brand of Respisure and Respisure One. ${ }^{1423}$ In Seagate/Hitachi HDD, the Hitachi (the acquired)'s business of 3.5-inch drives had to be divested by the merged firm. ${ }^{1424}$ In the recent case NXP/Freescale, the acquirer NXP proposed, during the primary investigation, to divest all Freescale's business concerning RF power transistors to a Beijing firm, which was later accepted by MOFCOM. ${ }^{1425}$ This case can also be regarded as the first case in which an up-front buyer was found for the divestiture package.

The only case in which the divestiture package is composed of the business from both sides of the merging parties is Panasonic/Sanyo, in which the divestiture package was arranged as follows:

1. Sanyo had to divest all its business regarding the rechargeable coin-shape lithium batteries. It is worth pointing out that Sanyo's factory in Japan had to be divested to

\footnotetext{
1417 See: European Commission Press Release, 'Mergers: Commission Approves AB InBev's Acquisition of SABMiller, Subject to Conditions' (EUROPA, 2 August 2016) < http://europa.eu/rapid/press-release_IP-161900_en.htm> accessed 3 May 2017.

1418 See: United States v. Anheuser-Busch InBev SA/NV and SABMiller, Case 1:16-cv-01483 (2016) <https://www.justice.gov/atr/file/877596/download> accessed 3 May 2017.

1419 See: Case COMP/M.5476, Pfizer/Wyeth (European Commission Decision) [17 July 2009] <http://ec.europa.eu/ competition/mergers/cases/decisions/m5476_20090717_20212_en.pdf> accessed 3 May 2017.

1420 See: Case COMP/M.6410, UTC/ Goodrich (European Commission Decision) [26 July 2012]

<http://ec.europa.eu/competition/mergers/cases/decisions/m6410_20120726_20600_3206581_EN.pdf> accessed 3 May 2017.

14212005 EC Merger Remedies Study (n 27) para. 10.

1422 See: 2012 FTC Remedies Statement (n 36); 2012 DOJ Policy Guide (n 1415).

1423 Pfizer/Wyeth (n 1381).

${ }^{1424}$ Seagate/Samsung HDD (n 1406).

${ }^{1425} \mathrm{NXP} /$ Freescale (n 1390).
} 
a suitable buyer. It was the first time for MOFCOM to require the divestment of business which was outside the territory of China.

2. Either Panasonic or Sanyo had to divest all the business of nickel-hydrogen batteries for general use. If the merged firm would decide to divest the business of Sanyo, Sanyo's factory in Japan should also be divested to a third party.

3. Panasonic had to divest all its business of nickel-hydrogen batteries for vehicles, including its factory in Japan to a third party. ${ }^{1426}$

Besides these requirements, MOFCOM also decided that all the production equipment, information and data regarding marketing, sales, $\mathrm{R} \& \mathrm{D}$ and customers' resources of the above-mentioned three products should be transferred to the independent third party (buyer). Furthermore, patents concerning these three products should also be available to the buyer.

As is explored in sec.2.1.2, Panasonic's and Sanyo's overlapping products, rechargeable coin-shape lithium batteries, the nickel-hydrogen batteries for general use and the nickelhydrogen batteries for vehicles were three stand-alone and on-going businesses.

Accordingly, it can be observed from this case that the stand-alone and on-going business was selected from both parties of the merged firm to clear the overlaps. In fact, in most of the cases in which typical forms of divestitures were imposed, a clean-sweep approach was more likely to be employed by MOFCOM. Take UTC/Goodrich as an example.

UTC proposed to acquire Goodrich and notified the proposed transaction to MOFCOM on 12 December 2012. ${ }^{1427}$ The notified horizontal merger concerned four overlapping markets between the merging parties, aircraft power supply system, lighting system, control actuation system, and engine control system. MOFCOM concluded after its investigations that the transaction would eliminate or restrict competition in the market of aircraft power supply. Accordingly, Goodrich has to divest its business of power supply, including its business of AC power systems, low-voltage DC power systems and power distribution systems in both Pitstone (UK) and Twinsburg (US). Relevant production equipment, marketing department, $\mathrm{R} \& \mathrm{D}$ department, customer services and patent will also be transferred.

Based on the published cases in which structural remedies are imposed, it can be concluded that regarding the determination of scope and composition of the divestiture package, MOFCOM seems to prefer to choose stand-alone and on-going business from one of the merging parties to clear the overlaps. Besides, it is possible that MOFCOM requires the merged firm to divest business which is out of the territory of China.

\subsubsection{Composition Risk:s: Crown Jewels in Glencore/Xstrata}

Composition risks can arise when the divestiture package is inappropriately configured or the scope of the package is too constrained. According to Chapter 6, such risks can be caused by the information asymmetry (hidden characteristics) between the merging parties and the buyer. These risks can be reduced by applying risk-reducing provisions, such as upfront buyer provisions or crown jewel provisions. From a legal perspective, according to Art. 7 of the MOFCOM Provisions on Merger Remedies, a crown jewel can be required if

${ }_{1426}$ MOFCOM Public Notice 2009/82: Conditional Approval for the Notified Merger - Panasonic/Sanyo (MOFCOM Decision) [30 October 2009] < http://fldj.mofcom.gov.cn/article/ztxx/200910/20091006593175.shtml> accessed 30 April 2017.

1427 UTC/Goodrich (n 1370). 
there is a risk that the originally proposed divestiture cannot be implemented. ${ }^{1428}$ In practice, until 20 June 2017, there was only one case in which a crown jewel provision was included.

It was decided that the transaction between Glencore and Xstrata would raise competition concerns in the copper concentrate, zinc concentrate and lead concentrate markets. ${ }^{1429}$ Accordingly, to clear the potential anti-competitive effects, MOFCOM ordered a combination of both structural remedies and behavioural remedies in the case. Regarding the zinc concentrate and lead concentrate markets, the merged firm was required to continue to provide the Chinese customers with long-term supply contracts and offers of spot contracts from 2013 to the end of 2020. In relation to copper concentrate, the decisions required that:

- After the completion of the notified transaction, Glencore should divest all its rights and interests in Las Bambas, which was a copper project at the time being explored by Xstrata in Peru.

- If (a) Glencore failed to enter into a binding agreement with a MOFCOM-approved buyer before 30 September 2014, or (b) Glencore failed to close the transaction of divesting Las Bambas to the MOFCOM-approved buyer before 30 June 2015 (despite a formal agreement being reached), then, unless MOFCOM approved, Glencore should appoint a divesting trustee from (a)1 October 2014 or (b) 1 July 2015 to divest all Glencore's rights and interests in any of the following four projects with no reserved prices: Tampakan, Frieda, River, El Pachon, or Alumbrera. MOFCOM will decide in which projects Glencore's interest and rights should be divested.

It is clear that if Glencore did not manage to either find a suitable buyer and reach an agreement, or finish the divestment within a certain time limit (self-divesting period), then a trustee-divesting period would follow, in which a divestiture package of more value will be divested with a unreserved price.

The reasons for the inclusion of a crown jewel provision in this case can be that, first, the transaction concerns the mining industry, which is quite sensitive to the development of the national economy. This was also the only case (until 20 June 2017) considers the mining industry. Considering that China relies heavily on the import of copper concentrate, zinc concentrate and lead concentrate, MOFCOM may be extremely cautious about any anti-competitive effect generated from the notified cases. Second, the same transaction was also reviewed by the European Commission and was approved subject to structural remedies, ${ }^{1430}$ which was almost five months earlier than MOFCOM's decision. Accordingly, due to the consideration of its impact on the national economy and the European Commission's prior decisions, MOFCOM may decide to approve the transactions subject to divestitures. To further ensure the success of the divestiture, a crown jewel provision was included.

\footnotetext{
${ }^{1428}$ MOFCOM Provisions on Merger Remedies (n 1226). For the detailed exploration of crown jewels in China from the legal perspective, see: Chapter 10, sec.4.2.1.2.

1429 See: Glencore/Xstrata (n 1390).

1430 See: European Commission Press Release, 'Mergers: Commission approves Glencore's acquisition of Xstrata, Subject to Conditions' (EUROPA, 22 November 2012) <http://europa.eu/rapid/press-release_IP-121252_en.htm> accessed 2 May 2017.
} 


\subsubsection{Asset Risks: An HSP in Thermo Fisher/Life Tech}

Asset risks, referring to the risks of deterioration in the value of the to-be-divesting assets during the divestiture process before its completion, have been identified as one of the risks that can reduce the effectiveness of a divestiture. As explored in Chapter 7, asset risks can be caused by the merging parties' unobservable actions, which can intentionally or unintentionally, physically or intangibly reduce the value of the assets to be divested. To reduce the risks, in practice, the HSPs and trustees are used by the CAs in the US and the EU. In China, Art. 20 of the MOFCOM Provisions on Merger Remedies stipulates that the merging parties have the responsibility to keep the viability, competitiveness and saleability of the to-be-divested assets during the interim period. In addition, a special manager can be appointed to manage the to-be-divested business.

Almost all these seven published divestiture remedies included the HSPs. ${ }^{1431} \mathrm{It}$ should be noted that MOFCOM may require the merging parties to maintain the to-be-divested assets without requiring them to operate the business separately, such as NXP/Freescale, ${ }^{1432}$ AB InBev/SAB Miller, ${ }^{1433}$ Abbott/St. Jude Medical, ${ }^{1434}$ and Dow/E. I. Du Pont. ${ }^{1435}$ In Baxter/Gambro ${ }^{1436}$ and Thermo Fisher/Life Tech ${ }^{1437}$, the merging parties were required to maintain the value of the to-be-divested business by operating it separately from their retained business. Furthermore, in both cases, hold separate managers were appointed to manage the separately-operated business. In this section, Thermo Fisher/Life Tech is analysed to explore how MOFCOM deals with asset risks by requiring an HSP and a manager.

Both divestitures and behavioural remedies are imposed in Thermo Fisher/Life Tech. The merging parties were required to comply with the following requirements. ${ }^{1438}$

\section{A. Ensure the viability, saleability and competitiveness}

According to this requirement, the merging parties have to ensure the viability, saleability and competitiveness of the to-be-divested business and operate it in a manner that will not negatively affect the value of the business from the enactment of the commitment until the completion of divestment. As a result, the merging parties have to fulfil the requirements of:

a. not behave in a manner which may have significant negative impact on the value, management or competitiveness of the to-be-divested business, or in a way that can

\footnotetext{
1431 Although MOFCOM published all its conditional approvals, there are only seven decisions in which detailed divestiture arrangements were published, whereas other divestiture arrangements were just briefly introduced in MOFCOM's final decisions. The above-mentioned seven cases are: Dow/E.I. Du Pont (n 1390); MOFCOM Public Notice 2016/88: Conditional Approval for the Notified Merger - Abbott/St. Jude Medical (MOFCOM Decision) [30 December 2016] <http://fldj.mofcom.gov.cn/article/ztxx/201612/20161202440204.shtml> accessed 29 April 2017; MOFCOM Public Notice 2016/38: Conditional Approval for the Notified Merger - AB InBev/SABMiller (MOFCOM Decision) [29 July 2016] <http://fldj.mofcom.gov.cn/article/ztxx/201607/20160701369044.shtml> accessed 29 April 2017; NXP/Freescale (n 1390); Thermo Fisher/Life Tech (n 1383); MOFCOM Public Notice 2013/58: Conditional Approval for the Notified Merger - Baxter/Gambro (MOFCOM Decision) [13 August 2013] <http://fldj.mofcom.gov.cn/article/ztxx/201308/20130800244176.shtml> accessed 30 April 2017; Glencore/Xstrata (n 1390). For the detailed published remedies, see: List of all conditionally approved cases and prohibited cases (n 1364).

${ }_{1432} \mathrm{NXP} /$ Freescale (n 1390).

1433 AB InBev/SABMiller (n 1431).

1434 Abbott/St. Jude Medical (n 1431).

1435 Dow/E. I. Du Pont (n 1390).

${ }^{1436}$ Baxter/Gambro (n 1431).

${ }_{1437}$ Thermo Fisher/Life Tech (n 1383).

1438 ibid.
} 
change the nature and scope, the concerned industry and commercial strategy, and the investment policy of the to-be-divested business;

b. provide the to-be-divested business with sufficient and necessary resources to continue its commercial plan; and

c. offer an appropriate stimulation plan to encourage the personnel to stay within the to-be-divested business.

This obligation can be regarded as the general requirements concerning the preservation of the value of the to-be-divested business during the interim period, which is the same to the US or the EU's practice. Considering that the merging parties may have the incentives to undermine the value of the divestiture package since they are reluctant to make the buyer a strong rival, such obligations can to some extent reduce such "moral hazard".

\section{B. Keep the independence of the to-be-divested business}

Under this requirement, the merging parties have to keep the business to be divested independently from the retained business and operate the business as a stand-alone and saleable entity.

To realise the aim, the merging parties have to first appoint an independent holdseparate manager who is in charge of the management of the business to be divested. Such a manager works under the supervision of the monitoring trustee and has to ensure the viability, saleability and competitiveness of the to-be-divested with the requisite of maintaining the business' best interest.

Second, the merging parties have to ensure that the key personnel of the to-be-divested business will no longer engage in other activities of the retained business. Once the personnel are transferred to the buyer, they should not report to anyone else except the buyer. Third, the merging parties should assist the monitoring trustee in overseeing their compliance with the obligations and ensuring the independence of the to-be-divested business.

It is interesting to find out that hold-separate provisions appear again in the context of divestitures, whereas they are also used as behavioural remedies by MOFCOM in some cases. Evidently, the aim of the inclusion of these two types of hold separate provisions is different. In divestitures, they are used as an interim appliance to reduce assets risks, which is the same to the practice in the US and the EU. In the context of behavioural remedies, they are used as a condition to restrict the merging parties' conduct and reduce any potential anti-competitive effects.

\section{Asset Isolation}

To ensure the independence of the to-be-divested business, MOFCOM further required the merging parties to take reasonable measures to "isolate" the business, meaning that the merging parties should no longer have access to all the business secrets, commercial information or other confidential and exclusive information of the to-be-divested business. Especially, the to-be-divested business should be kept isolated from the central information administration network of the merging parties with the requisite that no negative impact should be caused to the viability of the business to be divested. The merging parties can access the information within a reasonable range and this information should be revealed to the public according to relevant laws and regulations.

This requirement theoretically can reduce asset risks because it can enhance the independence of the to-be-divested business. The only concern is that it can be difficult to determine the border of "a reasonable range". The merging parties can still have access to 
such commercial information if such information is regarded as within a reasonable range. However, in some complex transactions, such as transactions involving large numbers of products or concerning high-tech industry, professional knowledge may be required to determine "the reasonable range". Accordingly, to fully use this provision, a monitor with professional knowledge may be needed to oversee the merging parties' compliance.

Generally, the accepted remedy commitment in Thermo Fisher/Life Tech indicated that MOFCOM had taken measures to prevent the merged firm from adversely affecting the value of the divestiture package during the interim period. It is reasonable to conclude that the solutions MOFCOM uses are similar to the practice of the CAs in the US and the EU.

\subsubsection{Collusion Risks: Purchaser Requirements and Transitional Agreement in Baxter/Gambro}

As explored in Chapter 8, collusion risks can arise when the merged firm colludes with the purchaser after the completion of the divestment due to, e.g. the post-merger symmetry, multi-market contacts or a continuing relationship. Thus, solutions, such as considering post-divestiture effects, scrutinising the purchaser's incentives, and appointing trustees if a continuing relationship is necessary between the merged firm and the buyers, can be used to mitigate collusion risks.

Art. 11 of MOFCOM Provisions on Merger Remedies stipulates that a suitable buyer should have the necessary resources, ability and incentives to join the competition by operating the divested business. Art. 12 pointed out that any agreement between the seller and the purchaser, such as the sale agreement and transitional agreement, should not contain any clause that is inconsistent with MOFCOM's decisions. Thereby, there is little to be gained from the legal perspective that is relevant to collusion risks.

In practice, according to the published seven divestiture remedies, requirements about a qualified purchaser and the consideration of post-divestitures effects were included in Glencore/Xstrata, Baxter/Gambro, and Thermo Fisher/Life Tech. In general, the buyer clause in the divestiture arrangements states that a qualified buyer should have the incentives to maintain and develop the divested business to compete with the merged firm and other competitors viably and actively. Besides, divesting to the purchaser should not cause additional significant competition concerns.

Furthermore, transitional agreements were included in two cases: Baxter/Gambro and Abbott/St. Jude Medical. Baxter/Gambro is taken as an example here to explore how MOFCOM deals with collusion risks.

The transition Baxter/Gambro was notified to MOFCOM at the last day of 2012 and and was finally approved by MOFCOM subject to divestiture in June 2013. ${ }^{1439}$ The merging parties promised that based on the purchaser' needs and wishes, Baxter or its affiliated companies would provide the purchaser with certain products (e.g. upstream products) and services (e.g. human resources/financial/information services) during the transactional period to realise a smooth transfer of the divested business.

Moreover, a clause of "insulation" and a clause of "no inducing employment" was included. As the name suggests, under the clause of insulation, after the completion of divestitures, the merged firm and the purchaser would be prohibited from obtaining or exchanging any commercial secrets, exclusive technology, commercial information or any other confidential or exclusively information. The provision of not inducing employment

${ }^{1439}$ Baxter/Gambro (n 1431). 
prohibited the merged firm and its affiliated company from inducing the key personnel that had transferred to the purchaser together with the divested business to work for them within two years after the completion of the divestitures.

Generally, the concept of key personnel generally refers to the managers, or those who have access to the confidential information of the divested business. By prohibiting the seller and the purchaser from obtaining or exchanging information and by prohibiting the seller from employing the key personnel, the collusion risk can be reduced because the merged firm and the purchaser have fewer opportunities to reach a tacit or explicit collusion.

\subsubsection{Fix-It-First: NXP/Freescale}

A fix-it-first remedy is the divestiture remedy submitted by the merging parties before the start of or during the merger review. In a fix-it-first remedy, a binding agreement between the merging parties and the potential buyer is reached, so that the CA has known the identity of the potential buyer and thus assess the suitability of the purchaser, the divestiture agreements, and the proposed transaction simultaneously. By 20 June 2017, there were three cases in which the fix-it-first remedies were accepted by MOFCOM. They are: NXP/Freescale, ${ }^{1440} A B$ InBev/SAB Miller, ${ }^{1441}$ and Abbott/St. Jude Medical. ${ }^{1442}$ $\mathrm{NXP} /$ Freescale is the first case that a fix-it-first was used.

MOFCOM worried that the proposed transaction was likely to eliminate or restrict competition in the RF power transistors market. To clear MOFCOM's competition concern, during the merging parties' first-time merger review, NXP proposed to divest all its RF power transistors business to JAC Capital Management Ltd ("JAC"), but this proposed remedy was not accepted by MOFCOM.

After withdrew the notification just before the expiration of the extension of stage II investigation and re-filed again, the merging parties submitted a binding agreement with JAC regarding JAC's purchase of NXP's RF power transistors business, resulting in a rather prompt approval from MOFCOM. ${ }^{1443}$ MOFCOM evaluated the agreement from the perspectives of e.g. the scope of the divestiture package and the validity, the viability, competitiveness and marketability of the to-be-divested business, the suitability of the buyer, and the downstream customer's attitude towards the proposed divestitures.

A fix-it-first remedy may be proposed by the merging parties when they want to take the initiative to convince the CA that their notified transaction will not harm competition by being remedied. Once the agency approves the merger transaction, the merging party can implement the transaction and finish divestitures as soon as possible without searching for a suitable purchaser again. However, different CAs may have different attitudes towards this remedy. For example, a fix-it-first remedy is frequently used by the DOJ in a consent agreement. In contrast, the FTC has no formal policy on it ${ }^{1444}$. It is hard to predict whether the MOFCOM favours a fix-it-first remedy since there is only one case in which it is used. Nevertheless, NXP/Freescale and other two cases indicate that at least MOFCOM is willing to accept it. Furthermore, a fix-it-first remedy can reduce the risk of value reduction

\footnotetext{
${ }^{1440} \mathrm{NXP} /$ Freescale (n 1390).

1441 AB InBev/SABMiller (n 1431).

1442 Abbott/St. Jude Medical (n 1431).

1443 According to the decision, the re-filed notification was accepted by MOFCOM on 10 November 2015, whereas MOFCOM made its conditional approval on 27 November 2015. This means that it only took MOFCOM 16 days to make the final decisions.

${ }_{1444}$ Majoras (n 376) 8. More detailed reasons why the DOJ and the FTC have difference preference regarding the fix-it-first remedies, see: sec.6.2.1. in Chapter 2.
} 
of the to-be-divested assets during the interim period of searching for a purchaser. Considering the MOFCOM's limited resources, such risk-reducing advantage of the fix-itfirst remedy may support the MOFCOM to accept the fix-it-first remedies.

\subsection{MOFCOM's Preference: Structural Remedies or Behavioural Remedies?}

In contrast to the CAs in the US and the EU's explicit preference to divestitures, MOFCOM's attitude towards this question is rather ambiguous.

Since most of the conditional approvals concern manufacturing, it is difficult to determine whether a divestiture remedy will be more likely to be imposed in transactions of certain industries. Besides, the vast majority of the conditional approvals involve foreign investors. Accordingly, an indicator such as the involvement of foreign investors can also provide few clues regarding MOFCOM's preference of divestitures or the behavioural remedies.

What can be observed, however, is that MOFCOM uses the behavioural remedies more frequently than divestitures. Among all the 29 conditional approvals, at least 15 transactions were imposed with pure behavioural remedies. The number would be even higher if the cases in which both structural and behavioural remedies are imposed are counted. Ming Shang claimed that MOFCOM has no general preference over the types of merger remedies, while it takes a case-by-case approach when determining which types of remedies should be imposed. ${ }^{1445}$ It seems too early to conclude that MOFCOM has a preference for behavioural remedies. The possible reasons why behavioural remedies are used more frequently than divestitures are explored in detailed in Chapter 12, sec.3.3.2. and Chapter 13, sec.4.

\section{Conclusion}

A series of provisions, measures and guidelines are published by MOFCOM, covering the aspects of e.g. the substantive assessment of a merger, the threshold for a mandatory premerger notification, or the restrictive conditions imposed on a transaction. With regard to merger remedies, different forms of behavioural remedies and structural remedies have been used in notified transactions.

Based on the analysis of the 29 conditional approvals, it can be observed that a more economic approach has been employed by MOFCOM when reviewing a notified transaction. By enriching the toolkit and applying more economic methods, the scientific creditability of merger review is expected to be enhanced.

During the merger review, trade policy, industrial policy and the protection of the national economy are taken into consideration by MOFCOM in some cases. Such considerations will not only have an impact on the decisions of merger review, but also influence the design of merger remedies. Behavioural remedies may to some extent serve as merger conditions to address these concerns.

A clean-sweep approach is applied by MOFCOM when determining the scope of a divestiture package, in which the to-be-divested business is generally selected from one side of the merging parties. Crown jewel provisions are used by MOFCOM to reduce

${ }^{1445}$ Deng and Zhang (n 1380). 
composition risks, while asset risks and collusion risks are reduced by MOFCOM's hold separate provisions and non-solicitation provisions.

The timing of a merger review is expected to be shortened since MOFCOM has reorganised the composition of the AMB. However, to further speed up the whole procedures, more efforts should be made to overcome the difficulties brought by MOFCOM's limited resources and experience.

Accordingly, answers to some of the questions mentioned in Chapter 9 can be found in this Chapter on the basis of the case analyses conducted. However, other questions, such as the ambiguities concerning three competition agencies' unclear authority, no distinction between fully-functional/non-fully-functional JV, or whether there exists any detailed "fitting-test" to determine the potential buyer's suitability remain unknown. These questions will be further explored in Chapter 12 from an empirical perspective. 


\section{Chapter}

\section{INSIGHTS OF MOFCOM'S MERGER CONTROL AND MERGER REMEDIES - EMPIRICAL EVIDENCE}





\section{Introduction}

The analysis conducted in Chapter 10 draws an aerial picture of the legal framework of China's merger review and merger remedies policies. In Chapter 11, case analyses have been further conducted to analyse MOFCOM's practice in merger review and the use of merger remedies. There, however, remains some questions unanswered or of which require further exploration, such as, how MOFCOM conducts the substantive assessment, given the ambiguities in the Chinese substantive EERC test ("Effects of Eliminating or Restricting Competition") ${ }^{1446}$; whether and how non-competition policies would be taken into account by MOFCOM ${ }^{1447}$; and what is MOFCOM's attitude toward the use of riskreducing strategies in divestitures.

Empirical insights can be of great importance to answer these questions and to deepen the understanding of China's merger review and merger remedies system. As explored in Part I, studies or policy guides regarding merger remedies have been published by the CAs in the US and the EU, which assess the effectiveness of merger remedies, summarise the policy and practice of the CAs' with respect to merger remedies or provide suggestions for future improvements.1448 However, as of May 2017, there is no such officially published document in China.

Furthermore, although there are quite a few written articles from China and foreign countries exploring China's merger review and remedies practice, most of them focussed either on the substantive and procedural aspects of merger review in a general way or on case analyses. ${ }^{1449}$ One of the most relevant articles in that regard is Ezrachi and Han (2015). ${ }^{1450}$ The authors analysed the pattern and implications of Chinese merger remedies by exploring relevant legislation as well as case decisions and further explored the reasons behind the prevalence of behavioural remedies in China. It seems that there is little work which explores MOFCOM's practice in merger review and merger remedy in depth and from an empirical perspective. In order to fill this gap, semi-structured interviews were conducted by the author. This Chapter summarises the results from these interviews. The remainder of this chapter is structured as follows.

Subsequent to this Introduction, the methodology of interviews is explained in sec.2, where the lists of the participants and interview questions are presented. In sec.3, the results of interviews are communicated from the perspectives of general questions, questions regarding merger reviews, questions regarding merger remedies and the general assessment of MOFCOM's practice and suggestions for improvements. A conclusion is drawn in sec.4. Please note that, to better follow the flow of the whole dissertation, detailed discussions of these results will be presented in the next Chapter.

\footnotetext{
1446 See: AML (n 42).

${ }^{1447}$ In the context of competition law in China, a non-competition policy is a concept in contrast to a competition policy. Such policies include, for example, foreign investment policy, international trading policy or industrial policy.

1448 See: for example, 2011 DOJ Policy Guide (n 56); 2012 FTC Remedies Statement (n 36); 1999 FTC Divestiture Study (n 38); 2005 EC Merger Remedies Study (n 27).

1449 Such as: Wang (n 64); Han and Ryan (n 1412); Lin and Zhao (n 1227); Hao (n 1414); Hamp-Lyons (n 1214); Zhang and Zhang (n 1216).

1450 Ariel Ezrachi and Wei Han, 'Merger Remedies - Chinese Experience' (2015) 3(Suppl. 1) J Antitrust Enforcement 69.
} 


\section{Methodology}

\subsection{Participants}

Face-to-face semi-structured interviews were adopted to conduct this empirical survey, taking into account the flexibility of semi-structured interviews and the possibility of observing the respondents during the face-to-face interviews. ${ }^{1451}$

There were in total six participants who took part in the interviews. They are grouped into two groups, the lawyer group and the scholar group, with 3 participants in each group. Attempts had been made for several times to invite officers from the AMB of MOFCOM to join the interviews so that first-hand or inside information can be obtained. No further reply, however, was received from those invitees.

All the participants in the lawyer group work for top-tier Chinese law firms, who have their expertise in dealing with merger transactions. Rongrong $\mathrm{Xu}$ is a partner in the Hong Kong office of JUNHE Law Firm. Liang Ding is a partner in DeHeng Law Offices in Beijing. Ying Yang is a senior lawyer in Broad \& Bright Law Firm in Beijing. They have frequent contacts with MOFCOM by representing their clients in front of MOFCOM or attending various seminars held by MOFCOM. Moreover, they have not only domestic clients, but also international clients, participating in different industries, such as biotechnology or the hotel industry. Therefore, these lawyers have a rich practical knowledge and experience of China's merger review and merger remedies policy and practice. By interviewing these lawyers, practical insights into MOFCOM's practice are expected to be revealed.

The academic group consist of three prestigious Chinese professors. They are the leading scholars in the field of China's competition law and enjoy a high reputation in China as well as foreign jurisdictions in the domain of competition law. Xiaoye Wang, professor and director of the Economic Law Department of the Law School Chinese Academy of Social Sciences, is designated as one of the members of the Expert Committee of the Anti-Monopoly Commission of the State Council. ${ }^{1452}$ She was also engaged in the drafting work of the AML before it came into force. Shiying Xu is professor and director of the Competition Law Research Institute of East China University of Political Science and Law. (NB One of the participants in the scholar group required to remain anonymous. ${ }^{1453}$ ) These professors have close contacts with the Anti-Monopoly Commission of the State Council as well as with the three competition agencies (NDRC, SAIC and MOFCOM) ${ }^{1454}$ by e.g. giving lectures, attending seminars, or providing their

\footnotetext{
1451 See: Lawless, Robbennolt and Ulen (n 51) 80-82.

1452 The Expert Committee was established by the Anti-Monopoly Commission of the State Council in 2011. The Expert Committee consists of prestigious scholars in the field of either competition law or economics. They are selected and designated by the Anti-Monopoly Commission and work as a "brains trust". See: Jie Gao and Xinran Tang, 'Professor Liming Wang and Other Professors Are Appointed as Members of the Expert Committee of the Anti-Monopoly Commission (wang li ming deng jiao shou shou pin guo wu yuan fan long duan wei yuan hui zhuan jia zi xun zu cheng yuan 王利明等教授受聘国务院反垄断委员会专家咨询组成员)' (Renmin University of China, Law School, 28 December 2011) <http://ruc.zuolang.com/introduce/ShowArticle.asp?ArticleID=35265> accessed 5 May 2017.

1453 A professor's requirement of being anonymous during an interview might be a bit striking to some western readers. In the context of China, however, it is quite common, considering the fact that in China, a personal judgement or opinion concerning some sensitive topics or information may bring a negative impact on that person.

${ }^{1454}$ For the introduction of Chinese anti-monopoly legal system and competition authorities, see: Chapter 10, sec.2.2.
} 
opinions concerning, for example, drafted guides or measures. Thus, they not only have a comprehensive knowledge of competition law, but also have up-to-date information regarding e.g. future developments that can be pursued by MOFCOM. The shortcoming of the absence of officers from MOFCOM is expected to be recovered to a large extent.

\subsection{Interview Questions}

Interview questions for both groups of participants (lawyers and scholars) can be categorised into four groups: general questions, merger review, merger remedies and personal opinions. Several topics are included in each group. These topics mainly concern questions that remain unsolved after the explorations in Chapter 10 and Chapter 11.

Generally, all participants were asked similar questions. Considering the difference between lawyers and scholars, questions for the lawyer groups put more emphasis on practical aspects, whereas questions for the scholar groups were more theoretical. The outlines of these topics are as follows:

1. General Questions

a. Questions for the lawyer group

- General development of the numbers of merger notifications

b. Questions for the academic group:

- Welfare standard of China's merger review policy

2. Merger Review

- The loopholes in the EERC test.

- Time limits of merger review

- Consideration of non-competition policies during merger assessment;

- Other relevant questions of merger review

3. Merger Remedies

a. Common questions for both groups:

- Non-traditional forms of behavioural remedies

- MOFCOM's preference for behavioural remedies or structural remedies

- MOFCOM's awareness of the following risks during divestitures and what are the adopted solutions:

- Composition risks

- Asset risks

- Collusion risks

b. Questions for the lawyer group

- Use of the fix-it-first remedy

4. General Assessment, personal Opinions or Suggestions

- MOFCOM's quality of assessment, role of economic analyses

- Whether MOFCOM follows up on these notified transactions.

- Suggestions for future improvements

Question lists were sent to the participants before the interviews, so that they could get prepared. It is worth pointing out that since the method of semi-structured interviews was adopted, the above-mentioned questions just served as a general outline. It is possible that particular participants were asked questions that were excluded from the lists, depending 
on their responses and the timing of the interviews. The results of these interviews are summarised in the next section.

\section{Results}

\subsection{General Questions}

\subsubsection{Lawyer Group}

According to the statistics published by MOFCOM, the number of decided merger cases is increasing these years. ${ }^{1455}$ As the practitioners, lawyers are likely to be able to verify the possible reasons for this increase. Accordingly, lawyers were asked the question whether they think the number of merger cases will keep on rising and if so, why.

Generally, all lawyers pointed out that the number of merger cases has increased significantly since the enactment of the AML in 2008. ${ }^{1456}$ The enactment of the MOFCOM Fail-to-Notify Provisions in early $2012^{1457}$ and the MOFCOM Provisions of Simple Cases in late $2014^{1458}$ may to some extent lead to the growth of a number of notifications.

Yang

According to Yang, with the development of the Chinese economy, mergers and acquisitions between firms happen much more frequently than before. Moreover, firms are gaining awareness of making pre-merger notifications and have been getting familiar with the merger review procedures during these years since the enactment of the AML in 2008. ${ }^{1459}$ She further explained that the publications of the MOFCOM Fail-to-Notify Provisions and the MOFCOM Provisions of Simple Cases incentivise the merging parties to make pre-merger notifications given the risk of being fined if they fail to make such notifications according to the MOFCOM Fail-to-Notify Provisions. More importantly, the MOFCOM Provisions of Simple Cases significantly speed up the whole procedures if the notified case is regarded as "simple" by MOFCOM, ${ }^{1460}$ which to a large extent clears the merging parties' concerns of a lengthy wait before their transactions are approved.

\footnotetext{
${ }^{1455}$ For the annual number of MOFCOM's decided transactions from 1 August 2008 to 30 December, see: Chapter 11, Table 12.

1456 AML (n 42).

${ }^{1457}$ MOFCOM Fail-to-Notify Provisions (n 1234).

1458 MOFCOM Provisions of Simple Cases (n 1235).

${ }^{1459}$ Interview with Ying Yang (杨瑛), Lawyer, Broad \& Bright Law Firm (shi ze lv shi shi wu suo 世泽律师事务 所) (Beijing, China, 31 May 2016).

1460 ibid. A simple merger case generally refers to a transaction which involves fewer turnovers or has no negative impact on the competition. Art. 2 of the MOFCOM Provisions of Simple Cases (n1235) state that mergers which satisfy the following criteria can be regarded as simple cases:

1. For a horizontal merger: if the merging parties are in the same relevant market, their combined market share is less than $15 \%$ in such market;

2. For a vertical merger: if the merging parties have an upstream-downstream relationship, their combined market share is less than $25 \%$ in both the upstream market and the downstream market;

3. For a conglomerate merger: if the merging parties are neither in the same relevant market nor in an upstream-downstream relationship, their combined market share is less than $25 \%$ in any of the transaction-relevant market;

4. For the establishment of a joint venture which is outside the territory of China: such joint venture shall not engage in business activities within the territory of China;
} 
$X u$

It is pointed out by $\mathrm{Xu}$ that one of the largest differences of merger review between China and other jurisdictions is whether there is an "expressway" designed for simple cases. Before the enactment of the MOFCOM Provisions of Simple Cases, on average, the merging parties had to wait for at least four to six months after all the documents were submitted to MOFCOM. For complex cases, it could even take nine months to one year before any decision was made. After the enactment of the MOFCOM Provisions of Simple Cases, generally, it only takes two to three months for a simple case to be decided, which largely shortens the duration and speeds up the whole procedure. Thus, this is considered as a quite inspirational and welcoming development. ${ }^{1461}$

The combined use of the MOFCOM Fail-to-Notify Provisions and the MOFCOM Provisions of Simple Cases can also incentivise the merging parties to make notifications to MOFCOM because on the one hand, a simple merger can be decided within a short period; on the other hand, if they do not make notifications, they may be fined. Therefore, the time limit of the merger review is now considered more reasonable and acceptable for the notifying parties.

Furthermore, when being asked whether the deterrence of the MOFCOM Fail-toNotify Provisions would be limited considering that the upper limit of the fine was only half a million RMB, which can be extremely low compared to the turnovers of mergers, Xu gave a negative answer. She explained that despite the limited amount of financial penalty, the Provisions can still have some deterrence because MOFCOM would publish the name of these fail-to-notify firms which can harm their reputation.

\subsubsection{Scholar Group}

The AML, as the core of Chinese competition law, has multi-dimensional objectives to protect fair competition in the market, enhance efficiency, maintain consumer welfare and the public interest, and promote a healthy development of the socialist market economy. ${ }^{1462}$ As was mentioned in Chapter 5, it is inevitable for the CAs to make tradeoffs between different goals. Different welfare standards can not only lead to different policy prescriptions, but also influence the formulation of merger remedies.

Accordingly, the participants in the academic group were asked the questions of what is the welfare standard that the AML adopts, how MOFCOM trades off between different goals if contradictions arise, and whether the Harvard school of thought or the Chicago school of thought was adopted by MOFCOM. ${ }^{1463}$

5. For the acquisition of equity or assets from an overseas enterprise: such overseas enterprise shall not engage in business activities within the territory of China;

6. For the reduction of numbers of controlling shareholders: through the proposed merger, a joint venture which was controlled by two or more undertakings will be controlled by one or more undertakings.

For the detailed exploration, see: Chapter 10, sec.3.1.2.

${ }^{1461}$ Interview with Rongrong Xu (许蓉蓉), Lawyer and Partner, Hong Kong Office (currently working in Beijing Office), JunHe Law Firm (jun he lv shi shi wu suo 君合律师事务所) (Beijing, China, 30 May 2016).

1462 AML (n 42), Art 1.

1463 The Harvard school of thought featured as the "structuralist" approach to competition law and its enforcement, while the Chicago school of thought contended that actually markets can be relied on to deliver important benefits to consumers, so that intervention should occur only in exceptional cases (when market failure occurs). See: Dabbah (n 47) 251. 
$W$

According to $\mathrm{W}$, these questions have a close link to the goals of the AML. ${ }^{1464}$ Competition, efficiency, consumer welfare and the development of the national economy are the four main goals of the AML. Among them, the first three goals are the hard-core and are of same importance. Should there arise any contradiction among these goals, W argued that according to his opinion and experience, priority is very likely to be given to the protection of consumer welfare. W explained that generally speaking, protection of consumer welfare is in line with the realisation of efficiencies. Realisation of potential merger-specific efficiencies can result in, e.g. the improvements in technology and costsavings. Consumers can also benefit from those efficiencies. In some exceptional situations where protection of consumer welfare is divergent from the preservation of efficiencies, consumers are likely to be put in the first place. Therefore, W believed that under the AML, consumer welfare may be given priority when contradictions arise.

Regarding the choice between the Harvard school of thought and the Chicago school of thought, $\mathrm{W}$ pointed out that from the perspective of the formulation of the text, the AML is closer to the competition law in Germany and to the EU competition law. However, some European scholars may believe that the AML's fundamental idea is more similar to the competition law in the US, where the Chicago school of thought may play an important role. Therefore, W summarised that, on the one hand, in general, the AML was more inclined to the Chicago school of thought in the sense that it does not pay much attention to the market structure. On the other hand, however, the merger review system in itself is to some degree structure-oriented, meaning that the merger review system is designed to prevent a certain anti-competitive market structure. Put differently, within the framework of competition law, competition policies that combat anti-trust agreements and abuse of dominant market position preserve competition by punishing market participants' anticompetitive behaviour, whereas the merger control system preserves competition by restructuring the market concerned. Such restructuring can eliminate potential unilateral or bilateral anti-competitive effects generated from a merger.

$X u$

$\mathrm{Xu}$ argued that currently, it seems to be difficult to conclude which school of thought the AML adopts. ${ }^{1465}$ According to her opinion, the economy is developing rapidly in China, whereas the potential obstacles that may impede the economic development and competition in the market come from governments. Thus, in order to promote competition in China, at the current stage, efforts should be made to eliminate the obstacles caused by governmental documents and policies. The State Council's recent publication Opinions on Establishing a Review System to Ensure Fair Competition in the Market is a good example, which, to a large extent, demonstrate China's determination to clear the governmental obstacles in order to promote competition. ${ }^{1466}$

\footnotetext{
${ }^{1464}$ Interview with Anonymous, Professor and Dean, Law Faculty, a Chinese University (Beijing, China, 30 May 2016) (hereinafter: W).

1465 Interview with Shiying Xu (徐士英), Professor and Director, Competition Law Research Institute, East China University of Political Science and Law (hua dong zheng fa da xue 华东政法大学) (Shanghai, China, 15 June 2016).

1466 State Council of the People's Republic of China, Opinions on Establishing a Review System to Ensure Fair Competition in the Market (1 June 2016). The Opinions confirm the fundamentality of the competition policy among all the policies and require the establishment of a review system to ensure that regulations, regulatory documents and other policies published by governments and administrative departments at all levels in China should not impede fair competition in the market. For the full text of the Opinions, see: State Council, 'State Council published the Opinions on Establishing a Review System to Ensure Fair Competition in the Market (guo wu yun
} 


\subsection{Merger Review}

\subsubsection{Substantive Assessment}

According to Art. 3 and Art. 28 of the AML, a merger should be prohibited if it will or may have the Effects of Eliminating or Restricting Competition ("EERC test"). ${ }^{1467}$ The potential loophole in the substantive test EERC, as discussed in Chapter 10, is that it is not known to what degree competition in the market will or may be eliminated in such a way that it can lead to a prohibition of the merger. For example, in the US, according to Sec.7 of the Clayton Act, a merger will be prohibited if it Substantially Lessens Competition, or tends to create a monopoly ("SLC test"). ${ }^{1468}$ In the EU, Art. 2 of the 2004 EUMR stipulates that '[A]ny concentration which could Significantly Impede Effective Competition in the common market or in a substantial part of it, in particular as a result of the creation or strengthening of a dominant position, shall be declared incompatible with the common market' ("SIEC test"). In contrast to "substantively" in the SLC test or "significantly" in the SIEC test, neither the AML nor other rules and provisions mention a word on the degree of "eliminating or restricting competition".

Such ambiguity may give rise to difficulties in determining whether an in-depth investigation is necessary in the first place. It can also lead to the reduction of predictability of MOFCOM's merger review decisions. Both groups of participants were thus asked questions in this regard.

\subsubsection{Lawyer Group}

All lawyers shared the same opinion that although there is no explicit answer to the abovementioned question regarding the ambiguity in the EERC test, there are still some clues to follow. MOFCOM will make its decision by comprehensively considering all these factors and relevant information. Besides, it was pointed out that economic analysis is playing an important role during MOFCOM's substantive assessment.

$X u$

Market share is the first factor that will be taken into account during the assessment. ${ }^{1469}$ According to $\mathrm{Xu}$, although there is no explicit safe harbour in the AML or in relevant provisions, the proposed transactions, in general, will be deemed as safe if the post-merger market shares are below 30\%. A notified merger could be regarded as comparatively safe if the post-merger market shares are between $35 \%-40 \%$. Xu indicated that when dealing with a merger, in general, lawyers will start to feel a bit nervous if their clients' post-merger market shares will be higher than $30 \%$.

Second, the economic analysis will also be used as an important tool to assess the competition situation in the market. Xu added that the HHI is one of the most frequently used indexes. MOFCOM will make a comprehensive assessment, combining with the factors, such as the HHI, the number of competitors and the post-merger market shares.

guan yu zai shi chang ti xi jian she zhong jian li gong ping shen cha zhi du de yi jian 国务院关于在市场体系建 设中建立公平竞争审查制度的意见)' (Sina, 26 August 2016) < http:// finance.sina.com.cn/roll/2016-0826/doc-ifxvixsh6709984.shtml> accessed 6 May 2017. For the detailed exploration of this Review System, see: Chpter 13.

1467 AML (n 42) art 3 and art 28.

1468 Sec. 7 of the Clayton Act, 15. U.S.C. $\$ 18$.

${ }^{1469} \mathrm{Xu}(\mathrm{n}$ 1461). 
Third, Xu pointed out that MOFCOM will also solicit opinions and collect information by consulting with relevant industry associations, upstream/downstream competitors, or even consumers. According to $\mathrm{Xu}$, one of the concerns in this regard is the limited communications between the merging parties and MOFCOM. MOFCOM's limited manpower and large workload may reduce the possibility of such communications. With the increase of notifications, these problems become more severe, possibly leading to a delay in reply.

Ding

Ding shared the same opinion with $\mathrm{Xu}$ in the sense that MOFCOM will take a comprehensive consideration of all factors before making decisions. ${ }^{1470}$ Further, Ding pointed out that the economic analysis in China' merger review has no substantial difference from that in the EU. The economic analysis in China has several features. First, for those complex notified transactions, external experts specialising in economics are likely to be invited to conduct economic analyses. Second, third-party consultants who have an expertise in economic analysis can also be invited by MOFCOM. Such consultants can not only be Chinese, but also be foreigners. According to Ding's experience, these consultants have the capability of taking into account the special conditions of the industries in China and the unique nature of the transactions when conducting the analyses. Third, although MOFCOM invites external parties to conduct the analyses, it will keep objective and independent rather than resting its judgement completely on these analyses.

Ding believed that MOFCOM can understand the economic analysis better, compared to the other two CAs, NDRC and SAIC. During the substantive assessment, MOFCOM can conduct the economic analysis based on the economic framework learnt from the west on the one hand, while combining the results of the analysis with other factors such as market shares on the other hand.

\subsubsection{Scholar Group}

$W$

W explained that MOFCOM's practice in the substantive assessment can be understood from three perspectives. ${ }^{1471}$ First, general principles. As mentioned above, the substantive tests in the US, the EU and China are respectively the SLC test, the SIEC test and the EERC test. W believed that these three tests are in general similar. Second, other factors, such as market shares, the degree of concentration of the market, or the possible impact on consumers, other competitors, and national economy. ${ }^{1472}$ Third, different defences, such as efficiency defence. ${ }^{1473}$

The considerations of other factors are of the highest importance. However, there are some debates regarding the consideration of some factors. For example, whether the possible impact on the competitors and the national economy should be taken into account when MOFCOM assesses a notified merger. W argued that attention should be focused on

\footnotetext{
${ }^{1470}$ Interview with Liang Ding (丁亮), Lawyer and Partner, Beijing Office, DeHeng Law Offices (de heng lv shi shi wu suo 德恒律师事务所) (Beijing, China, 31 May 2016).

${ }^{1471} \mathrm{~W}$ (n 1464).

1472 See: AML (n 42) art. 27, or, MOFCOM Provisions on Assessment of Mergers (n 1233). In the MOFCOM Provisions on the Assessment of Merger, MOFCOM formulated in detailed the factors that shall be taken into account when assessing a notified merger. Such factors include, for example, the market position of the merging parties, market concentration, or market entry barrier.

1473 See: AML (n 42) art 28; MOFCOM Provisions on Assessment of Mergers (n 1233) art 8 and art 9.
} 
analysing the possible impact that the notified merger may cause to the competition in the market concerned.

Wang

Wang, on the other hand, indicated that according to her understanding, although there is no requirement for the degree to which the competition will or may be reduced in such a way that it can lead to a prohibition, MOFCOM will assess the transactions by considering various factors. ${ }^{1474}$ For example, the effects on horizontal and vertical competition should be taken into account. In general, comprehensive assessment criteria are adopted by MOFCOM. ${ }^{1475}$

\subsubsection{Time Limit}

The whole time frame of China's merger review can take up to 180 days: 30-day preliminary investigations, possibly followed by 90 -day in-depth investigations and another 60 days for extensions after the expiration of the in-depth investigations. ${ }^{1476}$ The duration can be even longer in practice if the interim waiting time is counted after the notifying parties submit their documents and before the case is formally accepted by MOFCOM. Moreover, there were also several cases in which the notifying parties had to withdraw their notifications just a few days before the expiration of the 60-day extension of the in-depth investigations to avoid prohibitions and refiled the cases again, resulting in an extremely lengthy review. ${ }^{1477}$

MOFCOM claims that the time frame of the merger review has been shortened successfully through various methods, such as re-structuring the AMB. ${ }^{1478}$ In order to further explore how MOFCOM practices in this regard, both groups of participants were asked the questions how do they think of the time limit of merger review in China, what can be the reasons behind the possible lengthy reviews, and what improvements MOFCOM is making to shorten the time frame.

\subsubsection{Lawyer Group}

Ding

Ding pointed out that during 2008 and 2014, there were quite a lot of complaints about the lengthy merger review in China. ${ }^{1479}$ The merging parties had to wait for several months even if it was believed that their transaction could barely cause any anti-competitive effect. This can be caused by the increasing numbers of notifications, whereas MOFCOM's manpower was limited. The staffing of any national ministry in China is fixed, meaning that it can be difficult to enlarge the manpower. ${ }^{1480}$ Factors such as MOFCOM's limited manpower, the increasing numbers of notifications, and the complexity of the notified

\footnotetext{
${ }^{1474}$ Interview with Xiaoye (王晓晔), Professor and Director, Economic Law Department, Chinese Academy of Social Sciences (zhong guo she hui ke xue yuan 中国社会科学院) (Beijing, China, 30 May 2016).

${ }^{1475}$ MOFCOM Provisions on Assessment of Mergers (n 1233).

1476 AML (n 42) art 24 and art 26.

1477 These cases are Western Digital/Hitachi Vivit (n 1390), Marubeni/Gavilon (n 1390), Mediatek Inc./Mstar (n 1390), Glencore/Xstrata (n 1390) and NXP/Freescale (n 1390).

1478 MOFCOM (n 1280).

${ }^{1479}$ Ding (n 1470).

${ }^{1480}$ In China, staff working for MOFCOM are public servants. They have to pass the Public Servant Exam in the first place and be appointed by MOFCOM after being interviewed. The number of these public servants is determined by MOFCOM. This means that compared with private corporations, MOFCOM cannot enlarge the manpower by hiring any external person as it wants.
} 
transactions, largely lead to MOFCOM's protraction of the procedures. During 2008 and 2014, there were many cases that would not be decided until the latter half of the in-depth investigations.

After the enactment of the MOFCOM Provisions of Simple Cases in 2015, ${ }^{1481}$ the duration of the merger review was shortened significantly for those simple transactions. Ding believed that according to some unpublished statistics, generally, simple cases can be decided within 30 days after the formal acceptances of notifications. The time limit for those simple cases can be shortened greatly. Furthermore, the normal cases are also expected to be decided within a shortened time limit, considering that the MOFCOM Provisions of Simple Cases enable MOFCOM to relocate its resources and focus its limited resources on these complex "normal transactions". ${ }^{1482}$

The second reason for the shortened merger review procedures is the realisation of electronic notifications. In the past few years, the notifications had to be submitted in writing and MOFCOM had to sort out the information manually. Nowadays, the standard notification form can be downloaded online and can be sent electronically. This cannot only save the notifying parties a lot of time, but also increase the efficiency of MOFCOM's information collection in the sense that the electronic data makes it easier for MOFCOM to look up information.

Third, compared with other governmental ministries or departments, the structure of the $\mathrm{AMB}$ of MOFCOM is simpler because it does not involve a complex hierarchical bureaucracy. Almost all the staff in the AMB devote their time to the review notified mergers rather than to administrative work.

Ding summarised that the enactment of the MOFCOM Provisions of Simple Cases, the electronic development in the pre-merger notifications, and the feature of the structure of the AMB lead to a shortened merger review. Although the number of notifications is higher than in the past, the general reviewing time is shorter. Regarding particular complex transactions, the time frame can still be long. In fact, this can to some extent be regarded as the result of bargaining between MOFCOM, the merging parties and those non-merging parties. For example, the competitors of the merging parties may put pressure on MOFCOM and obstruct the process of merger review to make the merging parties give up the transactions.

$X u$

According to Xu's experience, one of the most controversial aspects of the time frame of China's merger review is the waiting time before the notifications are officially accepted by MOFCOM. ${ }^{1483}$ Due to the uncertainties and opacity, a notification can possibly be accepted either within a short time limit or after a lengthy wait.

Some practical reasons may explain the lengthy merger review. First, in phase I (preliminary investigation stage), MOFCOM may conduct its investigations by consulting with third parties through, e.g. questionnaires. ${ }^{1484}$ It can be quite time-consuming for releasing, collecting back and analysing these questionnaires, resulting in large difficulties in

1481 See: MOFCOM Provisions of Simple Cases (n 1235) and (n 1460).

1482 Normal cases here refer to those cases which do not satisfy the criteria as simple cases according to the MOFCOM Provisions of Simple Cases (n 1235).

${ }^{1483} \mathrm{Xu}$ (n 1461). The time limit of merger review will not start to count until the merger notifications are formally accepted by MOFCOM.

${ }^{1484}$ MOFCOM Measures for Merger Review (n 1231) art 6 states that during merger review, MOFCOM can solicit opinions from relevant governmental departments, industry associations, relevant market players, or consumers. Such questionnaires are designed and handed out by MOFCOM to the above-mentioned individuals and departments. These respondents are required to finish the questionnaires within a certain period. 
completing the preliminary investigations within a 30-day limit. This is also the reason why most normal cases will be decided in phase II.

Second, during phase II (in-depth investigation stage), there are several rounds of discussions regarding the likelihood of generating anti-competitive effects. Generally, most transactions can be approved during this period if no remedy is required. An extension is likely to follow after the expiration of period II if a remedy is required.

Third, there are generally two situations in which a transaction will not be approved until the end of the maximum 60 days' extension. First, there are many complaints, doubts or opinions that were received by MOFCOM. In this situation, several rounds of arguments, debate and negotiations would be needed. The second situation may consider a global transaction. This implied that the same transaction was also being reviewed by the foreign CAs in other jurisdictions. Thus, MOFCOM may choose to wait and see whether the remedies required by the foreign CAs would be sufficient to eliminate the potential anti-competitive effects in China. It is noteworthy that, in recent years, the second situation happens less because MOFCOM is obtaining more experience and is becoming more sophisticated. As the outside consultants, M\&A lawyers practising in China are also becoming more experienced.

In accordance with Ding's opinion, Xu explained that after the MOFCOM Provisions of Simple Cases came into force, $80 \%$ of the notifications were dealt with as simple cases. Therefore, MOFCOM can better relocate its resources and better focus on dealing with complex cases.

Yang

Yang's opinion regarding the time limit of merger reviews was similar to Ding and $\mathrm{Xu}$ in terms of that, first, for those normal cases, they were mostly decided in phase II, whereas these simple cases were generally decided in the first phase. ${ }^{1485}$ Second, merger review can be lengthy depending on the complexity of the mergers and whether the negotiations of remedies were involved. Third, the pre-acceptance period can be lengthy, depending on whether the submitted documents were sufficient as well as how fast the notifying parties can provide supplementary information and documents as required by MOFCOM. In general, she believed that the whole time frame for merger review is now shortening.

After confirming the effectiveness of the MOFCOM Provisions of Simple Cases in shortening the time frame for simple cases as Ding and Xu did, Yang further pointed out that there is a risk that some merging parties may notify their transactions to MOFCOM as simple cases, whereas the fact was that the transactions may not satisfy the criteria in the MOFCOM Provisions of Simple Cases. ${ }^{1486}$ Therefore, to avoid this risk, MOFCOM now pays much more attention to the pre-acceptance document check to ensure that the notified simple cases are real simple cases.

Yang emphasised that although if a global transaction is reviewed in several jurisdictions, MOFCOM is likely to be the last one to make its decision. But changes are happening. First, the whole working process of the AMB is streamlined after the abolishment of the pre-acceptance consultation office.

\footnotetext{
1485 Yang (n 1459).

1486 See: MOFCOM Provisions of Simple Cases (n 1460).
} 
Figure 21 Merger Review Process of the AMB of MOFCOM ${ }^{1487}$

\begin{tabular}{r|l|c|} 
Pre-acceptance Consultation office & Case Team & $\begin{array}{c}\text { Before Sep. } \\
2015\end{array}$ \\
\hline Case & Team & \\
\hline Cormal acceptance of notifications) & After Sep. \\
2015
\end{tabular}

(Formal acceptance of notifications)

Both Yang and $\mathrm{Xu}$ argued that before the reform, there was a pre-acceptance consultation office which was assigned the responsibility to check the adequacy of the submitted documents and answering the notifying parties' questions. ${ }^{1488}$ After the notifications were formally accepted, another case team would be delegated to conduct the substantive assessment. In other words, in phase I, all the information and documents that had been obtained and read by the pre-acceptance consultation office had to be read again by the case team. Such repeated work wasted time and resources. Both respondents pointed out that after the abolishment in September 2015, the merger review was streamlined and the entire process was thus speeded up.

Yang pointed out that another change is that the case teams are now divided into three groups. They review different notifications simultaneously. Although MOFCOM has not explicitly explained the standard of such divisions, it was believed that the divisions were probably made according to the groups' different expertise as well as the different industries that transactions concerned. Such divisions can be helpful in increasing the timeefficiency and help these teams to gain professional experience.

Yang also judged that MOFCOM is making progress these years and learns a lot from the practice of the CAs in the US and the EU.

\subsubsection{Scholar Group}

$W$

W indicated that before the enactment of the MOFCOM Provisions of Simple Cases, the merging parties complained a lot about huge time costs caused by the lengthy merger reviews, which can reduce the potential efficiencies that are expected to be obtained from the notified mergers. ${ }^{1489}$ For example, the price that the merging parties agreed upon may no longer be suitable after a long-time wait for MOFCOM's decision, or the losses due to the deferred settlement of the transactions.

The possible delay in merger review can be caused by MOFCOM's limited resources, which can lead to a lengthy waiting time before a notification is formally accepted by MOFCOM. Although the notifying parties may submit their notifications promptly, due to the limited resources and consideration of the fact that once the notifications are accepted,

\footnotetext{
1487 (Summarised by the author).

1488 Yang (n 1459); Xu (n 1461).

${ }^{1489} \mathrm{~W}$ (n 1464).
} 
the time frame clock will start to run, MOFCOM may decide not to immediately accept the notifications.

Similar to the lawyers' opinions, W first mentioned that the MOFCOM Provisions of Simple Cases streamline the merger review for simple cases, under which a transaction would be approved if no objection from third parties, such as upstream/downstream competitors, is submitted to MOFCOM. Second, W pointed out that the Pre-Acceptance Consultation Office was abolished. W further emphasised that MOFCOM will invite thirdparty consultants, who can either be individuals or agencies, to participate in the substantive assessments when necessary. There used to be an economic analysis office within the AMB which was also abolished. Despite this, the Expert Committee has been established, in which economists are also appointed. ${ }^{1490}$ Upon the requirement of MOFCOM, these experts will also take part in the merger evaluations.

Wang

Wang pointed out that the time limit of these published cases was long because these cases were generally complex. ${ }^{1491}$ The time limit for these unpublished less complex cases is believed to be shorter than the published ones. Wang believed that the MOFCOM Provisions of Simple Cases can shorten the time limits. Furthermore, Wang indicated that if a transaction satisfies the standards in the MOFCOM Provisions of Simple Cases, this implies that the case is unlikely to bring about anti-competitive effects. ${ }^{1492}$ Such standards may to some extent provide us with some clues about how MOFCOM assesses the likelihood of potential anti-competitive effects when the degree requirement is absent in the EERC test.

Besides the problem of limited resources that has been mentioned by lawyers and by W, Wang also argued that MOFCOM's unfamiliarity with the industry concerned may also to some extent result in the long merger review. Wang pointed out that compared with the EU, where the time limit refers to "working days", China refers to "days". Therefore, China's time limit can be shorter than that in the EU, especially when there are national holidays. Besides, the EU also has the possibility to "stop the clock", whereas the AML does not have this possibility.

$X u$

"Before the MOFCOM Provisions of Simple Cases came into force, generally, the procedures of merger review in China were quite lengthy", Xu replied. ${ }^{1493}$ She explained that the reasons can be various, such as MOFCOM's limited manpower, complex procedures, no rules regarding the "stop the clock", and lack of experience. These reasons are largely similar to the other respondents' opinions to this question.

$\mathrm{Xu}$ considered that according to her experience, there are no such simplified merger review procedures in the US. The CAs in the US will decide the process of the merger review procedures according to their experiences. They may end the investigations if they believe that the transactions will not generate anti-competitive effects. However, the realisation of the effectiveness of this approach largely depends on the CAs' experience, as well as on the sufficiency of information regarding the industries concerned. In China, the data and information on various industries are incomplete and MOFCOM is unfamiliar

\footnotetext{
${ }^{1490}$ Professor Liming Wang and Other Professors Are Appointed as Members of the Expert Committee of the Anti-Monopoly Commission (n 1452).

1491 Wang (n 1474).

1492 See: Provision of Simple Cases (n 1458) and (n 1460).

${ }^{1493} \mathrm{Xu}$ (n 1465).
} 
with some industries. Therefore, the MOFCOM Provisions of Simple Cases were adopted to legislatively differentiate between simple cases and normal cases. Nevertheless, it is possible that the merging parties deliberately notify their normal cases as simple cases in order to make use of the shortened merger reviews. Such fraud can only be detected after the substantive assessment. Thus, time is wasted in this situation since the merging parties have to re-notify the transaction as normal cases, while MOFCOM has to assess the cases again.

Furthermore, approximately $98 \%$ of the notified cases were approved directly without conditions. For these cases, normal merger review procedures were too long. The MOFCOM Provisions of Simple Cases are effective in shortening the time frame. In Xu's opinion, the publication of the Provisions was just a question of time. MOFCOM had limited experience in merger review by the time when the AML was enforced. MOFCOM now is becoming experienced after several years' practice and is thus able to figure out the features which indicate the unlikelihood of severe anti-competitive effects. Nevertheless, $\mathrm{Xu}$ emphasised that the US approach in determining whether a case is simple or not is good and the MOFCOM Provisions of Simple Cases in China still need further improvements.

The time limit can be further shortened by abolishing the Pre-Acceptance Consultation Office. Xu explained that the office was set up because MOFCOM, as well as the merging parties and the lawyers, were all unfamiliar with the merger review procedures when the AML had just been enacted in 2008. With more practice, things are on the right track and the pre-acceptance consultation is no longer needed. Xu believed that the divisions of case teams are based on different industries concerned. Such divisions can increase efficiency by reducing the merger review time.

The following table summarises the possible reasons for the lengthy merger review and the recent changes that MOFCOM has made to shorten the time limit.

Table 19 Possible Reasons for the Lengthy Merger Review in China and the Improvements Made by MOFCOM

\begin{tabular}{lll}
\hline \multicolumn{2}{l}{ Reasons } & From whose opinions \\
\hline 1 & MOFCOM's limited manpower & Ding, W, Xu' \\
\hline 2 & Increasing numbers of notifications & Ding \\
\hline 3 & Complexity of transactions & Ding, Wang \\
\hline 4 & Long waiting time before acceptance & Xu, Yang \\
\hline 5 & $\begin{array}{l}\text { Possible several rounds of negotiations and discussions of complex } \\
\text { transactions }\end{array}$ & Xu, Yang \\
\hline 6 & MOFCOM's unfamiliarity with industry concerned & Wang \\
\hline 7 & No rules of “stop the clock" & Wang, Xu \\
\hline 8 & MOFCOM's lack of experience & Xu \\
\hline Improvements & From whose opinions \\
\hline 1 & Enactment of the MOFCOM Provisions of Simple Cases & Ding, Xu, Yang, W, Wang, Xu \\
\hline 2 & Less hierarchical bureaucracies in the AMB & Ding \\
\hline 3 & Electronic notification form & Ding \\
\hline 4 & Abolishment of the pre-acceptance consultation office & Xu, Yang, Xu \\
\hline 5 & Case team divided based on expertise and industry concerned & Yang \\
\hline
\end{tabular}

${ }^{1494} \mathrm{Xu}$ of the Scholar Groups will be marked in italics. 


\subsubsection{Consideration of Non-Competition Policies}

As explored in Chapter 11, the non-competition policies, such as trade policy, industry policies, or foreign investment policies, seemed to have been taken into account in several decisions. ${ }^{1495}$ Consideration of non-competition policies, however, may reduce the predictability of merger review in terms of causing difficulties for the notifying parties to prepare for the merger review. In order to clarify this question, both groups of participants were asked the question whether MOFCOM considers those non-competition policies when making decisions and if so, what possible effects can be caused by such considerations.

\subsubsection{Lawyer Group}

$X u$

$\mathrm{Xu}$ considered that it is possible for MOFCOM to consider these non-competition policies during the merger review. ${ }^{1496}$ It is quite understandable because, first, promoting the development of the national economy is one of the goals in the AML. The impact of the transaction on the development of the national economy is one of the factors that need to be considered during the assessment. ${ }^{1497}$ Besides, competition law may to some degree comprise or reflect a country's policies. The range of the policies that the laws cover may vary depending on different competition law in different jurisdictions. One may be wider; whereas another one may be narrower.

Ding

Another respondent, Ding, pointed out that according to Ming Shang, the former Director General of the AMB ("DG-AMB"), only competition policy would be considered when MOFCOM reviews a notified transaction, without considering non-competition policies, such as industrial policy. ${ }^{1498}$ During the assessment, MOFCOM may consult with third parties such as industry associations and it is possible that these industry associations delivered their opinions based on the industrial policy. This does not mean, however, that MOFCOM will definitely consider industrial policy. Ding believed that MOFCOM will analyse the cases mainly from the perspective of competition policy.

When being asked how to explain the decision and merger remedies in Glencore/Xstrata, ${ }^{1499}$ Ding replied that the imbalance in the international trading can also be regarded as the imbalance in the competition. Therefore, emphasising the role of trade policy in the decision of Glencore/Xstrata may to some degree overstate the difference between competition policy and trade policy. Many countries, in fact, take strategies to promote the development of certain industries to strengthen the dominant positions in the global competition. For example, one country may have rich resources in minerals. Domestically, fierce competition in the mineral industry is still possible even if two of these competitors merge. Globally, however, such a merger may bring anti-competitive effects in other countries because these countries may rely heavily on these two merging firms.

\footnotetext{
${ }^{1495}$ For these cases, see: Chapter 11, sec.2.3.

$1496 \mathrm{Xu}$ (n 1461).

1497 AML (n 42) art 27.

${ }^{1498}$ Ding (n 1470).

${ }^{1499}$ In this case, a hybrid merger remedy was required. It was pointed out that the post-merger market share of the merging parties would be quite low, which may be regarded as a sign of the unlikelihood of causing anticompetitive effects. Another important fact was that China relies heavily on the importation of these three minerals concerned.
} 
Accordingly, even the same transaction can obtain different decisions when being reviewed by different CAs, given the different market and economy situations in different countries, possibly resulting in different competition concerns.

According to Ding's opinion, on the one hand, Shang's answer that MOFCOM does not consider non-competition policy when assessing mergers can be regarded as the official answer. On the other hand, in practice, it is acceptable even if the non-competition policy might be one of the considerations, as long as MOFCOM's economic analysis was reliable, convincing and sufficient.

Ding emphasised that MOFCOM is cautious about the consideration of noncompetition policies.

\subsubsection{Scholar Group}

Wang

Wang indicated that according to the regulations in the AML, consideration of noncompetition policy is legal. ${ }^{1500} \mathrm{~A}$ notified merger may to some extent involve special industrial policy. Accordingly, considering such non-competition policy is acceptable and sometimes also inevitable. However, Wang believed that, first, competition policy should have the fundamental position among all the policies when reviewing a merger. Second, competition is good for the market participants, as well as for consumers. ${ }^{1501}$

Besides, Wang pointed out that when reviewing a notified merger, both the domestic and global competition situation of the industry concerned should be taken into account.

$X u$

Similar to Wang's opinion, Xu first pointed out that consideration of non-competition policy is legal according to the AML because the transaction's impact on the development of the national economy is one of the factors that need to be considered according to the AML and relevant provisions. ${ }^{1502}$ Furthermore, she emphasised that no matter whether a non-competition policy is considered or not during merger review, protection of consumers should be given priority, while this idea seems to attract little attention if one looks at the decisions published by MOFCOM.

\section{$W$}

W argued that generally, it is uncertain whether MOFCOM will consider non-competition policy when it reviews mergers. ${ }^{1503}$ However, some cases do cause such suspicion. The consideration of the transaction's potential impact on the development of the national economy is the main issue in this regard. Take Coca-Cola/Huiyuan Juice as an example. ${ }^{1504} \mathrm{~W}$ pointed out that the reason why this transaction was prohibited was rather ambiguous from the perspective of competition concerns. It was likely that the case was prohibited due to the huge pressure from the public's patriotic sentiment, given that Huiyuan Juice was a

\footnotetext{
${ }^{1500}$ Wang (n 1474). According to the AML (n 42) art 27, when reviewing a notified merger, factors, such as potential impact other competitors and the development of the national economy should be taken account.

${ }^{1501}$ For the details of this point, see, Xiaoye Wang, 'Comments on Merger Control under China's Anti-Monopoly Law' in The Evolution of China's Anti-Monopoly Law (Edward Elgar in association with the Social Sciences Academic Press 2014) para. 306-307.

1502 See: MOFCOM Provisions on Assessment of Mergers ( $\mathrm{n}$ 1233). There are some factors that are noncompetition factors among all these factors that need to be considered, such as the impact on the development of the national economy.

${ }^{1503} \mathrm{~W}$ (n 1464).

${ }^{1504}$ Huiyuan Fruit Juice/Coca-Cola (n 1317).
} 
welcoming national enterprise with a long history. "I have heard some news that MOFCOM has consulted the relevant industrial policy departments when investigating this case; meanwhile these departments thought the transaction may have a negative impact on the development of the national economy," revealed by W, "thus, finally MOFCOM adopted their opinions and prohibited the transaction". In this case, it is evident that noncompetition policy was considered.

It is pointed out by W that foreign scholars also wonder how MOFCOM deals with the relationship between industrial policy and competition policy. W argued that although the MOFCOM always emphasises the importance of competition policy, these noncompetition policies seem also to play a quite important role. This may be caused by the fact that MOFCOM used to be the Ministry of Foreign Trade and Economic Cooperation ("MOFTEC"), which laid its emphasis on international trade. ${ }^{1505}$ Although MOFCOM has never explicitly stated its consideration of non-competition policy in its decisions, W believed that such policy can be considered in some situations, while such consideration, according to the AML, is legal.

\subsubsection{Other Relevant Questions of Merger Review}

Since semi-structured interviews were adopted, some questions were only discussed with some of the respondents, depending on the flow of conservations and timing. The following issues were discussed in addition to these points explored above.

\subsubsection{No Differentiation between Fully-Functional and Non-Fully-Functional Joint Venture} According to the MOFCOM Guiding Opinions on Merger Declarations, the creation of a $\mathrm{JV}$ will fall within the scope of merger control if it is jointly controlled by two or more undertakings. ${ }^{1506}$ However, compared with the practice in the EU, where a distinction between fully-functional JVs and non-fully-functional JVs is made, there is no such distinction in China. As discussed in Chapter 10, this approach may to some extent reduce the effectiveness of the AML since some cases may be more suitable to be dealt with by competition law which combats anti-trust agreements or abuse of dominant position rather than by merger control law. Besides, MOFCOM may face the risks of overload.

Wang considered that in practice, MOFCOM will assess the transaction on a case-bycase basis. ${ }^{1507} \mathrm{Xu}$ explained that no matter whether a JV is fully-functional or non-fullyfunctional, it can notify itself as a "simple case" according to the MOFCOM Provisions of Simple Cases, which can be possibly approved within a short time. ${ }^{1508}$

$\mathrm{Xu}$ pointed out that there might be practical reasons why China does not make the differentiation between these two kinds of JVs. For example, in China, corporations can change a fully-functional JV into a non-fully-functional JV by simply changing some information on the Business License without being supervised and assessed strictly, implying that some enterprises might use this to avoid the application of laws. Moreover, enterprises are gaining awareness of the fact that the creation of a JV may also need to be notified to MOFCOM.

\footnotetext{
${ }^{1505}$ MOFCOM was re-organised mainly based on the MOFTEC in 2003. For the detailed information regarding this question, see: Department of Human Resources of MOFCOM, 'Brief Introduction of the History of MOFCOM of China (zhong hua ren min gong he guo shang wu bu jian jie 中华人民共和国商务部简介) (Department of Human Resources, MOFCOM, 18 February 2005) <http://rss.mofcom.gov.cn/aarticle/Nocategory/ 200502/20050200017543.html> accessed 5 May 2017.

${ }^{1506}$ MOFCOM Guiding Opinions on Merger Declarations (n 1237) art 4.

1507 Wang (n 1474).

$1508 \mathrm{Xu}$ (n 1461).
} 


\subsubsection{MOFCOM's Different Admissible Degree of Information from Different Providers}

According to Ning and others (2013), information from different providers may be of a different degree of importance to MOFCOM. ${ }^{1509} \mathrm{~W}$ was thus asked whether this is true and how MOFCOM deals with information from different providers.

W replied that the process of MOFCOM's information-collecting is quite complex, which may involve a large number of participants, including relevant governmental departments, industry associations, or other competitors. ${ }^{1510}$ In W's opinion, MOFCOM generally values the opinions from relevant governmental departments the most and will reply to them even if their opinions are not adopted. Sometimes MOFCOM will also pay close attention to the information and opinions provided by important economic departments. Regarding opinions from the non-merging competitors, MOFCOM has to screen them in the first place and only reasonable opinions will be considered, considering that those non-merging competitors' opinions can be subjective and unfair given their selfinterest. W gave an example in this regard.

A merger between two internet enterprises was notified to MOFCOM. The transaction, however, received strong complaints and objections from their competitors. It is actually understandable because these non-merging internet enterprises' interests may be jeopardised if the transaction was approved. A possible danger of these competitors' future interests and profits, however, does not directly mean reduction in competition. The case was ultimately approved by MOFCOM. The goal of MOFCOM to collect information is to find out any valuable information, but this does not mean that any protestors' information will have a decisive impact on MOFCOM's decision.

\subsubsection{Possible Conflicts Caused by the Three CAs}

There are three CAs in China, MOFCOM, NDRC and SAIC. They respectively take the responsibility of reviewing mergers, enforcing price-related anti-trust behaviour and enforcing non-price related anti-trust behaviour. As discussed in Chapter 10, the potential problem is that such a three-way split may reduce the efficiency and protract the time limit of merger review if they pass the buck to each other.

$\mathrm{Xu}$ replied that this potential problem is unlikely to happen considering that all these CAs have the responsibility to preserve competition in the market. ${ }^{1511}$ Generally, they do not shirk their responsibilities or extend their responsibilities. "The division of responsibilities may not be the best," added by Xu, "the division is determined by our antitrust history. They gain their authority from different laws. But before these three CAs are unified or a new agency is created, such division is not bad." 1512

$\mathrm{Xu}$ further specified that although in general there is no conflict between MOFCOM, NDRC and SAIC regarding the division of responsibilities, it is possible that conflicts can happen between NDRC and SAIC in the fields of administrative monopoly or anticompetitive regional protection, which may involve both price related and non-price related monopolistic conducts. In this situation, a close assessment is necessary to determine whether the case is closer to price-related or non-price related monopolistic behaviours. Sometimes a case can be transferred between NDRC and SAIC if one CA, after investigating, finds that it can be more suitable for the case to be handled by the other

\footnotetext{
${ }^{1509}$ Ning and others (n 1386).

${ }^{1510} \mathrm{~W}(\mathrm{n}$ 1464).

${ }^{1511} \mathrm{Xu}(\mathrm{n}$ 1465)

${ }^{1512}$ For the detailed information of the history of China's antitrust legislation and the CAs in China, see: Chapter 10.
} 
CA. The conflict between the CAs can be solved through the CAs' ex post negotiations about the jurisdictions.

\subsection{Merger Remedies}

\subsubsection{Diverse and Non-traditional Forms of Behavioural Remedies}

The case analyses in Chapter 11 indicate that forms of behavioural remedies in China are diverse. Some of the remedies are quite unique.

For example, hold separate provisions are usually used as an interim tool in the divestiture remedies to preserve the value of the to-be-divested assets before completion. In contrast, such provisions are used as behavioural remedies in China, which the merged firms are required to observe when they operate their business independently after completion of the merger. ${ }^{1513}$ Another example is that, according to the remedy in one transaction, the notifying parties were required to reduce the price for certain products, which placed MOFCOM in an embarrassing price-fixing position. ${ }^{1514}$

Both groups were asked to give their opinions regarding the behavioural remedies in China to further explore the reasons and possible effects of those controversial behavioural remedies.

\subsubsection{Lawyer Group}

Ding

"Time is needed to assess the effectiveness of the hold separate behavioural remedies," answered Ding, "but in my opinion, it can be problematic because it may lay too many burdens on the notifying parties." 1515

According to Ding's experience, MOFCOM is unlikely to regard the use of hold separate provisions as behavioural remedies as an optimal choice. It is very likely that it is the lawyers who suggest their clients propose such a remedy, given that lawyers can be incentivised to get the transactions approved without involving divestitures. When the notified transaction is regarded as anti-competitive and thus a merger remedy is required by MOFCOM, the notifying parties should take the initiative to propose their remedy plan. Generally, the merging parties do not favour divestitures. Thus, as a lawyer, he has to help his client to propose a remedy which is acceptable to both the merging parties and MOFCOM. A hold separate remedy can thus be the mutually acceptable result.

The hold separate remedies may lay too many burdens on the notifying parties because the merged firms have to operate certain businesses separately even after the completion of mergers. Therefore, Ding believed that the hold separate remedies can be used less frequently in the future given that, on the one hand, the merged firms may realise the possibly huge burden resulted from the remedy and thus avoid proposing it in the first place; on the other hand, MOFCOM will not impose such remedies on the notifying parties if such remedies are not first proposed by the notifying parties.

\footnotetext{
1513 Such as: MediaTek/Mstar (n 1390), Marubeni/Gavilon (n 1390), Western Digital/Hitachi Vivit (n 1390) and Seagate/Samsung HDD (n 1406). For the detailed exploration of MOFCOM's practice of using hold separate provisions as behavioural remedies, see: sec.3.1.1 in Chapter 11.

1514 See: Thermo Fisher/Life Tech (n 1383). For a detailed exploration, see: sec.3.1.2. in Chapter 11.

1515 Ding (n 1470).
} 
$X u$

$\mathrm{Xu}$ considered that every coin has two sides and this is also true of China's diverse forms of behavioural remedies. ${ }^{1516}$ Compared with the practice in other jurisdictions, some forms of behavioural remedies in China are quite different or unique. However, this can be regarded as the development of MOFCOM's enforcement, which should be encouraged. "In my opinion, a competition agency should be open and creative," said Xu. Be open and creative to some extent means the acceptance of various forms of merger remedies, as long as they can clear the possible anti-competitive effects. Xu argued that MOFCOM's open attitude toward non-traditional forms of behavioural remedies is welcoming. MOFCOM can conduct some market tests or consult with third parties to ensure that the proposed unique behavioural remedies are sufficient to clear competition concerns.

On the one hand, such diversity and flexibility of the behavioural remedies may to some degree reduce the predictability of MOFCOM's merger remedy policy in terms of there being no rule to be followed. On the other hand, the merging parties are also given more freedom in formulating their remedy proposal. They can propose any remedy and it is possible for MOFCOM to accept this as long as the remedy can eliminate potential anticompetitive effects.

Moreover, MOFCOM's willingness to accept behavioural remedies regardless the monitoring burden also reflects MOFCOM's high sense of responsibility.

\subsubsection{Scholar Group}

Wang

It is pointed out by Wang that no matter what form the merger remedy takes, the key is to ensure that the remedy follows the principle of proportionality and is used within a reasonable range. ${ }^{1517}$ Wang emphasised that remedies are basically an adjustment to the proposed transaction, through which the merging parties can implement their transactions on the one hand, and potential anti-competitive effects can be eliminated on the other hand.

There are also some behavioural remedies, which prevent the merging parties from business expansion within a certain period. Wang believed that the reason behind this could be MOFCOM's fear that competition can be harmed if the merged firm further expands its business.

Wang believed that the scientific creditability of MOFCOM's decisions has been increasing. More economic tools are used when MOFCOM assesses a merger before designing a remedy. A third party can also be invited to conduct relevant analyses. Decisions are also written in a more detailed way compared with those published around 2008. Accordingly, in general, MOFCOM has improved a lot.

$W$

W argued that the use of non-traditional behavioural remedies can be regarded as an innovation and reflects MOFCOM's open attitude toward merger remedies. ${ }^{1518}$ The design of the innovation can be various depending on the nature of the transactions. A remedy is acceptable to MOFCOM as long as it can clear the concerns.

\footnotetext{
$1516 \mathrm{Xu}(\mathrm{n}$ 1461).

1517 Wang (n 1474).

1518 W (n 1464).
} 
According to the merger control laws and policies in China, although MOFCOM can require the inclusion of merger remedies when reviewing a transaction, it is the notifying parties who should propose such a remedy plan. ${ }^{1519}$ MOFCOM should first indicate its competition concerns before requiring a merger remedy. Such concerns can also be raised by relevant parties, such as consumers or the non-merging competitors. Then the notifying parties can submit their remedy proposal to MOFCOM to indicate what they can do to clear MOFCOM's competition concerns. Negotiations will follow and the design of a remedy in most situations is the result of compromises. Therefore, behavioural remedies can be so diverse because a remedy will be acceptable by MOFCOM as long as it can clear its concerns, while such remedies are based on the merging parties' proposals.

Furthermore, W pointed out that the effectiveness of some unique behavioural remedies, such as the hold separate remedies, needs further assessments. Such assessment can be conducted by observing whether complaints are made to MOFCOM, complaining about the reduction of competition in the market concerned or impediments to consumer welfare. However, $\mathrm{W}$ also argued that the shortcoming of this assessment is that there may be malicious complaints from the peers of the merging parties.

\subsubsection{MOFCOM's Preference: Behavioural Remedies or Divestitures}

In contrast to the CAs' explicit preference for divestitures in the US and the EU, which can be observed from various policy guides or studies published by these CAs, MOFCOM's attitude is rather ambiguous. Observations obtained from the decisions in those published mergers indicate that behavioural remedies were used more frequently than divestitures in China. ${ }^{1520}$ To better understand MOFCOM's approach in merger remedies, all the respondents were asked the questions whether MOFCOM has any preference between behavioural remedies and divestitures, and what can be the reason for the prevalence of behavioural remedies.

\subsubsection{Lawyer Group}

The general answers from the respondents in the lawyer group can be summarised as follows. First, MOFCOM has no preference for either type of merger remedy. Second, one of the most important reasons why behavioural remedies are used more frequently than divestitures is that the merging parties are not willing to propose a divestiture remedy plan in the first place. Third, all the participants pointed out that the choice and design of merger remedies are the results of a compromise between MOFCOM and the merging parties.

$X u$

"I don't think MOFCOM has any preference," replied Xu, "from the perspective of postmerger monitoring costs, divestitures should be favoured by the CA. In some internal seminars, MOFCOM has indicated that structural remedies can reduce their burden and workload. The fact, however, is that, in practice, behavioural remedies are used more frequently than divestitures." 1521

$\mathrm{Xu}$ pointed out that the first possible reason for the prevalence of behavioural remedies is that the merging parties are not willing to propose a divestiture remedy when a merger remedy is required by MOFCOM. Most of the merging parties do not favour, some even

\footnotetext{
${ }^{1519}$ MOFCOM Provisions on Merger Remedies (n 1226) art. 5.

1520 See: Chapter 11, sec.3.3.

$1521 \mathrm{Xu}$ (n 1461).
} 
strongly refuse to propose divestitures, considering the extremely complex divestiture process and the difficulties of implementations. Besides, they may also think it is unjustified for them to use a divestiture since their transactions may not cause severe anti-competitive effects.

Second, a remedy can be required by MOFCOM in some cases because on the one hand, it is not justified to employ divestitures; on the other hand, MOFCOM may feel that the notified transactions cannot be approved directly without being remedied. Therefore, considering the merging parties' reluctance to use divestitures, a behavioural remedy can be a compromising result between the merging parties and MOFCOM.

Third, behavioural remedies can be used as a tool to address some non-competition issues. $\mathrm{Xu}$ indicated that this is one of the most discussed questions with regard to China's merger remedies practice. In some decisions, the remedies seemed to have little to do with the competition issues. In contrast, these remedies can be regarded as the implementations of some non-competition policies, such as the foreign investment policy or international trading policy. Xu emphasised that as she has said, a non-competition policy can be taken into account by MOFCOM when reviewing a merger.

Fourth, when a global transaction was reviewed by different CAs in several jurisdictions, including China, it was possible that a divestiture was included by the other CAs, while behavioural remedies were included in MOFCOM's decision. This is because the design of merger remedies can be determined by different competition situations.

When being asked whether the behavioural remedies will still be used more frequently than divestitures in the future, Xu replied that it is hard to predict. A merger remedy is the result of a balance among various factors.

Ding

Similar to Xu's answer, Ding believed that MOFCOM has no preference to any type of merger remedies and one of the reasons for the frequent use of behavioural remedies is the merging parties' reluctance to propose divestitures. ${ }^{1522}$

Ding argued that the merging parties prefer behavioural remedies to divestitures, given that the latter can be rather complex. For example, the merging parties have to find buyers and negotiate prices of the to-be-divested assets with the buyer. The behavioural remedy, by contrast, can be quite general or does not even require any change. For example, during the negotiation of a merger remedy, in order to address MOFCOM's competition concern of potential foreclosure effects, the merging parties may commit themselves to maintaining the price of certain upstream resources and continue to supply the downstream entities. In other words, the merging parties can possibly get their transaction approved by committing themselves to a remedy, under which MOFCOM requires nothing from the merging parties but to keep the current business.

Therefore, Ding was further asked why MOFCOM would be willing to accept the above-mentioned "keep the status quo" remedies, Ding replied that this may be caused by the fact that there are three CAs in China.

If there was only one competition agency, then merger review and investigations on post-merger anti-trust conducts would be easier since it was an internal allocation of authority between different sections. Information gathered from the merger review section can be easily transferred to other sections. However, the reality is that there are three different, parallel, and independent competition agencies in China. The relationship between these agencies can be quite subtle. A merged firm which is suspicious of raising

${ }^{1522}$ Ding (n 1470). 
unilateral anti-competitive effects may use MOFCOM's merger approval as a defence against NDRC's or SAIC's investigations and can claim that its conduct is compatible with competition law because the conduct results from MOFCOM-approved mergers. This can especially be true when NDRC and SAIC have limited information regarding the originally notified mergers. To avoid such a situation and to put an end to any potential future problem, MOFCOM thus accepts the merging parties' proposed maintain-the-status-quo remedies or remedies of no further expansion.

Ding thus concluded that it is very likely that the use of behavioural remedies in merger cases can continue to be more than the use of divestitures, as long as there are three CAs in China.

Yang

Yang also held the opinion that MOFCOM does not have any preference between behavioural remedies or divestitures. ${ }^{1523}$ She pointed out that MOFCOM is a resultoriented agency, meaning that a remedy can be accepted by MOFCOM as long as it can address its competition concerns and eliminates the potential anti-competitive effects.

She emphasised that the design of a merger remedy was the result of a mutual compromise between the merging parties and MOFCOM. An agreement regarding merger remedies has to be reached before the notified transaction gets approved if it is believed that a remedy is necessary. Otherwise, there can only be two results: MOFCOM prohibits the notified transactions, or the notifying parties withdraw the notifications before MOFCOM makes its final decisions to avoid the prohibition and very likely followed by a re-notification. Either prohibitions or re-filing is not the most welcoming results for both parties. Considering that the merging parties are reluctant to use divestitures, to avoid the above-mentioned results, a behavioural remedy can be the only choice.

Moreover, Yang emphasised that the use of merger remedies is determined by various factors, such as competition concerns, national conditions, and industry conditions. Thus, a global transaction may receive different merger remedies after being reviewed by the CAs in different jurisdictions. Yang concluded that although in China, behavioural remedies are used more frequently than divestitures, the choice of remedies should be made on a caseby-case basis.

\subsubsection{Scholar Group}

Wang

Wang explained that the reasons why MOFCOM may accept the merging parties' proposal of behavioural remedies can be complex. First, it is possible that MOFCOM may think that behavioural remedies are gentler than divestitures. If two remedies can have the same effect, then a gentle one may be preferred over the other.

Wang further pointed out that, however, the burden resulting from the implementation of behavioural remedies is still an important concern. Some behavioural remedies are in fact not as "gentle" as MOFCOM may assume. For example, the hold separate remedies can be problematically "harsh" because they may put too many burdens on the merged firms, be difficult to implement, and increase the merged firms' operation costs. Wang believed that the hold separate remedies are behavioural remedies but structural in nature. It seems difficult to understand why such remedies are used.

${ }^{1523}$ Yang (n 1459). 
Moreover, Wang made a bold guess that another reason why the behavioural remedies are used more frequently may be that sometimes MOFCOM simply thinks that a remedy should be needed to avoid an impression that it is quite easy for a transaction to get approved in China. In this situation, a behavioural remedy is just sufficient. The postmerger monitoring is thus naturally no longer necessary if this is the case.

Wang concluded that it is sometimes hard to understand MOFCOM's decisions due to limited information. MOFCOM should publish more information regarding how and why a remedy is used and what lessons it has learnt from its practice.

$W$

W pointed out that structural remedies were rarely used in China, whereas behavioural remedies are used more frequently. ${ }^{1524}$ There can be possible four reasons for this.

First, behavioural remedies were generally disfavoured by the CAs in Europe or in the US due to the possible costly long-term monitoring. Moreover, the CAs in these jurisdictions do not have many approaches to implement the monitoring. In contrast, in China, it can be comparatively easier for MOFCOM to monitor the merged firms and punish them without involving the courts if they are found failing to comply with the remedies

Second, from the perspective of the merging parties, they are reluctant to propose structural remedies because the implementation of structural remedies can be costly and result in large structural changes for the merged firms.

Third, compared with structural remedies, behavioural remedies are easier to accept. An agreement between the merging parties and MOFCOM regarding the behavioural remedy proposal is also easier to be reached.

Fourth, the monitoring costs in China are not as high as imagined because they are dispersed widely. First, the merged firms' competitors and the upstream/downstream firms are likely to monitor the merged firms' compliance with the remedies to ensure that their interest will not be harmed. Complaints can be made to MOFCOM if any non-compliance is found, possibly followed by MOFCOM's investigations. Second, behavioural remedies and the market are dynamic. After several years of implementation of certain behavioural remedies, the competition concerns can no longer exist, meaning that monitoring is no longer necessary. Therefore, high monitoring costs can just be a theoretical assumption and it is not true in the context of China.

$X u$

When being asked the question of why behavioural remedies are used more often than divestitures in China, which is in a sharp contrast with the practice in the EU or the US, Xu replied that she asked exactly the same question to Ming Shang, and the former DG General regarded such an approach as a new try. ${ }^{1525} \mathrm{Xu}$ argued that although China has learnt a lot from the practice of the CAs in the EU and the US, it still has its own approaches when implementing the AML, given that China has different and special national conditions in terms of the economy reform. First, China is a country with a vast territory. Despite this, the economic development in different regions is rather unbalanced. Third, China is experiencing a transition from a planned economy to a socialist market economy. Accordingly, compared with the EU and the US, a different approach toward merger remedies can be adopted.

$1524 \mathrm{~W}(\mathrm{n} 1464)$.

$1525 \mathrm{Xu}$ (n 1465). 
Second, the prevalence of divestitures or other structural remedies in the western countries may have its deep roots in the Structure-Conduct-Performance paradigm. Such analytical approach has a huge impact on the practice of merger remedies in the EU and the US. However, competition in China needs more behavioural adjustments rather than structured-oriented ones. What are the features of China's economic development? What is the goal of its economic development? What are the possible obstacles during the economic development? The answers to these questions should be taken into account when reviewing a merger and designing a remedy. At least what is known at present is that the obstacles which need to be overcome are not simply changing the structure of markets.

Third, the AML, as the core of competition law in China, has multi-dimensional objectives, namely, to protect fair competition in the market, enhance efficiency, maintain consumer welfare and the public interest, and promote a healthy development of the socialist market economy. ${ }^{1526} \mathrm{Xu}$ pointed out that China is still a developing country. When the western countries are discussing how to protect consumer welfare through merger control laws, China's merger control system is still attaching its attention on how to promote the development of the national economy.

These factors and reasons may to some extent reveal why China's approach in merger remedies is different from the EU's and the US's. Regarding the prevalence of behavioural remedies in China, Xu explained that most of the mergers that were notified to MOFCOM involve at least one Chinese firm. Meanwhile, China has the traditional culture of "harmony as the fundamentality". In the context of merger remedies, it means that if a behavioural remedy and a structural remedy can have the same effect, the behavioural remedy is likely to be used given its perceived features of gentler and less harm brought to the merging parties.

Next, China has its traditions as well as a system advantage of corporate surveillance, which resulted from the national planned economy. The Chinese government is good at monitoring corporate bodies through various methods. Comparatively, the western countries may not have such traditions.

Therefore, compared with the structural remedies, the behavioural remedies' preserved features as gentle and less harsh to the merging parties, as well as China's advantage in corporate surveillance lead to the prevalence of the behavioural remedies.

The following table summarises the possible reasons for the prevalence of behavioural remedies in China.

\subsubsection{Use of the Fix-It-First Remedies}

The fix-it-first remedies have been used in NXP/Freescale, in which the merging parties entered into a binding agreement with the buyer regarding the divestiture package and notified the proposed transaction to MOFCOM along with the agreement. ${ }^{1527}$ This is also the first case in which a fix-it-first remedy was used. Only the lawyer group was asked the question about whether and why such a remedy would be used more often in the future, given that practical experience is required to answer this question.

${ }_{1526}$ AML (n 42) art 1.

1527 NXP/Freescale (n 1390). 
Table 20 Possible Reasons for the Prevalence of Behavioural Remedies in China

\begin{tabular}{|c|c|}
\hline Opinions from Whom & Reasons \\
\hline \multicolumn{2}{|l|}{ Lanyer Group } \\
\hline Yang & $\begin{array}{l}\text { - MOFCOM has no preference } \\
\text { - A solution to avoid a prohibition or a re-notification } \\
\text { - China's special national conditions } \\
\text { - Result of mutual compromise }\end{array}$ \\
\hline Ding & $\begin{array}{l}\text { - MOFCOM has no preference } \\
\text { - The merging parties favour behavioural remedies } \\
\text { - Resulted from the fact that there are three CAs in China }\end{array}$ \\
\hline $\mathrm{Xu}$ & $\begin{array}{l}\text { - MOFCOM has no preference } \\
\text { - The merging parties do not favour divestitures } \\
\text { - Sometimes it is not justifiable to use divestitures } \\
\text { - Use behavioural remedies to address non-competition issues } \\
\text { - China's special national conditions }\end{array}$ \\
\hline \multicolumn{2}{|l|}{ Scholar Group } \\
\hline $\mathrm{W}$ & $\begin{array}{l}\text { - Easy to punish if the merging parties do not comply with the } \\
\text { behavioural remedies } \\
\text { - The merging parties prefer behavioural remedies } \\
\text { - The monitoring costs are not as high as assumed }\end{array}$ \\
\hline Wang & $\begin{array}{l}\text { - Behavioural remedies are regarded as more gentle than divestitures } \\
\text { and bring less harm to the merging parties } \\
\text { - Sometimes MOFCOM just feels that a remedy is necessary and a } \\
\text { divestiture is not justifiable }\end{array}$ \\
\hline$X u$ & $\begin{array}{l}\text { - China's special national conditions } \\
\text { - The AML has multitudes of goals } \\
\text { - China's traditional culture: harmony as fundamentality } \\
\text { - China has the tradition and advantage in corporate supervisions }\end{array}$ \\
\hline
\end{tabular}

\section{Ding}

According to Ding, the merging parties may consider proposing to divest their business when they believe that their transactions are very likely to raise MOFCOM's competition concerns. ${ }^{1528}$ Ding pointed out that the divestiture remedies can be taken into account in the early stage when the merging parties are designing the structure of their transactions. Normally the questions such as what to divest, to whom the business should be divested, and how to implement the divestitures have been discussed and settled before the merging parties make their notifications.

As pointed out before, Ding emphasised that the choice of merger remedies largely depends on what the merging parties propose. According to his observations, a global transaction is more likely to use the fix-it-first remedies because the domestic merging parties are more likely to get the transaction approved by proposing behavioural remedies or just by changing the targeted corporate to reduce merger review risks. However, if it is a global transaction, the merging parties have to consider the merger review situations in several jurisdictions and possibly consider a divestiture when they design the structure of the transaction.

Accordingly, Ding summarised that whether the fix-it-first remedies will be used in the future largely depends on whether this is proposed by the merging parties. Moreover, the merging parties who propose a global transaction are more likely to propose a fix-it-first remedy.

${ }^{1528}$ Ding (n 1470). 
Yang

Similar to Ding's opinion, Yang considered that generally, a fix-it-first remedy is more likely to be used by the merging parties to global transactions. ${ }^{1529}$ According to Yang, the fix-itfirst remedies are very high-level strategies. The merging parties have to design the transactions strategically.

Regarding MOFCOM's attitude toward the proposals of the fix-it-first remedies, Yang pointed out that it may be closely related to the AMB's internal evolutions. As she pointed out before, the pre-acceptance consultation office was abolished in September 2015, being replaced by the case teams. The case teams will be responsible for the notified transactions from the very beginning of the procedures. Under the previous working structure of the $\mathrm{AMB}$, the pre-acceptance consultation office, in general, would not conduct a substantive assessment. Considering that the evaluation of the appropriateness of a fix-it-first remedy requires substantive assessment of the notified transactions, a fix-it-first remedy was likely not to be considered. However, the above-mentioned reform within the AMB enables the case teams to start the substantive assessment much earlier than before. It thus makes it possible to consider the proposed the fix-it-first remedies at an earlier stage of the merger review procedures.

Yang further pointed out that MOFCOM will first assess the appropriateness of the fix-it-first remedies by itself. When necessary, it will also solicit opinions from third parties. It is hard to conclude what is MOFCOM's attitude to these remedies, but the reform of the AMB makes it possible for these remedies to be better assessed at an early stage.

$X u$

"In all the merger cases that I have dealt with, there is no single global transaction which was subject to divestitures only in China," answered Xu. ${ }^{1530} \mathrm{Xu}$ pointed out that it is difficult to predict whether the fix-it-first remedies will be used more often in the future due to the lack of clues. Generally, the merging parties are reluctant to propose divestitures, while divestiture can be preferred by the CA given that divestitures do not require longterm monitoring. In practice, if the merging parties of a global transaction are not required to divest by the CAs in other jurisdictions, it can be hard for them to accept a divestiture only in China.

Thus, $\mathrm{Xu}$ summarised that until now, there were some global cases in which divestitures were required by the CAs in foreign jurisdictions, while only behavioural remedies were included in MOFCOM's decision. However, there were no global cases in which, the merging parties were subject to a divestiture only in China.

\subsubsection{Potential Risks of Divestitures and the Effectiveness of Solutions}

A successful divestiture remedy requires, but is not limited to, a sufficient and appropriately-configured divestiture package, preservation of the to-be-divested assets' value during the interim period before a divestiture is completed, the availability of a suitable buyer, and the purchaser's viable competition with the merged firms after the transactions. Nevertheless, various risks, such as composition risks, assets risks, buyer risks and post-merger collusion risks can arise due to the inappropriate design in the abovementioned aspects, resulting from information asymmetry and collusion.

Theoretically, according to Part II, solutions, such as including an up-front buyer provision in divestiture agreements, can effectively reduce certain risks if designed cautiously.

${ }^{1529}$ Yang (n 1459).

${ }^{1530} \mathrm{Xu}(\mathrm{n}$ 1461). 
Chapter 11 has explored how MOFCOM deals with these risks. In order to find out whether asymmetric information or collusion exist, and whether the solutions used in these cases can reduce these risks, both groups of respondents were asked questions in this regard.

\subsubsection{Lawyer Group}

Ding

Ding argued that some information, such as the possible post-merger market shares are quite transparent between the merging parties and MOFCOM. ${ }^{1531}$ But asymmetric information still exists between the merging parties and MOFCOM in so far as the former can have private information regarding the proposed divestiture package; while the latter can have more knowledge about the whole competition situation in the market concerned. Both parties can have an information advantage concerning different aspects.

Accordingly, in the context of divestitures, to reduce the information asymmetry, MOFCOM will not only assess the proposed divestitures by itself, it will also consult with third parties, such as the non-merging competitors. Ding pointed out that MOFCOM generally does not care about the question of which side of the merging parties will divest the business. What MOFCOM cares about the most is the identity of the buyer and the buyer's ability to compete with the merged firms after the transaction to restore competition. Moreover, MOFCOM also relies on the buyer to determine whether the proposed divestiture package is sufficient.

Thus, by doing this, asymmetric information between MOFCOM and the merging parties is expected to be reduced.

$X u$

$\mathrm{Xu}$ judged that there does exist information asymmetry and collusion risks. ${ }^{1532}$ Information can be asymmetric between the merging parties and MOFCOM regarding the divestiture packages. Besides, it is possible that competition between the buyer and the merged firm was not as viable as expected.

When proposing a divestiture remedy, the merging parties will clearly point out what is included in the divestiture package. Then MOFCOM will evaluate the appropriateness of the divestiture package by consulting with, e.g. industry associations, scholars, or the third parties. Assessments will be conducted to verify the sufficiency of the divestiture package.

It is emphasised by $\mathrm{Xu}$ that the purchaser can also be rather helpful to determine the sufficiency of the divestiture packages. It is believed that almost all the potential purchasers will conduct a background research of the to-be-divested business and analyse the commercial value of the business. The potential purchaser will explain to MOFCOM what are the key assets and what else should be included in the divestiture packages.

Furthermore, when designing a divestiture, different strategies can be required by MOFCOM to ensure a successful implementation. For example, crown jewel provisions, up-front buyer provisions or the appointment of trustees. These strategies can reduce the information asymmetry and incentivise the purchaser to compete with the merged firms. However, $\mathrm{Xu}$ also pointed out that although these strategies can reduce potential risks, by now, they have not been frequently used by MOFCOM.

${ }^{1531} \operatorname{Ding}(\mathrm{n}$ 1470).

$1532 \mathrm{Xu}(\mathrm{n}$ 1461). 


\subsubsection{Scholar Group}

$W$

W's opinion was similar to the lawyer group's main opinion in the sense that, first, during merger review, there does exist information asymmetry between MOFCOM and the merging parties regarding, for example, the true value of the merging parties' proposed divestiture package; second, MOFCOM can use various methods to reduce such information asymmetry by soliciting opinions from the non-merging parties by holding hearings or conducting questionnaires. ${ }^{1533} \mathrm{~W}$ pointed out that the amount of the feedback to the questionnaires can to some extent reflect the likelihood of the notified transaction to cause competition problems. W explained that if there is a lot of feedback or complaints received from the non-merging parties, this implies that the notified transaction attracts wide attention and a detailed assessment will be necessary. In the contrast, limited feedback may suggest that the transaction may not bring severe competition problems.

W further pointed out that the use of risk-reducing provisions can reduce the potential risks arising during divestitures and can ensure a successful implementation of divestitures. Moreover, $\mathrm{W}$ added that a crown jewel provision can also be used in behavioural remedies to incentivise the merging parties to comply with their merger remedies.

When being asked whether and how MOFCOM takes strategies to prevent any postmerger collusion between the merged firms and the purchaser, W replied that according to the MOFCOM Provisions on Merger Remedies enacted in January 2015, there are relevant provisions which specifically deal with this problem. ${ }^{1534}$ Furthermore, regarding the use of these risk-reducing strategies, W summarised that, first, they can be used in both the divestitures and the behavioural remedies. Second, these strategies actually have been used even before the publication of the MOFCOM Provisions on Merger Remedies. In practice, MOFCOM will negotiate with the merging parties to find out a solution when it believes that risks may arise during the implementation of remedies.

$X u$

According to $\mathrm{Xu}$, she believed that it is true that there is information asymmetry between the CAs and the merging parties. ${ }^{1535}$ However, she further pointed out that the severity of the potential problem resulting from information asymmetry can depend on how hard the CAs and the merging parties try in order to obtain information.

$\mathrm{Xu}$ emphasised that from the perspective of the CAs, they may have limited information regarding the industry concerned, which may lead to difficulties for them to determine the sufficiency of the proposed divestitures. Nevertheless, they can make up for this by collecting information through various methods. It largely depends on the CAs itself to decide whether investigations are necessary, how much information they can obtain, or to what degree this information can be useful to reduce the information asymmetry.

The merging parties generally are more informed concerning, e.g. the notified transaction, the industry concerned, or the details of the proposed divestiture packages. However, Xu pointed out that there can be one-sidedness when the merging parties collect and analyse information, considering that they are generally profit-driven. In contrast, the CAs will analyse the information from a competition perspective. This is because what information one can get largely depends on what one wants. Put differently, the goals and incentives for one to

\footnotetext{
${ }^{1533} \mathrm{~W}(\mathrm{n}$ 1464).

1534 MOFCOM Provisions on Merger Remedies (n 1226).

${ }^{1535} \mathrm{Xu}$ (n 1465). Xu emphasised that considering her limited practical experience, her answers to these questions are mainly from the perspective of theory.
} 
collect information can have an impact on how the information is explained and used. The explanation of the information can be value-oriented depending on the goals and incentives behind it and sometimes can deviate from the truth. Therefore, information can be more asymmetric between parties due to their different explanation and use of information.

Moreover, $\mathrm{Xu}$ pointed out that the design of a divestiture should consider the possible deviations of goals between the CAs and the merging parties. For example, the merging parties can be more informed about the technical aspects of the business. By answering the question of why to divest, what to divest, who is the suitable buyer, and what should be the appropriate price, the merging parties are likely to design the divestiture in a way that they can benefit from. The CAs should be aware of the deviations. Although it is the merging parties who propose the divestiture plan in the first place, MOFCOM has to assess the appropriateness of the divestiture packages.

Regarding the use of risk-reducing provisions, such as up-front buyer provisions or the fix-it-first remedies, $\mathrm{Xu}$ believed that MOFCOM is result-oriented, meaning that it will spare no efforts to ensure that the merger remedies can successfully eliminate the anticompetitive effects.

\subsection{General Assessment and Suggestions}

It has been more than eight years since the AML entered into force in 2008. During the eight years, several provisions and guidelines have been published by MOFCOM to improve the merger review system. Does the merger review system in China work well? Is MOFCOM capable of dealing with complex transactions? Does MOFCOM follow up these conditionally-approved transactions to assess the effectiveness of the remedies? What needs to be further improved? The answers from the respondents may to some extent provide some clues.

\subsubsection{General Assessment}

\subsubsection{Lawyer Group}

Yang

When being asked whether MOFCOM follows up these conditionally-approved transactions, Yang replied that MOFCOM can directly or indirectly follow up these behavioural remedies by these trustees appointed in the cases that behavioural remedies are applied. 1536 Trustees have to report to MOFCOM regularly about the merged firms' compliance with their behavioural obligations. Besides, the merged firms have to submit applications to MOFCOM if they want to change or abolish their behavioural obligations. MOFCOM will then conduct investigations and assessments to ensure that the competition has been restored to the market concerned or the abolishment or change of certain behavioural obligations will not raise competition concerns.

However, Yang pointed out that it is not known whether MOFCOM has the resources and capability to conduct the assessment and investigations concerning the questions of whether those structural remedies fulfil the expected goal of restoring competition or to what degree these remedies restore competition. It is also not known by now whether MOFCOM has systematically conducted such assessments.

${ }^{1536}$ Yang (n 1459). 
In the US or the EU, divestitures are preferred by the CAs and studies have been done to evaluate the effectiveness of divestitures. In contrast, there is no such study in China. Yang emphasised that the market is dynamic, while the merger remedies are static. It can be really hard to control the future impact of the remedies even if one can predict some future developments.

$X u$

Xu believed that MOFCOM's ability to deal with complex transactions has improved in recent years. ${ }^{1537}$ She pointed out that the composition of senior officers within the AMB of MOFCOM is now comparatively stable. MOFCOM, in fact, has many contacts with those international economists, who can speak Chinese and are familiar with the national conditions of China. Thus, from this perspective, MOFCOM has rich resources, although it does not have its own economist team, implying that it cannot complete the economic analyses independently. This is also one of the differences between MOFCOM and other CAs, such as the FTC.

\subsubsection{Scholar Group}

$W$

W replied that he did not know exactly whether MOFCOM has ever followed up on these conditionally-approved transactions and assessed the effectiveness of the merger remedies. ${ }^{1538} \mathrm{He}$ believed that a merger remedy can be regarded as successful if no complaints are received after the completion of divestitures or during the implementation of the behavioural remedies.

$\mathrm{W}$ was asked the question of how to exactly determine the effectiveness of divestiture, considering that even if no complaints are received, it does not mean that the remedies are surely effective in restoring competition. He replied that the merging parties and the nonmerging competitors are in fact much more informed regarding the situation of the industry concerned. No further complaints received from the non-merging competitors after completion of divestiture implies that competition concerns are likely to have been addressed.

$X u$

$\mathrm{Xu}$ pointed out that the economic analysis is playing a more and more important role in MOFCOM's merger review. ${ }^{1539}$ Economic analyses will be used to analyse whether the notified transaction will result in unilateral or bilateral anticompetitive effects.

Although $\mathrm{Xu}$ did not know whether MOFCOM has a fixed economist team, she argued that there are several economists who are frequently invited by MOFCOM to conduct economic analyses. Further, it is emphasised that even an economic analysis can have a bias, resulting from different economic models employed. It is quite common and acceptable that different economists and agencies can reach different conclusions concerning the same transactions. Therefore, the CAs will determine which results of the economic analyses should be adopted by considering several factors, such as, the authenticity of the data used in the analyses, the authoritativeness of the agencies or economists who conducted the analyses, the degree of the reliability of the analysis. Xu said that the quality of the economic analyses is improving but still needs further improvements.

\footnotetext{
${ }^{1537} \mathrm{Xu}(\mathrm{n}$ 1461).

$1538 \mathrm{~W}$ (n 1464).

${ }^{1539} \mathrm{Xu}$ (n 1465).
} 
In addition, MOFCOM also cares about the reputation and the academic capability of the economists and appointed external consultants.

$\mathrm{Xu}$ suggested that although the economic analysis is important, in some situations, the CAs should not rely too much on it. For example, some transactions can cause competition concerns even according to the "common sense" and previous experience. For those cases, the CAs can just make their decisions without involving complicated economic analysis.

\subsubsection{Suggestions}

\subsubsection{Lawyer Group}

Ding

Generally speaking, Ding believed that MOFCOM has done satisfactorily. ${ }^{1540}$ It is making significantly progress these years and generally, these officers from MOFCOM are capable of dealing with complex merger cases. Ding argued that during the preparation period from 2006 to 2008 before the AML entered into force, MOFCOM has already had a better command of the competition law knowledge than the other two CAs. MOFCOM can conduct high-quality economic analyses and have a comprehensive understanding of some industries concerned.

The potential problem, however, is that, first, the structural remedies, especially divestitures, are not used frequently by MOFCOM, resulting in its limited experience in this regard. MOFCOM has to enrich its experience by applying more divestitures. Second, the hold separate remedy is a good example to show that although MOFCOM is trying to be open, it has to pay more attention to the details when designing a remedy, such as the strategies used in a remedy to assure a successful implementation, the change of the market which can influence the design of a remedy, the potential impact of the remedies on the merged firms, and the degree to which a transaction should be remedied. MOFCOM can thus improve its enforcement and increase the effectiveness of the remedies, taking into account these factors.

$X u$

"More communication, more transparency" answered Xu when being asked the question of what would be her suggestion for MOFCOM's future improvement. ${ }^{1541} \mathrm{Xu}$ explained that during merger review, it would be better if MOFCOM could communicate with the merging parties in a timely manner regarding the question of, e.g. MOFCOM's competition concerns, the complaints from the non-merging competitors, the main issues in the transactions, the economists that MOFCOM invited to conduct analyses, and the data that MOFCOM uses in its assessment. Sometimes, the merging parties are not well informed about the above-mentioned aspects given the need for confidentiality. Xu judged that although this problem is improving, further improvement is still needed.

Yang

Yang argued that there would be two aspects that she believed need to be improved, MOFCOM's decision process regarding a merger remedy and the enforcement of the remedies. ${ }^{1542}$

\footnotetext{
${ }^{1540}$ Ding (n 1470).

${ }^{1541} \mathrm{Xu}(\mathrm{n}$ 1461).

1542 Yang (n 1459).
} 
First, Yang pointed out that the design of the merger remedies depends on many factors, such as the results of the substantive assessment of the transaction, the features of the industry concerned, or the special competition conditions in China. It seems that the MOFOCM is now quite flexible in accepting some controversial remedies. Some forms of the behavioural remedies are quite controversial and rarely used in other jurisdictions, such as the hold separate behavioural remedies. The appropriateness of this remedy is debatable. It is understandable for such flexibility since the market is changing, the merger review system is evolving, and the forms of merger remedies are also developing. However, it would be better if MOFCOM's merger remedies decision process can be more transparent, so that the merging parties can stop guessing.

Second, market supervision is one of the most important aspects of MOFCOM's responsibilities, which can be quite time-consuming and require large resources. It is noteworthy that some merger remedies are supposed to be sufficient to restore competition, whereas the difficulties in implementation or the merging parties' incompliance can largely reduce the effectiveness of the remedies in restoring competition and realising the goals of merger review. Therefore, attention should also be attached to the needs of post-merger monitoring when designing a merger remedy.

\subsubsection{Scholar Group}

$X u$

In general, the merger review system in China is constantly being improved these years. ${ }^{1543}$ Some details of the system are also refined. "Problems, however, still exist", pointed out by $\mathrm{Xu}$, "for example, the sanctions for those fail-to-notify merging parties are too mild and the definition of the 'merging parties' is still ambiguous." Thus, some practical guidelines should be published. Further exploration regarding the connotation of "control" or "decisive influence" in determining whether a transaction should be notified to MOFCOM should also be made. Xu believed that some problems can be naturally solved with MOFCOM's accumulated experiences obtained from practice.

Moreover, $\mathrm{Xu}$ emphasised that communications are also very important during merger review. Communications are the important channel for information exchange and information collection. Thus, attention should be paid to ensure the reliability and authenticity of the information. This can be extremely important because China's integrity systems are evolving and in some cases still have to prove itself in the international arena.

$\mathrm{Xu}$ further argued that the monitoring system of the merger remedies should be improved. In China, structural remedies are used much less than behavioural remedies for some reasons. This means that a sound monitoring system is critical in assuring the realisation of the expected goals of behavioural remedies. Besides, such post-merger monitoring mechanisms can also be de-centralized by appointing agencies.

$W$

MOFCOM has formed its own policies when dealing with merger review, whereas these policies have not been published yet. ${ }^{1544}$ This is because MOFCOM is now focusing its attention on improving its performance in merger review, rather than on building a platform for more public participation.

$1543 \mathrm{Xu}$ (n 1465).

$1544 \mathrm{~W}$ (n 1464). 
Moreover, W added that the detailed procedural rules for those "simple cases" were absent and need further clarification. By now, only the standards to determine what is a simple case are published. Although in practice, MOFCOM has its own way in reviewing simple cases, which is known to those lawyers and scholars, others may find it difficult to find the relevant information. Accordingly, W suggested that publications of a policy guide or a study is quite necessary, in which MOFCOM can summarise what has been done in the regard of merger review, what are the key issues when reviewing a merger, what are the obstacles that can impede the effectiveness of merger review, and what are the suggestions for future improvements.

Wang

"Some foreign corporations and scholars may feel confused when they analyse some merger review decisions", answered Wang, "this may be because they are not familiar with China's competition situations in some industries." 1545 Wang pointed out that some markets concerned in China are unique and different compared with those in other counties. For example, in Nokia/Microsoft, the merging parties were permitted to proceed with the transaction subject to behavioural remedies, considering that China is the biggest Android-system cell phone producer, whereas the notified transaction was approved directly without being loaded with any remedies in other jurisdictions. ${ }^{1546}$ Thus, Wang suggested that a good understanding of China's competition and national conditions can be important to understand MOFCOM's decisions.

Wang pointed out that MOFCOM's decisions need to be more substantive and be written in a more detailed way. The published decisions were so terse that it can be difficult for one to fully understand the reasons and basis for the conclusions reached. Wang admitted that there were practical reasons for this, such as MOFCOM's limited manpower and limited resources. These reasons may also explain (if true) why MOFCOM does not follow up these conditionally-approved transactions.

\section{Conclusion}

In general, all the participants believe that the merger control system in China has developed fast during the past several years and MOFCOM is making progress to improve its performance in merger review. MOFCOM is a result-oriented competition agency, which focuses its attention on how to clear the competition issues through acceptable solutions. It also holds an open attitude toward the use of merger remedies.

This chapter provided the readers with some empirical insights of China's merger review and merger remedies through interviews with M\&A lawyers and competition law scholars. To further explore MOFCOM's practice, a more detailed analysis will be provided in the next chapter.

\footnotetext{
1545 Wang (n 1474).

1546 MOFCOM Public Notice 2014/24: Conditional Approval for the Notified Merger - Nokia/Microsoft (MOFCOM Decision) [8 April 2014] <http://fldj.mofcom.gov.cn/article/ztxx/201404/20140400542415.shtml> accessed 5 May 2017.
} 


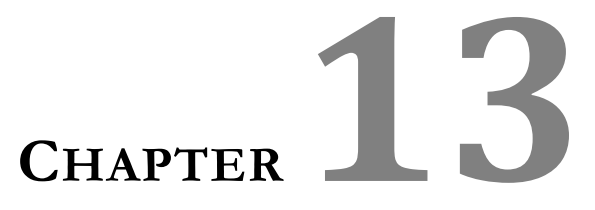

A COMPARATIVE LAW AND ECONOMICS ANALYSIS OF MERGER DIVESTITURES

IN CHINA 



\section{Introduction}

It was pointed out by Wang (2007) that China's Anti-Monopoly Law makes reference to other jurisdictions' legal and practical experience, especially from the US and the EU. ${ }^{1547}$ It is believed that legal transplants provide Chinese decision-makers with an easier and more efficient approach to build and refine China's competition law. ${ }^{1548}$ Nevertheless, whether the transplanted law and policies can lead to a satisfying result depends on various factors. One of the most important factors is whether such legal transplants can be recontextualised to adapt to the new environment.

In the US, it has been more than 125 years since the Sherman Act, the first federal competition law, was enacted in 1890. ${ }^{1549}$ The development and evolution of competition law in the US suggests its tradition of combating anti-competitive behaviour. Since the enactment of the Sherman Act, the scope of application of competition law has been enlarged and the system of merger control has been refined. Gerber pointed out that the concept of protecting competition was deeply rooted in the US culture and the process of competition is valued highly there. ${ }^{1550}$

The European Commission gained its authority to control mergers at the EU level for the first time from the Merger Regulation of 1989, which was revised and replaced by the Merger Regulation of 2004. ${ }^{1551}$ The emergence and development of competition law at the EU level imply that one of the missions that competition law is assigned with in Europe is to promote economic development in the EU by reducing barriers to trade and deepening the relationship of economic alliance between the Member States. ${ }^{1552}$

In general, China's development of competition law harmonises with the development of its economy. It has been observed and pointed out in Chapter 10 that China's determination of implementing economic reform from a centrally-planned economy into a social market economy provides a large impetus to the enforcement of competition law. ${ }^{1553}$ Its entry into the World Trade Organization ("W'TO") in 2001 also incentivised the publication of the AML. Thus, it is believed that China's competition law is assigned with the responsibility not only to protect competition, but also to promote the healthy development of the national economy. ${ }^{1554}$ This observation is also in accordance with Xu's opinions that the Chinese government has a determined mind to promote competition in the markets. ${ }^{1555}$

\footnotetext{
1547 Xiaoye Wang, 'Anti-Monopoly Law: A Milestone in China's Economic Reform (fan long duan fa— zhong guo jing ji ti zhi gai ge de li cheng bei 反垄断法——中国经济体制改革的里程碑)' (iolaw, 2 September 2007) <https://www.iolaw.org.cn/showArticle.aspx?id=2154> accessed 30 April 2017.

1548 See: Gerber (n 81) 315.

${ }^{1549}$ Dabbah (n 47) 238. For a detailed exploration of the history of competition law in the US, see: Chapter 2.

1550 Gerber (n 81) 321 .

15512004 EUMR (n 3).

1552 It is generally believed that the competition law at the EU level is assigned with a multitude of goals. For example, according to recital (6) of the 2004 EUMR (n 3), the 2004 EUMR is designed to promote market integration and to assure "an open market economy with free competition." For a brief review of the history of merger control at the EU level, see: Chapter 3, sec.2.1.

${ }^{1553}$ For a detailed exploration of China's development in competition law, see: Chapter 10. For the interaction and relationship between China's economic development and the development path of its competition law, see: for example, Wang (n 1204) 3; Xiaoye Wang, 'Anti-monopoly Law and China's Economic Reform', in The Evolution of China's Anti-Monopoly Law (Edward Elgar in association with the Social Sciences Academic Press 2014) 29.

1554 See: AML (n 42). This point is discussed in detail in sec.2.2.2. below. Actually the goals of the AML can have an impact on MOFCOM's merger review, namely, MOFCOM may consider the non-competition issues arising out of the proposed transactions. ${ }^{1555} \mathrm{Xu}(\mathrm{n}$ 1465). For the detailed opinions from Xu in this regard, see: Chapter 12, sec.3.1.2.
} 
In addition to different features and goals of competition law, different institutions are also adopted in the US, the EU, and China. The US is one of the typical examples that apply the judicial enforcement model in the anti-trust field because courts are the prime decision-makers. ${ }^{1556}$ In contrast, the administrative model is adopted by the EU. As the only competition agency that is responsible for reviewing merger notifications at the EU level, the European Commission has a multi-role as an investigator, prosecutor and decision-maker. ${ }^{1557}$

China adopts the administrative model. Wang has comprehensively analysed the reasons for this choice in one of her papers and the author's opinions can be summarised as follows: first, China's choice of the administrative model can be the result of China's management culture, namely, the government should take responsibility for competition law enforcement. ${ }^{1558} \mathrm{It}$ is hard for the law-maker to suddenly change the deep-rooted idea and assign the enforcement authority to the courts. Second, long before the enactment of the AML, these three CAs, NDRC, SAIC and MOFCOM, had obtained their enforcement authority to combat anti-trust conduct respectively from different competition law and provisions. ${ }^{1559}$ Although the AML is the first piece of law that systematically regulates antitrust behaviour, it has its origins from these said laws and provisions. It is almost impossible for the AML to totally change these rules in relation to depriving these competition agencies of anti-trust authorities and assigning the authority to the courts. Third, complex economic analysis and professional knowledge concerning certain industries will be involved during merger review. The fear that the courts in China may not be qualified to carry out complex merger review analyses also restricts the use of the judicial enforcement model. Gerber also indicated that US practice provides few lessons to China because China lacks competition culture and the US relies heavily on the judges. ${ }^{1560}$ Although there are three CAs in China, all of which act as investigators, prosecutors and judges, $\mathrm{Xu}$ believes that they are unlikely to pass the buck to each other. ${ }^{1561}$ Transferring cases within the CAs is possible if there are jurisdiction issues arising out of these cases.

Different development paths may lead to mixed features and goals and institutions of competition law. Furthermore, such differences are likely to further result in different merger policies. Thus, merger remedies, as an important aspect of merger review policies, naturally vary from one jurisdiction to another. Therefore, the remainder of this chapter is structured as follows to analyse and evaluate whether China's divestiture policies are adequate to reduce divestiture risks and realise the goals of competition law from a comparative law and economics perspective.

Sec. 2 presents a general comparison of merger control policies between the US, the EU and China from both procedural and substantive aspects. A comparative law and economics analysis is conducted in sec.3 to assess the effectiveness of China's merger remedies (mainly divestitures). In sec.4, an analysis of the reasons for the prevalence of behavioural remedies in China is made. Sec. 5 draws a conclusion.

\footnotetext{
${ }^{1556}$ For the detailed information in this regard, see: Chapter 2, sec.2.1 and sec.2.2.

${ }^{1557}$ For a detailed introduction on the competition agency in the EU, see: Chapter 3.

1558 Wang (n 64) 236.

${ }^{1559}$ For a detailed introduction in this regard, see: Chapter 10, sec.1 and sec.2.

1560 Gerber (n 81) 321.

${ }^{1561} \mathrm{Xu}$ (n 1465). See also: Chapter 12, sec.3.2.4.3.
} 


\section{Merger Control Policies in the US, the EU and China}

\subsection{Procedural Aspects}

In general, the merger review procedures in China are quite similar to those in the US and the EU in a sense that all these jurisdictions adopt a two-phase review framework with a mandatory pre-merger notification requirement if the notification thresholds are satisfied. Such procedures allow mergers which raise few competition concerns to be approved in the preliminary stages.

The time limit for the whole merger review is slightly different in these three jurisdictions. In China, the time limit is: $30 \mathrm{~d}+90 \mathrm{~d}+$ (potential extension of: $60 \mathrm{~d}$ ). ${ }^{1562} \mathrm{In}$ the EU, the time limit is: $25 \mathrm{~d}+$ (potential extension of: $10 \mathrm{~d})+90 \mathrm{~d}+$ (potential extension of: $20 \mathrm{~d}$ ). ${ }^{1563}$ In the US, the time limit is $30 \mathrm{~d}$ (in the case of a cash tender offer or a bankruptcy: 15d) $+30 \mathrm{~d}$ (in the case of a cash tender offer or a bankruptcy: 10d). ${ }^{1564}$ Hence, the US has the shortest time limit, while the time limit in China is the longest.

In practice, the vast majority of those conditionally-approved transactions were decided in stage II or during the extension of the in-depth investigations. ${ }^{1565}$ Moreover, there were six cases (by 20 June 2017) in which the notifications were withdrawn just before the expiration of the extension of the in-depth investigations to avoid prohibitions. ${ }^{1566}$ This means that the merging parties have to submit the notifications again to re-start the "clock". Interviewees believed that the protraction in merger review procedures can be caused by the following reasons: ${ }^{1567}$

- MOFCOM's limited manpower; ${ }^{1568}$

- The increasing numbers of the pre-merger notifications; ${ }^{1569}$

- The complexity of the notified transactions; ${ }^{1570}$

- Long waiting period before the pre-merger notifications were formally accepted by MOFCOM; ${ }^{1571}$

- Possibilities of the involvements of negotiations and discussions during the investigations of complex transactions for several rounds; ${ }^{1572}$

- MOFCOM's unfamiliarity with the industry concerned;1573

- The absence of the rules concerning "stopping the clock" in the AML;1574

- MOFCOM's lack of experience. ${ }^{1575}$

\footnotetext{
1562 AML (n 42) art 25 and art 26.

15632004 EUMR (n 3) art 10.

1564 FTC, 'Pre-merger Notification and the Merger Review Process' (Federal Trade Commission)

<https://www.ftc.gov/tips-advice/competition-guidance/guide-antitrust-laws/mergers/premerger-notification-

and-merger> accessed 6 May 2017.

1565 See: Chapter 11, sec.2.2, Table 15.

1566 See: (n 1390).

${ }^{1567}$ For the full results of interviews regarding this question, see: Chapter 11, sec.3.2.2.

${ }_{1568}$ Ding (n 1470); W (n 1464); Xu (n 1465).

${ }^{1569}$ Ding, ibid.

${ }^{1570}$ Ding (n 1470); Wang (n 1474).

1571 Yang (n 1459); Xu (n 1461).

1572 Yang, ibid; Xu, ibid.

1573 Wang (n 1474)

1574 Wang (n 1474); Xu (n 1465).

${ }^{1575} \mathrm{Xu}$ (n 1465). For the full interview results, see: Chapter 12, sec.3.2.2.
} 
The good news is that the time limit for China's merger control has been shortening since 2015 according to one of MOFCOM's Press Conferences. ${ }^{1576}$ One of the significant changes which contribute to the shortened time limit is the abolishment of the preacceptance consultation office within the AMB. ${ }^{1577}$

Figure 21 Merger Review Process of the AMB of MOFCOM

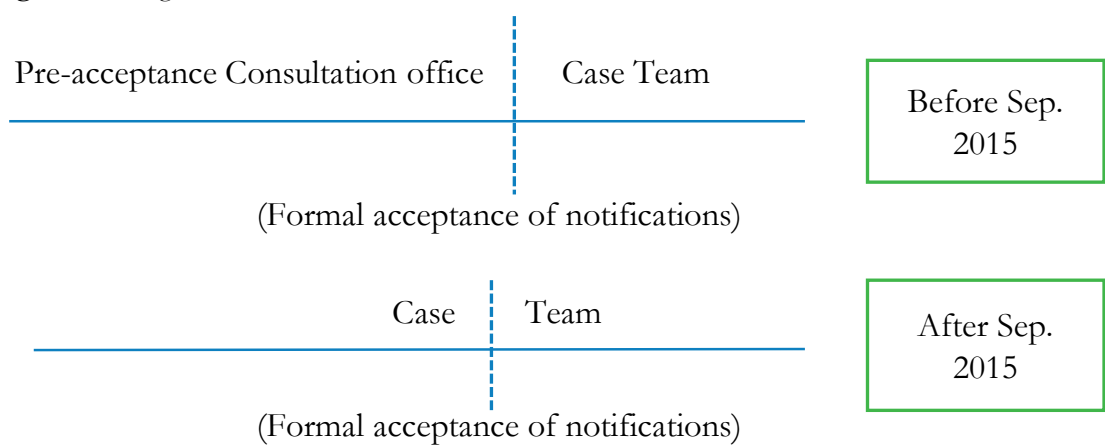

(The abolishment of pre-acceptance consultation office in September 2015 streamlines the merger review process and avoids repeated work. ${ }^{1578}$ )

As pointed out in Chapter 12, some interviewees noted that besides the abolishment of the pre-acceptance consultation office, other factors and changes, such as, the enactment of the MOFCOM Provisions of Simple Cases in 2015, ${ }^{1579}$ the AMB's feature of less hierarchical bureaucracy, ${ }^{1580}$ the use of an electronic notification form, ${ }^{1581}$ and the AMB's trial to divide case teams based on different expertise and industry concerned ${ }^{1582}$, also further shorten the time limit of China's merger control. It is reasonable to expect that transactions raising few competition concerns can be decided within a shorter period. Meanwhile, the average time limit will be also shortened in general.

\subsection{Substantive Aspect}

\subsubsection{Substantive Test}

The substantive test of merger review in the AML is called the EERC test, namely, whether the merger will or may have the Effects of Eliminating or Restricting Competition. ${ }^{1583}$ The substantive tests in the US and the EU are, respectively, the SLC test (Substantially Lessen Competition) ${ }^{1584}$ and the SIEC test (Significantly Impede Effective Competition) ${ }^{1585}$. It is believed that these tests are in general similar in the sense that they all focus on assessing

\footnotetext{
1576 See: MOFCOM (n 1280).

1577 Yang (n 1459); Xu (n 1461); Xu (n 1465).

1578 See: Chapter 12, sec.3.2.2.1. for a detailed introduction of these changes.

${ }^{1579} \mathrm{Xu}$ (n 1465); Wang (n 1474); W(n 1568); Ding (n 1470); Yang (n 1459); Xu (n 1461).

${ }^{1580}$ Ding (n 1470).

${ }^{1581}$ Ding (n 1470).

1582 Yang (n 1459).

1583 AML ( $\mathrm{n} 42$ ), art 3 and art 28. For a detailed exploration of China's substantive test of merger review under the AML, see: Chapter 10, sec.3.2.

1584 Sec.7 of the Clayton Act, 15. U.S.C. $\$ 18$ (2013).

15852004 EUMR (n 3) art 2.
} 
the potential anti-competitive effects of a merger. ${ }^{1586}$ One of the differences is: the US seems to lay more focus on defining "substantial lessening of competition", whereas the EU SIEC test pays more attention to the creation or strengthening of a dominant position that impedes competition. ${ }^{1587}$ From this perspective, the position of the EERC test is believed to be closer to the US SLC test. ${ }^{1588}$

Nevertheless, in contrast to the degree requirement in the SLC test ("substantively") or that in the SIEC test ("significantly"), such degree requirement is missing in the EERC test. Moreover, there are no other relevant rules and provisions in China which clarify such absence. Literally, such ambiguity may give rise to difficulties in determining whether an indepth investigation is necessary. It can also lead to the reduction of predictability of MOFCOM's merger review decisions. In practice, it is pointed out by those interviewees that MOFCOM will take a rather comprehensive consideration of all relevant factors before making any decision. ${ }^{1589}$ In fact, the absence of the degree requirement could be a special design rather than negligence (see sec.2.3 below).

MOFCOM's published conditional approvals indicate that a more economic approach is taken to increase the scientific credibility of the merger review. ${ }^{1590}$ This approach is also similar to that in the US and the EU. ${ }^{1591}$ Interviewees' opinions corroborate this observation. They noted that the economic analysis is playing an increasingly important role in MOFCOM's merger review. ${ }^{1592}$ Furthermore, they argued that during the merger review process, MOFCOM can solicit opinions and collect information by consulting with relevant third parties, such as, upstream/downstream competitors and consumers, or appointing external experts. ${ }^{1593}$

\subsubsection{Consideration of Non-Competition Policies}

$\mathrm{W}$, one of the interviewees, pointed out that those factors that are considered by MOFCOM during the substantive assessment of a merger can be divided into three categories: the general assessment test (the EERC test), other relevant factors, such as the possible impact on the development of the national economy, and different defences, e.g. efficiency defences. ${ }^{1594}$ The consideration of the possible impact on the national economy is believed to be the result of the goals of the AML, namely, inter alia, to promote a healthy development of the socialist market economy. ${ }^{1595}$ This is because China is a country with a vast territory, where the economic development in different regions varies considerably. ${ }^{1596}$ It is also a country which is experiencing the transition from a planned economy to a socialist market economy. Competition law, as one of the most typical economic laws, is naturally assigned with the responsibility to help to realise a successful transition.

\footnotetext{
${ }^{1586} \mathrm{~W}$ (n 1464); Ding (n 1470).

${ }^{1587}$ This has a close relevance to the development of the substantive test in the EU, namely, from a dominance test to an SIEC test. For a detailed explanation of this point, see Chapter 3, sec.3.2.

${ }_{1588}$ Shouzhi An, 'Convergence or Parallel Paths? Comparison of Substantive Tests of Merger Control in the EU and China' (2010) 31 ECLR 248, 253.

${ }^{1589}$ Ding (n 1470); Wang (n 1474).

${ }^{1590}$ Deng and Zhang (n 1380). See also Chapter 11, sec.2.1.2.

1591 The CAs in the US have the tradition of applying economic toolkits in merger review. In the EU, the EC's intention of employing a more economic approach is reflected in the change of substantive test from a "dominant test" to the SIEC test. See Chapter 3, sec.3.2.

1592 Xu (n 1461); Ding (n 1470); W (n 1568).

${ }^{1593} \mathrm{Xu}$ (n 1461); Ding (n 1470).

${ }^{1594} \mathrm{~W}$ (n 1464). See: AML (n 42) art 28 and MOFCOM Provisions on the Assessment of Mergers (n 1233) art 8 and art 9 .

1595 AML (n 42) art 1.

${ }^{1596} \mathrm{Xu}(\mathrm{n}$ 1465).
} 
Therefore, the AML has multi-dimensional objectives to protect fair competition in the market, enhance efficiency, maintain consumer welfare and the public interest, and promote a healthy development of the socialist market economy. ${ }^{1597}$ When formulating remedies, MOFCOM has to consider the realisation of the AML's multiple goals, resulting in its consideration of non-competition issues, such as industrial policy or the protection of the national economy.

Accordingly, it is possible that although a proposed merger may not significantly impede competition in the relevant market, it may have the likelihood of impeding the healthy development of the national economy. Such transaction might thus be blocked or approved with additional remedies (could be unnecessary from the competition perspective) in order to realise the goal.

Such an approach, however, is quite different from the US and the EU. According to the US Horizontal Merger Guidelines and the US Non-Horizontal Merger Guides which were jointly released by the DOJ and the FTC in 2010, the CAs will consider the following factors: market definition, market concentration, competitive effects, ease of entry and efficiencies. ${ }^{1598}$ In the EU, the following factors will be taken into account by the European Commission: market shares and concentration degree in the concerned industry, possible anti-competitive effects, countervailing buyer power, ease of market entry, efficiency defence and the failing firm defence. ${ }^{1599}$

According to several conditional approvals published by MOFCOM, during a merger review, the consideration of the post-merger impact on the national economy can take the form of considering non-competition policies, such as trade policies or industrial policy. For example, Glencore/Xstrata was a case which implied the consideration of trade policy. ${ }^{1600}$ Although Ming Shang, former Director General of the AMB, pointed out that MOFCOM would only consider competition policies during merger review, ${ }^{1601}$ most of the interviewees argued that non-competition policies are actually considered by MOFCOM. ${ }^{1602}$ They further explained that such consideration is reasonable and sometimes inevitable in the context of China because, first, MOFCOM used to be the Ministry of Foreign Trade and Economic Cooperation, suggesting that its perspective of assessing mergers may be influenced by its previous experience. ${ }^{1603}$ Second, consideration of trade policy is sometimes necessary because unbalanced trade to some extent indicates an imbalance in competition, and such unbalanced competition requires redress. ${ }^{1604}$ Third, some proposed mergers involve special industries which are subject to special industrial policies and laws, such as the mineral industry. ${ }^{1605}$

On the other hand, interviewees also emphasised and suggested that to realise other goals of the AML in addition to promoting a healthy development of the national economy, the quality of MOFCOM's economic analyses during merger review should be

\footnotetext{
1597 AML (n 42) art 1.

1598 See: 2010 US Horizontal Merger Guidelines (n 11). For detailed information regarding the consideration factors in the US merger review, see: Chapter 2, sec.3.2.

15992004 EC Horizontal Merger Guidelines (n 522). For detailed information regarding the consideration factors in the EU merger review, see: Chapter 3, sec.3.2.

${ }^{1600}$ Full text of this decision, see: Glencore/Xstrata (n 1390). For the detailed analysis of this case, see: Chapter 11, sec.2.2.

${ }^{1601}$ Ding (n 1470).

${ }_{1602} \mathrm{Xu}$ (n 1461); Wang (n 1474) W (n 1464); Xu (n 1465). For the full interview results regarding this question, see: Chapter 12, sec.3.2.3

$1603 \mathrm{~W}$ (n 1464).

${ }^{1604}$ Ding (n 1470).

1605 Wang (n 1474).
} 
enhanced to assure scientific reliability. ${ }^{1606}$ Furthermore, competition policy should be foremost among all the policies (such as industrial policy or trade policy), ${ }^{1607}$ and priority should be given to protecting consumers. ${ }^{1608}$ It may be noted that according to the State Council's very latest publication, competition policy has established its fundamental position among all the policies, such as industrial policies or trade policies. ${ }^{1609}$

\section{Merger Divestitures in China: a Comparative Law and Economics Analysis}

On the one hand, similarities and differences of merger control policies between the US, the EU and China may result from different development paths, goals, and institutions of competition law. On the other hand, such similarities and differences can further lead to similar or different merger remedies policies and practice among these three jurisdictions.

As a typical structural remedy, an effective divestiture requires a comprehensive consideration of several factors, such as, the sufficiency of the divested business, the preservation of the competitive capability of the to-be-divested assets during the interim period before the completion of divestitures, and possibility of viable competition between the merged firms and the purchasers after divestitures. Accordingly, the design of an effective divestiture can be highly strategic in order to avoid various potential risks. Moreover, the negotiations of divestitures can also be regarded as a process of third-party bargaining among the merging parties, the potential purchaser and the CA.

\subsection{Composition Risks}

\subsubsection{Application of Screening Theory in Merger Divestitures 1610}

A divestiture package with a too constrained scope or inappropriately configured assets may give rise to a composition risk, which can lead to the lack of a suitable purchaser or the divested assets being incapable of being operated successfully. ${ }^{1611}$ Ideally, such a risk will seldom occur if there is full information between the merging parties and the CA. Such full information, referring to all information that is necessary for an accurate assessment regarding the sufficiency of a proposed divestiture package, can be, e.g., the proposed divestiture package's market value, the key technology and the key personnel concerned in the divestiture package. After the merging parties propose the divestiture package, the CA will assess the sufficiency of the package based on this full information and finally decide whether to accept or reject such a proposal. However, the fact is that it can be difficult and rather costly for the CA to gain all the necessary information, suggesting that the CA is

\footnotetext{
${ }^{1606}$ Ding (n 1470).

1607 Wang (n 1474).

$1608 \mathrm{Xu}(\mathrm{n}$ 1465).

${ }^{1609}$ Recently, the State Council of China released "Opinions on the Censorship of Establishing Fair Competition in Building Market Economy”, which confirmed the fundamental position of competition policy. See: People's Daily, The Critical Step in Establishing the Fundamental Position of Competition Policy (que li jing zhen ce chu xing di wei de guan jian yi bu 确立竞争政策基础性地位的关键一步)(Central Government of P.R.C., 2016), <http://www.gov.cn/zhengce/2016-06/22/content_5084234.htm> accessed 25 April 2017.

1610 The section only serves as the brief summary of the application of information asymmetry and screening theory in the context of merger divestitures. For a more detailed exploration, see: Chapter 6.

${ }^{1611}$ UK Competition Guidelines (n 39) sec.3.3 (a).
} 
very likely to be the uninformed party, compared to the merging parties. ${ }^{1612}$ In this situation, the CA can have difficulties in determining the sufficiency of the proposed divestiture package.

Such (possible) asymmetric information between the merging parties and the CA, from the perspective of information asymmetry, is called bidden characteristics. It means in a relationship that there may be information that one side of a transaction knows about itself and which the other side would like to know but does not. ${ }^{1613}$ Screening devices can thus be used by the uninformed parties to screen the quality of the informed parties' offers to ensure that only desirable offers are accepted. In the context of merger divestitures, such screening devices can be risk-reducing provisions, including up-front buyer provisions or crown jewel provisions. ${ }^{1614}$ Figure 15 (adopted from Chapter 6) presents the application of screening theory in merger divestitures by using risk-reduction provisions as screening devices to reduce composition risks.

Figure 15 Screening Divestiture Packages by Risk-Reducing Provisions

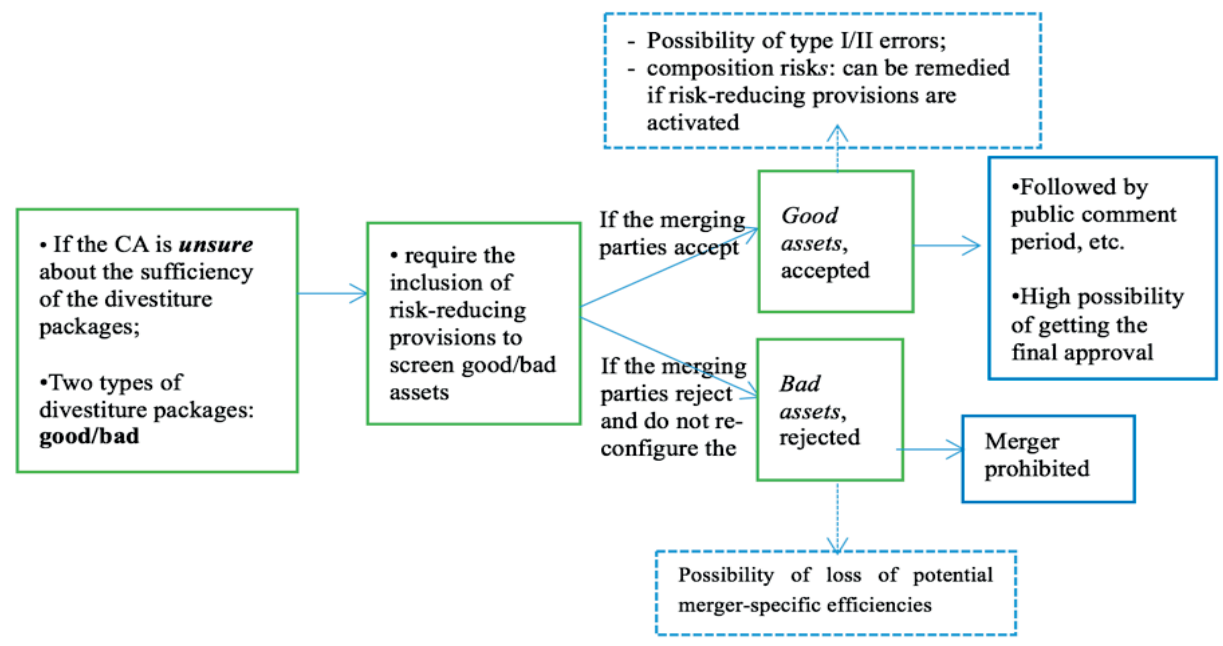

Figure 15 indicates that the CA can screen the quality of the merging parties' proposed divestiture packages by requiring the inclusion of one or more risk-reducing provision(s). The proposed package can be regarded as good (sufficient) assets if such provisions are included and thus are accepted by the CA; otherwise, the package will be rejected, probably followed by the CA's prohibitions if no further revisions are made to improve the originally

\footnotetext{
1612 It is worth pointing out that the CA may take various measures to obtain the unknown information by investigating or consulting with the third parties. However, information asymmetry can still exit. See: Chapter 6, Introduction.

1613 Katz and Rosen (n 891) 554.

1614 Risk-reducing provisions refer to provisions that can reduce various risks which could occur during the implementation of divestitures, such as up-front buyer provisions, crown jewel provisions, provisions of appointments of trustees, or hold-separate provisions. In the context of composition risks, risk-reducing provisions especially refer to up-front buyers and crown jewels.
} 
proposed packages. Screening a merger remedy proposal before it is accepted can be helpful to reduce the composition risks of divestitures. ${ }^{1615}$

It may be noted that using risk-reducing provisions as screening devices can only reduce composition risks, not eliminate them. It is possible that the merging parties behave opportunistically by accepting the CA's suggestion to include a risk-reducing provision, while their proposed divestiture package is actually inadequate. In this situation, composition risks can still exist. Nevertheless, the possible results caused by composition risks can be remedied when the included risk-reducing provisions are "activated", for example, the inadequate divestiture package can be improved once the merging parties have to divest their alternative packages with at least equal value to their original divestiture package once the crown jewel provisions are activated.

\subsubsection{US and EU Practice}

In the relevant merger divestiture policies in the US and the EU, the possible problems caused by insufficient divestiture packages have been recognised. For example, the 1999 Merger Divestiture Study published by the FTC states that the too limited scope of the divestiture packages is one of the obstacles to realising effective divestitures. ${ }^{1616}$ The DOJ's 2011 Merger Remedy Policy Guide reads that the scope of divestitures should have a clear identification of divestiture assets that are enough for the buyer to compete effectively in a timely fashion and over the long-term. ${ }^{1617}$ The European Commission has clearly stated in its 2005 EC Merger Remedies Study that the inadequate scope of the divested business was the most frequent among all design and/or implementation problems. ${ }^{1618}$ Accordingly, strategies have been adopted to assure the sufficiency of the to-be-divested assets so that composition risks can be reduced. Significantly, although there are differences in the use of risk-reducing provision between the FTC and the DOJ, it is observed that a convergence can be found. ${ }^{1619}$

\subsubsection{Crown Jewel Provisions}

A crown jewel provision is one of the most frequently mentioned risk-reducing provisions that can be used to reduce composition risks. The inclusion of a crown jewel provision means that the merging parties will have to divest assets which should be at least as good as the original divestiture package if they fail to divest the original divestiture package within a certain time span. Crown jewel provisions can, on the one hand, assure the sufficiency of a divestiture package by requiring the merging parties to divest an alternative package, and on the other hand, increase the likelihood of the availability of a qualified purchaser by increasing the attractiveness of the divestiture packages.

\footnotetext{
${ }^{1615}$ Even when a risk-reducing provision has been included, a type I/II error can still occur. A type I error (excessive divestitures) can arise when the merging parties are required to accept a risk-reducing provision, whereas their original proposed divestiture package is already sufficient to clear anti-competitive effects. A type II error (insufficient divestitures) can occur considering that a risk-reducing provision can only reduce composition risks rather than completely eliminating them. For a detailed analysis, see: Chapter 6, sec.4.3.3.2.

16161999 FTC Divestiture Study (n38) 16

16172011 DOJ Policy Guide (n 56) 7.

16182005 EC Merger Remedies Study (n 27) 23

${ }^{1619}$ For a detailed analysis regarding differences and similarities on merger divestitures policies between the FTC and the DOJ, see: Chapter 2, sec.6.2.2.2.
} 
US

The FTC pointed out that crown jewel provisions can incentivise the merging parties to propose a sufficient divestiture package to avoid divesting "crown jewel assets". ${ }^{1620}$ The FTC also states in the 2012 FTC Remedies Statement that the use of crown jewel provisions in the consent orders is necessary should the respondent fail to comply with the original divestiture in a timely manner. ${ }^{1621}$ For example, in the merger cases regarding Rhone-Poulenc S.A. ("RP") and Hoechst AG ("Hoechst") which formed a new company, "Aventis", a crown jewel provision was required by the FTC. ${ }^{1622}$

The DOJ has a changing attitude toward the use of crown jewel provisions. According to the 2004 DOJ Policy Guide, the DOJ explicitly and strongly disliked crown jewel provisions. ${ }^{1623}$ In contrast, the 2011 DOJ Policy Guide confirms the use of crown jewel provisions by stating that such provisions can increase the availability of a suitable buyer by ensuring the value of the divestiture package. ${ }^{1624}$

In general, the FTC uses crown jewel provisions more frequently than the DOJ. However, it is pointed out that the use of crown jewel provisions by the FTC may be on the decline. ${ }^{1625}$ The FTC is currently changing its preference to up-front buyer provisions and orders them more often than before. ${ }^{1626}$

\section{$E U$}

The use of crown jewel provisions has been introduced generally in the 2001 EC Merger Remedies Notice by stating that the merging parties have to divest an alternative divestiture package if they find it difficult to divest the original divestiture package "within an appropriately short time period." ${ }^{1627}$ Despite this, the 2005 EC Merger Remedies Study noted that crown jewel provisions were not used very frequently in the EU. ${ }^{1628}$ Later in the 2008 version of the Merger Remedies Notice, crown jewel provisions are introduced in a more detailed way and the requirements for an acceptable alternative divestiture package are set out as follows: it should have the viability (if being operated by a suitable buyer) that is at least as good as the original divestiture package, and; it should not involve any uncertainties during implementation and should be capable of being implemented quickly. ${ }^{1629}$

\subsubsection{Up-front Buyer Provisions}

Another risk-reducing provision which can reduce composition risks is an up-front buyer provision, meaning that the merging parties have to find a suitable purchaser and such a proposed buyer should be approved by the CA before their proposed mergers get

16201999 FTC Divestiture Study (n38) 30.

16212012 FTC Remedies Statement (n 36) 21.

${ }^{1622}$ Federal Trade Commission, 'Hoechst AG, No. C-3919, Order Reporting and Modifying Order' (22 November 2002) <http://www.ftc.gov/sites/default/files/documents/cases/2002/12/hoechsmod.htm> accessed 20 March 2017.

For an introduction to this case, see: Chapter 2, sec.6.2.2.3. For more information regarding the FTC's use of crown jewel provisions in practice, see: George S. Cary, 'Merger Remedies' (Federal Trade Commission, 10 April 1997) <https://www.ftc.gov/public-statements/1997/04/merger-remedies> accessed 7 May 2017.

16232004 DOJ Policy Guide (n 321) 37.

16242011 DOJ Policy Guide (n 56) 23. For more information regarding the FTC's and the DOJ's practice of crown jewel provisos, see: Chapter 2, sec.6.2.2.3.

1625 Byowitz \& Sherman (n 360) 27.

${ }^{1626}$ Katz and Perlgut (n 422) 78.

16272001 EC Remedies Notice (n 440) para. 22-23.

16282005 EC Merger Remedies Study (n 27) 52.

16292008 EC Remedies Notice (n 35) para. 45. 
approved. The merging parties can be incentivised to propose an adequate and attractive divestiture package so that they can find a qualified purchaser as soon as possible. In other words, up-front buyer provisions can also assure the availability of suitable buyers. Moreover, it can shorten the interim period during the implementation of divestitures, so that the risks of the divestiture package losing value during the interim period can be reduced (asset risks, see sec.3.2. below).

\section{US}

In the 2012 FTC Remedies Statement, it has been noted that 'the Commission will typically require an up-front buyer if the parties seek to divest assets comprising less than an autonomous, on-going business or if the to-be-divested assets are susceptible to deterioration pending divestiture'. ${ }^{1630}$ It was once pointed out by the FTC that it 'routinely consider[s] insisting on up-front buyers as a part of every settlement' for the reasons that, first, up-front buyers provide important indications for the FTC to assess the sufficiency of the proposed divestiture package (meaning that the FTC can be greatly convinced that the package is sufficient if a suitable purchaser is willing to purchase it); second, up-front buyers confer upon the FTC the chance to evaluate "the marketability of the divestiture package with more concrete evidence"; third, it allows a quicker divestiture by shortening the time the merging parties spend on seeking a buyer after their merger is approved. ${ }^{1631}$ Such as in Procter \& Gamble Company ("P\&G") and Gillette Company, Church \& Dwight was identified as an up-front buyer before the transaction's implementation. ${ }^{1632}$

In contrast, the DOJ has no preference for up-front buyer provisions. The 2004 DOJ Policy Guide did not mention the use of up-front buyers. The 2011 Policy Guide confirms the use of an up-front buyer provision by identifying several advantages: first, it can shorten the whole divestiture process, and thus provides more certainties about the transaction compared with searching for an acceptable buyer after the implementation of the merger. Second, such provisions can be cost-saving because they enable the DOJ to spend less time on investigating the notified transactions. ${ }^{1633}$ The DOJ has used up-front buyers more frequently than before as it is pointed out that since 2014, 'the DOJ has required up-front buyers in each of the five TV and radio station mergers that involved divestitures'. ${ }^{1634}$

It is believed that both the CAs are likely to scrutinise the proposed merger remedies carefully and up-front buyers have a high likelihood to continue to be used in the "foreseeable future".1635

\section{EU}

The 2008 EC Remedies Notice has stated that an up-front buyer can be considered in two situations: first, there are obstacles and uncertainties about the availability of qualified buyers; second, there is a risk that the value of the divestiture package can be reduced during the interim period before the completion of divestitures. ${ }^{1636}$ As explored in Chapter 3, although, in general, compared with the FTC and the DOJ, the EC uses up-front buyers

\footnotetext{
16302012 FTC Remedies Statement (n 36) 7.

1631 Gary (n 1622).

1632 See: FTC Docket No. C-4151, Procter \& Gamble and Gillette Company (FTC Letter Approving the Divestitures) [28 April 2006].

16332011 DOJ Policy Guide (n 56) 24.

1634 See: Luib (n 741). See: footnote 5 in Luib's article for these cases in which up-front buyer provisions are required by the DOJ.

1635 See: Luib (n 741).

16362008 EC Remedies Notice (n 35) para. 54 - 55.
} 
less frequently, it seems that the use of up-front buyers in the EU is a "rising tide" in 2016. ${ }^{1637}$

\subsubsection{MOFCOM Practice}

\subsubsection{Background1638}

The only effective document by April 2017 regarding China's merger remedy policies is the MOFCOM Provisions on Merger Remedies, which was enacted in January 2015 and replaced the Interim Provisions of Divestiture Remedies. ${ }^{1639}$ Risk-reducing provisions are introduced in the MOFCOM Provisions on Merger Remedies. Art. 7 reads, 'an alternative divestiture package (crown jewels) can be required to be included in the divestiture arrangement when there are difficulties in implementing the divestitures. The selection of the alternative divestiture package should be stricter than the original divestiture package's'. Art. 14 states that an up-front buyer can be required by MOFCOM if, a. there is a difficulty in preserving the marketability and the competitiveness of the to-be-divested assets can be reduced during the interim period; or, b. the identification of the purchaser can have a significant impact on a successful restoration of competition by operating the divested business viably; or, c. there is a third party that claims rights from the to-be-divested assets.

In practice, no up-front buyer has been required by MOFCOM, while the only case in which a crown jewel provision was included was Glencore/Xstrata. ${ }^{1640}$ To clear MOFCOM's competition concerns in the copper concentrate market, Glencore and Xstrata committed themselves to a divestiture remedy. Furthermore, a crown jewel provision was included and such a provision would be activated if the merging parties fail to find a suitable buyer and reach an agreement within the time frame set by MOFCOM or they fail to finish the divestment within a certain time limit. Once the provision was activated, the divestingtrustee would take charge of the divestment and be assigned with the authority to sell the divestiture packages with no lower limit of the price.

\subsubsection{Observations}

From the legal perspective, the wording and the approach that the MOFCOM Provisions on Merger Remedies adopts regarding crown jewels and up-front buyers are actually quite similar to the repealed 2001 EC Merger Remedies Notice, which was featured as simple and general. In other words, crown jewels and up-front buyers are introduced in a quite general way. Moreover, it could be even more difficult to figure out MOFCOM's divestitures policies considering that at present, no studies or analyses have been published by MOFCOM to explain how those risk-reducing provisions are used in practice.

Accordingly, although crown jewels have been introduced in Art. 7 of the MOFCOM Provisions on Merger Remedies, some issues need further clarification. These unsolved issues (see below), to some degree, reflect MOFCOM's limited knowledge and understanding regarding the importance of crown jewels in reducing composition risks.

\footnotetext{
1637 Competition Policy International (n 669).

${ }^{1638}$ For a detailed exploration of these risk-reducing provisions in China or MOFCOM's practice of using these risk-reducing provisions, see: Chapter 10, sec.4.2. and Chapter 11, respectively.

1639 MOFCOM Provisions on Merger Remedies (n 1226). These provisions replaced the 2010 MOFCOM Divestiture Provisions (n 1321).

${ }^{1640}$ Full text of this decision, see: Glencore/Xstrata (n 1390). For a detailed analysis of MOFCOM's decision of this case, see: Chapter 11, sec.3.2.3.
} 
- First, the meaning of "difficulties in implementing divestitures" is ambiguous. It is unclear whether it refers to those difficulties caused by an insufficient or an inappropriately configured divestiture package or by other factors such as the unavailability of a suitable buyer.

- Second, the rationale and incentives for MOFCOM to use crown jewels to solve the above-mentioned "difficulties in implementing divestitures" may require further explanation so that the merging parties can better understand MOFCOM's divestiture policies and practice.

- Third, the situations where the merging parties have to sell an alternative divestiture package according to the crown jewel provisions are unknown.

- Fourth, as mentioned, although it is stipulated that an alternative divestiture package will be selected more strictly, the practical approach to realise this stipulation remains unclear.

- Fifth, the standards for an acceptable alternative divestiture package are unclear.

The provision (Art. 14) of up-front buyers in the MOFCOM Provisions on Merger Remedies is to some extent more practical compared with the provision of crown jewels because at least Art. 14 clarifies the situations where an up-front buyer can be considered. Art. 14 implies that MOFCOM can use up-front buyer provisions to reduce asset risks and buyer risks (unavailability of a suitable buyer). However, the standards for MOFCOM to assess the suitability of the proposed up-front buyer are unclear.

As mentioned above, Glencore/Xstrata is the only case by April 2017 in which a crown jewel provision was included. Although the MOFCOM Provisions on Merger Remedies do not explain why and when a crown jewel provision can be included and be activated, Glencore/Xstrata indicated that such provision can be activated when there is a risk that a qualified buyer cannot be found or a risk that the merging parties may not manage to complete the divestitures on time, and such an approach is quite similar to US and EU practice in this regard.

\subsection{Asset Risks}

\subsubsection{Moral Hazard in Merger Divestitures 1641}

There is a risk that the competitive capability of a divestiture package can be diminished during the implementation of a divestiture ${ }^{1642}$ by the merging parties' intentional or unintentional undesirable behaviour. The merging parties may also have the incentives to intentionally reduce the competitiveness of the divestiture package so that the purchaser will not be transformed into a strong rival.

Asset risks can be largely reduced if the merging parties' undesirable behaviour is observed by the purchaser because, in such a situation, the purchaser will then restrain the merging parties from slacking off in operating the pending business by expressly writing down in the divestiture agreement that any dysfunctional behaviour will be penalised. Nevertheless, similar to the situation in composition risks, such full observation is almost impossible due to the possible requirements of enormous financial, manpower and material resources, which can be very costly. Furthermore, the result of the merging parties' shirking

1641 The section only serves as the brief summary of the application of information asymmetry and moral hazard in the context of merger divestitures. For a more detailed exploration, see: Chapter 7.

1642 UK Competition Guidelines (n 39) sec.3.3 (a). 
behaviour may appear after the completion of divestitures, suggesting the difficulty in observing during the interim period.

According to the law and economics theory of information asymmetry, the merging parties' unobservable behaviour is considered as bidden actions, meaning that actions are taken by one side of an economic relationship that the other side of the relationship cannot observe. ${ }^{1643}$ Hidden actions can further lead to moral hazard. It may occur when the informed party of an economic relationship takes actions which may increase the risks of loss that are borne by the other. ${ }^{1644}$ In the context of merger divestitures, a moral hazard situation can arise when the merging parties behave undesirably because it can be difficult for the purchaser (uninformed party) to observe how much effort or what actions the merging parties (informed party) take to preserve the viability and marketability of the divestiture packages during the interim period, whereas the actions the merging parties take will affect the benefits of the buyer. According to Kraakman and others, legal strategies can be used to reduce the moral hazard (in a principal-agent context).

Figure 17 Legal Strategies to Protect Principals ${ }^{1645}$

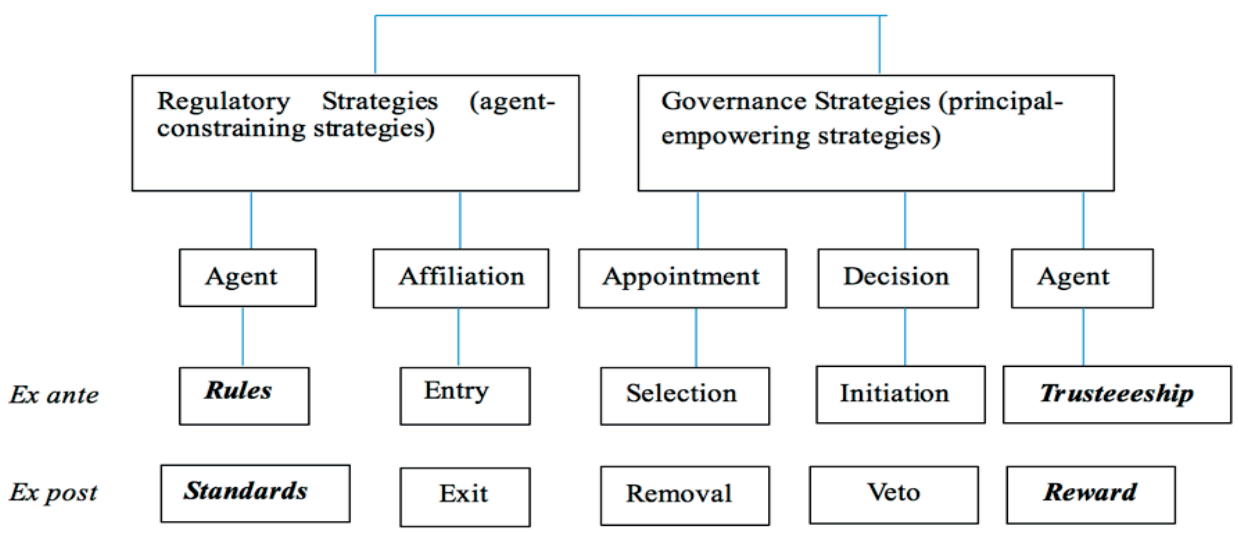

According to the analysis conducted in Chapter 7, agent-constraining strategies "rules and standards" and principal-empowering strategies "trusteeship and reward" can be used as solutions to reduce moral hazard in the context of merger divestitures. ${ }^{1646}$ Rules refer to specific constraints that are formulated by the lawmakers to require or prohibit certain agents' behaviour. Standards refer to a situation where only general requirements or criteria are formulated, while the adjudicators are assigned to determine whether such requirements

1643 Katz and Rosen (n 891) 554.

1644 See: Holmstrom (n 960).

1645 This figure is adapted from Kraakman and others (n 963) 39. See also: Chapter 7.

${ }^{1646}$ Kraakman and others analysed moral hazard in the context of the principal-agent relationships. The informed party is considered the agent, while the uninformed party is regarded as the principal. Therefore, in the context of divestitures, the merging parties are considered agent, and the purchaser is considered the principal. We may note that despite this, the CA, as the third party, can still use strategies to reduce the possibility of the merging parties' moral hazard because first, the CA is the public authority which is assigned the authority to control mergers. Second, it is possible that the notified merger and proposed divestiture plan have been approved by the CA before any formal divestiture agreement is reached between the merging parties and the buyer. This indicates that there will be a time gap after the approval is granted and before a divestiture agreement is reached. During this gap, a moral hazard problem can also occur. Thus, the CA has to use strategies to reduce asset risks during the time gap. Third, it is generally believed that the buyer shares the same goal with the CA in so far as they both want a successful divestiture. For a detailed explanation of this point, see: Chapter 7, sec.3.3. 
or standards are satisfied by the agents after they act. The reward strategy means that the agents will be rewarded if they successfully advance the interests of their principal. ${ }^{1647} \mathrm{~A}$ trusteeship strategy seeks to remove conflicts of interest ex ante so that no personal gains will be obtained if the agent does not serve his principal well. ${ }^{1648}$

Considering the effectiveness and feasibility, as well as the irreversibility of merger divestitures, rules and the trusteeship strategy can be more practical and easier to be applied, compared with the use of standard and reward. Standards can reduce asset risks by providing the CA with criteria to determine ex post whether the merging parties comply with their obligations. The problem of this strategy is that even if the CA improves its decisions expost according to the standards, it is not known whether the lost value caused by the lack of effort by the merging parties can be restored. The reward strategy aims at facilitating the buyer to control the merging parties' behaviour by providing them with monetary incentives expost. But it is difficult to ensure the effectiveness of the reward strategy since it has some important limitations.

\subsubsection{US and EU Practice}

As already pointed out, up-front buyer provisions can also to some extent reduce asset risks by shortening the divestiture process. Moreover, in practice, the use of the hold separate provisions provides the merging parties with "behavioural rules", which lay constraints on the merging parties ex ante. Trustees are appointed to further ensure the merging parties' compliance with their obligations by incentivising them to behave desirably.

\subsubsection{Hold Separate Provisions (HSPs)}

Once a hold separate provision is included, the merging parties have to operate the to-bedivested business separately until the completion of the transfer of this business. Such a provision can be regarded as the "behavioural rules", which can induce the merging parties to behave desirably and thus prevent asset risks ex ante. An HSP can preserve the competitiveness and viability of the divestiture package because a successful operation of the to-be-divested business separately during the interim period requires the continuing supply of all necessary resources. In other words, the merging parties can be incentivised to raise their efforts in keeping the pending assets viable and competitive in order to comply with their obligations

US

The FTC pointed out in the 1999 FTC Divestiture Study that the merging parties can sometimes behave strategically and impede the purchaser's success. ${ }^{1649}$ They can have adverse incentives to avoid making the purchaser into a strong rival. Accordingly, the Study concluded that the merging parties' adverse incentives should be taken into account during the divestiture process. ${ }^{1650}$ The 2012 FTC Remedies Statement emphasises that a hold separate provision will be required by the agency when there is a risk that the competitive capability of the pending divestiture package can be reduced during the interim period. ${ }^{1651}$ Furthermore, it states that an independent third party will be appointed when a hold

\footnotetext{
${ }^{1647}$ Kraakman and others (n 963) 42.

1648 ibid, 43.

16491999 FTC Divestiture Study (n38) 18.

1650 ibid, 19.

16512012 FTC Remedies Statement (n 36) 17.
} 
separate order is required by the agency to monitor the merging parties' compliance with the order. ${ }^{1652}$ Besides, some "benchmark" can be included in the HSP to measure the merging parties' compliance. For example, the merging parties may be required to submit plans "that describe previously anticipated or planned levels of spending". ${ }^{1653}$

The 2011 DOJ Policy Guide states that a hold separate provision and an asset preservation clause will be considered to maintain the competitiveness and independence of the divestiture package during the interim period before the completion of divestitures. ${ }^{1654}$ It is pointed out that it is very important to assure the "separate, distinct and saleable" aspects of the divestiture package. The HSPs can also be helpful in maintaining the effective competition in the market concerned before the completion of divestitures.

EU

The EC indicates in the 2008 EC Remedies Notice that it is the merging parties' responsibility to preserve the value of the divestiture package and protect it from any possible risk of loss of competitiveness before the completion of divestitures. ${ }^{1655}$ Therefore, HSPs can be included by the agency to ensure the divestiture package's "economic viability, marketability, competitiveness and independence" from the merging parties' retained business. ${ }^{1656}$ Moreover, the Notice states that an HSP manager with the necessary expertise will be appointed by the merging parties to take care of the management of the to-be-divested business and the implementation of "hold-separate and ring-fencing obligations". ${ }^{1657}$

\subsubsection{Trustees}

In the context of merger divestitures, the principal-empowering trusteeship strategy can alleviate asset risks resulting from moral hazard by monitoring the merging parties' behaviour to incentivise them to take appropriate actions. In practice, different trustees are appointed during the divestiture process to serve as the CAs' "ears and eyes" 1658 to oversee the merging parties' compliance with their obligations.

\section{US}

Based on the responsibility of a trustee, generally, there are two types of trustees that may be appointed by the FTC, divestiture trustees and monitoring trustees. A divestiture trustee is assigned with the responsibility to divest assets when the merging parties fail to divest assets as required by the FTC. ${ }^{1659}$ The responsibility of a monitoring trustee is to oversee the merging parties' conduct and to ensure that their conduct complies with their obligations under the consent order. ${ }^{1660} \mathrm{~A}$ monitoring trustee can be, for example, an auditor trustee or a hold separate trustee. ${ }^{1661}$ The merging parties' moral hazard can be

\footnotetext{
1652 ibid, 18 .

1653 ibid, 17.

16542011 DOJ Policy Guide (n 56) 25.

16552008 EC Remedies Notice (n 35) para. 108

1656 ibid, para. $109-110$.

1657 ibid, para. 109, 112.

16582012 FTC Remedies Statement (n 36) 18; 2008 EC Remedies Notice (n 35) para. 118

1659 See: FTC, 'Frequently Asked Questions About Merger Consent Order Provisions' (Federal Trade Commission,

2015) < https://www.ftc.gov/tips-advice/competition-guidance/guide-antitrust-laws/mergers/merger-faq

Trustee Provision> accessed 3 February 2017.

1660 ibid.

1661 ibid. See also: 2012 FTC Remedies Statement (n 36) 17.
} 
reduced by the appointment of a hold separate trustee, who will monitor the merging parties to assure that they do not behave strategically to undermine the competitive capability of the to-be-divested assets. In Glaxo/SmithKline Beecham, the FTC decided to approve the merger application subject to a condition that the parties had to divest pharmaceutical products in six markets. ${ }^{1662}$ Further, in this case, a hold separate provision was included and a hold separate monitor was also appointed. ${ }^{1663}$

The 2011 DOJ Policy Guide generally divides trustees into three categories, operating trustees, monitoring trustees, and selling trustees. ${ }^{1664}$ To prevent the merging parties from mismanaging the to-be-divested business which is incompatible with the requirements under the HSPs, an operating trustee can be appointed.

EU

Similar to the FTC's approach, the EC distinguishes two types of trustees: monitoring trustees and divestiture trustees. ${ }^{1665}$ The responsibilities of these trustees in the context of the EU are also similar to that in the US. Monitoring trustees' responsibilities to "oversee the safeguards for the business to be divested in the interim period" can reduce asset risks. It may be noted that in the US, these trustees are appointed by the CAs. ${ }^{1666}$ In contrast, both types of trustees in the EU should initially be proposed by the merging parties once the Commission has made its conditional approval decisions. ${ }^{1667}$ The proposed trustee will then be appointed by the merging parties based on the appointment mandate, after being assessed and approved by the Commission. ${ }^{1668}$

\subsection{3. $M O F C O M$ Practice}

\subsubsection{Backeground1669}

According to Art. 20 of the MOFCOM Provisions on Merger Remedies, to assure the viability, competitiveness and saleability, the merging parties have the responsibility to keep the to-be-divested business independent from their retained business and operate it in an appropriate way. Moreover, the merging parties are prohibited from any conduct which can have an adverse impact on the to-be-divested business. A hold separate manager can be appointed by the merging parties to operate the business under the supervision of a monitoring trustee.

MOFCOM's trustee policies are more similar tothe European Commission's from the perspectives of that, first, trustees are divided into two types, monitoring trustees and divestiture trustees; second, trustees should be proposed by the merging parties and appointed by them after approval by MOFCOM. ${ }^{1670}$ One of monitoring trustees'

\footnotetext{
1662 FTC Dockt. No. C-3990 Glaxo/SmithKline Beecham (FTC Decision and Order) [18 December 2000].

1663 See: ibid, Order to Maintain Assets; Trust Agreement.

1664 See: 2011 DOJ Policy Guide (n 56) 26-7. For a detailed exploration of these trustees of the DOJ, see: Chapter 2, sec.6.2.2.4; Chapter 7, sec.4.2.2.2.

16652008 EC Remedies Notice (n 35) para. 117-22. For a detailed exploration of these trustees in the EU, see: Chapter 3, sec.6.3.2.

1666 See: 2012 FTC Remedies Statement (n 36)17, 18; 2011 DOJ Policy Guide (n 56) 26, 27.

16672008 EC Remedies Notice (n 35) para. 123

1668 ibid, para. 124.

${ }^{1669}$ For a detailed exploration of the provisions regarding trustees in China or MOFCOM's practice of using these risk-reducing provisions, see, Chapter 10, sec.4.3. and Chapter 11, respectively.

${ }^{1670}$ MOFCOM Provisions on Merger Remedies (1226) art 18.
} 
responsibility is to oversee the merging parties' compliance with their obligations during the self-divesting period. ${ }^{1671}$

There were five cases in which the merging parties were required to maintain the to-bedivested assets. ${ }^{1672}$ Readers may note that only in Baxter/Gambro ${ }^{1673}$ and Thermo Fisher/Life Tech ${ }^{1674}$ did MOFCOM explicitly require the merging parties to operate the to-be-divested business separately. Hold separate managers were appointed in these two cases.

\subsubsection{Observations}

According to the analysis conducted in Chapter 7, HSPs and trustees can reduce asset risks by inducing the merging parties to behave desirably. HSPs provide the merging parties with behavioural rules, and meanwhile, trustees incentivise the merging parties to raise their efforts in operating the to-be-divested business appropriately to preserve its viability, saleability and competitiveness during the interim period.

From the legal perspective, Art. 20 of the MOFCOM Provisions on Merger Remedies is different from HSPs in the US and the EU because it is actually an asset-maintaining provision, under which the merging parties are generally required to keep the to-bedivested assets independent and preserve the value. Assets-maintaining provisions and HSPs are similar, but they are actually different. The former, as a general requirement, can be included in any divestiture remedy, while the latter is a very specific solution that can be considered when the CAs worry that the merging parties might behave undesirably, leading to a reduction in the value of the to-be-divested business during the interim period. More importantly, HSPs can preserve the competitive capability of the pending divestiture business because an HSP actually requires a continuing supply of all necessary resources. Nevertheless, assets-maintaining provisions do not suggest the inclusion of all these requirements.

In MOFCOM's practice, however, assets-maintaining provisions can also include a "hold separately requirement", meaning the merging parties can be required to maintain the assets by operating the business to be divested separately. As mentioned above, in the published six divestiture remedies, assets-maintaining provisions were included in five of them, while only in two cases were the merging parties required to maintain the business by holding it separately. Considering that all these five cases were horizontal mergers between foreign companies, it is not known whether the inclusion of an HSP rather than a general asset-maintaining provision is relavant to merger types. If MOFCOM cannot detect the right situation to require an HSP, then a general assets-maintaining provision may be inadequate to reduce the possible asset risks.

Whether the merging parties' moral hazard can be further reduced by a trustee who actually has a close link to the design of assets-maintaining provisions, is not clear. The effectiveness of a trustee in reducing asset risks is limited when a supposed-to-be included HSP is missing.

\footnotetext{
1671 ibid, art 21.

1672 Although there are 13 decisions which included divestitures, only seven divestiture remedies were published in detail. Among these seven published divestiture remedies, six cases included assets-maintaining provisions. They are: Dow/E. I. Du Pont (n 1390); Abbott/St. Jude Medical (n 1431); AB InBev/SABMiller (n 1431); NXP/Freescale (n 1390); Thermo Fisher/Life Tech (n 1383) and Baxter/Gambro (n 1431).

1673 Baxter/Gambro (n 1431).

1674 Thermo Fisher/Life Tech (n 1383).
} 


\subsection{Collusion Risks}

\subsubsection{Post-Divestitures: Collusion Risks}

A divestiture can restore competition by making an existing competitor stronger or by creating a new market entrant, so that they can compete with the merged firms viably after purchasing the divested assets. In other words, the ultimate aim of assuring an adequate divestiture package, searching for a qualified buyer or preserving the competitiveness of the pending business during the interim period is to ensure that the purchaser can operate the divested business successfully and compete with the merged firms viably. Such an expectation, however, can be frustrated if the purchaser colludes with the merged firms. This situation is called a collusion risk. Collusion here refers to these "agreements" (explicit or tacit), which enable the firms to realise anti-competitive goals, such as raise prices above the competitive level. Such "agreements", in general, include a mechanism of rewards and punishments that can facilitate the sustainability of such agreements. ${ }^{1675}$ Collusion risks in the context of merger divestitures refer to the situation where the merged firm and the purchaser of the divested assets have the tendency or incentives to collude rather than to compete to maximise their profits.

Generally, profit-seeking companies compete for economic reasons, which suggests that they may choose to collude with each other if collusion can bring them more benefits and profit. Collusion can be realised if, first, collusion can bring all the parties more benefits and profits than competition; second, the distribution of the cooperative surplus (additional profits obtained from collusion) is acceptable to all the parties; third, bargaining is efficient. 1676

Although after the completion of divestitures, collusion can occur between the merged firm and any remaining competitor in the market, collusion between the merged firm and the purchaser can be more likely to occur because divestitures can result in collusionfacilitating factors: symmetry, 1677 multi-market contacts, 1678 and continuing relationships. ${ }^{1679}$

According to the analysis in Chapter 8, to reduce collusion risks after the completion of divestitures between the merged firm and the purchaser, the following factors can be taken into consideration when designing a divestiture: ${ }^{1680}$

- First, consideration of post-divestiture effects, that is, what affects the divestiture will have on the structure of market if the divested business is purchased by the proposed purchaser.

- Second, evaluation of the purchaser' incentives, which can to some extent be reflected by the price negotiations between the merging parties and the purchaser.

- Third, the monitoring required when a continuing relationship is needed. Considering that avoiding a continuing relationship can be impossible due to the necessary of transitional support, a trustee can be appointed when a continuing

\footnotetext{
1675 Kuhn (n 1058) 107.

1676 See: Chapter 8, sec.3.

1677 Symmetry is a recognised collusion-facilitating factor. See: Motta (n 1070) 147. It means that firms in a similar position with similar resources are more likely to cooperate with each other to ameliorate their situations.

1678 See: Ivaldi and others (n 1068) 48. It refers to "the same firms meeting in more than one market". See also: Motta, ibid, 148.

${ }^{1679} \mathrm{It}$ is pointed out that cooperative agreements/continuing relationship can facilitate collusion. See: Ivaldi and others, ibid, 54. For a detailed exploration of how and why these factors can facilitate collusion, see: Chapter 8, sec.4.1.

${ }^{1680}$ For a detailed exploration of how and why these factors can facilitate collusion, see: Chapter 8, sec.4.2.
} 
relationship is needed to assure that there is no tacit agreement between the merged firm and the purchaser.

\subsubsection{US and EU Practice}

\subsubsection{US}

Both the FTC and the DOJ have recognised the possibility of a collusion risk and such awareness is reflected in their studies or policy guides. In these documents, the CAs analysed the reasons for collusion risks and proposed possible solutions.

FTC

The 1999 FTC Divestiture Study points out that the buyer's interests can be different from the FTC's. ${ }^{1681}$ According to the four cases introduced in the Study, the buyer's may lack incentives to compete with the merged firms. Accordingly, the FTC states that divestitures should be designed to ensure that the buyer of the divested assets should compete with the merged firm rather than cooperate or collude. ${ }^{1682}$

Similarly, the 2012 FTC Remedies Statement states that although it will mainly consider the information it gets from the buyer, the staff of the FTC will not rely on the buyer's information solely, considering that sometimes the buyer's interests and incentives are different from the FTC's objectives. ${ }^{1683}$ Furthermore, the FTC explicitly indicates that a continuing relationship can cause competitive issues and thus requires complex monitoring. ${ }^{1684}$ On the one hand, it confirms that sometimes a continuing relationship between the merged firm and the purchaser, such as transitional arrangements and services, is necessary after the completion of divestitures to help the purchaser better operate the purchased business. Such arrangement will especially be considered if the divested assets are not stand-alone and on-going. ${ }^{1685}$ On the other hand, it argues that it will attempt to avoid transitional services to the extent possible to ensure that a continuing relationship will not be developed. If such post-divestment supports are inevitable, the staff of the FTC will at least seek to shorten the duration of these agreements and may require independent monitoring. 1686 The 2012 FTC Remedies Statement also emphasises that a qualified purchaser should be competitively and financially viable to compete with the merged firms. ${ }^{1687}$

DOJ

The DOJ has also been aware of the post-divestiture collusion risks by first indicating that a successful divestiture (in the sense of preserving competition in the market) requires appropriate divested business and the purchaser's adequate incentives to compete. ${ }^{1688}$

Second, it argues that when assessing the suitability of a purchaser, the purchaser itself must not cause additional competition harm. ${ }^{1689} \mathrm{~A}$ joint dominance can be a concern if the merged firm and the purchaser are evenly matched and both enjoy great market power in

\footnotetext{
16811999 FTC Divestiture Study (n 38) 26.

1682 ibid, 27.

16832012 FTC Remedies Statement (n 36) 13.

1684 ibid, 9.

1685 ibid, 16.

1686 ibid, 9.

$1687 \mathrm{ibid}, 10$.

16882011 DOJ Policy Guide (n 56) 7.

$1689 \mathrm{ibid}, 28$.
} 
the market concerned. Divesting the business to such a purchaser can lead to collusionfacilitating symmetry. In addition, the DOJ notes that a new market entrant may be chosen as a purchaser to make it as a maverick because it believes that harmful collusion can be caused if a merger leads to the loss of a maverick. ${ }^{1690}$

Third, the DOJ emphasises that a suitable purchaser should have the incentives to compete with the merged firm. It points out that the seller can sell its assets to a weak buyer by sacrificing a higher price to ensure that the purchaser will not become a strong rival. Moreover, a firm with strong incentives to compete will be willing to accept higher prices.

\subsubsection{2. $E U$}

The 2008 EC Remedies Notice states that a qualified purchaser should be independent of the seller and have the financial resources, expertise, incentives and ability to operate the purchased business to participate in the competition with the merged firm and other competitors in the market. ${ }^{1691}$ Except this, there are no direct statements that are exactly related to collusion risks in the context of the merger divestiture remedy.

In the 2005 EC Merger Remedies Study, the Commission first specifies that the purchaser may lack incentives to compete with the merged firm, which may result in an ineffective divestiture. ${ }^{1692}$ Similar to the 1999 FTC Divestiture Study, the Commission presents several cases in which that those purchasers stopped operating the purchased business, quickly resold the business, or operated the business half-heartedly. Thus, to raise the purchasers' incentives to manage and operate the purchased business viably, the 2005 EC Merger Remedies Study suggests that a business plan explaining how the purchaser would operate the divested business should be submitted to the Commission after its successful purchase. ${ }^{1693}$ It also mentions that in some cases, a smaller new market entrant may be favoured as the purchaser because they were more aggressive than those large established companies to operate and develop the product to compete. ${ }^{1694}$

Second, the 2005 EC Merger Remedies Study identifies that the independence of a purchaser can be important to realise the effectiveness of divestitures. ${ }^{1695}$ Transactional agreements can reduce the purchasers' independence because those agreements can lead to a continuing relationship between the seller and the purchaser.

Third, it is pointed out that a purchaser should not cause new competition concerns. ${ }^{1696}$ This can be understood from two perspectives. First, a purchaser which is believed to be suitable from the Commission's viewpoint may cause competition concerns at the national level. Second, as mentioned above, sometimes a small player will be chosen not only because of its stronger incentives to operate and develop the business in the competition, but also because divesting the merging parties' business to such a purchaser is unlikely to cause joint dominance or confer upon the purchaser a position similar to the merged firm's.

\footnotetext{
16902012 FTC Remedies Statement (n 36) footnote 54, 28.

16912008 EC Remedies Notice (n 35) para. 48.

16922005 EC Merger Remedies Study (n 27) 102.

1693 ibid, 104.

1694 ibid, 104.

1695 ibid, 105.

1696 ibid, 106.
} 


\subsubsection{MOFCOM Practice}

\subsubsection{Background}

Regarding collusion risks, Art. 11 of the MOFCOM Provisions on Merger Remedies stipulates that a suitable buyer should have the necessary resources, ability and incentives to join the competition by operating the divested business. Art. 12 regulates that any agreement between the seller and the purchaser, such as a sale agreement and transitional agreement, should not contain any clause that is inconsistent with MOFCOM's decisions.

According to the case analyses in Chapter 11, MOFCOM has explicitly listed the requirements for a qualified buyer in three out of six published divestiture remedies (the other three involved the fix-it-first remedies), namely, Glencore/Xstrata, Baxter/Gambro, and Thermo Fisher/Life Tech. Briefly speaking, a qualified purchaser should at least have the incentives to compete and will not cause significant competition concerns.

Transitional agreements were included in two divestiture remedies, Baxter/Gambro and Abbott/St. Jude Medical. Note that insulation provision and non-inducing employment provision were further included in Baxter/Gambro to prevent any future connection between the merged firm and the purchaser after the completion of divestitures. ${ }^{1697}$

\subsubsection{Observations}

From the legal perspective, Art.11 of the MOFCOM Provisions on Merger Remedies specifies the requirements for an acceptable buyer, namely, it should have the incentives to compete with the merged firm and other players in the market. Except this, there is no further guide or provision to explain or regulate how such incentives can be measured. According to the US and EU approach, however, such incentives, to some extent, can be reflected by the price negotiations between seller and buyer, the buyer's business plan for the divested business, or other substantive methods.

MOFCOM generally states that transitional agreements between the seller and the buyer should be consistent with MOFCOM's decisions in Art. 12 of the MOFCOM Provisions on Merger Remedies, implying that transitional agreements or other similar agreements are allowed by MOFCOM as long as they are compatible with MOFCOM's decisions. However, such a provision can be inadequate. According to the analysis in Chapter 8, those transitional agreements may gradually develop into a continuing relationship between the merged firm and the purchaser, whereas such a relationship can confer on them the opportunity to cooperate (collude). Accordingly, to avoid collusion risk, such agreements should be limited. Moreover, as mentioned above, trustees can be appointed to monitor the merging parties' compliance if such agreements are included.

There is no provision in China which considers the post-divestiture effects. Consideration of post-divestiture effects requires a sophisticated scrutiny about the identification of the purchaser to avoid the creation of collusion-facilitating factors such as symmetry or multi-market contracts. Negligence of this consideration during the design of divestitures may result in additional competition concerns after the completion of divestitures.

From the practical perspectives, first, in some cases, MOFCOM has mentioned that the purchaser should have the incentives to compete with merged firms and other competitors in some cases. These cases, nevertheless, did not provide any clue about how MOFCOM determines such incentives.

${ }^{1697}$ For a detailed analysis of this case, see: Chapter 11, sec.3.2.5. 
Second, it is true that transitional agreements are sometimes important to assure a smooth transfer of the divested business from the merged firm to the buyer so that the buyer can operate the divested business viably. Baxter/Gambro indicated that in practice, MOFCOM may include an insulation provision and a non-inducing employment provision to ensure that the merged firm and the purchaser will not have connections after the completion of divestitures. This actually can be quite helpful to reduce collusion risks by depriving both parties of the opportunity to communicate or exchange commercially sensitive information. It could be better if monitoring can be included to oversee both parties' compliance with these two provisions after the completion of divestitures. A monitoring mechanism can increase the certainties of reducing collusion risks.

Third, although the MOFCOM Provisions on Merger Remedies do not mention a word on the consideration of post-divestiture effects, it is good to see that MOFCOM in practice pointed out that a suitable purchaser should not cause additional significant competition concerns. This approach is actually similar to that in the US and the EU. Nevertheless, there are some issues which require further clarification. First, according to the analyses in Chapter 8, considering the likelihood of additional competition concerns is only one aspect in reducing post-divestiture collusion. More importantly, collusionfacilitating factors such as symmetry and multi-market contracts should also be taken into account when designing a divestiture. ${ }^{1698}$ Second, such stipulation can be obscure from the perspective that on the one hand, a purchaser can be acceptable by MOFCOM as long as the choice of such a purchaser will not cause significant competition concerns; on the other hand, there is even no explicit "degree requirement" in China's EERC test. ${ }^{1699}$ The interpretation of "significant" in practice will have an important impact on the determination of the suitability of a purchaser, whereas MOFCOM does not provide any explanation in this regard.

\subsection{Use of the Fix-It-First Remedies}

As the name suggests, a fix-it-first divestiture remedy means that the merging parties voluntarily submit a divestiture remedy to the CAs before they make their final decisions. Although compared with those provisions (strategies) mentioned above, a fix-it-first remedy is not a strategy that can be used by the CAs, it can still reduce asset risks by shortening the time spent on searching for a qualified buyer (this means that the whole interim period will be shortened).

Generally speaking, a fix-it-first provision is frequently used by the DOJ in a consent agreement. In contrast to the DOJ's willingness to employ the fix-it-first remedies, the FTC has no formal policy on it. ${ }^{1700}$ The FTC has stated that it will not entertain a "fix-it-first" proposal and historically has not favoured the use. ${ }^{1701}$ However, in recent years, the FTC's attitude toward the acceptance of the fix-it-first remedies is changing. The FTC for the first

\footnotetext{
1698 This is also the problem that the US and the EU have. See: Chapter 8, Conclusion.

1699 According to the AML (n 42) art 3, art 28, the substantive test applied in China's merger control laws is: whether the merger will or may have the Effect of Eliminating or Restricting Competition (EERC test). However, the requirement of "degree" is absent, namely, it is unclear if a notified merger will be prohibited when it has or may have the effect of significantly eliminating or restricting competition, or when it has or may have the effect of leading to any elimination or restriction of competition. For a detailed exploration regarding this question, see: Chapter 10, sec.3.2.

1700 Majoras (n 376) 8.

${ }^{1701}$ Breed and Michnal (n 351) 38. See Chapter 2, sec.6.2.2.1 for a detailed analysis of the FTC and the DOJ's different attitude toward the fix-it-first remedies.
} 
time accepted a fix-it-first remedy in Reynolds/Lorillard in $2015 .{ }^{1702}$ The EC clarifies that a fix-it-first remedy is especially welcomed if the identification of the purchaser has a significant influence on the viability and competitiveness of the divested business. ${ }^{1703} \mathrm{It}$ is believed that there is a rising tide of the use of fix-it-first remedies at the EU level. ${ }^{1704}$

In China, by April 2017, there are three cases in which the fix-it-first remedies were accepted by MOFCOM, they are NXP/Freescale (2015), ${ }^{1705}$ AB InBev/SAB Miller (2016), ${ }^{1706}$ and Abbott/St.Jude Medical (2016). ${ }^{1707}$ It is interesting to notice that although the AML was enacted almost ten years ago in 2008, the fix-it-first remedies have not been used until recent years since 2015. Is this just a coincidence? What can be the reasons for the increasing use of the fix-it-first remedies in China?

Ding argued that according to his experience and observations, whether the merging parties will propose a fix-it-first remedy largely depends on the design of their transaction structure, meanwhile the merging parties in a global transaction are more likely to use a fixit-first remedy than the parties to a domestic transaction. ${ }^{1708}$ It is believed that a fix-it-first divestiture remedy is highly strategic. Ding explained that for the merging parties to a domestic transaction, they prefer to get their transaction approved by committing themselves to behavioural remedies, or simply changing another target company to reduce the risks of being required to divest. In contrast, for those merging parties to a global transaction, they have to submit their merger notifications in several jurisdictions, suggesting that they may possibly consider divestitures at a very early stage when they design the transaction structure in a global context and finally decide to fix the potential problem by themselves in the first place so that they can get their transactions approved in several jurisdictions as soon as possible.

Xu shares similar opinions to Ding's in the sense that the merging parties are generally reluctant to divest assets. ${ }^{1709}$ She further mentioned that there were some global transactions which were approved in foreign jurisdictions subject to divestitures, whereas they were approved in China subject to behavioural remedies. However, there was no global transaction which was approved subject to divestitures only in China.

According to Yang, the increased use of the fix-it-first remedies can be relevant to the internal evolutions of the AMB, namely, the abolishing of the pre-acceptance consultation office and the AMB's trial to assign transactions to the case teams based on their different expertise. ${ }^{1710}$ The merger review process is thus streamlined and case teams can better obtain and accumulate professional knowledge in the concerned industries. Such changes make it possible for the case teams to start the substantive assessment much earlier than before and negotiate merger remedies in an earlier stage with the merging parties.

Generally speaking, it can be observed that, first, MOFCOM is willing to accept the fixit-first remedies as long as they can address its competition concerns. Second, the merging parties of global transactions are more likely to use the fix-it-first remedies than the parties to domestic transactions. Third, the internal evolution of the AMB not only shortens the time limit of merger review but also makes it possible for the case teams to start the

${ }^{1702}$ FTC File No. 1410168, Reynolds/Lorillard, In the Matter of Reynolds American Inc., a corporation, and Lorillard, Inc., a corporation (FTC Decision and Order) [31 July 2015].

17032008 EC Remedies Notice (n 35) para. 57.

${ }^{1704}$ Competition Policy International (n 669).

${ }^{1705} \mathrm{NXP} /$ Freescale (n 1390).

${ }_{1706}$ AB InBev/SABMiller (n 1431).

1707 Abbott/St. Jude Medical (n 1431).

${ }^{1708}$ Ding (n 1470).

${ }^{1709} \mathrm{Xu}$ (n 1461).

${ }^{1710}$ Yang (n 1459). 
substantive assessment of the proposed transaction and consider suitable merger remedies at an earlier stage.

\subsection{Assessment of MOFCOM's Practice: Evidence from Interviews}

W indicated that these risk-reducing provisions have been used by MOFCOM even before the publication of the MOFCOM Provisions on Merger Remedies. ${ }^{1711} \mathrm{~W}$ added that in practice, MOFCOM would negotiate with the merging parties to find out a mutuallyacceptable solution to address its concerns. ${ }^{1712}$ Table 21 and Table 22 summarise the use of the fix-it-first remedies and other strategies that MOFCOM employs to deal with composition risks, asset risks, and collusion risks based on all seven published divestiture remedies (by 20 June 2017).

From the legal perspective, composition risks, asset risks and collusion risks have been recognised by MOFCOM, which is reflected in the MOFCOM Provisions on Merger Remedies. In practice, different strategies have been used by MOFCOM to avoid such risks (as indicated in Table 21 and Table 22). Although, as pointed out above, there is still plenty of room for improvement, it is evident that MOFCOM is making progress in this regard. Besides the analyses, based on legal and case studies, and results from interviews, also to some extent shed light on the question of whether MOFCOM's strategies can effectively reduce these three risks.

Interviewees generally agree that there is asymmetric information between the merged firm and the purchaser; furthermore, the merging parties can be more informed than MOFCOM concerning the proposed divestiture packages. ${ }^{1713}$ In addition, Xu specified that collusion risks actually can occur after the completion of divestitures because according to her observations and experience, competition between the purchaser and the merged firm in the market seems not to be viable as expected. ${ }^{1714}$

Table 21 Use of Risk-Reducing Provisions and the Fix-It-First Remedies in Conditional Approvals in China by 20 June 20171715

\begin{tabular}{ll}
\hline Strategy & Year of Decision and Case Name \\
\hline Fix-it-first remedies & $2015 \mathrm{NXP} /$ Freescale \\
& $2016 \mathrm{AB}$ InBev/SAB Miller \\
& Abbott/St. Jude Medical \\
\hline Crown jewel provisions & 2013 Glencore/Xstrata \\
\hline Up-front buyer provisions & - \\
\hline
\end{tabular}

\footnotetext{
$1711 \mathrm{~W}(\mathrm{n}$ 1464).

$1712 \mathrm{~W}$ (n 1464).

${ }^{1713}$ Ding (n 1470); W (n 1464); Xu (n 1465); Xu (n 1461).

$1714 \mathrm{Xu}$ (n 1461).

1715 This table is based on all MOFCOM's decisions in which divestitures were included. See: Chapter 11, Table 13.
} 


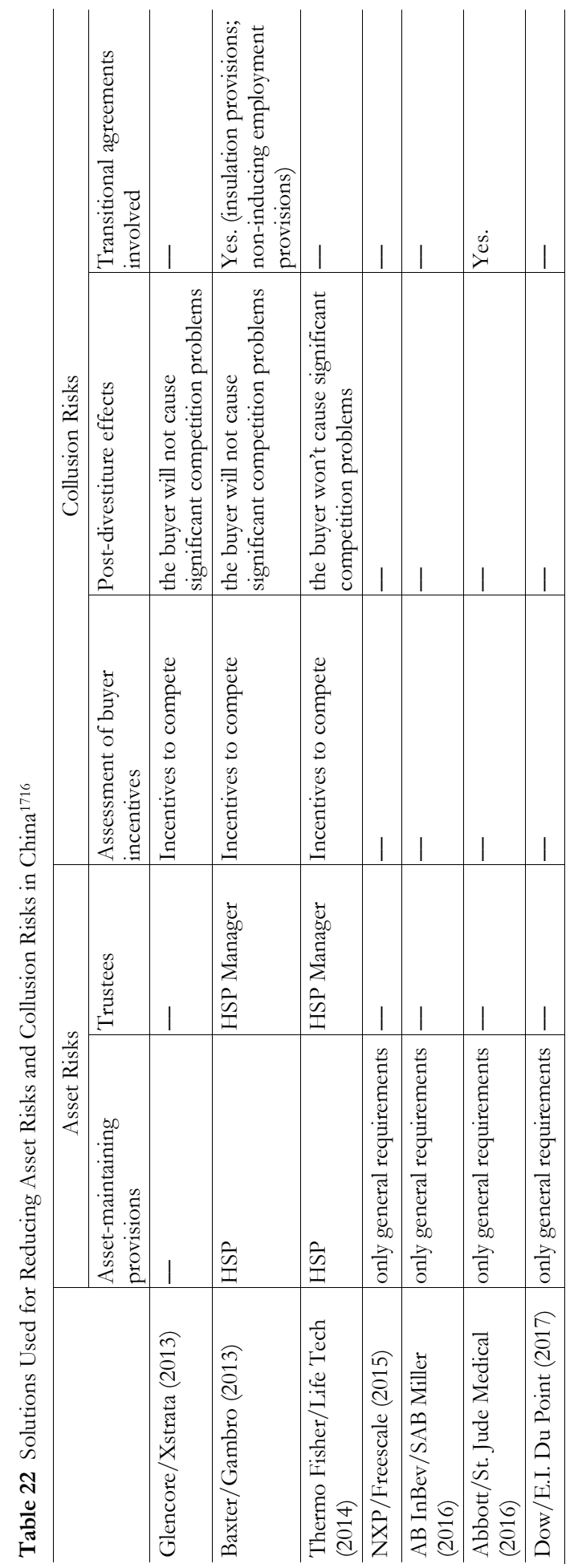

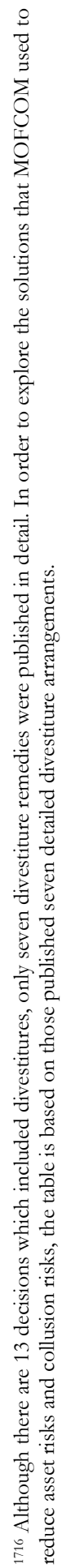


Ding considered that the merging parties may have private information regarding the proposed divestiture package, while MOFCOM evidently is more familiar with the competition policies and the competition situation in the concerned industry from a macro perspective. ${ }^{1717}$ Contrary to Ding's opinions, Xu argued that MOFCOM sometimes can have limited information regarding the industry concerned, resulting in difficulties for it to determine whether a divestiture is appropriate or adequate to eliminate potential anticompetitive effects. ${ }^{1718}$ The merging parties, on the other hand, are generally more informed regarding the proposed transaction or the details of the proposed divestiture package Moreover, problems caused by information asymmetry can be made worse due to different incentives and goals of the merging parties and MOFCOM to use, explain and analyse the information they obtain.

Although interviewees have divergent opinions regarding whether MOFCOM is informed about the concerned industries, at least they all agree that information is asymmetric between the merging parties and MOFCOM. Therefore, to reduce such information asymmetry, during merger review, MOFCOM employs various methods. The most discussed methods are consulting with third parties and soliciting information from the purchaser.

$\mathrm{Xu}$, Ding and $\mathrm{W}$ all pointed out that when assessing a proposed transaction or the suitability of a proposed divestiture, MOFCOM will consult with third parties, such as industry associations, scholars, the merging parties' competitors or upstream/downstream companies. ${ }^{1719}$ Especially, W noted that MOFCOM can assess whether the proposed transaction will cause severe competition problems by assessing the amount of the feedback of the questionnaires. ${ }^{1720} \mathrm{~W}$ explained that a large amount of feedback implies that the transaction receives wide attention from the respondents and thus a scrutiny will be a necessary.

Furthermore, these interviewees also emphasised that the purchasers play a very important role to help MOFCOM to determine the sufficiency of a proposed divestiture package. ${ }^{1721} \mathrm{Xu}$ considered that MOFCOM believes that the purchaser will conduct background research regarding the divestiture package and they thus know what is the key business that should be included in the package. ${ }^{1722}$ Ding argued that MOFCOM relies on the information from the purchaser during the assessment of the proposed divestiture packages.

Regarding the use of risk-reducing provisions or other provisions, such as HSPs, interviewees held a similar opinion, that is, according to their observations and experience, those strategies can reduce risks by e.g. incentivising the merging parties to search for a qualified buyer with a shortened period or encourage them to behave desirably. ${ }^{1723}$ Despite this, they have not been used frequently by MOFCOM so far. ${ }^{1724}$

\footnotetext{
1717 Ding (n 1470).

${ }^{1718} \mathrm{Xu}(\mathrm{n}$ 1465).

${ }^{1719}$ Ding (n 1470); W (n 1464); Xu (n 1461).

${ }^{1720} \mathrm{~W}$ (n 1464). According to art 6 of MOFCOM Measures for Merger Review (n 1231), during merger review, MOFCOM can solicit opinions from relevant governmental departments, industry associations, relevant market players, or consumers. Questionnaires can be used as a method to obtain their opinions. Questionnaires are designed and handed out by MOFCOM to the above-mentioned individuals and departments. These respondents are required to finish the questionnaires within a certain period and return them to MOFCOM.

${ }^{1721}$ Ding (n 1470); Xu (n 1461).

${ }^{1722} \mathrm{Xu}$ (n 1461).

${ }^{1723} \mathrm{Xu}$ (n 1461); W (n 1464).

${ }^{1724} \mathrm{Xu}$ (n 1461).
} 
Ding added that generally, MOFCOM does not care about the question of from which side of the merging parties the divestiture business comes. ${ }^{1725}$ What MOFCOM cares about the most is the identification of the purchaser and its ability to operate the divested business. ${ }^{1726} \mathrm{Xu}$ believed that MOFCOM is resulted-oriented, suggesting that it is very likely to accept a merger remedy as long as it can eliminate the potential anti-competitive effects, regardless of the forms of the remedy. ${ }^{1727} \mathrm{~W}$ argued that in practice, generally, MOFCOM will not impose requirements on the merging parties if they are unwilling to accept; instead, MOFCOM will negotiate with them to seek a mutually-acceptable solution when it believes that additional risks may occur during the divestiture process. ${ }^{1728}$

On the one hand, all these interviewees confirmed the existence of information asymmetry between the merging parties and the purchaser, which is consistent with the theoretical analyses conducted in the previous chapters. Collusion risks are also mentioned by $\mathrm{Xu}$. On the other hand, it is pointed out that MOFCOM has its own methods to reduce asymmetric information during its assessments of the proposed mergers. Furthermore, when divestitures are required, different divestiture strategies have been used by MOFCOM to reduce possible risks that can occur, although such divestiture strategies are not very often used. Several observations can also be made.

First, it seems that the purchaser plays a crucial role to help MOFCOM to determine the composition of the divestiture packages. In general, the purchasers are reliable because they are supposed to be the "ally" of the CAs. As pointed out in the 1999 FTC Divestiture Study, however, a purchaser's interests can be different from the CAs. ${ }^{1729}$ To rely too heavily on the purchaser can thus be problematic in the sense that the divestiture may be designed in a way that provides the purchaser with the opportunity to cooperate with the merged firm instead of competing.

Second, although consulting with or soliciting information from the third parties can to some extent reduce information asymmetry, composition risks can still occur due to some unforeseeable factors. Besides, these methods cannot effectively prevent asset risks, which are caused by the merging parties' moral hazard and post-divestiture collusion risks. Considering that MOFCOM does not frequently use risk-reducing provisions or other strategies in the decisions, the design of a divestiture may be inadequate to prevent the occurrence of these risks.

Third, there seems to be an impression that MOFCOM is not a compelling competition agency in the sense that it will not impose requirements on the merging parties if they are unwilling to accept them (as pointed by W). Instead, it is quite flexible with the design of a merger remedy. Further, some provisions in the MOFCOM Provisions on Merger Remedies are to some extent quite general, which leaves room for MOFCOM and the merging parties to negotiate. On the one hand, such flexibility confers upon both parties the freedom to negotiate. On the other hand, the flexibility may also result in the lack of transparency and predictability of MOFCOM's merger remedies policies.

Actually, MOFCOM's non-compelling features may also lead to another two features of MOFCOM's practice in merger remedies, diverse and non-traditional forms of behavioural remedies and the prevalence of behavioural remedies.

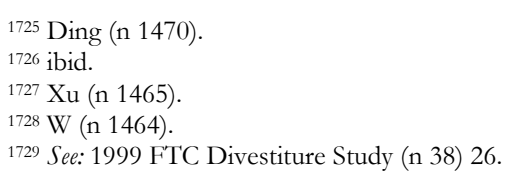




\section{Prevalence of Behavioural Remedies in China}

\subsection{Behavioural Remedies: Diverse and Flexible}

According to Chapter 11, behavioural remedies in China are characterised as diverse and flexible. This is reflected in two aspects: forms and possibility of modifications.

First, forms. Compared with the practice in the US and the EU, there are more unconventional forms of behavioural remedies that are used in China in practice. Such flexibility in forms confers on both the merging parties and MOFCOM the opportunity to tailor the remedy in a way that can exactly address the concerns. For example, requirements of price-reduction in Thermo Fisher/Life Tech directly addressed MOFCOM's concern about post-merger price-rising; ${ }^{1730}$ and no market expansion in $\operatorname{InBev} / A B$ explicitly reflected MOFCOM's concern that the merged firm's future expansion would impede competition in the Chinese brewery market.

Second, the possibility of after-enforcement modifications. The hold separate behavioural remedies may serve as one of the best examples to explain this point. ${ }^{1731}$ After several years of enforcement, upon the application of the merged firm, MOFCOM can decide whether the merged firm's application of revising or abolishing all or part of the obligations in the hold separate remedies should be approved, after assessing the competition situation in the market. MOFCOM is very likely to approve such an application if it thinks the original hold separate remedies have been effective in preserving competition and the possible anti-competitive effect of the merger have been eliminated by the original remedies. This possibility enables the merging parties to be relieved from certain behavioural obligations. ${ }^{1732}$

MOFCOM has strong incentives to accept the merging parties' proposed merger remedies as long as the remedies can address its concerns, without scientifically evaluating the effectiveness of the proposed remedies. Such an approach may result from the time pressure. ${ }^{1733}$ Although this approach confers upon the notifying parties more freedom and choices in formulating the proposals for remedies, it may also possibly lead to the use of unconventional behavioural remedies, which may cause additional problems. For example, Ding argued that hold separate behavioural remedies can be problematic because they seem to lay too many burdens on the merging parties. ${ }^{1734} \mathrm{He}$ believed that it was the merging parties' lawyer who suggested this remedy to the merging parties in the first place. Ding further noted that in his opinion, the use of hold separate behavioural remedies is very likely to decrease in the future when the merged firms gradually realise how many burdens

\footnotetext{
1730 Such as Thermo Fisher/Life Tech (n 1383).

${ }^{1731}$ For detailed explanation of this point, see: Chapter 11, sec.3.1.2.

1732 There are several cases in China in which all or part of the behavioural obligations have been abolished or changed by MOFCOM. They are: MOFCOM Public Notice 2016/23: Cancellation of the Restrictive Conditions in Walmark/Niuhai Holding Case (MOFCOM Decision) [8 June 2016], <http://fldj.mofcom.gov.cn/ article/ztxx/201606/20160601335200.shtml> accessed 6 May 2017; Seagate/ Samsung HHD (n 1408); MOCOM Public Notice 2015/41: Alterations of the Restrictive Conditions in West Digital/Hitachi Vitit Case (MOFCOM Decision) [19 October 2015] <http://fldj.mofcom.gov.cn/article/ztxx/201510/20151001139040.shtml> accessed 7 May 2017; MOFCOM Public Notice 2015/02: Cancellation of Partial Restrictive Conditions in Motorola/Google Case (MOFCOM Decision) [19 January 205] <http://fldj.mofcom.gov.cn/article/ztxx/201501/20150100862331. shtml> accessed 7 May 2017.

1733 This is related to MOFCOM's compromise-seeking approach during the negotiations of merger remedies with the merging parties. See sec.4.2.1. below for a detailed analysis.

${ }^{1734}$ Ding (n 1470).
} 
they have to bear. W also considered that the effectiveness of some unique behavioural remedies, such as hold separate provision require further assessment. ${ }^{1735}$

Interviewees regarded MOFCOM's acceptance of flexible and diverse behavioural remedies as a gratifying change from the perspective of the development in MOFCOM's enforcement. ${ }^{1736} \mathrm{Xu}$ pointed out that although such diversity and flexibility of behavioural remedies may to some degree reduce the predictability of MOFCOM's remedy policies, it provides the merging parties with more freedom to formulate their proposals for remedies. ${ }^{1737}$

\subsection{Prevalence of Behavioural Remedies and Reasons}

Divestitures are traditionally favoured over behavioural remedies in the US and the EU because they are deemed as straightforward and no long-term monitoring is required, whereas behavioural remedies are to some degree less enforceable because they require long-term monitoring. ${ }^{1738}$ In China, according to the observations made in the previous chapters, behavioural remedies are used more frequently than divestitures. According to Table 13, among all the 29 conditional approvals (by the end of 20 June 2017), there were 15 transactions which were approved subject to pure behavioural remedies and pure structural remedies were only included in 5 decisions, implying that MOFCOM seems to be taking a different path.

Figure 22 Use of Remedies in MOFCOM's 29 Conditional Approvals ${ }^{1739}$

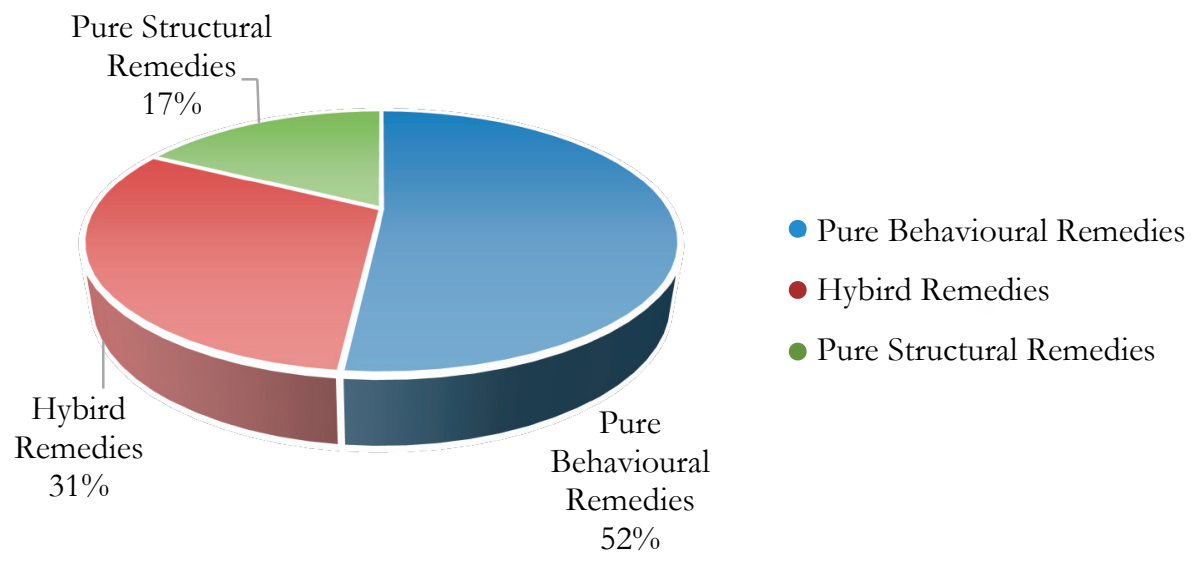

Figure 22 indicates that pure behavioural remedies were used in $52 \%$ of the conditional approvals. The number would be $83 \%$ if including hybrid remedies. In contrast, pure structural remedies were used in only $17 \%$ of the conditionally-approved transactions, of which the number was far lower than that of the behavioural remedies. What can be the reasons behind the prevalence of behavioural remedies in China? Does MOFCOM actually

\footnotetext{
$1735 \mathrm{~W}$ (n 1464).

${ }^{1736} \mathrm{Xu}$ (n 1461); W (n 1464).

$1737 \mathrm{Xu}(\mathrm{n}$ 1461).

${ }^{1738}$ For a detailed exploration of the CAs' preference for structural remedies in the US, see: Chapter 2, sec.6.1.1.; for that in the EU, see: Chapter 3, sec.4.2.1.

1739 See: Chapter 11, Table 13 for the full list of MOFCOM's conditional approvals.
} 
have a preference for one of these remedies? Or, does the use of types of remedies have any link to the industry concerned, parties concerned, or merger types?

It can be observed from Table 13 (Chapter 11) that, first, the vast majority of conditionally-approved transactions concern manufacturing industry. Thus, it is difficult to determine whether a divestiture remedy or a behavioural remedy will be more likely to be imposed on transactions that concern certain industries. Second, similarly, another indicator, the involvement of foreign investors, can also provide limited clues regarding MOFCOM's preference because almost all the conditional approvals involve one or more foreign investors. Third, the only link is the merger types. As observed, all the structural remedy-included transactions are horizontal mergers. This is in line with the consensus that divestitures can be effective and more suitable in horizontal mergers where the merged firm's market power can be crippled by divesting the overlapping business to another competitor directly.

Thus, what are the other factors that lead to the frequent use of behavioural remedies in China? All the interviewees in the lawyer group believed that MOFCOM has no preference for behavioural remedies or structural remedies. ${ }^{1740}$ Interviewees in the scholar group further shared their opinion regarding the reasons behind the prevalence of behavioural remedies. ${ }^{1741}$ Reasons presented in the following section may to some extent shed light on one of the most discussed topics regarding MOFCOM's practice in merger remedy. ${ }^{1742}$

\subsubsection{The Merging Parties' Reluctance to Propose Divestitures and MOFCOM's Compromise- Seeking Behaviour}

It is generally believed that the merging parties' reluctance to propose divestitures and their preference for behavioural remedies to some degree lead to the prevalence of behavioural remedies in China. ${ }^{1743}$ This is actually understandable from the perspective of the merging parties. First, divestitures can involve large transaction costs and bring large pressure to them for e.g. searching for a suitable buyer within a limited timeframe or adjusting price lists. Second, divestitures can also be rather complicated, involving not only the transfer of physical assets, but also intangible assets, such as intellectual property rights, and rearrangement of personnel. It is believed that divestiture can be harsh due to their irreversibility and can bring harm to the merging parties through re-structuring. ${ }^{1744}$ Third, the merging parties may be reluctant to create a new competitor or make their existing rival even stronger by transferring their divested business to them. Therefore, it is evident that compared with proposing a complex divestiture, the merging parties are more willing to get their transaction approved by making some general behavioural commitments, such as maintain the status quo of their business plan, which will minimise their costs spent on merger remedies. ${ }^{1745}$

Furthermore, there is no clue, either from a legal perspective or from a practical perspective, about whether MOFCOM has a preference for divestitures such as the CAs in the US and the EU do. Although MOFCOM once indicated in one of its internal meetings

\footnotetext{
${ }^{1740} \mathrm{Xu}$ (n 1461); Yang (n 1459); Ding (n 1470).

1741 Wang (n 1474); W (n 1464); Xu (n 1465).

1742 See: Table 20 in Chapter 12, which has summarised the possible reasons that these interviewees believed may to a large degree give rise to the prevalence of behavioural remedies.

${ }^{1743} \mathrm{Xu}$ (n 1461); W(n 1568); Ding (n 1470).

${ }^{1744}$ Wang (n 1474).

${ }^{1745}$ Ding (n 1470).
} 
that it would be easier if more structural remedies could be used, ${ }^{1746}$ in practice it still accepts more behavioural remedies proposals. Such an approach may result from MOFCOM's compromise-seeking attitude during remedy negotiations.

A merger remedy proposal should be submitted to MOFCOM by the merging parties, followed by bargaining and negotiations between the merging parties and MOFCOM. On the one hand, the merging parties try to get their transactions approved by making some commitments; on the other hand, MOFCOM has to ensure that the merging parties' commitments are sufficient to clear potential anti-competitive effects. The bargaining process has several features that are noteworthy. First, it was argued by Ding that MOFCOM, in general, would be unlikely to compel the merging parties to make certain commitments if they do not propose them in the first place. ${ }^{1747}$ This to some extent implies that MOFCOM is not a compelling competition agency at least during the remedies negotiations. Second, both the merging parties and MOFCOM wish to enter into an agreement, otherwise, MOFCOM has to prohibit the proposed transactions, (resulting in the possible loss of efficiencies) or the merging parties have to withdraw their notifications before the expiration of the merger review time limit to avoid a prohibition. ${ }^{1748}$

Under the combined effects of the above-mentioned factors, the negotiations of merger remedies can be quite flexible in the sense that behavioural remedies can also be accepted as long as they can address MOFCOM's concerns if they are proposed by the merging parties in the first place. ${ }^{1749}$ The results of negotiations of merger remedies can be deemed as the result of a mutual choice and compromise. ${ }^{1750}$

MOFCOM's compromise-seeking behaviour and non-compelling approach actually may have been influenced by China's traditional culture of barmony as fundamentality. ${ }^{1751}$ Harmony as fundamentality is a principle of moral practice advocated by Confucianism, meaning that one of the critical standards when assessing the success of the enforcement and practice of laws and ethics is whether the people concerned are satisfied. From the Chinese culture perspective, a mild (behavioural) remedy might be preferred in order to avoid contradictions and conflicts and to strike a mutually-satisfying result, even if two types of merger remedies may have the same effects, considering the merging parties' reluctance to propose divestitures in the first place.

\subsubsection{Traditions of Corporate Surveillance and Dispersed Monitoring Costs}

The CAs' lack of sufficient resources or an effective system for long-term monitoring may explain their lack of favour for behavioural remedies. Although a monitoring trustee is generally appointed to work as the ears and eyes for the CAs, such long-term monitoring can still be quite costly. However, theoretically, in certain situations, the perceived difficulties of behavioural remedies will not impede their effectiveness. For example, for sectors which are subject to industry-specific regulatory intervention, behavioural remedies may be favourable, rather than other remedies, since there is already a regulatory industry

\footnotetext{
${ }^{1746} \mathrm{Xu}(\mathrm{n}$ 1461).

${ }^{1747}$ Ding (n 1470).

1748 Yang (n 1459). Withdrawal of the notifications of transactions can also be an option, meaning the notifying parties withdraw their transaction before MOFCOM makes its final decisions to avoid a prohibition decision. Normally, the merging parties will revise their transaction plan and refill again to MOFCOM. The merger review procedures will start over again. Such as: NXP/Freescale (n 1390).

1749 Wang (n 1474); W (n 1464).

${ }^{1750}$ Yang (n 1459); Wang (n 1474); W (n 1464).

$1751 \mathrm{Xu}$ (n 1465).
} 
monitoring scheme, which can be a complement to the competition agency. ${ }^{1752}$ Besides, long-term monitoring can also be achieved by market participants, ${ }^{1753}$ such as competitors or consumers. These will to some extent reduce the burden of monitoring and lower the enforcement costs.

This might exactly be the situation in China. Xu pointed out that China has the tradition and system advantage of corporate surveillance, ${ }^{1754}$ which started and resulted from China's nationally planned economy. As explored in the Introduction of Chapter 10, China's economy transition can be divided into three periods. In the first period until 1978, China had a nationally planned economy, during which the State-Owned Enterprises (SOEs) dominated every aspect of China's industrial sectors. ${ }^{1755}$ The government had the ownership of, and was also involved in the management of, the SOEs. Since 1978, separation of ownership and control began with the implementation of Reform and OpenDoor policy brought more freedom to the market. ${ }^{1756}$ Such reforms were further deepened after 1992. Although China is transiting its economy mode from a nationally planned economy to a socialist market economy and the government is changing its approach from patriarchal to service-oriented, ${ }^{1757}$ the tradition and system advantage of corporate monitoring are preserved. For example, in the first half of 1997, Provisions for the Alteration of Investors' Equities in Foreign-funded Enterprises were published, with the aim of strengthening the supervision and surveillance for the foreign-funded enterprises. ${ }^{1758}$

Moreover, behavioural remedies' monitoring costs bore by the CAs are not as high as perceived because they are dispersed among other "supervisors", such as the relevant industry associations, the merged firms' competitors, its upstream/downstream firms, as well as consumers. ${ }^{1759}$ The more supervisors are, the lower monitoring costs each supervisor will bear. Further, W noted that China's peer-monitoring is very powerful. ${ }^{1760}$ The merged firm's competitors may be highly incentivised to monitor the merged firm's compliance with the obligations because any non-compliance may have a significant impact on their interests and rights. A complaint can be made to MOFCOM when the abovementioned parties notice any non-compliance. MOFCOM can thus start an investigation after receiving a complaint. Furthermore, there are numerous market participants in China due to its vast territory and fast developing economy. Monitoring costs are thus further dispersed, which may largely raise the enforceability of the behavioural remedies.

\footnotetext{
1752 Papandropoulos \& Tajana (n 617) 449.

1753 ibid, 449.

$1754 \mathrm{Xu}$ (n 1465).

${ }^{1755}$ Justin Yifu Lin, Fang Cai and Zhou Li, 'Competition, Policy Burdens and State-Owned Enterprise Reform' (1988) 88 The American Economic Review 422, 422. For detailed information regarding history regarding China’s transition, see: Ronald Coase and Ning Wang, How China Became Capitalist (2012 edn, Palgrave Macmillan 2012). 1756 See: ibid.

1757 See: CPC Central Committee , 'CPC Central Committee's Decisions on Some Significant Issues Concerning Comprehensively Deepening the Reform' (China.Org, 2013) <http://www.china.org.cn/china/third_ plenary_session/2014-01/16/content_31212602.htm> accessed 7 May 2017.

1758 Ministry of Foreign Trade \& Economic Cooperation \& State Administration for Industry \& Commerce, Provisions for the Alteration of Investors' Equities in Foreign-funded Enterprises: Provisions for the Alteration of Investors' Equities in Foreign-funded Enterprises (wai shang tou zi qi ye tou zi zhe gu quan bian geng de ruo gan gui ding 《外商 投资企业投资者股权变更的若干规定》(Issued and entered in force 28 May 1997).

${ }^{1759} \mathrm{~W}$ (n 1464).

$1760 \mathrm{Xu}(\mathrm{n}$ 1465).
} 


\subsubsection{Other Reasons}

In addition to the above-mentioned reasons, other factors and considerations can also explain the prevalence of behavioural remedies in China.

First, the use of some behavioural remedies, such as no market expansion or requiring a continuing supply of certain products, may result from the practical consideration that there are three independent competition agencies in China. ${ }^{1761}$ According to sec.2.2 of Chapter 10, these three competition agencies are NDRC, SAIC, and MOFCOM, which gain their authority to enforce competition law from different laws. ${ }^{1762}$ They are independent and at the same administrative level. If there was only one competition agency, then merger review and investigations of post-merger anti-trust conduct would be easier since it would be an internal allocation of authority between different sections. ${ }^{1763}$ Information gathered from the merger review section can be easily transferred to other sections within the whole agency. However, the reality is that there are three different and independent competition agencies in China. The relationship between these agencies can be quite subtle. A merged firm which brings unilateral anti-competitive effects might use MOFCOM's merger approval as a defence against NDRC or SAIC's investigations and charges, and further claim that its conduct is compatible with competition law because the conduct is the result of the merger, while the said merger was approved by MOFCOM in the first place. This can be especially true when NDRC and SAIC have limited information regarding the original merger review. To avoid such a situation and to put an end to any potential future problem, MOFCOM thus requires the inclusion of behavioural remedies, under which the merging parties simply continue to do what they are currently doing.

Second, sometimes it seems not to be justifiable to require divestitures, or MOFCOM has to address its non-competition concerns. ${ }^{1764} \mathrm{It}$ is possible that MOFCOM's competition concerns can be addressed by a behavioural remedy despite such behavioural remedies being unique. For example, in Thermo Fisher/Life Tech, MOFCOM's concern of a post-merger price-raising was exactly addressed by a behavioural remedy, under which the merged firm had to reduce the price list for SSP kit and SDS-PAGE protein standards in the Chinese market at a rate of $1 \%$ annually with no reduction on discount offered to the Chinese dealers for the next 10 years after the publication of MOFCOM's decision (2014). ${ }^{1765}$ Furthermore, as explored in sec.2.2.2. above, case analyses imply that MOFCOM may consider non-competitive policies during merger review. Such consideration can be the result of the goals of the AML, namely, to promote a healthy development of the national economy. Therefore, a proposed transaction, such as Marubeni/Gavilon, ${ }^{1766}$ may be unlikely to cause significant competition concerns while a behavioural remedy can be required to address MOFCOM' concern regarding China's international trade policy.

Accordingly, the need of addressing non-competitive concerns as well as the fact that divestitures may not be justified in some situations lead to the inclusion of diverse and

\footnotetext{
${ }^{1761}$ Ding (n 1470).

${ }^{1762}$ NDRC has its authority originated from: Interim Provisions on Preventing Acts of Price Monopoly (n 1222). SAIC obtains its authority from: Anti-Unfair Competition Law of the People's Republic of China (n 1215). MOFCOM obtains its authority from: Ministry of Commerce (MOFCOM), Provisions on the Takeover of Domestic Enterprises by Foreign Investors (2006 Revision) (n 1223).

${ }^{1763}$ Ding (n 1470).

1764 Wang (n 1474); Xu (n 1465); Xu (n 1461).

1765 Thermo Fisher/Life Tech (n 1383).

1766 See: Marubeni/Gavilon (n 1390).
} 
flexible behavioural remedies. Behavioural remedies' flexibility, in turns, assists in solving MOFCOM's various concerns.

\section{Conclusion}

Although it is true that markets change quickly, the effectiveness of a divestiture can still to a large extent be expected by first, assuring an appropriate composition of the divestiture package before the CAs approve the transactions and divestiture proposal; second, assuring the preservation of the competitive capability of the to-be-divested business during the divestiture process and; third, assuring that the purchaser competes with the merged firm and other competitors after the completion of a divestiture.

Composition risks. Theoretical analysis in Chapter 6 has pointed out that the use of riskreducing provisions, such as crown jewels and up-front buyers, can effectively reduce composition risks if they are designed appropriately. The CAs' practice in the US and the EU is consistent with the theory and generally, they seem to work well. Regarding China, from the legal perspective, the MOFCOM Provisions on Merger Remedies have introduced risk-reducing provisions. In practice, there is one case in which a crown jewel provision was included (Glencore/Xstrata). The legal provision as well as the case indicated that although MOFCOM seems to have limited knowledge regarding the use of the riskreducing provision in reducing composition risks, it is making progress in this regard.

Asset risks. Chapter 7 reveals that the merging parties' moral hazard can lead to asset risks. HSPs (agent-restraining rules) and trustees (principal-empowering strategies) can be used to reduce the risks. These solutions are also used by the CAs in the US and the EU to reduce asset risks. MOFCOM's trustee policies are actually quite similar to the EU's. Slightly different from HSPs, MOFCOM has used asset-maintaining provisions, which require the merging parties, generally, to keep the viability, competitiveness and marketability of a divestiture package. In practice, furthermore, the merging parties in some cases were required to operate the to-be-divested assets separately from their retained business. In other words, a requirement to "hold the business separately" can be included in asset-maintaining provisions, whereas it is unknown when such a requirement will be included.

Collusion risks. Collusion can especially occur between the purchaser and the merged firm due to those collusion-facilitating factors (symmetry, multi-markets contacts and continuing relationships) resulting from divestitures. The possible solutions can be: consideration of post-divestiture effects, scrutiny of the purchaser' incentives and appointment of trustees when a continuing relationship is needed. The FTC, the DOJ and the EC all have developed their solutions in this regard. It can be observed from both the legal and practical perspectives that MOFCOM is aware of this risk and divestiture strategies have also been used. However, they may be to some extent inadequate.

In addition to these strategies, the fix-it-first remedies can also reduce asset risks by shortening the interim time spent on searching for a buyer. Interviewees believed that the merging parties to a global transaction are more likely than those to a domestic transaction to submit a fix-it-first remedy. They also pointed out that there is information asymmetry between the merging parties and the purchaser and collusion risks may occur. Observations were that, first, MOFCOM seems to rely heavily on the buyer, which can be problematic. Second, MOFCOM does not often use risk-reducing provisions and other strategies and the design of divestitures seems to be less technical compared with the CAs' decisions in 
the US and the EU. Third, MOFCOM, to some extent, is a non-compelling competition agency.

Having considered the practice of behavioural remedies in China, it is easy to notice that they are featured as diverse and flexible from the perspectives of forms and possibility of modifications. Furthermore, behavioural remedies are used more frequently than structural remedies in China. It is believed that MOFCOM does not have any preference for any type of remedy, which is in a sharp contrast to the approach that the CAs in the US and the EU take. In these two jurisdictions, divestitures are explicitly preferred to behavioural remedies.

The possible reasons behind such an approach include, first, the merging parties' reluctance to propose divestitures and MOFCOM's strong incentives to accept any form of remedies as long as it can address its competition concerns; second, China's tradition of corporate surveillance and the dispersed monitoring costs of behavioural remedies; third, other reasons. Such as the fact that there are three competition agencies in China and MOFCOM's consideration of non-competition issues during merger review. The prevalence of behavioural remedies in China is thus understandable and reasonable, although it remains unknown whether such an approach can be effective in reducing anticompetitive effects and can be helpful for MOFCOM to realise the aims of the AML.

Law and economics theory indicates that potential risks may occur during divestitures and ideal solutions can be used to reduce these risks. Although MOFCOM is a young competition agency regarding merger control enforcement and divestitures have been used less frequently than behavioural remedies in China, MOFCOM should still be aware of these risks and discover suitable solutions to reduce these risks based on the law and economics analysis to better realise the goals of competition law. The CAs in the US and the EU have used various divestiture strategies to reduce such risk. MOFCOM has transplanted some of these solutions. Generally speaking, MOFCOM's divestiture policies can to some extent reduce the above-mentioned three risks. It is trying to realise the goals of the AML by designing an effective divestiture or tailor a behavioural remedy into the way that can exactly address the potential competition issues in the context of China. Despite this, there is still much room for improvements to increase the effectiveness of merger remedies. Therefore, policy recommendations will be provided in Chapter 14 next. 


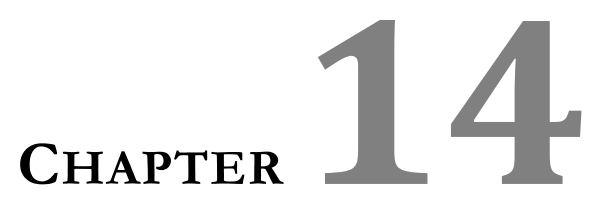

CONCLUDING REMARKS AND POLICY RECOMMENDATIONS 



\section{Answers to Research Questions and Main Findings}

The ultimate aim of this book is to examine whether China's merger divestiture policies can effectively reduce the above-mentioned divestiture risks (composition risks, asset risks and collusion risks) and thus serve the aims of the competition law (especially the AML ${ }^{1767}$ ), and further to provide policy recommendations for improvements. Therefore, the legislative analyses, case analyses and interview results were presented in Part III, providing comprehensive information regarding China's legislation and practice in merger divestiture. In addition, two other approaches, a comparative study of merger divestitures in the US and the EU and a law and economics analysis of merger divestitures, were also taken. To realise the above-mentioned aim, three main research questions were put forward and explored.

\subsection{Answers to Research Question 1 and Main Findings from Part I}

The first research question which was explored in Part I of this book is: what are the merger divestiture policies in the US and the EU and what are the main similarities and differences? The relevant legislation on merger review in these two jurisdictions was thus analysed to provide the readers with a general legal background.

\subsubsection{US}

The Sherman Act, which was enacted in 1890, was the first federal piece of legislation adopted in the US in the field of competition law. ${ }^{1768}$ The Sherman Act neither contained any provision on, nor explicitly expressed, the authorisation of a divestiture remedy, except for section 4, which, as believed, shows that the authority to order divestiture under the Sherman Act is nevertheless undisputed and is derived from the inherent equity powers of the federal courts. ${ }^{1769}$

In 1914, the US Congress enacted the Clayton Act to complement the Sherman Act of 1890 in maintaining a competitive economy. Section 11 of the Clayton Act authorises the FTC to order the offending corporation to 'cease and desist from such violations, and divest itself of the stock, or other share capital, or asset' illegally held. ${ }^{1770}$ The DOJ and the federal courts can, pursuant to Section 15 of the Clayton Act, order divestitures.

The enactment of the HSR Act in 1976 can be regarded as an important milestone during the development of merger control and merger divestitures in the US. It is pointed out that the legislative history of merger control in the US identifies two types of problems that have been addressed by the HSR Act through the pre-merger notification requirement and the mandatory waiting period after the notification: interim harm to competition and the inability to fully restore competition. ${ }^{1771}$

After the enforcement of the HSR Act, both the FTC and the DOJ are experiencing policy changes of their merger divestiture policies. Such changes have been reflected in various documents published by these two CAs. As observed, the developments of the FTC's divestiture policies can be summarised as follows. ${ }^{1772}$

\footnotetext{
1767 AML (n 42).

${ }^{1768}$ Dabbah (n 47) 238.

1769 See: (n 167).

1770 The Clayton Act \$11, 15 U.S.C. \ 21 (2013).

1771 ibid.

${ }^{1772}$ For more detailed information, see: Chapter 2, sec.5.1.3.
} 
- a likelihood of using a "clean sweep" approach ${ }^{1773}$ to determine the scope and composition of a divestiture package when the merger concerns the retail markets, such as supermarkets and petrol stations;

- requirements of divesting on-going business;

- requirements of continuing relationships between the buyers and the merged party in many divestitures to create viable competitors ${ }^{1774}$

With regard to the DOJ, several observable changes have been made in the 2011 DOJ Policy Guide compared with the 2004 version. ${ }^{1775}$ For example, first, the 2011 DOJ Policy Guide indicated a shift in its preference from structural remedies to more comprehensive and inventive conduct and/or hybrid remedies. ${ }^{1776}$ Second, a crown jewel provision, which was explicitly disliked by the DOJ according to the 2004 DOJ Policy Guide, is identified as necessary 'in those cases to ensure that the remedy will effectively preserve competition.' ${ }^{1777}$

On the one hand, there are some common grounds shared between the FTC and the DOJ of merger divestiture policies: (summarised as follows)

- structural remedies are preferred to behavioural remedies

- similar criteria when selecting the to-be-divested business

- similar standards when assessing a qualified buyer

- the requirement of a shorter divestiture period.

On the other hand, there are still some discrepancies between the FTC and the DOJ regarding their divestitures policies (see Table 23 below).

\subsection{2. $E U$}

The Merger Regulation was passed in 1989 (the 1989 MR), which was the first regulation that assigned the European Commission the authority to control mergers at the EU level. ${ }^{1778}$ Similar to the requirements under the HSR Act in the US, both the pre-merger notification and the mandatory waiting period were also introduced in the 1989 MR. Since the changed economic conditions and political situations, the revised EU Merger Regulation was enacted in 2004 after intensive negotiations (the 2004 EUMR), which replaced the 1989 MR. ${ }^{1779}$

The Commission published the Remedies Notice in 2001, which provided guidelines concerning both the substantive and the procedural aspects of merger remedies, laying special emphasis on divestitures. ${ }^{1780}$ It is believed that the policy, as well as the approach the EU applied towards merger remedies, is largely influenced by the established US practice in merger divestitures as well as the 1999 FTC Divestiture Study. ${ }^{1781}$ To improve the design and the implementation of merger remedies, the Commission published the

\footnotetext{
${ }^{1773}$ It refers to divestiture packages which mainly consist of the merging parties' overlapping business.

${ }^{1774}$ A continuing relationship between the merged firm and the purchaser can be required by FTC, despite such post-divestiture continuing relationships may increase the vulnerability of buyers. See: 1999 FTC Divestiture Study (n 38) 12.

1775 See: Chapter 2, sec.5.2.2.

1776 Hoffman (n 78) 387.

17772011 DOJ Policy Guide (n 56) 24.

17781989 MR (n 439).

17792004 EUMR (n 3).

17802001 EC Remedies Notice (n 440).

${ }^{1781}$ Monti (n 34) 3.
} 
Merger Remedies Study in 2005, ${ }^{1782}$ which identified several obstacles that can impede the effectiveness of a merger remedy and recommendations were further proposed. ${ }^{1783}$

In 2008, a new Remedies Notice was published to replace the 2001 version. ${ }^{1784}$ Divestitures are expressly favoured by the Commission. It can be observed from the 2008 EC Remedies Notice that, first, the Commission is likely to accept a proposed divestiture package if the business included is viable, on-going and stand-alone. Second, a buyer will be considered as qualified if it is independent, has the capability and incentives to compete and will not cause additional competition issues. Third, the to-be-divested business which is characterised as carve-outs or mix-and-match is generally not favoured by the Commission unless it is assured that such business is viable and stand-alone. Notably, it seems that the use of up-front buyers in the EU is increasing. ${ }^{1785}$ Similarly, it is observed that there is a rising tide of the use of the fix-it-first remedy at the EU level. ${ }^{1786}$

Similarities and differences of merger divestiture policies between the US and the EU are summarised as follows.

\section{Similarities}

- Preference for merger remedies: all the CAs (the FTC, the DOJ and the Commission) expressly prefer structural remedies to behavioural remedies;

- Requirements for an acceptable divestiture business: all the CAs will accept a proposed divestiture package with an business that is existing, viable and standalone;

- Out of favour approaches in determining the composition of divestiture package: mix-and-match or carve-outs;

- Requirements for acceptable buyers: independent and having the capability and resources to compete.

\section{Differences}

Merger control in the US and the EU has a different history and development path which may result in their different preferences or opinions of divestiture policies. Such differences are reasonable and acceptable considering, e.g. their different goals of competition law and different legal context. Nevertheless, according to the observations, convergence can be predicted regarding the future development of divestiture policies among these three CAs.

Furthermore, various risk-reducing provisions, such as crown jewels or up-front buyers, are used by the CAs in the US and the EU to reduce possible divestitures risks, so that the success of a divestiture can be assured to the extent possible.

\footnotetext{
17822005 EC Merger Remedies Study (n 27).

1783 ibid, 137.

17842008 EC Remedies Notice (n 35).

1785 Competition Policy International (n 669).

1786 ibid.
} 


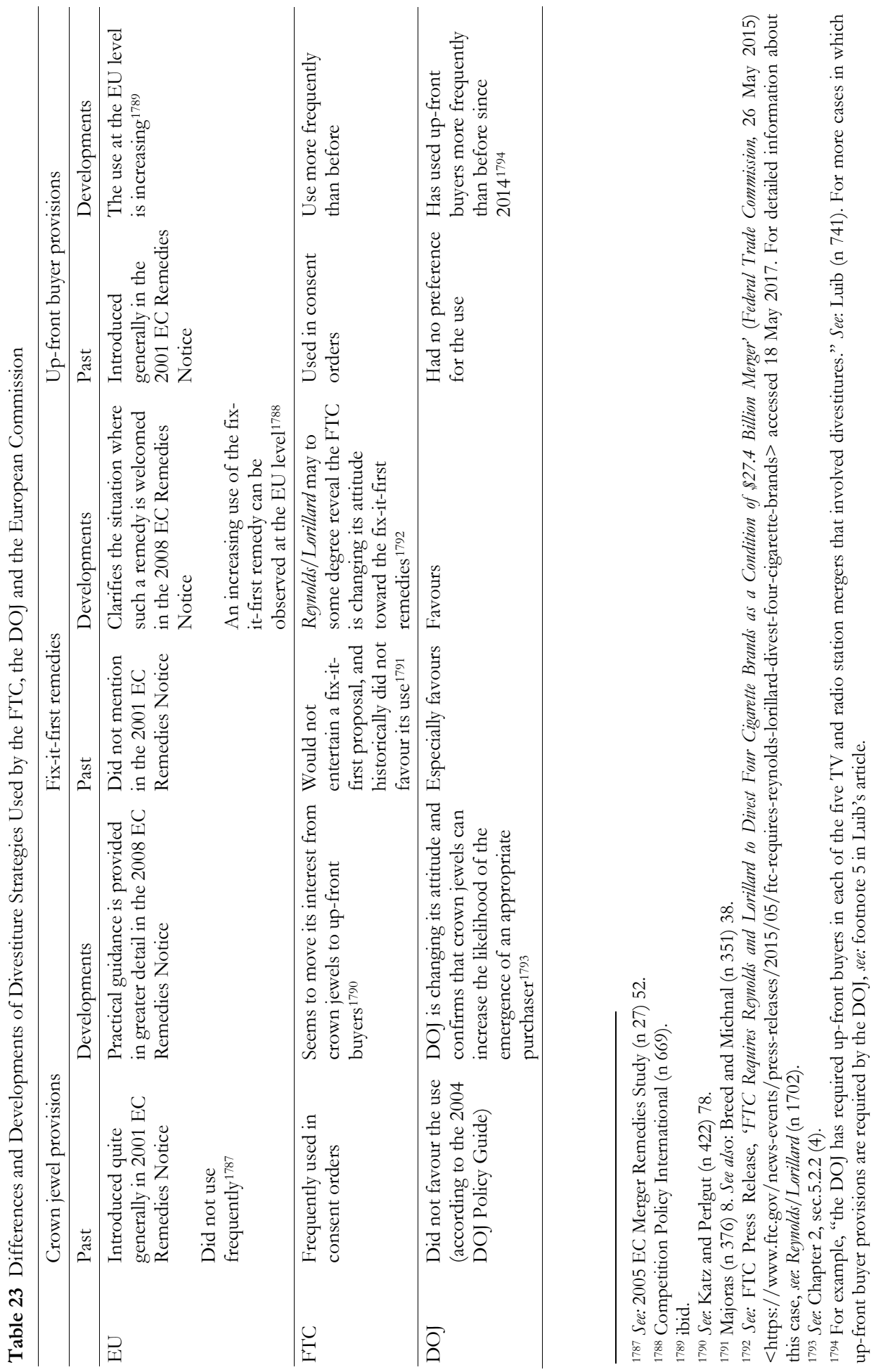




\subsection{Answers to Research Question 2 and Main Findings from Part II}

The second research question discussed in the theoretical part (Part II) was, what are the possible reasons for the occurrence of composition/assets/collusion risks in divestitures and what can be the solutions to reduce those risks? In addition, the relevant divestiture policies in the US and the EU were also explored in Part II as examples to study how the CAs in different jurisdictions deal with divestiture risks and whether these policies can effectively reduce such divestiture risks based on a law and economics perspective.

Chapters 6, 7 and 8 respectively explored composition risks, ${ }^{1795}$ asset risks ${ }^{1796}$ and collusion risks, ${ }^{1797}$ three risks that can occur during a divestiture. They can largely reduce the effectiveness of a divestiture in restoring competition to the market concerned. Law and economics analyses in the previous chapters indicate that some ideal solutions can be used to largely alleviate such risks.

Considering that a summary of Part II has been presented in the comparative law and economics analysis of China's divestitures in Chapter 13, sec.3, this section will not repeat it. Table 24 below provides a brief summary.

Table 24 A Summary of Reasons of and Theoretical Solutions to Three Divestitures Risks

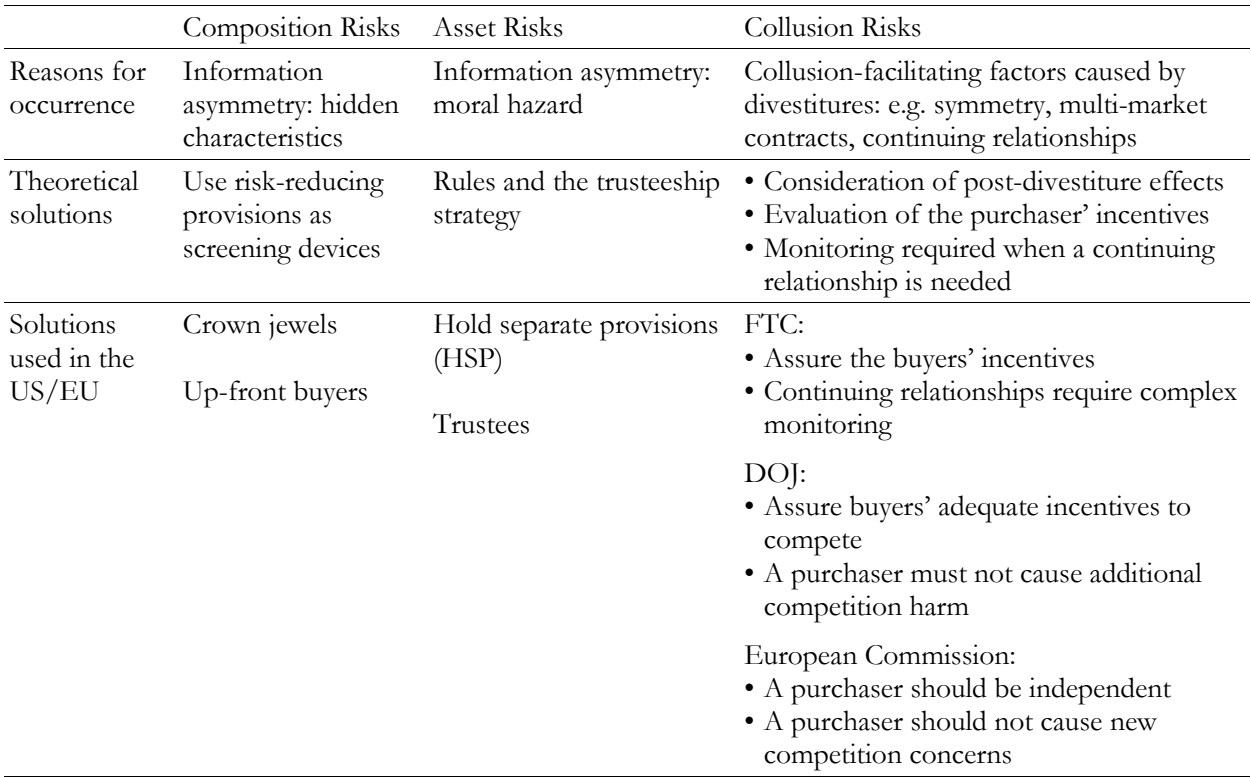

Effectiveness Generally, the solutions used by the CAs in the US and the EU can effectively reduce these of these three divestiture risks from the perspective of law and economics (if the solutions are US/EU designed and implemented well)

solutions

\footnotetext{
${ }^{1795}$ Composition risks can occur when a divestiture package has a too constrained scope or is inappropriately configured. See: Chapter 6, Figure 14 and Figure15.

${ }^{1796}$ Risks of reduction of the value of divestiture packages during the interim period of divestitures are called asset risks. See: Chapter 7, sec.3.3.

${ }^{1797}$ Collusion risks in this book refer to the risks that the merged party and the purchaser of the divested assets may have the incentives to collude rather than competing to maximise their profits. See: Chapter 8, sec. 4 .
} 
The solutions used by the CAs in the US and the EU seem to work well in alleviating these risks. Their practice can be regarded as examples (ideal solutions to follow rather than copying) which may to some extent provide MOFCOM with some clues and inspiration to formulate the appropriate solutions to effectively alleviate the possible divestitures risks, taking into account China's national conditions

\subsection{Answers to Research Question 3 and Main Findings from Part III}

The third research question explored in Part III is: are China's divestiture policies adequate and effective to reduce possible divestiture risks and serve the aims of the AML? This research question was analysed from a comparative law and economics perspective based on the conclusions and observations obtained from Part I and Part II. Moreover, relevant legislation of merger review and merger divestitures, case analyses, and results of interviews were presented in Part III in order to provide readers with comprehensive information about China's practice.

In order to reduce the composition/asset/collusion risks in divestitures, different regulations have been set out in relevant legal documents. In addition, MOFCOM is using different solutions in merger decisions. Table 25 below presents an overview regarding the relevant regulations and those solutions that were used. A summary of the assessment of the effectiveness of the legislation and practice is also included.

Considering that the MOFCOM Provisions on Merger Remedies, which were enacted in January 2015 and replaced the Interim Provisions of Divestiture Remedies, is the only effective document by now (June 2017) regarding China's merger remedy policies, the "provisions" mentioned in Table 25 only refer to those provisions in the MOFCOM Provisions on Merger Remedies.

Besides the divestiture strategies mentioned in Table 25, there were three cases in which the fix-it-first remedies were used, NXP/Freescale (2015), AB InBev/SAB Miller (2016) and Abbott/St. Jude Medical (2016) ${ }^{1798}$. Similar to the risk-reducing provisions mentioned above, the fix-it-first remedies can also reduce asset risks by shortening the interim period.

In general, MOFCOM is aware of the possible occurrence of divestiture risks. On the one hand, both the legal documents and MOFCOM's decisions indicate that MOFCOM has adopted some strategies to reduce these divestiture risks. On the other hand, there are still some issues that need to be further clarified. Compared to the US and the EU's preference for divestitures, MOFCOM claims that it has no preference for divestitures or behavioural remedies. Behavioural remedies are actually used more frequently than divestitures in China. The forms of behavioural remedies in China are quite flexible, which, as pointed out by the interviewees, can result from MOFCOM's consideration of noncompetition policy in order to promote a healthy development of the national economy. ${ }^{1799}$

Summing up, from the perspective of law and economics, MOFCOM's divestiture policies can to some extent reduce the possible divestiture risks, which can increase the effectiveness of divestitures. The realisation of the aim of the AML can thus be assured to some extent. It is unknown, however, whether the approach of using behavioural remedies more frequently than divestitures can effectively reduce anti-competitive effects brought by mergers due to the absence of a follow-up of these transactions. It seems that MOFCOM is heading forward in the right direction, while there are lots of uncertainties.

1798 Abbott/St. Jude Medical (n 1431).

${ }^{1799}$ For the detailed information regarding this, see: Chapter 12, sec.3.2.3. 

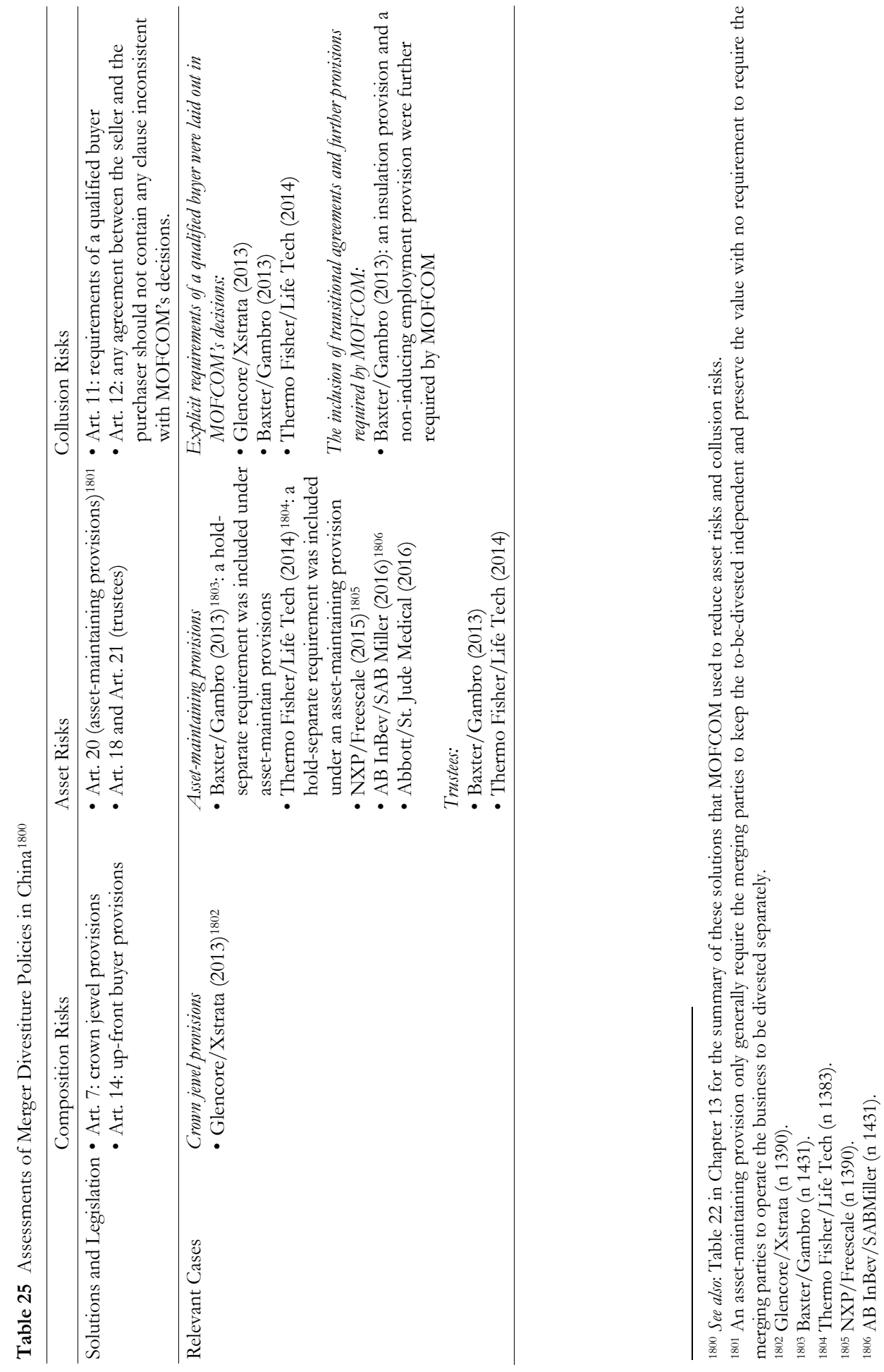


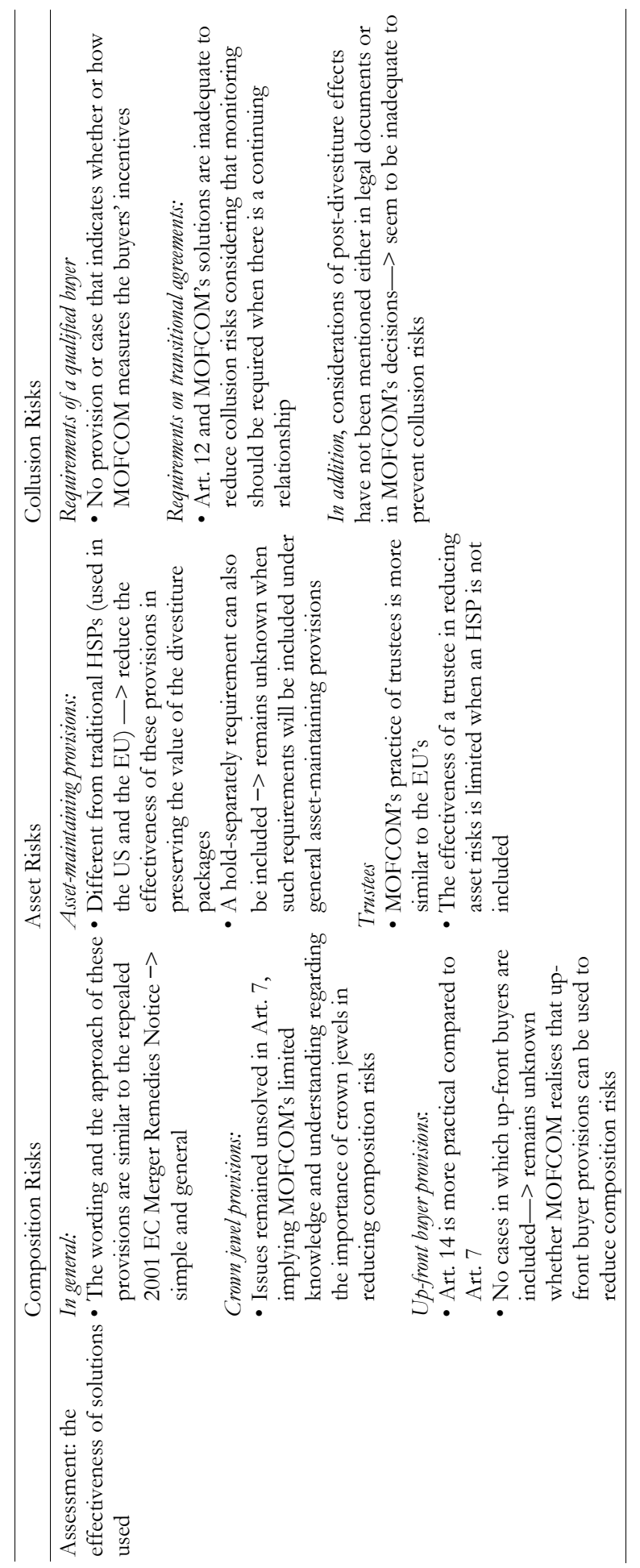




\section{Policy Recommendations}

Policy recommendations are provided in this section in order to increase the effectiveness of merger remedies (especially divestitures) in realising the aims of the AML. These policy recommendations consider the following factors.

First, China is still in the process of economic transition from a centrally-planned economy to a socialist market economy. Accordingly, as the core of the economic law, the AML is assigned with special goals to promote a healthy development of the national economy in addition to preserving competition in the market. ${ }^{1807}$

Second, the aim of analysing US and EU merger remedy legislation and practice was to study how the CAs in different jurisdictions design and implement merger divestiture policies so as to reduce potential divestiture risks. Such an approach, however, does not imply that the US or the EU practice will be regarded as the models for copying when formulating policy recommendations for China.

Third, the law and economics analyses in this book revealed some solutions to reduce possible divestiture risks so that the effectiveness can be increased to the extent possible. The solutions mentioned, however, are regarded as theoretical rather than as normative.

Recommendations will be mainly formulated based on law and economics theory and reference will be made to US or EU practice when appropriate.

\subsection{Conduct Empirical Merger Remedies Study}

More than 1400 merger applications have been dealt with by MOFCOM since the AML was enacted in 2008 until May 2017.1808 The number of the annual notifications is likely to keep increasing in the following years in China. To realise the goals of the AML, it is very important to ensure that merger remedies can fulfil their expectations to eliminate anticompetitive effects on the one hand, and to preserve possible efficiencies on the other hand. To my knowledge, however, by May 2017, no empirical study has been conducted by MOFCOM to review and explore whether remedies used in the past nine years have successfully restored competition in the markets concerned. In other words, the effectiveness of merger remedies used in China remains unknown.

In fact, documents of this kind have been published by the CAs in the US and the EU. For example, in the 1999 FTC Divestiture Study and the 2005 EC Merger Remedies Study. Both studies were conducted in a similar manner and came to essentially similar conclusions. ${ }^{1809}$

These two examples demonstrate that such empirical study is helpful to explore, e.g. the obstacles to an effective remedy and possible solutions that can be used to overcome the resulting difficulties. By empirically analysing merger remedies, MOFCOM can not only assess the effectiveness of merger remedies, but will also be able to improve the design and implementation of merger remedies by learning from the past.

\footnotetext{
${ }^{1807}$ The aims of the AML are to protect fair competition in the market, enhance efficiency, maintain consumer welfare and the public interest, and promote a healthy development of the socialist market economy. See: AML (n 42) art 1.

${ }^{1808}$ For the annual number of MOFCOM's decided transactions from 1 August 2008 to 30 December, see: Chapter 11, Table 12.

1809 Davidson (n 613) 1.
} 


\subsection{Publish Policy Guide Regarding Merger Divestitures}

Although MOFCOM has used different divestiture strategies to reduce composition/assets/ collusion risks, it seems that some of the strategies are inadequate to effectively alleviate those risks due to the lack of detailed guidance or MOFCOM's limited understanding of some strategies. In order to further reduce divestiture risks, policy guides or statements regarding merger divestitures should be published by MOFCOM to explain, clarify or improve its divestiture policies.

In those policy guides or statements, MOFCOM can comprehensively summarise, e.g. lessons that it learns from other CAs' practice (such as the US or the EU), or solutions or strategies that can be used by it to increase the effectiveness of merger divestitures. In addition, law and economics theory can also be taken into account by MOFCOM when recontextualising the legal transplants.

Moreover, publication of a policy guide or statement can also enable the merging parties and relevant practitioners to further understand MOFCOM's merger divestiture policies and thus propose more suitable remedies during remedy negotiations.

Evidently, publication of these guides or relevant documents not only requires MOFCOM's comprehensive understanding of merger review and merger remedies, but also requires empirical evidence to substantiate its observations. In other words, this is an iterative process.

\subsection{Consider More Standards during Merger Remedies Negotiations}

On the one hand, MOFCOM claims that it has no preference for divestitures or behavioural remedies; on the other hand, behavioural remedies are more prevalent than divestitures in China. This approach is in a sharp contrast with US and EU practice. The CAs there explicitly indicated that they prefer divestitures. Despite this, according to the reasons explained in Chapter 13, the prevalence of behavioural remedies in China seems to be quite reasonable and understandable.

It can be observed from Chapters 11 and 12 that regardless of the type of merger remedy (structural or behavioural), a proposed remedy can be accepted by MOFCOM if it can address its concerns and the non-merging parties have no objection. The concern in this approach is that a consideration of the appropriateness of a proposed remedy should be necessary. An appropriate remedy should be able to strike a balance between eliminating anti-competitive effects and preserving efficiencies generated from the notified transactions. In fact, the evaluation of the suitability of remedies is closely related to the evaluation of the notified mergers, which can decide whether or to what extent a remedy is needed to eliminate the potential competition issues. Economic toolkits can to some extent facilitate striking such a balance.

As explored in Chapter 5, Lévêque set out four criteria of effective merger remedies which aim at achieving the goal of merger laws at least costs, namely: effectiveness, minimising administrative costs in both design and enforcement; minimising the loss in efficiencies, and efficient re-allocation of assets, which particularly concerns merger divestiture. ${ }^{1810}$ There are also some other standards that might shed light on increasing the effectiveness of merger remedies, such as certainty. Balto pointed out that a remedy should

1810 See: Lévêque (n 850). For a detailed introduction of these four criteria proposed by Lévêque, see: Chapter 5 , sec.4.2. 
be selected if it will preserve competition with as much certainty as possible. ${ }^{1811}$ Oldale argued that transparency and accountability should also be considered when negotiating merger remedies. ${ }^{1812}$ Transparent and accountable procedural rules and negotiation processes can increase the predictability and impartiality of the result of merger remedy negotiation.

The standard that whether the proposed merger remedy is mutually-acceptable between the merging parties and MOFCOM is evidently inadequate to assure a suitable merger remedy. Considerations of multi-dimensional criteria can be helpful to assure the appropriateness of a particular merger remedy. In practice, due to the time pressure of merger review procedures, MOFCOM has to make a quick judgement regarding whether a proposed merger remedy should be accepted. Accordingly, this recommendation puts forward higher requirements for MOFCOM's deeper understanding of "what is an effective merger remedy" in a particular case and requires MOFCOM's capability of conducting a scientific reliable assessment of merger remedies within a short time.

\subsection{Use Intermediaries for Post-Divestitures Follow-Up}

It seems that MOFCOM does not follow up the merged firms after their completions of merger remedies due to MOFCOM's limited resources and manpower. Post-divestiture follow-up, nevertheless, can be quite important in the sense that it can provide empirical evidence of whether a divestiture ultimately fulfils its expectation to restore competition. Such evidence, in turn, confers upon MOFCOM the opportunity to review and improve its divestiture policies. To solve the contradiction between MOFCOM's limited resources and the necessity of post-divestiture follow-up, full play can be given to the intermediaries to assign them the responsibility to follow up and analyse the competition situation in the market concerned after the completion of divestitures.

Intermediaries such as law firms or accounting firms can be appointed by MOFCOM after the completion of divestitures to analyse the competition situation in the market concerned. When designing such a system, it suggests that, first, such a follow-up can be made selectively, depending on different indicators, such as different industries concerned in the transactions, the likelihood and severity of the anti-competitive effects generated from the transactions, or the scale of the transactions. This can be helpful to reduce the implementation costs of MOFCOM. Second, such follow-up can be executed during a certain period after the completion of the remedies, allowing some time for the remedies to work. Third, the intermediaries should be appointed by MOFCOM. MOFCOM can publish detailed selection criteria for these intermediaries so that they can apply for a position on the "expert lists".

In fact, such an approach can be adopted not only by MOFCOM in China, but also by the CAs in other jurisdictions, especially those CAs who have limited manpower and are still exploring a suitable approach for their merger remedy enforcement. In general, such a follow-up system can be a long-term mechanism to monitor the post-divestiture competition situation in the market.

1811 See: Balto (n 313).

1812 Oldale (n 856) 1. 


\section{Research Limitations and Suggestions for Future Research}

\subsection{Law and Economics Analysis}

Limitations

Law and economics theories were employed in this book to assess the effectiveness of US and EU divestiture policies. Moreover, theoretical solutions are presented, based on this analysis in order to increase the effectiveness of divestitures. The limitation, however, is that the assessment of effectiveness can be inaccurate to some extent due to the uncertainties in the market.

It has been pointed out in Chapter 9 that merger remedies are tools for the CAs to steer the markets based on their predictions of the future development of the markets. However, the markets change quickly, resulting in large uncertainties in the realisation of the merger remedies' expected goals. On the one hand, such uncertainties in merger review and merger remedies do not imply that it is unjustified and impossible for the CAs to make such predications. It is believed that the negative impact resulting from uncertainties can be reduced by various solutions, such as increasing the scientific creditability of the merger reviews' substantive tests, or by applying different risk-reducing provisions to increase the requisite degree of certainties in merger remedies. On the other hand, these uncertainties can bring difficulties in assessing whether or to what extent these risk-reducing provisions can effectively reduce the resulting negative effects. In other words, although this research suggests several theoretically effective solutions to reduce divestiture risks, the accuracy of these analyses can be inaccurate to some extent considering the uncertainties.

\section{Future Research}

It is pointed out that economics is playing an increasingly important role in competition law inquiries. ${ }^{1813}$ In the future research, a more economic approach could be taken to assess the effectiveness, possibly also the efficiency of a merger remedy by taking into account more practical factors, such as the uncertainties in the markets.

In fact, the efficiency of a merger remedy can be relevant to the choice between behavioural remedies and structural remedies. In addition to merger divestitures, behavioural remedies can also be appropriate in certain situations. ${ }^{1814}$ A suitable remedy can optimise the resources between the merged firm, the consumer and other market players. Thus, the future research could attach its attention also to behavioural remedies in addition to divestitures from an economic perspective.

\subsection{Empirical Study}

\section{Limitation}

Both reputable lawyers with their expertise in competition law and competition law professors were invited to join the interviews in order to obtain empirical evidence regarding MOFCOM's practice in merger review and merger remedy. The empirical study could be further enriched if representatives from the merged firms whose transactions were approved subject to divestitures could take part in the interviews.

\footnotetext{
1813 Bishop and Walker (n 10) 2.

1814 The analysis regarding the situations where a behavioural remedy can be more appropriate than divestitures, see: Chapter 5, sec.4.3.
} 
Information from those representatives can be important to assess the appropriateness of MOFCOM's merger remedies. Such approach can be helpful to find out the obstacles in realising the expected aims of merger remedy which may be unobservable from the perspective of lawyers, professors, or MOFCOM. During the preparations of interviews, attempts have been made to invite these representatives, but no reply was received. Despite this, the observations in this book are still valid from the perspective that at least they reflect those senior competition law lawyers and academics' opinions of China's merger remedies, which are rather important to understand and explore merger divestitures in China.

\section{Future Research}

An empirical study can provide important insights into the effectiveness of the merger remedies in China. Such a methodology could be used in my future research to not only further explore merger control and merger remedy policies in China, but also to study competition law or merger control laws in other jurisdictions. A quantitative empirical study can be adopted, such as a large sample survey or coded law cases, to assess the efficiency of merger divestiture or to study the relevant legal system in some jurisdictions.

Furthermore, an event study can be used to e.g. statistically assess the impact of an event on the CA's practice in merger control. For example, the event of the publication of an industrial policy in China may to some extent have an impact on MOFCOM's decisions about some transactions concerning a particular industry.

\subsection{Comparative Study}

\section{Limitation}

One of the findings in this research is that divestitures are preferred by the CAs in the US and the EU, while behavioural remedies are prevalent in China. Although in Chapter 13, reasons for the prevalence of behavioural remedies have been presented, due to the limitation of length of this book, there are no further analyses that have been conducted on why the situations are so different in these jurisdictions.

\section{Future Research}

It can be interesting to study the above-mentioned questions from a legal-historical perspective. This book observed that the development of competition law and merger review is closely relevant to the development of a country's economy (at least in the US, EU and China). This is especially true in China, where the transition of the economy from a centrally-planned market to a social market economy is happening. Exploring the abovementioned questions from a historical perspective can provide an interesting perspective to understand the differences of merger control systems in different jurisdictions.

Further, another question regarding such differences is, do these differences arise because China is an Asian country? To answer this question, a detailed inter-Asia comparative study could also be interesting to see how other Asian countries practice merger review and merger remedies and what are the similarities and differences between China and other Asian counties, such as Japan, South Korea or Singapore. 

EPILOGUE 

In 2008, the year of the enactment of the anti-monopoly law in China, the eyes of the entire world were focused on China, wondering how China would bring its competition law into practice. China itself was also looking towards the world. China more particularly focused on the EU as well as on the US. It partially transplanted US and EU legislation into its own competition law, but re-contextualising the contents of EU and US law to the particular institutional features of China. This historical influence of the EU and the US is noticeable in the institutional design and legal wording of China's anti-monopoly law, and also in the domain central to this book of merger control. Meanwhile the anti-monopoly law has grown out of its infancy stage and has (almost) reached its $10^{\text {th }}$ anniversary.

The question which was central to this book was to what extent the merger remedies that are available and used in practice in China can contribute to one of the central aims of Article 1 of the anti-monopoly law, being the transition of China's economy towards a socialist market economy. The analysis in this book showed that to a large extent the application of the merger remedies in China is in line with similar experiences in the US and in the EU. It is, moreover, important to stress that especially with a view on potential reforms, one should always be careful with regard to solutions in the EU and the US as "models" for China. Precisely because the institutional settings are so different, blind transplants may not always lead to the desirable results. The relevant question for this book was rather whether the way the merger remedies are applied in China in practice contributes to serving the goals of the anti-monopoly law. The reader may have noticed that it is not easy to provide a straight-forward answer to that question. On the one hand, the general impression that one gets, also from interviews with privileged witnesses and experts, is that MOFCOM is taking its tasks very seriously and trying to achieve the aims of the AML. Also as far as the merger remedies imposed in practice are concerned, one can observe that MOFCOM has been taking important steps in improving the application of those remedies. On the other hand, as was indicated above in this concluding chapter, there still are a lot of important questions that arise, more particularly with respect to the application of merger remedies in China. It is more particularly for that reason that specific recommendations and improvements were formulated.

Of course an equally interesting question is how the application of merger remedies in China might be expected to evolve in the (near) future. It has often been said that China has been in a mode of transition since the rising to power of Deng Xiaoping in 1978. This implies that this transition mode has now already lasted for almost 40 years. As a result, the building of the socialist market economy has almost come to its completion. The question that was central to this book is what the specific role was of merger control and more particularly merger remedies in promoting this march towards the market economy in China. Obviously in this respect merger control can be considered as an important instrument in the hands of the government, more particularly the competition authorities, to steer the economy in the direction of a market economy. Although competition authorities clearly desire to use the instruments available to them to further the market economy it was equally shown that the competition authorities encounter serious difficulties in reaching that goal. The competition authorities, just like the parties themselves, have to act with limited information (and often with limited capacity as well). In addition, formulating merger remedies supposes that the government is able to make predictions on how those merger remedies may work out in the market. This to some extent requires the competition authorities to look into the symbolic crystal ball which obviously is difficult, if not impossible. To some extent competition authorities are therefore unavoidably engaging in a trial and error process. However, we could also notice in the literature, and also in the other jurisdictions examined, that there are clear attempts 
to rationalize this trial and error process in order to increase the effectiveness of the steering exercised by the competition authorities.

The fundamental question of this book was therefore whether the government is at all able to use the available instruments (and more particularly merger remedies) to effectively steer the behaviour of market participants. In that respect we made clear that there are still many questions that arise concerning the effectiveness of the approach followed by the competition authorities. One of the tools to answer remaining questions may be to engage much more strongly than is currently the case in different types of empirical research. There is in fact a lot of scope for empirical research, also in China. It only requires a fundamental change of attitude, especially among government bureaucracies. One now can often notice a hostile attitude of bureaucracies, often scared and as a result unwilling to collaborate with academics, fearing that it may endanger their position and interests.

We posit that government authorities in China, such as the merger control authority MOFCOM, can learn from academic exercises like this one and may equally benefit from a stronger collaboration with academics. It can be hoped that in the future Chinese bureaucracies like MOFCOM show a more open attitude and increase their willingness to collaborate with academics. If they share information and data, this can obviously be in the mutual interest of both and in the end also increase the effectiveness of merger remedies in China.

This book addressed the effectiveness of merger remedies in China, from the angle of the US and the EU. This angle was a particularly interesting one from an historical perspective as the EU and the US also inspired the AML. It can be assumed that at some moment and probably sooner rather than later, the transition towards a market economy in China will be completed. That of course raises the interesting question whether China at that moment has completely assimilated with Western economies like the US and Europe. And if that question would be answered affirmatively an equally interesting question is whether it has a different approach than other Asian countries. For that matter it could be equally interesting to take a different perspective than was taken in this book, being to look at merger remedies as they are applied in other Asian countries as well. In other words, an equally interesting topic that will undoubtedly be on the future research and policy agenda is whether it is possible to learn from other Asian countries (which to some extent are perhaps more comparable to China than the US or the EU). Such a comparison can equally contribute to answering the fascinating question how the government in China can use legal remedies to steer the behaviour of market participants towards greater efficiency. 


\section{VALORISATION ADDENDUM}





\section{Social Relevance of the Research}

When we discuss a merger review system, in most cases, we are actually trying to answer this question from two perspectives: how the system eliminates potential competition issues, such as price increases (typical unilateral-effects) or collusion (typical coordinatedeffects), on the one hand, 1815 and how it preserves potential merger-specific efficiencies, such as rationalisation of production or technological progress, on the other hand. ${ }^{1816}$ Merger remedies are evidently an important part of the merger review system, which changes the binary character of merger review decisions and makes it possible to draw a balance between the preservation of possible efficiencies and the elimination of anticompetitive effects. An effective merger remedy should have the capability of restoring the lost competition caused by the notified mergers to the concerned market and realising the aims of competition law.

MOFCOM is a young competition agency regarding the enforcement of merger control. Its practice in merger divestitures is limited. The available information regarding its practice is also rather limited. Thus, studying its practice in merger divestitures is difficult. Despite this, the research still tried to overcome these obstacles. For MOFCOM, it is very important to learn from other jurisdictions' practice in merger review and to ensure that the merger remedies imposed can serve the aims of the AML. Accordingly, this book has its social relevance.

First, this research answered the question what are the merger divestiture policies in the US and the EU and what are the main similarities and differences between them? As pointed out, it can be easier and more efficient for China's decision-makers to learn from other jurisdictions when building its legislation in a certain field rather than creating a completely new one. ${ }^{1817}$ Moreover, legal borrowing is also one of the solutions that MOFCOM can take to solve the problems that it is facing regarding the merger review enforcement.

Second, in this book, divestiture risks were analysed from the perspective of law and economics to explore the reasons for their occurrence and the theoretical solutions to reduce such risks. Although the use of divestitures in China is limited, those divestiture risks can also occur in China. Therefore, attention should be paid to reduce the divestiture risks and the ideal solutions observed from the law and economics perspective can provide an important perspective for MOFCOM to improve enforcement in divestitures.

Third, this book assessed MOFCOM's divestiture policies from a comparative law and economics perspective. It observed that China has a totally different competition culture compared to the US and the EU and it is experiencing a transition economy. Accordingly, improvements should be made based on law and economics theory and references can be made to US and EU practice when appropriate, taking into China's special national conditions.

Fourth, although the aim of this book is to assess the effectiveness of MOFCOM's merger divestitures policies in realising the aim of the AML, it can also be relevant to other countries by learning from the law and economics analyses or from the comparative study of divestiture policies in the US and the EU. These lessons can provide insight for the CAs in other counties to improve their enforcement in divestitures.

\footnotetext{
${ }^{1815}$ For the competition concerns caused by mergers, see: Chapter 5, sec.3.1.

${ }^{1816}$ For the possible efficiencies generated from mergers, see: Chapter 5, sec.3.2.

1817 Gerber (n 81) 315.
} 


\section{Target Groups for the Research Results}

Various groups may be interested in the research results. The first group can be academics, especially those who have their expertise in competition law or law and economics. This research adds value to law and economics research by analysing the possible risks that could occur in divestitures from a law and economics perspective and further assess the effectiveness of China's divestiture policies in realising the AML's aims from a comparative law and economics perspective.

Second, the research results are also of great importance to Chinese policy makers. They can not only learn from the comparative analysis in this research about how the CAs in other jurisdictions (the US and the EU) deal with divestiture risks, but also learn from the law and economics analyses regarding the reasons for the occurrence of divestiture risks and the possibly effective solutions. Chinese policy makers should be aware that the design and implementation of an effective divestiture can be quite technical and strategic. Therefore, law and economics theory should be taken into account when re-contextualising legal plants in the context of China.

Third, companies, especially those global companies, can also obtain good insights from this research. Briefly speaking, this research reveals that in China, behavioural remedies are used more frequently than divestitures. In addition, different strategies have been used by MOFCOM in divestitures to reduce possible risks. These observations and findings can be helpful for the merging parties to get prepared during remedy negotiations with MOFCOM and formulate their merger remedy proposals in a way that can address MOFCOM's competition concerns as well as satisfy MOFCOM's standards and preferences for merger remedies. Furthermore, it is quite common that global transactions have to be notified in several jurisdictions. In addition to the US and the EU, China is becoming one of the most important jurisdictions as far as the pre-merger notification is concerned. Accordingly, this research enables these companies to have comprehensive knowledge with regard to the merger review procedures and merger divestitures policies in these three jurisdictions.

Fourth, competition law (especially M\&A) lawyers, practitioners, or other legal professions can be interested in this research too. Knowledge of the practice and case law in several jurisdictions can be important for this group of readers. Thus, the case analyses of merger divestitures in the US, the EU and China in this research can provide them with good insights.

\section{Concrete Products, Services, Processes and Activities into which the Research Results will be Translated and Shaped}

First, the research results will be published as a book. The book will present a comprehensive analysis of merger divestitures in the US and the EU, an analysis of risks that can occur in divestiture from a law and economics perspective, and an assessment of China's merger review legislation and MOFCOM's practice in merger divestitures from a comparative law and economics perspective.

Second, some parts of the research results have been published in different forms. For example, Merger Divestitures under the Dual Enforcement Mechanism: Whether A Convergence Exists between the FTC and the DOJ was published in Whittier Law Review, Volume 37, Number 2 (2015). 
Third, some preliminary results of this research were presented at different conferences and seminars. For example, the seminars held by Ius Commune Research School in Leuven and Utrecht, and the $6^{\text {th }}, 7^{\text {th }}$ and $8^{\text {th }}$ Joint Seminars of the Future of Law and Economics.

\section{Innovation of the Research}

This research has innovations in mainly two aspects. First, law and economics theory is applied to explore the reasons for the occurrence of compositions risks, asset risks and collusion risks of merger remedies and ideal solutions were proposed to reduce those risks. Furthermore, divestiture policies in the US and the EU were assessed from law an economics perspective to analyse their effectiveness in alleviating the above-mentioned divestiture risks. Although law and economics theory concerning information asymmetry (mainly hidden characteristics) has been applied in the analysis of merger remedies, ${ }^{1818}$ to my knowledge, there seems to be no literature which analyses the effectiveness of using risk-reducing provisions as screening devices to reduce composition risks in divestitures. Similarly, there seems to be no literature which applies moral hazard theory in merger divestitures to reduce asset risks or analyses how to reduce collusion risks between the merged firm and the buyer of the divested assets in the context of merger divestitures. ${ }^{1819}$ This research filled the gaps in the above-mentioned fields and pointed out that composition/assets/collusion risks in divestitures that can be caused by asymmetric information and post-divestiture collusion can be effectively reduced by certain divestiture strategies (if those strategies are designed and implemented appropriately).

The second aspect of the innovation of this research is that it systematically explored China's merger review system and MOFCOM's practice in merger remedies (mainly divestitures) by reviewing all relevant legislation, studying all the up-to-date divestitures remedies in the published conditionally-approved cases and interviewing lawyers and professors to obtain empirical insights. After comprehensively exploring China's merger review and divestiture policies, a comparative law and economics analysis was conducted to evaluate the effectiveness of China's divestiture policies. Although there is quite a lot of literature which studies China's merger review system from a comparative perspective, the amount of literature regarding China's merger remedies is limited. Furthermore, to my knowledge, there seems no literature that assesses the effectiveness of MOFCOM's divestiture policies from a comparative law and economics perspective.

\section{Schedule and Implementation of the Research Results}

First, presentations at conferences or seminars can be the ideal channel to make the results of this research available to a wide audience, especially the policy makers, academics and legal professions. Such conferences or seminars are generally academic ones, which mean that more peer reviews and opinions can be obtained for further improvements.

\footnotetext{
${ }^{1818}$ For a detailed literature review in this regard, see: Chapter 6, Literature Review.

${ }^{1819}$ For a detailed literature review regarding the application of moral hazard in competition law, see: Chapter 7, Literature Review. For a detailed literature review concerning the economics of collusion or collusion in merger divestitures, see: Chapter 8, Literature Review.
} 
Second, considering the fast development of the internet and the changing reading habits of the public, e-newspapers or blogs can be a good choice to make the research results reach wider public audiences.

Last but not least, companies or other groups who are of relevance to this research results can be provided with a handbook or brochures which briefly introduce China's merger review system and MOFCOM's practice in merger remedies. 


\section{LIST OF CASES}

\section{China}

1. MOFCOM Public Notice 2008/95: Conditional Approval for the Notified Merger -InBev/AB (MOFCOM Decision) [18 November 2008]

2. MOFCOM Public Notice 2009/28: Conditional Approval for the Notified Merger - Mitsubishi Rayan/Lucite (MOFCOM Decision) [24 September 2009]

3. MOFCOM Public Notice 2009/77: Conditional Approval for the Notified Merger - Pfizer/Wyeth (MOFCOM Decision) [29 September 2009]

4. MOFCOM Public Notice 2009/82: Conditional Approval for the Notified Merger - Panasonic/Sanyo (MOFCOM Decision) [30 October 2009]

5. MOFCOM Public Notice 2011/90: Conditional Approval for the Notified Merger - Seagate/Samsung HDD (MOFCOM Decision) [12 December 2011]

6. MOFCOM Public Notice 2012/09: Conditional Approval for the Notified Merger- Western Digital/Hitachi Vivit (MOFCOM Decision) [2 March 2012]

7. MOFCOM Public Notice 2012/35: Conditional Approval for the Notified Merger -UTC/Goodrich (MOFCOM Decision) [15 June 2012]

8. MOFCOM Public Notice 2013/20: Conditional Approval for the Notified Merger- Glencore/Xstrata (MOFCOM Decision) [16 April 2013]

9. MOFCOM Public Notice 2013/22: Conditional Approval for the Notified Merger Marubeni/Gavilon (MOFCOM Decision) [24 April 2013]

10. MOFCOM Public Notice 2013/58: Conditional Approval for the Notified Merger - Baxter/Gambro (MOFCOM Decision) [13 August 2013]

11. MOFCOM Public Notice 2013/61: Conditional Approval for the Notified Merger- Mediatek Inc./Mstar (MOFCOM Decision) [27 August 2013]

12. MOFCOM Public Notice 2014/03: Conditional Approval for the Notified Merger - Thermo Fisher/Life Tech (MOFCOM Decision) [15 January 2014]

13. MOFCOM Public Notice 2014/24: Conditional Approval for the Notified Merger - Nokia/Microsoft (MOFCOM Decision) [8 April 2014]

14. MOFCOM Public Notice 2014/30: Conditional Approval for the Notified Merger - Merck/AZ (MOFCOM Decision) [30 April 2014]

15. MOFCOM Public Notice 2014/46, Moller-Maersk/MSC Mediterranean/CMA CGM (MOFCOM Decision) [17 June 2015]

16. MOFCOM Public Notice 2015/02: Cancellation of Partial Restrictive Conditions in Motorola/Google Case (MOFCOM Decision) [19 January 205]

17. MOFCOM Public Notice 2015/41: Alterations of the Restrictive Conditions in West Digital/Hitachi Vitit Case (MOFCOM Decision) [19 October 2015]

18. MOFCOM Public Notice 2015/43: Alterations of the Restrictive Conditions in Seagate/ Samsung HHD Case (MOFOCM Decision) [22 October 2015].

19. MOFCOM Public Notice 2015/64: Conditional Approval for the Notified Merger- NXP/Freescale (MOFCOM Decision) [27 November 2015]

20. MOFCOM Public Notice 2016/23: Cancellation of the Restrictive Conditions in Walmart/Niuhai Holding Case (MOFCOM Decision) [8 June 2016]

21. MOFCOM Public Notice 2016/38: Conditional Approval for the Notified Merger - AB InBev/SABMiller (MOFCOM Decision) [29 July 2016] 
22. MOFCOM Public Notice 2016/88: Conditional Approval for the Notified Merger - Abbott/St. Jude Medical (MOFCOM Decision) [30 December 2016]

23. MOFCOM Public Notice 2017/25: Conditional Approval for the Notified Merger - Dow/E. I. Du Pont (MOFCOM Decision) [2 May 2017]

24. MOFCOM Public Notice 2009/22, Prohibition on Merger - Huiyuan Fruit Juice/Coca-Cola (MOFCOM Decision) [18 March 2009]

\section{EU}

1. Case 6-72, Europemballage Corporation and Continental Can Company Inc. v Commission of the European Communities (Judgement of the European Court of Justice) [21 February 1973]

2. Case C-12/03, Commission v. Tetral Laval BV (Judgement of the European Court of Justice) [15 February 2005]

3. Case C-327/91, French Republic v Commission of the European Communities (Judgment of the Court) [9 August 1994]

4. Case C-440/07P, Schneider Electric SA v. Commission (Judgement of the European Court of justice) [16 July 2009]

5. Case COMP/M.5355 -BASF/ CIBA (European Commission Decision) [12 March 2009]

6. Case COMP/M.2060, Bosch/Rexroth (European Commission Decision) [2 December 2000]

7. Case COMP/M.1892, Sare Lee/Courtaulds (European Commission Decision) [8 May 2000]

8. Case COMP/M.2220, General Electric/ Honeywell (European Commission Decision) [3 July 2011]

9. Case COMP/M.2337, Nestle/Ralston Purina (European Commission Decision) [27 July 2001]

10. Case COMP/M.5152, Posten AB / Post Danmark A/S (European Commission Decision) [21 April 2009]

11. Case COMP/M.5253, Sanofi-Aventis/Zentiva (European Commission Decision) [4 February 2009]

12. Case COMP/M.5476, Pfizer/Wyeth (European Commission Decision) [17 July 2009]

13. Case COMP/M.1990, Unilever/Bestfoods (European Commission Decision) [28 September 2000]

14. Case COMP/M.6410, UTC/ Goodrich (European Commission Decision) [26 July 2012]

15. Case COMP/M.6905, INEOS / SOLVAY / JV (European Commission Decision) [8 May 2014]

16. Case COMP/M.6944, Thermo Fisher Scientific/Life Technologies (European Commission Decision) [26 November 2013]

17. Case COMP/M.2050, Vivendi/Canal+/Seagram (European Commission Decision) [13 October 2000]

18. Case IV/M.603, Crown Cork \& Seal/CarnaudMetalbox (European Commission Decision) [23 March 1996]

19. Case IV/M.623, Kimberley/Scott (European Commission Decision) [16 January 1996]

20. Case IV/M.938, Guinness/Grand Metropolitan (European Commission Decision) [5 October 1997]

21. Case IV/M190, Nestle/Perrier (European Commission Decision) [22 July 22 1992]

22. Case T-2/93, Air France v. Commission of the European Communities (Judgment of the Court of First Instance) [ 19 May 1994]

23. Case T-102/96, Gencor v. Commission (Judge of the Court of First Instance) [25 March 1999]

24. Case T-156/98, RJB Mining v Commission of the European Communities (Judgment of the Court of First Instance) [31 January 2001]

25. Case T-210/01, General Electric Co. v Commission of the European (Judgement of the Court of First Instance) [14 December 2005]

26. Case T-351/03, Schneider Electric SA v Commission of the European Communities (Judgement of the Court of the First Instance) [11 July 2007]

27. Case T-77/02, Schneider/Legrand (COMP/M.2283) (European Commission Decision) [30 January 2002]

28. Case T-87/05, Energias de Portugal SA (EDP) v. Commission of the Europea'(Judgement of the Court of First Instance) [21 September 2005]

29. Joint Cases C-68/94 and C-30/95, French Republic and Société commerciale des potasses et de l'azote (SCPA) and Entreprise minière et chimique (EMC) v Commission of the European Communities ("Kali und Salz") (Judgement of the Court of Justice) [31 March 1998] 
1. Bd. of Trade of Chi. v. United States, 246 U.S. 231 (1918)

2. Broadcast Music Inc. v. Columbia Broadcasting Systems, Inc., 441 U.S. 1 (1979)

3. Brown Shoe Co. v. United States, 370 U.S. 294 (1962)

4. Business Electronics v. Sharp Electronics, 485 U.S. 7178 (1988)

5. California v. Am. Store Co., 495 U.S. 271(1990)

6. Cascade Nat. Gas Corp. v. El Paso Nat. Gas Co., 386 U.S. 129 (1967)

7. Cont'l T.V. Inc. v. GTE Sylvania, Inc., 433 U.S. 36 (1977)

8. Continental T.V. Inc. v. GTE Sylvania, Inc., 433 U.S.36 (1977)

9. Fed. Trade Comm'n v. Arch Coal, Inc., 329 F. Supp. 2d 109 (D.D.C. 2004)

10. Fed. Trade Comm'n v. Cardinal Health, Inc., 12 F. Supp. $2 d 34$ (D.D.C. 1998)

11. Ford Motor Co. v. United States, 405 U.S. 562 (1972)

12. FTC Dockt. No. C-3990 Glaxo/SmithKline Beecham (FTC Decision and Order) [18 December 2000]

13. FTC Docket No. C-4151, Procter \& Gamble and Gillette Company (FTC Letter Approving the Divestitures) [28 April 2006]

14. FTC File No. 1410168, Reynolds/Lorillard, In the Matter of Reynolds American Inc., a corporation, and Lorillard, Inc., a corporation (FTC Decision and Order) [31 July 2015]

15. FTC v. Arch Coal, Inc., 329 F. Supp. 2d 109 (D.D.C. 2004)

16. FTC v. Libbey, Inc., 211 F. Supp. $2 d 34$ (D.D.C. 2002)

17. International Shoe Co v Federal Trade Commission, 280 U.S. 291 (1930).

18. N. Sec. Co. v. United States, 193 U.S. 197 (1904)

19. NCAA v. Board of Regents of University of Oklahoma, 468 U.S. 85 (1984)

20. Northern Sec. Co. v. United States, 193 U.S. 197 (1904)

21. Northwest Wholesale Stationers, Inc. v. Pacific Stationery and Printing Co., 472 U.S. 284 (1985)

22. Standard Oil Co. of N.J. v. United States, 221 U.S. 1(1911)

23. Tampa Elec. Co. v. Nashville Coal Co., 365 U.S. 320 (1961)

24. Unites States v. Aluminium Co. of America, 148 F. 2d 416 (1945)

25. United States v. Am. Tobacco Co., 221 U.S. 106 (1911)

26. United States v. Anheuser-Busch InBev SA/NV and SABMiller, Case 1:16-cv-01483 (2016)

27. United States v. Cont'l Can Co., 1964 Trade Cases 80 (S.D.N.Y. 1964)

28. United States v. Cont'l Can Co., 378 U.S. 441 (1964)

29. United States v. Crescent Amusement Co., 323 U.S. 173 (1944)

30. United States v. E.I. du Pont de Nemours \& Co., 366 U.S. 316 (1961)

31. United States v. El Paso Nat. Gas Co., 291 F. Supp. 3 (D. Utah 1968)

32. United States v. El Paso Nat. Gas Co., 376 U.S. 651 (1964)

33. United States v. El Paso Nat. Gas Co., 465 F. Supp. 249 (D. Colo. 1978)

34. United States v. Microsoft Corp., 159 F.R.D. 318 (D.D.C. 1995).

35. United States v. Microsoft Corp., 56 F.3d 1448 (D.C. Cir. 1995)

36. United States v. Nat'l Lead Co., 332 U.S. 319 (1947)

37. United States v. Pabst Brewing Co., 384 U.S. 546 (1966)

38. United States v. Philadelphia National Bank, 374 U.S. 321 (1963)

39. Utah Pub. Serv. Comm'n v. El Paso Nat. Gas Co., 395 U.S. 464 (1969) 



\section{LIST OF LEGISLATION}

\section{China}

Law

1. Standing Committee of the National People's Congress, Anti-Monopoly Law of the People's Republic of China (zhong hua ren min gong he guo fan long duan fa 中华人民共和国反垄断法) (Adopted 30 August 2007, entered into force 1 August 2008)

2. Standing Committee of the National People's Congress, Anti-Unfair Competition Law of the People's Republic of China (zhong hua ren min gong he guo fan bu zheng dang jing zheng fa 中华人民共和国 反不正当竞争法) (Adopted 2 September 1993, entered into force 1 December 1992)

3. Standing Committee of the National People's Congress, Bidding Law of the People's Republic of China (zhong hua ren min gong he guozhao biao tou biao fa 中华人民共和国招标投标法) (Adopted 30 August 1999, entered into force 1 January 2000)

4. Standing Committee of the National People's Congress, Price Law of the People's Republic of China (zhong hua ren min gong he guo jia ge fa 中华人民共和国价格法) (Adopted 29 December 1997, entered into force 1 May 1998)

\section{Other Legal Documents}

1. Anti-Monopoly Bureau of the Ministry of Commerce, Measures for the Undertaking Concentration Declaration (jing ying zhe ji zhong shen bao ban fa 经营者集中申报办法) (Issue 11 November 2009, entered into force 1 January 2010)

2. Anti-Monopoly Bureau of the Ministry of Commerce, Guiding Opinions of the Anti-Monopoly Bureau of the Ministry of Commerce on Declaration of Simple Cases of Concentration of Undertakings (for Trial Implementation) (guan yu jing ying zhe ji zhong jian yi an jian shen bao de zhi dao yi jian (shi xing) 关于经营者集中简易案件申报的指导意见(试行)) (Issued and entered into force 18 April 2014)

3. Anti-Monopoly Bureau of the Ministry of Commerce, Guiding Opinions on Declaring the Concentration of Undertakings ((guan yu jing ying zhe ji zhong shen bao de zhi dao yi jian 关于经营 者集中申报的指导意见) (Issued and entered into force 6 June 2014)

4. Anti-Monopoly Bureau of the Ministry of Commerce, Measures for the Undertaking Concentration Examination (jing ying zhe ji zhong shen cha ban fa 经营者集中审查办法) (Issued 24 November 2009, entered into force 1 January 2010)

5. Anti-Monopoly Committee of the State Council, Guide of the Anti-Monopoly Committee of the State Council for the Definition of the Relevant Market (guo wu yuan fan long duan wei yuann hui guan yu xiang guan shi chang jie ding de zhi nan 国务院反垄断委员会关于相关市场界定的指南) (Issued and entered into force 24 May 2009)

6. Ministry of Commerce, Implementation Measures for Administrative Reconsideration of the Ministry of Commerce (shang wu bu xing zheng fu yi shi shi ban fa 商务部行政复议实施办法) (Adopted 9 April 2001, entered into force 1 July 2004) 
7. Ministry of Commerce, Interim Measures for Investigating and Handling Failure to Legally Declare the Concentration of Undertakings (wei yi fa shen bao jing ying zheji zhong tiao cha chu li zan xing ban fa 未依法申报经营者集中调查处理暂行办法)' (Issued 30 December 2011, entered into force 1 February 2012)

8. Ministry of Commerce, Interim Provisions on Implementing the Divestitures of Assets or Business under Mergers Control (guan yu shi shi jing ying zhe ji zhong zi chan huo ye wu bo li de zan xing gui ding 关于实施经营者集中资产或业务剥离的暂行规定) (Issued and entered into force 5 July 2010, repealed 5 January 2015)

9. Ministry of Commerce, Interim Provisions on Standards Applicable to Simple Cases of Concentration of Undertakings (guan yu jing ying zhe ji zhong jian yi an jian shi yong biao zhun de zan xing gui ding 关于经营者集中简易案件使用标准的暂行规定) (Issued 11 February 2014, entered into force 12 February 2014)

10. Ministry of Commerce, Interim Provisions on the Assessment of the Effect of the Concentrations of Undertakings on Competition (guan yu ping gu jing ying zhe ji zhong ying xiang de zan xing gui ding 关于评估经营者集中竞争影响的暂行规定) (Issued 29 August 2011, entered into force 5 September 2011)

11. Ministry of Commerce, Provisions on Imposing Restrictive Conditions on Concentrations of Undertakings (for Trial Implementation) (jing ying zhe ji zhong fu jia xian zhi xing tiao jian de gui ding (shi xing) 经营者集中附加限制性条件的规定（试行）) (Adopted 04 December 2014, entered into force 5 January 2015)

12. Ministry of Commerce, Provisions on the Takeover of Domestic Enterprises by Foreign Inverstors (2006 Revision) (guan yu wai guo tou zi zhe bing gou jing nei qi ye de gui ding 关于外国投资者并购 境内企业的规定) (Adopted 8 August 2006, entered into force 8 September 2006)

13. Ministry of Commerce, The Ministry of Commerce's Decision on Revising $<$ Provisions on the Takeover of Domestic Enterprises by Foreign Investors > (shang wu bu guan yu xiu gai < (guan yu wai guo tou zi zhe bing gou jing nei qi ye de gui ding $>$ de jue ding 商务部关于修改 <关于外国投资者 并购境内企业的规定 $>$ 的决定(Adopted and entered in force 22 June 2009)

14. Ministry of Foreign Trade \& Economic Cooperation \& State Administration for Industry \& Commerce, Provisions for the Alteration of Investors' Equities in Foreign-funded Enterprises: Provisions for the Alteration of Investors' Equities in Foreign-funded Enterprises (wai shang tou zi qi ye tou zi zhe gu quan bian geng de ruo gan gui ding 《外商投资企业投资者股权变更的若干规定 $\gg$ (Issued and entered in force 28 May 1997)

15. National Development \& Reform Commission, Interim Provisions on Preventing the Acts of Price Monopoly (zhi zhi jia ge long duan xing wei de zan xing gui ding 制止价格垄断行为暂行规定) (Adopted 18 June 2003, entered into force 1 November 2003)

16. State Administration for Industry \& Commerce, Certain Regulations on Prohibiting anticompetitive practices of Public Enterprises (guan yu jin zhi gong yong qi ye xian zhi jig zheng xing wei de ruo gan gui ding 关于禁止公用企业限制竞争行为的若干规定) (Adopted and entered into force 24 December 1993)

17. State Council of the People's Republic of China, Provisions of the State Council On Prohibiting Regional Blockade in Market Economic Activities (guo wu yuan guan yu jing zhi zai shi chang jing ji huo dong zhong shi xing di qu feng suo de gui ding 国务院关于禁止在市场经济活动中实行地区 封锁的规定) (Adopted and entered into force 21 April 2001, revised 8 January 2011)

18. State Council of the People's Republic of China, Provisions of the State Council on Thresholds for Prior Notification of Concentration of Undertakings (guo wu yuan guan yu jing ying zhe ji zhong shen bao biao zhun de gui ding 国务院关于经营者集中申报标准的规定) (Issued and entered into force 3 August 2008)

19. State Council of the People's Republic of China, Provisions Rules on the Development and Protection of Socialist Competition (guo wu yuan guan yu kai zhan he bao hu she hui zhu yi jing zheng de zan xing gui ding 国务院关于开展和保护社会主义竞争的暂行规定) (Adopted and entered into force 17 October 1980, repealed 6 October 2001)

20. State Council of the People's Republic of China, Regulations on the Administration of Advertising (guang gao guan li tiao li 广告管理条例) (Adopted 26 October 1987, entered in force 1 December 1987) 


\section{EU}

\section{Treaty}

1. Treaty Establishing the European Coal and Steel Community created the European Coal and Steel Community [1952]

2. Treaty on the Functioning of the European Union [2007] OJ C326/47

\section{European Council Regulations}

1. Council Regulation (EC) No 1310/97 of Amending Regulation (EEC) No 4064/89 on the Control of Concentrations between Undertakings [1997] OJ L180

2. Council Regulation (EC) No 139/2004 on the Control of Concentration between Undertakings [2004] OJ L24

3. Council Regulation (EEC) No 4064/89 on the Control of Concentrations between Undertakings [1989] OJ L395

4. EEC Council: Regulation 17/62: First Regulation Implementing Articles 85 and 86 of the Treaty [1962] OJ 13

\section{Other Legal Documents}

1. Agreement between the European Communities and the Government of the United States of America on the Application of Positive Comity Principles in the Enforcement of Their Competition Laws [1998] OJ L173

2. Agreement between the Government of the United States of America and the Commission of the European Communities Regarding the Application of Their Competition Laws - Exchange of Interpretative Letters with the Government of the United States of America [1995] OJ L95

3. Commission Consolidated Jurisdictional Notice under Council Regulation (EC) No 139/2004 on the Control of Concentrations between Undertakings [2008] OJ C95/01

4. Commission Notice on a Simplified Procedure for Treatment of Certain Concentrations under Council Regulation (EC) No 139/2004 [2013] OJ C366

5. Commission Notice on A Simplified Procedure for Treatment of Certain Concentrations under Council Regulation (EEC) No 4064/89 [2000] OJ C207

6. Commission Notice on Remedies Acceptable under Council Regulation (EEC) No. 4064/89 and under Commission Regulation (EC) 447/98 [2001] OJ C68

7. Commission Notice on Remedies Acceptable under Council Regulation No 139/2004 and under Commission Regulation No 802/2004 [2008] OJ C267

8. Commission Regulation (EC) No. 802/2004 of 7 April 2004 Implementing Council Regulation (EC) No. 139/2004 on the Control of Concentration between Undertakings [2004] OJ L133

9. DG COMP European Commission, Merger Remedies Study (2005)

10. DG COMP European Commission: Best Practices on the Conduct of EC Merger Control Proceedings (2004)

11. DG COMP, European Commission, Best Practice Guidelines: The Commission's Model Texts for Divestiture Commitments and the Trustee Mandate under the EC Merger Regulations (2003)

12. DG COMP, European Commission, Best Practice Guidelines: The Commission's Model Texts for Divestiture Commitments and the Trustee Mandate under the EC Merger Regulation (2013)

13. Guidelines on the Assessment of Horizontal Mergers under the Council Regulation on the Control of Concentrations between Undertakings [2004] OJ C31/03

14. Guidelines on the Assessment of Non-Horizontal Mergers Under the Council Regulation on the Control of Concentrations between Undertaking [2008] OJ C265/07.

15. Notes on Council Regulation (EEC) 4064/89[1998]

16. Rules of procedure of the General Court (2015) OJ L105

17. US-EU Merger Working Group: Best Practices on Cooperation in Merger Investigations (2011) 


\section{UK}

1. UK Competition Commission, Merger Remedies: Competition Commission Guidelines (November 2008)

\section{US}

Act

1. 15 U.S.C.A. $\iint 1-3$ (West 2004)

2. 15 U.S.C.A. $\iint 4-7$ (West 2015)

3. 16 C.F.R. $\int 801.1(2013)$

4. 16 C.F.R. $\int 802.1(2005)$

5. 16 C.F.R. $\int 803.1(2006)$

6. 15 U.S.C.A. $\$ 45$ (West 2006)

7. Clayton Act, 15 U.S.C. $\$ 18$ (2013)

8. $\quad$ HSR Act, 5 U.S. C, $\$ 18 a(2013)$

\section{Other Legal Documents}

1. Antitrust Procedure and Penalties Act (Tunney Act), 15 U.S.C. $\int 16$ (2013)

2. Bureau of Competition of the Federal Trade Commission, Statement of The Federal Trade Commission's Bureau of Competition on Negotiating Merger Remedies (2003)

3. Bureau of Competition of the Federal Trade Commission, Statement of The Federal Trade Commission's Bureau of Competition on Negotiating Merger Remedies (2012)

4. Bureau of Competition of the Federal Trade Commission, A Study of the Commission's Divestiture Process (1999)

5. The Federal Trade Commission and the U.S. Department of Justice, Antitrust Enforcement Guideline for International Operations (1995)

6. U.S. Department of Justice and the Federal Trade Commission, Horizontal Merger Guidelines (2010)

7. U.S. Department of Justice, Antitrust Division, Antitrust Division Policy Guide to Merger Remedies (2004)

8. U.S. Department of Justice, Antitrust Division, Antitrust Division Policy Guide to Merger Remedies (2012)

9. U.S. Department of Justice, Merger Guidelines (1982)

10. U.S. Department of Justice, Non-Horizontal Merger Guidelines (1984) 


\section{BIBLIOGRAPHY}

1. -, 'AAI Warns FTC of Dangers in Supermarket Mergers, Urges Careful Scrutiny of Ahold Acquisition in Northeast' (Am. Antitrust Inst., 18 June 1999), < http://www.antitrustinstitute.org/node/10135 > accessed 20 March 2017.

2. -, 'About the Federal Register' (US National Archives, updated on 15 September 2016) $<$ http://www.archives.gov/federal-register/the-federal-register/about.html> accessed 19 March 2017.

3. -, 'Availability of Divestiture in Private Litigation as a Remedy for Violation of Section 7 of the Clayton Act' (1964) 49 Min L Rev 267

4. -, 'Bergen Brunswig Targets Managed Care' (L. A. Times, 30 September 1995) < http://articles.latimes. com/1995-09-30/business/fi-51563_1_bergen-brunswig> accessed 25 March 2017.

5. -, 'Marshall Plan' (Wikipedia, last modified on 16 April 2017) < http://en.wikipedia.org/wiki/Marshall_ Plan\#cite_note-1>, accessed 17 April 2017.

6. Abbott Labs, 'Alza Call off Merger' (L. A. Times, 17 December 1999), <http://articles.latimes.com/ 1999/dec/17/business/fi-44783 > accessed 27 March 2017.

7. Akerlof GA, 'The Market for "Lemons": Quality and the Market Mechanism' (1970) 84(3) Q J Econ 48

8. Alexiads P and Sependa E, 'Structural Remedies under European Union Antitrust Rules' (Gibson Dunn, 1 February 2013) < http://www.gibsondunn.com/publications/Documents/AlexiadisSependaStructuralRemedies.pdf $>$ accessed 2 May 2017.

9. An S 'Convergence or Parallel Paths? Comparison of Substantive Tests of Merger Control in the EU and China' (2010) 31 ECLR 248

10. Anti-Monopoly Bureau of the Ministry of Commerce, 'Anti-Monopoly Bureau of the Ministry of Commerce: Some Insights Concerning the Provisions of Merger Remedies (shang wu bu fan long duan ju fu ze ren guan yu 《guan yu jing ying zhe ji zhong fu jia xian zhi xing tiao jian de gui ding (shi xing) de jie du》商务部反垄断局负责人关于《关于经营者集中附加限制性条件的规定（试行 ）》的解读) (MOFCOM, 17 December 2014) <http://www.mofcom.gov.cn/article/zhengcejd/bl/ 201412/20141200835988.shtml> accessed 29 April 2017.

11. Armengod H, 'Merger Control Procedure' (Latham \& Watkins, 2012) <https://www.lw.com/presen tations/ eu-merger-control-procedures-2012> accessed 20 April 2017.

12. Arrow KJ, 'Uncertainty and the Welfare Economics of Medical Care' (1968) 53(5) Am Econ Rev 941

13. Auronen L, 'Asymmetric Information: Theory and Applications' (CiteSeerX, 21 May 2013) $<$ http://citeseerx.ist.psu.edu/viewdoc/download?rep=rep1\&type=pdf\&doi=10.1.1.198.9252> accessed 22 April 2017.

14. Baer WJ, 'Reflections on Twenty Years of Merger Enforcement under the Hart-Scott-Rodino Act' (1997) 65 Antitrust L J 825

15. Baer WJ, 'The Dollars and Sense of Antitrust Enforcement' (Federal Trade Commission, 25 January 1996) <https://www.ftc.gov/public-statements/1996/01/dollar-and-sense-antitrust-enforcement> accessed 16 March 2017.

16. Baker DI, 'To Indict or Not to Indict: Prosecutorial Discretion in Sherman Act Enforcement' (19771978) 63 Cornell L Rev 405

17. Baker JB and Shapiro C, 'Reinvigorated Merger Enforcement in the Obama Administration' (Lawprofessors, 2012) <http://lawprofessors.typepad.com/antitrustprof_blog/2012/06/reinvigoratedmerger-enforcement-in-the-obama-administration.html> accessed 16 March 2017.

18. Baker JB, 'Mavericks, Mergers and Exclusion: Proving Coordinated Competitive Effects under the Antitrust Laws' (2002) 77(1) NYU L Rev 135 
19. Baker T, 'On the Genealogy of Moral-Hazard' (1996) 75(2) Tex Law Rev 237

20. Balto D, 'Lessons from the Clinton Administration: The Evolving Approach to Merger Remedies' (2001) 69(5-6) Geo Wash L Rev 952

21. Baron DP and Besanko D, 'Monitoring, Moral Hazard, Asymmetric Information, and Risk Sharing in Procurement Contracting' (1987) 18(4) Rand J Econ 509

22. Bernheim BD and Whinston MD, 'Chapter 21: Asymmetric Information' in Bernheim BD and Whinston MD, Microeconomics (Irwin/McGraw-Hill 2008).

23. Bernheim BD and Whinston MD, 'Multi-Market Contact and Collusive Behaviour' (1990) 21(1) Rand J Econ 1

24. Bishop S and Walker M, The Economics of EC Competition Law: Concepts, Application and Measurement (Sweet \& Maxwell 2002).

25. Blumenthal W, 'Reconciling the Debate over Merger Remedies: A Discussant's Proposed Decision Rule' (2001) 69 Geo Wash L Rev 978

26. Bougette P and Turolla S, 'Market Structures, Political Surroundings, and Merger Remedies: An Empirical Investigation of the EC's Decisions' (2008) 25(2) Eur J Law Econ 125

27. Breed LM and Michnal DJ, 'Merger Remedies: The DOJ's New Guide to Old Differences with the FTC' (2005) 19 Antitrust 37

28. Bris A, Cabolis C and Janowski V, 'Chapter 2: The Effect of Merger Laws on Merger Activity: International Evidence' in Gregoriou GN and Renneboog L (eds), Corporate Governance and Regulatory Impact on Mergers and Acquisitions: Research and Analysis on Activity Worldwide Since 1990 (Academic Press 2007).

29. Bruecker JS and Hoehn T, 'Monitoring Compliance with Merger Remedies - The Roles of the Monitoring Trustee' (2010) 6 Competition L Int'1 73

30. Burnside A and Meyntjens C, 'The EEC Merger Regulation and its Impact on Non-EEC Business' (1990) 1990 BYU L Rev 1373

31. Bush-Hansen H, 'Rethinking the History of European Level Merger Control: A Critical Political Economy Perspective' (PhD thesis, Department of Intercultural Communication and Management of Copenhagen Business School 2008).

32. Byowitz MH and Sherman LS, 'U.S. Antitrust Merger Remedies: FTC vs. DOJ?' (Wachtell, Lipton, Rosen \& Katz, 2009). <http://apps.americanbar.org/intlaw/calendar/spring2006/papers/WED2304 10BYOWITZ_516.DOC $>$ accessed 5 March 2017.

33. Cabral LMB, 'Horizontal Mergers with Free-Entry: Why Cost Efficiencies May Be a Weak Defence and Asset Sales a Poor Remedy' (2003) 21(5) Int J Ind Organ 607

34. Cahn A and Donald DC, Comparative Company Law: Text and Cases on the Laws Governing Corporations in Germany, the UK and the USA (Cambridge University Press 2010).

35. Canedy D, 'Royal Ahold in Deal to Acquire Pathmark Stores' (N.Y.Times, 1999) <http://www.nytimes.com/1999/03/10/business/royal-ahold-in-deal-to-acquire-pathmarkstores.html> accessed 20 March 2017.

36. Capobianco A, 'Working Party No.3 on Co-operation and Enforcement: Remedies in Merger Cases' (EUROPA, 15 June 2011) < http://ec.europa.eu/competition/international/multilateral/2011_jun_ remedies.pdf $>$ accessed 19 April 2017.

37. Cary GS, 'Merger Remedies' (Federal Trade Commission, 10 April 1997) <https://www.ftc.gov/ public-statements/1997/04/merger-remedies> accessed 7 May 2017.

38. Chang AY, John IG \& Sunshine SC, 'FTC Increasingly Accepts Consent Agreements Without Upfront Buyers' (SKADDEN, 29 November 2010), <https://www.skadden.com/sites/default/files/ publications/Publications2299_0.pdf > accessed 18 March 2017.

39. China Pictorial, 'China's 11th Five-year Plan and the Future Development ("shi yi wu" gui hua yu zhong guo wei lai fa zhan fang xiang“十一五”规划与中国未来发展方向) ' (Xinhua net, 29 November 2005) <http://news.xinhuanet.com/politics/2005-11/29/content_3852517.htm> accessed 29 April 2017.

40. Christiansen A, The "More Economic Approach" in EU Merger Control - A Critical Assessment [2005] Deutsche Bank Research Working Paper Series: Research Note 21

41. CNN Money, 'Competition Watchdog FTC approves media marriage, but with conditions' (CNN Money, 2000) <http://money.cnn.com/2000/12/14/deals/aoltimewarner/> accessed 30 March 2017.

42. CNN Money, 'Exxon-Mobil Merger Done' (CNN Money, 30 November 1999) <http://money.cnn. com/1999/11/30/deals/exxonmobil/ > accessed 18 March 2017. 
43. Competition Policy International, 'Rising Tide of 'Fix-It-First' and 'Up-front Buyer' Remedies in EU and UK Merger Cases' (Competition Policy International, 2016) < https://www.competitionpolicyinter national.com/ rising-tide-of-fix-it-first-and-up-front-buyer-remedies-in-eu-and-uk-merger-cases $/>$ accessed 25 January 2017.

44. Compte O, Jenny F and Rey P, 'Capacity Constraints, Mergers and Collusionv (2002) 46 (1) Eur Econ Rev 1

45. Cook CJ and Kerse CS, EC Merger Control (5 edn, Sweet \& Maxwell 2009).

46. Cooter R and Ulen T, Law and Economics (6 edn, Prentice Hall 2011).

47. Cosnita A and Tropeano J, 'Negotiating Remedies: Revealing the Merger Efficiency Gains' (2009) 27(2) Int J Ind Organ 188

48. Cosnita A and Tropeano J, Screening Divestitures: Structural Merger Remedies with Asymmetric Information [2005] Working paper, Amsterdam Centre for Law \& Economics

49. Court of Justice of the European Communities, 'The Treaty of Lisbon and the Court of Justice of the European Union' (EUROPA, 20 November 2009) <http://curia.europa.eu/jcms/upload/docs/appli cation/pdf/2009-12/cp090104en.pdf> accessed 21 April 2017.

50. Court of Justice of the European Communities, 'The Treaty of Lisbon and the Court of Justice of the European Union' (EUROPA, 20 November 2009) <http://curia.europa.eu/jcms/upload/docs/appli cation/pdf/2009-12/cp090104en.pdf> accessed 21 April 2017.

51. CPC Central Committee, 'CPC Central Committee's Decisions on Some Significant Issues Concerning Comprehensively Deepening the Reform' (China.Org, 2013) <http://www.china.org.cn/china/ third_plenary_session/2014-01/16/content_31212602.htm> accessed 7 May 2017.

52. Craig PP and de Búrca C, EU Law: Text, Cases and Materials (4 edn, Oxford University Press 2008).

53. Dabbah MM, 'Chapter 5: US Competition Law Regime' in Dabbah MM, International and Comparative Competition Law (Cambridge University Press 2010).

54. Davidson K, 'The Reports on Divestiture Remedies of the US FTC and EU DG Comp' (Antitrustinstitute, 15 February 2006) <http://www.antitrustinstitute.org/files/482.pdf $>$ accessed 18 April 2017.

55. Davies S and Lyons B, Merger and Merger Remedies in the EU: Assessing the Consequences for Competition (Edward Elgar 2007).

56. Daviesy S, Olczakz M and Coles H, Tacit Collusion, Firm Asymmetries and Numbers: Evidence from EC Merger Cases [2007] Working Paper No 07-7, Centre for Competition Policy Working

57. Davis Polk \& Wardwell LLP, 'China Antitrust Review 2013' (Davis Polk \& Wardwell LLP, 27 January 2014) <http://www.davispolk.com/sites/default/files/01.27.14.China_.Antitrust.Review.2013.pdf> accessed 3 May 2017.

58. de Valois Turk M, 'The European Commission's Revised Remedies Notice-the Trustee's Perspective' (2009) 7 ECLR 332

59. Dembe AE and Boden LI 'Moral Hazard: A Question of Morality?' (2000) 10(3) New Solut 257

60. Deneckere R and Davidson C, 'Coalition Formation in Non-Cooperative Oligopoly Models, mimeo' (1985b) 11(1-4) Nw U L Rev 241

61. Deneckere R and Davidson C, 'Incentives to Form Coalitions with Bertrand Competition' (1985a) 16(4) Rand J Econ 473

62. Deng F and Zhang Y, Interview with Ming Shang, former Director General of the Anti-Monopoly Bureau under the Ministry of Commerce of the People's Republic of China (Beijing, 7 March 2014).

63. Deng F, Harris HS and Zhang Y, Interview with Ming Shang, former Director General of the AntiMonopoly Bureau under the Ministry of Commerce of the People's Republic of China (Beijing, 7 January 2011).

64. Department of Human Resources of MOFCOM, 'Brief Introduction of the History of MOFCOM of China (zhong hua ren min gong he guo shang wu bu jian jie 中华人民共和国商务部简介' (Department of Human Resources, MOFCOM, 18 February 2005) <http://rss.mofcom.gov.cn/ aarticle/ Nocategory/200502/20050200017543.html> accessed 5 May 2017.

65. Department of Justice, 'Merger Review Process Initiative' (Department of Justice, updated on 25 June 2015) <https://www.justice.gov/atr/merger-review-process-initiative-policy> accessed 2 June 2017.

66. Department of Treaty and Law of MOFCOM, MOFCOM's Decisions of Administrative Penalty No.2016/965' (AMB of MOFCOM, 4 January 2017), <http://fldj.mofcom.gov.cn/article/ztxx/ 201701/20170102495433.shtml> accessed 2 May 2017. 
67. Directorate for Financial and Enterprise Affairs, 'Failing Firm Defence (Note by the European Commission)' (EUROPA, 22 September 2009) <http://ec.europa.eu/competition/international/ multilateral/failingfirmdefence.pdf $>$ accessed 17 April 2017.

68. Dow SC, 'Economics and Moral Sentiments: The Case of Moral Hazard' (CES Workshop on 'Facts, Values and Objectivity, Coimbra, March 2010)

69. Duso T, Gugler K and Yurtoglu B, EU Merger Remedies: A Preliminary Empirical Assessment [2006] Paper No.81, GESY

70. Edwards S, Allen AJ and Shaik S, 'Market Structure Conduct Performance (SCP) Hypothesis Revisited using Stochastic Frontier Efficiency Analysis' <http://ageconsearch.tind.io/record/21350/files/ sp06ed01.pdf?version=1> accessed 30 March 2017.

71. Elzinga K, 'The Antimerger Law: Pyrrhic Victories?' (1969) 12(1) J L \& Econ 43

72. European Commission 'Monitoring Trustee in Case COMP/M.6944 - Thermo Fisher Scientific/ Life Technologies'(EUROPA, 2013) <http://ec.europa.eu/competition/mergers/cases/additional_data/ m6944_4108_3.pdf> accessed 25 April 2017.

73. European Commission Press Release 'Mergers: Commission clears acquisition of Life Technologies by Thermo Fisher, subject to conditions' (EUROPA, 26 November 2013) < http://europa.eu/rapid/ press-release_IP-13-1167_en.htm> accessed 26 April 2017.

74. European Commission Press Release, 'Mergers: Commission Approves AB InBev's Acquisition of SABMiller, Subject to Conditions' (EUROPA, 2 August 2016) <http://europa.eu/rapid/pressrelease_IP-16-1900_en.htm> accessed 3 May 2017.

75. European Commission Press Release, 'Mergers: Commission approves Glencore's acquisition of Xstrata, Subject to Conditions' (EUROPA, 22 November 2012) <http://europa.eu/rapid/pressrelease_IP-12-1252_en.htm> accessed 2 May 2017.

76. European Commission, 'Bilateral Relations - United States of America' (EUROPA, last update 16 April 2012) <http://ec.europa.eu/competition/international/bilateral/usa.html> accessed 18 April 2017.

77. European Commission, 'Control of Concentrations between Companies' (EUROPA, 20 May 2014) <http://europa.eu/legislation_summaries/competition/firms/126096_en.htm> accessed 17 April 2017.

78. European Commission, 'Departments and Executive Agencies' (EUROPA) <http://ec.europa.eu/ about/ds_en.htm> accessed 16 April 2017.

79. European Commission, 'Merger Statistics: 21 September 1990 to 31 March 2017' (EUROPA, March 2017) < http://ec.europa.eu/competition/mergers/statistics.pdf> accessed 17 April 2017.

80. European Commission, 'Reports on Competition Policy' (EUROPA) <http://ec.europa.eu/competition/ publications/annual_report/index.html> accessed 20 April 2017.

81. European Commission, 'Commission Authorises Acquisition of Control of Rexroth by Robert Bosch GmbH subject to Conditions' (EUROPA, 13 December 2000) < http://europa.eu/rapid/pressrelease_IP-00-1457_en.htm > accessed 17 April 2017.

82. European Commission, 'Crown Cork \& Seal/CarnaudMetalbox: The Commission Imposes Strict Conditions' (EUROPA, 1995) < http://europa.eu/rapid/press-release_IP-95-1245_en.htm > accessed 17 April 2017.

83. European Commission, 'Judgments in Cases T-310/01 and T-77/02 (Schneider Electric SA v Commission): The Court of First Instance Annuls the Commission's Decisions Prohibiting the Concentration between Schneider and Legrand and Ordering Them to Separate Accordingly' (EUROPA, 2002) <http://curia.europa.eu/en/actu/communiques/cp02/aff/cp0284en.htm> accessed 18 April 2017.

84. European Commission, 'Mergers: Commission Approves Hutchison/VimpelCom Joint Venture in Italy, Subject to Conditions' (EUROPA, 1 September 2016) < http://europa.eu/rapid/press-release_ IP-16-2932_en.htm> accessed 19 April 2017.

85. European Commission, Mergers: Commission Clears Acquisition of Certain INEOS Chlorovinyls Businesses by ICIG and Approves ICIG as Buyer of Divested Assets Linked to Approval of INEOS / Solvay Joint Venture (EUROPA, 9 June 2015) < http://europa.eu/rapid/press-release_IP-155147_en.htm> accessed 19 April 2017.

86. European Commission, 'Old Merger Control Regulation' (EUROPA, last update 25 November 2014) <http://ec.europa.eu/competition/mergers/legislation/archive.htm> accessed 16 April 2017. 
87. European Union, 'Proportionality Principle' (EUROPA) <http://europa.eu/legislation_summaries/ glossary/proportionality_en.htm> accessed 19 April 2017.Ezrachi A and Han W, 'Merger Remedies Chinese Experience' (2015) 3(Suppl. 1) J Antitrust Enforcement 69

88. Falvey RE and Lloyd PJ, 'An Economic Analysis of Extraterritoriality' (Research Paper, University of Nottingham 1999), 5 <http://www.nottingham.ac.uk/gep/documents/papers/1999/99-03.pdf> accessed 21 April 2017.

89. Farrell J, 'Negotiation and Merger Remedies: Some Problems' in Lévêque F and Shelanski H (eds), Merger Remedies in American and European Union Competition Law (Edward Elgar 2003).

90. Faure M and Zhang X, 'Towards an Extraterritorial Application of the Chinese Anti-Monopoly Law that Avoids Trade Conflicts' (2013) 45 Geo Wash Int'l L Rev 501

91. Federal Trade Commission, 'Analysis of Agreement Containing Consent Orders to Aid Public Comment - In the Matter of Alan B. Miller and Universal Health Services, Inc.' (2012) <http://www.ftc.gov/sites/default/files/documents/cases/2012/10/121005uhsascendanal.pdf > accessed 25 March 2017.

92. Federal Trade Commission, 'Federal Trade Commission Announces 2014 Threshold Revisions for HSR Act and for Clayton Act Section 8 Prohibition on Interlocking Directorates' (Proskauer, 21 January 2014) <http://www.proskauer.com/publications/client-alert/federal-trade-commission-announces-2014threshold-revisions/> accessed 14 March 2017.

93. Federal Trade Commission, 'FTC Increases HSR Act Thresholds: "Size of Transaction" Test Raised to $\$ 70.9$ (2013) ' (WTP, 14 January 2013) < http://www.wtplaw.com/documents/2013/01/ftc-increaseshsr-act-thresholds-size-of-transaction-test-raised-to-709-million> accessed 14 March 2017.

94. Federal Trade Commission, 'Hoechst AG, No. C-3919, Decision and Order' (7 December, 1999) <http://www.ftc.gov/sites/default/files/documents/cases/1999/12/hoechst.do_.htm> accessed 20 March 2017.

95. Federal Trade Commission, 'Hoechst AG, No. C-3919, Order Reporting and Modifying Order' (22 November 2002), <http://www.ftc.gov/sites/default/files/documents/cases/2002/12/hoechsmod.htm> accessed 20 March 2017.

96. Federal Trade Commission, 'Nestle Holdings, Inc., Dreyer's Grand Ice Cream Holdings, Inc., and Dreyer's Grand Ice Cream, Inc., No. C-4082, 0210174' (Federal Trade Commission, 6 November 2003), <https://www.ftc.gov/enforcement/cases-proceedings/0210174/nestle-holdings-inc-dreyersgrand-ice-cream-holdings-inc $>$ accessed 20 March 2017.

97. Federal Trade Commission, 'Procter \& Gamble Co. and Gillette Co., No. C-4151, 0510115' (Federal Trade Commission, 15 December 2005), <https://www.ftc.gov/enforcement/cases-proceedings/ 0510115/procter-gamble-company-gillette-company-matter> accessed 25 April 2017.

98. Federal Trade Commission, 'Statement of the Commission in the Matter of Arch Coal, Inc., et al.' <https://www.ftc.gov/system/files/documents/public_statements/568531/050613commstatement.p df $>$ accessed 16 March 2017.

99. Federal Trade Commission, 'The Antitrust Laws' < https://www.ftc.gov/tips-advice/competitionguidance/guide-antitrust-laws/antitrust-laws> accessed 16 March 2017.

100. Foer AA, 'Toward Guidelines for Merger Remedies' (2001) 52 Case W Res L Rev 211

101. Fonseca MA and Normann H, 'Mergers, Asymmetries and Collusion: Experimental Evidence' (2008) 118(527) Econ J 387

102. Fountoukakos K, 'Judicial Review and Merger Control: The CFI's Expedited Procedure' [2002] 3 Competition Policy Newsletter <http://ec.europa.eu/competition/publications/cpn/2002_3_7.pdf> accessed 17 April 2017.

103. Fox EM, 'Monopolisation and Dominance in the United States and the European Community: Efficiency, Opportunity, and Fairness' (1986) 61 Notre Dame L Rev 981

104. Fraidin S, 'Dissolution and Reconstitution: A Structural Remedy, and Alternatives' (1965) 33 Geo Wash L Rev 809

105. Frank RH, Microeconomics and Behaviour (McGraw-Hill 1991).

106. Freshfields Bruckhaus Beringer, 'China's Anti-Monopoly Law: The Story So Far and What's Next?' (Lexology, 23 September 2015) <http://www.lexology.com/library/detail.aspx?g=2f59e1e2-d4d04d21-b4eb-b47af28fc0c9> accessed 2 May 2017.

107. Fridolfssona S and Stenneka J, 'Hold-up of Anti-Competitive Merger' (2005) 23 (9-10) Int J Ind Organ 753

108. FTC Press Release, 'FTC Requires Reynolds and Lorillard to Divest Four Cigarette Brands as a Condition of \$27.4 Billion Merger' (Federal Trade Commission, 26 May 2015) 
<https://www.ftc.gov/news-events/press-releases/2015/05/ftc-requires-reynolds-lorillard-divestfour-cigarette-brands> accessed 18 May 2017.

109. FTC Press Release, 'FTC Will Seek to Block Mergers of Nation's Four Largest Drug Wholesalers into Two Companies' (Federal Trade Commission, 1998) < https://www.ftc.gov/news-events/pressreleases/1998/03/ftc-will-seek-block-mergers-nations-four-largest-drug-wholesalers $>$ accessed 20 March 2017.

110. FTC Press Release, 'FTC Will Seek to Block Rite Aid/Revco Merger' (Federal Trade Commission, 17 April 1996), <http://www.ftc.gov/news-events/press-releases/1996/04/ftc-will-seek-block-riteaidrevco-merger $>$ accessed 37 March 2017.

111. FTC Press Release, 'With Conditions, FTC Approves Joint Acquisition of Seagram Spirits and Wine by Diageo PLC and Pernod Ricard S.A.' (Federal Trade Commission, 2001) <https://www.ftc.gov/news-events/press-releases/2001/12/conditions-ftc-approves-jointacquisition-seagram-spirits-and $>$ accessed 16 March 2017.

112. FTC, 'Chevron Corp., No. C-4023, Decision and Order' <https://www.ftc.gov/sites/default/ files/documents/cases/1997/02/c3740.do.pdf> accessed 19 April 2017.

113. FTC, 'Frequently Asked Questions About Merger Consent Order Provisions' (Federal Trade Commission) < http://www.ftc.gov/tips-advice/competition-guidance/guide-antitrust-laws/mergers/ merger-faq\#Crown Jewels> accessed 23 March 2017.

114. FTC, 'Hart-Scott-Rodino Premerger Notification Program: Introductory Guide II- to file or not to file' (Federal Trade Commission, 2008), <http://www.ftc.gov/sites/default/files/attachments/premergerintroductory-guides/guide2.pdf > accessed 14 March 2017.

115. FTC, 'Steps for Determining Whether an HSR Filing is Required' (Federal Commission Trade) <https://www.ftc.gov/enforcement/premerger-notification-program/hsr-resources/stepsdetermining-whether-hsr-filing > accessed 30 April 2017.

116. FTC, 'Frequently Asked Questions about Merger Consent Order Provisions: Are there any industries in which the Commission has been more likely to require a buyer up front?' (Federal Trade Commission) < <http://www.ftc.gov/tips-advice/competition-guidance/guide-antitrustlaws/mergers/merger-faq\#Buyer Up Front> accessed 20 April 2017.

117. Gao J and Tang X, 'Professor Liming Wang and Other Professors Are Appointed as Members of the Expert Committee of the Anti-Monopoly Commission (wang li ming deng jiao shou shou pin guo wu yuan fan long duan wei yuan hui zhuan jia zi xun zu cheng yuan 王利明等教授受聘国务院反垄断委 员会专家咨询组成员) ' (Renmin University of China, Law School, 28 December 2011) <http://ruc.zuolang.com/introduce/ShowArticle.asp?ArticleID=35265> accessed 5 May 2017.

118. Garrod L, Lyons B and Medvedev A, 'Three Types of Inefficiency in Strategic Offers: Empirical Identification from Merger Remedy Settlements' (CCP, October 2008) <https://editorialexpress.com/ cgi-bin/conference/download.cgi?db_name=IIOC2009\&paper_id=162> accessed 24 April 2017.

119. Gerber DJ, 'Europe and The Globalization of Antitrust Law' (1999) 14 Conn J Int'l L 15

120. Gerber DJ, Law and Competition in Twentieth-Century Europe: Protecting Prometheus (Oxford University Press 1998).

121. Gerber, DJ 'Constructing Competition Law in China: The Potential Value of European and U.S. Experience' (2004) 3(2) Wash U Global Stud L Rev 315

122. Gifford DJ and Kudrle RT, ' EU Competition Law and Policy: How Much Latitude for Convergence with the U.S.?' (2003) 48 Antitrust Bull 727

123. Gifford DJ and Kudrle RT, 'Alternative National Merger Standards and the Prospects for International Cooperation' in Kennedy DLM and Southwick JD (eds), The Political Economy of International Trade Law: Essays in Honor of Robert E Hudec (Cambridge University 2002).

124. Giotakos D, 'GE/Honeywell: A Theoretic Bundle Assessing Conglomerate Merger Across the Atlantic' (2002) 23(3) U Pa J Int'l L 469

125. Green EJ and Porter RH, 'Non-cooperative Collusion under Imperfect Price Information' (1984) 52(1) Econometrica 87

126. Green J and Staffiero G, 'Economics of Merger Control', The 2007 Handbook of Competition Economics: Global Competition Review Special Report (GCR 2007).

127. Gregory P and Stuart RC, Comparing Economic Systems in the Twenty-First Century (7edn, George Hoffman 2004).

128. Halverson J and Ewing K, 'Recent Developments in EU and US Merger Remedies' (Steptoe \& Johnson LLP, May 2004) <http://www.steptoe.com/assets/attachments/27.pdf> accessed 17 April 2017. 
129. Hamp-Lyons C, 'The Dragon in the Room: China's Anti-Monopoly Law and International Merger Review' (2009) 62(5) Va L Rev 1577

130. Han M and Ryan S, 'Remedies in Chinese Merger Control Law - Themes, Recent Cases and Developments' (2014) 15(3) B L I 201

131. Hao Q, 'Merger Remedies in China: Developments and Issues' (2010) 6(2) C L I 13

132. Harris HS, 'The Making of an Antitrust Law: The Pending Anti-Monopoly Law of the People's Republic of China' (2006) 7(1) Chi J Int'l L 169

133. Harris M and Raviv A, 'Optimal Incentive Contracts with Imperfect Information' (1979) 20(2) J Econ Theory 231

134. Herbert Smith LLP, 'ECJ Rules on Damages Clain in Schneider/Legrand Merger'(Herbert Smith LLP, 20 July 2009) <http://documents.lexology.com/8362fa68-f8e2-4469-b07f-5c47a2cdfcdb.pdf> accessed 18 April 2017.

135. Hoffman DB, 'Chapter 57: USA' in Parr N and Hammon C (eds), The International Comparative Legal Guide to: Merger Control 2012 (Global Legal Group 2012).

136. Hoffman E and Spitzer ML, 'Experimental Tests of the Coase Theorem with Large Bargaining Groups' (1986) 15(1) J Legal Stud 149

137. Hoffman E and Spitzer ML, 'The Coase Theorem: Some Experimental Tests' (1982) 25(1) Journal Law Econ 73

138. Holmes S and Christian G, 'European Union: Blocking Mergers Unlawfully: Following The Schneider / Legrand Decision, The Commission Now Risks Liability in Tort' (Mondaq, 6 June 2008) <http://www.mondaq.com/x/61592/Antitrust+Competition/Blocking+Mergers+Unlawfully++Foll owing+The+Schneider+Legrand+Decision+The+Commission+Now+Risks+Liability+In+Tort $>$ accessed 18 April 2017.

139. Holmstrom B, 'Moral Hazard and Observability' (1979) 10(1) Bell J Econ 74

140. Homann K and Suchanek A, Ökonomik, Eine Einführung (Mohr Sieberk 2005).

141. Huron JG, 'Section 16 of the Clayton Act: Divestiture an Intended Type of Injunctive Relief' (1987) 19 PAC L J 143

142. IIzkovitz F and Meiklejohn R, 'European Merger Control: Do we need an Efficiency Defence' in IIzkovitz F and Meiklejohn R(eds), European Merger Control: Do we need an Efficiency Defence (Edward Elgar 2006).

143. Interview with Anonymous, Professor and Dean, Law Faculty, a Chinese University (Beijing, China, 30 May 2016).

144. Interview with Liang Ding (丁亮), Lawyer and Partner, Beijing Office, DeHeng Law Offices (de heng lv shi shi wu suo 德恒律师事务所) (Beijing, China, 31 May 2016).

145. Interview with Rongrong Xu (许蓉蓉), Lawyer and Partner, Hong Kong Office, JunHe Law Firm (jun he lv shi shi wu suo 君合律师事务所) (Beijing, China, 30 May 2016).

146. Interview with Shiying Xu (徐士英), Professor and Director, Competition Law Research Institute, East China University of Political Science and Law (hua dong zheng fa da xue 华东政法大学) (Shanghai, China, 15 June 2016).

147. Interview with Xiaoye Wang (王晓晔), Professor and Director, Economic Law Department, Chinese Academy of Social Sciences (zhong guo she hui ke xue yuan 中国社会科学院) (Beijing, China, 30 May 2016).

148. Interview with Ying Yang (杨瑛), Lawyer, Broad \& Bright Law Firm (shi ze lv shi shi wu suo 世泽律 师事务所) (Beijing, China, 31 May 2016).

149. Italianer A, 'Legal Certainty, Proportionality, Effectiveness: The Commission's Practice on Remedies' (Charles River Associates Annual Conference, Brussels, 5 December 2012) $<$ http://ec.europa.eu/competition/speeches/text/sp2012_07_en.pdf> accessed 21 April 2017.

150. Japsen B, 'Regulators Block Abbott Deal for Firm' (Chi. Trib, 17 December 1999), <http://articles.chicagotribune.com/1999-12-17/business/9912170346_1_alza-abbott-shares-viadur> accessed 25 March 2017.

151. Johnson \& Johnson, 'Johnson \& Johnson Announces Completion of Merger with ALZA Corporation' (Investor, 22 June 2001) <http://www.investor.jnj.com/releasedetail.cfm?releaseid=63804> accessed 25 March 2017.

152. Johnson T, 'Internet leader and entertainment firm to join forces; new company worth $\$ 350$ Billion' (CNN Money, 10 January 2010) <http://money.cnn.com/2000/01/10/deals/aol_warner/> accessed 19 March 2017 
153. Jovanovic MN, The Economics of International Integration (Edward Elgar Publishing 2006).

154. Kaplow L, 'Rules Versus Standards: An Economic Analysis,' (1992) 42(3) Duke L J 557

155. Katz E and Perlgut L, 'Appraising Crown Jewel Provisions in the United States, Canada, and Europe' (Cahill, 2009) < http://www.cahill.com/publications/antitrust-monthly-column/000086/_res/id=Attach ments $/$ index $=0 /$ Appraising $\% 20$ Crown $\% 20$ Jewel $\% 20$ Provisions $\% 20$ in $\% 20$ the $\% 20$ United $\% 20$ States $>$ accessed 20 April 2017.

156. Katz E and Perlgut L, 'Appraising Crown Jewel Provisions in the United States, Canada, and Europe'(Cahill Gordon \& Reindel LLP, 2009) <http://www.cahill.com/publications/antitrust-monthlycolumn/000086/_res/id=Attachments/index $=0 /$ Appraising $\% 20$ Crown $\% 20 J$ ewel $\% 20$ Provisions $\% 20$ in $\% 20$ the $\% 20$ United $\% 20$ States $>$ accessed 19 March 2017

157. Katz ML and Rosen HS, Microeconomics (3 edn, McGraw-Hill 1998).

158. Kintner EW, An Antitrust Primer: A Guide to Antitrust and Trade Regulation Laws for Businessmen (Macmillan 1964).

159. Kirchner C, 'Goals of Antitrust and Competition Law Revisited' in Schmidtchen D, Albert M and Voigt S (eds), The More Economic Approach to European Competition Law, vol 24 (Mohr Siebeck 2007).

160. Kirkwood JB and Lande RH, 'The Fundamental Goal of Antitrust: Protecting Consumers, Not Increasing Efficiency' (2008) 84(1) Notre Dame L Rev 191

161. Kishor V., 'Competitive Merger Control Regulations - Lessons from EU and US' (Unpublished internship dissertation, Competition Commission of India, The West Bengal National University of Juridical Sciences 2012).

162. Kovacic WE and others, 'Plus Factors and Agreement in Antitrust law' (2012) 110(3) Mich L Rev 393

163. Kovacic WE and others, Quantitative Analysis of Coordinated Effects [2005] CAPCP Working Paper, Penn State University.

164. Kovacic WE, 'Antitrust Policy and Horizontal Collusion in the 21st Century' (1997) 9 (2) Loyola Consum Law Rev 97

165. Kraakman R and others, The Anatomy of Corporate Law-A Comparative and Functional Approach (2 edn, Oxford University Press 2009).

166. Kuhn K, 'The Coordinated Effects of Mergers' in Buccirossi P (ed), Handbook of Antitrust Economics (The MIT Press 2008).

167. Lagerlof JNM and Heidhues P, 'On the Desirability of an Efficiency Defences in Merger Control' (2005) 23(9-10) Int J Ind Organ 803

168. Laskowska M, 'Dynamic Efficiencies and Technological Progress in EC Merger Control' (SSRN, 2013) $<$ https://papers.ssrn.com/sol3/papers.cfm?abstract_id=2336956> accessed 20 April 2017.

169. Laskowska M, 'Introduction to the Analysis of Technological Progress in Merger Control' (SSRN, October 2013) <http://ssrn.com/abstract=2337177> accessed 18 April 2017.

170. Lawless RW, Robbennolt JK and Ulen TS, Empirical Methods in Law (Aspen Publishers 2010).

171. Leary TB, 'The Essential Stability of Merger Policy in the United States' in Lévêque F and Shelanski H (eds), Merger Remedies in American and European Union Competition Law (Edward Elgar 2003).

172. Lee K, 'Moral Hazard, Insurance and Public Loss Prevention' (1992) 59(2) J Risk Insur 275

173. Lévêque F, 'A Preliminary Assessment of Merger Remedies in the EU Electricity Sector' (Symposium of M\&As in the European Electricity Sector, Centre for Industrial Economics, 4 October 2001).

174. Lin P and Zhao J, 'Merger Control Policy Under China's Anti-Monopoly Law' (2012) 41(1) Rev Ind Organ 109

175. Lindsay A, Lecchi E and Williams G, 'Econometrics Study into European Commission Merger Decision since 2000' (2003) 24(12) ECLR 673

176. Lorenz M, 'The New Chinese Competition Act' (2008) 29(4) ECLR 257

177. Louis F, Vallery A and Volcker S, 'Commission Merger Control Analysis Again Severely Sanctioned by the European Court in the Schneider Case'(Wilmer, Culter \& Pickering, 23 October 2002) <http://www.wilmerhale.com/uploadedFiles/Shared_Content/Editorial/Publications/German_Publ ications/Schneider_Judgment2002-10-22_bulletin.pdf> accessed 18 April 2017.

178. Luib GP, 'DOJ, FTC: More 'Upfront' About Divestiture Requirements Than Ever' (Dechert, 16 July 2016) <https://www.dechert.com/files/Uploads/Documents/DOJ,_FTC_More_'Upfront'_About_ Divestiture_Requirements_Than_Ever_-_Dechert_-_25072016.pdf> accessed 24 January 2017.

179. Ma J, 'Market Integration as the Goal of Competition Law: The EU Experience and Its Implications for China' in Philipsen N, Weishaar SE and Xu G (eds), Market Integration: The EU Experience and Implications for Regulatory Reform in China (Springer 2015). 
180. MacLaren M, 'The GE/Honeywell Merger Case: Reaching the Limits of International Competition Policymaking' [2001] 2 Ger. Law J. <https://static1.squarespace.com/static/56330ad3e4b0733dcc 0c8495/t/56bc3fcf2eeb81bc2dc741df/1455177680024/GLJ_Vol_02_No_12_MacLaren.pdf> accessed 20 April 2017.

181. Majoras DP, 'Looking Forward: Merger and Other Policy Initiatives at the FTC' (Speech delivered at ABA Antitrust Section Fall Forum, Washington DC, 18 November 2004) <http://www.ftc.gov/sites/ default/files/documents/public_statements/looking-forward-merger-and-other-policy-initiatives$\mathrm{ftc} / 041118$ abafallforum_0.pdf $>$

182. Majoras DP, 'Looking Forward: Merger and Other Policy Initiatives at the FTC' (Federal Trade Commission, 18 November 2004) <http://www.ftc.gov/sites/default/files/documents/ public_statements/looking-forward-merger-and-other-policy-initiatives-ftc/041118abafallforum_0.pdf > accessed 3 May 2017.

183. Marc Ivaldi and others, The Economics of Tacit Collusion (Report for DG Comp, European Commission, 2003) < http://ec.europa.eu/competition/mergers/studies_reports/the_economics_ of_tacit_collusion_en.pdf $>$ accessed 26 April 2017.

184. Marshall RC and Marx LM, The Economics of Collusion: Cartels and Bidding Rings (The MIT Press 2012).

185. Mattei U, 'Legal Change: The Comparative Law and Economic Perspective', Comparative Law and Economics (University of Michigan 1997).

186. McNutt PA, Law, Economics and Antitrust: Towards a New Perspective (Edward Elgar 2005).

187. Medvedev A, Efficiency Defence, Administrative Fuzziness, and Commitment in Merger Regulation [2006] Working Paper No 06-8, Centre for Competition Policy

188. Medvedev A, Structural Remedies in Merger Regulation in a Cournot Framework [2004] Working paper, Amsterdam Centre for Law \& Economic.

189. Moe TM, 'Political Institutions: The Neglected Side of the Story' (1990) 6 (Special Issue) J L Econ \& Org 213

190. MOFCOM, 'Lists for Unconditional Approved Cases' (MOFCOM) < http://fldj.mofcom.gov.cn/ article/zcfb/> accessed 2 May 2017.

191. MOFCOM, 'Press Conference of MOFCOM's Anti-monopoly Progress in 2012 (shang wu bu zhao kai "2012 nian fan long duan gong zuo jing zhan"zhuan ti xing wen fa bu hui 商务部召开 “2012 年反 垄断工作进展” 专题新闻发布会') ' (MOFCOM, 28 December 2012) <http://www.mofcom. gov.cn/article/ae/slfw/201212/20121208504842.shtml> accessed 2 May 2017.

192. MOFCOM's Routine Press Conferences, 'The 9th Report of MOFCOM's 2015 Working Summary: to actively promote the enforcement of anti-monopoly law and to maintain fair competition in the market (2015 nian shang wu gong zuo nian zhong zong shu zhi jiu: ji ji tui jin fan long duan zhi fa, wei hu shi chang gong ping jing zheng 2015 年商务工作年终综述之九: 积极推进反垄断执法维护市 场公平竞争) ' (MOFCOM, 1 January 2016), http://www.mofcom.gov.cn/article/ae/ai/201601/2016 0101235053.shtml accessed 29 April 2017.

193. Monti M, 'The Commission Notice on Merger Remedies - One Year After' in Lévêque F and Shelanski H (eds), Merger Remedies in American and European Union Competition Law (Edward Elgar 2003).

194. Moore HN, 'Beware of the F.T.C.' (INTL'L N.Y. TIMES: DEALBOOK, 4 November 2010) <http://dealbook.nytimes.com/2010/11/04/beware-of-the-f-t-c/?_php=true\&_type=blogs\&_r=0.> accessed 16 March 2017.

195. Morgan E, 'Steering Mergers Through the EU's Regulatory Rocks: Remedies under the EU Merger Control Regulation' (2002) 20(5) EMJ 549

196. Motta M, Composition Policy: Theory and Practice (Cambridge University 2004).

197. Motta M, Polo M and Vasconcelos H, 'Merger Remedies in the European Union: An Overview' in Lévêque F and Shelanski H (eds), Merger Remedies in American and European Union Competition Law (Edward Elgar 2003).

198. Muris TJ, 'Comments on The FTC-DOJ Clearance Process: before the Antitrust Modernization Commission' (Govinfo, 2005) < http://govinfo.library.unt.edu/amc/commission_hearings/pdf/Muris_ Statement.pdf $>$ accessed 17 March 2017.

199. Muthoo A, 'A Non-Technical Introduction to Bargaining Theory' (2000) 1(2) World Econ 145

200. National Bureau of Statistics of China, 'China's National Economic Industry Classification Standard (GB/T 4754-2011) (guo min jing ji hang ye fen lei 国民经济行业分)' (NBSC, 23 October 2013) <http://www.stats.gov.cn/tjsj/tjbz/hyflbz/> accessed 2 May 2017. 
201. Navarro E and others, Merger Control in the EU --- Law, Economics and Practice $(2$ edn, Oxford University Press 2005).

202. Neale AD and Goyder DG, The Antitrust Laws of the United States of America: A Study of Competition Enforced by Law (3 edn, Cambridge University Press 1980).

203. Nechyba TJ, 'Chapter 22: Asymmetric Information in Competitive Markets' in Nechyba TJ, Microeconomics: An Intuitive Approach with Calculus (with Study Guide) (South-Western Cengage Learning 2010).

204. Ning $X$ and others, 'China's Merger Control: 5-year's Enforcement Review (zhong guo jing ying zhe ji zhong shen cha ji fu tiaojian zhi fa wu nian zong shu 中国经营者集中审查及附条件执法五年综述 )' (Westlaw China, 23 August 2013) <http://www.westlawchina.com/NewsLetter/view.php?id=86> accessed 5 May 2017.

205. Ning X, Ran D and Zheng M, 'MOFCOM Has One Important Step Forward on Building Simple Merger Cases Procedures: Publication of the MOFCOM Provisions of Simple Cases (shang wu bu zai jian yi cheng xu zhi du jian she shang mai chu de zhong yao yi bu: shi shi jian yi an jian shi yong biao zhun 商务部在简易程序制度建设上迈出的重要一步：实施简易案件适用标准)'(Chinalawsight, 6 March 2014)<http://www.chinalawinsight.com/2014/03/articles/corporate/antitrust-competition/ $\% \mathrm{E} 5 \% 95 \% 86 \% \mathrm{E} 5 \% 8 \mathrm{~A} \% \mathrm{~A} 1 \% \mathrm{E} 9 \% 83 \% \mathrm{~A} 8 \% \mathrm{E} 5 \% 9 \mathrm{C} \% \mathrm{~A} 8 \% \mathrm{E} 7 \% \mathrm{AE} \% 80 \% \mathrm{E} 6 \% 98 \% 93 \% \mathrm{E} 7 \% \mathrm{~A} 8 \% 8$ B $\% \mathrm{E} 5 \% \mathrm{BA} \% 8 \mathrm{~F} \% \mathrm{E} 5 \% 88 \% \mathrm{~B} 6 \% \mathrm{E} 5 \% \mathrm{BA} \% \mathrm{~A} 6 \% \mathrm{E} 5 \% \mathrm{BB} \% \mathrm{BA} \% \mathrm{E} 8 \% \mathrm{AE} \% \mathrm{BE} \% \mathrm{E} 4 \% \mathrm{~B} 8 \% 8 \mathrm{~A} \% \mathrm{E} 8 \% \mathrm{~B}$ F\%88\%E5\%87\%BA $\%$ E7\%9A $\% 84 \%$ E9\%87\%8D $\%$ E8\%A6\%81\%E4\%B8\%80\%E6\%AD $\%$ A5\%EF $\% \mathrm{BC} \% 9 \mathrm{~A} \% \mathrm{E} 5 \% \mathrm{AE} \% 9 \mathrm{E} />$ accessed 29 April 2017.

206. OCED, 'Glossary of Statistical Terms - Cournot (Nash) Equilibrium' (OECD, 1993) $<$ https://stats.oecd.org/glossary/detail.asp?ID=3183> accessed 20 April 2015.

207. O'Connor KJ, 'The Divestiture Remedy in Sherman Act, Section 2 Cases' (January 01, 1976) 13 Harv J on Legis 687

208. O'Connor MC, 'Comments, Divestiture in Light of the EL PASO Experience' (1969-1970) 48 Tex Law Rev 792

209. Office of Fair Trading (UK), 'The Analytical Framework of Merger Control' (ICN Annual Conference).

210. Oldale A, 'Fixing Remedies in European Merger Control' (2002) July/August NERA Competition Policy Insights 1

211. Olsen G, 'Revised EU Merger Remedy Guidance' (2008) 23 Antitrust 80

212. Oppenheim S.C., 'Divestiture as Remedy' (1950-1951) 19 Geo Wash L Rev 120

213. Orosi PL, 'Claim Efficiencies or Offer Remedies? An Analysis of Litigation Strategies in EC Mergers' (2012) 30(5) Int J Ind Organ 578

214. Papandropoulos P and Tajana A, 'The Merger Remedies Study-In Divestiture We Trust?' (2006) 8 ECLR 443

215. Parisi F, 'Rules Versus Standards' in Rowley C and Schneider F (eds), The Encyclopaedia of Public Choice (Springer 2004).

216. Parisi JJ, 'A Simple Guide to the EC Merger Regulation' < http://www.americanbar.org/content/ dam/aba/publishing/antitrust_source/03_Jan05_parisi.authcheckdam.pdf> accessed 17 April 2017.

217. Parker RG and Balto DA, 'The Evolving Approach to Merger Remedies' (Federal Trade Commission, May 2000) <https://www.ftc.gov/public-statements/2000/05/evolving-approach-merger-remedies> accessed 15 April 2017.

218. Pate PH, 'Antitrust Enforcement at the United States Department of Justice: Issues in Merger Investigations and Litigation' (2003) 2003 Colum Bus L Rev 411

219. Pauly MV, 'The Economics of Moral Hazard: Comment' (1968) 58(3, Part 1) Am Econ Rev 531

220. People's Daily, 'The Critical Step in Establishing the Fundamental Position of Competition Policy (que li jing zhen ce chu xing di wei de guan jian yi bu 确立竞争政策基础性地位的关键性一步) ' (Central Government of P.R.C., 2016), <http://www.gov.cn/zhengce/2016-06/22/content_5084234.htm> accessed 25 April 2017.

221. Perry MK and Porter RH, 'Oligopoly and the Incentives for Horizontal Merger' (1985) 75(1) Am Econ Rev 219

222. Pfunder MR, 'The New "Non-Corporate Interest" Rules Under the Hart-Scott-Rodino Act-A Detailed Look at How They Will Work' (The Antitrust Source, March 2005) <http://www.gibson dunn.com/fstore/documents/pubs/Antitrust_Source-NonCorpInterestHSR-Mar05-Pfunder.pdf > accessed 19 April 2017. 
223. Pitofsky R, 'Efficiency Consideration and Merger Enforcement: Comparison of U.S. and EU Approach' (2007) 30(5) Fordham Int'l LJ 1413

224. Pollack M and Altman L, Callmann on Unfair Competition, Trademark and Monopolies (4edn, Clark Boardman Callaghan 2004).

225. Porter ME, Competitive Strategy: Techniques for Analysing Industries and Competitors (Free Press 1980).

226. Potters J and van Winden F, 'Lobbying and Asymmetric Information' (1992) 74(3) Public Choice 269

227. PR Newswire, 'ALZA Corporation Stockholders Approve Merger Agreement with Abbott Laboratories' (PR Newswire, 21 September 1999), <http://www.prnewswire.com/news-releases/alzacorporation-stockholders-approve-merger-agreement-with-abbott-laboratories-74483762.html > accessed 25 March 2017.

228. Priest GL, 'The Current Insurance Crisis and Modern Tort Law' (1987) 96(7) Yale L J 1521

229. Rakovsky C and others, 'EC Merger Regulation Contribute to More Efficient Merger Control in EU' (EUROPA, 2009) < http://ec.europa.eu/competition/publications/cpn/2009_2_4.pdf> accessed 17 April 2017.

230. Renshaw A and Blockx J, 'Judicial Review of Mergers in the EU' (2013) 58(2-3) Antitrust Bulletin 495

231. Rey P, 'Economic Analysis and the Choice of Remedies' in Lévêque F and Shelanski F(eds), Merger Remedies in American and European Union Competition Law (Edward Elgar 2003).

232. Rodriguez J, 'Merger Referrals under the EU Merger Regulation' < http://www.sullcrom.com/siteFiles/ Publications/Rodriguez_EAR_Merger_Referrals3.pdf $>$ accessed 25 April 2017.

233. Roller L and de la Mano M, 'The Impact of the New Substantive Test in European Merger Control' (2006) 2(1) ECJ 9

234. Roller L, Stennek J and Verboven F, 'Efficiency Gains from Mergers' (EUROPA, 2005) <http://ec.europa.eu/dgs/competition/economist/efficiency_gains.pdf > accessed 28 August 2017.

235. Rowley JW and Baker DI, International Mergers: The Antitrust Process, vol. 2 (Sweet \& Maxwell 1996).

236. Salant SW, Switzer S and Reynolds RJ, 'Losses from Horizontal Merger: The Effects of an Exogenous Change in Industry Structure on Cournot-Nash Equilibrium' (1983) 28(2) Q J Econ 427

237. Sanchirico CW, 'Relying on the Information of Interested-and Potentially Dishonest-Parties' (2001) 3(2) Am L \& Econ Rev 320

238. Schlag PJ, 'Rules and Standards' (1985) 33 UCLA L Rev 379

239. Schotter A, 'Chapter 19: The World of Oligopoly: Preliminaries to Successful Entry' in Schotter A, Microeconomics: A Modern Approach (South-Western Cengage Learning 2009).

240. Schwalbe U and Zimmer D, Law and Economics in European Merger Control (Oxford University Press 2009).

241. Shang M, 'Antitrust in China- a Constantly Evolving Subject' (2009) 5(1) Competition L Int'l 4

242. Shang M, Qi ye bing gou fan long duan kong zhi - ou meng ji bu feng cheng yuan guo li fa zhi fa jing yan (Merger Control in EU and Several Member States - Legislation and Enforcement Practice 《企业 并购反垄断控制一欧盟及部分成员国立法执法经验》) (Fa Lü chu ban she 2008).

243. Shapiro C and Sohn M, "'Crown Jewel" Provisions in Merger Consent Decrees' (1997) 12 Antitrust 27

244. Shavell S, 'Risk Sharing and Incentives in the Principal and Agent Relationship' (1979) 10(1) Bell J Econ 55

245. Shelanski H.A. and Sidak G, 'Antitrust Divestiture in Network Industries' (Winter 2001) 68(1) U Chi L Rev 1

246. Shi M, 'Merger Divestitures under the Dual Enforcement Mechanism: Whether A Convergence Exists Between the FTC and the DOJ?' (2016) 37 Whittier L Rev 67

247. Slaughter and May, 'Competition Law in China' (Slaughter and May, November 2016) <https://www.slaughterandmay.com/media/879862/competition-law-in-china.pdf $>$ accessed 29 April 2017.

248. Slaughter and May, 'The EU Merger Regulation: An Overview of the European Merger Control Rules' (Slaughter and May, 2012) <https://www.slaughterandmay.com/media/64572/the-eu-mergerregulation.pdf> accessed 10 April 2016.

249. Sorinas S, 'European Union: EU Merger Remedy' [2009] I F L R, <http://www.iflr.com/Article/ 2324298/European-Union-EU-merger-remedies.html> accessed 19 April 2017.

250. Spence M and Zeckhauser R, 'Insurance, Information, and Individual Action' (1974) 61(2) Am Econ Rev 296

251. Spence M, 'Job Market Signalling' (1973) 87(3) Q J Econ 355 
252. Standard Oil Company and Trust, (Encyclopaedia Britannica, updated on 4 March 2015) <http://www.britannica.com/topic/Standard-Oil-Company-and-Trust > accessed 17 March 2017.

253. Standard Oil, (Wikipedia) < https://en.wikipedia.org/wiki/Standard_Oil > accessed 18 March 2017.

254. State Council, 'State Council published the Opinions on Establishing a Review System to Ensure Fair Competition in the Market (guo wu yun guan yu zai shi chang ti xi jian she zhong jian li gong ping shen cha zhi du de yi jian 国务院关于在市场体系建设中建立公平竞争审查制度的意见) ' (Sina, 26 August 2016) <http:// finance.sina.com.cn/roll/2016-08-26/doc-ifxvixsh6709984.shtml> accessed 6 May 2017.

255. Stennek J and Verboven F, 'Merger Control and Enterprise Competitiveness- Empirical Analysis and Policy Recommendations' in IIzkovitz F and Meiklejohn R (eds), European Merger Control: Do We Need an Efficiency Defence? (Edward Elgar 2006).

256. Stevens DE and Thevaranjan A, 'A Moral Solution to the Moral Hazard Problem' (SSRN, 22 May 2008) <http://dx.doi.org/10.2139/ssrn.1138279> accessed 25 April 2017.

257. Stiebale J, 'The impact of cross-border mergers and acquisitions on the acquirers' R\&D — Firm-level evidence' (2013) 31(4) Int J Ind Organ 307

258. Stigler GJ, 'A Theory of Oligopoly' (1964) 72(1) J Pol Econ 44

259. Stigler GJ, 'Monopoly and Oligopoly by Merger' (1950) 40(2) Am Econ Rev 23

260. Stiglitz JE, 'The Theory of "Screening," Education, and the Distribution of Income' (1975) 65(3) Am Econ Rev 283

261. Stiglitz JE, 'Risk, Incentives and Insurance: The Pure Theory of Moral Hazard' (1983) 8(26) Geneva Pap Risk Ins 4

262. Strock JC, 'Setting The Terms of a Break-up: The Convergence of Federal Merger Remedy Policies' (2012) 53 Wm. \& Mary L. Rev 2147

263. Stroux S, 'Book Review: Merger Control in the EU. Law, Economics and Practice. Second Edition Edurne Navarro, Andras Font, Janmie Folguera, and Juan Briones' (2006) 33(2) L I E I 199

264. Sullivan E.T, 'Antitrust Remedies in the US and EU: Advancing a Standard of Proportionally' (2003) 48(2) The Antitrust Bulletin 377

265. Sullivan ET, 'The Jurisprudence of Antitrust Divestiture: The Path Less Travelled' (2002) 86 Minn Law Rev 565

266. Svetlicinii A, 'Cooperation between Merger Control Authorities of the EU and the U.S.: A Viable Solution for Transatlantic Mergers?' (2006) 7(3) UC Davis Bus L J 171

267. The Legislative Affairs Office of the State Council, 'Opening of Public Comments for the Anti-Unfair Competition Law of the People's Republic of China (drafted revised version) (guo wu yuan fa zhi ban gong shi guan yu gong bu 《zhong hua ren min gong he guo fan bu zheng dang jing zheng fa (xiu ding cao an song shen gao)》gong kai zheng qiu yi jian de tong zhi 国务院法制办公室关于公布《中华 人民共和国反不正当竞争法 (修订草案送审稿) 》公开征求意见的通知'(Chinalaw, 25 February 2016)<http://www.chinalaw.gov.cn/article/cazjgg/201602/20160200480277.shtml> accessed 29 April 2017.

268. 'The Structure Conduct Performance Framework In Industrial Organizations Economics Essay' (UK Essays, 2015) <https://www.ukessays.com/essays/economics/the-structure-conduct-performanceframework-in-industrial-organizations-economics-essay.php> accessed 1 April 2017.

269. The Unilateral Conduct Working Group, 'Report on Tying and Bundled Discounting' (The 8th Annual Conference of the International Competition Network, Zurich, June 2009) <http:/ / www.international competitionnetwork.org/uploads/library/doc356.pdf > accessed 22 April 2017.

270. Thomas TA (ed) $\mathbb{S} 54$ ', American Jurisprudence, Monopolies, Restraints of Trade, and Unfair Trade Practices (2 edn, Lawers Cooperative Publishing 2004).

271. Tirole J, The Theory of Industrial Organization (The MIT Press 1988).

272. Titus JW, 'Note: Stop, Look and Listen: Premerger Notification under The Hart-Scott-Rodino Antitrust Improvement Act' (1979) 1979 Duke L J 355

273. Triggs C.R., 'Shielding Consumers from Risk: FTC Divestiture Policy' (2002) 17 Antitrust 75

274. Van den Bergh R and Camesasca PD, European Competition Law and Economics: A Comparative Perspective (Sweet \& Maxwell 2006).

275. van den Bergh R, 'The Economics of Competition Policy and the Draft of the Chinese Competition Law' in Eger T, Faure M and Zhang N (eds), Economic Analysis of Law in China (Edward Elgar 2007).

276. van Huyck JB, Battalio RC and Beil RO, 'Tacit Coordination Games, Strategic Uncertainty, and Coordination Failure' (1990) 80(1) Am Econ Rev 234 
277. van Kerckhove M, 'EU Remedies Study: Toward Further Transatlantic Convergence in Merger Remedies' (2006) 21 Antitrust 6

278. Vasconcelos H, 'Tacit Collusion, Cost Asymmetries, and Mergers' (2005) 36 (1) RAND J Econ 39

279. Vasconcelos H, 'Can the Failing Firm Defence Rule Be Counterproductive?' (Oxford Economic Papers, 07 September 2012) <http://oep.oxfordjournals.org/content/65/2/567> accessed 18 March 2017.

280. Vickers J, 'Abuse of Market Power' in Buccirossi P (ed), Handbook of Antitrust Economics (The MIT Press 2007).

281. Wang X, 'Anti-Monopoly Law: A Milestone in China's Economic Reform (fan long duan fa- zhong guo jing ji ti zhi gai ge de li cheng bei 反垄断法——中国经济体制改革的里程碑)' (iolaw, 2 September 2007) <https://www.iolaw.org.cn/showArticle.aspx?id=2154> accessed 30 April, 2017.

282. Wang X, 'Comments on Concentrations of Undertakings in the China's AML (zhong guo fan long duan fa “jing ying zhe ji zhong”de ping xi 中国反垄断法“经营者集中”的评析” (iolaw, 2008) < http://www.iolaw.org.cn/showNews.aspx?id=17210> accessed 29 April 2017.

283. Wang X, 'Some Issues Surrounding the Anti-Monopoly Enforcement Authority in China', in Wang X, The Evolution of China's Anti-Monopoly Law (Edward Elgar in association with the Social Sciences Academic Press 2014).

284. Wang X, 'Why does China Need an Anti-Monopoly Law?' in Wang X, The Evolution of China's AntiMonopoly Law (Edward Elgar 2014).

285. Watson P, 'Portolio Effects in EC Merger Law' (2003) 48 Antitrust Bull 781

286. Wetzstein ME, 'Chapter 23: Asymmetric Information' in Wetzstein ME, Microeconomic Theory: Concepts and Connections (2 edn, Routledge 2012).

287. Williamson O, 'Economics as an Antitrust Defence: The Welfare Trade-offs' (1968) 58(1) Am Econ Rev 18

288. Wilson R, 'The Theory of Syndicates' (1968) 36(1) Econometrica 119

289. Winckler A, 'Some Comments on Procedure and Remedies under EC Merger Control Rules: Something Rotten in the Kingdom of the EC Merger Control?' in Lévêque F and Shelanski H (eds), Merger Remedies in American and European Union Competition Law (Edward Elgar 2003).

290. Wise DS, 'Divestiture as A Private Remedy' (1982) 20(4) Duq L Rev 613

291. Wood DP, 'A Comparison of Merger Review and Remedy Procedures in the United States and the European Union' in Lévêque F and Shelanski H(eds), Merger Remedies in American and European Union Competition Law (Edward Elgar 2003).

292. Yo C and Sang Y, 'The Enforcement of Merger Control in China: A Critical Analysis of Current Decisions by MOFCOM' (2013) 44(8) ICC 948

293. Zhang X and Zhang Y, 'Chinese Merger Control: Patterns and Implications' (2009) 6(2) J C L \& E 477

294. Zhang X and Zhang Y, 'The Anti-Monopoly Law in China: Where Do We Stand?' (2007) 3(2) CPI 185

295. Zhu D, 'Historical Review: Establishing the Socialist Market Economy (li shi jie dian: jian li she hui zhu yi shi chang jing ji ti zhi 历史节点: 建立社会主义市场经济体制)' (People, 11 October 2011) <http://cpc.people.com.cn/GB/104019/104740/8150356.html> accessed 29 April 2017. 



\section{CURRICULUM VITAE 作者简历}

Mengmeng Shi was born on 23 July 1988 in Zhejiang Province (China); Shanghaineese.

Ms. Shi was admitted to the Faculty of Law (School of Economic Laws) of East China University of Policy Science and Law (Shanghai, P.R.C.) in 2007 and graduated as Cum Laude in 2011, holding a Bachelor Degree in Laws.

In August 2011, Ms. Shi was enrolled to the Faculty of Law (corporate and commercial law track) of Maastricht University (Maastricht, the Netherlands). She graduated in August 2012, holding a Master Degree in Laws. Her master thesis is: The Administrator Designation System in Chinese Bankruptcy Law: find the objectiveness and faireness.

Ms. Shi joined the Department of Institute for Transnational Legal Research (METRO), the Faculty of Law of Maastricht University in 2013 as a junior researcher and started her $\mathrm{PhD}$ research. Her research interests are: law and economics, competition law, merger control and merger remedies.

施梦梦，1988 年 7 月 23 日生; 祖籍中国浙江; 上海人。

2007 年起就读于华东政法大学经济法学专业, 并于 2011 年取得法学学士学位, 为 2007 级优秀毕业生。

2011 年 8 月, 施梦梦赴荷兰马斯特里赫特大学法学院攻读法学硕士学位 (公 司法与商法方向）并于 2012 年 8 月顺利毕业。其硕士毕业论文为《中国破产法 框架下的破产管理人选任制度: 寻找公平与公正》。

2013 年起, 施梦梦成为荷兰马斯特里赫特大学法学院跨国法研究中心初级研 究员并攻读法学博士学位。其主要研究方向为: 法与经济学、竞争法学、公司兼 并制度以及公司兼并救济制度。 